SANDIA REPORT

SAND2011-6202

Unlimited Release

Printed August 2011

\title{
Generic Repository Design Concepts and Thermal Analysis (FY11)
}

Ernest Hardin, SNL

Jim Blink, Harris Greenberg, Mark Sutton \& Massimiliano Fratoni, LLNL

Joe Carter \& Mark Dupont, Savannah River

Rob Howard, ORNL

Prepared by

Sandia National Laboratories

Albuquerque, New Mexico 87185 and Livermore, California 94550

Sandia National Laboratories is a multi-program laboratory managed and operated by Sandia Corporation, a wholly owned subsidiary of Lockheed Martin Corporation, for the U.S. Department of Energy's

National Nuclear Security Administration under contract DE-AC04-94AL85000.

Approved for public release; further dissemination unlimited. 
Issued by Sandia National Laboratories, operated for the United States Department of Energy by Sandia Corporation.

NOTICE: This report was prepared as an account of work sponsored by an agency of the United States Government. Neither the United States Government, nor any agency thereof, nor any of their employees, nor any of their contractors, subcontractors, or their employees, make any warranty, express or implied, or assume any legal liability or responsibility for the accuracy, completeness, or usefulness of any information, apparatus, product, or process disclosed, or represent that its use would not infringe privately owned rights. Reference herein to any specific commercial product, process, or service by trade name, trademark, manufacturer, or otherwise, does not necessarily constitute or imply its endorsement, recommendation, or favoring by the United States Government, any agency thereof, or any of their contractors or subcontractors. The views and opinions expressed herein do not necessarily state or reflect those of the United States Government, any agency thereof, or any of their contractors.

Available to DOE and DOE contractors from

U.S. Department of Energy

Office of Scientific and Technical Information

P.O. Box 62

Oak Ridge, TN 37831

Telephone: $\quad$ (865) 576-8401

Facsimile: $\quad$ (865) 576-5728

E-Mail: reports@adonis.osti.gov

Online ordering: http://www.osti.gov/bridge

Available to the public from

U.S. Department of Commerce

National Technical Information Service

5285 Port Royal Rd.

Springfield, VA 22161

Telephone: $\quad$ (800) 553-6847

Facsimile: (703) 605-6900

E-Mail: $\quad$ orders@ntis.fedworld.gov

Online order: $\quad$ http://www.ntis.gov/help/ordermethods.asp?loc=7-4-0\#online

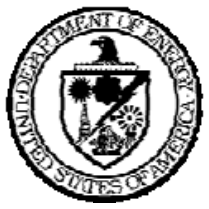


SAND2011-6202

Unlimited Release

Printed August 2011

\title{
Generic Repository Design Concepts and Thermal Analysis (FY11)
}

\author{
Ernest Hardin \\ Nuclear Fuel Cycle System Engineering \& \\ Integration Department \\ PO Box 5800 \\ Albuquerque, New Mexico 87185-MS1370 \\ Jim Blink, Harris Greenberg, Mark Sutton \& Massimiliano Fratoni \\ Lawrence Livermore National Laboratory \\ PO Box 808, L-090 \\ Livermore, CA 94550 \\ Joe Carter \& Mark Dupont \\ Savannah River Nuclear Solutions \\ Building 703-42A \\ Aiken, SC 29808 \\ Rob Howard \\ Oak Ridge National Laboratory \\ MS 6170 \\ PO Box 2008 \\ Oak Ridge, TN 37831-2008
}

\begin{abstract}
U)
Reference concepts for geologic disposal of used nuclear fuel and high-level radioactive waste in the U.S. are developed, including geologic settings and engineered barriers. Repository thermal analysis is demonstrated for a range of waste types from projected future, advanced nuclear fuel cycles. The results show significant differences among geologic media considered (clay/shale, crystalline rock, salt), and also that waste package size and waste loading must be limited to meet targeted maximum temperature values.
\end{abstract}




\section{CONTENTS}

Executive Summary

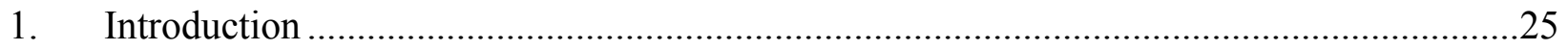

1.1 Disposal Design Concept Development Approach ............................................25

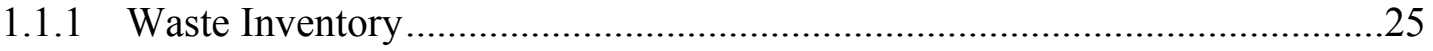

1.1.2 Geologic Setting and Geologic Media....................................................26

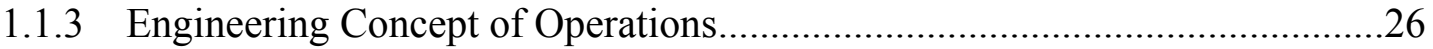

1.2 Disposal Concepts Considered .....................................................................27

1.3 Existing Concepts Proposed for Repositories in Various Geologic Media...............28

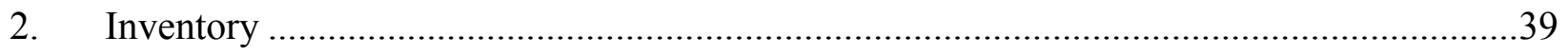

2.1 Once-Through Used Nuclear Fuel Cycle .............................................................39

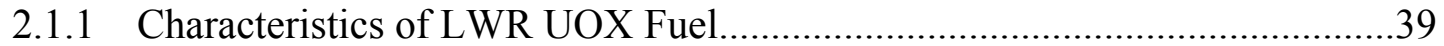

2.1.2 Characteristics of Once-Through Cycle Secondary Waste ...........................40

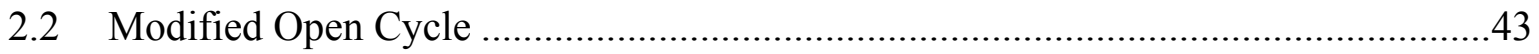

2.2.1 Overall Mass Flows for a Modified Open Fuel Cycle...................................43

2.2.2 Characteristics of Waste Generated by Co-Extraction Reprocessing LWR UOX Fuel...............................................................................44

2.2.3 Characteristics of Used MOX Fuels .......................................................... 47

2.2.4 Characteristics of Modified Open Cycle Secondary Waste ..........................53

2.3 Closed Fuel Cycle.........................................................................................54

2.3.1 Overall Mass Flows for a Closed Fuel Cycle .............................................55

2.3.2 Characteristics of LWR New Extraction Reprocessing Wastes .....................59

2.3.3 Characteristics of Waste Generated by Reprocessing SFR Metal Fuel.........65

2.3.4 Characteristics of the Heat Generating Wastes from SFR Processes .............65

2.3.5 Characteristics of Closed Cycle Secondary Waste ......................................75

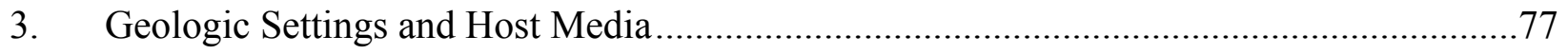

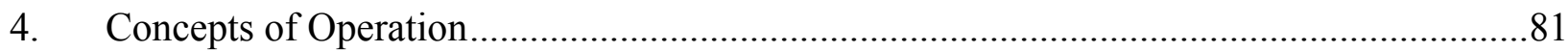

4.1 Concepts of Operation: Thermal Management...................................................81

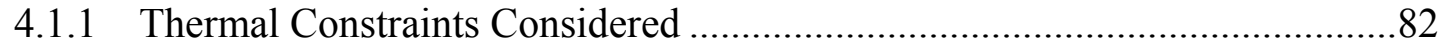

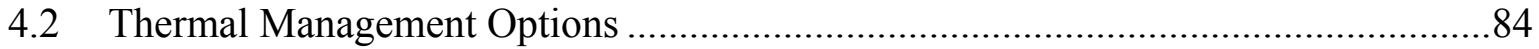

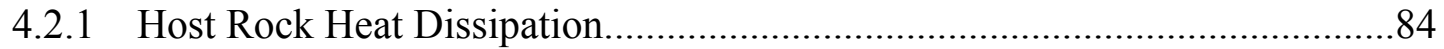




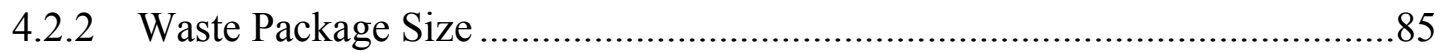

4.2.3 Blending of Waste Types, and Sequencing of Emplacement.........................85

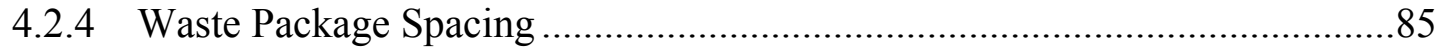

4.2.5 Emplacement Drift, Alcove, and Borehole Spacing .....................................85

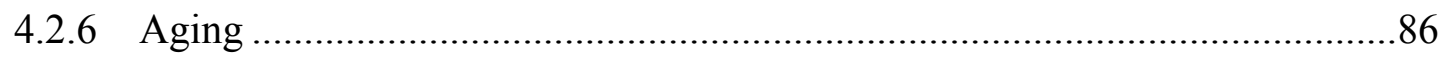

4.2.7 Segregated Disposal of Waste Forms ..........................................................

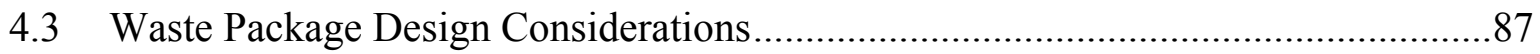

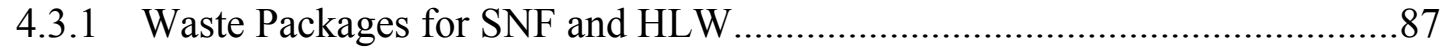

4.3.2 Waste Packages for LLW ..........................................................................

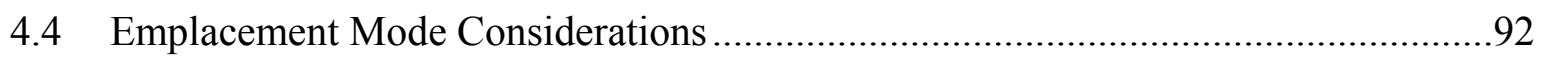

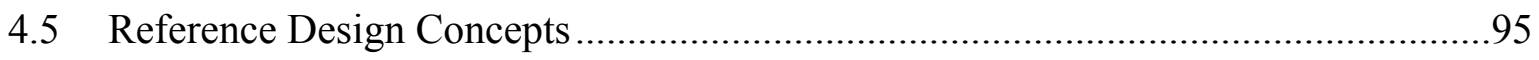

4.5.1 Reference Mined Crystalline/Granite Repository Design Concept.................95

4.5.2 Reference Clay/Shale Repository Design Concept ………………………......96

4.5.3 Reference Salt Repository Design Concept.....................................................98

4.5.4 Reference Deep Borehole Disposal Concept...................................................100

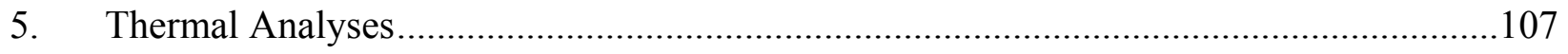

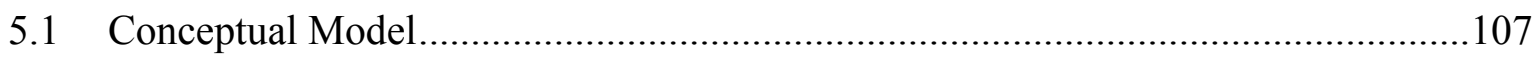

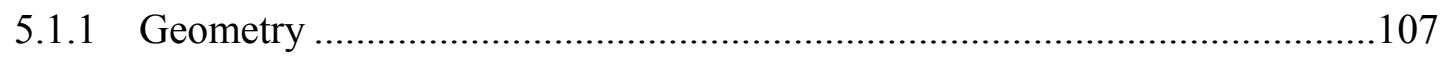

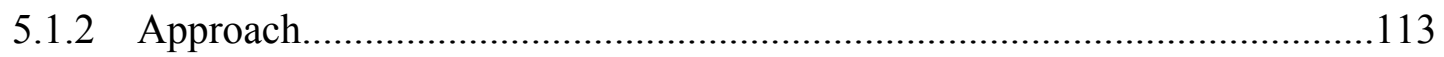

5.1.3 Input Data and Assumptions......................................................................113

5.2 Mathematical Modeling Approach ...................................................................116

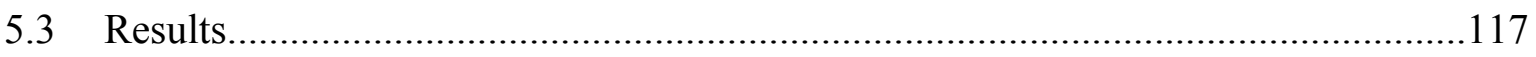

5.3.1 Host Rock and Waste Package Temperatures ……………………..............117

5.3.2 Waste Package and EBS Peak Temperatures ................................................121

5.3.3 Waste Package Surface Peak Temperature for Salt.......................................123

5.3.4 Peak Temperature as a Function of Decay Storage and Package

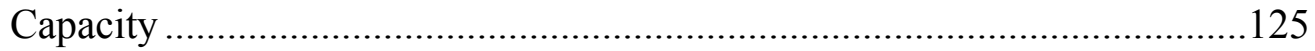

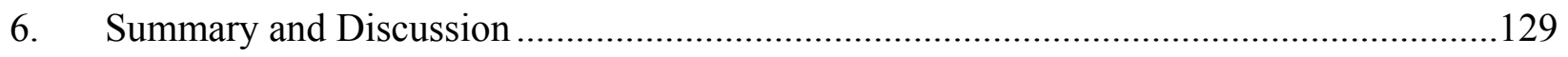

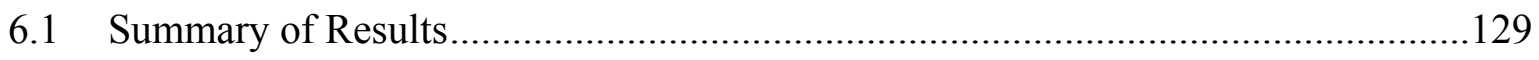

6.2 Discussion of Future Work ...................................................................................132

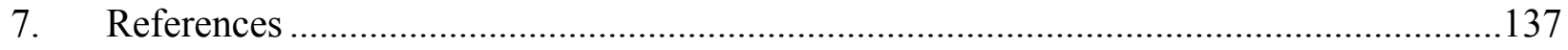


Appendix A Isotopic Compositions of 60 GW-d/MT PWR Fuel................................................145

Appendix B Isotopic Compositions of Co-Extraction Borosilicate Glass ...................................157

Appendix C Isotopic Compositions of 50 GW-d/MT MOX Fuel ...............................................167

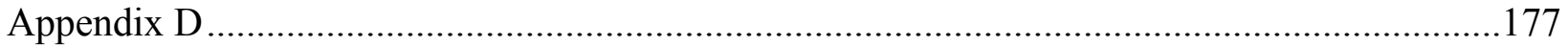

Sodium Fast Reactor Equilibrium Core Overall Material Balance for $\mathrm{CR}=0.75$........................177

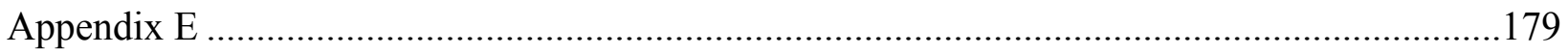

Isotopic Composition of Borosilicate Glass from the New Extraction Process ...........................179

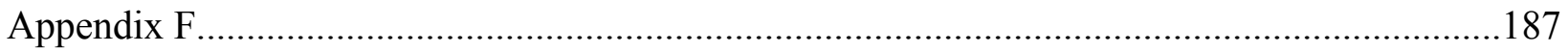

Isotopic Composition of Electrochemical Process Wastes .........................................................187

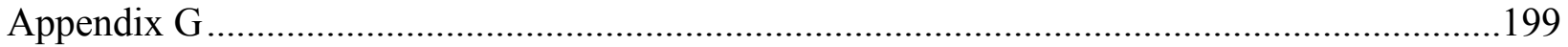

Mathematical Models for Thermal Analysis of Reference Disposal Concepts ............................199

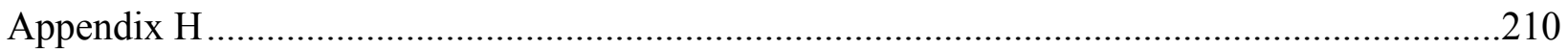

Results From Thermal Analysis of Reference Disposal Concepts ..............................................210

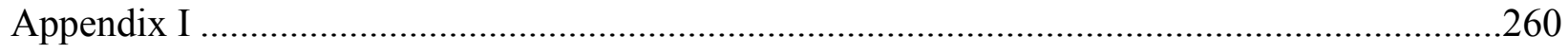

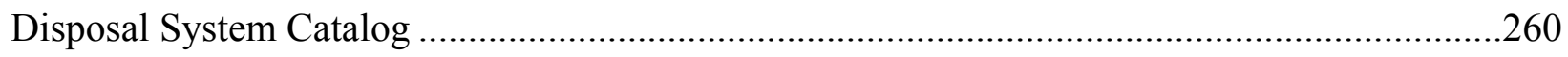

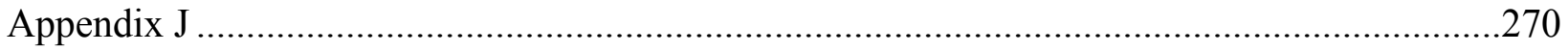

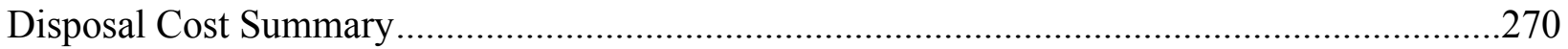




\section{FIGURES}

Figure 1-1 Schematic of Developed Repository in Bedded Salt (DOE 1986a).

Figure 1-2 Schematic of Horizontal Borehole/Drift Emplacement of Heavy Spent

Fuel Waste Packages (Bosgiraud et al. 2008).

Figure 1-3 Schematic of Disposal Galleries for Spent Fuel and Vitrified HLW in a Repository in the Boom Clay (ONDRAF/NIRAS 2001).....

Figure 1-4 Schematic of the KBS-3 Vertical and Horizontal Disposal Concepts (SKB 2010).

Figure 1-5 Schematic of the Facility for Final Disposal of Spent Nuclear Fuel, Finland (Petrakka 2010).

Figure 1-6 Schematic of Prefabricated EBS Concept for Waste Package and Buffer Emplacement in Long Horizontal Boreholes (not to scale; Posiva Oy 2010).

Figure 1-7 Schematic of Deep Borehole Disposal Concept (not to scale; after KASAM 2007). .36

Figure 2-1 PWR $60 \mathrm{GW}$-d/MT Used Fuel Decay Heat.

Figure 2-2 Low Level Waste Volume From Repository Operations.

Figure 2-3 Decay heat of UOX and MOX Fuel Assemblies Depending on Burnup and Cooling Time for Discharge Burnup of 55 and $69 \mathrm{GW}-\mathrm{d} / \mathrm{MTHM}$ (after IAEA 2003).

Figure 2-4 Borosilicate Glass Decay Heat Generated by Co-Extraction Processing of $51 \mathrm{GW}-\mathrm{d} / \mathrm{MT}$ 5-year Cooled PWR Fuel. .50

Figure 2-5 Mixed Oxide Fuel 50 GW-d/MT Used Fuel Decay Heat....................................52

Figure 2-6 Sodium Fast Reactors Used Fuel Decay Heat................................................57

Figure 2-7 Borosilicate Glass Decay Heat Generated by New Extraction

Processing of $51 \mathrm{GW}-\mathrm{d} / \mathrm{MT}$ 5-year Cooled PWR Fuel.

Figure 2-8 Electrochemical Glass Bonded Zeolite Decay Heat Generated by Processing Sodium Fast Reactor Metal Fuel with a TRU CR of 0.75 .....

Figure 2-9 Electrochemical Lanthanide Glass Decay Heat Generated by Processing Sodium Fast Reactor Metal Fuel with a TRU CR of 0.75.

Figure 2-10 Electrochemical Metal Alloy Decay Heat Generated by Processing Sodium Fast Reactor Metal Fuel with a TRU CR of 0.75 . .73

Figure 4-1 Schematic of Reference Disposal Concept for Crystalline Host Media. . .96

Figure 4-2 Schematic of Reference Disposal Concept for HLW in Clay/Shale Media. .98

Figure 4-3 Schematic of Reference Disposal Concept for HLW and SNF in Bedded Salt. 
Figure 4-4 Schematic of Reference Deep Borehole Disposal Concept. 102

Figure 5.1-1 Illustration of Terminology for EBS Regions, from Waste Canister to Host Rock.

Figure 5.1-2 Layout of Waste Packages for Thermal Analysis (plan and elevation views).

Figure 5.1-3 Graphical Representation of EBS Configuration for the Reference Disposal Concept in Crystalline Rock, for SNF (left) and HLW (right).

Figure 5.1-4 Graphical Representation of EBS Configuration for the Reference Disposal Concept in Clay/Shale, for SNF (left) and HLW (right).

Figure 5.1-5 Graphical Representation of EBS Configuration for the Reference Disposal Concept in Salt, for SNF (left) and HLW (right).

Figure 5.1-6 Graphical Representation of the Deep Borehole Disposal Concept, for SNF (left) and HLW (right).

Figure 5.1-7 Decay Heat Curves for 1 Assembly or 1 Canister per Waste Package for UOX, MOX, Co-Extraction, New Extraction, EC-Ceramic, and ECMetal Waste Types.

Figure 5.1-8 Decay Heat Curves for 1 UOX or MOX Assembly and 0.291 CoExtraction, New Extraction, EC-Ceramic or EC-Metal Canisters per Waste Package (deep borehole).

Figure 5.1-9 Decay Heat Curves for 1, 2, 3, 4 and 12 UOX or MOX Assemblies per Waste Package.

Figure 5.3-1 Temperature Histories at the "Calculation Radius" After Decay Storage of 10, 50 and $100 \mathrm{yr}$ for Waste Packages Containing 1, 2, 3, 4 and 12 UOX Assemblies, for a Repository in Clay/Shale Media.

Figure 5.3-2 Temperature Histories at the "Calculation Radius" After Decay Storage of 10, 50 and $100 \mathrm{yr}$, for Packages Containing 1, 2, 3, 4 and 12 MOX Assemblies, in Crystalline Rock.

Figure 5.3-3 Contributions to Temperature at the "Calculation Radius" from the Central Package, Adjacent Packages, and Neighboring Drifts for a Waste Package Containing 4 UOX Assemblies in Clay/Shale Media (10 yr Decay Storage).

Figure 5.3-4 Contributions to Temperature at the "Calculation Radius" from the Central Package, Adjacent Packages, and Neighboring Drifts for a Waste Package Containing 4 MOX Assemblies in Crystalline Rock (10 yr Decay Storage).

Figure 5.3-3 Calculated Waste Package Temperature After Decay Storage of 10, 50 and $100 \mathrm{yr}$, for Packages Containing 4 MOX Assemblies, for a Repository in Crystalline Rock,

Figure 5.3-4 Calculated Waste Package Temperature After 10 yr Decay Storage, for Waste Packages Containing 4 MOX Assemblies, for the Salt Disposal 
Concept, and Assuming that Backfill has the Thermal Conductivity of Crushed, Intact, or $75 \%$ of Intact Salt.

Figure 5.3-5 Minimum Decay Storage Duration to Limit Peak Waste Package Temperature to $100^{\circ} \mathrm{C}$ (for clay buffer or clay/shale media) or $200^{\circ} \mathrm{C}$ (for salt) as a Function of UOX Assemblies, for Crystalline, Clay/Shale, and Salt (75\% Intact) Media.

Figure 5.3-6 Minimum Decay Storage Duration to Limit Peak Waste Package Temperature to $100^{\circ} \mathrm{C}$ (for clay buffer or clay/shale media) or $200^{\circ} \mathrm{C}$ (for salt) as a Function of MOX Assemblies, for Crystalline, Clay/Shale, and Salt (75\% Intact) Media.

Figure G.4-1 Normalized Thermal Resistance of Each EBS Layer. .206

Figure G.5-1 Effects of Porosity and Temperature on Thermal Conductivity of Crushed Salt. .207

Figure G.5-2 Effects of Porosity and Temperature on Thermal Diffusivity of Crushed Salt.

Figure H.2-1 Contributions to Temperature at the "Calculation Radius" from the Central Package, Adjacent Packages, and Neighboring Drifts, for Packages Containing 4 UOX Assemblies (UOX-4) in Crystalline Rock.

Figure H.2-2 Contributions to Temperature at the "Calculation Radius" from the Central Package, Adjacent Packages, and Neighboring Drifts, for Packages Containing 4 MOX Assemblies (MOX-4) in Crystalline Rock.

Figure H.2-3 Contributions to Temperature at the "Calculation Radius" from the Central Package, Adjacent Packages, and Neighboring Drifts, for Packages Containing a Single Co-Extraction HLW (Co-Extraction-1) Canister, in Crystalline Rock.

Figure H.2-4 Contributions to Temperature at the "Calculation Radius" from the Central Package, Adjacent Packages, and Neighboring Drifts, for Packages Containing a Single New Extraction HLW (New Extraction-1) Canister, in Crystalline Rock.

Figure H.2-5 Contributions to Temperature at the "Calculation Radius" from the Central Package, Adjacent Packages, and Neighboring Drifts, for Packages Containing a Single EC-Ceramic HLW (ECC-1) Canister, in Crystalline Rock.

Figure H.2-6 Contributions to Temperature at the "Calculation Radius" from the Central Package, Adjacent Packages, and Neighboring Drifts, for Packages Containing a Single EC-Metal HLW (ECM-1) Canister, in Crystalline Rock.

Figure H.2-7 Contributions to Rock Temperature at the "Calculation Radius" from the Central Package, Adjacent Packages, and Neighboring Drifts for UOX-4 in Clay/Shale. 
Figure H.2-8 Contributions to Rock Temperature at the "Calculation Radius" from the Central Package, Adjacent Packages, and Neighboring Drifts for MOX-4 in Clay/Shale.

Figure H.2-9 Contributions to Rock Temperature at the "Calculation Radius" from the Central Package, Adjacent Packages, and Neighboring Drifts for CoExtraction-1 in Clay/Shale.

Figure H.2-10 Contributions to Rock Temperature at the "Calculation Radius" from the Central Package, Adjacent Packages, and Neighboring Drifts for New Extraction-1 in Clay/Shale.

Figure H.2-11 Contributions to Rock Temperature at the "Calculation Radius" from the Central Package, Adjacent Packages, and Neighboring Drifts for ECC-1 in Clay/Shale.

Figure H.2-12 Contributions to Rock Temperature at the "Calculation Radius" from the Central Package, Adjacent Packages, and Neighboring Drifts for ECM-1 in Clay/Shale.

Figure H.2-13 Contributions to Rock Temperature at the "Calculation Radius" from the Central Package, Adjacent Packages, and Neighboring Drifts for UOX-4 in Salt.

Figure H.2-14 Contributions to Rock Temperature at the "Calculation Radius" from the Central Package, Adjacent Packages, and Neighboring Drifts for MOX-4 in Salt.

Figure H.2-15 Contributions to Rock Temperature at the "Calculation Radius" from the Central Package, Adjacent Packages, and Neighboring Drifts for CoExtraction-1 in Salt.

Figure H.2-16 Contributions to Rock Temperature at the "Calculation Radius" from the Central Package, Adjacent Packages, and Neighboring Drifts for New Extraction-1 in Salt.

Figure H.2-17 Contributions to Rock Temperature at the "Calculation Radius" from the Central Package, Adjacent Packages, and Neighboring Drifts for ECC-1 in Salt.

Figure H.2-18 Contributions to Rock Temperature at the "Calculation Radius" from the Central Package, Adjacent Packages, and Neighboring Drifts for ECM-1 in Salt.

Figure H.2-19 Contributions to Temperature at the "Calculation Radius" from the Central Package, Adjacent Packages, and Neighboring Boreholes, for UOX-1 in a Deep Borehole.

Figure H.2-20 Contributions to Temperature at the "Calculation Radius" from the Central Package, Adjacent Packages, and Neighboring Boreholes, for MOX-1 in a Deep Borehole. 
Figure H.2-21 Contributions to Temperature at the "Calculation Radius" from the Central Package, Adjacent Packages, and Neighboring Boreholes, for One Narrow Co-Extraction (Co-Extraction-0.291) HLW Canister in a Deep Borehole. .223

Figure H.2-22 Contributions to Temperature at the "Calculation Radius" from the Central Package, Adjacent Packages, and Neighboring Boreholes, for One Narrow New Extraction (New Extraction-0.291) HLW Canister in a Deep Borehole.

Figure H.2-23 Contributions to Temperature at the "Calculation Radius" from the Central Package, Adjacent Packages, and Neighboring Boreholes, for One Narrow EC-Ceramic (ECC-0.291) HLW Canister in a Deep Borehole.

Figure H.2-24 Contributions to Temperature at the "Calculation Radius" from the Central Package, Adjacent Packages, and Neighboring Boreholes, for One Narrow EC-Metal (ECM-0.291) HLW Canister in a Deep Borehole.

Figure H.3-1 Host Rock Temperature at the "Calculation Radius" After Decay Storage of 10, 50 and $100 \mathrm{yr}$, for a Waste Package Containing 1, 2, 3, 4 and 12 UOX Assemblies in Crystalline Rock.

Figure H.3-2 Host Rock Temperature at the "Calculation Radius" After Decay Storage of 10, 50 and $100 \mathrm{yr}$, for a Waste Package Containing 1, 2, 3, 4 and 12 MOX Assemblies in Crystalline Rock.

Figure H.3-3 Host Rock Temperature at the "Calculation Radius" After Decay Storage of 10, 50 and $100 \mathrm{yr}$, for Co-Extraction-1 in Crystalline Rock.

Figure H.3-4 Host Rock Temperature at the "Calculation Radius" After Decay Storage of 10, 50 and $100 \mathrm{yr}$, for New Extraction-1 in Crystalline Rock. .227

Figure H.3-5 Host Rock Temperature at the "Calculation Radius" After Decay Storage of 10, 50 and $100 \mathrm{yr}$, for ECC-1 in Crystalline Rock.

Figure H.3-6 Host Rock Temperature at the "Calculation Radius" After Decay Storage of 10, 50 and $100 \mathrm{yr}$, for ECM-1 in Crystalline Rock. .228

Figure H.3-7 Host Rock Temperature After Decay Storage of 10, 50 and $100 \mathrm{yr}$, for Waste Packages Containing 1, 2, 3, 4 and 12 UOX Assemblies in Clay/Shale.

Figure H.3-8 Host Rock Temperature After Decay Storage of 10, 50 and $100 \mathrm{yr}$, for Waste Packages Containing 1, 2, 3, 4 and 12 MOX Assemblies in Clay/Shale.......230

Figure H.3-9 Host Rock Temperature at the "Calculation Radius" After Decay Storage of 10, 50 and $100 \mathrm{yr}$, for Co-Extraction-1 in Clay/Shale. .231

Figure H.3-10 Host Rock Temperature at the "Calculation Radius" After Decay Storage of 10, 50 and $100 \mathrm{yr}$, for New Extraction-1 in Clay/Shale.

Figure H.3-11 Host Rock Temperature at the "Calculation Radius" After Decay Storage of 10, 50 and $100 \mathrm{yr}$, for ECC-1 in Clay/Shale.

Figure H.3-12 Host Rock Temperature at the "Calculation Radius" After Decay Storage of 10, 50 and $100 \mathrm{yr}$, for ECM-1 in Clay/Shale. 
Figure H.3-13 Host Rock Temperature at the "Calculation Radius" After Decay Storage of 10, 50 and $100 \mathrm{yr}$, for Waste Packages Containing 1, 2, 3, 4 and 12 UOX Assemblies in Salt. ..... .233

Figure H.3-14 Host Rock Temperature at the "Calculation Radius" After Decay Storage of 10, 50 and 100 yr, for Waste Packages Containing 1, 2, 3, 4 and 12 MOX Assemblies in Salt.

Figure H.3-15 Host Rock Temperature at the "Calculation Radius" After Decay Storage of 10, 50 and $100 \mathrm{yr}$, for Co-Extraction-1 in Salt.

Figure H.3-16 Host Rock Temperature at the "Calculation Radius" After Decay Storage of 10, 50 and $100 \mathrm{yr}$, for New Extraction-1 in Salt.

Figure H.3-17 Host Rock Temperature at the "Calculation Radius" After Decay Storage of 10, 50 and $100 \mathrm{yr}$, for ECC-1 in Salt. .236

Figure H.3-18 Host Rock Temperature at the "Calculation Radius" After Decay Storage of 10, 50 and $100 \mathrm{yr}$, for ECM-1 in Salt. .236

Figure H.3-19 Host Rock Temperature at the "Calculation Radius" After Decay Storage of 10, 50 and $100 \mathrm{yr}$, for UOX-1 in a Deep Borehole.

Figure H.3-20 Host Rock Temperature at the "Calculation Radius" After Decay Storage of 10, 50 and $100 \mathrm{yr}$, for MOX-1 in a Deep Borehole.

Figure H.3-21 Host Rock Temperature at the "Calculation Radius" After Decay Storage of 10, 50 and $100 \mathrm{yr}$, for Co-Extraction-0.291 in a Deep Borehole......

Figure H.3-22 Host Rock Temperature at the "Calculation Radius" After Decay Storage of 10, 50 and 100 yr, for New Extraction-0.291 in a Deep Borehole. .238

Figure H.3-23 Host Rock Temperature at the "Calculation Radius" After Decay Storage of 10, 50 and $100 \mathrm{yr}$, for ECC-0.291 in a Deep Borehole.

Figure H.3-24 Host Rock Temperature at the "Calculation Radius" After Decay Storage of 10, 50 and $100 \mathrm{yr}$, for ECM-0.291 in a Deep Borehole.

Figure H.4-1 Calculated Waste Package Temperature After Storage Times of 10, 50 and 100 yr for UOX-4 in Crystalline Rock.

Figure H.4-2 Calculated Waste Package Temperature After Storage Times of 10, 50 and 100 yr for MOX-4 in Crystalline Rock.

Figure H.4-3 Calculated Waste Package Temperature After Storage Times of 10, 50 and 100 yr for Co-Extraction-1 in Crystalline Rock.

Figure H.4-4 Calculated Waste Package Temperature After Storage Times of 10, 50 and 100 yr for New Extraction-1 in Crystalline Rock.

Figure H.4-5 Calculated Waste Package Temperature After Storage Times of 10, 50 and 100 yr for ECC-1 in Crystalline Rock.

Figure H.4-6 Calculated Waste Package Temperature After Storage Times of 10, 50 and 100 yr for ECM-1 in Crystalline Rock. 
Figure H.4-7 Calculated Waste Package Temperature After Storage Times of 10, 50 and 100 yr for UOX-4 in Clay/Shale.

Figure H.4-8 Calculated Waste Package Temperature After Storage Times of 10, 50 and $100 \mathrm{yr}$ for MOX-4 in Clay/Shale.

Figure H.4-9 Calculated Waste Package Temperature After Storage Times of 10, 50 and 100 yr for Co-Extraction-1 in Clay/Shale. .245

Figure H.4-10 Calculated Waste Package Temperature After Storage Times of 10, 50 and $100 \mathrm{yr}$ for New Extraction-1 in Clay/Shale.

Figure H.4-11 Calculated Waste Package Temperature After Storage Times of 10, 50 and $100 \mathrm{yr}$ for ECC-1 in Clay/Shale.

Figure H.4-12 Calculated Waste Package Temperature After Storage Times of 10, 50 and 100 yr for ECM-1 in Clay/Shale.

Figure H.4-13 Calculated Waste Package Temperature After Decay Storage of 10, 50 and 100 yr for UOX-4 in Salt (75\% of intact salt conductivity).

Figure H.4-14 Calculated Waste Package Temperature After Decay Storage of 10, 50 and $100 \mathrm{yr}$ for MOX-4 in Salt (75\% of intact salt conductivity).

Figure H.4-15 Calculated Waste Package Temperature After Decay Storage of 10, 50 and 100 yr for Co-Extraction-1 in Salt (75\% of intact salt conductivity). .248

Figure H.4-16 Calculated Waste Package Temperature After Decay Storage of 10, 50 and $100 \mathrm{yr}$ for New Extraction-1 in Salt (75\% of intact salt conductivity).

Figure H.4-17 Calculated Waste Package Temperature After Decay Storage of 10, 50 and $100 \mathrm{yr}$ for ECC-1 in Salt (75\% of intact salt conductivity).

Figure H.4-18 Calculated Waste Package Temperature After Decay Storage of 10,50 and $100 \mathrm{yr}$ for ECM-1 in Salt (75\% of intact salt conductivity).

Figure H.4-19 Calculated Waste Package Temperature After Decay Storage of 10, 50 and 100 yr for UOX-1 in a Deep Borehole.

Figure H.4-20 Calculated Waste Package Temperature After Decay Storage of 10, 50 and $100 \mathrm{yr}$ for MOX-1 in a Deep Borehole.

Figure H.4-21 Calculated Waste Package Temperature After Decay Storage of 10, 50 and $100 \mathrm{yr}$ for Co-Extraction-0.291 in a Deep Borehole.

Figure H.4-22 Calculated Waste Package Temperature After Decay Storage of 10, 50 and $100 \mathrm{yr}$ for New Extraction-0.291 in a Deep Borehole.

Figure H.4-23 Calculated Waste Package Temperature After Decay Storage of 10, 50 and $100 \mathrm{yr}$ for ECC-0.291 in a Deep Borehole.

Figure H.4-24 Calculated Waste Package Temperature After Decay Storage of 10, 50 and $100 \mathrm{yr}$ for ECM-0.291 in a Deep Borehole.

Figure H.5-1 Peak Waste Package Surface Temperature as a Function of Decay Storage for UOX in Crystalline Rock. 
Figure H.5-2 Peak Waste Package Surface Temperature as a Function of Decay Storage for MOX in Crystalline Rock.

Figure H.5-3 Peak Waste Package Surface Temperature as a Function of Decay Storage for UOX in Clay/Shale.

Figure H.5-4 Peak Waste Package Surface Temperature as a Function of Decay Storage for MOX in Clay/Shale.

Figure H.5-5 Peak Waste Package Surface Temperature as a Function of Decay Storage for UOX in Salt (75\% of intact salt conductivity).

Figure H.5-6 Peak Waste Package Surface Temperature as a Function of Decay Storage for MOX in Salt (75\% of intact salt conductivity).

Figure H.6-1 Minimum Decay Storage Needed to Meet Prescribed Maximum Waste Package Temperatures, as a Function of UOX Assemblies per Package in Crystalline, Clay/Shale, and Salt (75\% of intact salt conductivity).

Figure H.6-2 Minimum Decay Storage Needed to Meet Prescribed Maximum Waste Package Temperatures, as a Function of MOX Assemblies per Package in Crystalline, Clay/Shale, and Salt (75\% of intact salt conductivity).

Figure I-1 Potential Range of Waste Form Types for Geologic Disposal. .266

Figure I-2 Geologic Settings Considered for Disposal of SNF and HLW. .266

Figure I-3 Hydrogeologic Settings Considered for Disposal of SNF and HLW.

Figure I-4 Host Rock Geochemical Settings Considered for Disposal of SNF and HLW.

Figure I-5 Geomechanical Settings Considered for Disposal of SNF and HLW. .268

Figure I-6 Engineered Features Considered for Disposal of SNF and HLW. .268 


\section{TABLES}

Table ES-1 Summary of Characteristics for Reference Repository Design Concepts.

Table 1-1 Thermal Constraints Associated with Previously Proposed Disposal Concepts

Table 2-1 Current and Projected Characteristics of Used Nuclear Fuel.

Table 2-2 PWR 60 GW-d/MT Used Fuel Decay Heat.

Table 2-3 LWR Derived MOX Fuel Summary. .44

Table 2-4 Co-Extraction Fuel Reprocessing Off-Gas Waste Summary...............................46

Table 2-5 Co-Extraction Fuel Reprocessing Metal Waste Summary...................................46

Table 2-6 Co-Extraction Fuel Reprocessing Fission Product Waste Summary. ...............46

Table 2-7 Co-Extraction Fuel Reprocessing Recovered Uranium Summary. .....................46

Table 2-8 Borosilicate Glass Decay Heat Generated by Co-Extraction Processing of $51 \mathrm{GW}-\mathrm{d} / \mathrm{MT}$ 5-year Cooled PWR Fuel.

Table 2-9 Mixed Oxide Fuel $50 \mathrm{GW}$-d/MT Used Fuel Decay Heat

Table 2-10 Annual Secondary Waste Volume from an 800 MTHM/year Co-

Extraction Facility.

Table 2-11 Annual Secondary Waste Volume from a MOX Fuel Fabrication

Facility (3.5 MT Pu/year) Processing Pu Recovered from LWR UNF with Burnup of $60 \mathrm{GW}-\mathrm{d} / \mathrm{MT}$. .54

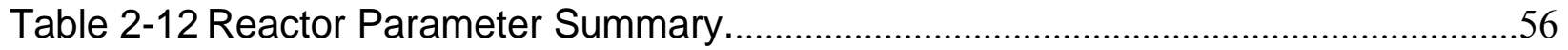

Table 2-13 Overall Reactor Material Balance Result. ........................................................56

Table 2-14 New Extraction Reactor Fuel Reprocessing Off-Gas Waste Summary. ........61

Table 2-15 New Extraction Fuel Reprocessing Metal Waste Summary.

Table 2-16 New Extraction Reactor Fuel Reprocessing Fission Product Waste Summary.

Table 2-17 New Extraction Fuel Reprocessing Recovered Uranium Summary.

Table 2-19 Advanced Burner Reactor Fuel Reprocessing Off-Gas Waste

Summary.

Table 2-20 Advanced Burner Reactor Fuel Reprocessing Metal Waste Summary.

Table 2-21 Advanced Burner Reactor Fuel Reprocessing Fission Product Waste Summary.

Table 2-23 Electrochemical Metal Alloy Decay Heat Generated by Processing SFR Metal Fuel with a TRU CR of 0.75 . 
Table 2-24 Electrochemical Lanthanide Glass Decay Heat Generated by Processing SFR Metal Fuel with a TRU CR of 0.75 ...

Table 2-25 Annual Secondary Waste Volume from an 800 MTHM/year New Extraction Facility. .75

Table 2-26 Summary of Annual Waste Volume Estimates For Electrochemical Recycling Of Sodium Fast Reactor Used Fuel. .76

Table 4-1 Summary of Characteristics for Reference Repository Design Concepts.

Table 4-2 Comparison of Available Additional Repository Volume With LLW and GTCC Waste Production.

Table 5-1 Peak Temperature at the "Calculation Radius" and Corresponding Time of the Peak for Four Disposal Concepts, Six Waste Types and Four Decay Storage Periods.

Table 5-2 Peak Waste Package Surface Temperature and the Time When the Peak Occurs, for Crystalline, Clay/Shale, and Deep Borehole Concepts.

Table 5-3 Peak Waste Package Surface Temperature and the Time When the Peak Occurs, for the Salt Disposal Concept.

Table A-1 60 GW-d/MT Pressurized Water Reactor Radionuclide Inventory (enrichment 4.73\%).

Table B-1 Isotopic Composition of Co-Extraction Borosilicate Glass at 5, 30, 100 and 500 years Isotopic Composition (grams) of Co-Extraction Glass from reprocessing $51 \mathrm{GW}-\mathrm{d} / \mathrm{MT}$ LWR Fuel.....

Table C-1 50 GW-d/MT LWR Mixed Oxide Fuel Radionuclide Inventory. 168

Table D-1 Oxide Equilibrium Core LWR SNF CR=0.75.

Table E-1 Isotopic Composition of New Extraction Borosilicate Glass from Reprocessing $51 \mathrm{GW}$-d/MT LWR Fuel, at 5, 30, 100 and $500 \mathrm{yr}$ Out-of-Reactor.

Table F-1 Isotopic Composition of E-Chem Glass Bonded Zeolite from

Reprocessing of Metal Fuel from SFRs with CR $=0.75$ and $100 \mathrm{GW}-\mathrm{d} / \mathrm{MT}$ Burnup, at 5, 30, 100 and 500 yr Out-of-Reactor.

Table F-2 Isotopic Composition of E-Chem Lanthanide Glass from Reprocessing of Metal Fuel from SFRs with CR $=0.75$ and $100 \mathrm{GW}$-d/MT Burnup, at 5, 30, 100 and 500 yr Out-of-Reactor.

Table F-3 Isotopic Composition of E-Chem Metal Alloy from Reprocessing of Metal Fuel from SFRs with CR $=0.75$ and $100 \mathrm{GW}-\mathrm{d} / \mathrm{MT}$ Burnup, at 5, 30, 100 and 500 yr Out-of-Reactor.

Table J-1 Cost Summary for Geologic Disposal of SNF (AFCI 2009)..............................272

Table J-2 Cost Summary for Geologic Disposal of HLW (FCI 2009). ..............................273

Table J-3 Cost Summary from Nutt (2009).................................................................275 


\section{Executive Summary}

In this study, the UFD R\&D Campaign has developed a set of reference geologic disposal concepts for a range of waste types that could potentially be generated in advanced nuclear FCs. A disposal concept consists of three components: waste inventory, geologic setting, and concept of operations. Mature repository concepts have been developed in other countries for disposal of spent LWR fuel and HLW from reprocessing UNF, and these serve as starting points for developing this set. Additional design details and EBS concepts will be considered as the reference disposal concepts evolve.

The waste inventory considered in this study includes: 1) direct disposal of SNF from the LWR fleet, including Gen III+ advanced LWRs being developed through the Nuclear Power 2010 Program, operating in a once-through cycle; 2) waste generated from reprocessing of LWR UOX $\mathrm{UNF}$ to recover $\mathrm{U}$ and $\mathrm{Pu}$, and subsequent direct disposal of used Pu-MOX fuel (also used in LWRs) in a modified-open cycle; and 3) waste generated by continuous recycling of metal fuel from fast reactors operating in a TRU burner configuration, with additional TRU material input supplied from reprocessing of LWR UOX fuel.

The geologic setting provides the natural barriers, and establishes the boundary conditions for performance of engineered barriers. The composition and physical properties of the host medium dictate design and construction approaches, and determine hydrologic and thermal responses of the disposal system.

Clay/shale, salt, and crystalline rock media are selected as the basis for reference mined geologic disposal concepts in this study, consistent with advanced international repository programs, and previous investigations in the U.S. The U.S. pursued deep geologic disposal programs in crystalline rock, shale, salt, and volcanic rock in the years leading up to the Nuclear Waste Policy Act, or NWPA (Rechard et al. 2011). The 1987 NWPA amendment act focused the U.S. program on unsaturated, volcanic rock at the Yucca Mountain site, culminating in the 2008 license application. Additional work on unsaturated, crystalline rock settings (e.g., volcanic tuff) is not required to support this generic study. Reference disposal concepts are selected for the media listed above and for deep borehole disposal, drawing from recent work in the U.S. and internationally. The main features of the repository concepts are discussed in Section 4.5 and summarized in Table ES-1.

Temperature histories at the waste package surface and a specified distance into the host rock are calculated for combinations of waste types and reference disposal concepts, specifying waste package emplacement modes. Target maximum waste package surface temperatures are identified, enabling a sensitivity study to inform the tradeoff between the quantity of waste per disposal package, and decay storage duration, with respect to peak temperature at the waste package surface. For surface storage duration on the order of 100 years or less, waste package sizes for direct disposal of SNF are effectively limited to 4-PWR configurations (or equivalent size and output). Thermal results are summarized, along with recommendations for follow-on work including adding additional reference concepts, verification and uncertainty analysis for thermal calculations, developing descriptions of surface facilities and other system details, and cost estimation to support system-level evaluations. 
Table ES-1 Summary of Characteristics for Reference Repository Design Concepts.

\begin{tabular}{|c|c|c|c|c|}
\hline Reference Concept $\gg$ & Mined Crystalline & Mined Clay/Shale & Mined Bedded Salt & Deep Borehole \\
\hline Repository depth & $\sim 500 \mathrm{~m}$ & $\sim 500 \mathrm{~m}$ & $\sim 500 \mathrm{~m}$ & $>3000 \mathrm{~m}$ \\
\hline Hydrologic setting & Saturated & Saturated & Saturated & Saturated \\
\hline Ground support material & $\begin{array}{l}\text { Rockbolts, wire } \\
\text { cloth \& shotcrete }\end{array}$ & $\begin{array}{l}\text { Steel sets \& } \\
\text { shotcrete }\end{array}$ & Rockbolts & Not used \\
\hline $\begin{array}{l}\text { Normalized Areal Loading } \\
\text { (GWe-yr/acre) }\end{array}$ & 1 to 10 & 1 to 10 & 1 to 10 & $<1$ \\
\hline SNF Emplacement Mode & $\begin{array}{c}\text { Vertical } \\
\text { emplacement } \\
\text { boreholes in floor }\end{array}$ & $\begin{array}{l}\text { Horizontal in-drift } \\
\text { emplacement }\end{array}$ & $\begin{array}{c}\text { Horizontal } \\
\text { emplacement in } \\
\text { alcoves containing } \\
\text { single packages }\end{array}$ & $\begin{array}{l}\text { Vertical } \\
\text { emplacement, } \\
\text { stacked }\end{array}$ \\
\hline WP configuration & 4-PWR & 4-PWR & 4-PWR & $\begin{array}{l}1 \text { PWR assembly } \\
\text { (rod consolidation) }\end{array}$ \\
\hline Overpack material & Copper or steel $^{\mathrm{B}}$ & Steel $^{\mathrm{B}}$ & Steel $^{\mathrm{B}}$ & Steel $^{\mathrm{B}}$ \\
\hline Drift/borehole dia. & $1.66 \mathrm{~m}$ (boreholes) & $2.64 \mathrm{~m}$ (drifts) & $5 \mathrm{~m}$ (nominal; alcoves) & $45 \mathrm{~cm}$ (boreholes) \\
\hline Drift/borehole spacing & $\begin{array}{c}20 \text { m (drifts) } \\
10 \text { m (boreholes) }\end{array}$ & $\begin{array}{c}30 \text { m (drifts) } \\
10 \text { m (packages) }\end{array}$ & $\begin{array}{c}40 \mathrm{~m} \text { (drifts) } \\
20 \mathrm{~m} \text { (alcoves) } \\
\text { Result: packages on } \\
\text { 20-meter grid }\end{array}$ & >100 m (boreholes) \\
\hline Borehole liner material & NA & Steel $^{\mathrm{B}}$ & NA & Steel $^{\mathrm{B}}$ \\
\hline Buffer material & Bentonite clay & Bentonite clay & NA & Bentonite clay \\
\hline Backfill material & Clay/sand mixture & Crushed clay/shale & Crushed salt & NA \\
\hline Line or point loading & Point & Point & Point & Line \\
\hline HLW Emplacement Mode & $\begin{array}{c}\text { Vertical } \\
\text { emplacement } \\
\text { boreholes in floor }\end{array}$ & $\begin{array}{c}\text { Horizontal parallel } \\
\text { boreholes } \\
\text { containing multiple } \\
\text { packages }\end{array}$ & $\begin{array}{c}\text { Horizontal } \\
\text { emplacement in } \\
\text { alcoves containing } \\
\text { single packages }\end{array}$ & $\begin{array}{l}\text { Vertical } \\
\text { emplacement, } \\
\text { stacked }\end{array}$ \\
\hline Overpack material & Steel $^{\mathrm{B}}$ & Steel $^{B}$ & Steel $^{\mathrm{B}}$ & Steel $^{\mathrm{B}}$ \\
\hline Drift/borehole dia. & $1.52 \mathrm{~m}$ & $0.75 \mathrm{~m}$ (boreholes) & 5 m (nominal; alcoves) & $>45 \mathrm{~cm}$ (boreholes) \\
\hline Drift/borehole spacing & $\begin{array}{c}20 \text { m (drifts) } \\
10 \text { m (boreholes) }\end{array}$ & $\begin{array}{l}30 \mathrm{~m} \text { (boreholes) } \\
6 \mathrm{~m} \text { (packages) }\end{array}$ & $\begin{array}{c}40 \mathrm{~m} \text { (drifts) } \\
20 \mathrm{~m} \text { (alcoves) } \\
\text { Result: packages on } \\
\text { 20-meter grid }\end{array}$ & >100 m (boreholes) \\
\hline Borehole liner material & NA & Steel $^{B}$ & NA & Steel $^{\mathrm{B}}$ \\
\hline Buffer material & Bentonite clay & NA & NA & Bentonite clay \\
\hline Backfill material & Clay/sand mixture & Crushed clay/shale & Crushed salt & NA \\
\hline Line or point loading & \begin{tabular}{|l|} 
Point \\
\end{tabular} & Line & Point & Line \\
\hline \multicolumn{5}{|c|}{$\begin{array}{l}\text { Notes: } \\
\text { A Smaller diameter, and possibly shorter HLW pour canisters would be used for deep borehole applications. } \\
\text { B The types of steel to be used in these applications, are to-be-determined, but for this study they are considered to be } \\
\text { readily available and relatively low-cost. }\end{array}$} \\
\hline
\end{tabular}




\section{Acronyms}

\begin{tabular}{|c|c|}
\hline ABR & Advanced Burner Reactor \\
\hline AFCI & Advanced Fuel Cycle Initiative \\
\hline ANL & Argonne National Laboratory \\
\hline BWR & Boiling-Water Reactor \\
\hline $\mathrm{CH}$ & Contact Handled \\
\hline CLAB & Centralized Used-Fuel Storage Facility (Sweden) \\
\hline Co-Extraction & Co-Extraction Process \\
\hline $\mathrm{CR}$ & Conversion Ratio \\
\hline DOE & U.S. Department of Energy \\
\hline EBS & Engineered Barrier System \\
\hline EC, E-Chem & Electrochemical \\
\hline EDZ & Excavation Damage Zone \\
\hline FA & Fuel Assembly \\
\hline $\mathrm{FC}$ & Fuel Cycle \\
\hline FCR\&D & Fuel Cycle Research and Development \\
\hline FCT & Fuel Cycle Technology \\
\hline FEP & Features, Events and Processes \\
\hline FY & Fiscal Year \\
\hline GTCC & Greater Than Class C \\
\hline GW-d & Gigawatt-Days \\
\hline $\mathrm{GW}-\mathrm{d} / \mathrm{t}$ & Gigawatt-Days per Metric Ton (also GW-d/MT) \\
\hline GWe & Gigawatts-Electrical \\
\hline GWt & Gigawatts-Thermal \\
\hline HEPA & High Efficiency Particulate Air \\
\hline $\mathrm{HIC}$ & High Integrity Container \\
\hline HLW & High Level (Radioactive) Waste \\
\hline HM & Heavy Metal \\
\hline HTGR & High Temperature Gas Reactor \\
\hline $\mathrm{IC} / \mathrm{MC} / \mathrm{OC}$ & Inner Core/Middle Core/Outer Core \\
\hline LLNL & Lawrence Livermore National Laboratory \\
\hline LLW & Low Level Waste \\
\hline LWR & Light Water Reactor \\
\hline MOX & Mixed Oxide Reactor Fuel \\
\hline $\mathrm{MPa}$ & Megapascals \\
\hline
\end{tabular}




$\begin{array}{ll}\text { MT } & \text { Metric Ton } \\ \text { MTHM } & \text { Metric Tons of Heavy Metal } \\ \text { MTIHM } & \text { Metric Tons of Initial Heavy Metal } \\ \text { MTU } & \text { Metric Tons of Uranium } \\ \text { MW-d } & \text { Megawatt-Days } \\ \text { MW }_{\text {th }} & \text { Megawatts-Thermal } \\ \text { NEA } & \text { Nuclear Energy Agency } \\ \text { NGNP } & \text { Next Generation Nuclear Plant } \\ \text { NE } & \text { DOE-Nuclear Energy } \\ \text { NWPA } & \text { Nuclear Waste Policy Act } \\ \text { NWPAA } & \text { Nuclear Waste Policy Act Amendment } \\ & \\ \text { OCRWM } & \text { Office of Civilian Radioactive Waste Management (DOE) } \\ \text { ORNL } & \text { Oak Ridge National Laboratory } \\ & \\ \text { PUREX } & \text { Plutonium-Uranium Extraction Process } \\ \text { PWR } & \text { Pressurized Water Reactors } \\ & \\ \text { R\&D } & \text { Research and Development } \\ \text { RH } & \text { Remote Handled } \\ \text { RW } & \text { Radioactive Waste } \\ & \text { Sodium Fast Reactor } \\ \text { SFR } & \text { Spent Nuclear Fuel } \\ \text { SNF } & \text { Spent Nuclear Fuel Assemblies } \\ \text { SNFA } & \text { Sandia National Laboratories } \\ \text { SNL } & \text { Savannah River National Laboratory } \\ \text { SRNL } & \text { Savannah River Site } \\ \text { SRS } & \text { Standard Waste Box } \\ \text { SWB } & \text { Transport/Aging/Disposal } \\ & \text { Trivalent Actinide Lanthanide Separation by Phosphorus-based Aqueous } \\ \text { TAD } & \text { [Komplexes } \\ \text { TALSPEAK } & \text { Tunnel Boring Machine } \\ \text { TBM } & \text { Technetium } \\ \text { Tc } & \text { Thermal-Hydrologic-Mechanical } \\ \text { THM } & \text { Thermal-Hydrologic-Mechanical-Chemical } \\ \text { THMC } & \text { Tri-Isotropic Coated Fuel Particles } \\ \text { TRISO } & \text { Transuranic } \\ \text { TRU } & \text { Transuranic Extraction } \\ \text { TRUEX } & \\ & \text { Undissolved Solids } \\ \text { UDS } & \text { Used Fuel Disposition } \\ \text { UFD } & \text { Used Fuel Disposition Campaign } \\ \text { UFDC } & \text { Used Nuclear Fuel } \\ \text { UNF } & \\ & \end{array}$




$\begin{array}{ll}\text { UOX } & \text { Uranium Oxide Fuel } \\ \text { UREX } & \text { Uranium Extraction } \\ \text { VHTR } & \text { Very High Temperature Gas Reactor } \\ \text { W } & \text { Waste } \\ \text { WP } & \text { Waste Package } \\ \text { WIPP } & \text { Waste Isolation Pilot Plant } \\ \text { YM } & \text { Yucca Mountain } \\ \text { WF_count } & \text { Waste Form Count }\end{array}$




\section{Introduction}

As noted in Used Fuel Disposition Campaign Disposal R\&D Roadmap (Nutt 2011), a fundamental part of any radioactive waste repository safety case is the disposal system concept: a description of the repository design including the engineered barriers, the geologic setting and its stability, how both engineered and natural barriers are expected to evolve over time, and how they are expected to provide safety. In order to develop its research and development (R\&D) program, the Used Fuel Disposition (UFD) campaign is developing safety concepts for generic disposal environments.

The UFD campaign (UFDC) will investigate ways to improve repository safety or the demonstration of future safety, and many of the scientific questions depend on specification of generic design concepts for geologic host media. As an example, R\&D focused on improving understanding of processes at material interfaces within the engineered barrier system (EBS), requires that barrier concepts be defined. Concepts for natural and engineered barriers will differ depending on the waste stream and the geologic medium.

In addition, fuel cycle (FC) scenarios under consideration by the U.S. Department of Energy (DOE) Fuel Cycle Technology (FCT) program generate waste streams and waste forms having different characteristics, such as radionuclide inventory and decay heat output, volume, mass, and chemical form. To evaluate alternative FCs, disposal of these wastes needs to be considered for different repository design concepts, to generate disposal-related metrics for system analysis and system engineering activities.

In this study, the UFDC has developed a set of repository design concepts for disposal of a range of waste forms that could potentially be generated in advanced nuclear FCs. We expect that this set will expand in the future as more FCs, and the resultant waste streams, are included. Mature repository design concepts have been developed in other countries for disposal of spent light water reactor (LWR) fuel and high level waste (HLW) generated from PUREX reprocessing, and these serve as starting points for developing this set of design concepts. Additional design details (e.g., single-level, multi-level, ramp vs. shaft access, etc.) and EBS concepts (e.g., capillary barrier, prefabrication, etc.) will be considered as the repository design concepts evolve.

These developed design concepts will support the capability of the UFDC to contribute to policyforming discussions on waste management strategy, locations for nuclear FC facilities, and disposal options. In addition, the reference disposal concepts described here will provide context for UFDC R\&D activities that seek to advance confidence in models of repository system performance. Also, the alternative future nuclear FCs considered here and in successive reports, are intended to be consistent with those being studied by ongoing System Analysis and System Engineering activities, and thus, to directly support those activities.

\subsection{Disposal Design Concept Development Approach}

A disposal design concept consists of three components: waste inventory, geologic setting (including geologic medium), and engineering concept of operations, which together constitute the overall disposal concept.

\subsubsection{Waste Inventory}

The DOE is examining a broad range of FC strategy options to inform decisions on how best to manage used fuel. This study supports that approach by addressing disposal options for a range 
of nuclear fuel types and waste forms that could be produced by future nuclear FCs. These options include "optimized once-through" and "modified-open" FCs that involve direct disposal of the used fuel when it is classified as "spent," and a "full-recycle" FC option in which HLW is disposed but not spent fuel.

We consider direct disposal of: 1) the current U.S. inventory of LWR UOX spent nuclear fuel (SNF); 2) SNF from reactors operating in the next few decades, including the current fleet; and (3) SNF from reactors that may be built and generate spent fuel under other once-through and modified-open FC options. (In this study we use SNF for reactor fuel that is to be directly disposed, while used nuclear fuel (UNF) is used nuclear fuel that is stored pending reprocessing or for which the manner of disposition has not been determined.) The DOE Fuel Cycle Technologies (FCT) program is identifying alternative reactor and fuel types, and performing supporting R\&D activities. Fuel types considered in this study represent, at least with respect to radionuclide inventory and heat output, those being evaluated in the FCT program.

Commercial used fuel as applied here includes the current inventory of used oxide fuel from commercial LWRs, and the projected future inventory from the LWR fleet, including Gen III+ advanced LWRs being developed through the DOE Nuclear Power 2010 Program. In addition, it may include fuels from the Next Generation Nuclear Plant (NGNP) gas-cooled reactor program and from future Gen IV advanced reactors (such as the very-high temperature gas reactor, VHTR) that may be introduced into the commercial reactor fleet. For fiscal year 2011 (FY11) this study will consider waste from: 1) Gen III LWRs operating in a once-through cycle; 2) reprocessing of LWR UOX fuel and direct disposal of used Plutonium-mixed oxide reactor fuel (Pu-MOX, or in this report simply MOX) also used in LWRs in a modified-open cycle; and (3) a full-recycle strategy that uses metal-fueled fast reactors operating in a transuranic (TRU) burning configuration with additional TRU material derived from recycling LWR UOX fuel. In the future, we expect to include direct disposal of other types of fuel from once-through cycles (e.g., high temperature gas reactor, or HTGR fuel consisting of tri-isotropic, or TRISO, coated fuel particles), and other advanced reactor fuels, in recycling strategies that correspond with promising options identified by the FCT program.

\subsubsection{Geologic Setting and Geologic Media}

The geologic setting provides the natural barriers, and establishes the boundary conditions for performance of engineered barriers (e.g., reducing chemical conditions inhibit degradation of certain waste forms). Characteristics of the host medium can play an important role in limiting the transport of radionuclides away from the engineered barriers, to other geologic units, and eventually to the accessible environment. The thickness, lateral extent, and heterogeneity of host units, and the relationships to other geologic units, are important. The composition and physical properties of the host medium dictate design and construction approaches, and determine hydrologic and thermal responses of the repository system.

\subsubsection{Engineering Concept of Operations}

Generally, the engineering concept of operations takes into account the characteristics of the inventory requiring disposal (i.e., waste form types) and the geologic setting, to develop a complete disposal system. The engineering concept of operations includes repository depth and layout, excavation approach (e.g., mined or deep borehole), construction details, emplacement mode, waste package size and materials, segregation of waste types, emplacement of non-heat generating waste, selection of engineered materials, operational details, seals and plugs, 
performance monitoring, and repository closure. This study considers concepts of operation at a high level, including emplacement mode, waste package type, major features of the EBS, and repository layout, as appropriate for generic disposal evaluations. Further specification of the engineering concept of operations is likely to require site-specific information.

\subsection{Disposal Concepts Considered}

The UFD campaign is currently evaluating the viability of mined geologic disposal concepts in three geologic media (clay/shale, salt, and crystalline rock). The hydrogeologic settings for these concepts are saturated, so the disposal environment would eventually become water saturated, although groundwater of usable quality and quantity cannot typically be produced from lowpermeability formations. Clay and shale formations include a broad range of fine-grained sedimentary rock types including soft shales, argillites, and claystones, as well as unconsolidated clays. Salt includes both bedded and domal salt formations. Crystalline rock includes gneissic and igneous rock types as well as "granite." Focus on saturated conditions maximizes the number and extent of potentially suitable formations, because hydrogeologic conditions are generally saturated at depths suitable for geologic repositories (e.g., up to $500 \mathrm{~m}$ ) except in some desert settings. Also, reference hydrogeologic conditions should be saturated if reducing chemical conditions are to exist in the host formation (air circulation in the unsaturated zone can produce locally oxidizing conditions). Candidate host formations would likely be deep, and have limited groundwater exchange with adjacent aquifers whether they are near the surface or at greater depth.

Selection of mined geologic disposal in clay/shale, salt, and crystalline media, and deep borehole disposal in crystalline basement rock, is justified from several considerations.

- Previous U.S. Experience - The U.S. undertook an extensive review of all available options for disposal and management during the 1970s, culminating in Environmental Impact Statement on Management and Disposal of Commercially Generated Radioactive Wastes (DOE 1980). This review considered a full range of alternatives to mined geologic repositories, including deep boreholes, sub-seabed disposal, space disposal, and ice sheet disposal. Mined repositories were the leading option, but sub-seabed disposal and deep boreholes were identified for further consideration. Sub-seabed disposal remained a technically promising option, but was precluded by international treaty in the 1990s. Deep boreholes were considered to require further technological advances, and disposal programs in both the U.S. and other nations focused on mined repositories beginning in early 1970s. The U.S. program evaluated various salt, granite, shale, basalt, and volcanic tuff formations before focusing exclusively on volcanic tuff at Yucca Mountain as a result of the 1987 Nuclear Waste Policy Amendments Act.

- International Experience - Conclusions reached by early work in the U.S., about the potential viability of clay/shale, salt, and granite as disposal media have been confirmed by extensive international work. As discussed in this report (Sections 1.3, 3, and 4.5) and supporting documents, repository concepts for granitic rock have been evaluated in Sweden, Finland, Switzerland, and Japan. Disposal concepts for clay/shale media have been evaluated in detail in France, Belgium, and Switzerland. Salt has been shown to be a viable medium for disposal of non-heat-generating transuranic waste at the Waste Isolation Pilot Plant in the U.S., while ongoing research in Germany shows promise for disposal of heat-generating waste in salt. Other geologic media are under consideration 
for specific purposes (e.g., Canada is investigating the use of a mined repository in carbonate rock to dispose of intermediate level waste, and the U.S. has disposed of lowlevel and transuranic waste in near-surface alluvium).

- Deep Borehole Alternative - Deep borehole disposal continues to be the primary viable alternative to mined repositories. The U.S. DOE investigated the concept in the 1990s for disposal of surplus plutonium, and studies have continued at Sheffield University in the United Kingdom, by the Swedish spent fuel disposal program, and by the Massachusetts Institute of Technology and Sandia National Laboratories in the U.S. This previous work is discussed further below, and in Sections 3 and 4.5.

The types of potential disposal systems to be considered have been categorized under the UFD features, events, and processes (FEP) activity (Freeze et al. 2010) and include mined repositories in saturated media (clay/shale, salt, granitic media), mined repositories in unsaturated media (granitic rock, or tuff), and deep boreholes (crystalline basement rock).

Further discussion of geologic media and disposal concepts is provided in Sections 3 and 4, respectively, of this report.

\subsection{Existing Concepts Proposed for Repositories in Various Geologic Media}

This section summarizes some disposal concepts that are currently under development internationally, or have been considered in the past. We note that no repository for used fuel or high-level waste presently exists. This summary emphasizes system concepts, while Section 3 focuses more on geologic settings. Where possible this summary is based on recent publications, but it is subject to change as the programs develop.

\section{Germany, U.S.A - Salt}

Disposal of radioactive wastes in domal or bedded salt formations has been studied for more than 50 years, tracing to a recommendation by the U.S. National Academy Science (NAS 1957). Former salt mines Asse II and Morsleben were used for disposal of intermediate and low-level wastes in Germany beginning in the 1960's. Disposal of transuranic wastes in bedded salt is currently being implemented at the Waste Isolation Pilot Project in southern New Mexico. Disposal of high-level waste and spent nuclear fuel in salt in the U.S. has been studied extensively in the past, with recent renewed interest as a possible alternative to the proposed repository at Yucca Mountain.

Salt offers a number of positive characteristics for a geologic repository, including:

- Relatively easy mining,

- Reconsolidation and creep cause entombment of waste packages with time,

- High thermal conductivity (e.g., $4 \mathrm{~W} / \mathrm{m}-\mathrm{K}$ or greater) compared to other media,

- Temperature limit of $200^{\circ} \mathrm{C}$ or higher (see Section 4.1.1.2),

- Very low permeability in the intact and reconsolidated states, and 
- Salt formations are found in the U.S. in regions with stable geologic conditions, where they tend to be unaffected over long time periods, by natural disruptive events such as faulting and seismicity.

As envisioned in the U.S. in the 1980's, a salt repository could be placed into a bedded-salt layer approximately 250 feet thick, approximately 2500 feet below the surface (Figure 1-1). This arrangement was determined by the geologic stratigraphy at the sites that were evaluated at the time, and by the need for sufficient depth to ensure isolation and promote closure of openings in salt. Waste packages could be emplaced either horizontally in emplacement drifts, or horizontally in boreholes or alcoves constructed from access tunnels, or vertically in boreholes drilled into the floor of access tunnels.

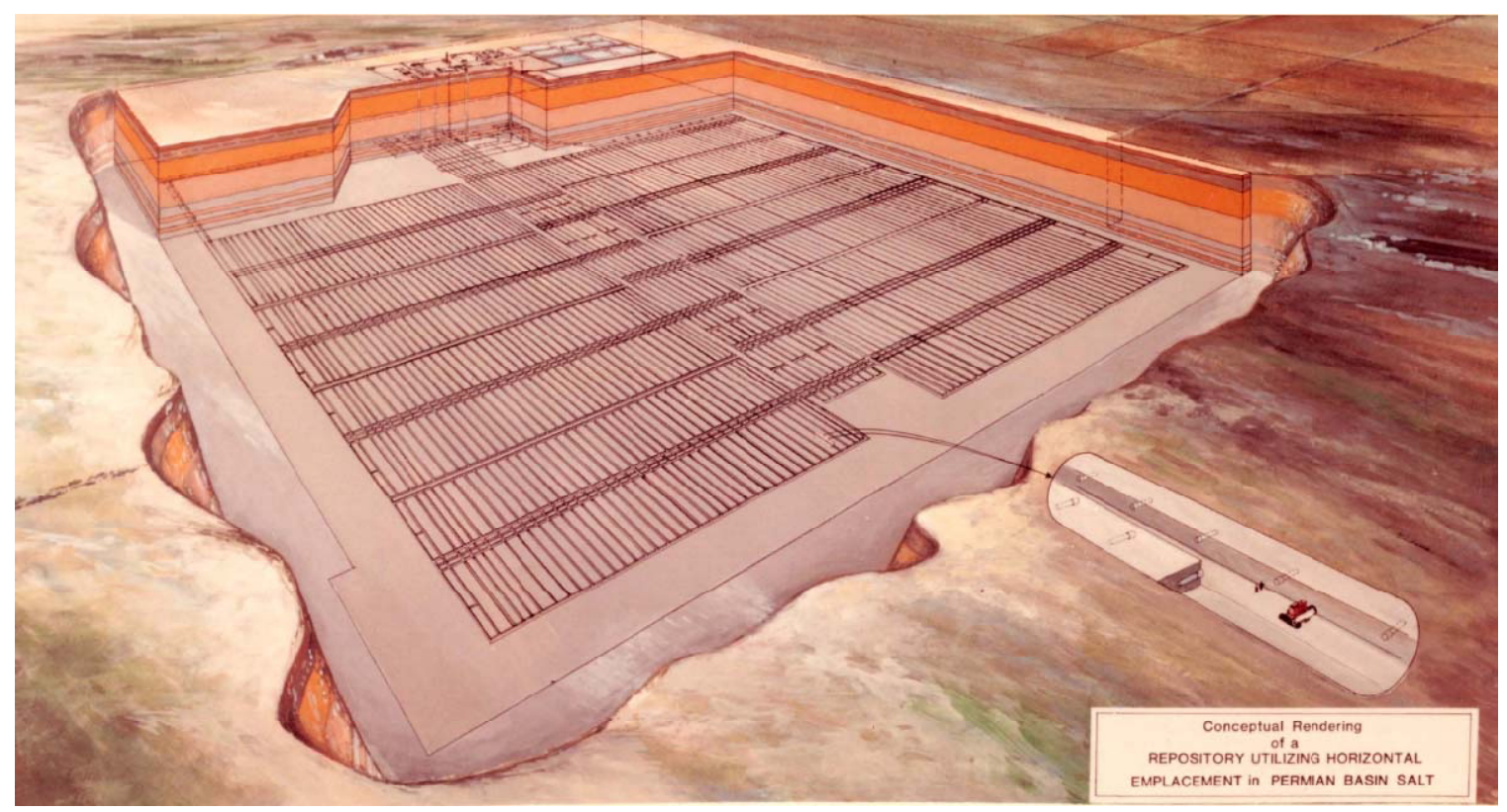

Figure 1-1 Schematic of Developed Repository in Bedded Salt (DOE 1986a).

Access to the repository horizon would be via vertical shafts, somewhat limiting the maximum waste package size due to weight and handling constraints. Ramp access to a repository in bedded salt has not been proposed because shaft access is more direct, but ramp access could be advantageous for waste handling, and is included in the recommendations of this report (Section 6.2). These shafts and the ends of the emplacement tunnels would be closed with multiple plugs and seals to prevent intrusion and to eliminate paths for radionuclide migration.

Waste packages would contain either 4 PWR or 9 boiling-water reactor (BWR) fuel assemblies, or larger numbers of assemblies in consolidated fuel bundles. The spent fuel was to be sealed in canisters of carbon steel, approximately 14 feet long and several feet in diameter, and placed into carbon steel disposal overpack containers (DOE 1986a).

\section{Belgium, France, Switzerland - Clay}

Disposal of spent fuel and HLW in clay or soft shale has been investigated principally by Belgium, France, and Switzerland (Figures 1-2 and 1-3). Like salt, clay is relatively easy to 
excavate. All types of clay and soft shale media can be expected to eventually deform and entomb the waste packages. More plastic clay media such as the Boom Clay, which has been extensively studied in Belgium, will completely seal around the waste packages. The effective thermal conductivity of clay is nominally less than $2 \mathrm{~W} / \mathrm{m}-\mathrm{K}$ (Section 5.1) and clay media are associated with limiting temperatures of approximately $100^{\circ} \mathrm{C}$ (Section 4.1 .1 .2 ), leading to lower limits on thermal loading. The European programs have addressed this temperature limit by limiting thermal output of the waste packages, although the Belgian program has also considered boosting the thermal conductivity of clay in the vicinity of the waste package by the addition of graphite. Maximum waste package heat output ranges from $188 \mathrm{~W} /$ package for disposal of UOX fuel in the Boom Clay, to $\sim 1600 \mathrm{~W} /$ package for spent fuel disposal in the Callovo-Oxfordian shale facies proposed for a French repository. The Belgian program has proposed canisters of stainless steel, nickel, or titanium, while the French and Swiss programs have proposed carbon steel. Emplacement would be horizontal, steel-lined drifts or borings constructed from access drifts. Package emplacement systems, and additional barriers of clay and other materials around the packages, have been demonstrated by the European programs.

Access to the repository horizon would be via ramps or vertical shafts and the repository would be placed 250 to 500 meters below ground, depending on local stratigraphy and hydrogeology. Repository openings would be backfilled, and plugs and seals installed to limit hydraulic conductivity to that of the surrounding, undisturbed formation.

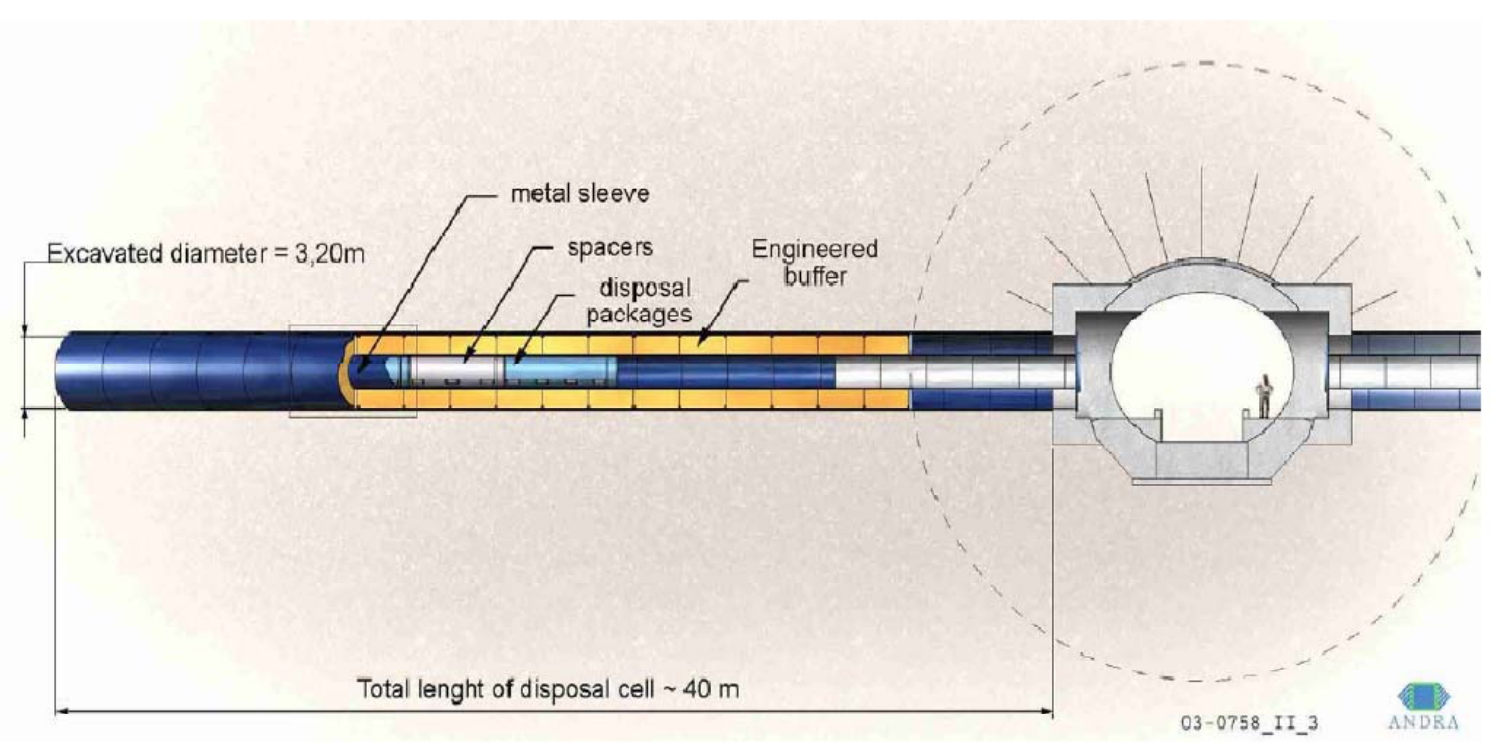

Figure 1-2 Schematic of Horizontal Borehole/Drift Emplacement of Heavy Spent Fuel Waste Packages (Bosgiraud et al. 2008). 


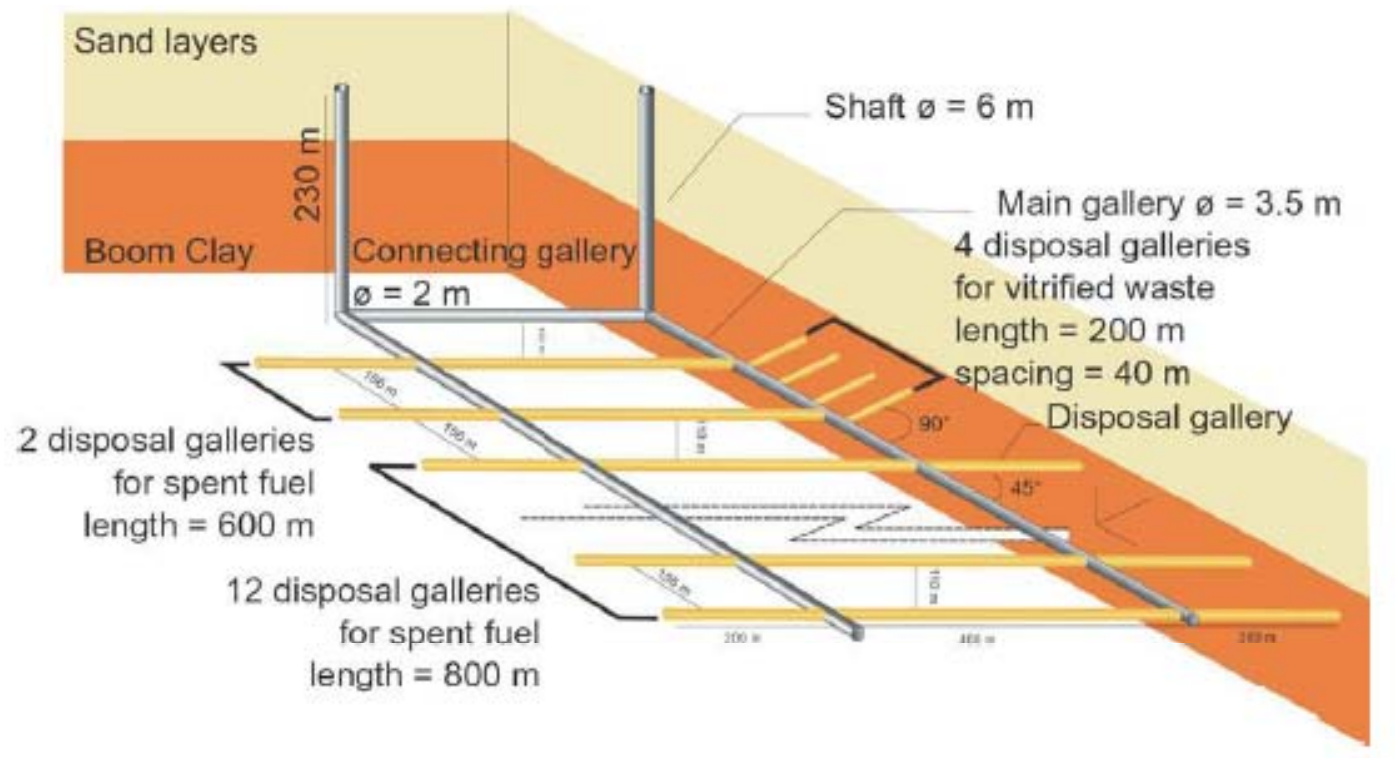

Figure 1-3 Schematic of Disposal Galleries for Spent Fuel and Vitrified HLW in a Repository in the Boom Clay (ONDRAFINIRAS 2001).

\section{Sweden, Finland - Crystalline Rock}

The most advanced crystalline rock repository programs are in Sweden and Finland, and are based on the KBS-3 disposal concept first proposed in the 1983 (SKB 2006). Crystalline rock has also been evaluated by France, Switzerland, Japan, the U.S., and elsewhere (Rechard et al. 2010).

The terms "crystalline" and "granite" are often used interchangeably in discussions of repository concepts. As stated in the Dossier 2005 Granite report (Andra 2005b):

"Granite is a hard rock with very low porosity and permeability. It can be excavated without the need for significant ground supports over volumes compatible with the dimensions and depth of a repository. It consists of quartz (crystallized silica) and feldspars (alumina silicates), where quartz contributes to the generally high thermal conductivity of the rock. Unfortunately, a granite massif is traversed by fractures of various sizes. Minor fractures, of one to tens of meters, are far more numerous than major fractures, extending from one to several kilometers. Minor fractures, which may be more or less connected, generally conduct very little water. Therefore, major fractures, or faults, are the principal vectors of water circulation in granite. The aim is to emplace the waste in the granite rock where it has no fractures or only minor fracturing conducting little or no water. Studies in Sweden anticipate a rejection rate of approximately $10 \%$ of the locations investigated for spent fuel disposal."

In the KBS-3 concept, the repository horizon is proposed to be at a depth of approximately 500 meters, which allows sufficient in situ stress to close many fractures, limits hydraulic gradients, and is below much of the influence of future glaciation. The repository would be accessed by both shafts and ramps, with ramps used for construction and waste transport. Waste packages can be emplaced either horizontally or vertically (Figures 1-4 and 1-5). 


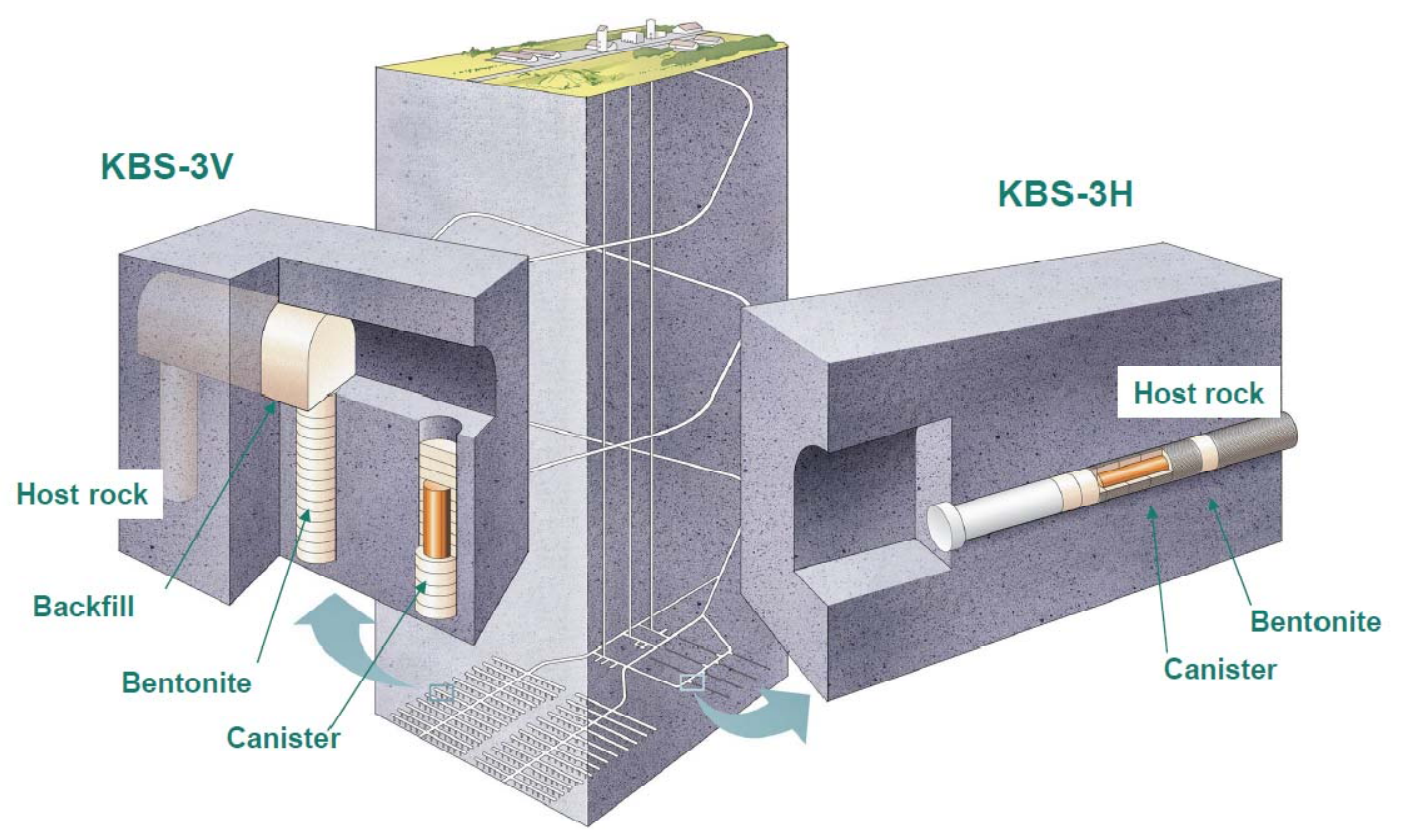

Figure 1-4 Schematic of the KBS-3 Vertical and Horizontal Disposal Concepts (SKB 2010).

The Swedish 2010 license application proposes disposal of spent nuclear fuel (SNF) canisters in vertical borings spaced approximately 6 meters apart along the floor of access drifts spaced $20 \mathrm{~m}$ apart. Horizontal emplacement would be more efficient with respect to the extent of excavation and backfilling, and has been investigated in collaboration between the Swedish and Finnish programs. One challenge that has been identified is characterizing the suitability of rock conditions along the horizontal borings.

The Swedish concept calls for waste packages to be fabricated from copper, with a cast steel insert to support the spent fuel assemblies. Copper corrodes very slowly, if at all, in the reducing conditions present in the selected host rock. Waste packages would be emplaced vertically, surrounded by at least $35 \mathrm{~cm}$ of swelling-clay buffer material in a dehydrated, compacted state. Hydration of the buffer will produce swelling pressure on the order of $6 \mathrm{MPa}$, ensuring that the buffer has low permeability and resistance to microbial activity and other influences. Access drifts would be backfilled with a mixture of swelling clay and sand or crushed rock. A prefabrication concept is being studied that would enclose the copper canister and compacted clay buffer in a perforated steel shell, for handling and emplacement (Figure 1-6). 


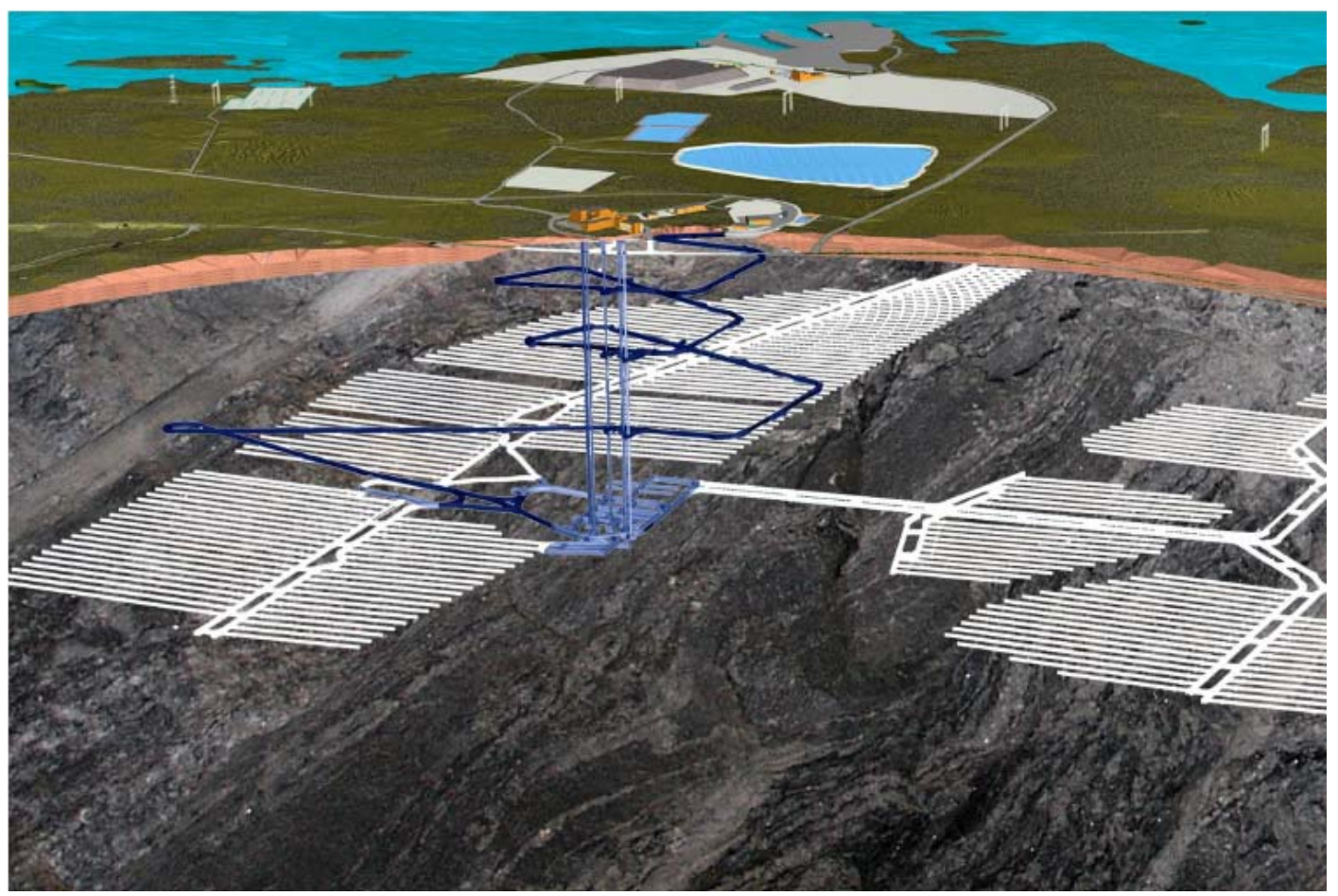

Figure 1-5 Schematic of the Facility for Final Disposal of Spent Nuclear Fuel, Finland (Petrakka 2010).

Thermal loading would be limited to about 1,700 W/package at emplacement (SKB 2011, Section 5.2.1) primarily to limit alteration of the clay buffer. Depending on the time out-ofreactor (see Sections 2 and 5), this generally limits the number of fuel assemblies per package to four PWR assemblies or 12 BWR assemblies. For advanced waste forms such as spent MOX fuel, fewer assemblies and/or longer decay storage would be needed (Section 5.3). 


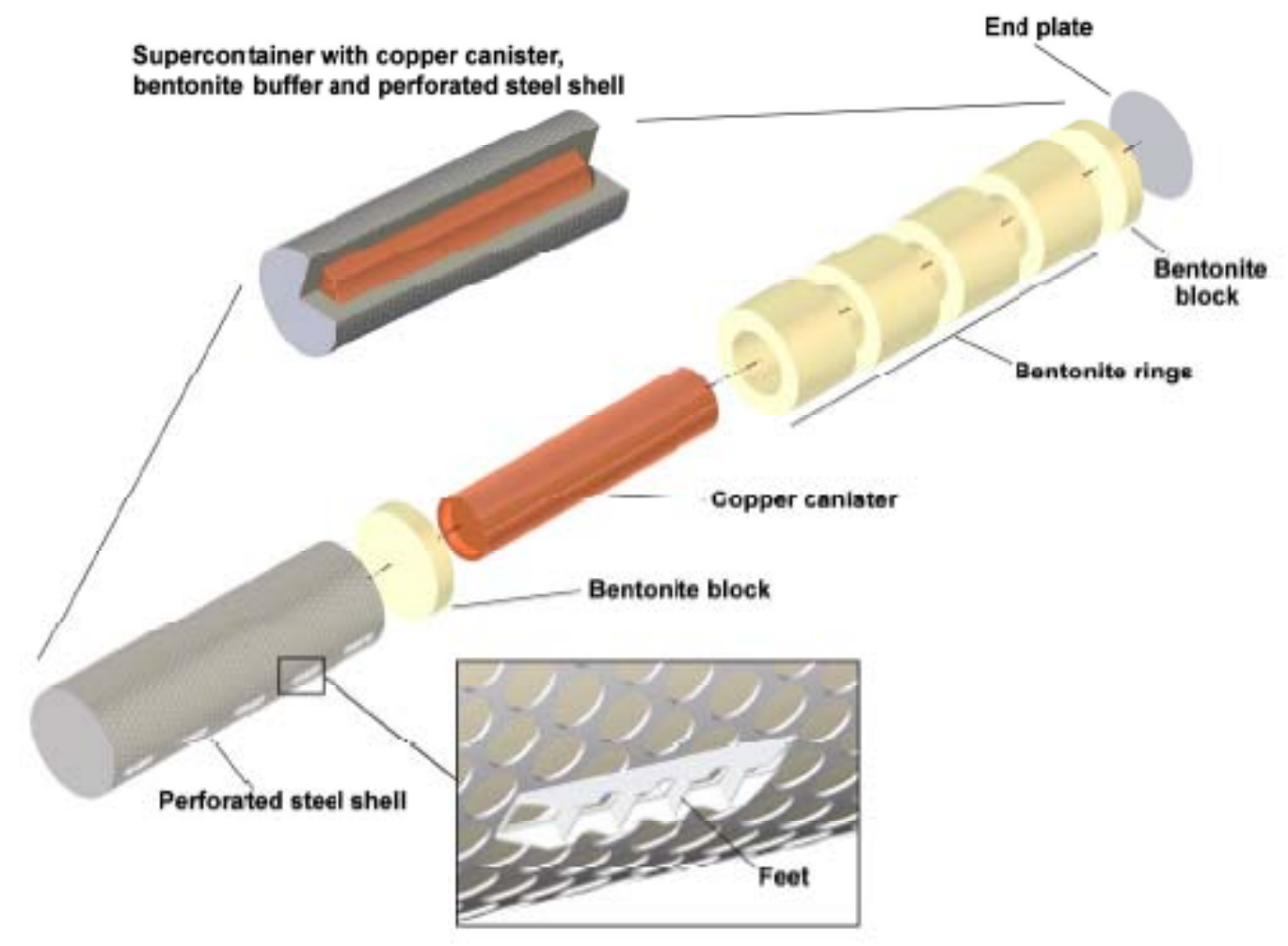

Figure 1-6 Schematic of Prefabricated EBS Concept for Waste Package and Buffer Emplacement in Long Horizontal Boreholes (not to scale; Posiva Oy 2010).

\section{U.S.A, Sweden - Deep Borehole}

Deep borehole disposal of spent fuel and HLW is currently being evaluated in the U.S. (Brady et al. 2009; Anderson 2004) and has been evaluated by others in the past. The following summary is excerpted from a Swedish alternative study for their KBS-3 repository (SKB 2010):

"The (deep borehole) concept entails that a number of holes are drilled vertically from the ground surface down to great depth in the bedrock. The spent nuclear fuel is encapsulated in canisters with an outside diameter of $0.5 \mathrm{~m}$ and a length of $5 \mathrm{~m}$. The canisters are lowered into the holes and stacked on top of one another. Deposition occurs at a depth of between 2 and $4 \mathrm{~km}$. The diameter of the borehole is $1 \mathrm{~m}$ down to $2 \mathrm{~km}$ and $0.8 \mathrm{~m}$ where the canisters are emplaced."

Favorable host rock would be geologically stable, crystalline "basement" rock with very slow groundwater circulation as indicated by its salinity and apparent isotopic age. In the Swedish concept, canisters would be surrounded by a clay buffer, and compacted bentonite would be placed between canisters. The canisters and buffer would probably not remain intact over the performance lifetime of a repository (i.e., $10^{5}$ to $10^{6}$ years), and thus, would not contribute significantly to isolation of radionuclides. However, the upper $2 \mathrm{~km}$ of the hole would be sealed with a combination of swelling clay, asphalt, and concrete (Figure 1-7), and the sealing system could function well beyond $10^{6}$ years.

A Sandia report (Brady et al. 2009) concluded that a smaller borehole could be acceptable for disposal of canisters containing a single BWR or PWR assembly. Borehole diameter at 
emplacement depth could be approximately 17.5-inch $(445 \mathrm{~mm})$ with 16-inch $(406 \mathrm{~mm})$ casing. With consolidation of fuel rods into bundles, the canister size and required borehole size could be much smaller than the Swedish proposal (see Section 4). Nevertheless, drilling of large diameter, deep deposition holes would be a technical challenge. Larger diameter increases the risk of borehole collapse, and breakouts from the effect of in situ stress at depth. Larger diameter also requires much heavier casings and increases costs.

Additional study, including a technical demonstration project, may be needed to determine conclusively if deep borehole disposal of SNF or HLW is technically feasible.

\section{Summary}

This short review of previously proposed disposal concepts forms the basis for further discussion of geologic settings (Section 3) and reference disposal concepts (Section 4). To support thermal analysis in Section 5, limiting thermal loads and temperatures associated with the concepts discussed above, are tabulated (Table 1-1). 

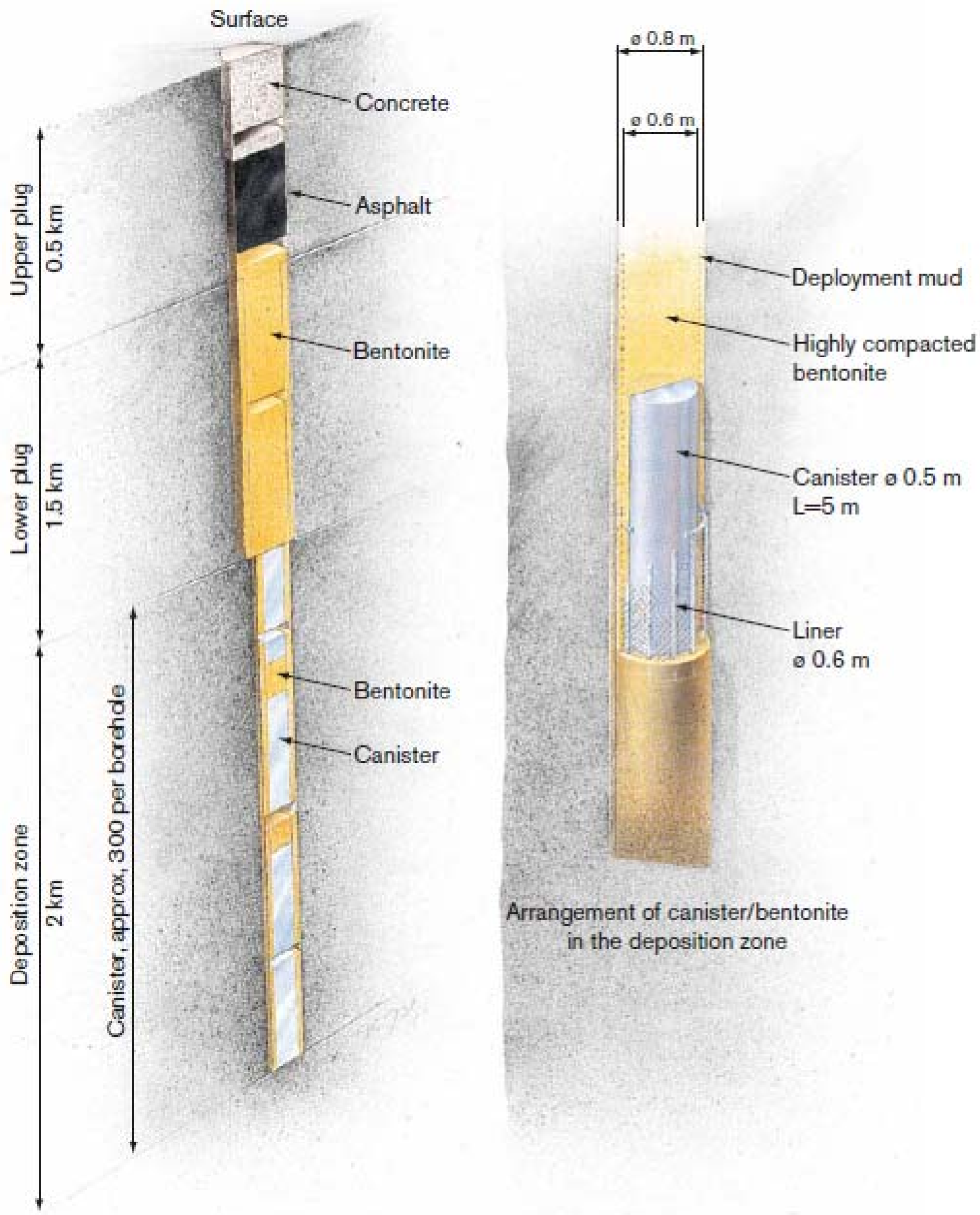

Figure 1-7 Schematic of Deep Borehole Disposal Concept (not to scale; after KASAM 2007). 
Table 1-1 Thermal Constraints Associated with Previously Proposed Disposal Concepts.

\begin{tabular}{|c|c|c|c|c|c|c|c|}
\hline Country & $\begin{array}{l}\text { Repository } \\
\text { Type }\end{array}$ & $\begin{array}{l}\text { Thermal } \\
\text { Conductivity }\end{array}$ & Drift Spacing & $\begin{array}{l}\text { Canister } \\
\text { Spacing }\end{array}$ & Temperature Constraint & Maximum Heat Output & Reference \\
\hline \multirow{4}{*}{ USA } & \multirow{4}{*}{ Salt } & & & 40 feet & $\begin{array}{l}\text { Salt } 200^{\circ} \mathrm{C} \text { max. } \\
\mathrm{HLW} \text { glass } 500^{\circ} \mathrm{C} \text { max. }\end{array}$ & $4.2 \mathrm{~kW} \mathrm{HLW}$ & Ref. 1 \\
\hline & & & $\begin{array}{l}\text { HLW: } 120 \mathrm{ft} . \\
\text { SNF: } 170 \mathrm{ft} .\end{array}$ & $\begin{array}{l}\text { HLW: } 8.7 \mathrm{ft} . \\
\text { SNF: } 10 \text { to } 42 \mathrm{ft} .\end{array}$ & $\begin{array}{l}\text { Fuel cladding } 375^{\circ} \mathrm{C} \text { max. } \\
\text { Salt } 250^{\circ} \mathrm{C} \text { max. } \\
\text { HLW glass } 500^{\circ} \mathrm{C} \text { max. }\end{array}$ & $\begin{array}{l}6.6 \mathrm{~kW} / \text { canister } \\
\text { (consolidated PWR SNF) } \\
1.6 \text { to } 5.4 \mathrm{~kW} \text { BWR/PWR }\end{array}$ & Ref. 2 \\
\hline & & $\begin{array}{l}3.09 \mathrm{~W} / \mathrm{m}-\mathrm{K} \\
@ 100^{\circ} \mathrm{C} \\
3.37 \mathrm{~W} / \mathrm{m}-\mathrm{K} \\
@ 29^{\circ} \mathrm{C}\end{array}$ & $\begin{array}{l}\text { HLW: } 120 \mathrm{ft} . \\
\text { SNF: } 170 \mathrm{ft} .\end{array}$ & $\begin{array}{l}\text { SNF: } 28 \text { to } 85 \mathrm{ft} . \\
\text { Defense HLW } \\
\text { glass: } 10 \mathrm{ft} .\end{array}$ & $\begin{array}{l}\text { Fuel cladding } 375^{\circ} \mathrm{C} \text { max. } \\
\text { Salt } 250^{\circ} \mathrm{C} \text { max. } \\
\text { HLW glass } 500^{\circ} \mathrm{C} \text { max. }\end{array}$ & $\begin{array}{l}2.2 \text { to } 4.4 \mathrm{~kW} \text { Intact PWR } \\
6.6 \mathrm{~kW} \text { consolidated PWR } \\
0.42 \mathrm{~kW} \text { DHLW glass }\end{array}$ & Ref. 3 \\
\hline & & $\begin{array}{l}4.7 \mathrm{~W} / \mathrm{m}-\mathrm{K} \\
\text { @ } 110^{\circ} \mathrm{C}\end{array}$ & & $7.5 \mathrm{~m}$ & $\begin{array}{l}\text { Fuel cladding } 375^{\circ} \mathrm{C} \text { max. } \\
\text { Salt } 250^{\circ} \mathrm{C} \text { max. }\end{array}$ & $6.6 \mathrm{~kW}$ PWR & Ref. 4 \\
\hline Germany & Salt & & & & Salt $200^{\circ} \mathrm{C}$ max. & & Ref. 5 \\
\hline Belgium & Clay & $\begin{array}{l}1.7 \mathrm{~W} / \mathrm{m}-\mathrm{K} \\
\text { horizontal, } \\
1.25 \mathrm{~W} / \mathrm{m}-\mathrm{K} \\
\text { vertical }\end{array}$ & $\begin{array}{l}\text { HLW: } 40 \mathrm{~m} \\
\text { SNF: } 110 \mathrm{~m}\end{array}$ & $\begin{array}{l}\text { HLW: } 1.6 \mathrm{~m} \\
\text { SNF: } 3 \mathrm{~m}\end{array}$ & $\begin{array}{l}\text { Backfill } 100^{\circ} \mathrm{C} \text { max. } \\
\text { HLW glass } 400^{\circ} \mathrm{C} \text { max. } \\
\text { SNF } 350^{\circ} \mathrm{C} \text { max. }\end{array}$ & $\begin{array}{l}188 \mathrm{~W} / \mathrm{pkg} . \text { UOX } \\
905 \mathrm{~W} / \mathrm{pkg} . \mathrm{MOX}\end{array}$ & Ref. 6 \\
\hline France & Clay & $\begin{array}{l}1.9 \text { to } 2.7 \mathrm{~W} / \mathrm{m}-\mathrm{K} \\
\text { parallel, } 1.3 \text { to } 1.9 \\
\mathrm{~W} / \mathrm{m}-\mathrm{K} \\
\text { perpendicular }\end{array}$ & 8.5 to $13.5 \mathrm{~m}$ & 2.5 to $4 \mathrm{~m}$ & Argillite host rock $100^{\circ} \mathrm{C}$ max. & $\begin{array}{l}1600 \text { W (4-UOX), } \\
1100 \text { W (1-MOX) }\end{array}$ & Ref. 7 \\
\hline Switzerland & Clay & $1.8 \mathrm{~W} / \mathrm{m}-\mathrm{K}$ & $40 \mathrm{~m}$ & $3 \mathrm{~m}$ & Bentonite buffer $125^{\circ} \mathrm{C}$ max. & 1500 W/canister & Ref. 8 \\
\hline Sweden & Granite & $\begin{array}{l}3.4 \text { to } 4 \mathrm{~W} / \mathrm{m}-\mathrm{K} \\
2.45 \text { to } 2.9 \\
\mathrm{~W} / \mathrm{m}-\mathrm{K}\end{array}$ & $40 \mathrm{~m}$ & $\begin{array}{l}6 \mathrm{~m} \\
7.2 \mathrm{~m}\end{array}$ & Bentonite buffer $100^{\circ} \mathrm{C}$ max. & 1700 W/canister & Ref. 9 \\
\hline France & Granite & 2.4 to $3.8 \mathrm{~W} / \mathrm{m}-\mathrm{K}$ & $25 \mathrm{~m}$ & $\begin{array}{l}\text { HLW: } 8 \mathrm{~m} \\
\text { SNF: } 12 \text { to } 15 \mathrm{~m}\end{array}$ & Canister surface $100^{\circ} \mathrm{C}$ max. & $\begin{array}{l}1600 \text { W (4-UOX) } \\
1100 \text { W (1-MOX) }\end{array}$ & Ref. 10 \\
\hline Finland & Granite & 2.3 to $3.2 \mathrm{~W} / \mathrm{m}-\mathrm{K}$ & & $11 \mathrm{~m}$ & Bentonite buffer $100^{\circ} \mathrm{C}$ max. & 1700 W/canister & Ref. 11 \\
\hline USA & Tuff & $\begin{array}{l}0.99 \text { to } 2.07 \\
\mathrm{~W} / \mathrm{m}-\mathrm{K}\end{array}$ & & & $\begin{array}{l}\text { Between tunnel temperature }<96^{\circ} \mathrm{C} \\
\text { Tunnel Wall temperature }<200^{\circ} \mathrm{C}\end{array}$ & 1500 W/Canister (DHLW) & Ref. $12 \& 13$ \\
\hline
\end{tabular}




\begin{tabular}{|c|c|c|c|c|c|c|c|}
\hline Country & $\begin{array}{c}\text { Repository } \\
\text { Type }\end{array}$ & $\begin{array}{c}\text { Thermal } \\
\text { Conductivity }\end{array}$ & Drift Spacing & $\begin{array}{l}\text { Canister } \\
\text { Spacing }\end{array}$ & Temperature Constraint & Maximum Heat Output & Reference \\
\hline \multicolumn{8}{|c|}{$\begin{array}{l}\text { Notes: } \\
\text { Bentonite buffer material thermal conductivity } 0.4 \mathrm{~W} / \mathrm{m}-\mathrm{K} \text { dry, } 1.35 \mathrm{~W} / \mathrm{m}-\mathrm{K} \text { saturated (Ref. 14) }\end{array}$} \\
\hline $\begin{array}{rr}\text { References } \\
\text { 1. } \mathrm{Cl} \\
\text { 2. } \\
\text { 3. } \mathrm{D} \\
\text { 4. } \\
\text { 5. } \mathrm{O} \\
\text { 6. } \\
\text { 7. } \mathrm{O} \\
\text { 8. } \mathrm{A} \\
\text { 9. } \mathrm{N} \\
\text { 10. } \mathrm{S} \\
\text { 11. } \\
\text { 12. } \mathrm{D} \\
\text { 13. } \mathrm{D} \\
\text { 14. } \mathrm{N}\end{array}$ & $\begin{array}{l}\text { ton \& Gable } 2 \\
\text { 1987a. Site } \\
\text { 1987b Site C } \\
\text { NI 1985. Wast } \\
\text { a, H.N. 1994. " } \\
\text { RAF/NIRAS } 2 \\
\text { ra 2005a. Doss } \\
\text { TRA 2003. Can } \\
\text { 3 2006. Long-te } \\
\text { ra 2005b. Doss } \\
\text { iva Oy 2010, In } \\
\text { E 2008a. Civilia } \\
\text { ison, D., et al. } \\
\text { GRA 2002. Pro }\end{array}$ & $\begin{array}{l}\text { 09. 3-D Thermal } \\
\text { aracterization P } \\
\text { aracterization Pl } \\
\text { Package/Reposi } \\
\text { imulated Waste } \\
\text { 01. Technical Ov } \\
\text { er } 2005 \text { Argile - } \\
\text { ster Options for } \\
\text { m Safety for KBS } \\
\text { er } 2005 \text { Granite } \\
\text { erim Summary R } \\
\text { Radioactive Wa } \\
\text { 006. "Benefits of } \\
\text { ct Opalinus Clay }\end{array}$ & $\begin{array}{l}\text { Inalyses of High } \\
\text { an Conceptual D } \\
n \text { Conceptual De } \\
\text { ory Impact Study } \\
\text { ackage Test in S } \\
\text { rview of the SAF } \\
\text { irchitecture and } \\
\text { e Disposal of Sp } \\
\text { - } \\
\text { Repositories a } \\
\text { Architecture anc } \\
\text { port of the Safe } \\
\text { te Management } \\
\text { Safety Report. N }\end{array}$ & $\begin{array}{l}\text { Iel Waste E } \\
\text { In Report fo } \\
\text { n Report fol } \\
\text { hal Report, } \\
\text { "Internatio } \\
2 \text { Report. } \\
\text { hagement o } \\
\text { Fuel. Tech } \\
\text { orsmark anc } \\
\text { anagement } \\
\text { ase 2009, F } \\
\text { stem, Wast } \\
\text { ycle on Rer } \\
\text {-02-05. }\end{array}$ & $\begin{array}{l}\text { ogical Disposal System. } \\
\text { port NTB 02-11. } \\
\text { ar - a First Evaluation. TR-0 } \\
\text { ological Repository. } \\
\text { y 2010-02, March } 2010 . \\
\text { tance Systems Requirements } \\
\text { Effective Capacity," Waste M }\end{array}$ & $\begin{array}{l}\text { Salt, Vertical Emplacemer } \\
\text { Salt, Horizontal Emplacem } \\
\text { Waste Repository in Salt. } \\
\text { lent Conference. }\end{array}$ & Mode. \\
\hline
\end{tabular}




\section{Inventory}

\subsection{Once-Through Used Nuclear Fuel Cycle}

The United States (U.S.) currently utilizes a once-through FC where used nuclear fuel is stored on-site in either wet pools or in dry storage systems with ultimate disposal in a deep mined geologic repository envisioned. Commercial nuclear power plants have operated in the United States since about 1960 . There are currently 104 operating nuclear power plants. This case assumes the current $\mathrm{FC}$ is maintained.

\subsubsection{Characteristics of LWR UOX Fuel}

The current and projected inventories for once-through fuel cycles have been estimated (Carter et al. 2011a) using scenarios discussed below, and all of the associated figures and tables presented here are based on those results. Use of these scenarios does not constitute an endorsement; the scenarios were selected to provide a wide range of LWR fuel inventory for use in future analyses such as this study. These scenarios previously examined include

- Current Inventory through December 2010.

- 100 gigawatts electrical production (GWe) assumes the amount of current nuclear generation is maintained at the current levels with new reactors replacing the existing reactors as the existing reactors are decommissioned.

- 200 GWe assumes the amount of nuclear generation will double from 2020 to 2060.

- 400 GWe assumes the amount of nuclear generation will quadruple from 2020 to 2060.

Methods developed for the Nuclear Energy Institute in 2005 were used to estimate the number of assemblies and metric tons (MTs) of uranium (Gutherman 2009). To estimate the average enrichment and burn-up, projections were made by utility companies, as documented in Calculation Method for the Projection of Future Spent Fuel Discharges (DOE 2002). These projections identified a burn-up increase of $2.38 \%$ per year for BWR UNF and $1.11 \%$ per year for PWR UNF. The enrichment increased at the same rate as burn-up until reaching the current enrichment limit of 5\%. Once the 5\% enrichment limit is reached, the enrichment and burn-up are assumed to remain constant. Table 2-1 summarizes the major attributes for UNF scenarios described above.

The maximum burn-up achieved in PWRs is approximately 54.2 gigawatt-days (GW-d) per MT and in BWRs is approximately $56.3 \mathrm{GW}-\mathrm{d} / \mathrm{MT}$. The current inventory has an average burn-up of approximately $39.6 \mathrm{GW}-\mathrm{d} / \mathrm{MT}$ for PWRs and $33.3 \mathrm{GW}-\mathrm{d} / \mathrm{MT}$ for BWRs. Use of the expanded nuclear capacity scenarios increase the average burn-up towards the maximum values.

This study uses $60 \mathrm{GW}-\mathrm{d} / \mathrm{MT}$ PWR fuel as a reference case, as a reasonable upper bound on burn-up for repository thermal analysis. To assess the potential repository thermal loads, decay heat as a function of time was calculated. Table 2-2 and Figure 2-1 provides the decay heat as a function of time for this fuel. Appendix A, Table A-1 provides the detailed isotopic compositions for this fuel. 


\subsubsection{Characteristics of Once-Through Cycle Secondary Waste}

Secondary wastes associated with the once-through FC are those generated by the handling and emplacement activities involved in the disposal of UNF at a geologic repository. Sources of secondary waste from repository operations include:

- Cask, facility and equipment decontamination activities

- Pool system skimming and filtration operations

- Used dual purpose canisters

- Tooling and clothing

- Facility ventilation filtration

- Chemical sumps

- Carrier and transporter washings

All of the radioactive waste streams from repository operations are classified as either Class A, B or C low level waste (LLW). No greater than Class C (GTCC) or mixed wastes are anticipated from repository operations.

\subsubsection{Secondary Waste from Repository Operations}

Secondary waste estimates from repository operations are dependent on the fraction of the UNF received in disposable canisters that do not require opening at the repository but can be directly placed into a waste package for disposal in the repository. (By handling UNF in canisters that were sealed elsewhere, production of contaminant particles and other fuel residues produced during handling is avoided.) Figure 2-2 shows the volume of LLW estimated from repository operations based on the fraction of UNF received in directly disposable containers. 
Table 2-1 Current and Projected Characteristics of Used Nuclear Fuel.

\begin{tabular}{|c|c|c|c|c|c|c|c|c|c|c|}
\hline & \multicolumn{4}{|c|}{ Number of Assemblies } & \multicolumn{2}{c|}{ Total Initial Uranium (MTU) } & \multicolumn{3}{c|}{$\begin{array}{c}\text { Average } \\
\text { Enrichment }\end{array}$} & $\begin{array}{c}\text { Average Burnup } \\
\text { (MW-d/MTU) }\end{array}$ \\
\hline & PWR & BWR & Totals & PWR & BWR & Totals & PWR & BWR & PWR & BWR \\
\hline $\begin{array}{c}\text { Current Inventory } \\
\text { (Dec 2010) }\end{array}$ & 97,400 & 128,700 & 226,100 & 42,300 & 23,000 & 65,200 & 3.74 & 3.1 & 39.600 & 33,300 \\
\hline $\mathbf{1 0 0}$ GWe & 401,000 & 527,000 & 928,000 & 175,000 & 95,000 & 270,000 & 4.68 & 4.53 & 50,600 & 50,600 \\
\hline $\mathbf{2 0 0}$ GWe & 605,000 & 794,000 & $1,397,000$ & 265,000 & 143,000 & 407,000 & 4.79 & 4.68 & 51,800 & 52,600 \\
\hline $\mathbf{4 0 0}$ GWe & $1,013,000$ & $1,329,000$ & $2,341,000$ & 444,000 & 239,000 & 682,000 & 4.87 & 4.80 & 52,800 & 54,100 \\
\hline
\end{tabular}

Table 2-2 PWR 60 GW-d/MT Used Fuel Decay Heat.

\begin{tabular}{|c|c|c|c|c|c|c|c|c|}
\hline \multirow{2}{*}{ Decay Heat (Watts/MT ) } & \multicolumn{8}{|c|}{ Time (years) } \\
\hline & 1 & 10 & 30 & 50 & 70 & 100 & 300 & 500 \\
\hline Gases H, C, Xe, Kr, I & 0 & 0 & 0 & 0 & 0 & 0 & 0 & 0 \\
\hline $\mathrm{Cs} / \mathrm{Sr} / \mathrm{Ba} / \mathrm{Rb} / \mathrm{Y}$ & 4,608 & 1,576 & 824 & 516 & 323 & 160 & 1 & 0 \\
\hline Noble Metals Ag, Pd, Ru, Rh & 3,447 & 14 & 0 & 0 & 0 & 0 & 0 & 0 \\
\hline Lanthanides La, Ce, Pr, Nd, Pm, Sm, Eu, Gd, Tb, Ho, Tm & 3,843 & 109 & 17 & 3 & 1 & 0 & 0 & 0 \\
\hline Actinides Ac, Th, $\mathrm{Pa}, \mathrm{U}$ & 0 & 0 & 0 & 0 & 0 & 0 & 0 & 0 \\
\hline Transuranic Np, Pu, Am, Cm, Bk, Cf, Es & 1,515 & 785 & 613 & 516 & 449 & 381 & 199 & 139 \\
\hline Others & 522 & 21 & 3 & 1 & 0 & 0 & 0 & 0 \\
\hline Total & 13,936 & 2,505 & 1,458 & 1,036 & 773 & 541 & 201 & 139 \\
\hline
\end{tabular}




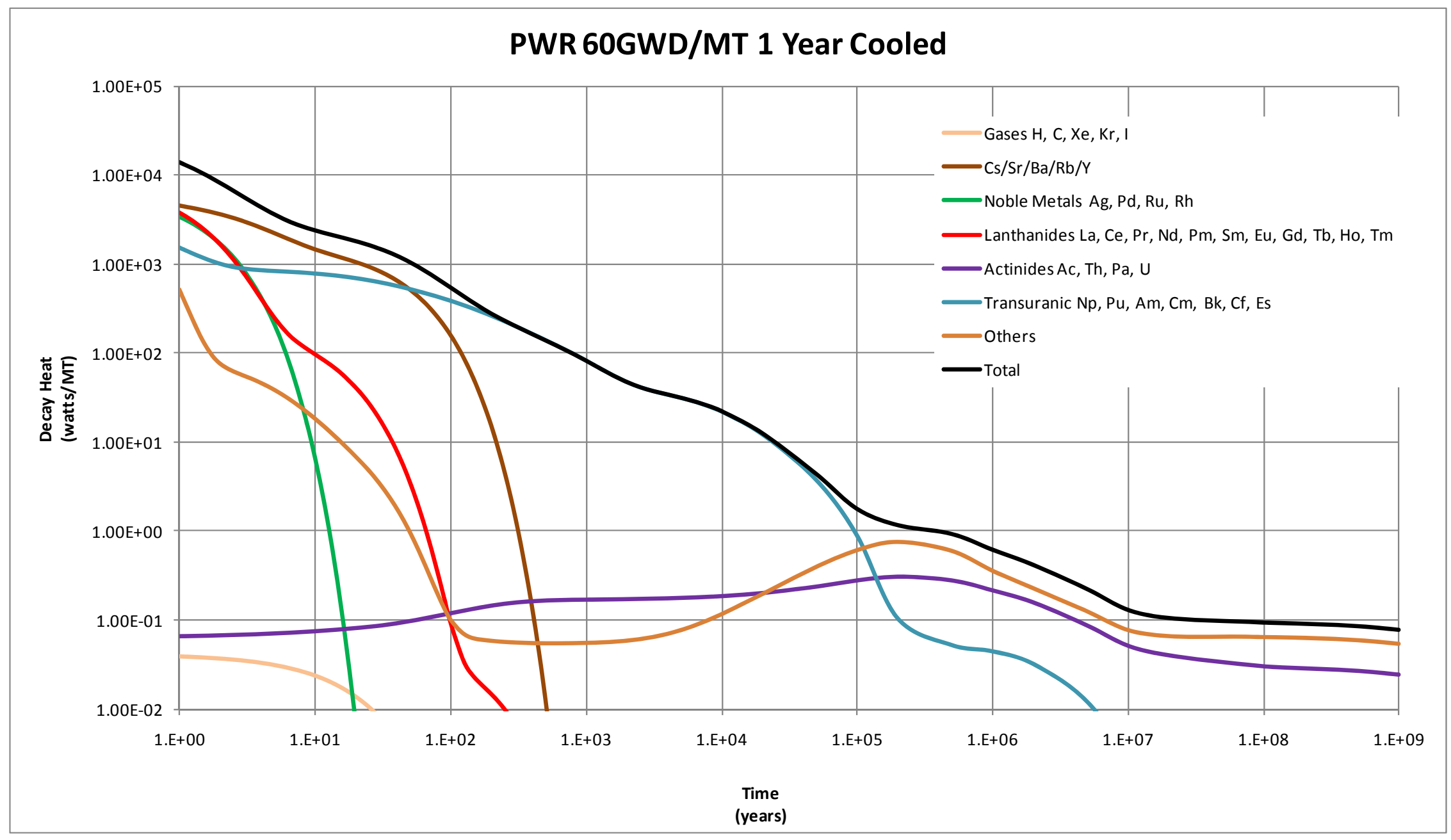

Figure 2-1 PWR 60 GW-d/MT Used Fuel Decay Heat. 


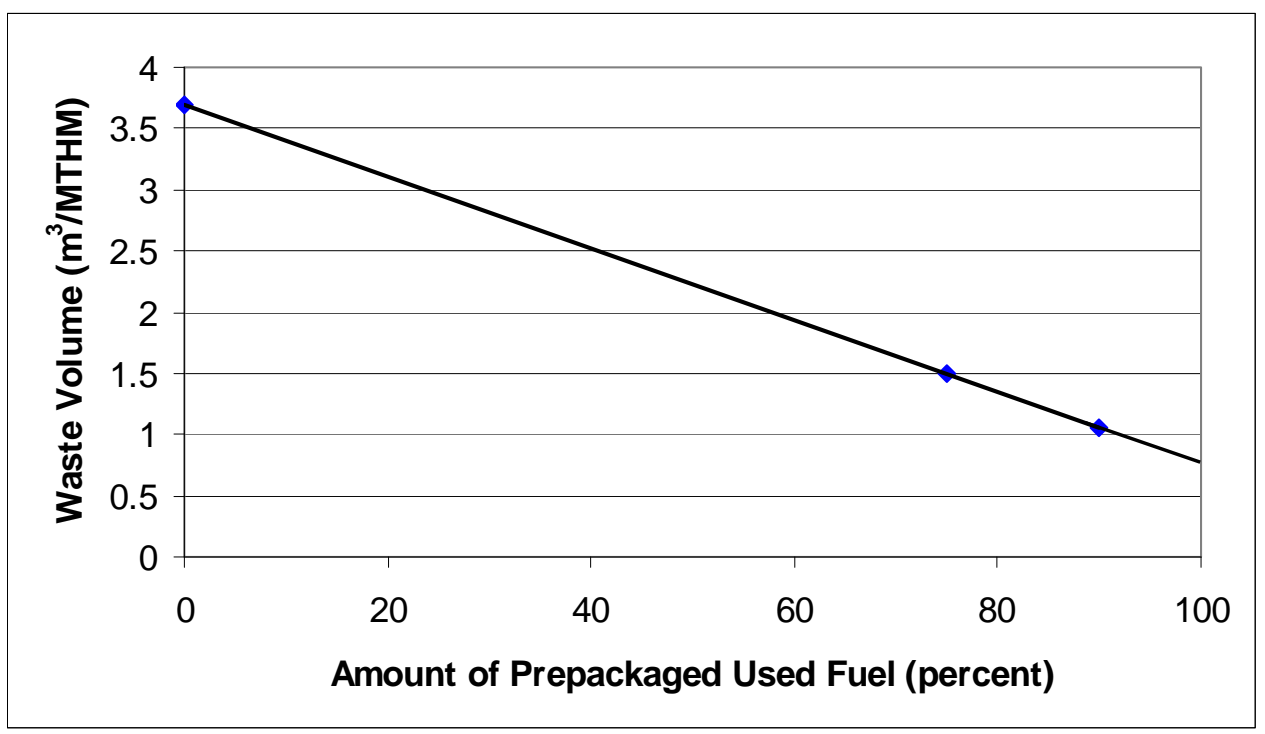

Figure 2-2 Low Level Waste Volume From Repository Operations.

\subsection{Modified Open Cycle}

This case is implemented by the recycling of LWR UOX fuel to recover uranium and plutonium $(\mathrm{U} / \mathrm{Pu})$. The $\mathrm{U} / \mathrm{Pu}$ product is converted into a LWR Mixed Oxide reactor fuel (MOX) fuel and burned in conventional LWR reactors to approximately $50 \mathrm{GW}-\mathrm{d} / \mathrm{MT}$. This MOX fuel is not recycled but is directly disposed in a geologic repository after a single reactor pass. The waste inventory for this case was estimated by Carter et al. (2011a), and all of the associated figures and tables presented here are based on those results.

\subsubsection{Overall Mass Flows for a Modified Open Fuel Cycle}

The FCT program has previously studied various MOX fuel alternatives (Taiwo et al. 2007). Specifically they studied the scenario in which LWR UOX UNF is burned to $51 \mathrm{GW}-\mathrm{d} / \mathrm{MT}$ and allowed to cool for 5 years post-irradiation and is then partitioned to separate the plutonium from the minor actinides, the other heavy metal (HM) nuclides, and the fission products. Because the Co-Extraction partitioning strategy is assumed, the spent fuel uranium in the LWR UOX SNF is assumed to be the uranium base of the MOX fuel (instead of natural or depleted uranium). This MOX fuel is stored for 2 years prior to introduction into the full MOX core. The delay time results in the build-up of Am-241 in the MOX fuel, which arises from the decay of Pu- 241 .

The full MOX fuel core is subsequently burned to an average value of 50GW-d/MT. The burnup of the MOX core is limited to $50 \mathrm{GW}-\mathrm{d} / \mathrm{MT}$ because of a constraint on the plutonium content in the MOX fuel. Previous studies (Salvatores et al. 2003) have shown that plutonium content less than $12 \%(\mathrm{Pu}$ in $\mathrm{HM})$ is necessary to ensure a negative void coefficient in a full MOX core; the specific value is actually plutonium isotopic vector dependent, but that dependence was not investigated in (Taiwo et al. 2007).

Table 2-3 provides a summary of the LWR derived MOX fuel parameters. The average plutonium enrichment is $10.74 \%$. Therefore, each MT of LWR fuel which is reprocessed allows fabrication of $108.9 \mathrm{~kg}$ of MOX fuel. 
Table 2-3 includes only the HM portion of the MOX fuel assembly (FA). The hardware (cladding, spacers, etc.) are not included. Estimates of the hardware mass are estimated based on the mass of a PWR assembly of $158 \mathrm{~kg}$ per assembly (Carter et al. 2011a).

Table 2-3 LWR Derived MOX Fuel Summary.

\begin{tabular}{|l|c|}
\hline LWR UOX fuel burnup (GW-d/t) & 51 \\
\hline LWR MOX fuel burnup (GW-d/t) & 50 \\
\hline LWR UOX core & 4.21 \\
\hline Uranium enrichment (\%U-235) & 52.7 \\
\hline Pu-239 in 5-yr cooled fuel (\% total Pu) & 64.7 \\
\hline Fissile Pu (239 \& 241) in 5-yr cooled fuel (\% total Pu) & 1.17 \\
\hline Total Pu in 5-yr cooled fuel (\% initial HM)) & 0.14 \\
\hline Total MA in 5-yr cooled fuel (\% initial HM) & 0.234 \\
\hline Total Pu in 5-yr cooled (kg/GWt-d) & 0.027 \\
\hline Total MA in 5-yr cooled (kg/GWt-d) & 495 \\
\hline Cycle length (Days) & 10.74 \\
\hline LWR MOX core (Note 1) & 4 \\
\hline Pu content in initial MOX fuel (\%Pu/HM) & 25 \\
\hline Uranium consumption (\%)s & 42 \\
\hline Pu consumption (\%) & 37 \\
\hline Pu-239 consumption (\%) & 450 \\
\hline Pu fissile consumption (\%) & 0.89 \\
\hline Am production (\%) & 0.99 \\
\hline Np content in 5-yr cooled fuel (kg / initial ton MOX fuel) & 495 \\
\hline Cm content in 5-yr cooled fuel (kg / initial ton MOX fuel) & \\
\hline Cycle length (Days) & \\
\hline Notes: & \\
\hline 1. Consumption, production, and content data are differences between charge and \\
\hline 5-year post-irradiation states. & \\
\hline
\end{tabular}

\subsubsection{Characteristics of Waste Generated by Co-Extraction Reprocessing LWR uOX Fuel}

The Co-Extraction method represents the simplest and most technically mature aqueous reprocessing method evaluated. The process envisioned is similar to the current generation of deployed reprocessing technology (e.g., the Rokkasho Reprocessing Facility). Uranium and plutonium are recovered together (no pure plutonium separation). The principal fission product wastes including the minor actinides are combined with the undissolved solids (UDS) and recovered Technetium into a single borosilicate glass waste form. 
The gaseous radionuclides I-129 and H-3 released during reprocessing are captured and converted to waste forms suitable for disposal while $\mathrm{C}-14$ and $\mathrm{Kr}-85$ are assumed to be released to the atmosphere.

While this process is similar in function to the industrial Co-Extraction ${ }^{\mathrm{TM}}$ process deployed by AREVA, the two processes assume different processing methods and steps and so the product and waste streams cannot be directly compared.

\subsubsection{Co-Extraction Baseline Waste Forms}

The Global Nuclear Energy Partnership Integrated Waste Management Strategy Baseline Study (Gombert et al. 2007) summarized the state-of-the-art in stabilization concepts for byproduct and waste streams. It also recommended a baseline of waste forms for the safe disposition of proposed waste streams from future fuel recycling processes. This baseline has been adopted for this study as applicable to the specific reprocessing method.

\section{Off-Gas Waste Forms}

Tritium (H-3) is not captured nor treated with current generation reprocessing methods (aqueous methods practiced commercially). Tritium is currently released to the environment via atmospheric or waste water discharges. This release is assumed to be an unacceptable practice in future domestic reprocessing applications. To prevent the aqueous phases from becoming contaminated with tritium, voloxidation is used to ensure tritium is released to off-gas system where it is captured as tritiated water. The tritiated water is converted to a grout and allowed to cure in a 10 liter container, which is subsequently contained in a double steel box.

I-129 is captured on silver mordenite. The mordenite is then grouted and allowed to cure in 55gal drums.

\section{Metal Waste Forms}

Compacted hulls and hardware after being separated from the fuel, the assembly hardware (principally stainless steels) and zirconium and stainless steel based cladding are decontaminated, compacted and placed inside a HLW canister. Each canister is $2 \mathrm{ft}$ in diameter by $10 \mathrm{ft}$ tall and contains $3,600 \mathrm{~kg}$ of waste material.

\section{Principal Fission Product Waste Forms}

In the aqueous processes most of the fission products are incorporated into a borosilicate glass. While this waste form is an accepted standard for reprocessing waste disposal, the waste form is limited by a number of attributes which must be considered in this study.

The limits to avoid the formation of multi-phase glasses include:

- Maximum decay heat of $14 \mathrm{~kW}$ per 2-ft diameter, 15-ft. long canister to prevent the canister centerline temperature from reaching the transition temperature

- Molybdenum trioxide solubility is limited to $2.5 \%$ by weight

- Noble metals (Ag, Pd, Rh, Ru) are limited to 3\% by weight

The limit selected for any representative fuel allows the maximum waste loading, and minimum projected waste volume and mass. The glass is cast into $2-\mathrm{ft}$ diameter by $15-\mathrm{ft}$ tall canisters containing $2,900 \mathrm{~kg}$ of glass. 


\subsubsection{Co-Extraction Waste Volumes, Masses and Containers}

The potential waste from Co-Extraction reprocessing a $51 \mathrm{GW}-\mathrm{d} / \mathrm{MT}$ fuel is provided in Tables 2-4 through 2-7.

Table 2-4 Co-Extraction Fuel Reprocessing Off-Gas Waste Summary.

\begin{tabular}{|c|c|c|c|c|c|c|c|}
\hline & \multicolumn{4}{|c|}{ Captured Tritium Grouted } & \multicolumn{3}{|c|}{$\begin{array}{c}\text { Captured I on Silver Mordenite } \\
\text { Grouted }\end{array}$} \\
\hline & \multicolumn{4}{|c|}{$\begin{array}{c}\text { Containers: } 10 \text { liter poly bottle contained within a } \\
\text { double steel box. } \\
\text { Each bottle contains } 23 \mathrm{~kg} \text { cured grout }\end{array}$} & \multicolumn{3}{|c|}{$\begin{array}{c}\text { Containers: } 55 \text { gallon drum. } \\
\text { Each drum contains } 460 \mathrm{~kg} \text { cured } \\
\text { grout }\end{array}$} \\
\hline $\begin{array}{l}\text { Burn-up } \\
\text { (GW-d/MT) }\end{array}$ & $\begin{array}{l}\text { Mass } \\
(\mathrm{kg} / \mathrm{MT})\end{array}$ & $\begin{array}{l}\text { Volume } \\
\left(\mathrm{ft}^{3} / \mathrm{MT}\right)\end{array}$ & $\begin{array}{l}\text { Containers } \\
\text { per MT }\end{array}$ & $\begin{array}{l}\text { Decay Heat } \\
\text { (W/container) }\end{array}$ & $\begin{array}{l}\text { Mass } \\
(\mathrm{kg} / \mathrm{MT})\end{array}$ & $\begin{array}{l}\text { Volume } \\
\left(\mathrm{ft}^{3} / \mathrm{MT}\right)\end{array}$ & $\begin{array}{l}\text { Containers } \\
\text { per MT }\end{array}$ \\
\hline 51 & 2.10 & 0.09 & 0.09 & 0.18 & 11.74 & 0.19 & 0.03 \\
\hline
\end{tabular}

Table 2-5 Co-Extraction Fuel Reprocessing Metal Waste Summary.

\begin{tabular}{|c|c|c|c|}
\hline \multirow[b]{2}{*}{$\begin{array}{l}\text { Burn-up } \\
\text { (GW-d/MT) }\end{array}$} & \multicolumn{3}{|c|}{$\begin{array}{c}\text { Compacted Metal } \\
\text { Containers: } 2 \mathrm{ft} \text { diameter } \times 10 \mathrm{ft} \text { tall canisters. Each } \\
\text { Canister Contains } 3,600 \mathrm{~kg} \text {. }\end{array}$} \\
\hline & $\begin{array}{c}\text { Mass } \\
(\mathrm{kg} / \mathrm{MT})\end{array}$ & $\begin{array}{l}\text { Volume } \\
\left(\mathrm{ft}^{3} / \mathrm{MT}\right)\end{array}$ & $\begin{array}{l}\text { Containers } \\
\text { per MT }\end{array}$ \\
\hline 51 & 300.5 & 2.62 & 0.084 \\
\hline
\end{tabular}

Table 2-6 Co-Extraction Fuel Reprocessing Fission Product Waste Summary.

\begin{tabular}{|c|c|c|c|c|}
\hline & \multicolumn{4}{|c|}{$\begin{array}{c}\text { Borosilicate Glass } \\
\text { Containers: } 2 \mathrm{ft} \text { diameter } \times 15 \mathrm{ft} \text { tall canisters. } \\
\text { Each Canister Contains 2,900 kg. }\end{array}$} \\
\hline $\begin{array}{c}\text { Burn-up } \\
(\mathbf{G W}-\mathbf{d} / \mathrm{MT})\end{array}$ & $\begin{array}{c}\text { Mass } \\
(\mathbf{k g} / \mathbf{M T})\end{array}$ & $\begin{array}{c}\text { Volume } \\
\left(\mathbf{f t}^{3} / \mathrm{MT}\right)\end{array}$ & $\begin{array}{c}\text { Containers } \\
\text { per } \text { MT }\end{array}$ & $\begin{array}{c}\text { Decay Heat } \\
\text { (W/container) }\end{array}$ \\
\hline 51 & 537.5 & 8.73 & 0.19 & 14,000 \\
\hline
\end{tabular}

Table 2-7 Co-Extraction Fuel Reprocessing Recovered Uranium Summary.

\begin{tabular}{|c|c|c|c|}
\hline & \multicolumn{3}{|c|}{$\begin{array}{l}\text { Recovered Uranium }\left(\mathbf{U}_{2} \mathbf{O}_{3}\right) \\
\text { Containers: } 55 \text { gal Drum canisters. } \\
\text { Each Canister Contains } 400 \mathrm{~kg} .\end{array}$} \\
\hline $\begin{array}{l}\text { Burn-up } \\
\text { (GW-d/MT) }\end{array}$ & $\begin{array}{l}\text { Mass } \\
(\mathrm{kg} / \mathrm{MT})\end{array}$ & $\begin{array}{l}\text { Volume } \\
\left(\mathrm{ft}^{3} / \mathrm{MT}\right)\end{array}$ & $\begin{array}{c}\text { Containers } \\
\text { per MT }\end{array}$ \\
\hline 51 & 1,097 & 20.2 & 2.74 \\
\hline
\end{tabular}




\subsubsection{Co-Extraction Borosilicate Glass Characteristics}

The isotopic composition for borosilicate glass, which is the principal heat generating waste from the Co-Extraction process, was decayed using the ORIGEN 2.2 methods and isotopic parameters. Table 2-8 and Figure 2-4 provide the decay heat characteristics as functions of time for the Co-Extraction borosilicate glass. Appendix B Table B-1 provides the detailed isotopic composition of the discharged MOX fuel after 5, 30, 100 and 500 years of cooling.

\subsubsection{Characteristics of Used MOX Fuels}

It is important to note the difference in thermal output between UOX spent fuel and MOX spent fuel. The MOX spent fuel is significantly hotter after discharge at the same burn-up, and the thermal output decays more slowly. Whereas a UOX PWR fuel assembly takes approximately 10 to 20 years to drop below $1 \mathrm{~kW}$, a MOX PWR assembly takes 100 to 200 years (Figure 2-3).

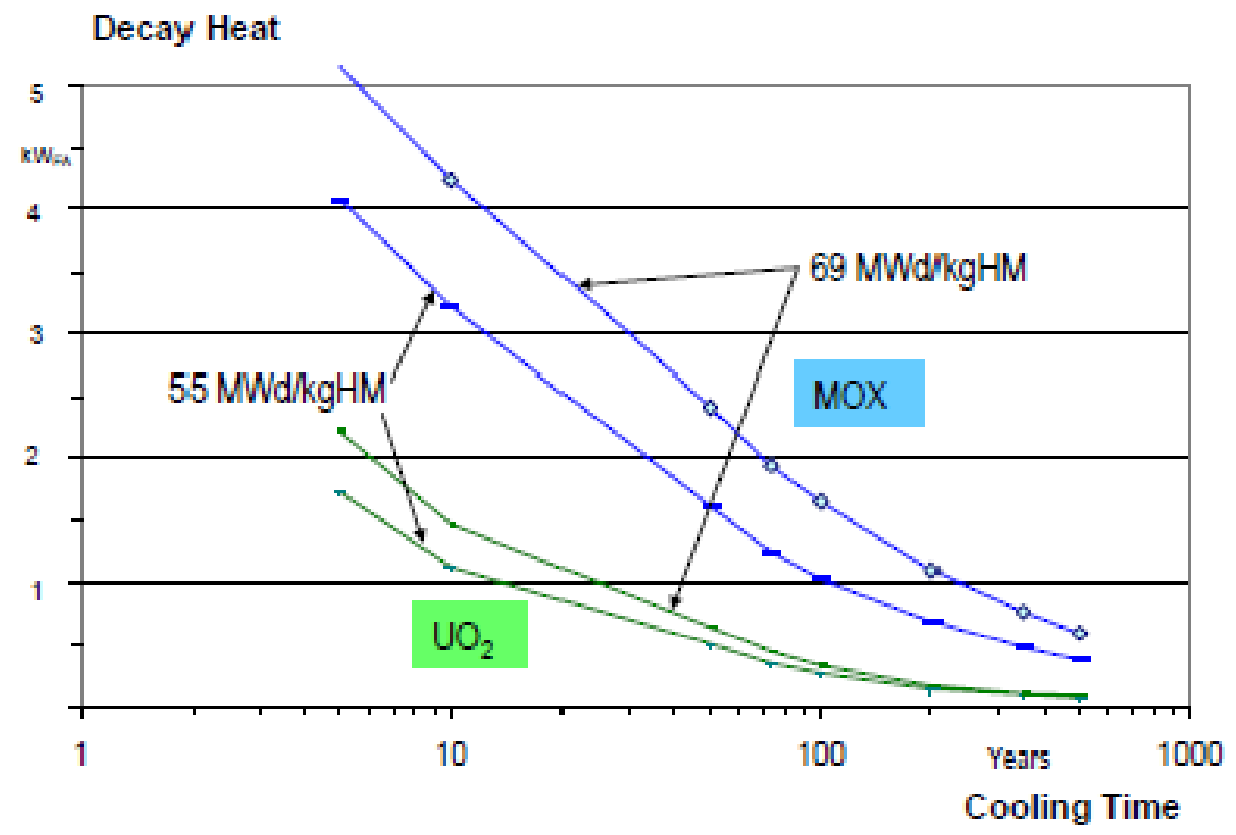

Figure 2-3 Decay heat of UOX and MOX Fuel Assemblies Depending on Burnup and Cooling Time for Discharge Burnup of 55 and 69 GW-d/MTHM (after IAEA 2003).

The difference in the decay heat is primarily that starting with $\mathrm{Pu}-239$ in the MOX results in more Am-241 and Pu-238, which dominate the heat from the MOX.

- At $100 \mathrm{yr}, \mathrm{Am}-241$ is responsible for approximately $30 \%$ of the heat in UOX, and 52\% of the heat in MOX. The heat contribution from $\mathrm{Pu}-238$ in MOX is approximately 5.5X the contribution in UOX.

- Overall, the thermal contribution from transuranics in MOX is over 7X the contribution in UOX.

The isotopic composition of discharged MOX fuel was obtained from the transmutation library maintained by the Systems Analysis Working Group. This discharge composition was decayed 
using the methods and isotopic parameters in ORIGEN 2.2 by adapting the method to an excel spreadsheet. Table 2-9 and Figure 2-5 provides the decay heat of the MOX fuel as a function of time.

Appendix C Table C-1 provides the detailed isotopic composition of the discharged MOX fuel after 5, 30, 100 and 500 years of cooling. The discharged MOX fuel is assumed to not be recycled and is considered potential waste requiring disposition. 
Table 2-8 Borosilicate Glass Decay Heat Generated by Co-Extraction Processing of 51 GW-d/MT 5-year Cooled PWR Fuel.

\begin{tabular}{|c|c|c|c|c|c|c|c|c|}
\hline \multirow[b]{2}{*}{ Decay Heat (Watts/Container ) } & \multicolumn{8}{|c|}{ Time (years) } \\
\hline & $\begin{array}{c}\text { Initial } \\
\text { Production }\end{array}$ & 10 & 30 & 50 & 70 & 100 & 300 & 500 \\
\hline Gases H, C, Xe, Kr, I & 0 & 0 & 0 & 0 & 0 & 0 & 0 & 0 \\
\hline $\mathrm{Cs} / \mathrm{Sr} / \mathrm{Ba} / \mathrm{Rb} / \mathrm{Y}$ & 10,156 & 5,727 & 3,518 & 2,201 & 1,377 & 682 & 6 & 0 \\
\hline Noble Metals Ag, Pd, Ru, Rh & 1,186 & 1 & 0 & 0 & 0 & 0 & 0 & 0 \\
\hline $\begin{array}{l}\text { Lanthanides La, Ce, Pr, Nd, Pm, Sm, Eu, } \\
\text { Gd, Tb, Ho, Tm }\end{array}$ & 1,282 & 268 & 52 & 11 & 2 & 0 & 0 & 0 \\
\hline Actinides Ac, Th, Pa, U & 0 & 0 & 0 & 0 & 0 & 0 & 0 & 0 \\
\hline Transuranic Np, Pu, Am, Cm, Bk, Cf, Es & 1,376 & 1,020 & 615 & 423 & 329 & 266 & 178 & 132 \\
\hline Others & 7 & 1 & 0 & 0 & 0 & 0 & 0 & 0 \\
\hline Total & 14,008 & 7,016 & 4,185 & 2,635 & 1,709 & 949 & 185 & 132 \\
\hline
\end{tabular}




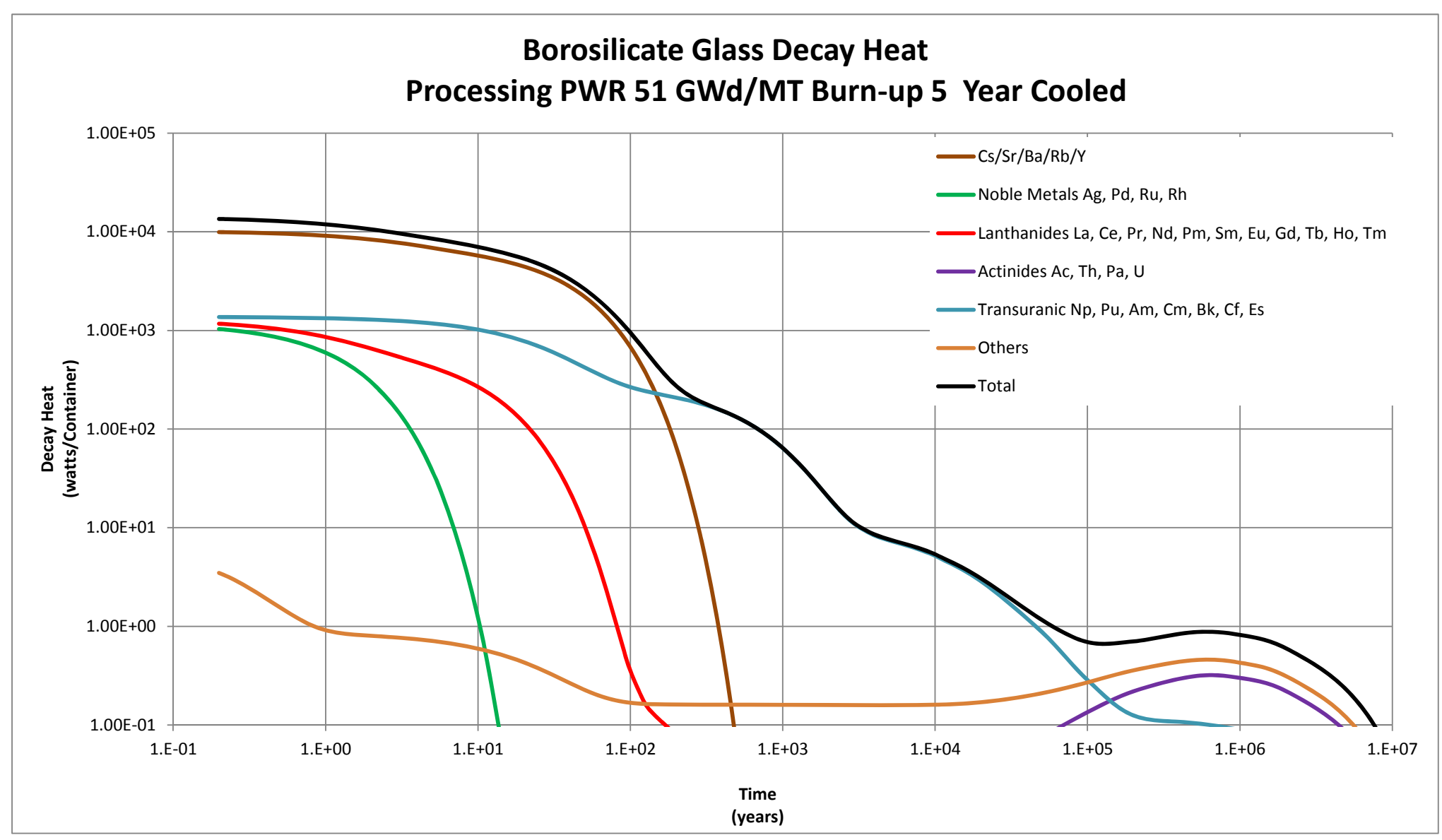

Figure 2-4 Borosilicate Glass Decay Heat Generated by Co-Extraction Processing of 51 GW-d/MT 5-year Cooled PWR Fuel. 
Table 2-9 Mixed Oxide Fuel 50 GW-d/MT Used Fuel Decay Heat

\begin{tabular}{|c|c|c|c|c|c|c|c|c|}
\hline \multirow[b]{2}{*}{ Decay Heat (Watts/MT ) } & \multicolumn{8}{|c|}{ Time (years) } \\
\hline & Discharge & 10 & 30 & 50 & 70 & 100 & 300 & 500 \\
\hline Gases H, C, Xe, Kr, I & 5,737 & 0 & 0 & 0 & 0 & 0 & 0 & 0 \\
\hline $\mathrm{Cs} / \mathrm{Sr} / \mathrm{Ba} / \mathrm{Rb} / \mathrm{Y}$ & 13,829 & 991 & 561 & 352 & 221 & 110 & 1 & 0 \\
\hline Noble Metals Ag, Pd, Ru, Rh & 23,181 & 12 & 0 & 0 & 0 & 0 & 0 & 0 \\
\hline $\begin{array}{l}\text { Lanthanides La, Ce, Pr, Nd, Pm, Sm, Eu, Gd, Tb, } \\
\text { Ho, Tm }\end{array}$ & 46,102 & 110 & 21 & 4 & 1 & 0 & 0 & 0 \\
\hline Actinides Ac, Th, Pa, U & 38,779 & 0 & 0 & 0 & 0 & 0 & 1 & 1 \\
\hline Transuranic Np, Pu, Am, Cm, Bk, Cf, Es & 76,896 & 4,878 & 4,062 & 3,504 & 3,110 & 2,697 & 1,517 & 1,068 \\
\hline Others & 19,517 & 13 & 2 & 1 & 0 & 0 & 0 & 0 \\
\hline Total & 224,040 & 6,004 & 4,647 & 3,860 & 3,332 & 2,807 & 1,519 & 1,068 \\
\hline
\end{tabular}




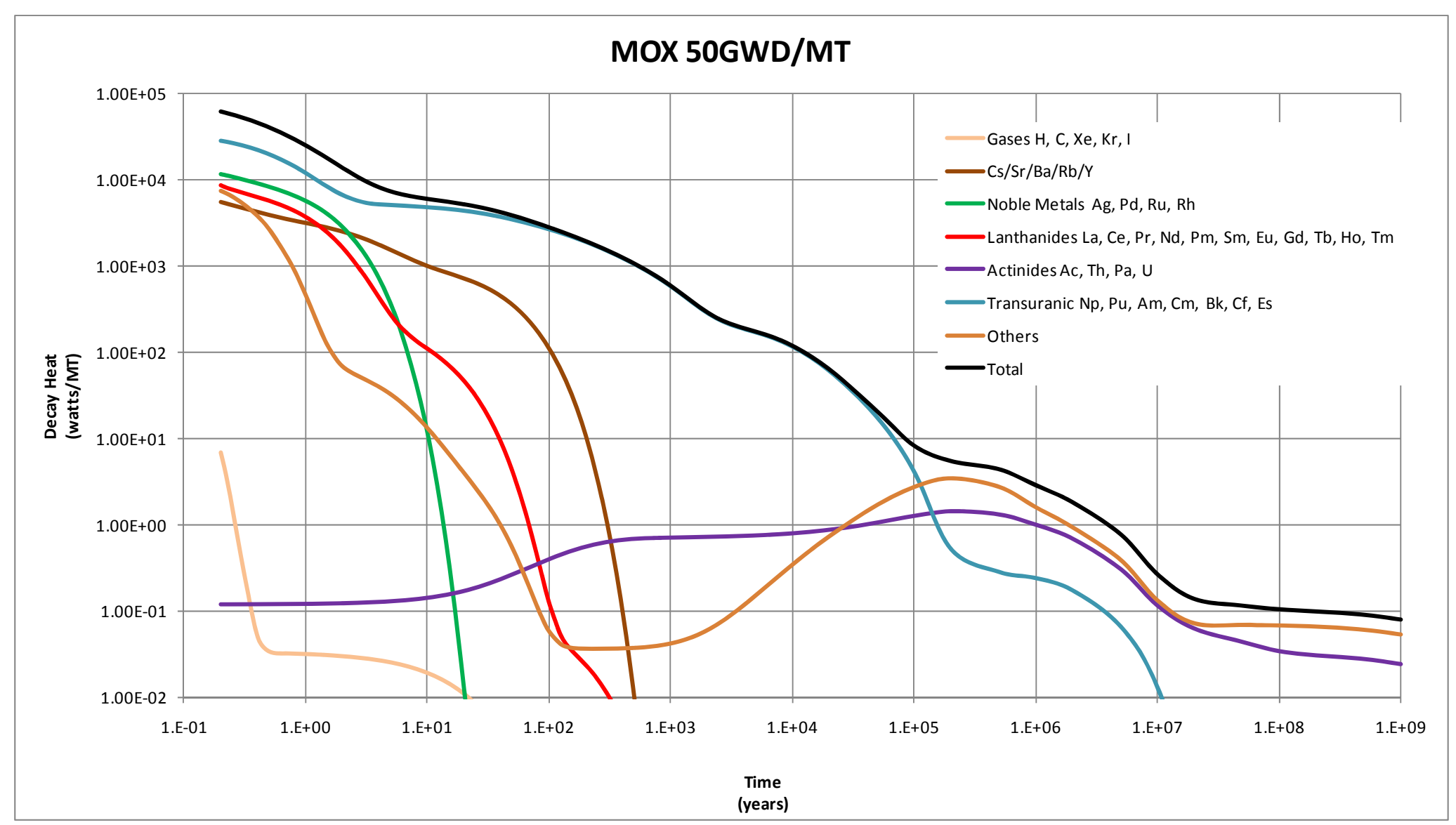

Figure 2-5 Mixed Oxide Fuel 50 GW-d/MT Used Fuel Decay Heat. 


\subsubsection{Characteristics of Modified Open Cycle Secondary Waste}

Secondary waste from the operation of modified open FC facilities includes

- Operational waste such as empty containers, solidified decontamination solutions, used process filters, etc.

- Job control waste such as protective clothing, plastic suits, contamination control materials, step-off pads, etc.

- Maintenance waste such as failed equipment, high efficiency particulate air (HEPA) filters, etc.

Secondary wastes are primarily characterized as low level (Class A, B and C) waste and GTCC waste. Relatively small quantities of mixed wastes are also anticipated from modified open FC facility operations (such wastes are subject to additional statutory and regulatory requirements, such as the Resource Conservation and Recovery Act enacted by the U.S. in 1976).

\subsubsection{Secondary Waste From Reprocessing LWR Fuel}

Estimates of the volume of secondary waste resulting from a variety of recycling processes were investigated by Jones (2010). Secondary waste from reprocessing operations is dependent on the reprocessing technology (in this case Co-Extraction) and the facility capacity. A facility capacity of 800 metric tons of heavy metal (MTHM)/year is a reasonable size for a reprocessing facility and is chosen as the basis for this study (recently constructed reprocessing plants at La Hague in France, and Rokkasho in Japan, are built in units that are approximately this size; see Todd 2008). Table 2-10 shows the annual volume of secondary waste expected from a Co-Extraction facility with a capacity of $800 \mathrm{MTHM} /$ year.

\section{Table 2-10 Annual Secondary Waste Volume from an 800 MTHM/year Co-Extraction Facility.}

\begin{tabular}{|l|c|c|}
\hline \multirow{2}{*}{\multicolumn{1}{|c|}{ Waste Type }} & \multicolumn{2}{c|}{ Annual Waste Volume } \\
\cline { 2 - 3 } & $\mathbf{m}^{\mathbf{3}}$ & $\mathbf{m}^{\mathbf{3}}$ /MTHM \\
\hline Low level Class A/B/C & 7,440 & 9.3 \\
\hline Greater than Class C (GTCC) & 235 & 0.3 \\
\hline Mixed low level Class A/B/C & 32 & 0.04 \\
\hline Mixed GTCC & 48 & 0.06 \\
\hline
\end{tabular}

\subsubsection{Secondary Waste From MOX Fuel Fabrication}

Estimates of the volume of secondary waste resulting from the fabrication of MOX fuel from plutonium recovered from LWR used fuel were investigated by Jones (2011). The volume of Class $\mathrm{A} / \mathrm{B} / \mathrm{C}$ secondary waste from MOX fuel fabrication is dependent on the facility capacity. The volume of GTCC secondary waste is dependent on the facility capacity and also the isotopic content of the plutonium used to fabricate the fuel which is in turn dependent on the burn-up and cooling time of the used fuel from which it is derived. The isotopic content of the plutonium 
being processed and present in the waste streams restricts the amount of waste that can be packaged per waste package. These restrictions are driven by safety requirements imposed by transportation and facility operations. In general, higher burn-up used fuels or shorter cooled used fuels contain plutonium with higher activity levels and processing of this plutonium into MOX fuel results in higher volumes of GTCC waste.

A facility capacity of 3.5 MT Pu/year is a reasonable size for a MOX fuel fabrication facility and is chosen as a basis for this study (similar to the MOX Fuel Fabrication Facility under construction at the Savannah River Site; see NRC 2010). As stated previously, used fuel with a burn-up of $60 \mathrm{GW}-\mathrm{d} / \mathrm{MT}$ is chosen as a basis for this study. Table 2-11 shows the annual volume of secondary waste expected from a MOX fuel fabrication facility processing plutonium recovered from LWR used fuel with a burn-up of $60 \mathrm{GW}-\mathrm{d} / \mathrm{MT}$. Data for cooling times of 5 years and 30 years are provided.

Table 2-11 Annual Secondary Waste Volume from a MOX Fuel Fabrication Facility (3.5 MT Pulyear) Processing Pu Recovered from LWR UNF with Burnup of $60 \mathrm{GW}-\mathrm{d} / \mathrm{MT}$.

\begin{tabular}{|c|c|c|c|}
\hline Waste Type & $\begin{array}{c}\text { Annual Waste } \\
\text { Volume } \\
\text { (m³/year) }\end{array}$ & $\begin{array}{l}\text { Equivalent } \\
\text { Recycling } \\
\text { Capacity } \\
\text { (MTHM/year) }^{1}\end{array}$ & $\begin{array}{c}\text { Waste Volume Relative } \\
\text { to Equivalent } \\
\text { Recycling Capacity } \\
\left(\mathrm{m}^{3} / \mathrm{MTHM}\right)^{1}\end{array}$ \\
\hline Low level Class A/B/C & 372 & 248 & 1.5 \\
\hline Greater than Class C (GTCC) & 1,680 & 248 & 6.78 \\
\hline
\end{tabular}

\subsubsection{Secondary Waste From Repository Operations}

Secondary waste resulting from the disposal of used fuel from a modified open cycle at a geologic repository is the same as shown in Section 2.1.2 for the once-through FC.

\subsection{Closed Fuel Cycle}

A key attribute of the "fully closed" nuclear FC is that no UNF is disposed, only UNF reprocessing wastes are disposed. Power reactor systems have been previously studied with the majority of such studies utilizing fast spectrum reactors. These prior studies include numerous variations related to:

- The start-up core which can be produced from low enriched $(<20 \%)$ uranium, weapons grade plutonium, or recovered TRU materials from existing LWR UNF

- "Equilibrium" core which can have design and operating parameters specified to result in TRU conversion ratios (CRs) of

Less than 1 for TRU burning modes, these cases require additional TRU materials to produce the next reactor fuel charge 
Equal to 1.0 for breakeven reactor operation such that the TRU production and consumption are balanced over each reactor cycle or

Greater than 1 for systems which have a net production of TRU elements over each reactor cycle

- Fuel type typically either oxide, metal alloy or carbon-based.

- The reactor coolant, typically molten sodium, or lead mixtures, or gases, to maintain the fast neutron spectrum.

Carter et al. (2011) investigated the waste generated by reprocessing oxide and metal fuel from reactors operated to produce a TRU conversion ratio (CR) of either 0.5 or 0.75 . It was found that the decay heat properties of the waste were essentially the same for either fuel (Carter et al. 2011a, Figure 6-2). All of the figures and tables for this case that are presented here, are based on results from Carter et al. (2011a).

To provide an example of an alternative (to aqueous) reprocessing method, this study assumes metal-based fuel with sodium-cooled fast reactor (SFR) operating parameters such that the CR is 0.75 . The fuel is reprocessed by an electrochemical (EC) method.

\subsubsection{Overall Mass Flows for a Closed Fuel Cycle}

Advanced burner reactor (ABR) core designs have been investigated and documented (Hoffman et al. 2006; Hoffman 2007; Yang et al. unpublished). These studies document the basic design and operating parameters for a 1000 Megawatts-thermal $\left(\mathrm{MW}_{\text {th }}\right)$ sodium cooled reactor using $\mathrm{U}$ TRU-Zr metal alloy fuel. Table 2-12 summarizes key parameters for TRU CR of 0.75 for the metal fuel type. Some parameters (e.g., fuel mass per assembly) were obtained from the references author's working papers.

The discharged fuel isotopic concentrations associated with these studies were obtained from the System Analysis transmutation library. Figure 2-6 provides the decay heat of these fuels which are all similar. The parameters in Table 2-12 and the UNF isotopic data were combined to generate an overall reactor, fuel recycling, and fuel fabrication material balance for the reactor configuration. The material balances are documented in Appendix D, Table D-1 and is summarized in Table 2-13. Since the reactors operate with a TRU CR of less than 1.0, additional TRU must be supplied to the reactor system each year. The TRU source described by the references cited above is LWR UOX fuel with a burn-up of $50 \mathrm{GW}-\mathrm{d} / \mathrm{MT}$ cooled for 5 years. Both the TRU quantity and quantity of LWR fuel which must be reprocessed annually is provided in Table 2-13.

The waste unit quantities resulting from reprocessing the advanced burner reactor (ABR) fuel (Section 2.3.3) are determined per MT of fuel recycled. However, the repository system analyst will likely need to know the total quantities of waste to be disposed. In order to determine the total quantities several additional parameters will need to be considered. These include the thermal efficiency and overall utility of the power plant if such studies are related to net power generation. The total quantities must also include the waste generated from reprocessing the LWR fuel as discussed in Section 2.3.2. 
Table 2-12 Reactor Parameter Summary.

\begin{tabular}{|c|c|}
\hline & $\begin{array}{c}\text { Metal Fuel Core } \\
1000 \mathrm{MW}_{\text {th }} \mathrm{CR}=0.75\end{array}$ \\
\hline Power, (MWth) & 1000 \\
\hline Cycle Length (effective full power days) & 232 \\
\hline Number of Batches $(\mathrm{IC} / \mathrm{MC} / \mathrm{OC})^{1}$ & $6 / 6 / 6.5$ \\
\hline Fuel Form & U-TRU-10\%Zr \\
\hline TRU Feed & $\begin{array}{l}\text { Recycled ABR fuel (2-yr cooled) + } \\
\text { LWR } 50 \text { GW-d/MT (5-yr cooled) }\end{array}$ \\
\hline TRU Enrichment (IC/MC/OC) ${ }^{1}$ & $16.1 / 20.1 / 24.2$ \\
\hline TRU Enrichment (avg.) & 21.3 \\
\hline Number of Batches (IC/MC/OC) ${ }^{1}$ & $6 / 6 / 6.5$ \\
\hline Conversion Ratio (TRU) & 0.75 \\
\hline BOEC Core Loading (HM/TRU, MT) & $13.4 / 2.85$ \\
\hline Discharge Burn-up (avg./peak, GW-d/MT) & $99.6 / 127$ \\
\hline Total Assemblies & 313 \\
\hline Drivers (IC/MC/OC) ${ }^{1}$ & $30 / 42 / 72$ \\
\hline Control Rods (primary/secondary) & $16 / 3$ \\
\hline Reflector & 90 \\
\hline Shield & 60 \\
\hline Mass HM per Assembly (IC/MC/OC, kg) ${ }^{1}$ & $97.6 / 97.7 / 97.8$ \\
\hline Mass Zr per Assembly (IC/MC/OC, kg) ${ }^{1}$ & $10.8 / 10.9 / 10.9$ \\
\hline Mass Bond Na (kg) & 2.34 \\
\hline Mass HT-9 Hardware (kg/assembly) & 359.9 \\
\hline \multicolumn{2}{|c|}{$\begin{array}{l}\text { Notes: } \\
\text { 1. IC / MC / OC refers to inner core/middle core/outer core. } \\
\text { 2. } \mathrm{Zr} \text { fraction is } 10 \mathrm{wt} \% \text { when the TRU fraction is less than } 30 \mathrm{wt} \%(\mathrm{TRU} / \mathrm{HM} \times 100) \text { and } \\
\text { increases to } 40 \% \mathrm{Zr} \text { at } 100 \% \mathrm{TRU}\end{array}$} \\
\hline
\end{tabular}

Table 2-13 Overall Reactor Material Balance Result.

\begin{tabular}{|l|c|}
\hline & $\begin{array}{c}\text { Metal Fuel Core } \\
1000 \mathrm{MW}_{\text {th }} \mathrm{CR}=0.75\end{array}$ \\
\hline Initial Core Charge (HM/TRU/Zr, MT) & $14.07 / 2.98 / 1.57$ \\
\hline Annual Fuel Requirements (HM/TRU/Zr, MT) & $3.55 / 0.75 / 0.25$ \\
\hline Annual LWR to Supply TRU (MT/yr) & 5.78 \\
\hline
\end{tabular}




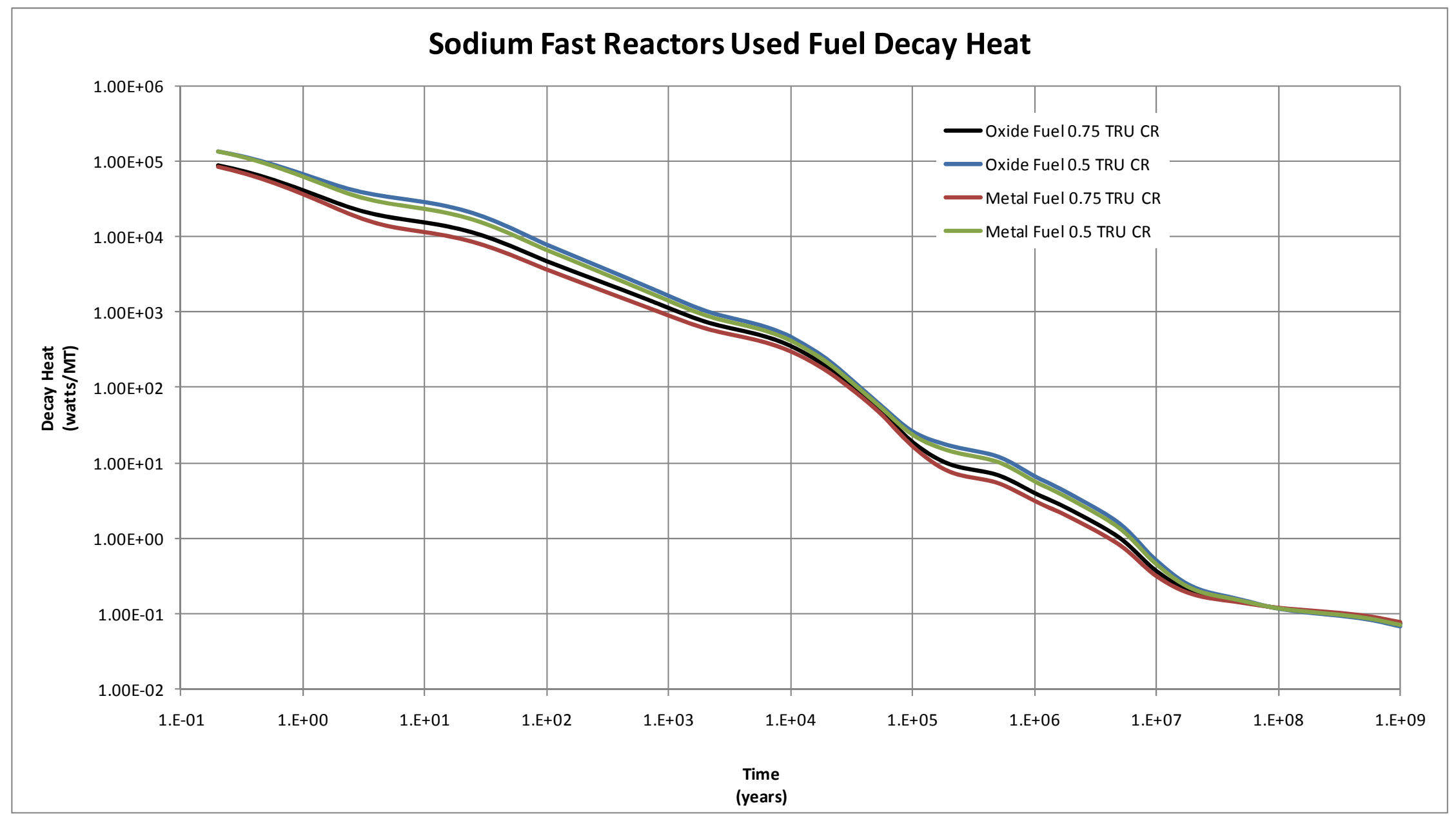

Figure 2-6 Sodium Fast Reactors Used Fuel Decay Heat. 
THIS PAGE INTENTIONALLY LEFT BLANK 


\subsubsection{Characteristics of LWR New Extraction Reprocessing Wastes}

New Extraction is an advanced aqueous process which recovers all of the transuranic (TRU) elements for re-use. The process envisioned includes Transuranic Extraction (TRUEX) and the Trivalent Actinide Lanthanide Separation by Phosphorus-based Aqueous [K]omplexes (TALSPEAK) process for complete TRU recovery. The principal fission product wastes are combined with the UDS and separated Tc into a single borosilicate glass waste form.

The principal gaseous radionuclides I-129, Kr-85, C-14 and H-3 released during reprocessing are captured and converted to waste forms suitable for disposal.

While this process is similar in function to the NUEX industrial process proposed by Energy Solutions, the two processes assume different processing methods and steps and so the product and waste streams cannot be directly compared.

\subsubsection{New Extraction Baseline Waste Forms}

\section{Off-Gas Waste Forms}

In addition to the grouted tritium waste and I-129 waste generated by the Co-Extraction process, the New Extraction process is assumed to capture and treat C-14 and $\mathrm{Kr}-85$.

- $\mathrm{C}-14$ is converted to carbonate and grouted. The grout is cured in a 55 gal drum.

- $\mathrm{Kr}-85$ is separated from the other off-gas components (including xenon) by cryogenic methods and the $\mathrm{Kr}-85$ is stored in high pressure type A gas cylinders.

\section{Metal Waste Forms}

Compacted Hulls and Hardware - After being separated from the fuel, the assembly hardware (principally stainless steels) and zirconium and stainless steel based cladding are decontaminated, compacted and placed inside a HLW canister. Each canister is $2 \mathrm{ft}$ in diameter by $10 \mathrm{ft}$ tall and contains $3,600 \mathrm{~kg}$ of waste material.

\section{Principal Fission Product Waste Forms}

Borosilicate Glass - In the aqueous processes most of the fission products are incorporated into a borosilicate glass. While this waste form is the accepted standard for reprocessing waste disposal, the waste form is limited by a number of attributes which must be considered in this study.

The limits to avoid the formation of multi-phase glasses include:

- Maximum decay heat of 14,000 watts per 2-ft diameter canister to prevent the canister centerline temperature from reaching the transition temperature.

- Molybdenum trioxide is limited to $2.5 \%$ by weight to maintain solubility.

- Noble (Ag, Pd, Rh, Ru) metals are limited to 3\% by weight.

The limit selected for any representative fuel allows the maximum waste loading and minimum projected waste volume, and mass. The glass is cast into a $2-\mathrm{ft}$ diameter by $15-\mathrm{ft}$ tall canister containing $2,900 \mathrm{~kg}$ of glass. 


\subsubsection{New Extraction Waste Volumes, Masses and Containers}

The potential waste from reprocessing the metal ABR fuels is described in Tables 2-14 through 2-17.

The isotopic composition for borosilicate glass, the principal heat generating waste from the New Extraction process, was decayed using the ORIGEN 2.2 methods and isotopic parameters. Table 2-18 and Figure 2-7 provide the decay heat characteristics as a function of time for the New Extraction borosilicate glass. Appendix E, Table E-1 provides the detailed isotopic composition of the discharged New Extraction borosilicate glass after 5, 30, 100 and 500 years of cooling. 
Table 2-14 New Extraction Reactor Fuel Reprocessing Off-Gas Waste Summary.

\begin{tabular}{|c|c|c|c|c|c|c|c|c|c|c|c|c|c|c|}
\hline \multirow[b]{3}{*}{$\begin{array}{l}\text { Burn-up } \\
\text { (GW-d/MT) }\end{array}$} & \multicolumn{4}{|c|}{ Captured Tritium Grouted } & \multicolumn{3}{|c|}{$\begin{array}{l}\text { Captured I on Silver } \\
\text { Mordenite Grouted }\end{array}$} & \multicolumn{3}{|c|}{$\begin{array}{l}\text { Captured C-14 as } \\
\text { Carbonate Grouted }\end{array}$} & \multicolumn{4}{|c|}{$\begin{array}{c}\text { Captured Kr in High Pressure } \\
\text { Cylinders }\end{array}$} \\
\hline & \multicolumn{4}{|c|}{$\begin{array}{l}\text { Containers: } 10 \text { liter poly bottle contained } \\
\text { within a double steel box. Each bottle } \\
\text { contains } 23 \mathrm{~kg} \text { of cured grout }\end{array}$} & \multicolumn{3}{|c|}{$\begin{array}{l}\text { Containers: } 55 \text { gallon } \\
\text { drum. Each drum contains } \\
460 \mathrm{~kg} \text { of cured grout }\end{array}$} & \multicolumn{3}{|c|}{$\begin{array}{l}\text { Containers: } 55 \text { gallon drum. } \\
\text { Each drum contains } 460 \mathrm{~kg} \\
\text { of cured grout }\end{array}$} & \multicolumn{4}{|c|}{$\begin{array}{c}\text { Containers: Standard Type } 1 \mathrm{~A} \text { high } \\
\text { pressure cylinders containing } 43.8 \text { liters at } \\
50 \mathrm{~atm} \text { pressure. }\end{array}$} \\
\hline & $\begin{array}{c}\text { Mass } \\
(\mathrm{kg} / \mathrm{MT})\end{array}$ & $\begin{array}{l}\text { Volume } \\
\left(\mathrm{ft}^{3} / \mathrm{MT}\right)\end{array}$ & $\begin{array}{c}\text { Containers } \\
\text { per MT }\end{array}$ & $\begin{array}{c}\text { Decay Heat } \\
\text { (W/container) }\end{array}$ & $\begin{array}{c}\text { Mass } \\
(\mathrm{kg} / \mathrm{MT})\end{array}$ & $\begin{array}{l}\text { Volume } \\
\left(\mathrm{ft}^{3} / \mathrm{MT}\right)\end{array}$ & $\begin{array}{c}\text { Containers } \\
\text { per MT }\end{array}$ & $\begin{array}{c}\text { Mass } \\
(\mathrm{kg} / \mathrm{MT})\end{array}$ & $\begin{array}{l}\text { Volume } \\
\left.\text { (ft }{ }^{3} / \mathrm{MT}\right)\end{array}$ & $\begin{array}{c}\text { Containers } \\
\text { per MT }\end{array}$ & $\begin{array}{l}\text { Mass } \\
(\mathrm{kg} / \mathrm{MT})\end{array}$ & $\begin{array}{l}\text { Volume } \\
\left(\mathrm{ft}^{3} / \mathrm{MT}\right)\end{array}$ & $\begin{array}{c}\text { Containers } \\
\text { per MT }\end{array}$ & $\begin{array}{l}\text { Decay Heat } \\
\text { (W/container) }\end{array}$ \\
\hline 50 & 2.10 & 0.09 & 0.09 & 0.18 & 11.74 & 0.19 & 0.03 & 9.41 & 0.15 & 0.02 & 0.70 & 3.72 & 0.085 & 170 \\
\hline
\end{tabular}

Table 2-15 New Extraction Fuel Reprocessing Metal Waste Summary.

\begin{tabular}{|c|c|c|c|}
\hline & \multicolumn{3}{|c|}{$\begin{array}{c}\text { Compacted Metal } \\
\text { Containers: } 2 \mathrm{ft} \text { diameter } \times 10 \mathrm{ft} \\
\text { tall canisters. Each Canister } \\
\text { Contains 3,600 kg. }\end{array}$} \\
\hline $\begin{array}{c}\text { Burn-up } \\
(\mathbf{G W}-\mathbf{d} / \mathbf{M T})\end{array}$ & $\begin{array}{c}\text { Mass } \\
\mathbf{( k g / M T )}\end{array}$ & $\begin{array}{c}\text { Volume } \\
\left.\mathbf{( f t}^{3} / \mathbf{M T}\right)\end{array}$ & $\begin{array}{c}\text { Containers } \\
\text { per } \mathbf{M T}\end{array}$ \\
\hline 50 & 300.5 & 2.62 & 0.084 \\
\hline
\end{tabular}


Table 2-16 New Extraction Reactor Fuel Reprocessing Fission Product Waste Summary.

\begin{tabular}{|c|c|c|c|c|}
\hline & \multicolumn{4}{|c|}{ Borosilicate Glass } \\
& \multicolumn{4}{|c|}{$\begin{array}{c}\text { Containers: } 2 \mathrm{ft} \text { diameter } \times 15 \mathrm{ft} \text { tall canisters. } \\
\text { Each Canister Contains 2,900 kg. }\end{array}$} \\
\hline $\begin{array}{c}\text { Burn-up } \\
\text { (GW-d/MT) }\end{array}$ & $\begin{array}{c}\text { Mass } \\
(\mathbf{k g / M T})\end{array}$ & $\begin{array}{c}\text { Volume } \\
\left(\mathbf{f t}^{\mathbf{3}} / \mathbf{M T}\right)\end{array}$ & $\begin{array}{c}\text { Containers } \\
\text { per MT }\end{array}$ & $\begin{array}{c}\text { Decay Heat } \\
\text { (W/container) }\end{array}$ \\
\hline 50 & 309.2 & 5.02 & 0.11 & 14,000 \\
\hline
\end{tabular}

Table 2-17 New Extraction Fuel Reprocessing Recovered Uranium Summary.

\begin{tabular}{|c|c|c|c|}
\hline & \multicolumn{3}{|c|}{$\begin{array}{r}\text { Recovered Uranium }{\left(\mathbf{U}_{2} \mathbf{O}_{3}\right)} \\
\text { Containers: 55 gal Drum } \\
\text { canisters. Each Canister } \\
\text { Contains 400 kg. }\end{array}$} \\
\hline $\begin{array}{c}\text { Burn-up } \\
(\mathbf{G W}-\mathrm{d} / \mathrm{MT})\end{array}$ & $\begin{array}{c}\text { Mass } \\
(\mathbf{k g} / \mathbf{M T})\end{array}$ & $\begin{array}{c}\text { Volume } \\
\left(\mathrm{ft}^{3} / \mathrm{MT}\right)\end{array}$ & $\begin{array}{c}\text { Containers } \\
\text { per MT }\end{array}$ \\
\hline 50 & 1,094 & 20.12 & 2.74 \\
\hline
\end{tabular}


Table 2-18 Borosilicate Glass Decay Heat Generated by New Extraction Processing of 51 GW-d/MT 5-year Cooled PWR Fuel.

\begin{tabular}{|c|c|c|c|c|c|c|c|c|}
\hline \multirow[b]{2}{*}{ Decay Heat (Watts/Container ) } & \multicolumn{8}{|c|}{ Time (years) } \\
\hline & $\begin{array}{l}\text { Initial } \\
\text { Production }\end{array}$ & 10 & 30 & 50 & 70 & 100 & 300 & 500 \\
\hline Gases H, C, Xe, Kr, I & 0 & 0 & 0 & 0 & 0 & 0 & 0 & 0 \\
\hline $\mathrm{Cs} / \mathrm{Sr} / \mathrm{Ba} / \mathrm{Rb} / \mathrm{Y}$ & 9,628 & 4,563 & 2,779 & 1,748 & 1,100 & 549 & 5 & 0 \\
\hline Noble Metals Ag, Pd, Ru, Rh & 1,820 & 2 & 0 & 0 & 0 & 0 & 0 & 0 \\
\hline $\begin{array}{l}\text { Lanthanides La, Ce, Pr, Nd, Pm, Sm, Eu, Gd, Tb, Ho, } \\
\text { Tm }\end{array}$ & 2,123 & 465 & 90 & 18 & 4 & 1 & 0 & 0 \\
\hline Actinides Ac, Th, Pa, U & 0 & 0 & 0 & 0 & 0 & 0 & 0 & 0 \\
\hline Transuranic Np, Pu, Am, Cm, Bk, Cf, Es & 1 & 1 & 1 & 1 & 1 & 1 & 1 & 1 \\
\hline Others & 8 & 1 & 0 & 0 & 0 & 0 & 0 & 0 \\
\hline Total & 13,581 & 5,032 & 2,871 & 1,768 & 1,105 & 551 & 6 & 1 \\
\hline
\end{tabular}




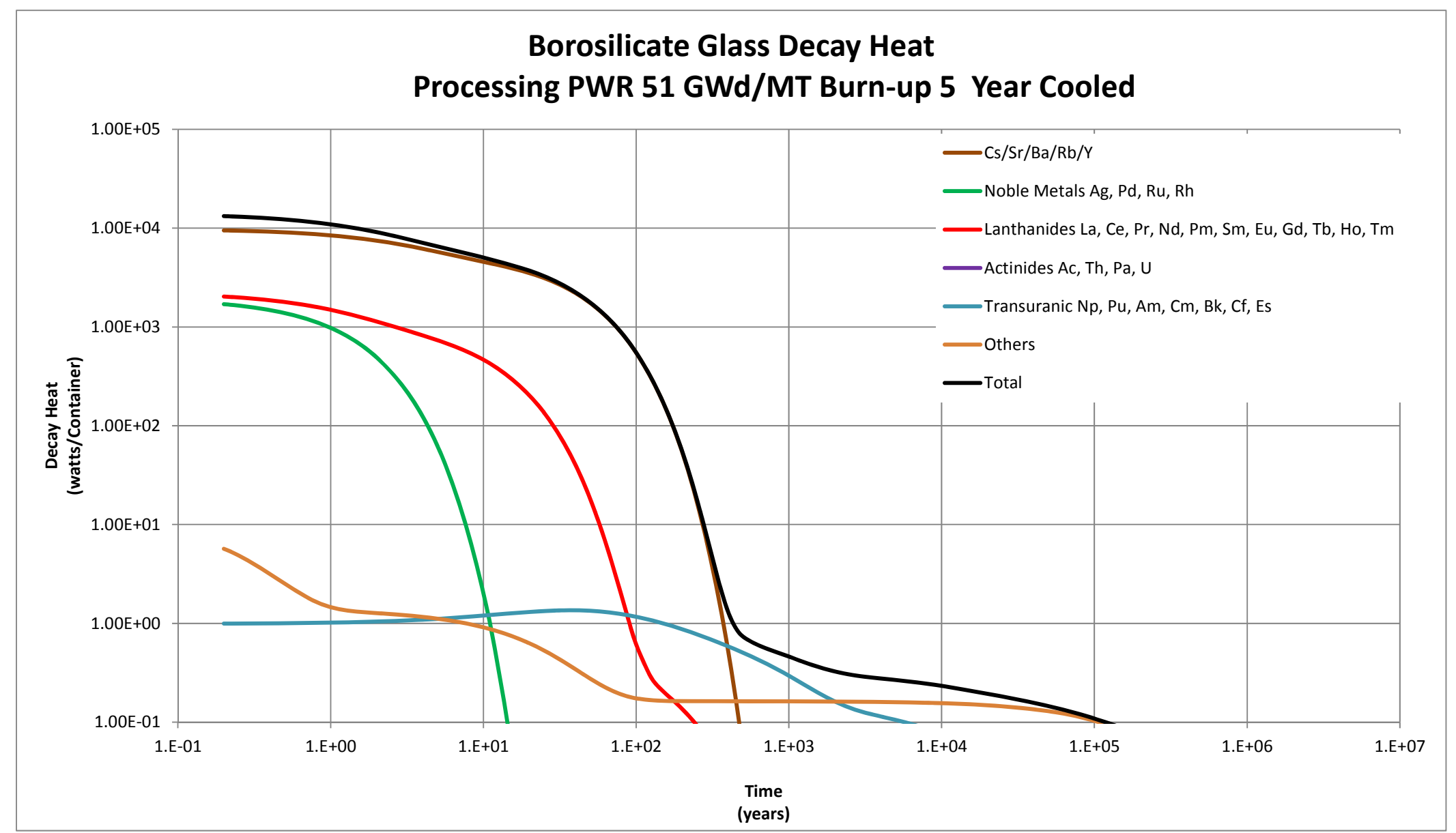

Figure 2-7 Borosilicate Glass Decay Heat Generated by New Extraction Processing of 51 GW-d/MT 5-year Cooled PWR Fuel. 


\subsubsection{Characteristics of Waste Generated by Reprocessing SFR Metal Fuel}

The EC process is a dry process using conductive molten salt baths to recover all the TRU elements. In this process the fission products are split between three waste streams. Elements which are more noble (as measured by EC potential) than uranium, such as fuel cladding and noble metal fission products, remain as metals and are incorporated into a metal alloy waste form. Elements less noble than uranium are converted to chloride salts. The lanthanide elements are recovered from the salt by electrolysis and converted to a lanthanide glass. Excess salt is purged; the chloride is adsorbed by zeolite and bonded with glass to make the final waste form.

The principal gaseous radionuclides I-129, Kr-85, C-14 and H-3 released during reprocessing are captured and converted to a waste form suitable for disposal, although most of the I-129 in this process is not released to the gaseous phase but is converted to a molten salt and purged with the excess salt.

Material balance parameters and assumptions from (Carter, available on request) were used.

\subsubsection{Electrochemical Process Baseline Waste Forms}

\section{Off-Gas Waste Forms}

The off-gas waste forms are the same as those of the New Extraction LWR reprocessing method.

\section{Principal Fission Product Waste Forms}

Glass Bonded Zeolite - The EC process purges excess salt and fission products which have been adsorbed onto zeolite. Additional zeolite is added to sequester the excess salt chloride and then bonded with borosilicate glass. The glass bonded zeolite is cast into a $2 \mathrm{ft}$ diameter by $15 \mathrm{ft}$ tall canister containing $2,900 \mathrm{~kg}$ of glass. The waste form is $25 \%$ glass binder.

Lanthanide Glass - The EC process also separates the lanthanides which are converted to a lanthanide based glass. The glass is cast into a 6" diameter by 60 in tall canister containing 500 $\mathrm{kg}$ of glass. The waste loading is $50 \%$ lanthanides.

Metal Alloy - In the EC process those elements which are more noble (as measured by EC potential) than uranium, such as the hulls, hardware and noble metal fission products, remain as metals. The metal waste is decontaminated by volatilizing any adhered salts and then cast into a HLW canister. Each canister is $2 \mathrm{ft}$ in diameter by $10 \mathrm{ft}$ tall and contains 3,600 kg of waste material.

\subsubsection{Electrochemical Waste Volumes, Masses and Containers}

The potential waste inventory from reprocessing the metal ABR fuels is provided in Table 2-19 through 2-21.

\subsubsection{Characteristics of the Heat Generating Wastes from SFR Processes}

The isotopic compositions, for the principal heat generating wastes from the electrochemical (EChem) process, the glass bonded zeolite and the lanthanide glass, were decayed using the ORIGEN 2.2 methods and isotopic parameters.

Table 2-22 and Figure 2-8 provide the decay heat characteristic as a function of time for the glass bonded zeolite. Appendix F, Table F-1 provides the detailed isotopic composition of the glass bonded zeolite after 5, 30, 100 and 500 years of cooling. Table 2-23 and Figure 2-9 provide the 
detailed isotopic composition for the lanthanide glass. Appendix F, Table F-2 provides the detailed isotopic composition of the lanthanide glass after 5, 30, 100 and 500 years of cooling. Table 2-24 and Figure 2-10 provide the decay heat of the metal alloy waste form. Appendix F, Table F-3 provides the detailed isotopic composition of the metal alloy after 5, 30, 100 and 500 years of cooling. 
Table 2-19 Advanced Burner Reactor Fuel Reprocessing Off-Gas Waste Summary.

\begin{tabular}{|c|c|c|c|c|c|c|c|c|c|c|c|c|c|c|c|}
\hline \multirow{2}{*}{\multicolumn{2}{|c|}{$\begin{array}{l}\text { Metal Based } \\
\text { Fuel }\end{array}$}} & \multicolumn{4}{|c|}{ Captured Tritium Grouted } & \multicolumn{3}{|c|}{$\begin{array}{l}\text { Captured I on Silver } \\
\text { Mordenite Grouted }\end{array}$} & \multicolumn{3}{|c|}{$\begin{array}{l}\text { Captured C-14 as } \\
\text { Carbonate Grouted }\end{array}$} & \multicolumn{4}{|c|}{$\begin{array}{c}\text { Captured Kr in High Pressure } \\
\text { Cylinders }\end{array}$} \\
\hline & & \multicolumn{4}{|c|}{$\begin{array}{l}\text { Containers: } 10 \text { liter poly bottle contained } \\
\text { within a double steel box. Each bottle } \\
\text { contains } 23 \mathrm{~kg} \text { of cured grout }\end{array}$} & \multicolumn{3}{|c|}{$\begin{array}{l}\text { Containers: } 55 \text { gallon drum. } \\
\text { Each drum contains } 460 \mathrm{~kg} \\
\text { of cured grout }\end{array}$} & \multicolumn{3}{|c|}{$\begin{array}{l}\text { Containers: } 55 \text { gallon drum. } \\
\text { Each drum contains } 460 \mathrm{~kg} \\
\text { of cured grout }\end{array}$} & \multicolumn{4}{|c|}{$\begin{array}{c}\text { Containers: Standard Type } 1 \mathrm{~A} \text { high } \\
\text { pressure cylinders containing } 43.8 \text { liters at } \\
50 \text { atm pressure. }\end{array}$} \\
\hline $\begin{array}{l}\text { Burn-up } \\
\text { (GW-d/MT) }\end{array}$ & $\begin{array}{l}\text { Conver- } \\
\text { sion } \\
\text { Ratio }\end{array}$ & $\begin{array}{c}\text { Mass } \\
(\mathrm{kg} / \mathrm{MT})\end{array}$ & $\begin{array}{l}\text { Volume } \\
\left(\mathrm{ft}^{3} / \mathrm{MT}\right)\end{array}$ & $\begin{array}{c}\text { Containers } \\
\text { per MT }\end{array}$ & \begin{tabular}{|c|} 
Decay Heat \\
(W/container)
\end{tabular} & $\begin{array}{l}\text { Mass } \\
(\mathrm{kg} / \mathrm{MT})\end{array}$ & $\begin{array}{l}\text { Volume } \\
\left(\mathrm{ft}^{3} / \mathrm{MT}\right)\end{array}$ & $\begin{array}{c}\text { Containers } \\
\text { per MT }\end{array}$ & $\begin{array}{c}\text { Mass } \\
(\mathrm{kg} / \mathrm{MT})\end{array}$ & $\begin{array}{l}\text { Volume } \\
\left(\mathrm{ft}^{3} / \mathrm{MT}\right)\end{array}$ & $\begin{array}{c}\text { Containers } \\
\text { per MT }\end{array}$ & $\begin{array}{c}\text { Mass } \\
(\mathrm{kg} / \mathrm{MT})\end{array}$ & $\begin{array}{l}\text { Volume } \\
\left(\mathrm{ft}^{3} / \mathrm{MT}\right)\end{array}$ & $\begin{array}{c}\text { Containers } \\
\text { per MT }\end{array}$ & $\begin{array}{l}\text { Decay Heat } \\
\text { (W/container) }\end{array}$ \\
\hline 99.6 & 0.75 & 2.10 & 0.09 & 0.09 & 0.65 & 0.00 & 0.00 & 0.000 & 19.62 & 0.31 & 0.043 & 0.93 & 4.89 & 0.112 & 201 \\
\hline
\end{tabular}

Table 2-20 Advanced Burner Reactor Fuel Reprocessing Metal Waste Summary.

\begin{tabular}{|c|c|c|c|c|c|}
\hline \multicolumn{2}{|c|}{ Metal Based Fuel } & \multicolumn{4}{|c|}{$\begin{array}{c}\text { Electrochemical Metal Alloy } \\
\text { Containers: } 2 \mathrm{ft} \text { diameter } \times 10 \mathrm{ft} \text { tall canisters. } \\
\text { Each Canister Contains } 3,600 \mathrm{~kg} \text {. }\end{array}$} \\
\hline $\begin{array}{l}\text { Burn-up } \\
\text { (GW-d/MT) }\end{array}$ & $\begin{array}{c}\text { Conversion } \\
\text { Ratio }\end{array}$ & $\begin{array}{c}\text { Mass } \\
(\mathrm{kg} / \mathrm{MT})\end{array}$ & $\begin{array}{l}\text { Volume } \\
\left(\mathrm{ft}^{3} / \mathrm{MT}\right)\end{array}$ & $\begin{array}{l}\text { Containers } \\
\text { per MT }\end{array}$ & $\begin{array}{l}\text { Decay Heat } \\
\text { (W/container) }\end{array}$ \\
\hline 99.6 & 0.75 & 4,403 & 38.41 & 1.22 & 3,905 \\
\hline
\end{tabular}


Table 2-21 Advanced Burner Reactor Fuel Reprocessing Fission Product Waste Summary.

\begin{tabular}{|c|c|c|c|c|c|c|c|c|c|}
\hline \multirow{2}{*}{\multicolumn{2}{|c|}{ Metal Based Fuel }} & \multicolumn{8}{|c|}{ Electrochemical } \\
\hline & & \multicolumn{4}{|c|}{$\begin{array}{c}\text { Glass Bonded Zeolite } \\
\text { Containers: } 2 \mathrm{ft} \text { diameter } \times 15 \mathrm{ft} \text { tall canisters. Each } \\
\text { Canister Contains } 2,900 \mathrm{~kg} \text {. }\end{array}$} & \multicolumn{4}{|c|}{$\begin{array}{l}\text { Lanthanide Glass } \\
\text { Containers: 6in diameter x 60in tall canisters. Each } \\
\text { Canister Contains } 500 \mathrm{~kg} .\end{array}$} \\
\hline $\begin{array}{l}\text { Burn-up } \\
\text { (GW-d/MT) }\end{array}$ & $\begin{array}{c}\text { Conversion } \\
\text { Ratio }\end{array}$ & $\begin{array}{l}\text { Mass } \\
(\mathrm{kg} / \mathrm{MT})\end{array}$ & $\begin{array}{l}\text { Volume } \\
\left(\mathrm{ft}^{3} / \mathrm{MT}\right)\end{array}$ & $\begin{array}{l}\text { Containers } \\
\text { per MT }\end{array}$ & $\begin{array}{l}\text { Decay Heat } \\
\text { (W/container) }\end{array}$ & $\begin{array}{c}\text { Mass } \\
(\mathrm{kg} / \mathrm{MT})\end{array}$ & $\begin{array}{l}\text { Volume } \\
\left(\mathrm{ft}^{3} / \mathrm{MT}\right)\end{array}$ & $\begin{array}{l}\text { Containers } \\
\text { per MT }\end{array}$ & $\begin{array}{c}\text { Decay Heat } \\
\text { (W/container) }\end{array}$ \\
\hline 99.6 & 0.75 & 2,641 & 42.77 & 0.91 & 225 & 58.39 & 0.11 & 0.12 & 21,165 \\
\hline
\end{tabular}


Table 2-22 Electrochemical Glass Bonded Zeolite Decay Heat Generated by Processing SFR Metal Fuel with a TRU CR of 0.75.

\begin{tabular}{|c|c|c|c|c|c|c|c|c|}
\hline \multirow[b]{2}{*}{ Decay Heat (Watts/Container ) } & \multicolumn{8}{|c|}{ Time (years) } \\
\hline & \begin{tabular}{|c|} 
Initial \\
Production
\end{tabular} & 10 & 30 & 50 & 70 & 100 & 300 & 500 \\
\hline Gases H, C, Xe, Kr, I & 0 & 0 & 0 & 0 & 0 & 0 & 0 & 0 \\
\hline $\mathrm{Cs} / \mathrm{Sr} / \mathrm{Ba} / \mathrm{Rb} / \mathrm{Y}$ & 2,255 & 1,785 & 1,106 & 693 & 435 & 216 & 2 & 0 \\
\hline Noble Metals Ag, Pd, Ru, Rh & - & - & - & - & - & - & - & - \\
\hline Lanthanides La, Ce, Pr, Nd, Pm, Sm, Eu, Gd, Tb, Ho, Tm & - & - & - & - & - & - & - & - \\
\hline Actinides Ac, Th, $\mathrm{Pa}, \mathrm{U}$ & 0 & 0 & 0 & 0 & 0 & 0 & 0 & 0 \\
\hline Transuranic Np, $\mathrm{Pu}, \mathrm{Am}, \mathrm{Cm}, \mathrm{Bk}, \mathrm{Cf}$, Es & 0 & 0 & 0 & 0 & 0 & 0 & 0 & 0 \\
\hline Others & - & - & - & - & - & - & - & - \\
\hline Total & 2,255 & 1,785 & 1,106 & 693 & 435 & 216 & 2 & 0 \\
\hline
\end{tabular}

Table 2-23 Electrochemical Metal Alloy Decay Heat Generated by Processing SFR Metal Fuel with a TRU CR of 0.75.

\begin{tabular}{|c|c|c|c|c|c|c|c|c|}
\hline \multirow[b]{2}{*}{ Decay Heat (Watts/Container ) } & \multicolumn{8}{|c|}{ Time (years) } \\
\hline & $\begin{array}{c}\text { Initial } \\
\text { Production }\end{array}$ & 10 & 30 & 50 & 70 & 100 & 300 & 500 \\
\hline Gases H, C, Xe, Kr, I & 0 & 0 & 0 & 0 & 0 & 0 & 0 & 0 \\
\hline $\mathrm{Cs} / \mathrm{Sr} / \mathrm{Ba} / \mathrm{Rb} / \mathrm{Y}$ & 0 & 0 & 0 & 0 & 0 & 0 & 0 & 0 \\
\hline Noble Metals Ag, Pd, Ru, Rh & 3,777 & 4 & 0 & 0 & 0 & 0 & 0 & 0 \\
\hline Lanthanides La, Ce, Pr, Nd, Pm, Sm, Eu, Gd, Tb, Ho, Tm & 113 & 9 & 1 & 1 & 1 & 1 & 0 & 0 \\
\hline Actinides Ac, Th, Pa, U & 0 & 0 & 0 & 0 & 0 & 0 & 0 & 0 \\
\hline Transuranic Np, Pu, Am, Cm, Bk, Cf, Es & 1 & 0 & 0 & 0 & 0 & 0 & 0 & 0 \\
\hline Others & 15 & 1 & 0 & 0 & 0 & 0 & 0 & 0 \\
\hline Total & 3,905 & 14 & 2 & 1 & 1 & 1 & 0 & 0 \\
\hline
\end{tabular}


Table 2-24 Electrochemical Lanthanide Glass Decay Heat Generated by Processing SFR Metal Fuel with a TRU CR of 0.75.

\begin{tabular}{|c|c|c|c|c|c|c|c|c|}
\hline \multirow[b]{2}{*}{ Decay Heat (Watts/Container ) } & \multicolumn{8}{|c|}{ Time (years) } \\
\hline & $\begin{array}{c}\text { Initial } \\
\text { Production }\end{array}$ & 10 & 30 & 50 & 70 & 100 & 300 & 500 \\
\hline Gases H, C, Xe, Kr, I & 0 & 0 & 0 & 0 & 0 & 0 & 0 & 0 \\
\hline $\mathrm{Cs} / \mathrm{Sr} / \mathrm{Ba} / \mathrm{Rb} / \mathrm{Y}$ & 1,030 & 815 & 505 & 317 & 199 & 99 & 1 & 0 \\
\hline Noble Metals Ag, Pd, Ru, Rh & - & - & - & - & - & - & - & - \\
\hline $\begin{array}{l}\text { Lanthanides La, Ce, Pr, Nd, Pm, Sm, Eu, Gd, Tb, } \\
\text { Ho, Tm }\end{array}$ & 20,135 & 297 & 52 & 10 & 2 & 0 & 0 & 0 \\
\hline Actinides Ac, Th, $\mathrm{Pa}, \mathrm{U}$ & 0 & 0 & 0 & 0 & 0 & 0 & 0 & 0 \\
\hline Transuranic Np, Pu, Am, Cm, Bk, Cf, Es & 0 & 0 & 0 & 0 & 0 & 0 & 0 & 0 \\
\hline Others & - & - & - & - & - & - & - & - \\
\hline Total & 21,165 & 1,112 & 556 & 327 & 201 & 99 & 1 & 0 \\
\hline
\end{tabular}




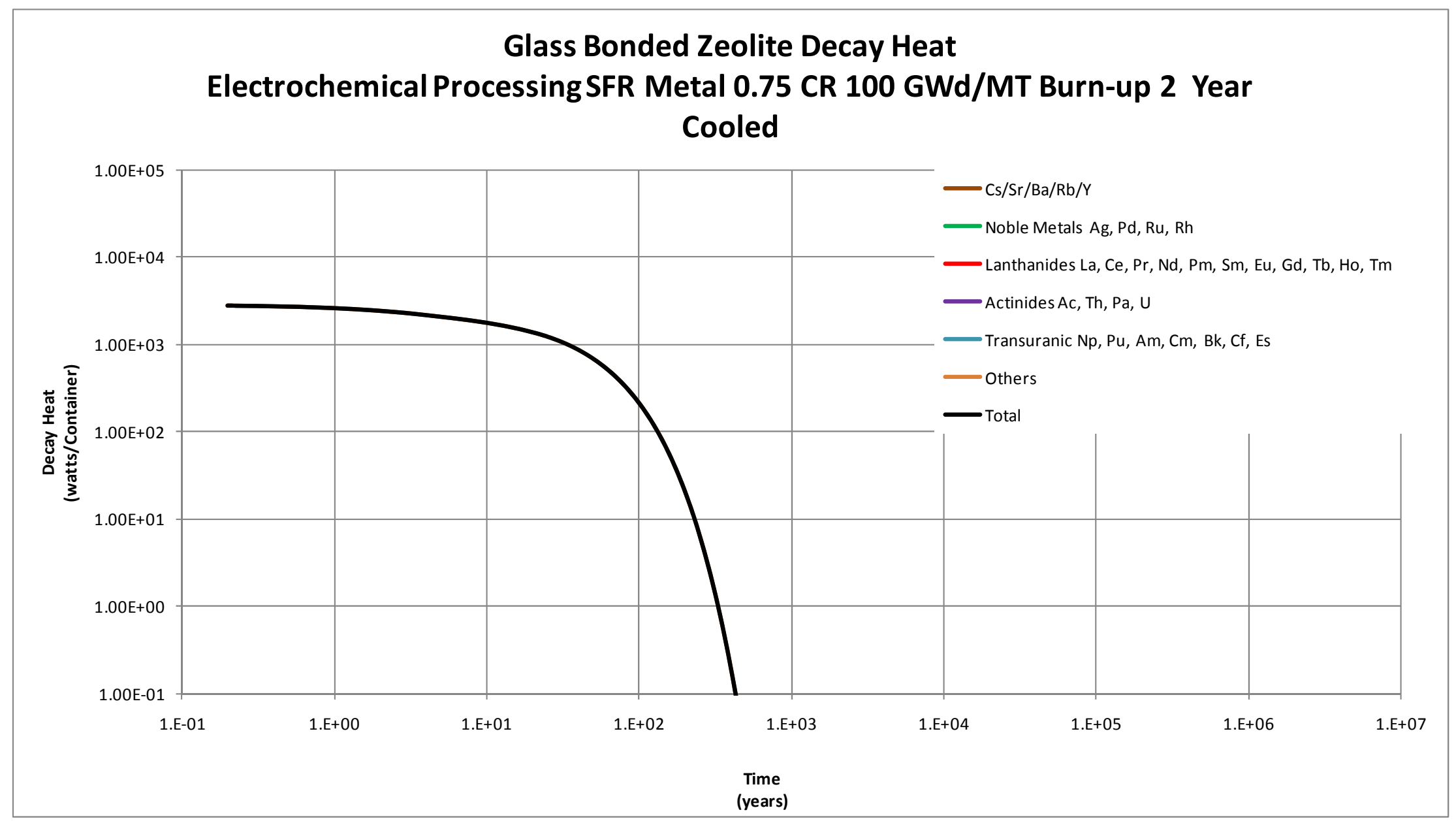

Figure 2-8 Electrochemical Glass Bonded Zeolite Decay Heat Generated by Processing Sodium Fast Reactor Metal Fuel with a TRU CR of $\mathbf{0 . 7 5 .}$ 


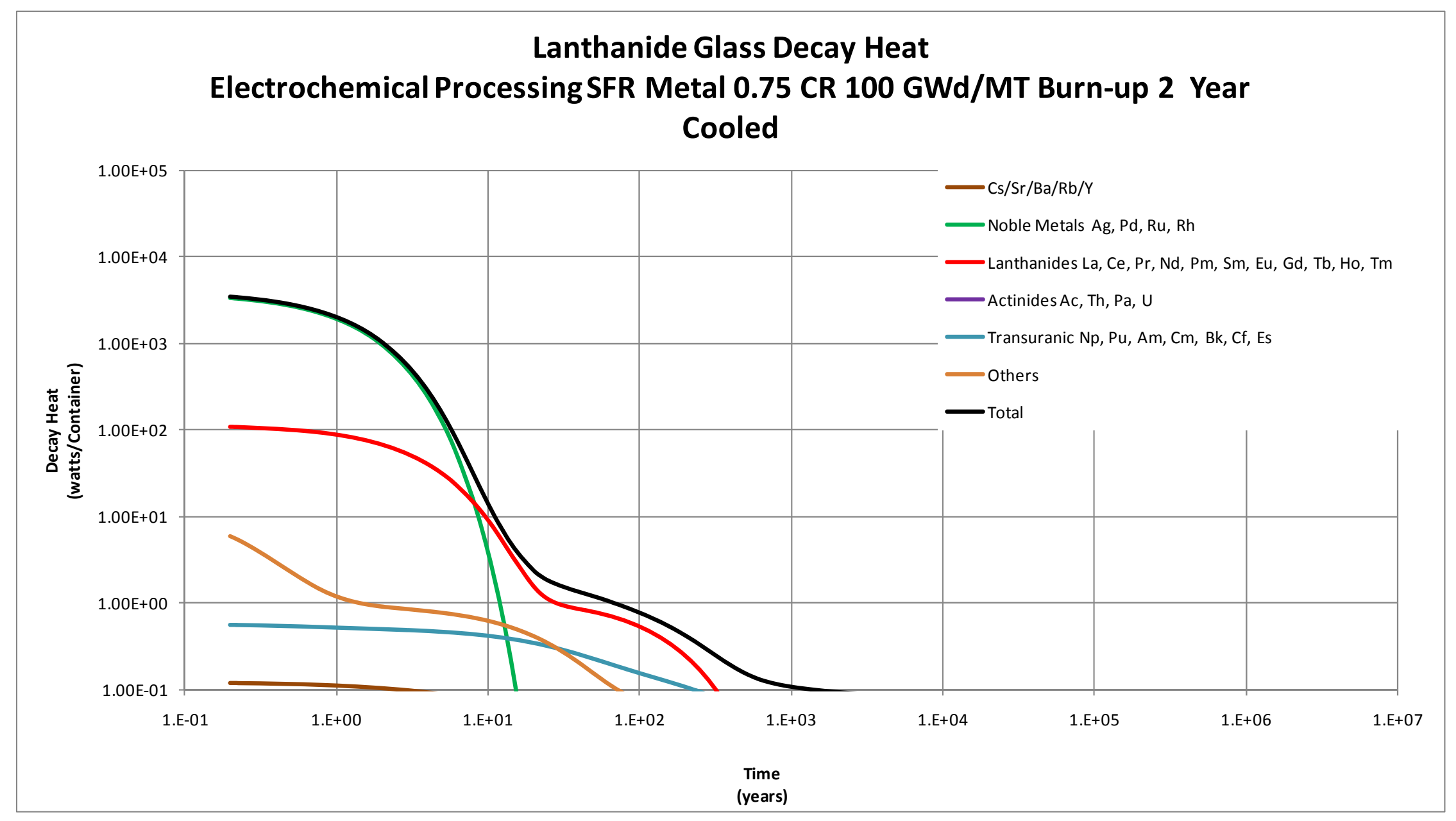

Figure 2-9 Electrochemical Lanthanide Glass Decay Heat Generated by Processing Sodium Fast Reactor Metal Fuel with a TRU CR of 0.75 . 


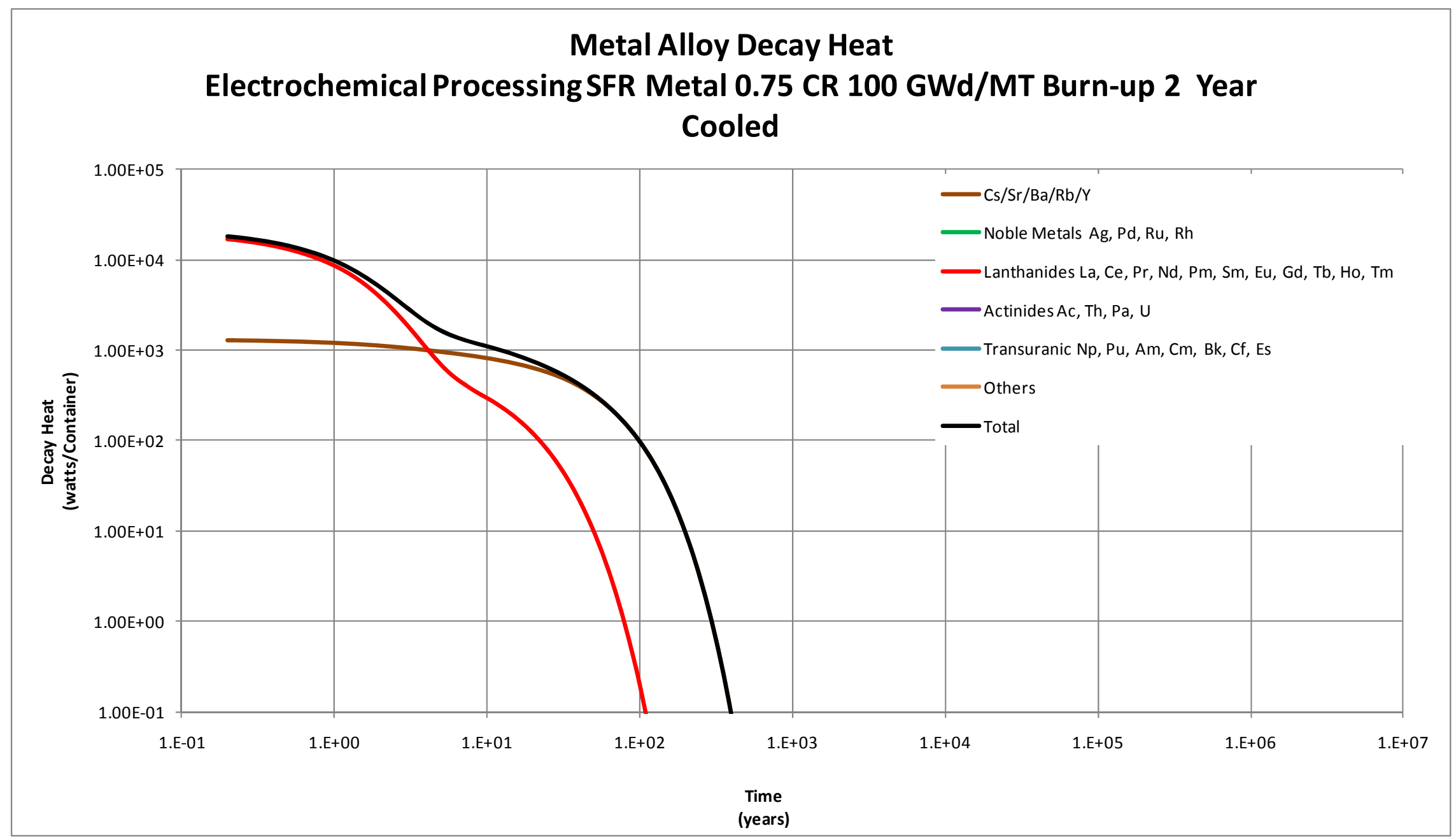

Figure 2-10 Electrochemical Metal Alloy Decay Heat Generated by Processing Sodium Fast Reactor Metal Fuel with a TRU CR of $\mathbf{0 . 7 5}$. 
THIS PAGE INTENTIONALLY LEFT BLANK 


\subsubsection{Characteristics of Closed Cycle Secondary Waste}

Secondary wastes from the operation of closed FC facilities include

- Operational waste such as empty containers, solidified decontamination solutions, used process filters, etc.

- Job control waste such as protective clothing, plastic suits, contamination control materials, step-off pads, etc.

- Maintenance waste such as failed equipment, HEPA filters, etc.

Secondary wastes are primarily characterized as low level (Class A, B and C) waste and GTCC waste. Relatively small quantities of mixed wastes are also anticipated from closed FC facility operations (such wastes are subject to additional statutory and regulatory requirements, such as the Resource Conservation and Recovery Act enacted by the U.S. in 1976).

\subsubsection{Secondary Waste From Reprocessing LWR Fuel}

Estimates of the volume of secondary waste resulting from a variety of recycling processes are investigated by Jones (2010). Secondary wastes from reprocessing operations are dependent on the reprocessing technology (in this case New Extraction) and the facility capacity. A facility capacity of $800 \mathrm{MTHM} / \mathrm{year}$ is a reasonable size for a reprocessing facility and is chosen as the basis for this analysis. Table 2-25 shows the annual volume of secondary waste expected from a Co-Extraction facility with a capacity of $800 \mathrm{MTHM} / \mathrm{year}$.

Table 2-25 Annual Secondary Waste Volume from an 800 MTHM/year New Extraction Facility.

\begin{tabular}{|l|c|c|}
\hline \multirow{2}{*}{\multicolumn{1}{|c|}{ Waste Type }} & \multicolumn{2}{c|}{ Annual Waste Volume } \\
\cline { 2 - 3 } & $\mathbf{m}^{\mathbf{3}}$ & $\mathbf{m}^{\mathbf{3}} \mathbf{\text { MTHM }}$ \\
\hline Low level Class A/B/C & 8,821 & 11.0 \\
\hline Greater than Class C (GTCC) & 477 & 0.6 \\
\hline Mixed low level Class A/B/C & 32 & 0.04 \\
\hline Mixed GTCC & 48 & 0.06 \\
\hline
\end{tabular}

\subsubsection{Secondary Waste From Advanced Burner Reactor Fuel Fabrication}

Secondary waste from the fabrication of ABR fuel using transuranic radionuclides from UNF has not been estimated. It is anticipated that the waste volume would be on the order of that estimated for MOX fuel fabrication using plutonium recovered from UNF (see Section 2.2.4.2). Waste volume from ABR fuel would be expected to be slightly higher though, given the expected higher activity level of the feedstock which would contain additional radionuclides. At this time, the waste volume estimates for MOX fuel fabrication given in Section 2.2.4.2 should be used for ABR fuel fabrication. 


\subsubsection{Secondary Waste From Repository Operations}

Secondary waste volumes specifically for the disposal of HLW forms (e.g., vitrified waste forms) have not been estimated. It is expected that the HLW forms will require some repackaging at the repository similar to that required for UNF in the once-through cycle (see Section 2.1.2). Accordingly, it is recommended that the waste volume estimates provided in Section 2.1.2.1 be used for secondary wastes associated with the disposal of HLW resulting from a closed FC.

\subsubsection{Secondary Waste From Electrochemical Reprocessing of ABR Fuel}

Secondary waste volume estimates for the electrochemical re-processing of ABR fuels were obtained from Jones (2010) and are shown in Table 2-26.

Table 2-26 Summary of Annual Waste Volume Estimates For Electrochemical Recycling Of Sodium Fast Reactor Used Fuel.

\begin{tabular}{|c|c|c|c|c|c|c|}
\hline $\begin{array}{c}\text { Data } \\
\text { Reference }\end{array}$ & $\begin{array}{c}\text { Estimate } \\
\text { Basis }\end{array}$ & $\begin{array}{c}\text { Waste } \\
\text { Volume }\end{array}$ & $\begin{array}{c}\text { LLW } \\
\text { Class A, } \\
\text { B \& C }\end{array}$ & $\begin{array}{c}\text { GTCC } \\
\text { Waste } \\
\text { (CH \& RH) }\end{array}$ & $\begin{array}{c}\text { Mixed } \\
\text { LLW }\end{array}$ & $\begin{array}{c}\text { Mixed } \\
\text { GTCC }\end{array}$ \\
\hline $\begin{array}{c}\text { EAS Electro- } \\
\text { chemical }\end{array}$ & $\begin{array}{c}300 \\
\text { MTHM/yr }\end{array}$ & $\mathrm{m}^{3} / \mathrm{yr}$ & 2,716 & 919 & 29 & 43.6 \\
\cline { 3 - 8 } & $\mathrm{m}^{3} / \mathrm{MTHM}$ & 9.1 & 3.1 & 0.1 & 0.15 \\
\hline
\end{tabular}




\section{Geologic Settings and Host Media}

The forty-eight contiguous U.S. states contain many geologic settings likely to be technically suitable for deep geologic disposal of nuclear waste. Given suitable repository concepts of operation, there is substantial confidence that compliance with regulatory standards for human and environmental protection can be demonstrated for various rock types including salt, clay, shale, volcanic rock, granite, and deep borehole settings (crystalline basement). The following discussion is based on reviews by Hansen et al. (2011) and Rechard et al. (2011) each of which cites some of the extensive, previous work done internationally and in the U.S. to investigate potential geologic host media.

As discussed in Section 1 of this report, consideration of alternative disposal concepts in the 1970s and 1980s included deep borehole, sub-seabed, shallow alluvium, rock melt, direct injection, and ice-sheet disposal, in addition to mined geologic disposal (Rechard et al. 2011). Hydrogeologic settings that have been considered include saturated, unsaturated, coastal, stable interior, and islands (Rechard et al. 2011). Mined geologic disposal was selected for development in the U.S. and other countries, based on the extent of R\&D that would be required, constraints from treaties and international law, and other considerations. Sub-seabed and deep borehole disposal concepts were identified as potentially promising alternatives. Deep borehole disposal has been further investigated more recently (SKB 1992, 2010; Brady et al. 2009) and remains the leading alternative to mined geologic disposal.

The U.S. pursued deep geologic repository programs in granite, shale, salt, and volcanic rock in the years leading up to the Nuclear Waste Policy Act (NWPA) (Rechard et al. 2011). Granite investigations included a full-scale emplacement demonstration in an underground research laboratory at the Climax Stock on the Nevada Test Site. Shale programs were supported by laboratory testing and limited field testing, but no underground research laboratory was developed nor was any disposal demonstration conducted in the U.S. Full-scale underground disposal demonstrations and/or extensive underground research laboratories were undertaken at salt sites including near Lyons, Kansas, at Avery Island in Louisiana, and near Carlsbad, New Mexico. The 1987 NWPA amendment act (NWPAA) directed that only volcanic rock at Yucca Mountain, Nevada would be characterized to support the License Application.

The disposal option in unsaturated, volcanic rock at Yucca Mountain site has been extensively described in many documents supporting the June, 2008 License Application for repository construction (DOE 2008b). Additional work on unsaturated, crystalline rock settings (including volcanic tuff) is not needed for the present generic study because much has already been learned from characterization of the Yucca Mountain site.

To summarize, mined geologic disposal of SNF and HLW was selected in the 1980s by the U.S. and other countries, as the most promising approach compared with various alternatives. Selection of clay/shale, salt, and crystalline media for reference disposal concepts in this study is consistent with international progress since the 1980's, and previous work in the U.S. Reference disposal concepts are selected for these media and for deep borehole disposal, in Section 4.

Suitable geologic formations typically exhibit favorable depth, thickness, tectonic stability, and other key geologic characteristics that limit waste dissolution and radionuclide transport: 
- Depth - The disposal horizon should be determined based on site-specific conditions. Geologic isolation is attained by ensuring significant separation between the repository and the biosphere, which would provide extensive zones for robust seal systems. Rock strength characteristics would also determine a practical and functional mining depth. For deep borehole concepts, proposed disposal zone depths are 2 to $5 \mathrm{~km}$.

- Thickness - Maximal thickness of the isolation medium is desired to ensure radionuclide migration does not exceed regulatory criteria or boundaries. Various "minimal" thicknesses have been put forward, generally of the order of $100 \mathrm{~m}$. However, the thickness of the formation is less important than its uniformity and structure.

- Uniformity and Structure - The potential repository interval and surrounding rock should be reasonably homogeneous both vertically and horizontally. The related benefits are simpler and more transparent characterization and performance assessments and safer repository mining and operations.

- Seismicity -Seismically quiescent regions favor simpler repository design and operations, and long term performance.

Key geologic and hydrologic attributes of the host rock should also include:

- Hydrogeology - Low hydraulic conductivity $\left(\sim 10^{-12} \mathrm{~m} / \mathrm{sec}\right.$ or lower).

- Self-sealing - Rocks with plastic deformation characteristics tend to reestablish diffusion-dominated transport after excavation effects and damage.

- Hydrogeochemistry - Reducing chemical conditions minimize degradation rates for engineered barriers and waste forms, reduce the solubilities for most radionuclides, and improve sorption. Oxidizing environments are also technically feasible but would require low hydraulic flux as found in desert environments.

Other considerations that could be important in a siting process include the potential for disruption by natural processes such as seismicity, human intrusion, and sociopolitical issues such as proximity to population centers.

Sandia has recently published in-depth technical reports on the performance of used fuel/HLW repositories in generic clay/shale, salt, crystalline rock, and deep borehole settings (Hansen et al. 2010; Hansen and Leigh 2011; Mariner et al. 2011; Brady et al. 2009). These reports contain maps, originally developed by others, that illustrate the occurrence of granite, shale, and salt. The following paragraphs briefly review the basis for including these geologic settings in this study. These settings exist in the U.S., with background information available showing that geologic conditions are suitable for waste disposal.

\section{Crystalline Rock Formations}

The 48 conterminous states have an abundance of crystalline rock formations (Hansen et al. 2010, Figure 1). Several countries have determined that crystalline rock (also called "granite") formations are adequate for mined geologic disposal. Following enactment of the NWPA in 1982, the U.S. had an active second-repository program that evaluated crystalline rock formations. The NWPAA in 1987 ended the crystalline repository program in the U.S., but R\&D programs for waste disposal in crystalline rock continued in Finland, Sweden, and Switzerland. Mined repositories in crystalline rock are currently scheduled to open in 2020 in Finland and 
2025 in Sweden. Crystalline rock is also considered as a possible host medium by several other countries including China, Japan, and the United Kingdom.

\section{Salt Formations}

Use of salt formations for nuclear waste disposal was originally recommended by the National Academy of Sciences (NAS 1957), and a geologic repository for TRU waste has been successfully operated at the Waste Isolation Pilot Plant near Carlsbad, New Mexico for 11 years. The conterminous U.S.A has many large salt formations, including bedded and domal salt (Hansen et al. 2011, Figure 3, taken from Johnson and Gonzales, 1978). Four major regions of the U.S. where salt formations are found include: 1) Gulf Coast; 2) Permian Basin; 3) MichiganAppalachian Region; and 4) Williston Basin. Domal salts are found in the Gulf Coast region and Paradox Basin, and bedded salts are present in the remaining three major salt regions of North America. In 1985, the Secretary of Energy nominated three salt sites for further consideration, and the President subsequently selected one of these three sites to fully characterize. Like the crystalline repository program, the salt repository program was ended by the 1987 enactment of the NWPAA.

\section{Clay or Shale Formations}

Shale formations meeting the general guidelines for depth, thickness, and other criteria summarized above are also common in the U.S.A (Hansen et al. 2010, Figure 2, taken from Gonzales and Johnson 1984). There are potentially significant differences in rock characteristics included in this category of sedimentary rock, as discussed in a recent study of the performance of shale repositories for HLW in the U.S.A. Shale includes a spectrum of rocks with different characteristics grading from unconsolidated clay stone, to lightly indurated mudstone having shale texture and composition, to a compact argillite. Because high clay content is needed to ensure low permeability and plasticity, the term "argillaceous rock" is also appropriate for this general rock type.

Gonzales and Johnson (1984) concluded that the most desirable host rocks should be between 300 and $900 \mathrm{~m}$ below ground level, at least $75 \mathrm{~m}$ thick, relatively homogeneous in composition, and in an area of low seismicity and favorable hydrology that is not likely to be intensively exploited for subsurface resources.

Some characterization of shale as a host medium for waste disposal in U.S. has been undertaken. From the 1970s until the mid 1980s Oak Ridge National Laboratory (ORNL) led the U.S. R\&D effort in this area, directing limited programs to characterize a few shale formations. Until such time as the U.S. repository program investigates specific shale formations in the U.S., international collaborations with France and Switzerland may be the most important sources of information.

\section{Deep Borehole Disposal}

Deep borehole disposal in generic crystalline basement rock could be located virtually anywhere that Precambrian basement rock is within about $2 \mathrm{~km}$ of the ground surface. Deep borehole disposal is potentially favorable in part due to the wide expanse of crystalline basement rock at appropriate depth in the lower 48 states (Hansen et al. 2010, Figure 4). Though the elevated temperature and salinity of deep fluids could accelerate corrosion of steel pipes, fuel assemblies, and the waste itself, the low permeability, high salinity, and geochemically reducing conditions 
at many locations in the deep crystalline basement would limit significant fluid flow and radionuclide transport.

\section{Other Geologic Media}

In addition to clay and shale, carbonate rock may prove to be suitable for hosting a HLW repository. Sedimentary carbonates (e.g., chalk and limestone) would provide abundant $\mathrm{pH}$ buffering capacity, and they are thought to have favorable physical adsorption and chemical fixation characteristics, and moderate resistance to thermal damage. Carbonate rock is commonly subject to dissolution processes, especially if fractured or otherwise permeable to groundwater, and suitability would depend on site-specific formation characteristics. Although not much HLW repository concept development has been done to date with respect to carbonate formations, the Ontario Power Generation company of Canada has proposed to build a repository for LLW and intermediate level waste (ILW) in limestone at a depth of $680 \mathrm{~m}$ (Rechard et al. 2011).

\section{Summary}

The forty-eight conterminous states contain many geologic formations that could be technically suitable for deep geologic disposal of nuclear waste. These include crystalline rock, clay/shale media, bedded salt, and crystalline basement rock, which are considered further in developing reference disposal concepts (Section 4.5). Given appropriate repository designs, it is likely that a geologic disposal system could be implemented in any of these settings, so as to meet technical performance objectives as they currently exist in the U.S. regulatory framework. 


\section{Concepts of Operation}

This section describes thermal limits as they might be used in a wide range of repository systems, and the design features or operational limits that are available to achieve such limits. The section then proposes reference concepts of operation (also called design concepts) for the host media selected in Section 3. The design feature discussion here focuses on thermal management, but there are many other aspects such as waste handling, packaging, storage, and emplacement details, other construction and operational details, and repository sealing, closure, and monitoring, that make up that overall concept of operations. These are beyond the scope of this study, but some are being studied separately (e.g., storage) or are included in generic R\&D studies (Jove-Colon 2010). Some of these details such as waste handling and packaging involve technologies that are not specific to the geologic host medium, while others such as sealing, closure, and monitoring are likely site specific and could be deferred to a later phase in the waste management program.

A range of alternatives is available for natural settings, and a range of technologies is available for engineered features, of the disposal system. A catalog that includes many of these alternatives is provided in Appendix I. This information is presented in outline form but is intended to be inclusive. In other words, one may select many items from throughout the list to describe a particular disposal system, and some combinations of items may not be possible or physically realizable. We expect the catalog will be useful in the future as concepts of operation, either generic or site-specific, are developed in more detail.

This section describes the types of thermal limits that can be imposed at different locations and various times, for typical disposal systems. It then presents some of the measures that can be used in repository design and operations, to achieve these limits. A discussion of emplacement modes is presented, to reinforce the central observation that "enclosed" modes have more stringent thermal limits than "open" ones. This is followed by a brief survey of waste containers and packages that are in use, or have been proposed. Finally, this section presents the reference design concepts selected for crystalline, clay/shale, salt, and deep borehole settings, and explains the dimensions and parameters selected for use in thermal analysis.

\subsection{Concepts of Operation: Thermal Management}

Experience with disposal concepts for heat-generating nuclear waste has demonstrated that the thermal loading considerations are important because they constrain such key requirements as repository layout, waste package size, design of other EBS components, and operations. Thermal processes in the EBS affect both the engineered and natural components of the disposal system. Within the EBS, thermally driven coupled processes can affect the degradation of engineered barriers and their associated properties, the rates that radionuclides are released from the waste forms, and radionuclide transport characteristics. The design of HLW repositories, specifically the density at which waste can be disposed, may be constrained by thermal limits. For design purposes, thermal constraints may be established for the waste form itself, worker safety, structural response, and design considerations. This initial generic exercise lays out possible reference configurations against which future FEP analyses can be developed. 


\subsubsection{Thermal Constraints Considered}

Thermal constraints may be imposed as limiting temperatures, or limiting results (minimal or maximal) for thermally driven processes. Such constraints may be imposed for the host rock (or other natural features) or for engineered systems.

\subsubsection{Far-Field Thermal Constraints}

1. Limit thermally induced stresses or displacements in the host rock or other units, close to the repository, to limit formation of new hydrologic flow paths, or to limit degradation of boreholes and mined openings. For some disposal concepts such as mined disposal in salt or clay/shale, large rock deformations are desirable because they close openings and seal the repository to fluid movement. Thermal loading has not been proposed to promote closure, but investigation of thermal-mechanical coupling would be part of any repository development program for heat-generating waste.

2. Limit large-scale thermal expansion, to limit or prevent induced fracturing or displacement along faults or fractures. For example, thermoelastic expansion throughout the repository host rock and other units will cause thermal stresses on faults and other discontinuities where potentially deleterious displacements may occur.

3. Limit thermally driven coupled processes, for example, thermal-hydrologic-mechanical (THM) processes in shale, which are caused by thermal expansion of pore fluid, and also where heat vaporizes and releases moisture, causing desiccation and shrinkage. Such processes may be sensitive to threshold temperature effects, such as the local boiling point of water, or they may be sensitive to thermal gradients. Boiling accelerates solute transport and chemical precipitation (which are THMC processes) while thermal gradients can facilitate processes such as thermally driven Onsager transport couples in low-permeability media (discussed by Hardin et al. 1997).

4. Limit the migration of brine-filled fluid inclusions, up the thermal gradient towards heatgenerating waste in salt media. The rate of brine migration may fall off rapidly with decreasing temperature gradient, and could thus be a threshold effect.

While some of these constraints pertain to the far-field (i.e., limit large-scale thermal expansion), most pertain to the near field where temperatures are greater. Constraining temperature history in the near-field effectively constrains temperatures in the far-field. The YM repository concept is unique in constraining far-field temperature separately, because its peak temperatures are well above the boiling point for water or brine, while the host medium supports hydrologic flow (which is assured in the far field by limiting temperature to below boiling). Other concepts as discussed in this report, have found near-field temperature limits to be sufficient.

\subsubsection{Near-Field/Engineered Barrier System Thermal Constraints}

1. Limit alteration of clay in buffers, for example by illitization or cementation. Alteration generally involves dissolution, aqueous transport, and precipitation. Alteration products can include illite (for temperature $>150^{\circ} \mathrm{C}$ in the presence of potassium ions), and silica (as a precipitate). Clay alteration generally degrades swelling pressure, increases rigidity promoting fracture, and potentially decreases sorption. For example, the French authority Andra proposed a $90^{\circ} \mathrm{C}$ limit for the hottest point in swelling clay buffers, while the Swedish program has adopted a peak temperature of $100^{\circ} \mathrm{C}$. Variations on clay buffer 
limits have been proposed, for example, limiting an outer portion of the buffer cross section to $125^{\circ} \mathrm{C}$ (NAGRA 2003). For this study, we adopt a target maximum temperature of $100^{\circ} \mathrm{C}$ for clay buffers.

2. Limit thermally induced micro-cracking in the less ductile crystalline rock types (e.g., crystalline, igneous or metamorphic), to avoid degradation of in situ mechanical properties or creation of flow paths. For example, the Yucca Mountain concept included a nominal limit of $200^{\circ} \mathrm{C}$ for the host rock, to limit thermal degradation of in situ rock characteristics (Hardin et al. 1997). Crystalline rock could exhibit this mode of degradation, but with the use of clay buffers (as in this study) the clay temperature limit is controlling.

3. Limit temperature of the host medium to control uncertainty in performance models. For salt, a more ductile material, a target value of $200^{\circ} \mathrm{C}$ has been proposed for the maximum temperature, to limit uncertainty in performance assessment, although higher peak temperatures may be possible if supported by test data (BMWI 2008). The Environmental Assessment for disposal of SNF and HLW at the Deaf Smith County, Texas site indicates that maximum allowable repository temperature is $250^{\circ} \mathrm{C}$ (DOE 1986b). For this study, we adopt a target maximum temperature of $200^{\circ} \mathrm{C}$ for salt media. For the deep borehole disposal concept no near-field temperature limits have been recognized because no performance credit is taken for the near-field host rock, and the boreholes would be spaced far enough apart to preserve the far-field natural barrier function (Brady et al. 2009).

4. Limit the temperature of argillaceous host media to avoid mineralogical changes (e.g., cementation) and thermally driven coupled processes (THM, THMC). Natural clay or shale formations typically contain more impurities such as potassium, which can react with clay minerals, thus temperature limits will be similar to, and possibly lower than for clay buffers. The French authority Andra has proposed a $90^{\circ} \mathrm{C}$ limit for the argillaceous material surrounding waste packages, in the proposed repository in Callovo-Oxfordian shale (Andra 2005a). For this study, we adopt a target maximum temperature of $100^{\circ} \mathrm{C}$ for argillaceous clay/shale media.

5. Limit the waste package surface temperature. Temperature at the waste package surface is used in this study to represent the peak temperature anywhere outside the waste package. This is appropriate because for typical disposal concepts, the waste package and its contents can withstand higher temperatures than the surrounding engineered or natural materials.

6. Limit cladding temperature to $400^{\circ} \mathrm{C}$ for normal conditions of storage and short-term preclosure operations (NRC 2003). During loading operations, repeated thermal cycling (repeated heatup/cooldown cycles) may occur but should be limited to less than 10 cycles, with cladding temperature variations that are less than $65^{\circ} \mathrm{C}$ each (NRC 2003).

7. Limit cladding temperature to $350^{\circ} \mathrm{C}$ during permanent disposal (SNL 2008).

8. Limit the peak centerline temperature of borosilicate glass waste forms below $500^{\circ} \mathrm{C}$ at all times, to avoid devitrification or crystallization. Similar limits have been established by the French program $\left(450^{\circ} \mathrm{C}\right.$; Andra $\left.2005 \mathrm{a}\right)$, the Swiss program $\left(500^{\circ} \mathrm{C}\right.$; NAGRA $2002,2003)$, and the former salt repository program in the U.S. $\left(500^{\circ} \mathrm{C}\right.$; DOE $\left.1986 \mathrm{a}\right)$. 
Preliminary temperature limits for lanthanide glass, glass-bonded zeolite, and metal alloy wastes from electrochemical processing have also been developed (Carter et al. 2011a).

We note that in saturated settings where the repository is situated at depths of hundreds of meters, the local boiling temperature for water may be well over $200^{\circ} \mathrm{C}$. The EBS may not be saturated when peak temperatures occur soon after emplacement, especially in low-permeability host media and in repository openings that are initially unsaturated or dehydrated, and have been backfilled, plugged, and/or sealed to inhibit water ingress. Thus, boiling could occur locally within the EBS with temperatures near $100^{\circ} \mathrm{C}$, and the European programs have adopted corresponding temperature limits.

There are two types of temperature limits that may be applied: peak temperature and temperature-time exposure. Peak temperature limits are appropriate to prevent relatively rapid processes that exhibit temperature threshold-like behavior (e.g., cementation in clay buffers). Engineered materials may exhibit temperature-time dependent degradation, whereby the time above a threshold temperature, or the integration of degradation as a function of both time and temperature, is more important (e.g., metal de-alloying). Other degradation processes may have rates that are functions of temperature and mechanical load (e.g. high temperature creep).

It is important to note that thermal constraints are considered here for the purposes of advancing repository design concepts, establishing reference configurations, and generating cost estimates for alternative disposal concepts. Ultimately, thermal constraints will be considered in the context of FEP screening, supported by performance assessment and risk-based consequence analyses. In other words, constraints discussed here likely do not describe all thermal limits that may be imposed. Repository designers may choose to use thermal limits as a basis for limiting or excluding FEP, or to limit the amount of R\&D needed to support FEP analysis, or in response to regulatory input. With that said, however, the limits considered here address some major FEPs, and the limits needed for further FEP analysis are likely to fall within those discussed here.

\subsection{Thermal Management Options}

\subsubsection{Host Rock Heat Dissipation}

The geologic setting (including groundwater and surface processes) is the immediate sink for heat generated in the repository. Host rock thermal conductivity determines the temperature increase from the far field, up the thermal gradient to the waste packages, for any particular repository heat input. Geologic media have different thermal conductivities, ranging from relatively porous, unsaturated, low-conductivity media, to high-conductivity media such as certain salt formations (see discussion in Section 5 of this report). As shown in Section 5, selecting a high-conductivity medium can lower peak temperatures (other factors held constant) and thereby provide greater flexibility in repository design and loading strategy.

Other host rock attributes that can affect heat dissipation include repository burial depth, and change in boundary conditions such as surface erosion, glaciation, etc. Changes imposed at greater distance $L$ affect repository temperature at later times $\Delta t$, according to the relationship $\Delta t \propto L^{2} / \kappa$ where $\kappa$ is thermal diffusivity. (The proportionality indicates that $\Delta t$ depends on the relative magnitude of temperature change.) The time at which an effect is felt varies as $L^{2}$, which means that future changes at the ground surface would influence the repository well after the peak waste package temperature occurs. 


\subsubsection{Waste Package Size}

The size of a waste package controls the amount of heat-generating waste that it contains, and the relative extent of surface area available for transfer of heat to the surroundings. Other factors held constant, smaller waste packages allow significantly cooler temperatures in the repository near field, while the number of packages, number of handling operations, and repository footprint are likely to be increased. Smaller waste packages can facilitate earlier emplacement in the repository and shorter duration of decay storage. The smallest waste packages for SNF considered in this study are for the deep borehole concept, while the largest (12-PWR or equivalent) are considered in sensitivity analyses.

\subsubsection{Blending of Waste Types, and Sequencing of Emplacement}

Where the nuclear FC produces wastes that differ with respect to heat output because of inventory, age, or other characteristics, co-disposal within individual packages can serve as a thermal management tool. Thus, high-burnup SNF assemblies can be combined with low-burnup assemblies, or with other cooler waste types. High-output HLW can be combined with cooler waste of many possible types, in the same packages.

Package sequencing, or blending at the waste package level, was used in the Yucca Mountain thermal management strategy (SNL 2008). For enclosed, mined emplacement modes selected in this report the maximum temperatures are expressed locally and depend heavily on the heat output of individual packages. Thus, blending within waste packages could have a greater impact than package sequencing by heat output.

\subsubsection{Waste Package Spacing}

Waste package spacing can vary from end-to-end emplacement, or "line loading" as proposed for the Yucca Mountain repository, to a "point loading" approach that separates the packages. Lineloading produces more uniform temperatures in the near-field host rock, and maximizes the repository loading density for in-drift emplacement, while point-loading enhances the spreading and dissipation of heat.

The thermal influence from adjacent waste packages is expressed from a few years to hundreds of years after emplacement. The relative contributions to waste package temperature from the immediate package, its neighbors in the same drift, and from adjacent drifts, are investigated in Section 5 of this report. The peak contribution from neighboring packages generally occurs well after the peak temperature, especially for younger SNF or HLW, so waste package spacing has limited value for controlling peak temperature. It can be used to limit longer-term temperatures (tens to hundreds of years). Also, for waste that is stored for a long time (tens to hundreds of years) before emplacement, the heat output is more slowly varying, and peak temperature occurs later. In this case, waste package spacing can have a stronger influence on peak temperature.

\subsubsection{Emplacement Drift, Alcove, and Borehole Spacing}

The spacing between adjacent emplacement drifts, alcoves, or boreholes has a similar effect to the in-drift waste package spacing discussed above. Within adjacent drifts, alcoves, or boreholes, line-loading or point-loading may be used. Drift, alcove, or borehole spacing can also be used to limit far-field host rock temperatures, as was the case for the proposed repository at Yucca Mountain (SNL 2008). 
A multi-level repository layout could be another way to achieve cooler repository temperatures. In the 1980's, when there were nine sites still under consideration in the United States, multilevel repository layouts were considered for the Richton Salt Dome site in Mississippi and the Cypress Creek and Vacherie Salt Dome sites in Louisiana. These are massive, domal salt formations whereas bedded salt could limit repository extent except parallel to bedding. A multilevel layout was also considered for the repository at Yucca Mountain (DOE 1999). Multi-level waste package arrays can increase repository capacity while meeting peak temperature limits within only a few years after emplacement. Over tens to hundreds of years (post-peak) they produce average temperatures in the host rock that may be (depending on waste inventory) significantly greater than for single-layer layouts.

\subsubsection{Aging}

Aging the UNF or HLW incidental to storage, or deliberate aging as part of repository staging and operations, can substantially reduce the thermal power emitted by the waste during repository operations and after permanent closure. The effectiveness of aging, also called decay storage, as a thermal management strategy will vary by waste form, and is generally limited to short-lived radionuclides (e.g., half-lives less than $100 \mathrm{yr}$ ). The simplest effect of aging is to allow decay of short lived fission products Cs-137 and Sr-90, which are present in UNF and many types of HLW, and typically produce the majority of decay heat for 30 years or longer. Aging also allows decay of short-lived actinides such as Pu-241 and Am-241, which are present in SNF and TRU-containing waste forms. In many waste forms including those described in Section 2 of this report (for example, Table 2-2 and Figure 2-1) peak temperatures at the waste package are caused by short-lived fission products, while post-peak temperatures, and the maximum average host rock temperature, are more strongly associated with decay of certain actinides (e.g., Am-241) with somewhat longer half-lives.

Over periods longer than approximately 100 years, alpha decay of various actinides - principally $\mathrm{Pu}$ and $\mathrm{Am}$ - dominates the decreased heat output of UOX UNF. The actinides account for the majority of the cumulative heat that is generated after decay of short-lived fission products, during the first 1,000 years after reactor discharge.

The effectiveness of aging for MOX SNF will differ from UOX SNF. The heat output of irradiated Pu-MOX fuel (Table 2-9 and Figure 2-4) is dominated by the TRU elements rather than fission products, for any time period relevant to practical storage or repository operations. Because of the longer half lives of the transuranics, aging MOX is not as effective at reducing heat output (for a given duration of aging) as aging of UOX UNF.

\subsubsection{Segregated Disposal of Waste Forms}

Another proposal for reducing the heat output of waste forms to be emplaced in a repository, is to separate the short-lived fission products (e.g., chemical separation of Cs and $\mathrm{Sr}$ ), and segregate them from other wastes in a different part of the repository. The segregated $\mathrm{Cs}$ and $\mathrm{Sr}$ (containing mostly Cs-137 and Sr-90) could overheat the part of the repository where they are emplaced, with limited impact on the overall repository performance because these radionuclides (and their short-lived daughters) decay to stable nuclides. The other fraction of the waste containing actinides and longer-lived fission products, would be emplaced elsewhere in the repository, in a lower temperature environment. This proposal could allow more dense loading of the long-lived waste in a different part of the repository if: 1) separation of all other long-lived

radioelements is essentially complete, and 2) Cs-135 (half-life 2.3 million years) is separated 
from Cs-137, or is sufficiently immobile in the disposal environment. Thus, for example, segregation of $\mathrm{Cs}$ and $\mathrm{Sr}$ could be an effective thermal management tool (without compromising waste isolation) if the disposal environment effectively traps Cs by chemical sorption.

Reactor transmutation of separated Cs (containing Cs-135) in targets has been proposed as a way to minimize the contribution of Cs-135 to radiotoxicity of a segregated waste form, but transmutation of fission products is relatively ineffective (Sevougian et al. 2011). Instead, a more feasible strategy may be to separate $\mathrm{Cs}$ and $\mathrm{Sr}$, age the waste form for 50 to 100 years for cooling, and then dispose with other cooler waste forms in a repository.

\subsection{Waste Package Design Considerations}

This section summarizes how different waste types, including SNF, HLW glass and other refractory waste types, and LLW, would be packaged for disposal in a geologic repository. A fundamental distinction is made between HLW canisters, or SNF containers, and overpacks for storage, transport, and disposal. Together the canister/container and disposal overpack are often referred to as a waste package. A waste canister/container is generally sealed permanently at the point of origin, thereby avoiding any further exposure of the waste during successive handling and repackaging operations. Overpacks provide economical means to meet different requirements such as heat dissipation, impact damage limits, and corrosion resistance. Overpacks for storage and transport would be re-useable, whereas those for disposal would become permanent parts of the EBS at emplacement.

\subsubsection{Waste Packages for SNF and HLW}

Containers for SNF provide structural integrity and support to the used fuel, criticality control, heat dissipation, containment during handling and repackaging, and containment after permanent disposal. These functions are met using internal features such as racks for fuel support, thermal shunts, moderator exclusion features, neutron absorbers, flux traps, and inserts or fillers. These internal features must be engineered "up front" for all storage, transport, and disposal functions, in order for the containers to be permanently sealed at the point of origin.

Containers for SNF are typically loaded in fuel pools, and are immersed in the boric acid solution used in most such pools. Accordingly, the containers are fabricated from materials such as stainless steel that limit corrosion and do not disperse particles or other products of corrosion into the pools. Carbon steel can be used and is a cost-effective alternative, but must be completely and effectively coated to prevent interaction with water and boric acid in fuel pools (NRC 1999). Stainless steels also provide more resistance to radiolytic corrosion during storage when high gamma fields exist, and traces of moisture, along with air, are present on the container surface.

Typical containers for SNF are thin-walled stainless steel structures, with internal stainless steel racks or "baskets" to hold fuel assemblies and provide strength and rigidity. Containers can have external features such as flanges, rings, or trunnions to facilitate handling. Neutron absorbing structures can be made from borated stainless steel, or other materials with protective coatings. Moderator exclusion can be addressed in container design by incorporating filler materials, or simply limiting the size of the containers and the amount of SNF they contain. The containers are sealed by welding, or less commonly, with bolted closures. During the sealing operation the water or boric acid solution must be drained, residual moisture removed by evacuation, and the 
containers charged with inert gas (helium for its heat transfer properties, or argon if needed to maintain the replacement atmosphere during welding).

The transport/aging/disposal (TAD) container for SNF proposed for the Yucca Mountain disposal system, incorporated a typical range of container features (DOE 2008b). The TAD container is unique among disposal containers proposed internationally because of the relatively large quantity of SNF that it can hold, due to the particular aspects of the Yucca Mountain disposal concept (i.e., "open" emplacement mode in an unsaturated host medium, such that heat can be removed by ventilation for 100 years).

Pour canisters for HLW glass, or other refractory waste forms, are typically made from stainless steel to resist corrosion in air at elevated temperature, and from radiolysis during storage. Pour canisters are simple, thin-walled vessels with welded closures, and are designed to have low mass and thus cool quickly. The same canister design may be used for other waste forms such as compacted hulls and hardware, or immobilized process waste.

Disposal overpacks have been proposed for repository projects in the U.S. and internationally. For the Yucca Mountain disposal system the overpack consisted of an additional, structural layer of stainless steel, enclosed by an outer layer of corrosion-resistant Alloy 22 (DOE 2008b). For SNF this overpack just fit over the TAD container, while for HLW it was configured with an internal basket to hold HLW pour canisters and stainless canisters containing defense SNF. This arrangement was designed to optimize the containment lifetime, i.e., the expected waste package longevity before any type of breach, in the Yucca Mountain disposal environment. Disposal overpacks typically provide structural support, and may provide no corrosion performance, or relatively short corrosion lifetime for limited waste containment (e.g., using corrosion allowance materials with lifetimes of thousands of years), or long corrosion lifetime for waste containment (e.g., using corrosion resistant materials).

For previous projects in the U.S., disposal overpacks of carbon steel and stainless steel have been proposed (e.g., ONWI 1985, ONWI 1987a,b). Carbon steel corrosion occurs by well understood mechanisms making it suitable as a "corrosion allowance" material in applications where waste containment is required for only a few thousand years (DOE 1998). Thick-walled carbon steel overpacks facilitate waste handling and ensure package integrity during repository operations, even if loaded by swelling buffer materials or deforming host rock (Section 4.5). Overpacks of titanium have been proposed for use in crystalline rock (see Section 4.3.1.4) where long containment lifetime is required.

For the Swedish KBS-3 disposal concept, a thick-walled package of pure copper is proposed (SKB 2011). Copper has a very small rate of corrosion in the chemically reducing conditions present in the proposed host rock. The package will contain a cast iron insert, designed to support the SNF, and to corrode slowly while consuming oxygen once waste package breach occurs. As proposed, the SNF waste will not be sealed in a stainless steel container, so dry handling will be used in the "encapsulation" facility.

For the French (Andra) disposal system in shale, HLW canisters of stainless steel are proposed, with direct disposal in boreholes lined with carbon steel (Andra 2005a). Used fuel would also be canistered in stainless steel, with a steel overpack, and emplaced in a clay buffer. A Swiss (NAGRA) proposal would embed HLW canisters in cast iron waste packages, to be emplaced in a clay buffer (NAGRA 2003). The Belgian approach envisions an engineered barrier consisting 
of stainless steel canisters holding HLW inside a carbon steel overpack surrounded by thick concrete (Hansen et al. 2010).

Storage and transportation overpacks are beyond the scope of this report. The following sections summarize some key selections that would be made in designing waste canisters/containers, and disposal overpacks for disposal in a geologic repository.

\subsubsection{Geometrical Constraints}

The number of used fuel assemblies per waste package (assuming no rod consolidation) is a consideration when choosing the size and other design details for SNF containers and packages. The goals are efficient arrangement in a round package configuration, heat transfer from the inner fuel assemblies, and the overall maximum heat output requirements for storage, transport, and disposal. Desirable arrangements typically use $1 / 4$ or $1 / 2$ symmetry to allow for a simple and more readily manufactured arrangement. The cells for individual fuel assemblies are arranged in rows, and junctions between neighboring cells form cross-shapes rather than T-shapes. (Tshaped intersections may be structurally inferior due to the increased possibility of buckling of the cell walls.) Using these geometric constraints, a limited number of SNF waste package configurations is possible without de-rating the capacity.

Previous studies have quantitatively evaluated SNF waste package arrangements by calculating packing efficiency by various measures. In general, larger waste packages are more efficient. However, efficiency in terms of wasted space is not linear with respect to the number of assemblies accommodated, and there are optimum arrangements that tend to bracket large, medium, and small waste package sizes. The following configurations are commonly considered for PWR and BWR SNF: 24-PWR/45-BWR, 21-PWR/44-BWR, 12-PWR/24-BWR, 9$\mathrm{PWR} / 21-\mathrm{BWR}$, and 5-PWR/12-BWR.

For this study, the 4-PWR/9-BWR reference configuration is selected because it is nearly as space-efficient as a 5-PWR configuration, is being considered in other repository concepts internationally, and serves to limit temperatures as discussed in Section 5. Preliminary thermal results from this study showed that reasonable maximum temperature targets (Section 4.1.1.2) for the mined disposal concepts cannot be met with larger waste packages (12-PWR, 21-PWR, etc., or thermally equivalent HLW loading) with decay storage of less than 100 years, or in some cases much longer. A single-PWR assembly container is selected for the deep borehole concept, possibly with rod consolidation.

\subsubsection{Integration with Surface Facilities and Storage and Transportation Systems}

As reactor operators run out of space in their spent fuel pools, UNF is being loaded into a range of dry storage and dual-purpose casks. Current trends in UNF storage and transportation indicate a preference for larger capacity containers. For example, cask vendors have been issued regulatory approval (10 CFR Part 72 certificates) for 32-PWR/64-BWR storage casks (NWTRB 2010). These trends are driven by cost savings in materials, handling, and packaging efficiency. Loading more UNF assemblies into a single canister decreases the number of steps needed to off-load fuel from pools (e.g., steps for canister preparation, drying, sealing, and transfer). The same economics also apply to disposal waste packages, such that higher capacity packages are associated with lower costs and fewer operations such as lifts and transfers. On the other hand, smaller waste packages are inherently cooler and allow less decay storage, or no decay storage. A reduction in waste package capacity by a factor of four results in an a four-fold increase in the 
number of operations at the surface and underground, including welding, inspection, handling, transport into the repository, and emplacement.

Hence, the establishment of centralized, interim storage capability for UNF involves tradeoffs between the economics of storage and fuel handling at the reactor plants, vs. the requirements of disposal (considering whether UNF will eventually be directly disposed or reprocessed). The reference repository concepts selected in this report (Section 4.5) for mined disposal concepts would use waste packages that are significantly smaller than the storage containers currently being loaded by U.S. nuclear utilities, to accommodate thermal limits. Thus, there is the opportunity to optimize the storage and disposal systems, to extend the range of efficient disposal solutions available in the future.

\subsubsection{Shielding}

The waste package concepts discussed above generally do not include radiological shielding of individual packages. The need for shielding would arise if human activity is required in the immediate disposal environment, for example, to inspect waste packages or other EBS features. Gamma radiation is the principal concern, so shielding would involve placement of metallic or other high-density materials, thus increasing the package size and weight. Some of the disposal concepts proposed in the U.S. and internationally, would emplace waste packages under cover of crushed rock (Carter et al. 2011b), or in boreholes behind shield plugs (Andra 2005a; DOE 1986a). In general, providing shielding on a reusable platform such as a waste package transporter is more efficient and economical than incorporating shielding individual packages. In addition, the thermal insulating qualities of shielding are noted, which could impact the duration of decay storage prior to waste emplacement in a repository.

\subsubsection{Waste Package Material Selection}

The disposal concepts considered in this study are appropriate for chemically reducing disposal environments. The most common materials considered for reducing environments are carbon steel, stainless steel, copper, and titanium (Shoesmith 2006; Rebak and McCright 2006). Corrosion performance of waste package materials will also be a function of temperature, ionic strength, $\mathrm{pH}$, and concentrations of halide ions.

Steel has a number of attributes that might make it a suitable candidate as a canister for spent nuclear fuel and HLW disposal. It is widely available at relatively low cost. Because steel is relatively easy to weld, waste packages made of steel will be easy to seal. Carbon steel and lowalloy steels have been extensively tested in ground water environments for several decades. Researchers in the Swedish repository program have studied the anoxic corrosion behavior of carbon steel and cast iron in ground water at $50^{\circ} \mathrm{C}$ and $85^{\circ} \mathrm{C}$ and the impact of the presence of copper on the type and the mechanical properties of the films formed on the iron alloys (Smart et al. 2001). Andra has specified the use of carbon steel for SNF container overpacks, in the Callovo-Oxfordian argillite formation (Andra 2005a). NAGRA has identified carbon steel as the primary candidate waste package material for the Swiss repository concept in Opalinus Clay (NAGRA 2009).

The waste package conceptual design for both vertical and horizontal emplacement concepts in the proposed salt repository at Deaf Smith, Texas was a heavy-walled container made of lowcarbon steel. These containers were sized to contain either 4 PWR or 12 BWR fuel assemblies. As an alternative for cooler SNF, the containers could be configured for consolidated spent fuel 
from 12 PWR or 30 BWR assemblies (ONWI 1987b). Carbon steel has also been identified as a candidate waste package material for salt repositories in Germany (Weber et al. 2011). Note that performance assessment models may take no significant containment credit for steel containers, particularly for long-term (i.e., $>10^{5}$ years) assessments.

Copper can be a suitable waste package material because it is thermodynamically stable under anoxic conditions and it has a tendency to undergo slow, uniform corrosion rather than localized corrosion in reducing environments. The SNF waste package planned for use in Sweden will consist of a nominally $50-\mathrm{mm}$ thick layer of copper over an insert of cast nodular iron which will provide mechanical strength (SKB 2006). Copper is also the identified waste package material for the Finnish repository concept. Since similar anoxic conditions will likely exists in clay/shale repositories after repository closure, copper may be an appropriate material for those systems as well. For this reason, copper is identified as an alternative to steel in the Swiss repository concept (NAGRA 2003).

As alternatives to active (corrosion allowance) canister materials such as copper and carbon steel, passive materials such as alloys of nickel and titanium, and stainless steel, have been considered as waste package. These materials form a passive, stable oxide film on the surface, and the chemical inertness of this film limits the general corrosion rate of the material. Passive materials may undergo localized corrosion (e.g., pitting or crevice corrosion) if the oxide film breaks down. The behavior of stainless steel has been studied in the Boom Clay, and it is a candidate material for the Belgium repository concept (Kursten et al. 2004).

Titanium alloys have also been studied as candidate waste package materials in Canada, Japan, and Germany. Titanium alloys were selected as potential alternatives because of their excellent performance in more aggressive brine solutions compared, for example, to stainless steels (Kursten et al. 2004; Rebak 2007).

Amorphous metal and ceramic thermal spray coatings have been developed with excellent corrosion resistance and neutron absorption. These coatings, with further development, could be cost-effective options to enhance the corrosion resistance of waste packages and other EBS components, and to limit nuclear criticality in canisters for transportation, aging, and disposal of SNF. Iron-based amorphous metal formulations with chromium, molybdenum, and tungsten have shown the corrosion resistance believed to be necessary for such applications. Rare earth additions enable very low critical cooling rates to be achieved. The boron content of these materials and their stability at high neutron doses enable them to serve as high efficiency neutron absorbers for criticality control. Another corrosion resistant option, ceramic coatings, may provide even greater corrosion resistance for EBS applications, although the boron-containing amorphous metals are still favored for criticality control applications. These amorphous metal and ceramic materials have been produced as gas-atomized powders and applied as nonporous coatings with nearly full density, using the high-velocity oxy-fuel process. Blink et al. (2009) summarize the performance of these coatings as corrosion-resistant barriers and as neutron absorbers, and also present a simple cost model to quantify the economic benefits possible with these new materials.

\subsubsection{Waste Packages for LLW}

This section summarizes the types of secondary containers or packages that are in use or have been proposed for LLW disposal, and could be used for co-disposal of LLW with HLW or SNF in a mined geologic repository. Whereas LLW can generally be disposed in near-surface 
facilities licensed for the purpose, this study considers the option to use otherwise uncommitted volume within a mined repository. For repositories in salt, and possibly in clay/shale, this means that access and main drifts or tunnels could be completely filled with LLW, similar to the disposal rooms at WIPP. Packages for LLW would be the same in this application as for nearsurface disposal. Low-level waste could also be used to fill extra volume in a repository in crystalline rock, but with the addition of low-permeability buffer or backfill material between the rock and the LLW.

Low-level waste is broadly categorized as contact-handled $(\mathrm{CH})$ or remote-handled $(\mathrm{RH})$ depending on the need for shielding during operations. Secondary waste containers for $\mathrm{CH}$ or RH waste can be 55-gal drums arranged singly or in pallets (e.g., 7-packs), shielded drums, waste boxes, and high-integrity containers (HICs):

- Standard 55-Gallon Drums - A standard 55-gal drum has gross internal volume of 7.4 $\mathrm{ft}^{3}\left(0.21 \mathrm{~m}^{3}\right)$. One or more filtered vents may be installed in the drum lid to prevent the escape of radioactive particulates and to eliminate any potential pressurization. Standard 55-gal drums are constructed of mild steel and may also contain rigid, molded polyethylene (or other compatible material) liners.

- Shielded 55-Gallon Drums - Shielding is used to reduce the surface radiation dose on 55 -gallon drums to less than $200 \mathrm{mrem} / \mathrm{hr}$, so that the waste container can be contact handled $(\mathrm{CH})$. Only I-129 waste is anticipated to use this type of additional shielding.

- Waste Boxes - Standard waste boxes (SWBs) have an internal volume of $66.3 \mathrm{ft}^{3}(1.88$ $\mathrm{m}^{3}$ ). Other waste boxes (e.g., B-25, B-12, special-purpose engineered boxes) may be larger or smaller. All have one or more filtered vents to prevent escape of radioactive particulates and to eliminate any potential pressurization.

- High Integrity Containers (HICs) - HICs are constructed of mild steel and may also contain rigid molded polyethylene (or other compatible material) liners. They typically have the same dimensions as 55-gallon drums.

\subsection{Emplacement Mode Considerations}

Emplacement modes influence repository layout, construction, waste package handling operations, and waste package sizes. The emplacement mode may also influence occupational exposures, facility inspections and monitoring (e.g., performance confirmation activities, and retrievability concepts.)

\section{Enclosed vs. Open Emplacement Modes}

An important categorization of emplacement concepts is to consider whether or not a concept calls for waste packages to be in direct contact with any surrounding medium such as buffer, backfill, or host geology. This impacts thermal management because it determines if there is air space around the waste packages, in which heat can be dispersed principally by thermal radiation, and natural or forced convection. Open emplacement concepts are amenable to rock types where excavated openings persist for long time periods, either because of the inherent stability of the opening or reliance on long-lived ground support. The emplacement concept for the reference Yucca Mountain repository design (DOE 2008b) is an example of an open system, such that emplacement drifts can be ventilated for up to 100 years after emplacement, and heat dispersion continues in the air spaces after repository closure. Open emplacement concepts are 
generally not suitable for saturated geologic conditions or low-permeability host media, because the open spaces can act as conduits for groundwater flow that degrades long-term waste isolation performance.

We note also that low-permeability media, particularly self-sealing clay/shale and salt media, and buffer/backfill materials, retain low permeability because of plastic deformation. Where such permanent deformation is possible, the emplacement mode is enclosed, not open. This virtually eliminates open emplacement modes with these media. Importantly, enclosed emplacement modes are usually less efficient at transmitting heat away from waste packages, and thus produce higher near field temperatures (other thermal loading details held constant). The higher temperatures can be offset by aging the waste before disposal, by smaller waste packages, and to a limited degree, by wider spacing between waste packages.

Forsberg and Dole pointed out that emplacement mode choices can influence the complexity and cost of retrieval at some future time (Forsberg and Dole 2011). In general, closed emplacement modes are associated with more complex retrieval operations. This can be at least partly addressed in self-sealing clay/shale or salt media, with use of appropriate ground support and/or liners for emplacement openings, until the end of repository operations.

As noted in Section 3 and by Hansen et al. (2010) clay/shale and salt media have relatively low permeability, as do clay-based buffer and backfill materials. Additionally, the disposal concepts described in this report are assumed to be in saturated geologic settings. Therefore, enclosed emplacement modes are adopted for the corresponding reference design concepts in this study.

\section{In-Drift-Emplacement Mode}

The in-drift emplacement mode concept consists of waste packages placed horizontally along or parallel to the axis of an emplacement drift. For normal loading operations, waste packages are placed sequentially in each drift. This is considered to be an open emplacement mode unless combined with backfill or a buffer material. Advantages are constructability and simplicity of operations. This emplacement mode does not provide any shielding features. Disadvantages for enclosed systems include potentially large amounts of backfill, and emplacement of backfill in the radiological disposal environment. Disadvantages for open systems may include rockfall damage to the EBS, or other damage caused by seismic ground motion.

\section{Vertical Borehole Emplacement Mode}

For this mode waste packages are emplaced in vertical boreholes drilled into the floor of access drifts. The depth of each vertical borehole is sufficient depth to accommodate a waste package, sealing or buffer materials, and possibly a shield plug. A liner may be installed in each vertical borehole, except where not needed for borehole stability and/or waste package alignment, or where access to the borehole wall is required for characterization. If a buffer around the waste package is part of the disposal design concept, the borehole is sized accordingly. Vertical borehole emplacement is considered a closed emplacement concept. Advantages of vertical emplacement include the ability to characterize the near-field rock exposed in the boreholes, and shielding to facilitate access after emplacement. Disadvantages include the complexity and cost of drilling many vertical boreholes. An important complication in handling heavy waste packages, is the need to either lower them down a shaft from the surface, or transport them down a ramp in the horizontal orientation and rotate prior to emplacement. 


\section{Horizontal Borehole Emplacement Mode}

One or more waste packages can be emplaced in horizontal boreholes drilled into the walls of emplacement access drifts or rooms. For some concepts such as the KBS-3H, the boreholes may be long enough for many packages. Advantages include efficient use of repository area, particularly if multiple waste packages are emplaced in each borehole. Another advantage is the possibility that waste packages will never be handled in the vertical orientation, which may require access to the repository by ramp (in addition to shaft access). Disadvantages include the complexity and cost of drilling many horizontal boreholes. Also, horizontal boreholes in virtually all host media will need to be lined to prevent collapse during operations. An important complication in handling heavy waste packages, is the need to either transport them down a ramp in the horizontal position, or lower them down a shaft from the surface in the vertical orientation and rotate prior to emplacement.

\section{Backfilled Alcove Emplacement Mode}

Waste packages are placed on the floor in small alcoves, and covered in crushed salt or other granular material derived from the host formation (Carter et al. 2011b). Advantages include simplicity and low cost, use of shielding from crushed rock, and the result that drifts are backfilled. Disadvantages may include inefficient heat transfer through the crushed rock backfill.

\section{Deep Borehole Emplacement Mode}

Figure 1-7 illustrates the deep borehole disposal concept. Potentially acceptable lowpermeability, crystalline basement rock is reasonably common in the U.S. at depths of 2 to $5 \mathrm{~km}$. A vertical borehole with a diameter of approximately $45 \mathrm{~cm}$ is drilled into crystalline basement rock to a total depth of approximately $5 \mathrm{~km}$. The borehole is assessed for stress conditions, mechanical stability, and other properties, including water chemistry, hydraulic conductivity of the wall rock, and geothermal gradient. If conditions are acceptable, then oilfield casing is grouted in place in the disposal interval, ensuring stable borehole conditions for emplacement operations. A linear array of waste containers is then placed in the lower $2 \mathrm{~km}$ of the borehole. Canisters are surrounded by bentonite slurry, and the upper (unlined) $3 \mathrm{~km}$ of the borehole is sealed by a combination of compacted bentonite or other sealing elements, and concrete plugs (Figure 1-7).

Waste packages or containers can be made from sections of standard oilfield casing $5 \mathrm{~m}$ in length, with inner diameter of $32 \mathrm{~cm}$ and outer diameter of $34 \mathrm{~cm}$. Each such canister could hold one PWR fuel assembly, or one BWR assembly with extra space (Brady et al. 2009). One canister could hold the contents of multiple assemblies with rod consolidation (or the canister diameter could be decreased to fit in a smaller diameter borehole). Welded end-caps seal the canisters. The disposal canister is strong enough to prevent radionuclide release during the waste emplacement phase, including recovery operations for canisters that become stuck or damaged in the wellbore. Canisters can be emplaced individually or as part of strings with as many as 10 to 20 canisters each. Crushing of underlying canisters during emplacement is prevented by installation of bridge plugs in the borehole.

The advantages of the deep borehole disposal concept are: enhanced reliance on natural barrier performance, and potentially low cost and flexible siting. Transport pathways to the biosphere are long, at least several kilometers, and transport velocities are demonstrably slow. The natural phenomena indicative of potential natural barrier performance, including flow permeability, 
hydraulic head, and geochemical and isotopic tracers, are relatively easy to measure and interpret. Disadvantages center on drilling feasibility and waste retrieval capability.

\subsection{Reference Design Concepts}

\subsubsection{Reference Mined Crystalline/Granite Repository Design Concept}

As noted previously, Sweden and Finland have advanced concepts for disposal of LWR spent fuel in crystalline rock (Sections 1 and 3). The KBS-3 disposal concept is currently accepted worldwide as a reference for disposal in crystalline rock. The Swedish program for SNF disposal is one of the most advanced internationally, considering investigations in all geologic media. Note also that Sweden has deployed interim storage at a centralized used-fuel storage facility (CLAB) which limits waste heat output at the time of emplacement in the repository, and is a basic component of their disposal system. Canada has also investigated granite repository concepts (Rechard et al. 2011). The reference generic mined granite repository design concept presented here draws heavily from those concepts. The proposed depths for developing repositories range from $420 \mathrm{~m}$ (Finland; Posiva Oy 2010) to $500 \mathrm{~m}$ (Sweden, SKB 2006). For consistency with those concepts and to facilitate future comparisons of analysis results, the reference mined crystalline repository concept is assumed to be nominally 500 meters below the surface in hydrologically saturated, low-permeability granitic host rock in which hydraulic gradients are very small. These conditions are expected to result in very slow groundwater flow typical of the Canadian Shield or the Baltic Shield, which may be corroborated by the presence of saline groundwater with great apparent age. The host rock chemical environment is expected to be reducing, which may be indicated by the presence of minerals such as pyrite.

The subsurface layout and arrangement of waste packages is similar to the KBS-3V design (see Section 1; Figure 1-4). The initial subsurface layout selected for thermal analyses consists of parallel emplacement drifts, with waste packages emplaced in vertical boreholes drilled into the floor from these emplacement drifts (Figure 1-4). Waste packages for SNF are thick-walled, made from copper or carbon steel (a choice to be made at some future time, based on economics and performance assessment), with welded closures. Waste packages for HLW are thick-walled carbon steel. The space between the canister and the emplacement borehole wall (approximately $35 \mathrm{~cm}$ on the radius) is filled with a low-permeability buffer material consisting of swelling clay (e.g., Wyoming bentonite) emplaced initially in its dry, compacted form and swells on contact with groundwater (swelling pressure on the order of $5 \mathrm{MPa}$ is readily resisted by the minimum in situ stress). Specific dimensions of the features discussed here are given in Table 4-1, and in the thermal analysis (Section 5.1). Construction may be expedited by use of prefabricated assemblies consisting of a single waste package and the surrounding clay buffer in compacted dry form, held together by a steel envelope (McKinley et al. 2006).

Access drifts have nominal 5.5-meter diameter to provide overhead clearance for drilling equipment and waste package transport, and are spaced 20 meters apart (equivalent to the KBS-3 concept). This is a point-loading configuration with a single 4-PWR/9-BWR waste package or a single HLW waste package in each vertical emplacement borehole. Vertical emplacement boreholes are spaced approximately 10 meters apart. This dimension is greater than the 6-meter spacing published for the KBS-3 concept, but a wider spacing allows somewhat hotter waste packages (the KBS-3 documentation acknowledges the possibility of different spacings). Recommendations for future sensitivity cases to investigate these dimensions are discussed in Section 6. 
The excavation method could be by drill-and-blast or tunnel boring machine (TBM). In either case the openings will be stable, requiring minimal ground support during operations, and an excavation damage zone (EDZ) will form around the mined openings. Backfill, plugs, and seals will ensure that: 1) drift backfill has lower permeability than the host rock; and 2) axial flow in the EDZ along backfilled openings, if it occurs, will be dispersed by plugs and seals. Swelling pressure in the clay buffer around waste packages, and in the emplacement drift backfill (which also contains swelling clay), will exert a compressive stress on the surrounding EDZ that tends to confine and close fractures.

Fuel assemblies are positioned inside the canister by an insert made of cast iron. This material is an economical choice, and in addition to structural support it provides a sink for oxygen in the disposal environment, and a source of corrosion products that can readily sorb radionuclides released from the waste form.

The crystalline concept has relatively large additional repository volume in access drifts, to accommodate LLW and GTCC waste (Table 4-2). Much of the additional volume could be available for enclosing the LLW in low-permeability buffer or backfill material.

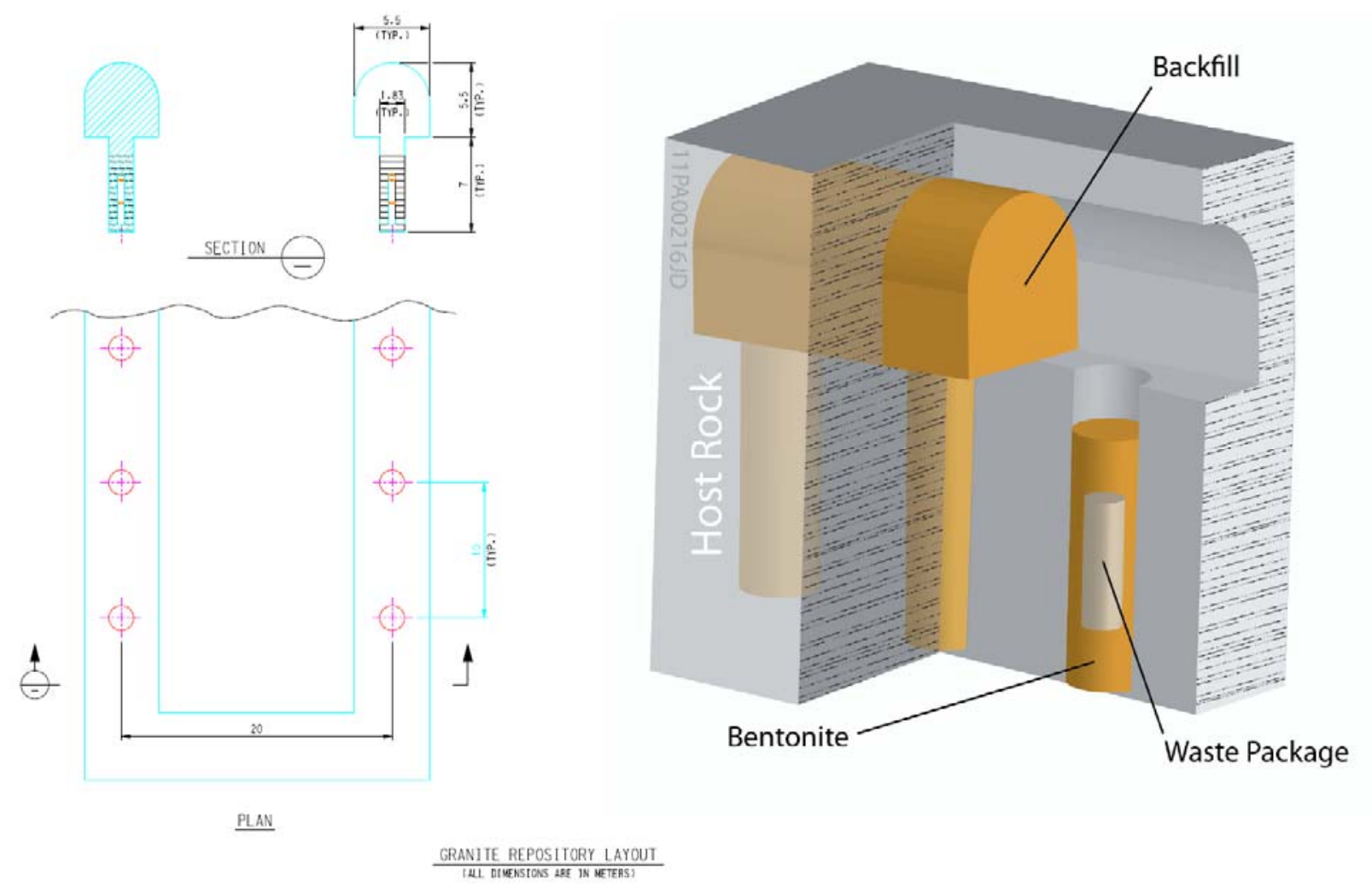

Figure 4-1 Schematic of Reference Disposal Concept for Crystalline Host Media.

\subsubsection{Reference Clay/Shale Repository Design Concept}

The French nuclear waste authority Andra has an advanced concept for a repository in the Callovo-Oxfordian argillite, and their experience will be used to inform the generic reference design concept. The French program has narrowed the candidate repository site to be within an 
area of approximately $200 \mathrm{~km}^{2}$ situated near Bure, in eastern France. The candidate rock unit is $130 \mathrm{~m}$ thick, centered at $500 \mathrm{~m}$ depth (Andra 2005a). For consistency with the French concept and to facilitate future comparisons of analysis results among the generic mined disposal concepts, the reference mined clay/shale concept is assumed to be nominally 500 meters below the surface in hydrologically saturated host rock with very small hydraulic gradients.

While sedimentary basins may have broad spatial extent, suitable repository host rock may be found in layers of limited thickness, situated within a sequence of argillaceous, evaporite, and/or carbonate sediments. For the reference disposal concept, low-permeability clay/shale sediments with total thickness of $150 \mathrm{~m}$ are assumed to exist between the repository and the ground surface (similar to the stratigraphy evident at the Bure location).

The clay or shale stratigraphy may be limited spatially, and constrain repository development. For example, the repository elevation may need to follow the host rock stratum, with the same inclination. Tunnels and drifts will be excavated using mechanized mining equipment. Horizontal emplacement boreholes are preferred over vertical ones, even short ones as in the KBS-3V concept for crystalline rock, to accommodate limited stratigraphic thickness. Accordingly, the reference clay/shale repository concept presented here will make use of horizontal emplacement boreholes, or emplacement directly in horizontal drifts.

The need for and amount of ground support in the emplacement openings and access drifts depends on the mechanical properties of the clay. Clay can be described as either plastic (soft) or indurated (hard), with widely varying mechanical properties. Soft clays (e.g., Boom Clay) with relatively high water content tend to behave plastically, rapidly filling underground openings, and may present challenges for supporting those openings during repository operations. More indurated clay rocks (e.g., clay shale, claystone or argillite) have less porosity and smaller water content, and greater strength and rigidity. Fractures can form in such media and may be evident in surface pits or quarry excavations, but are generally closed at depth (Arnould 2006). Regardless, ground support that ensures operational safety during construction, waste emplacement, and monitoring activities can be provided by steel sets and shotcrete.

Pour canisters containing HLW are placed into carbon steel overpacks with welded closures. These waste packages will be emplaced in horizontal, steel-lined boreholes approximately $0.75 \mathrm{~m}$ in diameter (Figure 4-2). Stainless steel containers with SNF will be inserted into carbon steel overpacks, and will be installed using the in-drift emplacement mode in horizontal, steellined tunnels with diameter of $2.64 \mathrm{~m}$, surrounded by bentonite buffer material. Emplacement of SNF waste packages is thus basically similar to HLW packages, except that emplacement drifts are larger and potentially longer than boreholes, and completely filled with clay buffer and backfill materials. Specific dimensions of the features discussed here are given in Table 4-1, and in the thermal analysis (Section 5.1). For the reference concept described here, the waste package spacing is 10 meters for in-drift emplacement of SNF (packages nominally 5 meters long), and 6 meters for borehole emplacement of HLW canisters (4.57 meters long). Borehole and emplacement drift spacings are 30 meters. These dimensions are comparable to those proposed for the clay/shale repository in France (Andra 2005a) but with larger inter-package spacings to allow for hotter SNF and HLW. Access drifts have nominal 5.5-meter diameter to provide clearance for drilling equipment and waste package transport, and are spaced approximately 50 meters apart for HLW (to accommodate 40-meter emplacement boreholes, following the French concept). A similar geometry is assumed here for SNF disposal (also following the French 
concept). Recommendations for future sensitivity cases to investigate these dimensions are discussed in Section 6.

As in the French concept, plugs and seals at the collar of each HLW emplacement borehole and SNF emplacement tunnel will limit dessication during repository operations, provide radiation shielding after emplacement, and inhibit movement of radionuclides into the access drift openings after repository closure. Access drift openings with sufficient dimensions for construction and waste handling equipment, will be backfilled at closure using mined clay/shale material processed for low-permeability and swelling potential on hydration in situ.

The clay/shale concept has some additional repository volume in access drifts, to accommodate LLW and GTCC waste (Table 4-2). Some of this additional volume could be needed to enclose the LLW in low-permeability buffer or backfill material. This is attributable to the use of boreholes and in-drift emplacement (with drifts completely filled with buffer material). Additional drifts or alcoves could be constructed between HLW/SNF alcoves to provide any needed additional volume.

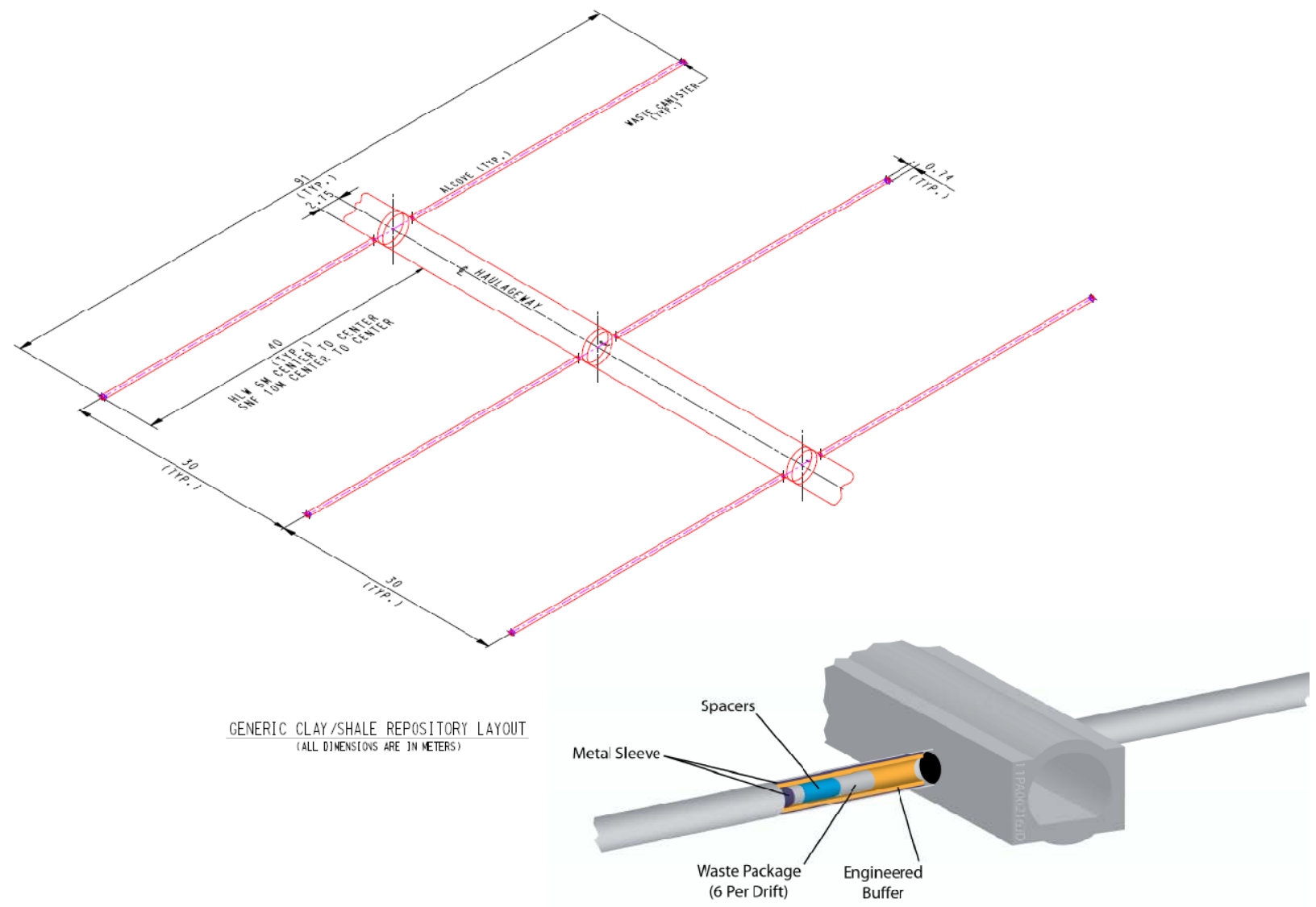

Figure 4-2 Schematic of Reference Disposal Concept for HLW in Clay/Shale Media.

\subsubsection{Reference Salt Repository Design Concept}

A recent conceptual salt repository study for HLW advanced a new disposal concept based on lessons learned from the WIPP and other salt excavations (Carter et al. 2011b). The generic study involved a conceptual mining layout that was developed for a high thermal load salt 
repository in bedded salt, based on experience and mining observations. The reference salt repository concept presented here draws from that work.

Contributors to the generic salt repository study developed a possible repository layout and also generated some basic operational and structural conclusions, including: 1) bedded salt is preferred over domal salt because it generally has much greater lateral extent; 2) use rubber-tire vehicles for construction and disposal operations; 3) avoid use of large diameter, pre-drilled emplacement holes; 4) do not use shielded containers for disposal; and 5) use narrow room widths to improve mining efficiency and structural stability. Although previous conceptual designs for HLW repositories in salt called for disposal of canisters in vertical or horizontal boreholes (DOE 1986a), a simpler disposal scheme was selected for the generic salt repository, whereby each canister is placed on the floor at the back of a mined alcove, using rubber-tired equipment (Carter et al. 2011b; Figure 4-3). Canisters for both SNF and HLW have carbon steel overpacks. Specific dimensions are given in Table 4-1, and in the thermal analysis (Section 5.1). Canisters are immediately covered with crushed salt from repository excavation, to provide radiation shielding. Note that borehole emplacement as was proposed in the Deaf Smith repository concept could be adopted if needed, for example, to promote heat transfer with the intact salt.

For thermal calculations in this report the drift spacing is set to 20 meters, somewhat larger than that used in the generic salt repository of Carter et al. (2011b). This is done to accommodate larger waste packages containing more HLW (and SNF). Recommendations for future sensitivity cases to investigate these dimensions are discussed in Section 6.

Height and width dimensions for the main access drifts and alcoves are selected accounting for waste package dimensions and the use of readily available mining equipment. Main access drifts are approximately 3 meters high and 5 meters wide (provide clearance for nominally 5-meter long waste packages). Alcoves are mined from both sides of access drifts, and are spaced approximately 20 meters apart. They are assigned dimensions of 3 meters high, 5 meters (nominal) wide, and 7.5 meters deep, oriented perpendicular to the access drifts (Figure 4-3). These dimensions are subject to change to accommodate mining equipment, and movement of waste packages into position (e.g., emplacement alcove height might be decreased to improve heat transfer and decrease cost). This is a point-loading arrangement where a single waste package is placed at the end of each alcove. The original authors suggested that additional, nonheat generating waste could also be emplaced in the same alcoves, thus increasing the waste loading of the repository (Carter et al. 2011b).

The alcove disposal concept uses mine-run crushed salt placed over the waste canisters for radiological shielding and to promote reconsolidation. The operation of placing crushed salt over the waste would involve remote controlled, low-haul-dump equipment similar to that used commonly in mining. Minimal ground support is required in a salt repository, because more substantial ground support impedes closure of the underground openings and could compromise containment and isolation functions.

The reference disposal concept for salt has sufficient additional repository volume in access drifts, to accommodate LLW and GTCC waste (Table 4-2). Additional drifts could be constructed between emplacement openings, to provide any needed additional volume. 


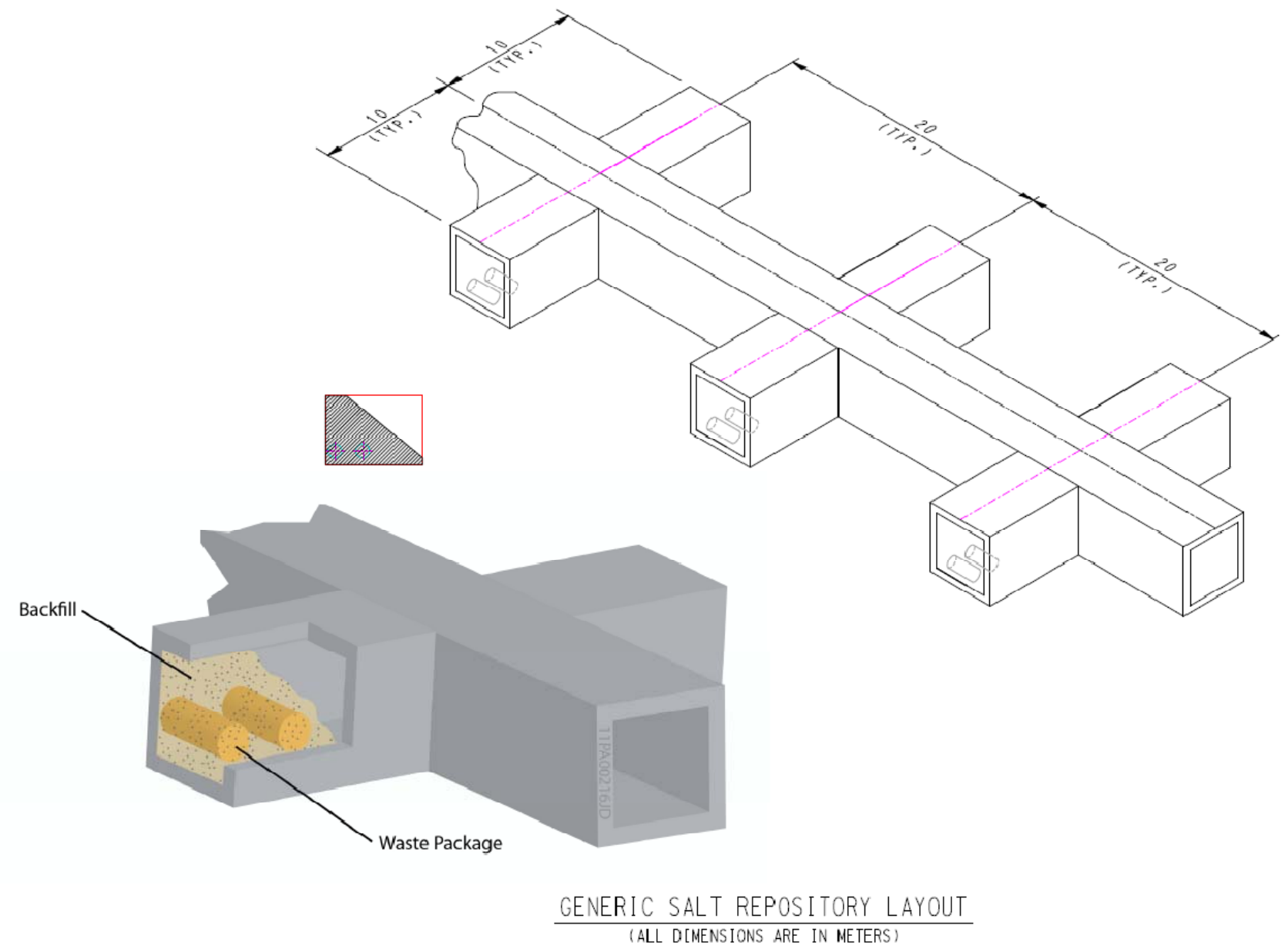

Figure 4-3 Schematic of Reference Disposal Concept for HLW and SNF in Bedded Salt.

\subsubsection{Reference Deep Borehole Disposal Concept}

The deep borehole disposal concept is described by Arnold et al. (2010) as follows:

“...consists of drilling a borehole into crystalline basement rock (typically granite) to a depth of about $5000 \mathrm{~m}$, emplacing waste canisters containing spent nuclear fuel or vitrified radioactive waste from reprocessing in the lower $2000 \mathrm{~m}$ of the borehole, and sealing the upper $3000 \mathrm{~m}$ of the borehole....

"The viability and safety of the deep borehole disposal concept are supported by several factors. Crystalline basement rocks are relatively common at depths of 2000 to $5000 \mathrm{~m}$ in the United States and many other countries, suggesting that numerous appropriate sites exist. Low permeability and high salinity in the deep continental crystalline basement at many locations suggest extremely limited interaction with shallow fresh groundwater resources, which is the most likely pathway for human exposure. The density stratification of groundwater would also oppose thermally induced groundwater convection from the waste to the shallow subsurface....Geochemically reducing conditions in the deep subsurface 
limit the solubility and enhance the sorption of many radionuclides in the waste, leading to limited mobility.

"Preliminary estimates for deep borehole disposal of the entire projected waste inventory through 2030 from the current U. S. fleet of nuclear reactors suggest a need for a total of about 950 boreholes, with a total cost that could be less than a mined repository disposal system at Yucca Mountain."

Deep disposal boreholes would be drilled to approximately $5 \mathrm{~km}$ depth, as discussed in Section 4.4, and spaced approximately $200 \mathrm{~m}$ apart to limit thermal interaction between boreholes and to allow for some borehole deviation (Figure 4-4). Specific dimensions of the waste packages, buffer, and liner for SNF and HLW disposal are given in Table 4-1 and in the thermal analysis (Section 5.1). The reference concept indicates no solid buffer material would be used between the waste packages and the borehole liner (Table 4-1), and the thermal calculations assume the properties of water (Section 5.3.2), although an earlier study proposes to use a waterbentonite slurry or "deployment mud" (Brady et al. 2009). Thermal properties of slurry and water are reasonably close and the annular thickness is small which limits the thermal resistance. The reference concept proposed here could be readily changed to accommodate future design information on slurry composition, without significantly impacting the thermal analysis results.

Nuclear waste disposal in very deep boreholes has been investigated in the U.S. and internationally for many years. Direct injection of liquid waste into deep boreholes was considered favorably in the 1957 review by the U.S. National Academy of Science (NAS 1957). Deep hole disposal was considered in a waste management environmental impact study (DOE 1980) supported by technical feasibility analysis (O'Brien et al. 1979). In 2000 the Swedish program conducted a feasibility study of deep drilling technology that would be used, including design details for well completions and waste canisters. A more recent review of drilling technology was performed for the British waste program (Gibb 2010). Both these reviews concluded that the required large-diameter holes could be drilled, but would technologically challenge the drilling industry.

Recent work has concluded that deep borehole disposal could more effectively isolate solid waste forms (SNF or HLW glass) than some mined disposal concepts (Brady et al. 2009). Deep borehole disposal could also have the advantage of less constraining thermal management requirements because emplacement boreholes would be situated hundreds of meters apart. Also, waste packages would be small and contain only one PWR fuel assembly, or a limited quantity of HLW. Groundwater boiling will not occur in the near field because of the hydrostatic pressure (Section 4.1.1.2). Isolation performance is provided predominantly by the far-field host medium and the long sealing system emplaced in the borehole above the waste, such that thermally driven changes to the waste form or the near-field host rock would not be significant. Suitability of the host medium can be determined using established methods for geophysical, geochemical, and hydrologic measurements in wells. The waste package for deep borehole disposal is simple and relatively cheap, since it has no containment longevity function after emplacement. Borehole arrays could scale in number and cost, directly to the inventory of waste for disposal.

Crystalline basement rock, possibly covered by as much as $2 \mathrm{~km}$ of sedimentary overburden, is readily available in the U.S. Distributed, regional disposal facilities could be constructed to share the burden of disposal, and to decrease the number and extent of waste shipments. Drilling technology would be a significant challenge, but drilling cost could be much less than for the 
corresponding activities to construct and operate a mined repository and associated surface facilities (Brady et al. 2009). Hence, disposal of SNF and solid HLW is included in this study as a reference concept, with recognition that additional $R \& D$ is needed to establish the technical basis to a degree comparable with mined repository concepts.
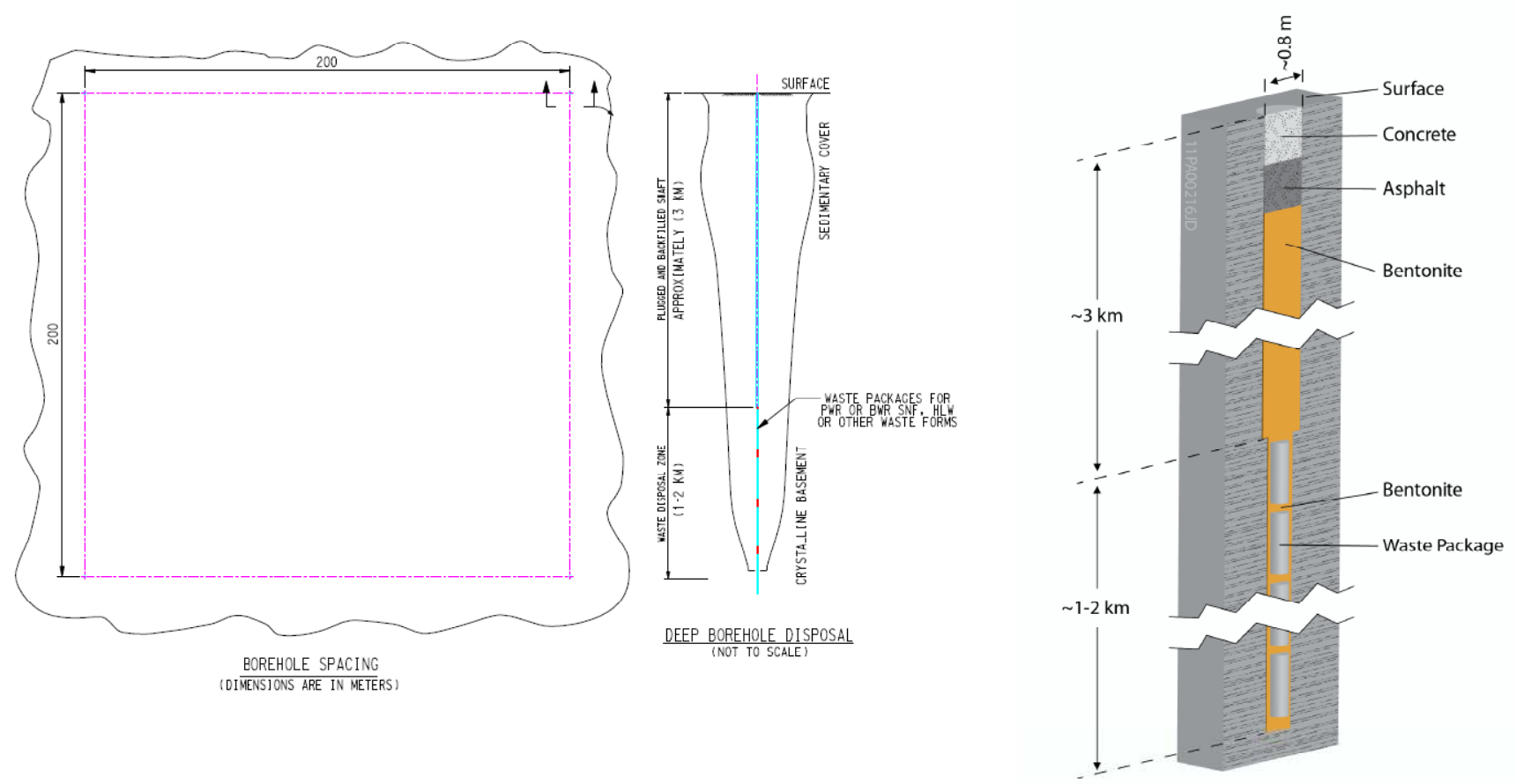

Figure 4-4 Schematic of Reference Deep Borehole Disposal Concept. 
Table 4-1 Summary of Characteristics for Reference Repository Design Concepts.

\begin{tabular}{|c|c|c|c|c|}
\hline Geologic Media/Concept & Mined Crystalline & Mined Clay/Shale & Mined Bedded Salt & Deep Borehole \\
\hline Repository depth & $\sim 500 \mathrm{~m}$ & $\sim 500 \mathrm{~m}$ & $\sim 500 \mathrm{~m}$ & $>3000 \mathrm{~m}$ \\
\hline Hydrologic setting & Saturated & Saturated & Saturated & Saturated \\
\hline Ground support material & $\begin{array}{l}\text { Rockbolts, wire cloth \& } \\
\text { shotcrete }\end{array}$ & Steel sets \& shotcrete & Rockbolts & Not used \\
\hline Seals and plugs & $\begin{array}{c}\text { Shaft \& tunnel plugs and } \\
\text { seals }\end{array}$ & $\begin{array}{c}\text { Shaft \& tunnel plugs and } \\
\text { seals }\end{array}$ & $\begin{array}{c}\text { Shaft \& tunnel plugs and } \\
\text { seals }\end{array}$ & Borehole seals \\
\hline $\begin{array}{l}\text { Normalized Areal Loading } \\
\text { (GWe-yr/acre) }\end{array}$ & 1 to 10 & 1 to 10 & 1 to 10 & $<1$ \\
\hline SNF Emplacement Mode & $\begin{array}{l}\text { Vertical emplacement } \\
\text { boreholes in floor }\end{array}$ & $\begin{array}{l}\text { Horizontal in-drift } \\
\text { emplacement }\end{array}$ & $\begin{array}{c}\text { Horizontal emplacement in } \\
\text { alcoves containing single } \\
\text { packages }\end{array}$ & $\begin{array}{l}\text { Vertical emplacement, } \\
\text { stacked }\end{array}$ \\
\hline WP configuration & 4-PWR & 4-PWR & 4-PWR & $\begin{array}{l}1 \text { PWR assembly } \\
\text { (rod consolidation) }\end{array}$ \\
\hline Overpack material & Copper or steel $^{\mathrm{B}}$ & Steel $^{\mathrm{B}}$ & Steel $^{\mathrm{B}}$ & Steel $^{\mathrm{B}}$ \\
\hline Package dimensions & $0.96 \mathrm{~m} \mathrm{D} \times 5 \mathrm{~m} \mathrm{~L}$ & $0.98 \mathrm{~m} \mathrm{D} \times 5 \mathrm{~m} \mathrm{~L}$ & $0.82 \mathrm{~m} \mathrm{D} \times 5 \mathrm{~m} \mathrm{~L}$ & $0.34 \mathrm{~m} \mathrm{D} \times 5 \mathrm{~m} \mathrm{~L}$ \\
\hline Drift/borehole dia. & $1.66 \mathrm{~m}$ (boreholes) & $2.64 \mathrm{~m}$ (drifts) & 5 m (nominal; alcoves) & $45 \mathrm{~cm}$ (boreholes) \\
\hline Drift/borehole spacing & $\begin{array}{c}20 \text { m (drifts) } \\
10 \text { m (boreholes) }\end{array}$ & $\begin{array}{c}30 \text { m (drifts) } \\
10 \text { m (packages) }\end{array}$ & $\begin{array}{c}40 \mathrm{~m} \text { (drifts) } \\
20 \mathrm{~m} \text { (alcoves) } \\
\text { Result: packages on } \\
\text { 20-meter grid }\end{array}$ & >100 m (boreholes) \\
\hline Borehole liner material & NA & Steel $^{\mathrm{B}}$ & NA & Steel $^{\mathrm{B}}$ \\
\hline Buffer material & Bentonite clay & Bentonite clay & NA & Bentonite clay \\
\hline Backfill material & Clay/sand mixture & Crushed clay/shale & Crushed salt & NA \\
\hline Line or point loading & Point & Point & Point & Line \\
\hline HLW Emplacement Mode & $\begin{array}{l}\text { Vertical emplacement } \\
\text { boreholes in floor }\end{array}$ & $\begin{array}{l}\text { Horizontal parallel } \\
\text { boreholes containing } \\
\text { multiple packages }\end{array}$ & $\begin{array}{l}\text { Horizontal emplacement in } \\
\text { alcoves containing single } \\
\text { packages }\end{array}$ & $\begin{array}{l}\text { Vertical emplacement, } \\
\text { stacked }\end{array}$ \\
\hline Overpack material & Steel $^{\mathrm{B}}$ & Steel $^{\mathrm{B}}$ & Steel $^{\mathrm{B}}$ & Steel $^{\mathrm{B}}$ \\
\hline Drift/borehole dia. & $1.52 \mathrm{~m}$ & $0.75 \mathrm{~m}$ (boreholes) & $5 \mathrm{~m}$ (nominal; alcoves) & $>45 \mathrm{~cm}$ (boreholes) \\
\hline Drift/borehole spacing & $\begin{array}{c}20 \mathrm{~m} \text { (drifts) } \\
10 \mathrm{~m} \text { (boreholes) }\end{array}$ & $\begin{array}{l}30 \mathrm{~m} \text { (boreholes) } \\
6 \mathrm{~m} \text { (packages) }\end{array}$ & $\begin{array}{c}40 \text { m (drifts) } \\
20 \text { m (alcoves) } \\
\text { Result: packages on } \\
\text { 20-meter grid }\end{array}$ & >100 m (boreholes) \\
\hline \multicolumn{5}{|l|}{ Package dimensions } \\
\hline Modified-Open Borosilicate Glass & $0.82 \mathrm{~m} \mathrm{D} \times 4.7 \mathrm{~m} \mathrm{~L}$ & $0.72 \mathrm{~m} \mathrm{D} \times 4.7 \mathrm{~m} \mathrm{~L}$ & $0.61 \mathrm{~m} \mathrm{D} \times 4.7 \mathrm{~m} \mathrm{~L}$ & $\sim 0.34 \mathrm{~m} \mathrm{D} \times 4.7 \mathrm{~m} \mathrm{~L}^{A}$ \\
\hline Closed Cycle Borosilicate glass & $0.82 \mathrm{~m} \mathrm{D} \times 4.7 \mathrm{~m} \mathrm{~L}$ & $0.72 \mathrm{~m} \mathrm{D} \times 4.7 \mathrm{~m} \mathrm{~L}$ & $0.61 \mathrm{~m} \mathrm{D} \times 4.7 \mathrm{~m} \mathrm{~L}$ & $\sim 0.34 \mathrm{~m} \mathrm{D} \times 4.7 \mathrm{~m} \mathrm{~L}^{A}$ \\
\hline Closed Cycle E-Chem zeolite & $0.82 \mathrm{~m} \mathrm{D} \times 4.7 \mathrm{~m} \mathrm{~L}$ & $0.72 \mathrm{~m} \mathrm{D} \times 4.7 \mathrm{~m} \mathrm{~L}$ & $0.61 \mathrm{~m} \mathrm{D} \times 4.7 \mathrm{~m} \mathrm{~L}$ & $\sim 0.34 \mathrm{~m} \mathrm{D} \times 4.7 \mathrm{~m} \mathrm{~L}^{\mathrm{A}}$ \\
\hline Closed Cycle La-glass (3) & $0.82 \mathrm{~m} \mathrm{D} \times 1.7 \mathrm{~m} \mathrm{~L}$ & $0.72 \mathrm{~m} \mathrm{D} \times 1.7 \mathrm{~m} \mathrm{~L}$ & $0.61 \mathrm{~m} \mathrm{D} \times 1.7 \mathrm{~m} \mathrm{~L}$ & $\sim 0.34{\mathrm{~m} \mathrm{D} \times 1.8 \mathrm{~m} \mathrm{~L}^{A}}^{A}$ \\
\hline
\end{tabular}




\begin{tabular}{|c|c|c|c|c|}
\hline Geologic Media/Concept & Mined Crystalline & Mined Clay/Shale & Mined Bedded Salt & Deep Borehole \\
\hline Closed Cycle Metal alloy & $0.82 \mathrm{~m} \mathrm{D} \times 3.3 \mathrm{~m} \mathrm{~L}$ & $0.72 \mathrm{~m} \mathrm{D} \times 3.3 \mathrm{~m} \mathrm{~L}$ & $0.61 \mathrm{~m} \mathrm{D} \times 3.3 \mathrm{~m} \mathrm{~L}$ & $\sim 0.34 \mathrm{~m} \mathrm{D} \times 4.7 \mathrm{~m} \mathrm{~L}^{\mathrm{A}}$ \\
\hline Borehole liner material & NA & Steel $^{\mathrm{B}}$ & NA & Steel $^{\mathrm{B}}$ \\
\hline Buffer material & Bentonite clay & NA & NA & Bentonite clay \\
\hline Backfill material & Clay/sand mixture & Crushed clay/shale & Crushed salt & NA \\
\hline Line or point loading & Point & Line & Point & Line \\
\hline Non-Heat Generating & Stacked in access tunnels & Stacked in access tunnels & Stacked in access tunnels & $\begin{array}{c}\text { Assume near-surface } \\
\text { disposal }\end{array}$ \\
\hline Package construction & Steel or cement ${ }^{B}$ & Steel or cement ${ }^{B}$ & Steel or cement ${ }^{B}$ & NA \\
\hline Drift/borehole dia. & NA & NA & NA & NA \\
\hline Borehole liner material & NA & NA & $\mathrm{NA}$ & NA \\
\hline Buffer material & NA & NA & NA & NA \\
\hline Radiation shielding & Backfill & Backfill & Backfill & NA \\
\hline Backfill material & Clay/sand mixture & Clay/sand mixture & Crushed salt & NA \\
\hline $\begin{array}{l}\text { Notes: } \\
\text { A Smaller diameter, and poss } \\
\text { B The types of materials to be } \\
\text { available and relatively low- }\end{array}$ & $\begin{array}{l}\text { orter HLW pour canisters } \\
\text { in these applications, suc }\end{array}$ & $\begin{array}{l}\text { Id be used for deep bore } \\
\text { the types of steel, are to }\end{array}$ & $\begin{array}{l}\text { oplications. } \\
\text { termined but for this stu }\end{array}$ & considered to be readily \\
\hline
\end{tabular}


Table 4-2 Comparison of Available Additional Repository Volume With LLW and GTCC Waste Production.

\begin{tabular}{|c|c|c|c|c|c|c|}
\hline \multicolumn{7}{|c|}{ Available Volume } \\
\hline & \begin{tabular}{c|} 
Drift \\
Diameter $(\mathrm{m})$ \\
\end{tabular} & $\begin{array}{l}\text { Drift Length } \\
\text { per "Cell" }(\mathrm{m})\end{array}$ & $\begin{array}{l}\text { \# Pkgs. per } \\
\text { "Cell" }\end{array}$ & $\begin{array}{l}\text { Available Drift } \\
\left.\text { ( } \mathrm{m}^{3} / \mathrm{Pkg} .\right)\end{array}$ & & \\
\hline \multicolumn{7}{|c|}{ Crystalline } \\
\hline HLW & 5.5 & 10 & 1 & 237 & & \\
\hline SNF & 5.5 & 10 & 1 & 237 & & \\
\hline \multicolumn{7}{|c|}{ Clay/Shale } \\
\hline HLW & 5.5 & 30 & 10 & 71 & & \\
\hline SNF & 5.5 & 30 & 10 & 71 & & \\
\hline \multicolumn{7}{|c|}{ Salt } \\
\hline HLW & 4.4 & 20 & 2 & 150 & \multirow{2}{*}{\multicolumn{2}{|c|}{ Diameter is equivalent circle for a $5 \times 3$ meter opening. }} \\
\hline SNF & 4.4 & 20 & 2 & 150 & & \\
\hline \multicolumn{7}{|c|}{ LLW+GTCC Waste Volume } \\
\hline & $\begin{array}{l}\text { MTHM } \\
\text { per Pkg. }\end{array}$ & $\begin{array}{c}\text { Reprocessing } \\
\text { Waste } \\
\left(\mathrm{m}^{3} / \mathrm{MTHM}\right) \\
\end{array}$ & $\begin{array}{c}\text { Fuel Fab. } \\
\text { Waste } \\
\left(\mathrm{m}^{3} / \mathrm{MTHM}\right)\end{array}$ & $\begin{array}{l}\text { Repository Waste } \\
\left.\text { ( } \mathrm{m}^{3} / \mathrm{MTHM}\right)\end{array}$ & $\begin{array}{c}\text { Total } \\
\text { LLW+GTCC } \\
\left(\mathrm{m}^{3} / \mathrm{Pkg} .\right)\end{array}$ & \\
\hline \multicolumn{7}{|c|}{ Once-Through } \\
\hline UOX SNF & 1.88 & 0 & 0 & 1 & 1.9 & \\
\hline \multicolumn{7}{|c|}{ Modified-Open } \\
\hline $\begin{array}{l}\text { HLW (Co- } \\
\text { Extraction) }\end{array}$ & 5.26 & 10 & 0 & 1 & 57.9 & $\begin{array}{l}\text { Approximate value representing } \\
\text { contributions from Table } 2-10 .\end{array}$ \\
\hline Pu MOX SNF & 1.88 & 0 & 5 & 1 & 11.3 & $\begin{array}{l}\text { Approximate value representing } \\
\text { contributions from Table } 2-11 \text {. }\end{array}$ \\
\hline \multicolumn{7}{|c|}{ Closed } \\
\hline HLW (New Extr.) & 9 & 12 & 0 & 1 & 117 & $\begin{array}{l}\text { Approximate value representing } \\
\text { contributions from Table } 2-25 \text {. }\end{array}$ \\
\hline HLW (E-Chem) & 1 to 10 & 12 & 0 & 1 & 13 to 130 & $\begin{array}{l}\text { Assume LLW+GTCC is similar to New Extr. } \\
\text { range is for different E-Chem waste types. }\end{array}$ \\
\hline ABR Metal Fuel & 0 & 0 & 5 & 1 & 0 & $\begin{array}{l}\text { Assume LLW+GTCC is similar to Pu-MOX } \\
\text { fabrication. }\end{array}$ \\
\hline
\end{tabular}


THIS PAGE INTENTIONALLY LEFT BLANK 


\section{Thermal Analyses}

The modeling tools generated in MathCAD $15^{\circledR}$, Microsoft Excel ${ }^{\circledR}$ 2007, and MatLab ${ }^{\circledR}$ Version 7.3. were used to calculate the temperature histories for combinations of disposal concept and waste type, assuming a particular emplacement layout for each concept (Sutton et al. 2011). Two types of SNF assemblies were considered, namely UOX from the open FC and MOX from the modified-open FC (fuel cycle cases are defined in Section 2). Four types of HLW packages were considered, containing Co-Extraction glass from the modified-open FC; and New Extraction glass (Section 2.3), electrochemical ceramic (EC-C) and electrochemical metal (ECM) from the closed FC. The modified-open FC has PWRs and MOX PWRs, and the closed FC has PWRs and sodium-cooled fast reactors (SFRs, a type of ABR) with CR of 0.75. In the closed FC, New Extraction glass is produced by reprocessing the PWR SNF, and the other three waste forms are produced by reprocessing the SFR metallic fuel. Thermal responses for these waste forms were investigated for disposal concepts in four generic host media (crystalline rock, clay/shale, bedded salt, and deep borehole emplacement). In addition, the number of assemblies per waste package was varied in a sensitivity study, to inform the trade-off between decay storage duration and waste package size, with respect to peak temperature at the waste package wall.

The reference design concepts used in this report, and shown in Figures 5.1-1 to 5.1-4, were finalized in a working group session hosted by LLNL on June 8 to 9, 2011. The group selected representative international design concepts for mined disposal in crystalline, clay/shale, and salt media (Andra 2005 and 2005b, European Commission 2010, SRNL 2011) and used recent work on deep borehole disposal by SNL and others (Brady et al. 2009).

\subsection{Conceptual Model}

The conceptual models presented in this report calculate: 1) temperature history at or near the interface between the EBS and the host medium, and 2) temperature history at selected locations within the EBS. For the EBS interface, the model assumes a homogeneous medium with the EBS simply replaced by the geologic media, and with the heat source being a combination of a finite line for the central waste package, point sources for nearby packages, and infinite line sources for neighboring drifts. For selected locations within the EBS, a steady-state calculation was performed at each point in time, propagating the thermal power through annular regions around the waste package, and using the interface solution as the outer temperature boundary condition, with appropriate thermal properties for each region of the EBS. This is an approximate solution that tends to slightly overestimate temperatures by neglecting heat storage in the EBS, and tends to slightly underestimate temperatures around the central package by neglecting lowconductivity EBS materials present at the waste package ends. Verification of the accuracy of this approach is addressed in the recommendations for future work (Section 6).

\subsubsection{Geometry}

Figure 5.1-1 shows a generic EBS, with names for the EBS regions adopted for this report. These names may differ slightly from those found in the technical literature for various design concepts. 


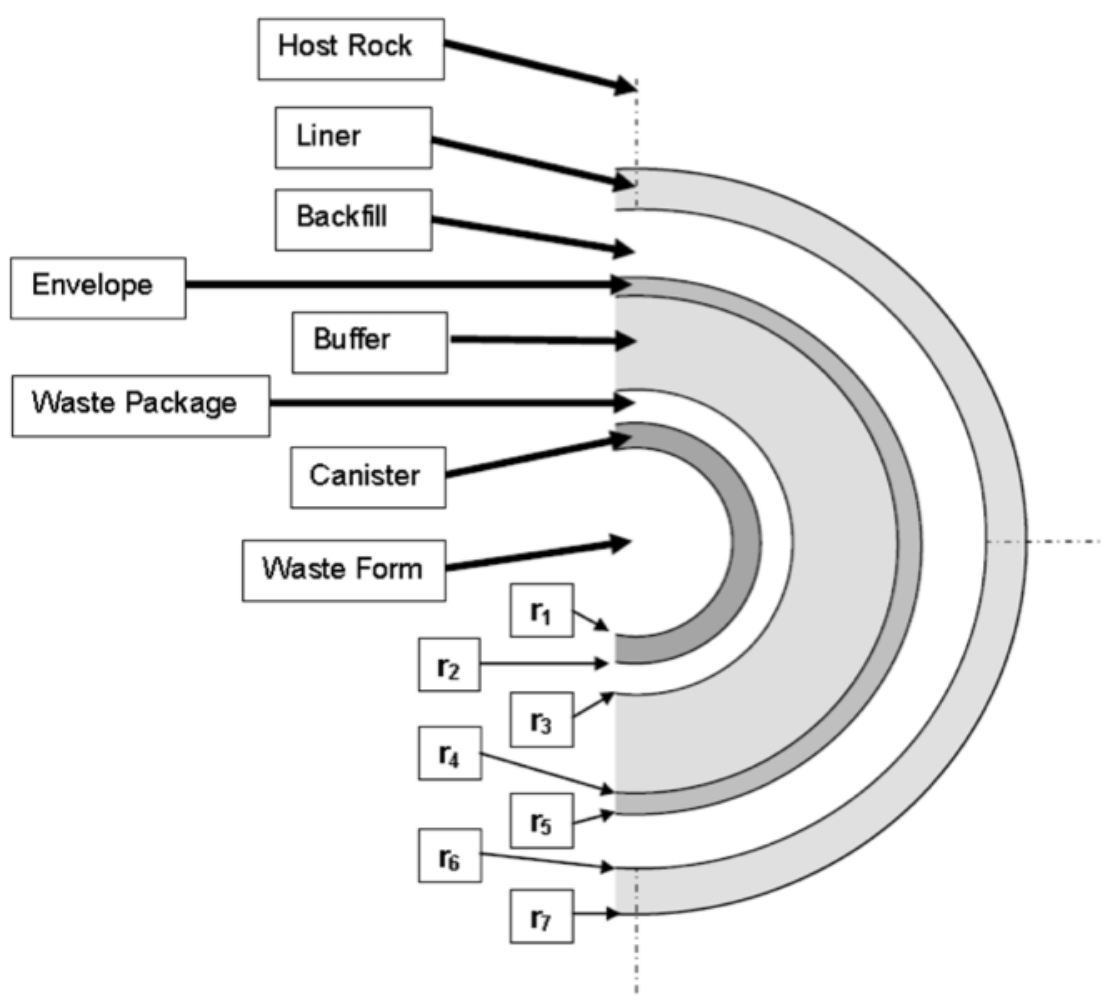

Figure 5.1-1 Illustration of Terminology for EBS Regions, from Waste Canister to Host Rock.

For each disposal concept and geologic medium, a waste package layout was selected (general rationale for these concepts and layouts is summarized in Section 4.5). Figure 5.1-2 is a generic layout that defines the layout dimensions, and can be used to interpret all of the disposal concepts (even the deep borehole concept). The waste package axis may be horizontal or vertical. For disposal in salt the axial direction is a line of alcoves, whereas for HLW disposal in clay/shale it is an array of parallel emplacement boreholes. The lateral direction is the separation of emplacement boreholes, or emplacement drifts, or linear arrays of alcoves containing waste packages.

The EBS regions and their dimensions are specific to each disposal concept and waste type (Figures 5.1-3 through 5.1-6). All SNF packages have 4-PWR/12-BWR capacities, except the deep borehole package which contains only one assembly. All HLW canisters have diameter of $0.61 \mathrm{~m}$ except the smaller pour canisters used in the deep borehole concept.

Figure 5.1-3 shows the EBS regions for the crystalline rock calculations. Waste packages of both types are surrounded by bentonite buffer material. Packages are emplaced individually in vertical emplacement boreholes. Emplacement drifts can be filled with LLW (including GTCC waste) prior to repository closure, but this does not significantly affect the thermal calculations presented here. The central package is modeled as a finite line source that is horizontal, rather than vertical, to conform to the uniform modeling approach, but this does not significantly affect the calculated temperatures. Finally, four adjacent emplacement drifts on either side of the central drift are modeled as infinite lines separated by 20 meters (lateral distance). 


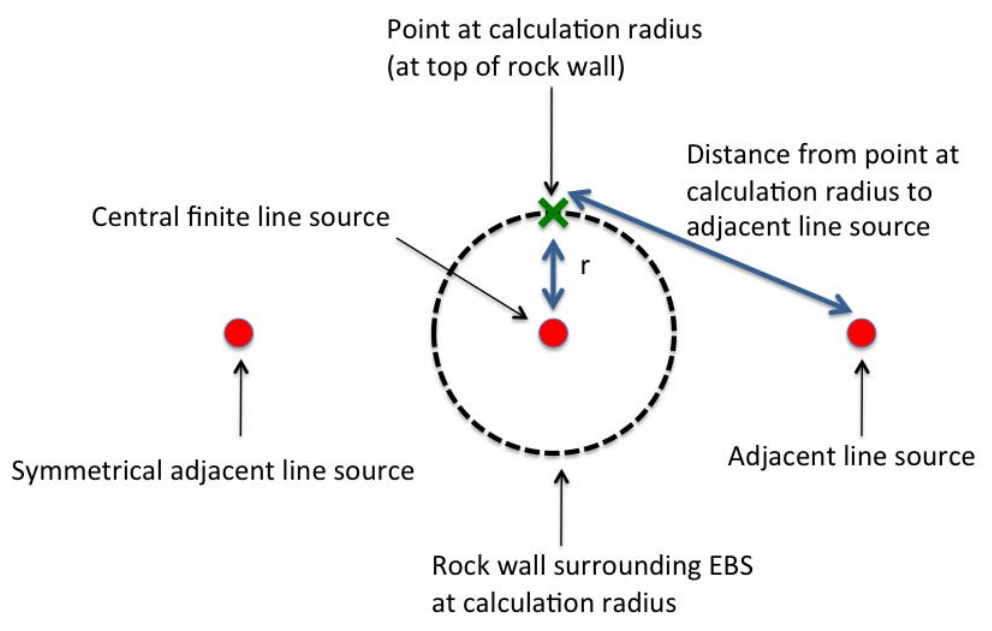

Figure 5.1-2 Layout of Waste Packages for Thermal Analysis (plan and elevation views). 

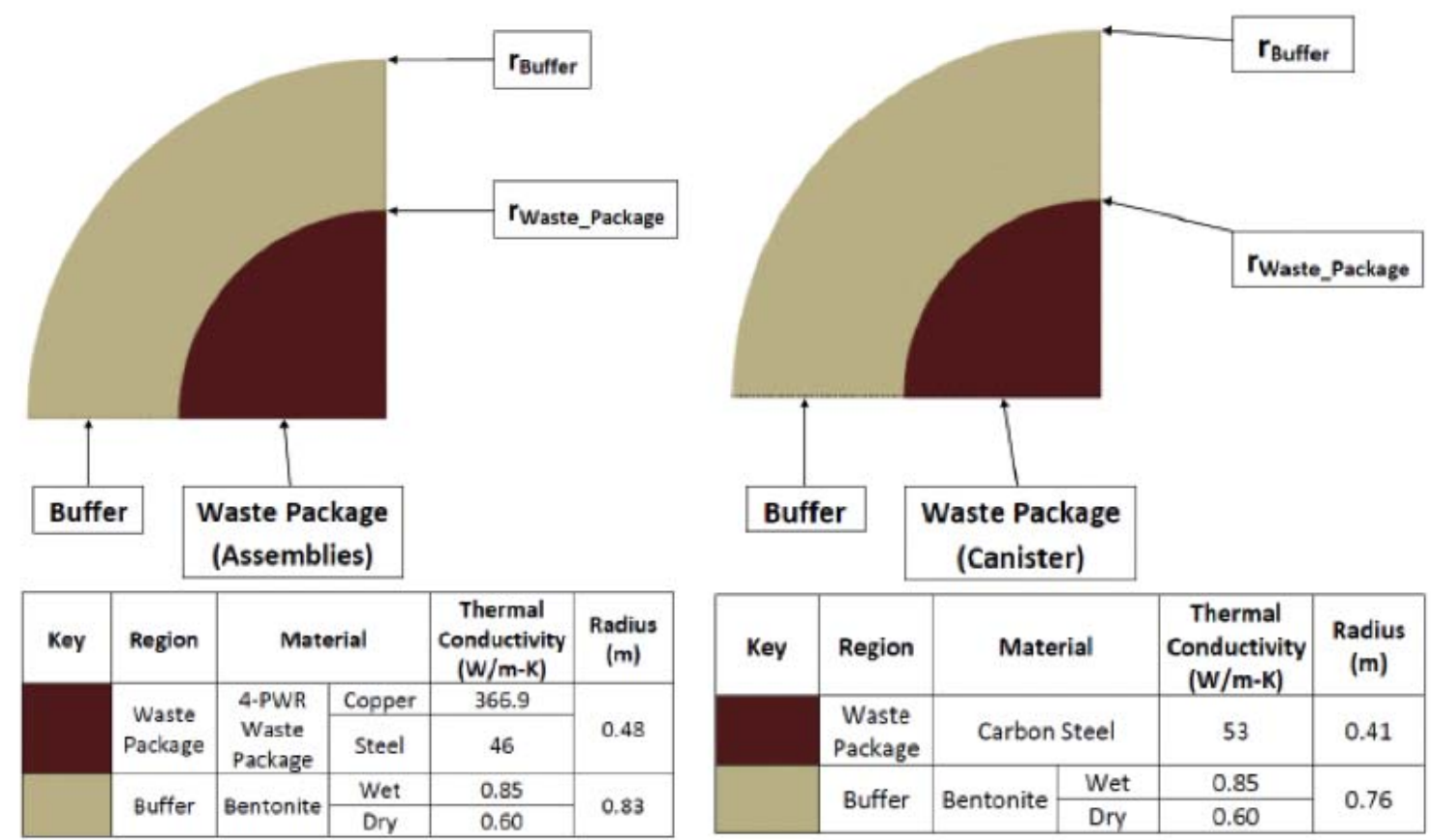

Figure 5.1-3 Graphical Representation of EBS Configuration for the Reference Disposal Concept in Crystalline Rock, for SNF (left) and HLW (right).

For this report we assume that the initially dry, compacted clay buffer remains dry during the period of peak EBS temperature, for the crystalline (SNF and HLW) and clay/shale (SNF disposal only) concepts. Thermal conductivity of $0.6 \mathrm{~W} / \mathrm{m}-\mathrm{K}$ is used, representing compacted, dry bentonite. With this approximation, the thermal resistance of the buffer layer can be as much as 2.5 to 4 times that of the host rock (Appendix G, Figure G.4-1).

The European (ONDRAF-NIRAS 2001, ONDRAF-NIRAS 2010), Japanese (JAEA 2000), and Korean (Choi and Choi 2008) design concepts include other engineered buffer materials. The JNC 2000 EBS buffer included approximately 30\% silica sand in bentonite, resulting in approximately $30 \%$ more thermal conductivity. The European designs have included bentonite mixtures with graphite and sand, as well as bentonite or cement blocks for improved thermal conductivity and structural stability. The Korean design (Choi and Choi 2008) have combined graphite in bentonite blocks to increase thermal conductivity up to $2.0 \mathrm{~W} / \mathrm{m}-\mathrm{K}$.

Figure 5.1-4 shows the EBS regions for the clay/shale calculations. Following the French concepts (Andra 2005a) the SNF waste packages are surrounded by a bentonite buffer, but the HLW packages are not. The EBS for SNF disposal consists of a carbon steel envelope enclosing a compacted clay buffer and a carbon steel disposal overpack around each SNF container. The entire assembly is designed for a clearance fit in a steel-lined emplacement drift. The EBS for HLW disposal consists of a horizontal, steel-lined borehole into which HLW canisters are emplaced directly. Both SNF and HLW disposal are modeled with nine WPs per drift or borehole (this number may deviate from published concepts but does not significantly affect calculated temperatures at the central package). The central WP is modeled as a finite line source, and the eight neighboring WPs are modeled as point sources 30 meters apart (axial 
distance). Finally, four adjacent emplacement boreholes on either side of the central borehole are modeled as infinite line sources 40 meters apart (lateral distance).

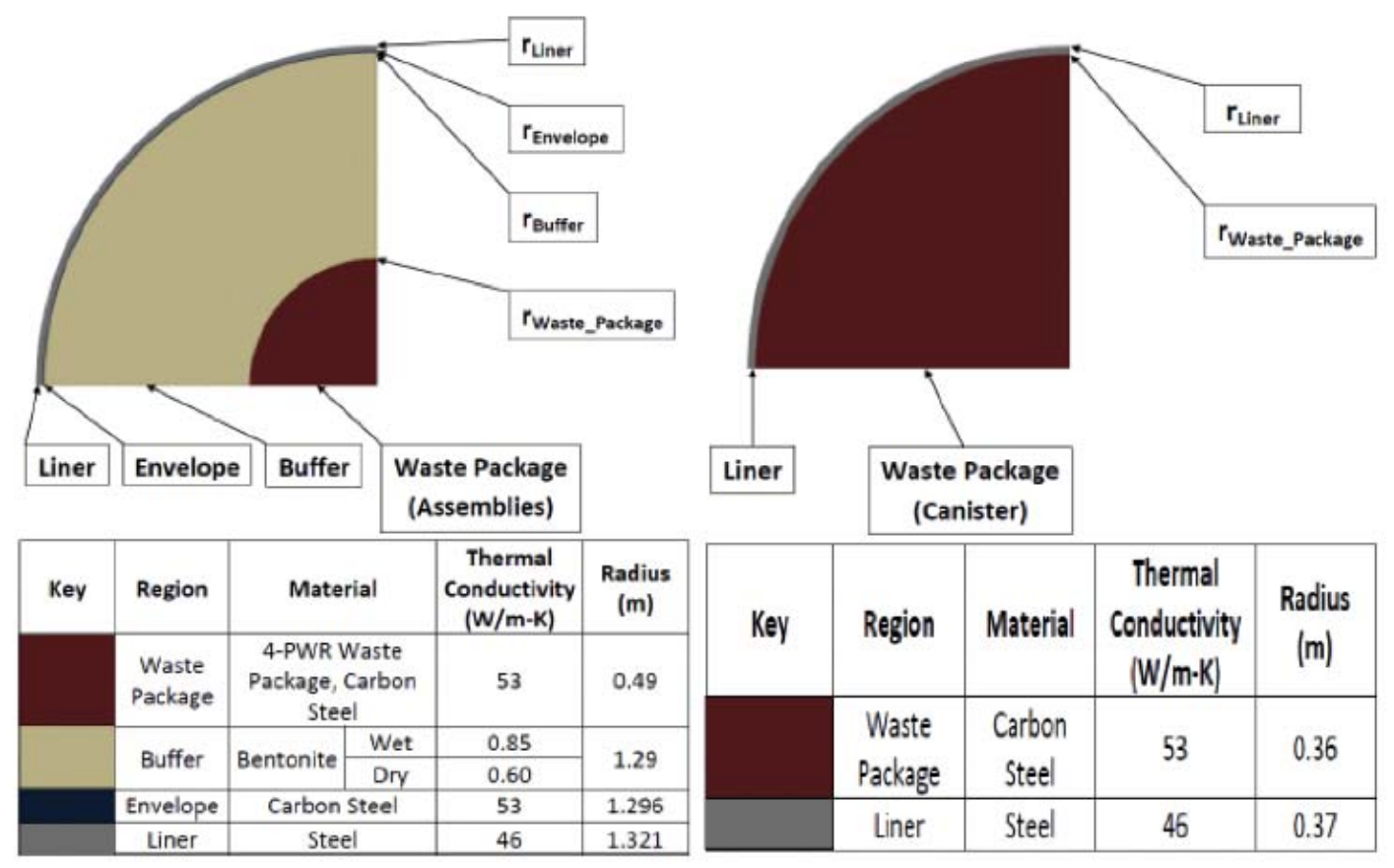

Figure 5.1-4 Graphical Representation of EBS Configuration for the Reference Disposal Concept in Clay/Shale, for SNF (left) and HLW (right).

Figure 5.1-5 shows the EBS regions for the salt calculations. Waste packages are emplaced on the floor at the back of a mined alcove, and covered with crushed salt. The axis of the waste package is parallel to the emplacement drift axis. The central WP is modeled as a finite line, and eight neighboring WPs (four on either end, as adjacent alcoves) are modeled as point sources with axial spacing of $20 \mathrm{~m}$. Finally, four adjacent emplacement drifts, on either side of the central drift, are modeled as infinite lines with lateral spacing of $40 \mathrm{~m}$. The backfill of crushed salt is expected to consolidate into intact salt in a few years, but not before the peak waste package temperature for hotter waste types. Because the thermal conductivity of crushed salt is more than seven times lower than intact salt, the calculation radius for the homogeneous calculation was set at $4 \mathrm{~m}$, somewhat farther than the $3.048 \mathrm{~m}$ radius if the backfill is converted, volumetrically, to a cylindrical geometry. Then, the EBS temperatures were calculated with intact salt inward to $3.048 \mathrm{~m}$, and either intact or crushed salt inward from that point (two cases to investigate sensitivity). Also, it was recognized that about $3 / 4$ of the waste package circumference is in close contact with intact salt at the floor and walls of the excavation, so a third sensitivity case used intact salt from $4 \mathrm{~m}$ inward to the waste package, but with only $75 \%$ of the periphery available to transfer heat. 

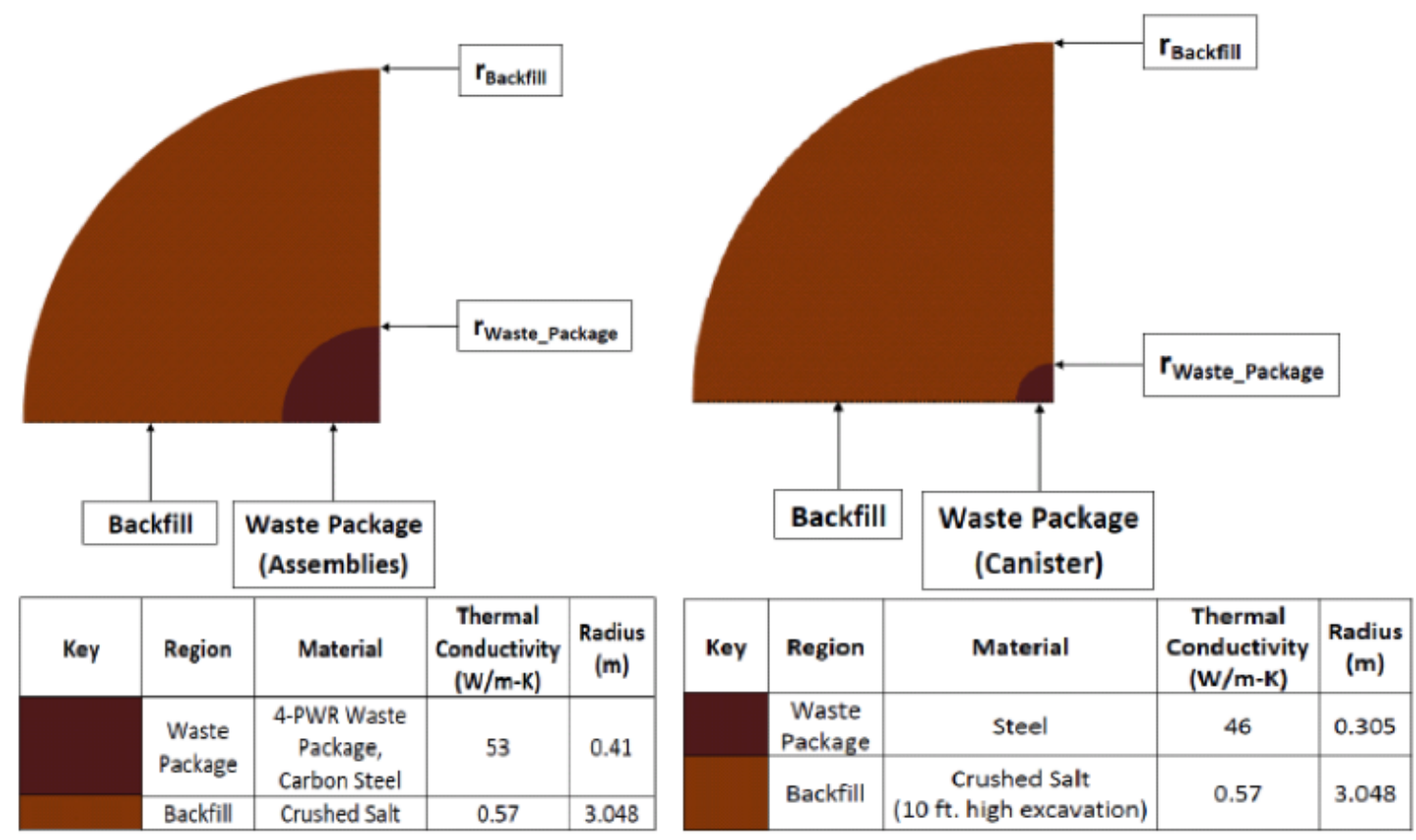

Figure 5.1-5 Graphical Representation of EBS Configuration for the Reference Disposal Concept in Salt, for SNF (left) and HLW (right).

Figure 5.1-6 shows the EBS regions for the deep borehole calculations. The deep borehole waste package contains one fuel assembly, while the HLW packages are limited by the borehole diameter and contain only $29 \%$ of the waste volume as the standard HLW packages used for the other disposal concepts. The waste packages are emplaced in deep vertical boreholes drilled from the surface, with nine packages per borehole for thermal calculations (this number is less than used in published descriptions of deep borehole disposal, but does not significantly affect the calculated temperature at the central waste package). The central waste package is represented as a finite line source, and the eight neighboring packages are represented as point sources with axial spacing of 6 meters. Finally, four adjacent emplacement boreholes on each side of the central borehole are represented as infinite line sources, at a distance of $200 \mathrm{~m}$ (this is fewer neighboring boreholes than used in published studies with lateral spacing of 200 meters, but the large borehole spacing means that there will be little effect on peak temperature at the central waste package). 

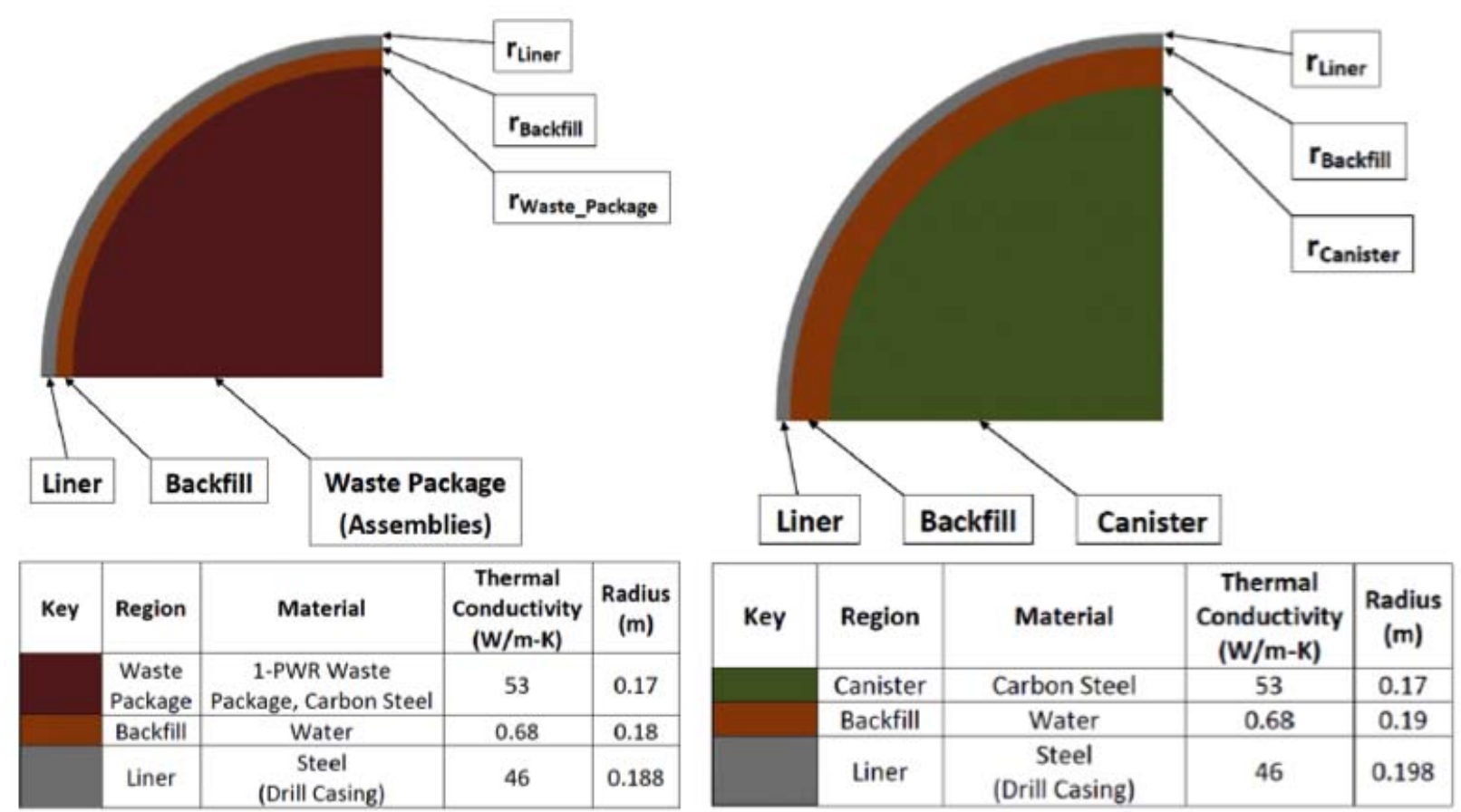

Note: Region labeled "Backfill" is assigned properties for water at $100^{\circ} \mathrm{C}$.

Figure 5.1-6 Graphical Representation of the Deep Borehole Disposal Concept, for SNF (left) and HLW (right).

\subsubsection{Approach}

For each disposal concept and waste type, time-dependent temperature calculations were performed: 1) for the interface of the EBS and the geologic medium, and 2) within the EBS. The central drift consists of one finite line source representing the central waste package, and eight point sources representing the four axial neighboring waste packages on each side, with nominal waste package center-to-center spacing (Figure 5.1-2). There are four neighboring emplacement lines on each side of the central waste package line represented by infinite line sources. This approach combines the correct local heat flux at the central package, and considers the effects of neighboring WPs and neighboring lines of waste packages. We note that the relative contributions to peak temperature from the central waste package, the axial neighbors, and the neighboring drifts, can provide insight into the effects of increasing or decreasing the waste package spacing or drift spacing. Hence, these three contributions to the temperature are tracked individually in the calculations.

\subsubsection{Input Data and Assumptions}

The decay heat curves for the six waste forms evaluated in this study, as described in Section 2, are shown in Figures 5.1-7 to 5.1-9 (the data extend to 10,000 years but only the first 100 years are shown). In Figure 5.1-7, the curves represent one assembly or canister per waste package, for storage times from 5 to 100 years (longer times were considered in the parametric calculations to determine the sensitivity of temperature to a wide range of storage times). 
The curves shown in Figure 5.1-8 represent the deep borehole concept, in which one fuel assembly is placed in each waste package. For HLW the narrower canister contains $29 \%$ of the inventory for standard canisters of the same length.

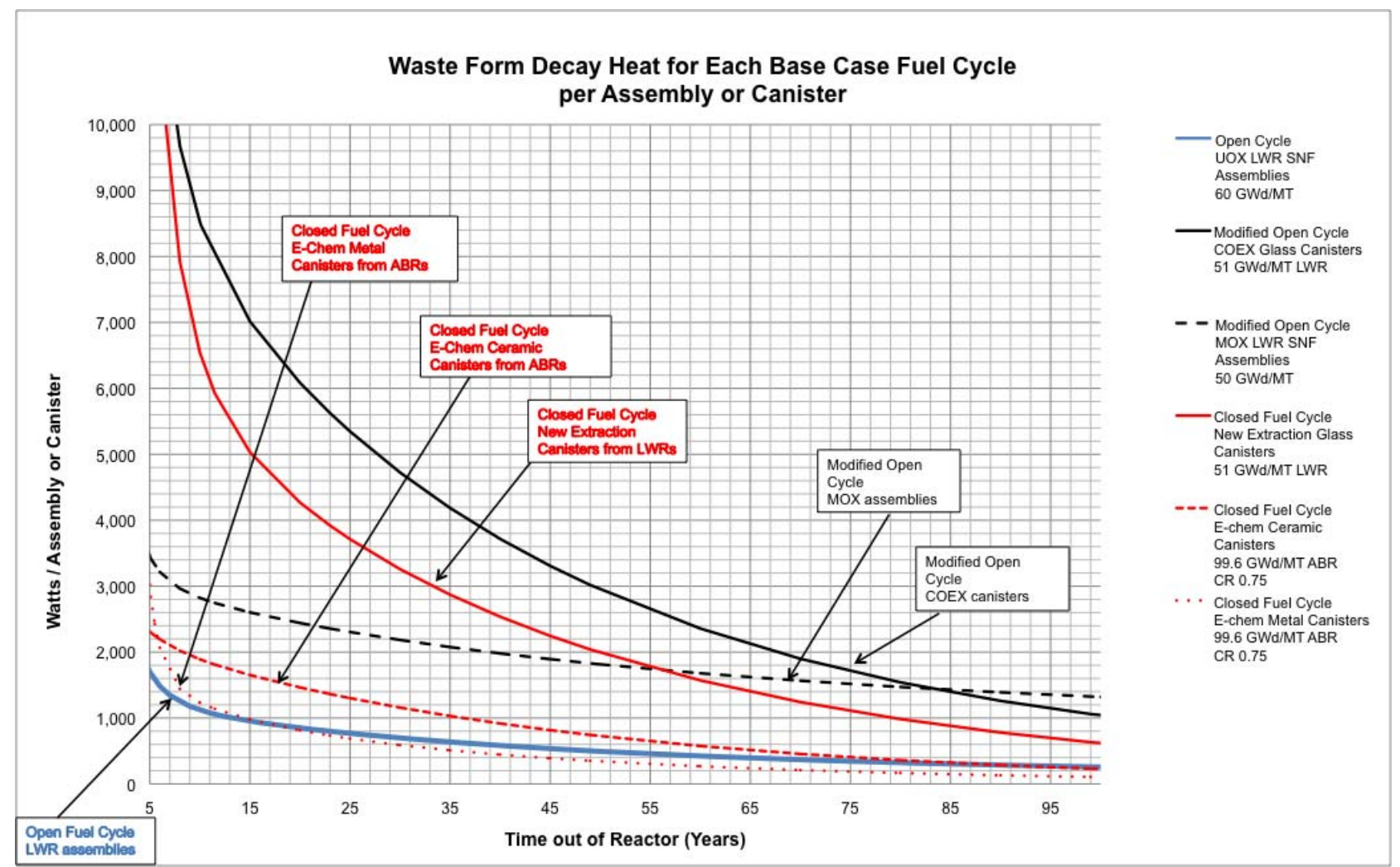

Figure 5.1-7 Decay Heat Curves for 1 Assembly or 1 Canister per Waste Package for UOX, MOX, Co-Extraction, New Extraction, EC-Ceramic, and EC-Metal Waste Types. 


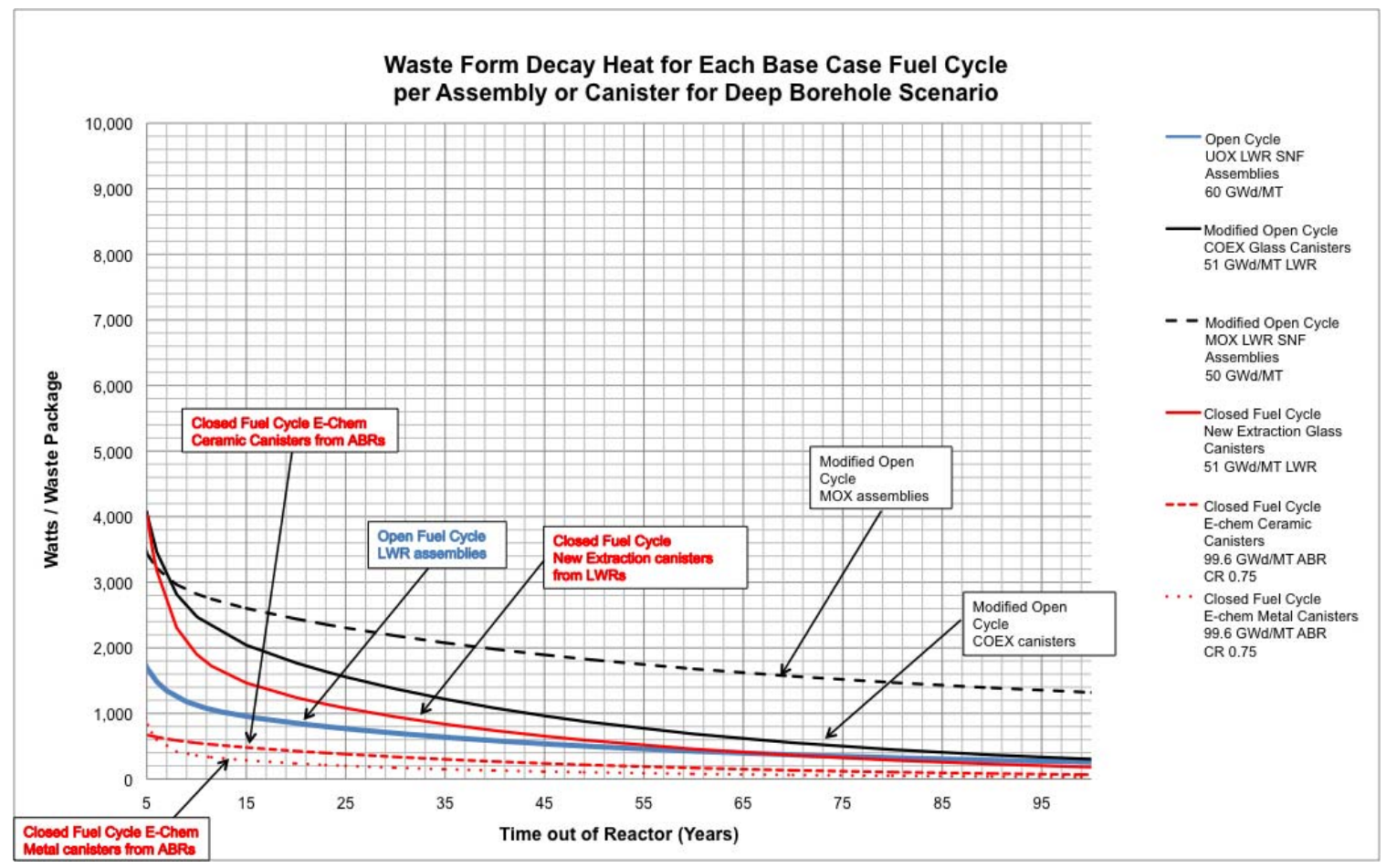

Figure 5.1-8 Decay Heat Curves for 1 UOX or MOX Assembly and 0.291 Co-Extraction, New Extraction, EC-Ceramic or EC-Metal Canisters per Waste Package (deep borehole).

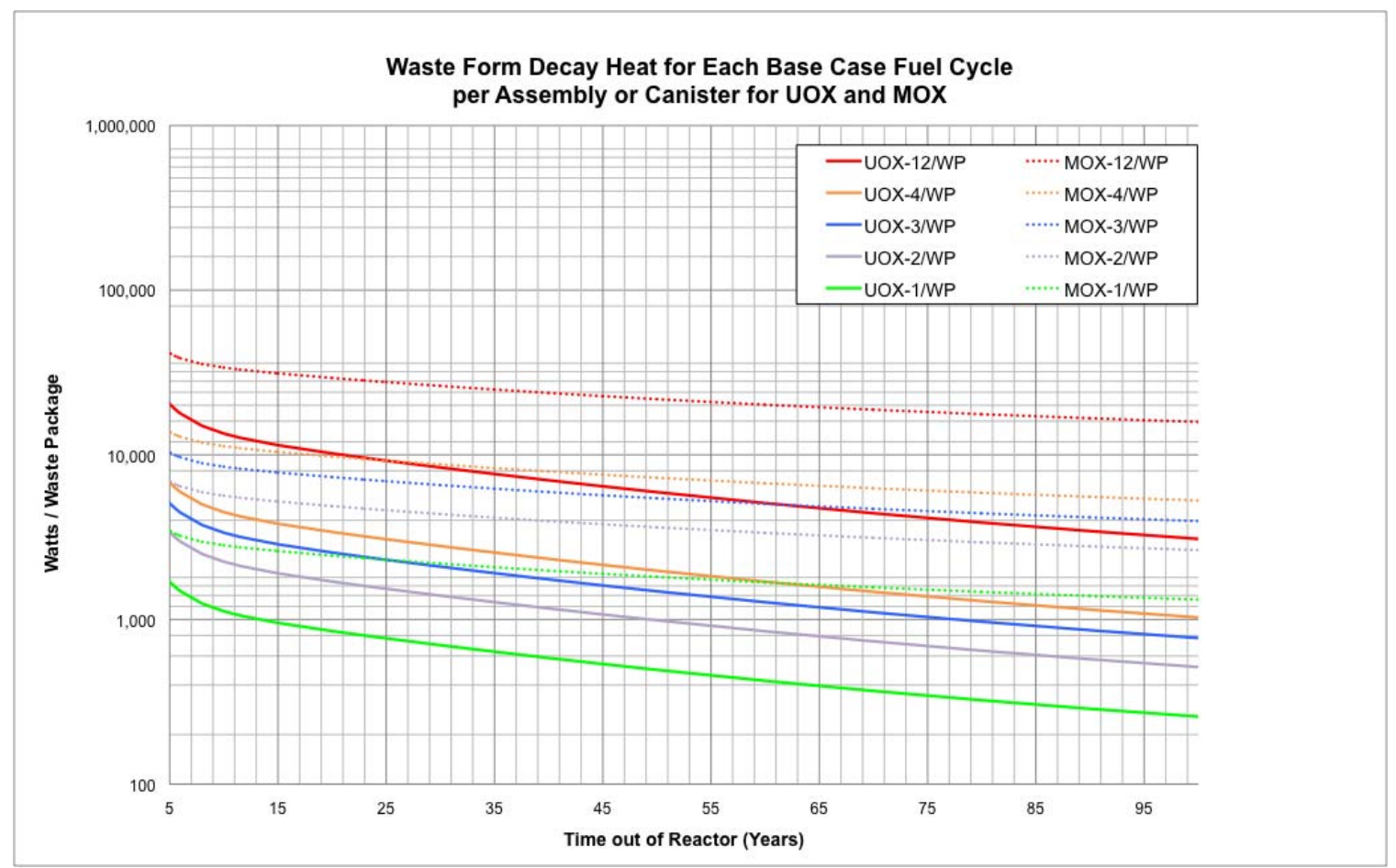

Figure 5.1-9 Decay Heat Curves for 1, 2, 3, 4 and 12 UOX or MOX Assemblies per Waste Package. 
Some geologic media, depending on storage time, can accommodate waste packages with multiple UOX or MOX assemblies. Figure 5.1-9 shows the heat per waste package for one, two, three, four and 12 assemblies per package.

An ambient average ground surface temperature of $15^{\circ} \mathrm{C}$ was assumed for all reference disposal concepts, with a natural geothermal gradient of $25^{\circ} \mathrm{C} / \mathrm{km}$. Host rock property data (Appendix G) for thermal conductivity $(\mathrm{W} / \mathrm{m}-\mathrm{K})$ and thermal diffusivity $\left(\mathrm{m}^{2} / \mathrm{s}\right)$ were developed by literature search and comparison to published data (Andra 2005a; European Commission 2010; SRNL 2011; Brady et al. 2009). Whereas thermal conductivity can be temperature dependent especially in salt, rock properties for this comparative analysis were evaluated at a uniform temperature of $100^{\circ} \mathrm{C}$.

At any given point at time the relatively low thermal mass of the EBS components, compared to the host rock medium, means that heat transfer between the waste package, other EBS components, and the host rock can be approximated as a quasi-steady state condition.

The calculation radius, associated with the radius of the host rock wall, was developed for each disposal concept. We recognized that the dimensions for UOX and MOX SNF waste packages are the same, and that all the HLW canisters have the same outer dimension (except for the deep borehole concept), so two general EBS configurations were developed for each host rock type. Using the reference disposal concepts and published descriptions of similar concepts, the inner radius and thickness of each engineered barrier component was tabulated, summing outward to the rock wall radius. This "calculation radius" was determined for all media except salt. The calculation radius for salt was based on the height of the excavation alcove for a generic salt repository (Carter et al. 2011b) with additional margin to approximate a circular shape filled with crushed salt. The calculation radius selected was $4 \mathrm{~m}$, where the maximum extent of the crushed salt layer was assumed to be $10 \mathrm{ft}(3.048 \mathrm{~m})$.

The design of the 4-PWR waste package was taken from NAGRA (2003, Figure 7). This same design diameter and wall thickness was assumed for waste packages containing two, three, and four assemblies. In the sensitivity studies a 1-PWR assembly waste package was assumed with half the diameter of the 4-PWR waste package, having the same wall thickness as the 4-PWR package. A 12-PWR waste package was also modeled, which assumed an inner diameter of the 12-PWR long waste package design (DOE 2001, Table 2) with the same wall material and thickness as the 4-PWR waste package.

\subsection{Mathematical Modeling Approach}

The physical and mathematical basis for the analytical solution approach used in this report is described in detail in Appendix G. The approach is based on heat transfer by conduction only, neglecting convection and thermal radiation. These simplifications are appropriate for low permeability media and enclosed modes of emplacement (Section 4.4). The approach involves approximation and simplification of the near-field geometry (particularly for the salt cases) and dimensionality of heat flow (using both point- and line-source solutions). Recommendations for future work include numerical simulation to verify the analytical solution approach and evaluate model uncertainty (Section 6.2).

Two mathematical/computational modeling methods can be applied to the geometry described in Section 5.1. The first is based on analytical models, and the second uses numerical simulation (e.g., the finite element method). The analysis presented in this report is limited to analytical 
models implemented in MathCAD 15 ${ }^{\circledR}$, Microsoft Excel $^{\circledR}$ 2007, and MatLab ${ }^{\circledR}$ Version 7.3. Recommendations for future analytical model analyses and numerical simulations are discussed in Section 6.

\subsection{Results}

The results of the homogeneous analytic solution model and the quasi-steady-state heterogeneous concentric cylinder model are presented in this section.

\subsubsection{Host Rock and Waste Package Temperatures}

Host rock temperature was calculated for all combinations of the four disposal concepts and six waste forms considered in this study. In addition, for UOX and MOX, the host rock temperature was evaluated as a function of the number of assemblies per waste package (1, 2, 3, 4 and 12 per package). Waste package length and thermal output, EBS geometry, rock properties, and the axial and lateral spacing of waste packages are discussed in Section 5.1.

The analytical modeling approach is implemented in two steps. The first step calculates the temperature at the host rock, or at a "calculation radius" within the host rock, due to a central finite-length waste package plus arrays of nearby packages in the same drift, and in neighboring drifts. The second step calculates the temperature differences across EBS regions, starting at the "calculation radius" and working back toward the waste package. The sum of the temperature at the "calculation radius" plus the temperature increase at the waste package wall, is the principal temperature estimate used in this study.

As examples, Figures 5.3-1 and 5.3-2 plot the temperature transient at the host rock "calculation radius" after surface decay storage times of 10, 50, and 100 years, for a repository in crystalline rock, for waste packages containing four UOX assemblies, and four MOX assemblies, respectively. The MOX SNF waste form is the hottest among those evaluated for this report, while the UOX SNF calculation is more typical. A full set of plots for all disposal concepts and waste types is provided in Appendix G.

Calculated temperature results from three contributions: the central waste package (finite line source), axially adjacent waste packages (point sources), and laterally adjacent emplacement arrays (infinite line sources). Waste package spacing (axial) and drift spacing (lateral) are discussed in Section 5.1. As examples, Figures 5.3-3 and 5.3-4 plot these three components at the host rock "calculation radius" after surface decay storage of 10 years, for a repository in crystalline rock, for waste packages containing four UOX assemblies, and four MOX assemblies, respectively.

Table 5-1 summarizes the host rock peak temperature and the corresponding time out-of-reactor when the peak occurs. For all cases except salt, the "calculation radius" corresponds to the wall of emplacement borehole or drift (for salt it is within the host rock), so this radius is correlated with peak temperature in Table 5-1. In the deep borehole setting, where the adjacent lines of packages are widely spaced $(200 \mathrm{~m})$, the temperature peaks sooner than for the other concepts. In the other media the temperature peaks after a few decades or more. Note that the time from emplacement to the peak temperature increases with decay storage, because after decay of the short-lived fission products the waste heat output decreases more slowly.

The limiting temperatures (called target maximum temperatures in Section 4.1.1.2) considered in this study depend on the design concept and host medium, and they are defined at the waste 
package surface in contact with sensitive buffer or host media. The waste package surface temperature is always greater than the rock temperature at the calculation radius. However, even without calculating temperatures at the waste package surface or elsewhere in the EBS, the rock temperatures summarized in Table 5-1 support some conclusions:

- A waste package containing four UOX assemblies requires surface storage of approximately 50 years before emplacement in crystalline or clay/shale media, and fewer than 10 years in salt.

- A waste package containing four MOX assemblies requires surface storage for more than 200 years before emplacement in crystalline or clay/shale media.

- In crystalline rock even a single MOX assembly package requires more than 100 years storage, whereas a single UOX assembly package may be emplaced in crystalline, clay, or salt media within 10 years out-of-reactor.

- Co-Extraction glass, the hottest of the HLW forms, requires more than 50 years storage before emplacement in crystalline rock or clay/shale media. 


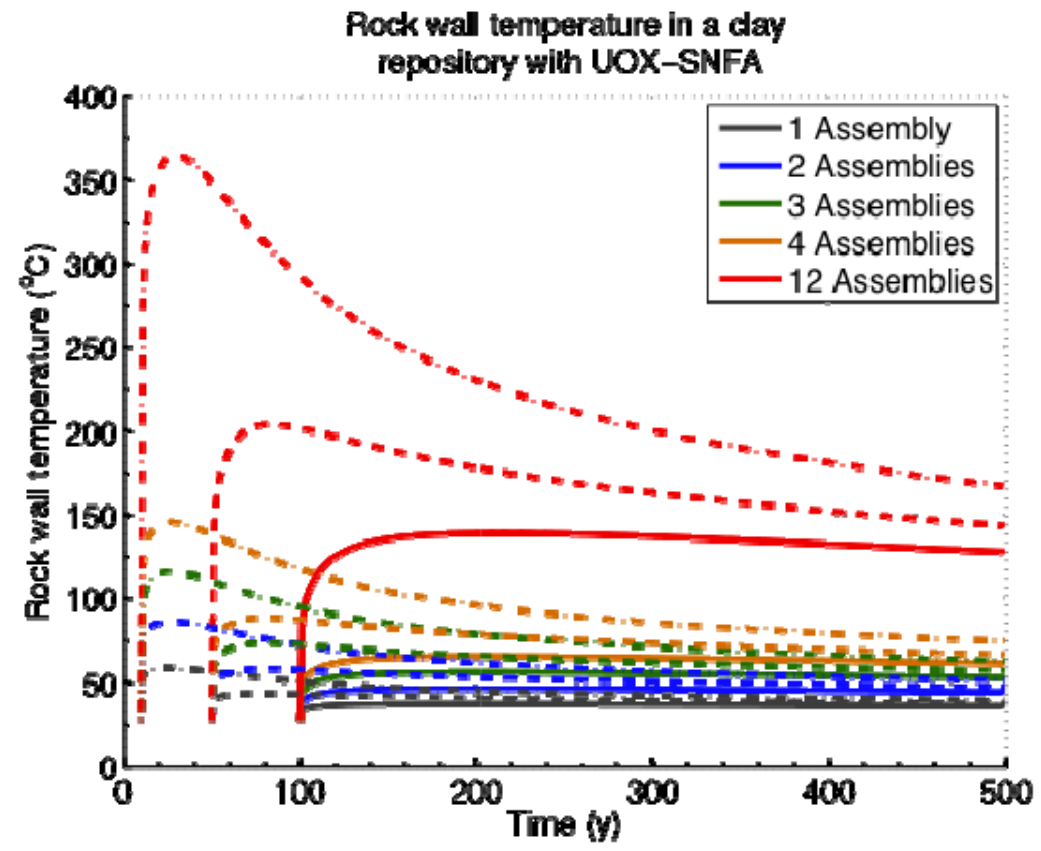

Note: Dash-dot lines are for $10 \mathrm{yr}$, dashed lines are for $50 \mathrm{yr}$, and solid lines are for $100 \mathrm{yr}$ decay storage.

Figure 5.3-1 Temperature Histories at the "Calculation Radius" After Decay Storage of 10, 50 and 100 yr for Waste Packages Containing 1, 2, 3, 4 and 12 UOX Assemblies, for a Repository in ClaylShale Media.

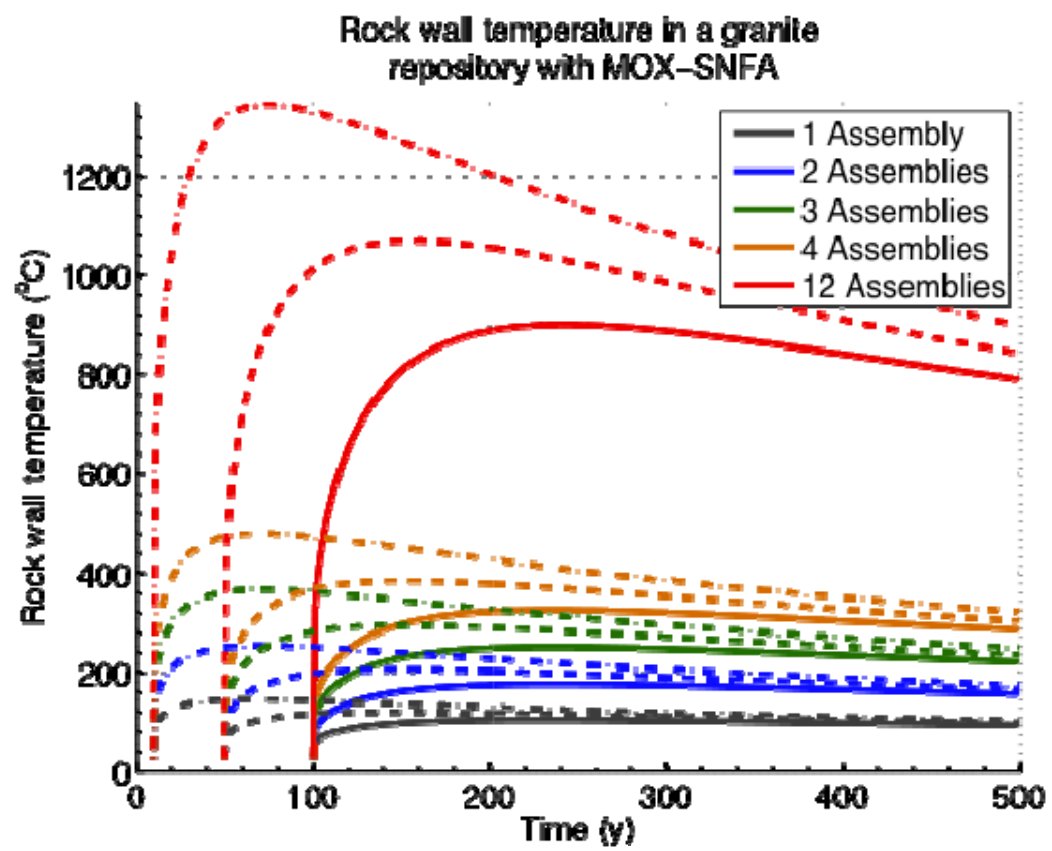

Note: Dash-dot lines are for $10 \mathrm{yr}$, dashed lines are for $50 \mathrm{yr}$, and solid lines are for $100 \mathrm{yr}$ decay storage.

Figure 5.3-2 Temperature Histories at the "Calculation Radius" After Decay Storage of 10, 50 and 100 yr, for Packages Containing 1, 2, 3, 4 and 12 MOX Assemblies, in Crystalline Rock. 


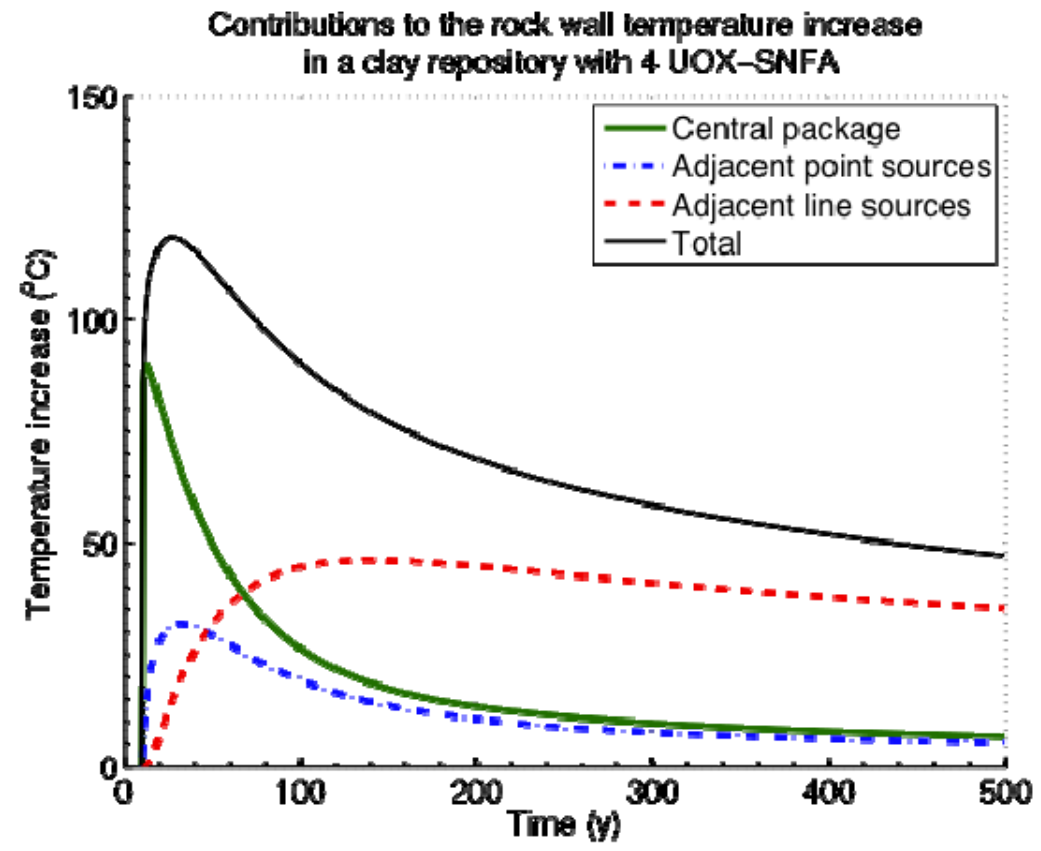

Figure 5.3-3 Contributions to Temperature at the "Calculation Radius" from the Central Package, Adjacent Packages, and Neighboring Drifts for a Waste Package Containing 4 UOX Assemblies in Clay/Shale Media (10 yr Decay Storage).

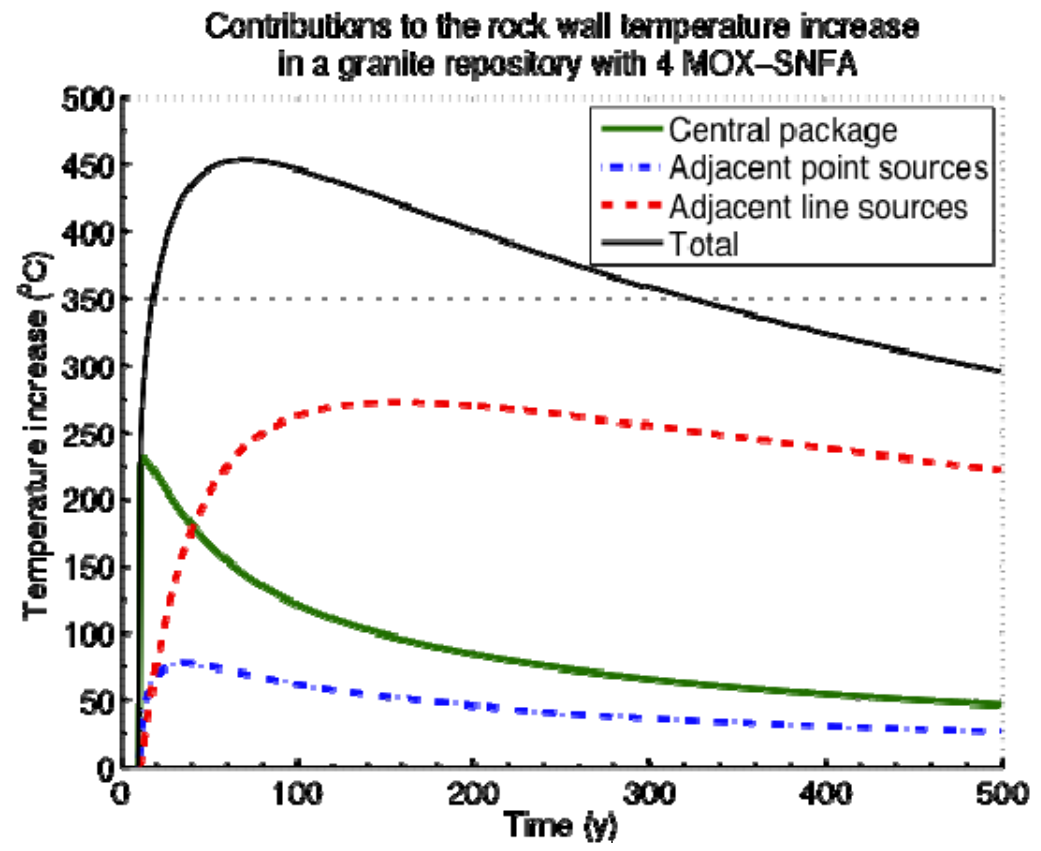

Figure 5.3-4 Contributions to Temperature at the "Calculation Radius" from the Central Package, Adjacent Packages, and Neighboring Drifts for a Waste Package Containing 4 MOX Assemblies in Crystalline Rock (10 yr Decay Storage). 
Table 5-1 Peak Temperature at the "Calculation Radius" and Corresponding Time of the Peak for Four Disposal Concepts, Six Waste Types and Four Decay Storage Periods.

\begin{tabular}{|c|c|c|c|c|c|c|c|c|c|c|c|}
\hline \multicolumn{4}{|c|}{ Disposal Scenarios } & \multicolumn{2}{|c|}{$\begin{array}{c}10 \text { Year Storage Peak } \\
\text { Values }\end{array}$} & \multicolumn{2}{|c|}{$\begin{array}{c}50 \text { Year Storage Peak } \\
\text { Values }\end{array}$} & \multicolumn{2}{|c|}{$\begin{array}{l}100 \text { Year Storage } \\
\text { Peak Values }\end{array}$} & \multicolumn{2}{|c|}{$\begin{array}{l}200 \text { Year Storage } \\
\text { Peak Values }\end{array}$} \\
\hline Geology & Waste Form & $\begin{array}{l}\text { Assemblies } \\
\text { / WP }\end{array}$ & $\begin{array}{l}\text { Calculation } \\
\text { Radius, m }\end{array}$ & $\begin{array}{c}\text { Peak } \\
\text { Temp, }{ }^{\circ} \mathrm{C}\end{array}$ & $\begin{array}{l}\text { Time of } \\
\text { Peak, Yr }\end{array}$ & $\begin{array}{c}\text { Peak } \\
\text { Temp, }{ }^{\circ} \mathrm{C}\end{array}$ & $\begin{array}{l}\text { Time of } \\
\text { Peak, Yr }\end{array}$ & $\begin{array}{c}\text { Peak } \\
\text { Temp, }{ }^{\circ} \mathrm{C}\end{array}$ & $\begin{array}{l}\text { Time of } \\
\text { Peak, } \mathrm{Yr}\end{array}$ & $\begin{array}{c}\text { Peak } \\
\text { Temp, }{ }^{\circ} \mathrm{C}\end{array}$ & $\begin{array}{l}\text { Time of } \\
\text { Peak, } \mathrm{Yr}\end{array}$ \\
\hline \multirow{8}{*}{ Granite } & UOX4-SNFA & 4 & 0.83 & 165.8 & 35 & 100.7 & 87 & 73.0 & 172 & 58.7 & 389 \\
\hline & UOX1-SNFA & 1 & 0.64 & 64.2 & 31 & 46.8 & 83 & 39.4 & 166 & 35.6 & 351 \\
\hline & MOX4-SNFA & 4 & 0.83 & 481.2 & 69 & 384.9 & 154 & 326.5 & 229 & 263.4 & 389 \\
\hline & MOX1-SNFA & 1 & 0.64 & 146.0 & 63 & 120.3 & 146 & 104.9 & 229 & 88.2 & 372 \\
\hline & COEX Glass & 1 & 0.76 & 279.9 & 26 & 126.0 & 69 & 64.9 & 126 & 43.4 & 372 \\
\hline & New Extraction & 1 & 0.76 & 205.2 & 24 & 92.7 & 67 & 47.9 & 118 & 29.6 & 217 \\
\hline & EC-Ceramic & 1 & 0.76 & 88.3 & 28 & 51.4 & 67 & 34.9 & 117 & 28.2 & 217 \\
\hline & EC-Metal & 1 & 0.76 & 65.5 & 17 & 39.7 & 64 & 31.2 & 115 & 27.9 & 215 \\
\hline \multirow{8}{*}{ Clay } & UOX4-SNFA & 4 & 1.32 & 146.0 & 27 & 88.9 & 80 & 65.8 & 201 & 55.5 & 477 \\
\hline & UOX1-SNFA & 1 & 1.13 & 59.1 & 24 & 43.7 & 76 & 37.4 & 186 & 34.7 & 452 \\
\hline & MOX4-SNFA & 4 & 1.32 & 406.5 & 76 & 335.8 & 211 & 291.0 & 299 & 239.7 & 477 \\
\hline & MOX1-SNFA & 1 & 1.13 & 126.2 & 69 & 106.9 & 201 & 95.2 & 299 & 81.9 & 461 \\
\hline & COEX Glass & 1 & 0.37 & 477.9 & 15 & 197.3 & 59 & 89.5 & 111 & 52.3 & 447 \\
\hline & New Extraction & 1 & 0.37 & 354.9 & 13 & 141.1 & 57 & 62.9 & 108 & 31.1 & 208 \\
\hline & EC-Ceramic & 1 & 0.37 & 133.5 & 17 & 69.0 & 57 & 40.4 & 108 & 28.8 & 208 \\
\hline & EC-Metal & 1 & 0.37 & 105.0 & 13 & 50.8 & 55 & 34.6 & 106 & 28.2 & 206 \\
\hline \multirow{8}{*}{ Salt } & UOX4-SNFA & 4 & 4.00 & 69.8 & 44 & 50.3 & 95 & 41.9 & 176 & 37.3 & 351 \\
\hline & UOX1-SNFA & 1 & 4.00 & 38.1 & 44 & 33.2 & 95 & 31.1 & 176 & 30.0 & 403 \\
\hline & MOX4-SNFA & 4 & 4.00 & 170.3 & 79 & 140.3 & 161 & 121.8 & 240 & 101.5 & 390 \\
\hline & MOX1-SNFA & 1 & 4.00 & 63.2 & 79 & 55.7 & 161 & 51.1 & 240 & 46.0 & 390 \\
\hline & COEX Glass & 1 & 4.00 & 99.6 & 36 & 56.1 & 80 & 38.6 & 139 & 32.4 & 405 \\
\hline & New Extraction & 1 & 4.00 & 77.9 & 35 & 46.2 & 76 & 33.4 & 128 & 28.1 & 230 \\
\hline & EC-Ceramic & 1 & 4.00 & 45.0 & 38 & 34.4 & 76 & 29.6 & 128 & 27.7 & 229 \\
\hline & EC-Metal & 1 & 4.00 & 36.9 & 32 & 30.7 & 77 & 28.5 & 127 & 27.6 & 229 \\
\hline \multirow{6}{*}{ Deep Borehole } & UOX-SNFA & 1 & 0.19 & 183.7 & 13 & 160.7 & 55 & 151.1 & 107 & 145.9 & 214 \\
\hline & MOX-SNFA & 1 & 0.19 & 257.6 & 16 & 219.5 & 59 & 199.5 & 113 & 182.3 & 218 \\
\hline & COEX Glass & 0.291 & 0.20 & 238.2 & 13 & 176.0 & 54 & 152.9 & 105 & 143.8 & 210 \\
\hline & New Extraction & 0.291 & 0.20 & 212.5 & 12 & 164.2 & 54 & 147.5 & 104 & 140.8 & 204 \\
\hline & EC-Ceramic & 0.291 & 0.20 & 162.7 & 14 & 148.9 & 54 & 142.8 & 104 & 140.3 & 204 \\
\hline & EC-Metal & 0.291 & 0.20 & 157.6 & 12 & 145.2 & 53 & 141.6 & 103 & 140.2 & 204 \\
\hline
\end{tabular}

Notes:

1. The heat source is a waste package with 4 neighboring waste packages on each end of the finite line (WP) with 4 neighboring lines on each side of the WP line.

2. Deep borehole canisters (Co-Extraction, New Extraction, EC-Ceramic, EC-Metal) are narrower (and thus have less heat) than the standard canisters used for the other three media.

3. All times are years out-of-reactor (rather than time after reprocessing or time after emplacement)

\subsubsection{Waste Package and EBS Peak Temperatures}

The waste package surface and other EBS temperature histories were calculated as discussed above. At each point in time, the steady-state heterogeneous model, described in Section 5.3.4, was used to offset the temperature at the "calculation radius" from the homogeneous model. As an example, Figure 5.3-3 (example) and Appendix A, Section 4, document the waste package surface transient temperature for the different host rocks and waste forms.

Table 5-2 presents peak temperatures at the waste package surface for crystalline rock, clay/shale, and deep borehole disposal concepts (salt is presented in Section 5.3.3). For some cases, particularly with the EC-C and EC-M waste types and longer storage times, the difference in temperature at the waste package surface and the "calculation radius" is only a fraction of a degree. For hotter and/or younger waste types, the use of a bentonite clay buffer, and the relatively low thermal conductivity of clay/shale media, produce greater temperature differences.

A target maximum temperature of $100^{\circ} \mathrm{C}$ for clay buffer materials or clay/shale media is used here for comparative purposes (Section 4.1.1.2). Also, we note that clay buffer material starts out dry with low conductivity, and gradually hydrates. An intermediate value for thermal conductivity is used here, but the results are subject to verification (see Section 6). 


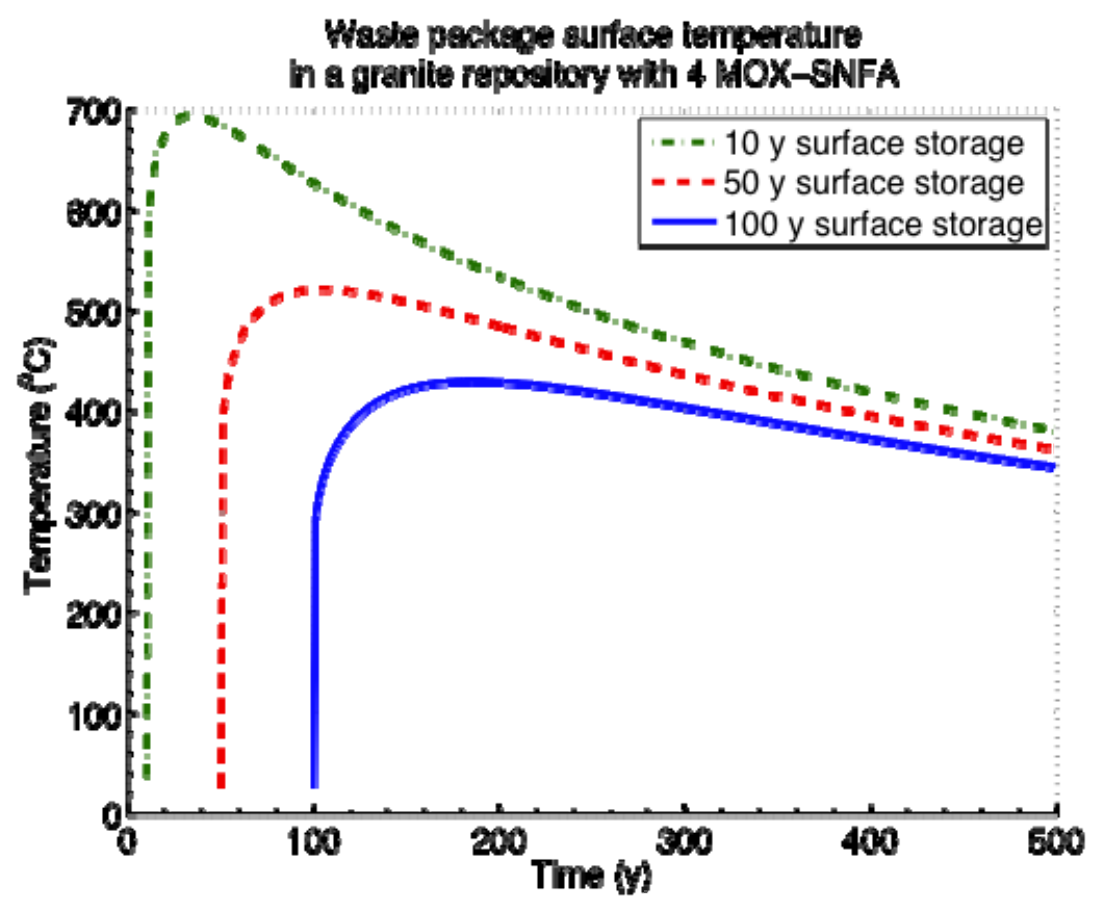

Figure 5.3-3 Calculated Waste Package Temperature After Decay Storage of 10, 50 and 100 yr, for Packages Containing 4 MOX Assemblies, for a Repository in Crystalline Rock,

With these caveats, the results from Table 5-2 can be summarized for crystalline and clay/shale disposal concepts:

- Waste packages containing a single MOX assembly require more than 200 years surface decay storage,

- LWR UOX waste packages containing four assemblies (4-PWR) could be emplaced after approximately 100 years of surface decay storage (this result is similar to SNF management practices being implemented by the Swedish program),

- LWR UOX waste packages containing one assembly (1-PWR) could be emplaced after approximately 10 to 50 years of surface decay storage,

- Co-Extraction and New Extraction glass waste types could be emplaced after approximately 50 to 100 years of surface decay storage, and

- EC-C and EC-M waste types can be emplaced after fewer than 50 years, and approximately 10 years, respectively, of surface decay storage. 
Table 5-2 Peak Waste Package Surface Temperature and the Time When the Peak Occurs, for Crystalline, Clay/Shale, and Deep Borehole Concepts.

\begin{tabular}{|c|c|c|c|c|c|c|c|c|c|c|}
\hline \multirow{2}{*}{\multicolumn{3}{|c|}{ Disposal Scenarios }} & \multicolumn{8}{|c|}{ Storage Time, $\mathrm{Yr}$} \\
\hline & & & \multicolumn{2}{|c|}{10} & \multicolumn{2}{|c|}{50} & \multicolumn{2}{|c|}{100} & \multicolumn{2}{|c|}{200} \\
\hline Geology & Waste Form & $\begin{array}{c}\text { Assemblies } \\
\text { / WP }\end{array}$ & $\begin{array}{c}\text { Peak } \\
\text { Temp, }{ }^{\circ} \mathrm{C}\end{array}$ & $\begin{array}{c}\text { Peak } \\
\text { Time, yr }\end{array}$ & $\begin{array}{c}\text { Peak } \\
\text { Temp, }^{\circ} \mathrm{C}\end{array}$ & $\begin{array}{c}\text { Peak } \\
\text { Time, yr }\end{array}$ & $\begin{array}{c}\text { Peak } \\
\text { Temp, }^{\circ} \mathrm{C}\end{array}$ & $\begin{array}{c}\text { Peak } \\
\text { Time, yr }\end{array}$ & $\begin{array}{c}\text { Peak } \\
\text { Temp, oC }\end{array}$ & $\begin{array}{c}\text { Peak } \\
\text { Time, yr }\end{array}$ \\
\hline \multirow{8}{*}{ Granite } & UOX4-SNFA & 4 & 256.9 & 17 & 141.2 & 65 & 92.8 & 134 & 68.9 & 299 \\
\hline & UOX1-SNFA & 1 & 100.5 & 17 & 62.6 & 59 & 47.0 & 122 & 39.4 & 273 \\
\hline & MOX4-SNFA & 4 & 694.6 & 35 & 521.7 & 104 & 430.1 & 186 & 337.1 & 324 \\
\hline & MOX1-SNFA & 1 & 229.8 & 25 & 172.9 & 88 & 144.0 & 166 & 116.2 & 299 \\
\hline & COEX Glass & 1 & 521.2 & 12 & 209.9 & 56 & 93.6 & 108 & 49.8 & 273 \\
\hline & New Extraction & 1 & 396.6 & 11 & 149.9 & 55 & 65.6 & 105 & 31.3 & 206 \\
\hline & EC-Ceramic & 1 & 142.0 & 15 & 72.2 & 55 & 41.4 & 105 & 28.9 & 206 \\
\hline & EC-Metal & 1 & 124.8 & 11 & 55.7 & 53 & 36.0 & 103 & 28.3 & 203 \\
\hline \multirow{8}{*}{ Clay } & UOX4-SNFA & 4 & 341.9 & 12 & 174.0 & 55 & 106.4 & 111 & 72.9 & 273 \\
\hline & UOX1-SNFA & 1 & 127.1 & 11 & 73.5 & 53 & 52.0 & 107 & 41.0 & 241 \\
\hline & MOX4-SNFA & 4 & 860.7 & 16 & 600.1 & 67 & 474.2 & 148 & 366.1 & 299 \\
\hline & MOX1-SNFA & 1 & 288.6 & 13 & 203.4 & 64 & 161.8 & 130 & 126.8 & 273 \\
\hline & COEX Glass & 1 & 478.0 & 15 & 197.3 & 59 & 89.5 & 111 & 52.4 & 447 \\
\hline & New Extraction & 1 & 355.0 & 13 & 141.1 & 57 & 62.9 & 108 & 31.1 & 208 \\
\hline & EC-Ceramic & 1 & 133.6 & 17 & 69.1 & 57 & 40.4 & 108 & 28.8 & 208 \\
\hline & EC-Metal & 1 & 105.0 & 13 & 50.8 & 55 & 34.6 & 106 & 28.2 & 206 \\
\hline \multirow{6}{*}{ Deep Borehole } & UOX-SNFA & 1 & 186.4 & 13 & 161.9 & 55 & 151.7 & 107 & 146.3 & 214 \\
\hline & MOX-SNFA & 1 & 264.5 & 16 & 224.1 & 59 & 202.9 & 112 & 184.7 & 217 \\
\hline & COEX Glass & 0.291 & 250.8 & 12 & 180.5 & 54 & 154.5 & 104 & 144.2 & 209 \\
\hline & New Extraction & 0.291 & 222.1 & 12 & 167.2 & 54 & 148.5 & 104 & 140.9 & 204 \\
\hline & EC-Ceramic & 0.291 & 165.6 & 13 & 150.0 & 54 & 143.1 & 104 & 140.3 & 203 \\
\hline & EC-Metal & 0.291 & 160.4 & 12 & 146.0 & 53 & 141.8 & 103 & 140.2 & 203 \\
\hline
\end{tabular}

Notes:

1. Derived from steady state calculation of EBS components between waste package and host rock.

2. See Notes 2 and 3 from Table 5-1.

For the deep borehole repository design, water or hydrated clay will fill the space between the borehole casing and the waste package (a representative thermal conductivity for water at $100^{\circ} \mathrm{C}$ is used in the analysis; see Section 4.5.4). The borehole size, rather than any potential temperature limit, will likely drive the design. The borehole size limits the UOX and MOX waste forms to one assembly per waste package, and for HLW the borehole diameter limits the canister cross-sectional area to $29.1 \%$ of that of a standard ( $2 \mathrm{ft}$ diameter) canister. Importantly, no temperature limit or need for one has been identified for the deep borehole disposal. For deep borehole disposal, the results in Table 5-2 are consistent with thermal calculations reported previously (Brady et al. 2009).

\subsubsection{Waste Package Surface Peak Temperature for Salt}

The heterogeneous temperature solution calculates the temperature distribution from the "calculation radius" (4 meters) inward to the waste package. At the time of emplacement, part of the salt around the package is crushed and has thermal conductivity and other characteristics that are significantly different from intact salt. Over a few years the crushed salt reconsolidates under the influence of heat and pressure. For this study, the calculation methods are not amenable to time- or temperature-dependent backfill properties. However, cases were run using three different assumptions for salt backfill conductivity to bracket the potential results:

- Intact salt reconsolidates immediately.

- Crushed salt retains its low conductivity, from the package surface out to $3.05 \mathrm{~m}$ radius, with intact salt to 4 meters. 
- Intact salt, but with the package contact area limited to $75 \%$ of the available surface. This $75 \%$ represents thermally intimate association of the waste package with the back wall and floor of the emplacement alcove. The other $25 \%$ of the package surface contacts crushed salt within the alcove, and no heat transfer credit is taken in this quadrant.

Because thermal conductivity for crushed salt $(0.57 \mathrm{~W} / \mathrm{m}-\mathrm{K})$ is less than that of intact salt $(4.2 \mathrm{~W} / \mathrm{m}-\mathrm{K})$, the temperature rise for the second case is large, particularly for waste packages containing four MOX assemblies (Figure 5.3-4). For the third case (75\% contact), the waste package peak temperature is limited to less than approximately $250^{\circ} \mathrm{C}$ with 100 years of decay storage (Table 5-3).

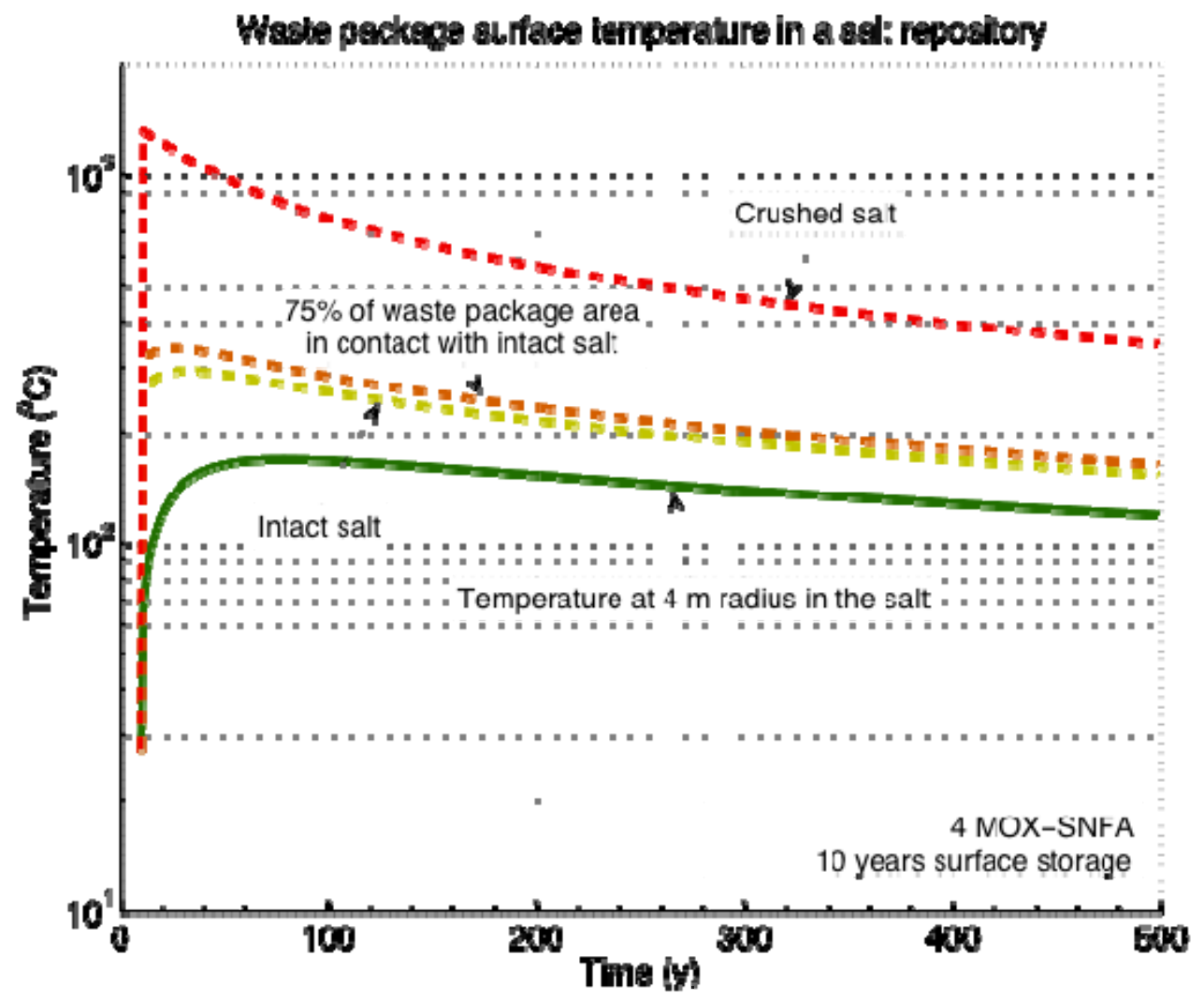

Figure 5.3-4 Calculated Waste Package Temperature After 10 yr Decay Storage, for Waste Packages Containing 4 MOX Assemblies, for the Salt Disposal Concept, and Assuming that Backfill has the Thermal Conductivity of Crushed, Intact, or $75 \%$ of Intact Salt. 
Table 5-3 Peak Waste Package Surface Temperature and the Time When the Peak Occurs, for the Salt Disposal Concept.

\begin{tabular}{|c|c|c|c|c|c|c|c|c|c|c|}
\hline \multirow{2}{*}{\multicolumn{3}{|c|}{$\begin{array}{c}\text { Disposal Scenario: } \\
\text { Salt, WP temperature }\end{array}$}} & \multicolumn{8}{|c|}{ Storage Time, $\mathbf{Y r}$} \\
\hline & & & \multicolumn{2}{|c|}{10} & \multicolumn{2}{|c|}{50} & \multicolumn{2}{|c|}{100} & \multicolumn{2}{|c|}{200} \\
\hline Model & Waste Form & $\begin{array}{c}\text { Assemblies } \\
\text { / WP }\end{array}$ & $\begin{array}{c}\text { Peak } \\
\text { Temp, }{ }^{\circ} \mathrm{C}\end{array}$ & $\begin{array}{l}\text { Peak } \\
\text { Time, yr }\end{array}$ & $\begin{array}{c}\text { Peak } \\
\text { Temp, }^{\circ} \mathrm{C}\end{array}$ & $\begin{array}{c}\text { Peak } \\
\text { Time, yr }\end{array}$ & $\begin{array}{c}\text { Peak Temp, } \\
{ }^{\circ} \mathrm{C}\end{array}$ & $\begin{array}{c}\text { Peak Time, } \\
\text { yr }\end{array}$ & $\begin{array}{c}\text { Peak Temp, } \\
{ }^{\circ} \mathrm{C}\end{array}$ & $\begin{array}{c}\text { Peak Time, } \\
\text { yr }\end{array}$ \\
\hline \multirow{6}{*}{ Intact salt } & UOX1-SNFA & 1 & 55.3 & 13 & 40.9 & 61 & 35.0 & 123 & 32.0 & 266 \\
\hline & MOX4-SNFA & 4 & 296.9 & 32 & 224.3 & 93 & 185.8 & 165 & 147.6 & 299 \\
\hline & MOX1-SNFA & 1 & 105.3 & 27 & 83.3 & 84 & 71.9 & 156 & 60.9 & 288 \\
\hline & COEX Glass & 1 & 230 & 12 & 102.2 & 56 & 54.5 & 108 & 36.4 & 252 \\
\hline & EC-Ceramic & 1 & 74.4 & 15 & 45.8 & 55 & 33.2 & 105 & 28.1 & 204 \\
\hline & EC-Metal & 1 & 69.2 & 11 & 39.5 & 52 & 31.1 & 103 & 27.9 & 202 \\
\hline \multirow{8}{*}{$\begin{array}{l}\text { Crushed salt to } \\
3.048 \mathrm{~m} \text { (all } \\
\text { times) }\end{array}$} & UOX4-SNFA & 4 & 534.4 & 11 & 256.4 & 51 & 147.2 & 101 & 89.3 & 208 \\
\hline & UOX1-SNFA & 1 & 191.7 & 11 & 101.7 & 51 & 66.3 & 101 & 47.4 & 204 \\
\hline & MOX4-SNFA & 4 & 1329.7 & 11 & 874.7 & 52 & 649.9 & 106 & 466.6 & 215 \\
\hline & MOX1-SNFA & 1 & 449.3 & 11 & 301.6 & 51 & 228.0 & 103 & 167.9 & 210 \\
\hline & COEX Glass & 1 & 1217.1 & 11 & 449.5 & 51 & 177.1 & 101 & 68.8 & 202 \\
\hline & New Extraction & 1 & 921.2 & 11 & 312.2 & 51 & 116.0 & 101 & 36.3 & 201 \\
\hline & EC-Ceramic & 1 & 296.2 & 11 & 131.4 & 51 & 59.9 & 101 & 30.6 & 201 \\
\hline & EC-Metal & 1 & 281.9 & 11 & 100.5 & 51 & 49.5 & 101 & 29.6 & 201 \\
\hline \multirow{7}{*}{$\begin{array}{l}75 \% \text { contact } \\
\text { with intact salt, } \\
25 \% \text { crushed } \\
\text { salt }\end{array}$} & UOX1-SNFA & 1 & 62.1 & 11 & 43.8 & 57 & 36.4 & 117 & 32.7 & 255 \\
\hline & MOX4-SNFA & 4 & 341.8 & 26 & 252.8 & 84 & 206.4 & 156 & 162.2 & 284 \\
\hline & MOX1-SNFA & 1 & 120.8 & 21 & 93.1 & 76 & 79.0 & 144 & 65.9 & 273 \\
\hline & COEX Glass & 1 & 281.5 & 11 & 119.1 & 54 & 60.4 & 105 & 37.8 & 236 \\
\hline & New Extraction & 1 & 218.4 & 11 & 89.2 & 53 & 46.7 & 103 & 29.4 & 204 \\
\hline & EC-Ceramic & 1 & 85.3 & 13 & 50.0 & 53 & 34.5 & 103 & 28.2 & 204 \\
\hline & EC-Metal & 1 & 80.3 & 11 & 42.6 & 51 & 32.1 & 102 & 27.9 & 202 \\
\hline
\end{tabular}

Notes:

1. Salt consolidation at high temperature is expected to consolidate crushed salt to resemble intact salt in a few years, so calculated temperatures for the crushed salt case are likely too high. Actual values will lie between this case and that for intact salt.

2. See notes 1 and 2 for Table 5-1.

\subsubsection{Peak Temperature as a Function of Decay Storage and Package Capacity}

An additional parametric study was done for UOX and MOX SNF disposal in crystalline, clay/shale, and salt media to discern the relationship between the number of assemblies per waste package and the surface storage time, for a given temperature limit. For crystalline and clay/shale media a target value of $100^{\circ} \mathrm{C}$ was used for the maximum waste package temperature, based on potential degradation of clay buffer material or clay/shale host rock. For salt the target maximum temperature was $200^{\circ} \mathrm{C}$, although salt may withstand higher temperatures (Section 4.1.1).

Five options were considered: one, two, three, four and 12 PWR assemblies per package. With two, three, and four assemblies, package size was held constant (i.e., the 4-PWR configuration with one or two positions not used). For one and 12 assemblies the engineering barrier thicknesses were kept the same as in the reference model, while the waste form radius was adjusted. The inner radius for a single-assembly package was assumed to be half of that of the 4PWR package. The 12-PWR waste package radius $(0.625 \mathrm{~m})$ was determined previously (DOE 2001). The storage time was varied from 10 to 300 years. Peak temperatures for all media, waste types, and decay storage durations are consistent with the plots in Appendix G.

The minimum storage times need to meet these maximum temperatures were interpolated from the peak temperature data above. The results are shown in Figure 5.3-5 for UOX SNF. For crystalline and clay/shale media, approximately 100 years of surface decay storage will limit clay buffer temperature to $100^{\circ} \mathrm{C}$, for up to $4 \mathrm{UOX}$ assemblies per package. In salt, which has higher 
thermal conductivity, only 5 years (minimum time considered in the analysis) are needed to cool the 4-PWR configuration. For a 12 UOX assembly package, approximately 50 years of decay storage are needed in salt, whereas more than 300 years would be needed for crystalline and clay/shale media. The results for MOX are qualitatively similar, but longer decay storage durations are needed (Figure 5.3-6). For crystalline and clay/shale media, approximately 300 or more years of decay storage are needed to emplace the single-assembly MOX package. For salt, a package containing four MOX assemblies needs fewer than 100 years of surface storage, while a single-assembly MOX package could be emplaced in approximately 5 years (minimum time considered in the analysis).

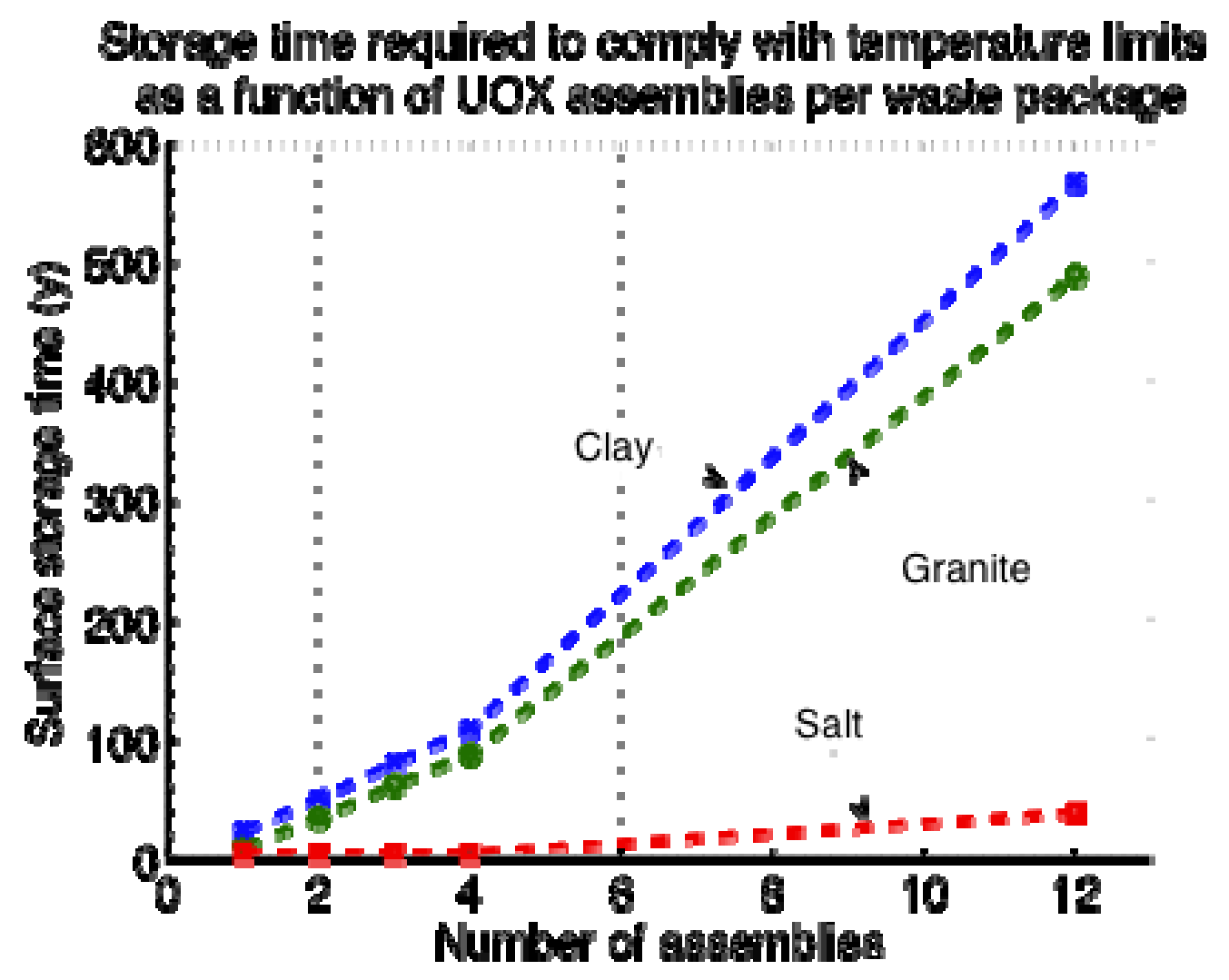

Figure 5.3-5 Minimum Decay Storage Duration to Limit Peak Waste Package Temperature to $100^{\circ} \mathrm{C}$ (for clay buffer or clay/shale media) or $200^{\circ} \mathrm{C}$ (for salt) as a Function of UOX Assemblies, for Crystalline, Clay/Shale, and Salt (75\% Intact) Media. 


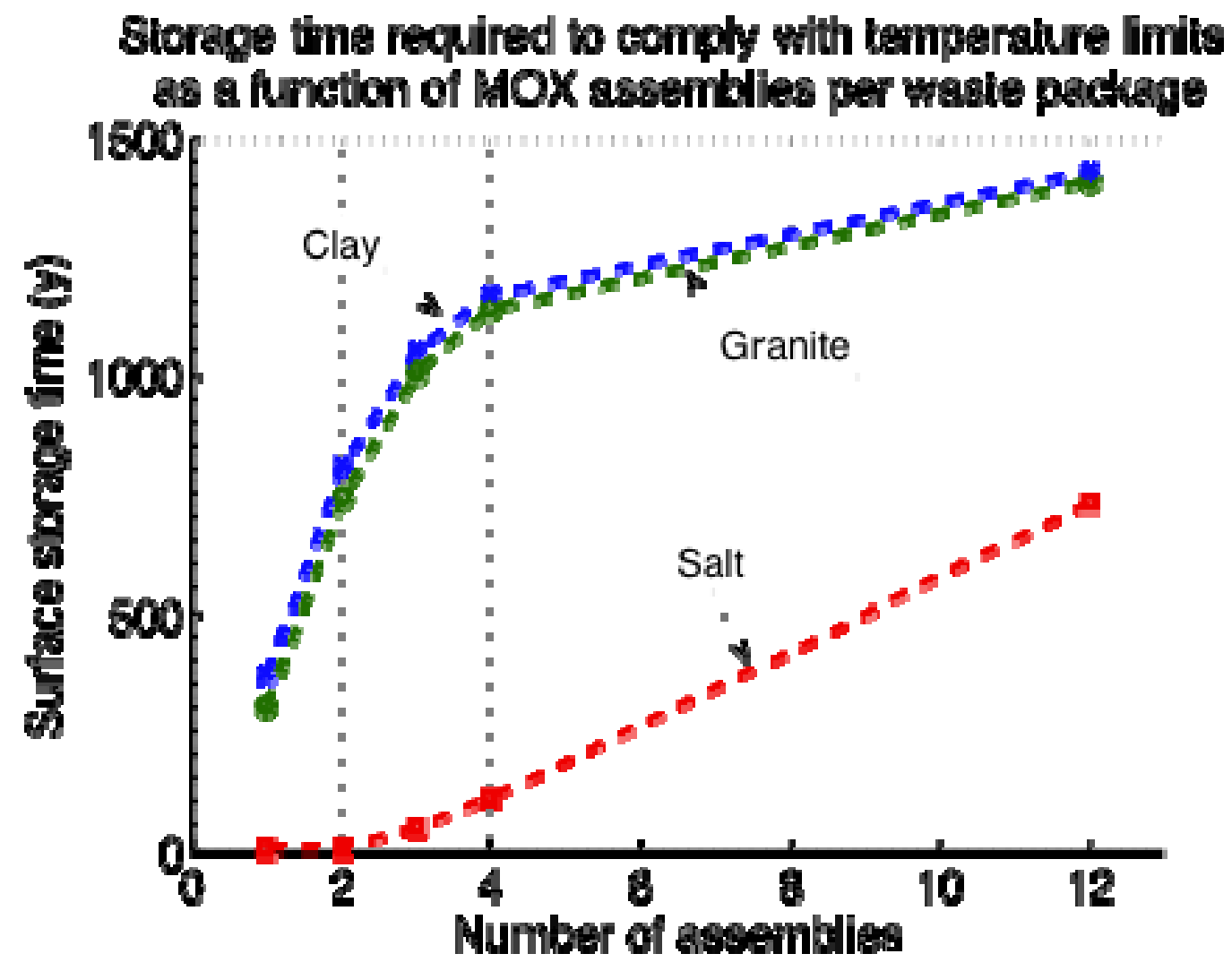

Figure 5.3-6 Minimum Decay Storage Duration to Limit Peak Waste Package Temperature to $100^{\circ} \mathrm{C}$ (for clay buffer or claylshale media) or $200^{\circ} \mathrm{C}$ (for salt) as a Function of MOX Assemblies, for Crystalline, Clay/Shale, and Salt (75\% Intact) Media. 
THIS PAGE INTENTIONALLY LEFT BLANK 


\section{Summary and Discussion}

This report represents the first milestone prepared in a multi-year work package to identify reference disposal concepts for generic studies in the Used Fuel Disposition R\&D Campaign. The work summarized here was performed from January through July, 2011. It is currently planned to continue the work through FY12 and beyond as the R\&D Campaign requires more specific descriptions of reference disposal concepts and their cost, an expanded list of such concepts, and analysis of thermal performance for additional FCs. This section provides a summary of the FY11 results, and a discussion of follow-on work that expresses recommendations based on the FY11 experience of the authors.

\subsection{Summary of Results}

\section{Identification of Thermal Constraints and Measures for Thermal Management}

The following thermal constraints are associated with far-field processes in the host rock or other units (Section 4.1.1.1):

- Limit thermally induced stresses or displacements in the host rock or other units.

- Limit large-scale thermal expansion.

- Limit thermally driven coupled processes in the host rock.

- Limit the migration of brine-filled fluid inclusions in salt.

While these constraints pertain to the far-field, most also pertain to the near field where temperatures are greater. Constraining temperature in the near-field effectively constrains temperatures in the far-field, for the disposal concepts considered here. International disposal concepts discussed in this report have found near-field temperature limits to be sufficient. The following thermal constraints are associated with near-field processes in the host rock and/or the EBS (Section 4.1.1.2):

- Limit physical and/or chemical changes to clay buffers.

- Limit thermally induced micro-cracking in the less ductile rock types.

- Limit temperature of the host medium to control uncertainty in performance models.

- Limit the temperature of argillaceous host media.

- Limit the waste package surface temperature, to represent peak temperature anywhere in the disposal system outside the waste package.

- Limit cladding temperature to $400^{\circ} \mathrm{C}$ for normal conditions of storage and short-term operations. Also limit thermal cycling, and maximum temperature during off-normal and accident conditions.

- Limit cladding temperature to $350^{\circ} \mathrm{C}$ during permanent disposal.

- Limit the peak centerline temperature of borosilicate glass waste forms below $500^{\circ} \mathrm{C}$.

Thermal management measures to meet the constraints above are available to repository designers and operators, and include the following (Section 4.2):

- Select host rock with strong conductive heat dissipation properties. 
- Use smaller waste packages to improve heat transfer and limit peak temperature.

- Blend different waste types, ages, etc. within waste packages to decrease heat output. Also, sequence hotter and cooler packages in adjacent emplacement locations.

- Increase waste package spacing (emplacement drift, alcove, or borehole spacing) to limit long-term and peak temperatures, particularly for waste types such as Pu-MOX SNF that contain minor actinides with intermediate half-lives.

- Surface decay storage (aging) of waste types prior to emplacement in the repository.

- Separate heat-generating radionuclides in waste, and segregate disposal of the hottest waste forms in the repository. Degradation or increased uncertainty in repository waste isolation performance caused by heating, can thus be limited to a particular waste type and location.

\section{Emplacement Modes}

This study identified two major categories for waste package emplacement modes: "open" modes such as that proposed for Yucca Mountain, and "enclosed" modes as proposed for systems with clay buffers, for clay/shale and salt media, and for deep boreholes. Within this framework the following emplacement modes were identified (Section 4.4):

- In-drift emplacement can be open or enclosed depending on whether buffer and/or backfill is used around waste packages.

- Vertical borehole emplacement in borings drilled from mined openings.

- Horizontal borehole emplacement in borings drilled from mined openings.

- Backfilled alcove emplacement as proposed for the generic salt repository.

- Deep borehole emplacement.

\section{Selection of Disposal Concepts}

As discussed in Section 1, a disposal concept consists of three parts: waste inventory, geologic setting, and the concept of operations. Waste inventory for this study (Section 2) consists of three cases: 1) direct disposal of high-burnup (60 GW-d/MT) LWR UOX SNF; 2) reprocessing of LWR UOX UNF (51 GW-d/MT) to produce Pu-MOX fuel, which is used once then directly disposed; and 3) reprocessing of LWR UOX UNF to produce U-TRU metal fuel for SFRs, and continuous recycle of the SFR UNF. These cases were selected as examples of simple oncethrough, modified-open, and full recycle strategies, which are related to the current inventory of LWR UOX SNF (and are thus can be readily related to transitional strategies for conversion from the current reactor fleet).

The geologic settings (Section 3) selected for reference mined disposal concepts are crystalline rock (including granite), clay/shale, and bedded salt. Bedded salt is preferred to salt domes, to accommodate a repository with large areal extent. These are reasonably representative of host media being investigated internationally (although geologic conditions vary). By choosing these media and expanding our focus to include advanced international programs, we benefit from decades of R\&D they have produced. 
The design concepts selected as reference concepts for the UFD R\&D Campaign (Section 4.5, Table 4-1) follow those developed by Sweden and France for the crystalline and clay/shale settings, respectively, and the generic repository concept developed by the U.S. (Carter et al. 2011b).

\section{Waste Package Size/Capacity Limitations for Enclosed Emplacement Modes}

An important result of this work is that the reference mined disposal concepts selected in this report (Section 4.5) would use relatively small packages for SNF (4-PWR/9-BWR) to limit peak temperatures. (Peak temperatures calculated for the various disposal concepts and waste types are summarized below.) These waste package size selections are consistent with current international repository concepts in Sweden, France, and elsewhere. These package sizes are significantly smaller than the transport-aging-disposal containers proposed for use at Yucca Mountain (DOE 2008b), and smaller than the storage containers currently being loaded by U.S. nuclear utilities. This result is discussed further in the recommendations section.

\section{Thermal Management for Reference Crystalline and Clay/Shale Disposal Concepts}

Thermal constraints that may apply to the EBS are discussed in Section 4.1.1.2. A clay buffer is part of the crystalline rock disposal concept for SNF and HLW, and part of the clay/shale disposal concept for SNF. Various temperature limits for buffers composed of swelling clay have been proposed, for example, the French authority Andra used a $90^{\circ} \mathrm{C}$ limit, while the Swedish program has adopted a peak temperature of $100^{\circ} \mathrm{C}$. Variations on clay buffer limits have been proposed, for example, limiting an outer portion of the buffer cross section to $125^{\circ} \mathrm{C}$ (NAGRA 2003). In the current analysis a target value for the maximum temperature of the clay buffer is assumed to be $100^{\circ} \mathrm{C}$, and the same target is used for clay/shale host media because of mineralogical similarity to buffer materials.

Thermal results for crystalline and clay/shale disposal concepts are similar because of the use of the clay buffer, and the similarity of the clay/shale host medium. Where used, the clay buffer constitutes the dominant thermal resistance in the EBS outside the waste package. The following results are obtained in Section 5.3:

- High-burnup (60 gigawatt days per metric ton (GW-d/t)) LWR SNF could be emplaced in 4-PWR waste packages (or equivalent), after approximately 100 years of surface decay storage, without exceeding the $100^{\circ} \mathrm{C}$ target temperature. This result is similar to SNF management practices being implemented by the Swedish program.

- Waste packages containing a single high-burnup LWR SNF assembly could be emplaced after approximately 10 years of surface decay storage.

- Waste packages containing a single Pu-MOX assembly would require more than 200 years decay storage to meet the target maximum temperature of $100^{\circ} \mathrm{C}$.

- HLW generated by reprocessing LWR UOX fuel by either method considered here, could be emplaced after approximately 50 to 100 years of decay storage.

- Other waste types from EC reprocessing of SFR metal fuel can be emplaced after fewer than 50 years of surface decay storage.

Larger waste packages could be used but would require additional decay storage, to maintain target values for maximum temperature in the clay buffer or clay/shale host medium. 


\section{Thermal Management for the Reference Salt Disposal Concept}

For salt a target value of $200^{\circ} \mathrm{C}$ for the maximum salt temperature is proposed here and would likely limit uncertainty in performance assessment, although higher peak temperatures may be possible if supported by test data (BMWI 2008). The Environmental Assessment for disposal of SNF and HLW at the Deaf Smith County, Texas site suggested a maximum salt temperature of $250^{\circ} \mathrm{C}$ (DOE 1986b) would be imposed. In more recent studies (Clayton and Gable 2009, and Carter et al. 2011b) a limit of $200^{\circ} \mathrm{C}$ was discussed. In the current analyses a target value of $200^{\circ} \mathrm{C}$ for the maximum temperature is used for comparative evaluations of surface decay storage time and waste package size/capacity. The following results are obtained in Section 5.3:

- High-burnup (60 GW-d/t) LWR SNF could be emplaced in 4-PWR waste packages (or equivalent), after approximately 10 years of decay storage, without exceeding $200^{\circ} \mathrm{C}$ at the waste package - host rock interface. In addition, 12-PWR packages could possibly be emplaced after approximately 40 years of decay storage without exceeding the $200^{\circ} \mathrm{C}$ target maximum temperature.

- Waste packages containing Pu-MOX SNF in the 4-PWR configuration would require approximately 110 years of decay storage to meet the $200^{\circ} \mathrm{C}$ target temperature.

- HLW generated by reprocessing LWR UOX fuel by either method considered here, could be emplaced after approximately 10 to 50 years of decay storage, without exceeding $200^{\circ} \mathrm{C}$.

\section{Thermal Management for the Deep Borehole Disposal Concept}

For the deep borehole disposal concept no near-field temperature limits have been recognized because no performance credit is taken for the near-field host rock, and the borehole seal interval extends well beyond the thermal near field. Also, the boreholes would be spaced far enough apart to preserve the far-field natural barrier function (Brady et al. 2009).

\section{Disposal of Non-Heat Generating Waste in Geologic Repositories}

Waste volume, including non-heat generating waste (Section 2) is generally comparable to, or less than the total volume available in repository access drifts (Table 4-2). Adequate volume (without additional mining) is available for the reference concepts in crystalline rock and salt. In crystalline rock, the volume is sufficient that LLW could be emplaced in access drifts and isolated from the host rock by an additional layer of low-permeability buffer or backfill material. This additional material would not be needed for salt (as demonstrated by disposal of TRU waste in the WIPP repository). For the clay/shale concept, limited volume is available for LLW, which could be isolated by a layer of low-permeability buffer or backfill, or emplaced directly if backfill does not serve a function to control water movement. For all mined disposal concepts, additional drifts or alcoves for emplacement of non-heat generating waste, could be easily incorporated without major changes to the layouts proposed here (Section 4.5).

\subsection{Discussion of Future Work}

The following recommendations are offered in approximate order of priority:

\section{Develop Open Emplacement Mode Reference Concept for Mined Disposal}


Enclosed emplacement modes have more stringent thermal limits than open emplacement modes, because of the limited mechanisms available to dissipate heat (Section 4.4). Enclosed emplacement modes are adopted for the reference disposal concepts in this study, consistent with current practice in international repository programs, and with the assumption of saturated hydrologic conditions in the host media. We recommended that future work consider one or more mined, open-emplacement disposal concepts because much larger waste packages can be used as demonstrated for the proposed Yucca Mountain repository. Such concepts require well indurated rock (e.g., granite, tuff, etc.) in which excavated openings persist for long time periods. They are also likely to require unsaturated hydrogeologic settings, because in saturated settings the openings could focus groundwater flow and act as conduits for radionuclide transport. (As noted in Section 1.2, unsaturated settings are often chemically oxidizing because air is present throughout the host rock and may exchange with the atmosphere.) Open emplacement mode concepts may prove to be more flexible regarding retrievable, long-term, underground storage and broaden the thermal envelope for waste emplacement in the repository. An open emplacement concept could accommodate larger, possibly multi-use canisters similar to those currently in use by industry for UNF storage and transportation.

\section{Establish Waste Package Size Interface with Storage and Transportation Packaging}

As noted in Section 4.3.1, current trends in UNF storage and transportation indicate a preference for larger capacity containers such as 32-PWR/64-BWR assembly storage casks. These trends are driven by cost savings in materials, handling, and packaging efficiency. The same economics could also apply to disposal waste packages. On the other hand, smaller waste packages are inherently cooler and allow for less decay storage, or no decay storage. Establishment of centralized, interim storage capability for UNF, would involve tradeoffs between the economics of fuel handling at the reactor plants, and subsequent storage, vs. the requirements of disposal (considering whether UNF will eventually be directly disposed or reprocessed). Opportunities to optimize the storage, transportation, and disposal systems, involving trade-offs on multi-use container size and configuration, could be explored in future system studies.

\section{Technical Feasibility of Disposal Concepts}

Further effort could be directed to refine and review the reference disposal concepts for technical feasibility, including such details as: waste package handling underground, types of conveyances (e.g., hoist, rail, rubber tire), ground support chemical interactions, excavation damage, plugging and sealing, and the feasibility of underground access in all potential host media using ramps.

\section{Develop Disposal Cost Estimates}

Develop cost estimates at an appropriate level of detail to support future system-level evaluations. Build on the studies summarized in Appendix J, using an approach similar to that used for the generic salt repository (Carter et al. 2011b). Cost estimates with sufficient detail could help to discern differences associated with alternative disposal concepts, and support studies to examine the use of decay storage for thermal management vs. other measures such as waste package size, spacing, etc.

\section{Verify Analytical Solutions}

The calculation approach described in Section 5.1 and Appendix G uses a few approximations that individually, may over- or underestimate calculated temperatures, but the combined effects 
are uncertain. The approach could be verified by comparison to three-dimensional numerical (e.g., finite-element) simulations such as those performed for a generic salt repository (Clayton and Gable 2009) and the deep borehole concept (Brady et al. 2009). The verification could evaluate the combined effects from use of point- and line-source analytical solutions, steadystate heat flow in annular regions of the EBS, and constant material properties. It would be most important to verify the approximation for near-field heat transfer in the reference disposal concept for salt, by comparison to 3-D simulation, because of the relatively large differences in peak temperatures depending on how crushed salt backfill is represented in the calculation (Section 5.3).

\section{Additional Geologic Settings}

Review technical literature on fracturing and thermal properties of geologic media in the U.S., to identify any additional geologic settings (i.e., rock type, geomechanical setting, geohydrologic setting, etc. as summarized in Appendix I) that would be appropriate to consider in future analyses. Note that ranges of key rock properties for each setting are addressed in the recommendation for uncertainty analysis.

\section{Evaluate Uncertainty in Thermal Calculations}

Uncertainty analysis with respect to calculated peak temperatures, could be undertaken to address uncertainty in parameters, boundary conditions, and model fidelity. Physical properties such as density and thermal conductivity, are uncertain for the host rock and engineered materials, and are expected to change with time (e.g., for hydration of swelling clay buffers). Examples of the behavior of thermal conductivity and thermal diffusivity in salt as functions of porosity and temperature are shown in Figures G.5-1 and G.5-2, respectively. Appropriate ranges of these parameters could be developed to envelope the uncertainty in thermal calculations. Uncertainty in waste inventory could be estimated as a key boundary condition on thermal calculations. Model uncertainty could be estimated using the verification exercise described above, and by comparison to available multi-physics simulations (e.g., repository thermal simulations for salt, combining thermal, mechanical, and hydrologic processes). Model uncertainty evaluations could be performed to address the impact of strong property anisotropy in layered clay/shale media. The combined effects of these different types of uncertainty would be combined using statistical principles to develop overall uncertainty estimates, to increase confidence in the uncertainty associated with thermal calculations such as those presented in this report.

\section{Current Commercial SNF Inventory}

Add a waste stream case to represent the current inventory of CSNF inventory, as represented using the Total System Model for the Yucca Mountain License Application (SNL 2008; DOE 2008b). Determine waste package size and/or decay storage requirements for the reference disposal concepts, for the range of CSNF characteristics identified for the current inventory. The purpose would be to better understand the relationship between thermal management constraints developed by this study for reference disposal concepts and projected future fuel cycles, and the constraints identified previously (SNL 2008).

\section{Develop Surface Facility Concepts}


Describe surface facilities in more detail, to support cost estimation and future system-level modeling. Surface facility descriptions would require collaboration between storage, transportation, and disposal experts within the UFD Campaign.

\section{Review Generic Thermal Constraints and Target Temperatures}

Thermal constraints (Section 4.1.1) are considered in this study for advancing disposal concepts and establishing reference configurations, and the selected target values for maximum waste package surface temperature are based on previous experience and international precedent. This generic approach may not describe all thermal limits that could be imposed by site-specific conditions (e.g., that could result from FEP screening) nor are the target values necessarily fixed limits. Further, repository designers may choose to use thermal limits to mitigate or exclude FEPs, or to limit the R\&D needed to support licensing, or in response to regulatory input. Researchers in EBS and near-field materials and technologies can be engaged to fine-tune the target temperatures for future generic thermal analysis. Ultimately, site-specific information could be used with a FEP-screening approach, to resolve repository temperature limits.

\section{Analyze Thermal Sensitivity to Waste Blending, Package Sequencing, and Spacings}

Define and demonstrate engineering analyses that could be used to optimize repository design and operations for thermal management. Prioritize among blending, sequencing, and alternative spacing options for limiting peak temperature. Identify which options, or combinations, are most promising for use in generic, dynamic system models representing storage, transport, and disposal. For example, determine the relative effect of blending hotter SNF with cooler SNF, compared to surface aging of the hotter fuel, or larger repository spacings, with the goal of earlier emplacement of all SNF. As another example, identify the specific disposal concepts and waste types, for which sequencing or spacings can either significantly decrease peak temperatures, or increase repository waste loading (and thereby decrease repository layout size). We note that optimizing repository design details such as borehole, alcove, and drift spacings, depends on site specific characteristics of the host rock, so that such analyses have limited applicability in a generic R\&D approach. 
THIS PAGE INTENTIONALLY LEFT BLANK 


\section{References}

Anderson, V.K. 2004. An evaluation of the feasibility of disposal of nuclear waste in very deep boreholes. Cambridge, MA: Dept. of Nuclear Engineering, Massachusetts Institute of Technology.

Andra 2005a. Dossier 2005 argile - architecture and management of a geological disposal system. December 2005. http://www.Andra.fr/international/download/Andra-internationalen/document/editions/268va.pdf.

Andra 2005b. Dossier 2005 granite - architecture and management of a geological repository. December 2005. http://www.Andra.fr/download/Andra-internationalen/document/editions/285va.pdf.

Arnold, B.W., P.N. Swift, P.V. Brady, S.A. Orrell, and G.A. Freeze 2010. "Into the deep." Nuclear Engineering International February 2010. pp. 18-20.

Arnould, M. 2006. "Discontinuity networks in mudstones: a geological approach. Implications for radioactive wastes isolation in deep geological formations in Belgium, France, Switzerland." Bulletin of Engineering Geology and the Environment 65, pp. 413-422.

Blink, J., J. Farmer, J. Choi, and C. Saw 2009. "Applications in the nuclear industry for thermal spray amorphous metal and ceramic coatings." Metallurgical and Materials Transactions A June 2009. 40A, pp. 1344-1354.

BMWI 2008. Final disposal of high-level radioactive waste in Germany—The Gorleben Project. Public Relations/IA8. www.bmwi.de. Berlin, Germany: Federal Ministry of Economics and Technology.

Bosgiraud, J.M., W.K. Seidler, L. Londe, E. Thurner, S. Pettersson 2008. "Application of the Air/Water Cushion Technology for Handling of Heavy Waste Packages in Sweden and France." International Conference on Underground Disposal Unit Design \& Emplacement Processes for a Deep Geological Repository.16-18 June 2008, Prague. http://www.iaea.org/inis/collection/NCLCollectionStore/Public/41/025/41025037.pdf.

Brady, P.V., B.W. Arnold, G.A. Freeze, P.N. Swift, S.J. Bauer, J.L. Kanney, R.P. Rechard, and J.S. Stein 2009. Deep borehole disposal of high-level radioactive waste. SAND2009-4401. Albuquerque, NM: Sandia National Laboratories.

Carslaw, H.S., and J.C. Jaeger, 1959. Conduction of heat in solids, Second Edition. Clarendon Press, Oxford.

Carter, J.T. (available on request). This reference is unclassified controlled information and is available from the author upon request.

Carter, J., A. Luptak, and J. Gastelum 2011a. Fuel cycle potential waste inventory for disposition. FCR\&D-USED-2010-000031, Rev. 3. April, 2011.

Carter, J.T., F. Hansen, R. Kehrman, and T. Hayes 2011b. A generic salt repository for disposal of waste from a spent nuclear fuel recycle facility. SRNL-RP-2011-00149 Rev. 0. Aiken, SC: Savannah River National Laboratory. 
Choi, H.-J., and J. Choi 2008. "Double-layered buffer to enhance the thermal performance in a high-level radioactive waste disposal system." Nuclear Engineering and Design. Vol. 238, No. 10. October, 2008. pp. 2815-2820.

Clayton, D.J., and C.W. Gable 2009. 3-D thermal analyses of high-level waste emplaced in a generic salt repository. AFCI-WAST-PMO-MI-DV-2009 000002. February, 2009.

Davison, D., et al. 2006. Benefits of an integrated fuel cycle on repository effective capacity. Waste Management '06 Conference. Tucson, AZ.

DOE (U.S. Department of Energy) 1980. Final environmental impact statement -- management of commercially generated radioactive waste. DOE/EIS-0046F. Washington, DC: U.S. Department of Energy. October, 1980.

DOE (U.S. Department of Energy) 1986a. Deaf Smith site characterization plan conceptual design report. U.S. Department of Energy. September, 1986.

DOE (U.S. Department of Energy) 1986b. Nuclear Waste Policy Act (Section 112), environmental assessment, Deaf Smith County Site, Texas. DOE/RW-0069-Vol.3. OSTI ID: 5492729.

DOE (U.S. Department of Energy) 1987a. Site characterization plan conceptual design report for a high-level nuclear waste repository in salt, vertical emplacement mode. DOE/CH/46656-15 (2 volumes). U.S. Department of Energy. December, 1987.

DOE (U.S. Department of Energy) 1987b. Site characterization plan conceptual design report for a high-level nuclear waste repository in salt, horizontal emplacement mode. DOE/CH/4665614 (2 volumes). U.S. Department of Energy. December, 1987.

DOE (U.S. Department of Energy) 1998. Viability assessment of a repository at Yucca Mountain: Overview. DOE/RW-0508. Office of Civilian Radioactive Waste Management. OSTI ID: 762971. MOL.19981007.0027. U.S. Department of Energy.

DOE (U.S. Department of Energy) 1999. License application design selection report. B00000000-01717-4600-00123 Rev. 01 ICN 01. MOL.19990908.0319. Las Vegas, NV: Office of Civilian Radioactive Waste Management, U.S. Department of Energy.

DOE (U.S. Department of Energy) 2000. YMP analysis Natural Resources Assessment. ANLNBS-GS-000001 Rev 00. MOL.20010406.0010. Office of Civilian Radioactive Waste Management, U.S. Department of Energy.

DOE (U.S. Department of Energy) 2001. Waste package outer barrier stress due to thermal expansion with various barrier gap sizes. CAL-EBS-ME-000011 Rev. 00. Office of Civilian Radioactive Waste Management, U.S. Department of Energy.

DOE (U.S. Department of Energy) 2002. Calculation Method for the Projection of Future Spent Nuclear Fuel Discharges. TDR-WAT-NU-000002 Rev. 01. Office of Civilian Radioactive Waste Management, U.S. Department of Energy.

DOE (U.S. Department of Energy) 2008a. Civilian Radioactive Waste Management System, Waste acceptance systems requirements document. DOC.20080310.0001. U.S. Department of Energy. 
DOE (U.S. Department of Energy) 2008b. Yucca Mountain repository license application for construction authorization. U.S. Department of Energy.

DOE (U.S. Department of Energy) 2008c. Analysis of the Total System Life-cycle Cost of the Civilian Radioactive Waste Management Program. DOE/RW-0591. Office of Civilian Radioactive Waste Management, Washington, DC. July, 2008.

European Commission 2010. The Joint EC/NEA Engineered Barrier System Project: Synthesis Report (EBSSYN). EUR 24232 EN.

Fetter, C.W., 1994. Applied hydrogeology. Third Edition.

Forsberg, C.W., and L.R. Dole 2011. Repositories with retrievable spent nuclear fuel: Four options, four geologies. Proceedings of the 13th International High-Level Radioactive Waste Management Conference (IHLRWMC). Albuquerque, NM.

Freeze, G.A., P. Mariner, J.E. Houseworth, and J.C. Cunnane 2010. Used Fuel Disposition Campaign Features, Events, and Processes (FEPs): FY10 Progress Report. SAND2010-5902. Sandia National Laboratories. September, 2010.

Gibb, F. 2010. "Looking down the bore." Nuclear Engineering International February 2010. pp. 21-22.

Gombert, D. 2007. Global Nuclear Energy Partnership integrated waste management strategy baseline study, volumes 1 and 2. GNEP-WAST-AI-RT-2007-000324. September, 2007.

Gonzales, S., and K.S. Johnson 1984. Shale and other argillaceous strata in the United States. ORNL/Sub/84-64794/1. Oak Ridge, TN: Oak Ridge National Laboratory.

Gutherman, B. 2009. ACI nuclear energy solutions. E-mail dated 12/08/09: "Fuel data" with attachments containing $P W R$ and BWR projections of assemblies and MTU.

Hansen, F.D., E. Hardin, and A. Orrell 2011. Geologic disposal options in the USA. Waste Management 2011, February 27-March 3, 2011. Phoenix, AZ.

Hansen, F.D., E.L. Hardin, R.P. Rechard, G.A. Freeze, D.C. Sassani, P.V. Brady, C.M. Stone, M.J. Martinez, J.F. Holland, T. Dewers, K.N. Gaither, S.R. Sobolik, and R.T. Cygan 2010. Shale disposal of U.S. high-level radioactive waste. SAND2010-2843. May, 2010.

Hansen, F.D., and C.D. Leigh 2011. Salt disposal of heat-generating nuclear waste. SAND20110161. OSTI ID: 1005078. Albuquerque, NM: Sandia National Laboratories. January, 2011.

Hardin, E.L., D.A. Chesnut, T.J. Kneafsey, K. Pruess, J.J. Roberts and W. Lun 1997. Synthesis report on thermally driven coupled processes. UCRL-ID-128495. OSTI ID: 16624. Livermore, CA: Lawrence Livermore National Laboratory. October 15, 1997.

Hoffman, E.A. 2007. Updated design studies for the advanced burner reactor over a wide range of conversion ratios. ANL-AFCI-189. May 31, 2007.

Hoffman, E.A., W.S. Yang and R.N. Hill 2006. Preliminary core design studies for the advanced burner reactor over a wide range of conversion ratios. ANL-AFCI-177. OSTI ID: 973480.

September 29, 2006. 
IAEA (International Atomic Energy Agency) 2003. Spent fuel performance assessment and research. Coordinated research project on spent fuel performance assessment and research. IAEA-TECDOC-1343. www-pub.iaea.org/MTCD/publications/PDF/te_1343 web.pdf.

JAEA (Japan Atomic Energy Agency) 2000. H12: Project to Establish Scientific and Technical Basis for HLW Disposal in Japan, Supporting Report 2 - Engineering Design and Engineering Technology. JNC TN1410 2000-003. www.jaea.go.jp/04/tisou/english/report/H12_sr2.html.

Johnson, K.S., and S. Gonzales 1978. Salt deposits In the United States and regional geologic characteristics important for storage of radioactive waste. Y/OWI/SUB-7414/1. Prepared for the Office of Waste Isolation, Union Carbide Corporation, Nuclear Division.

Jones, R.H. 2010. Low level waste disposition quantity and inventory. FCRD-USED-2010000033, Rev. 1. September, 2010.

Jones, R.H. 2011. Low level inventory from MOX fuel fabrication. FCRD-USED-201-000059, Rev. 0. March, 2011.

Jove-Colon, C.F. 2010. Disposal systems evaluations and tool development - Engineered Barrier System (EBS) evaluation. U.S. Department of Energy, Used Fuel Disposition Campaign. September 8, 2010.

Kalia, H.N. 1994. Simulated waste package test in salt. Proceedings of the International High Level Radioactive Waste Management Conference. May 1994, Las Vegas, NV. American Nuclear Society, Chicago, IL.

KASAM (Swedish Council for Nuclear Waste) 2007. Deep boreholes: An alternative for final disposal of spent nuclear fuel? Report 2007:6e. http://www.iaea.org/inis/collection/NCLCollectionStore/Public/40/054/40054933.pdf.

Kreith, F., 1966. Principles of Heat Transfer, Second Edition.

Kursten, B., E. Smailos, I. Askarate, L.,Werme, N.R. Smart, and G. Santarini 2004. State-of-theart document on the corrosion behavior of canistered materials (COBECOMA). European Commission Report.

Mariner, P.E., J. Lee, E. Hardin, F.D. Hansen, A.C. Snider Lord, B. Goldstein, and R. Price 2010. Granite disposal of U.S. high-level radioactive waste. SAND2010-(in review). Albuquerque, NM: Sandia National Laboratories.

McKinley, I.G., F.B. Neall, H. Kawamura, and H. Umeki 2006. "Geochemical optimisation of a disposal system for high-level radioactive waste." Journal of Geochemical Exploration 90, pp. $1-8$.

NAGRA (Swiss National Cooperative for the Disposal of Radioactive Wastes) 2002. Project Opalinus clay safety report. NAGRA Technical Report 02-05. December, 2002.

NAGRA (Swiss National Cooperative for the Disposal of Radioactive Wastes) 2003. Canister options for the disposal of spent fuel. NAGRA Technical Report NTB 02-11.

NAGRA (Swiss National Cooperative for the Disposal of Radioactive Wastes) 2009. A review of materials and corrosion issues regarding canisters for disposal of spent fuel and high-level waste in Opalinus Clay. NAGRA Technical Report NTB 09-02. 
NAS (U.S. National Academy of Science) 1957. The disposal of radioactive waste on land: Report of the Committee on Waste Disposal of the Division of Earth Sciences. Publication 519. Washington, DC: National Academy of Sciences/National Research Council. http://books.nap.edu/openbook.php?record id=10294\#toc.

NRC (U.S. Nuclear Regulatory Commission) 1999. Region IV morning report. U.S. Nuclear Regulatory Commission. July 30, 1999. http://www.nrc.gov/reading-rm/doc-collections/eventstatus/morning/1999/19990730mr.html.

NRC (U.S. Nuclear Regulatory Commission) 2003. Cladding considerations for the transportation and storage of spent fuel. SFST-ISG-11 Rev-3. Washington DC: U.S. Nuclear Regulatory Commission. November, 2003.

NRC (U.S. Nuclear Regulatory Commission) 2010. Draft Safety Evaluation Report for the License Application To Possess and Use Radioactive Material at the Mixed Oxide Fuel Fabrication Facility in Aiken, SC. Docket No. 70-3098. Shaw AREVA MOX Services. July, 2010. http://pbadupws.nrc.gov/docs/ML1022/ML102280191.pdf.

Nutt W.M. 2011. Used Fuel Disposition Campaign Disposal Research and Development Roadmap. U.S. Department of Energy, Used Fuel Disposition R\&D Campaign. FCR\&D-USED2011-00065 Rev. 0. March, 2011.

NWTRB (U.S. Nuclear Waste Technical Review Board) 2010. Evaluation of the technical basis for extended dry storage and transportation of used nuclear fuel. U.S. Nuclear Waste Technical Review Board. http://www.nwtrb.gov/reports/eds-final.pdf.

O'Brien, M.T., L.H. Cohen, T.N. Narasimhan, T.L. Simkin, W.F. Wollenberg, W.F. Brace, S. Green and H.P. Pratt 1979. The very deep hole concept: Evaluation of an alternative for nuclear waste disposal. Berkeley, CA: Lawrence Berkeley National Laboratory. http://www.escholarship.org/uc/item/07m0q8xf.

ONDRAF/NIRAS (Belgian Agency for Radioactive Waste and Enriched Fissile Materials) 2001. Technical overview of the SAFIR 2 report, safety assessment and feasibility interim report 2. NIROND 2001-05 E. December, 2001.

ONDRAF/NIRAS (Belgian Agency for Radioactive Waste and Enriched Fissile Materials) 2010, The Joint EC/NEA Engineered Barrier System Project: Synthesis Report (EBSSYN), EUR 24232 EN.

ONWI (Office of Nuclear Waste Isolation) 1987a. Waste package/repository impact study: Final report. BMI/ONWI/C-312. (OSTI ID: 6718042). Columbus, OH: Office of Nuclear Waste Isolation, Battle Memorial Institute. June, 1987.

ONWI (Office of Nuclear Waste Isolation) 1987b. Conceptual designs for waste packages for horizontal or vertical emplacement in a repository in salt for reference in the site characterization plan. BMI/ONWI/C-145 (OSTI ID: 6915229). Columbus, OH: Office of Nuclear Waste Isolation, Battle Memorial Institute. June, 1987.

Petrakka, E. 2010. The final disposal of spent nuclear fuel in Finland. Brussels: ITRE Public Hearing. Posiva. December, 2010.

Posiva Oy 2010. Interim summary report of the safety case. POSIVA 2010-02. Olkiluoto, Eurajoki, Finland: Posiva Oy. www.posiva.fi/files/1226/POSIVA_2010-02web.pdf. 
Rebak, R.B. 2007. Environmental degradation of materials for nuclear waste repositories engineered barriers. 3rd International Environmental Degradation of Engineered Materials (EDEM 2007). May 2007, Gdansk, Poland. UCRL-PROC-227056.

Rebak, R.B., and R.M. McCright 2006. "Corrosion of containment materials for radioactive waste isolation." Metals Handbook 13C(ASM International, 2006, Houston, TX).

Rechard, R.P., B, Goldstein, L.H. Brush, J. Blink, M. Sutton, and F.V. Perry 2011. Basis for identification of disposal options for research and development for spent nuclear fuel and highlevel waste. FCRD-USED-2011-000071. March, 2011.

Salvatores, M., G. Youinou, R.N. Hill, T. Taiwo and T.K. Kim 2003. Systematic assessment of LWR recycle strategies. ANL-AFCI-100. Argonne National Laboratory. September, 2003.

Sevougian S. D., M. Gross, E. Hardin, E. Hoffman, R. MacKinnon, L. Price, W. Halsey, J. Buelt, J. Gehin, M. Mullen, T. Taiwo, M. Todosow, and R. Wigeland, Initial Screening of Fuel Cycle Options. FCRD-SYSE-2011-000040 Rev. 0. U.S. Department of Energy Fuel Cycle

Technologies Program. March 11, 2011.

Shoesmith, D.W. 2006. "Assessing the corrosion performance of high-level nuclear waste containers." Corrosion. August, 2006. 62(08).

Shropshire, D.E., K. A. Williams, J. D. Smith, B. W. Dixon, M. Dunzik-Gougar, R. D. Adams, D. Gombert, J. T. Carter, E. Schneider, and D. Hebditch 2009. The Advanced Fuel Cycle Cost Basis. INL/EXT-07-12107 Rev. 2. Advanced Fuel Cycle Initiative, U.S. Department of Energy, Office of Nuclear Energy. December, 2009.

SKB (Swedish Nuclear Fuel and Waste Management Co.) 1992. Project on Alternative Systems Study (PASS). Final report. SKB TR-93-04.

SKB (Swedish Nuclear Fuel and Waste Management Co.) 2006. Long-term safety for KBS-3 repositories at Forsmark and Laxemar - A first evaluation. Technical Report TR-06-09.

SKB (Swedish Nuclear Fuel and Waste Management Co.) 2011. Long-term safety for the final repository for spent nuclear fuel at Forsmark: Main report of the SR-Site project, Volume I. Technical Report TR-06-09.

Smart, N.R., P.A.H. Fennell, R. Peat, K. Spahiu and L. Werme 2001. Electrochemical measurements during the anaerobic corrosion of steel. Scientific Basis for Nuclear Waste Management XXIV. Warrendale, PA: Materials Research Society. pp. 477-487.

SNL (Sandia National Laboratories) 2007. In-Drift natural convection and condensation. MDLEBS-MD-000001 REV 00 AD 01. DOC.20070907.0004.

SNL (Sandia National Laboratories) 2008. Postclosure analysis of the range of design thermal loadings. ANL-NBS-HS-000057 REV 00. DOC.20080121.0002.

SRNL (Savannah River National Laboratory) 2011. A generic salt repository for disposal of waste from a spent nuclear fuel recycle facility. SRNL-RP-2011-00149 PREDECISIONAL DRAFT Rev 0. January, 2011.

Sutton, M., J.A. Blink, M. Fratoni, H.R. Greenberg, W.G. Halsey, and T.J. Wolery. 2011. Disposal system evaluation framework (DSEF) version 1.0 - Progress report. LLNL-TR484011. May, 2011. 
Taiwo, T.A., E.A. Hoffman and T.K. Kim 2007. Core transmutation data for double-tier scenario studies - scenario 2. Intra-laboratory Memo. Argonne National Laboratory. August 22, 2007.

Todd, T. 2008. "Spent Nuclear Fuel Reprocessing." Idaho National Laboratory. Nuclear Regulatory Commission Seminar. Rockville, MD. March 25, 2008. http://www.ne.doe.gov/pdfFiles/NRCseminarreprocessing_Terry_Todd.pdf.

Weber, J.R., S. Keller, S. Mrugalla, J. Wolf, D. Buhmann, J. Mönig, W. Bollingerfehr, J. Krone, and A. Lommerzheim 2011. Safety strategy and assessment for a HLW repository in Germany. Proceedings of the International High Level Radioactive Waste Management Conference. April 2011, Albuquerque, NM. Chicago, IL: American Nuclear Society.

Yang, W.S., T.K. Kim and R.N. Hill unpublished. Performance characteristics of metal and oxide fuel core for a $1000 \mathrm{MW}_{\text {th }}$ advanced burner reactor. 
THIS PAGE INTENTIONALLY LEFT BLANK 


\section{Appendix A}

Isotopic Compositions of $60 \mathrm{GW}-\mathrm{d} / \mathrm{MT}$ PWR Fuel 
Table A-1 60 GW-d/MT Pressurized Water Reactor Radionuclide Inventory (enrichment 4.73\%).

\begin{tabular}{|c|c|c|}
\hline Cooling Time & 5 Years & 30 Years \\
\hline ISOTOPE & g/MTIHM & g/MTIHM \\
\hline $\mathrm{H} 1$ & $3.48 \mathrm{E}+00$ & $3.48 \mathrm{E}+00$ \\
\hline $\mathrm{H} 2$ & 7.92E-03 & 7.92E-03 \\
\hline H3 & 9.54E-02 & $2.34 \mathrm{E}-02$ \\
\hline HE 3 & $7.52 \mathrm{E}-03$ & $2.43 \mathrm{E}-02$ \\
\hline HE 4 & $7.30 \mathrm{E}+00$ & $1.14 \mathrm{E}+01$ \\
\hline LI 6 & $4.08 \mathrm{E}-03$ & $4.08 \mathrm{E}-03$ \\
\hline LI 7 & $1.08 \mathrm{E}+00$ & $1.08 \mathrm{E}+00$ \\
\hline BE 9 & $1.66 \mathrm{E}-03$ & $1.66 \mathrm{E}-03$ \\
\hline BE 10 & $4.14 \mathrm{E}-04$ & $4.14 \mathrm{E}-04$ \\
\hline B 10 & $2.20 \mathrm{E}-04$ & $2.20 \mathrm{E}-04$ \\
\hline B 11 & $1.00 \mathrm{E}+00$ & $1.00 \mathrm{E}+00$ \\
\hline C 12 & $1.55 \mathrm{E}+02$ & $1.55 \mathrm{E}+02$ \\
\hline C 13 & $1.56 \mathrm{E}+01$ & $1.56 \mathrm{E}+01$ \\
\hline C 14 & $4.55 \mathrm{E}-01$ & $4.54 \mathrm{E}-01$ \\
\hline N 14 & $1.06 \mathrm{E}+02$ & $1.06 \mathrm{E}+02$ \\
\hline N 15 & $4.40 \mathrm{E}-01$ & $4.40 \mathrm{E}-01$ \\
\hline 016 & $1.34 \mathrm{E}+05$ & $1.34 \mathrm{E}+05$ \\
\hline 017 & $5.44 \mathrm{E}+01$ & $5.44 \mathrm{E}+01$ \\
\hline O 18 & $3.09 E+02$ & $3.09 E+02$ \\
\hline F 19 & $1.07 \mathrm{E}+01$ & $1.07 \mathrm{E}+01$ \\
\hline NE 20 & $5.97 \mathrm{E}-04$ & $5.97 \mathrm{E}-04$ \\
\hline NE 21 & $2.19 \mathrm{E}-05$ & $2.19 \mathrm{E}-05$ \\
\hline NE 22 & $3.25 \mathrm{E}-05$ & $3.25 \mathrm{E}-05$ \\
\hline NA 23 & $1.50 \mathrm{E}+01$ & $1.50 \mathrm{E}+01$ \\
\hline MG 24 & $1.61 \mathrm{E}+00$ & $1.61 \mathrm{E}+00$ \\
\hline MG 25 & $2.06 \mathrm{E}-01$ & 2.06E-01 \\
\hline MG 26 & $2.36 \mathrm{E}-01$ & $2.36 \mathrm{E}-01$ \\
\hline AL 27 & $1.01 \mathrm{E}+02$ & $1.01 \mathrm{E}+02$ \\
\hline SI 28 & $3.48 \mathrm{E}+02$ & $3.48 E+02$ \\
\hline SI 29 & $1.83 \mathrm{E}+01$ & $1.83 \mathrm{E}+01$ \\
\hline SI 30 & $1.25 \mathrm{E}+01$ & $1.25 \mathrm{E}+01$ \\
\hline SI 32 & 7.14E-09 & 6.95E-09 \\
\hline P 31 & $1.84 \mathrm{E}+02$ & $1.84 \mathrm{E}+02$ \\
\hline P 32 & $4.30 \mathrm{E}-13$ & $4.19 \mathrm{E}-13$ \\
\hline S 32 & $1.92 \mathrm{E}+01$ & $1.92 \mathrm{E}+01$ \\
\hline S 33 & $1.75 \mathrm{E}-01$ & $1.75 \mathrm{E}-01$ \\
\hline S 34 & 9.03E-01 & $9.03 \mathrm{E}-01$ \\
\hline S 35 & $3.75 \mathrm{E}-10$ & $2.18 \mathrm{E}-41$ \\
\hline S 36 & $3.86 \mathrm{E}-03$ & $3.86 \mathrm{E}-03$ \\
\hline CL 35 & $3.47 E+00$ & $3.47 \mathrm{E}+00$ \\
\hline CL 36 & 5.01E-01 & 5.01E-01 \\
\hline CL 37 & $1.35 E+00$ & $1.35 \mathrm{E}+00$ \\
\hline AR 36 & $8.48 \mathrm{E}-06$ & 3.68E-05 \\
\hline AR 37 & $1.08 \mathrm{E}-21$ & $0.00 \mathrm{E}+00$ \\
\hline AR 38 & $2.04 \mathrm{E}-03$ & $2.04 \mathrm{E}-03$ \\
\hline AR 39 & $2.94 \mathrm{E}-06$ & $2.75 \mathrm{E}-06$ \\
\hline AR 40 & 9.59E-06 & 9.59E-06 \\
\hline K 39 & $5.70 \mathrm{E}-08$ & $2.40 \mathrm{E}-07$ \\
\hline
\end{tabular}


Table A-1, continued

\begin{tabular}{|c|c|c|}
\hline Cooling Time & 5 Years & 30 Years \\
\hline ISOTOPE & g/MTIHM & g/MTIHM \\
\hline K 40 & $9.07 \mathrm{E}-04$ & 9.07E-04 \\
\hline K 41 & 4.50E-05 & 4.56E-05 \\
\hline CA 40 & $1.93 \mathrm{E}+00$ & $1.93 \mathrm{E}+00$ \\
\hline CA 41 & $2.51 \mathrm{E}-03$ & 2.51E-03 \\
\hline CA 42 & 1.35E-02 & 1.35E-02 \\
\hline CA 43 & 2.80E-03 & 2.80E-03 \\
\hline CA 44 & 4.61E-02 & 4.61E-02 \\
\hline CA 45 & 1.13E-08 & 1.54E-25 \\
\hline CA 46 & $1.24 \mathrm{E}-04$ & $1.24 \mathrm{E}-04$ \\
\hline CA 48 & 4.53E-03 & 4.53E-03 \\
\hline SC 45 & 1.56E-04 & 1.56E-04 \\
\hline SC 46 & $2.32 \mathrm{E}-11$ & $3.64 \mathrm{E}-44$ \\
\hline TI 46 & $8.77 E+00$ & $8.77 \mathrm{E}+00$ \\
\hline TI 47 & $8.08 \mathrm{E}+00$ & $8.08 \mathrm{E}+00$ \\
\hline TI 48 & $8.04 \mathrm{E}+01$ & $8.04 \mathrm{E}+01$ \\
\hline TI 49 & $7.68 \mathrm{E}+00$ & $7.68 \mathrm{E}+00$ \\
\hline TI 50 & $6.07 E+00$ & $6.07 \mathrm{E}+00$ \\
\hline V 50 & 5.10E-02 & $5.10 \mathrm{E}-02$ \\
\hline V 51 & $1.55 E+01$ & $1.55 \mathrm{E}+01$ \\
\hline CR 50 & $3.86 \mathrm{E}+02$ & $3.86 \mathrm{E}+02$ \\
\hline CR 51 & $3.27 \mathrm{E}-21$ & $0.00 \mathrm{E}+00$ \\
\hline CR 52 & $7.86 \mathrm{E}+03$ & $7.86 \mathrm{E}+03$ \\
\hline CR 53 & $9.12 \mathrm{E}+02$ & $9.12 \mathrm{E}+02$ \\
\hline CR 54 & $2.51 \mathrm{E}+02$ & $2.51 \mathrm{E}+02$ \\
\hline MN 54 & $1.29 \mathrm{E}-03$ & $2.07 \mathrm{E}-12$ \\
\hline MN 55 & $7.07 \mathrm{E}+02$ & $7.08 \mathrm{E}+02$ \\
\hline FE 54 & $1.49 \mathrm{E}+03$ & $1.49 \mathrm{E}+03$ \\
\hline FE 55 & 4.69E-01 & 5.97E-04 \\
\hline FE 56 & $2.45 \mathrm{E}+04$ & $2.45 E+04$ \\
\hline FE 57 & $6.37 \mathrm{E}+02$ & $6.37 \mathrm{E}+02$ \\
\hline FE 58 & $8.44 \mathrm{E}+01$ & $8.44 \mathrm{E}+01$ \\
\hline FE 59 & $3.12 \mathrm{E}-15$ & $0.00 \mathrm{E}+00$ \\
\hline CO 58 & 3.34E-09 & $4.85 E-48$ \\
\hline CO 59 & $7.97 \mathrm{E}+01$ & $7.97 \mathrm{E}+01$ \\
\hline CO 60 & $5.73 \mathrm{E}+00$ & $2.14 \mathrm{E}-01$ \\
\hline NI 58 & $7.24 \mathrm{E}+03$ & $7.24 \mathrm{E}+03$ \\
\hline NI 59 & $5.09 \mathrm{E}+01$ & $5.09 \mathrm{E}+01$ \\
\hline $\mathrm{NI} 60$ & $2.89 \mathrm{E}+03$ & $2.90 \mathrm{E}+03$ \\
\hline NI 61 & $1.43 \mathrm{E}+02$ & $1.43 \mathrm{E}+02$ \\
\hline NI 62 & $4.00 \mathrm{E}+02$ & $4.00 \mathrm{E}+02$ \\
\hline $\mathrm{NI} 63$ & $1.04 \mathrm{E}+01$ & $8.63 \mathrm{E}+00$ \\
\hline NI 64 & $1.08 \mathrm{E}+02$ & $1.08 \mathrm{E}+02$ \\
\hline CU 63 & $1.36 \mathrm{E}+01$ & $1.54 \mathrm{E}+01$ \\
\hline CU 65 & $6.42 \mathrm{E}+00$ & $6.42 \mathrm{E}+00$ \\
\hline ZN 64 & $1.92 \mathrm{E}+01$ & $1.92 \mathrm{E}+01$ \\
\hline ZN 65 & 9.04E-05 & 4.84E-16 \\
\hline ZN 66 & $1.13 \mathrm{E}+01$ & $1.13 \mathrm{E}+01$ \\
\hline ZN 67 & $1.66 \mathrm{E}+00$ & $1.66 \mathrm{E}+00$ \\
\hline ZN 68 & $7.88 \mathrm{E}+00$ & $7.88 \mathrm{E}+00$ \\
\hline
\end{tabular}


Table A-1, continued

\begin{tabular}{|c|c|c|}
\hline Cooling Time & 5 Years & 30 Years \\
\hline ISOTOPE & g/MTIHM & g/MTIHM \\
\hline ZN 70 & $2.76 \mathrm{E}-01$ & $2.76 \mathrm{E}-01$ \\
\hline GA 69 & 5.05E-02 & 5.05E-02 \\
\hline GA 71 & 8.20E-05 & $8.20 \mathrm{E}-05$ \\
\hline GE 70 & 5.40E-04 & $5.40 \mathrm{E}-04$ \\
\hline GE 72 & 3.89E-02 & 3.89E-02 \\
\hline GE 73 & 7.75E-02 & 7.75E-02 \\
\hline GE 74 & 1.76E-01 & 1.76E-01 \\
\hline GE 76 & 8.86E-01 & 8.86E-01 \\
\hline AS 75 & 3.49E-01 & 3.49E-01 \\
\hline SE 76 & 1.81E-02 & 1.81E-02 \\
\hline SE 77 & $1.76 \mathrm{E}+00$ & $1.76 \mathrm{E}+00$ \\
\hline SE 78 & $4.39 \mathrm{E}+00$ & $4.39 \mathrm{E}+00$ \\
\hline SE 79 & $1.05 E+01$ & $1.05 \mathrm{E}+01$ \\
\hline SE 80 & $2.39 \mathrm{E}+01$ & $2.39 \mathrm{E}+01$ \\
\hline SE 82 & $5.98 \mathrm{E}+01$ & $5.98 \mathrm{E}+01$ \\
\hline BR 79 & 8.67E-04 & $3.66 \mathrm{E}-03$ \\
\hline BR 81 & $3.72 \mathrm{E}+01$ & $3.72 \mathrm{E}+01$ \\
\hline KR 80 & $4.25 \mathrm{E}-04$ & $4.25 \mathrm{E}-04$ \\
\hline KR 81 & 5.85E-05 & 5.85E-05 \\
\hline KR 82 & $2.92 \mathrm{E}+00$ & $2.92 \mathrm{E}+00$ \\
\hline KR 83 & $6.21 \mathrm{E}+01$ & $6.21 \mathrm{E}+01$ \\
\hline KR 84 & $2.12 \mathrm{E}+02$ & $2.12 \mathrm{E}+02$ \\
\hline KR 85 & $2.79 \mathrm{E}+01$ & $5.55 \mathrm{E}+00$ \\
\hline KR 86 & $3.36 \mathrm{E}+02$ & $3.36 \mathrm{E}+02$ \\
\hline RB 85 & $1.87 \mathrm{E}+02$ & $2.09 \mathrm{E}+02$ \\
\hline RB 86 & $1.65 \mathrm{E}-31$ & $0.00 \mathrm{E}+00$ \\
\hline RB 87 & $4.30 \mathrm{E}+02$ & $4.30 \mathrm{E}+02$ \\
\hline SR 86 & $1.45 \mathrm{E}+00$ & $1.45 \mathrm{E}+00$ \\
\hline SR 87 & $1.78 \mathrm{E}-02$ & $1.78 \mathrm{E}-02$ \\
\hline SR 88 & $6.18 \mathrm{E}+02$ & $6.18 \mathrm{E}+02$ \\
\hline SR 89 & $2.96 \mathrm{E}-10$ & $0.00 \mathrm{E}+00$ \\
\hline SR 90 & $8.05 E+02$ & $4.44 \mathrm{E}+02$ \\
\hline Y 89 & $8.04 \mathrm{E}+02$ & $8.04 \mathrm{E}+02$ \\
\hline Y 90 & 2.02E-01 & 1.11E-01 \\
\hline Y 91 & 1.47E-08 & 1.53E-55 \\
\hline ZR 90 & $1.28 \mathrm{E}+05$ & $1.28 \mathrm{E}+05$ \\
\hline ZR 91 & $2.89 \mathrm{E}+04$ & $2.89 \mathrm{E}+04$ \\
\hline ZR 92 & $4.46 \mathrm{E}+04$ & $4.46 \mathrm{E}+04$ \\
\hline ZR 93 & $1.47 \mathrm{E}+03$ & $1.47 \mathrm{E}+03$ \\
\hline ZR 94 & $4.63 \mathrm{E}+04$ & $4.63 \mathrm{E}+04$ \\
\hline ZR 95 & $1.70 \mathrm{E}-07$ & 1.85E-50 \\
\hline ZR 96 & $8.77 \mathrm{E}+03$ & $8.77 \mathrm{E}+03$ \\
\hline NB 93 & $7.14 \mathrm{E}+02$ & $7.14 \mathrm{E}+02$ \\
\hline NB 93M & 4.11E-03 & 1.01E-02 \\
\hline NB 94 & $9.58 \mathrm{E}+00$ & $9.57 \mathrm{E}+00$ \\
\hline NB 95 & 2.07E-07 & $2.26 \mathrm{E}-50$ \\
\hline NB 95M & 7.11E-11 & 7.76E-54 \\
\hline MO 92 & $5.70 \mathrm{E}+01$ & $5.70 \mathrm{E}+01$ \\
\hline MO 93 & 3.07E-02 & 3.06E-02 \\
\hline
\end{tabular}


Table A-1, continued

\begin{tabular}{|c|c|c|}
\hline Cooling Time & 5 Years & 30 Years \\
\hline ISOTOPE & g/MTIHM & g/MTIHM \\
\hline MO 94 & $3.66 \mathrm{E}+01$ & $3.66 \mathrm{E}+01$ \\
\hline MO 95 & $1.38 \mathrm{E}+03$ & $1.38 \mathrm{E}+03$ \\
\hline MO 96 & $2.07 \mathrm{E}+02$ & $2.07 \mathrm{E}+02$ \\
\hline MO 97 & $1.52 \mathrm{E}+03$ & $1.52 \mathrm{E}+03$ \\
\hline MO 98 & $1.55 \mathrm{E}+03$ & $1.55 \mathrm{E}+03$ \\
\hline MO100 & $1.72 \mathrm{E}+03$ & $1.72 \mathrm{E}+03$ \\
\hline TC 98 & 1.63E-02 & 1.63E-02 \\
\hline TC 99 & $1.28 \mathrm{E}+03$ & $1.28 \mathrm{E}+03$ \\
\hline RU 99 & 3.25E-02 & 1.37E-01 \\
\hline RU100 & $3.29 \mathrm{E}+02$ & $3.29 \mathrm{E}+02$ \\
\hline RU101 & $1.35 \mathrm{E}+03$ & $1.35 \mathrm{E}+03$ \\
\hline RU102 & $1.45 \mathrm{E}+03$ & $1.45 \mathrm{E}+03$ \\
\hline RU103 & 4.78E-13 & $0.00 \mathrm{E}+00$ \\
\hline RU104 & $1.01 \mathrm{E}+03$ & $1.01 \mathrm{E}+03$ \\
\hline RU106 & $6.70 \mathrm{E}+00$ & $2.29 \mathrm{E}-07$ \\
\hline RH102 & $6.03 \mathrm{E}-04$ & 1.53E-06 \\
\hline RH103 & $6.02 \mathrm{E}+02$ & $6.02 \mathrm{E}+02$ \\
\hline RH103M & $4.28 \mathrm{E}-16$ & $0.00 \mathrm{E}+00$ \\
\hline RH106 & $6.29 \mathrm{E}-06$ & $2.15 \mathrm{E}-13$ \\
\hline PD104 & $6.57 \mathrm{E}+02$ & $6.57 \mathrm{E}+02$ \\
\hline PD105 & $7.01 \mathrm{E}+02$ & $7.01 \mathrm{E}+02$ \\
\hline PD106 & $6.94 \mathrm{E}+02$ & $7.01 \mathrm{E}+02$ \\
\hline PD107 & $4.13 \mathrm{E}+02$ & $4.13 \mathrm{E}+02$ \\
\hline PD108 & $2.83 \mathrm{E}+02$ & $2.83 E+02$ \\
\hline PD110 & $9.51 \mathrm{E}+01$ & $9.51 \mathrm{E}+01$ \\
\hline AG107 & $4.02 \mathrm{E}-02$ & 4.13E-02 \\
\hline AG108 & $2.25 \mathrm{E}-12$ & $1.96 \mathrm{E}-12$ \\
\hline AG108M & 7.11E-04 & $6.20 \mathrm{E}-04$ \\
\hline AG109 & $1.21 \mathrm{E}+02$ & $1.21 \mathrm{E}+02$ \\
\hline AG109M & 3.87E-11 & $4.62 \mathrm{E}-17$ \\
\hline AG110 & 1.80E-10 & 1.80E-21 \\
\hline AG110M & 1.19E-02 & $1.19 \mathrm{E}-13$ \\
\hline CD106 & 3.06E-01 & 3.06E-01 \\
\hline CD108 & 2.24E-01 & 2.24E-01 \\
\hline CD109 & 3.92E-05 & 4.67E-11 \\
\hline CD110 & $1.13 \mathrm{E}+02$ & $1.13 \mathrm{E}+02$ \\
\hline CD111 & $5.69 \mathrm{E}+01$ & $5.69 \mathrm{E}+01$ \\
\hline CD112 & $3.84 \mathrm{E}+01$ & $3.84 \mathrm{E}+01$ \\
\hline CD113 & 1.86E-01 & 1.86E-01 \\
\hline CD113M & 4.36E-01 & 1.33E-01 \\
\hline CD114 & $5.13 \mathrm{E}+01$ & $5.13 \mathrm{E}+01$ \\
\hline CD115M & $3.71 \mathrm{E}-14$ & $0.00 \mathrm{E}+00$ \\
\hline CD116 & $1.67 \mathrm{E}+01$ & $1.67 \mathrm{E}+01$ \\
\hline IN113 & $1.16 \mathrm{E}+00$ & $1.46 \mathrm{E}+00$ \\
\hline IN113M & 9.98E-10 & 1.31E-33 \\
\hline IN114 & 1.35E-18 & $0.00 \mathrm{E}+00$ \\
\hline IN114M & 8.39E-14 & $0.00 \mathrm{E}+00$ \\
\hline IN115 & $2.47 \mathrm{E}+00$ & $2.47 \mathrm{E}+00$ \\
\hline IN115M & 1.03E-20 & $0.00 \mathrm{E}+00$ \\
\hline
\end{tabular}


Table A-1, continued

\begin{tabular}{|c|c|c|}
\hline Cooling Time & 5 Years & 30 Years \\
\hline ISOTOPE & g/MTIHM & g/MTIHM \\
\hline SN112 & $3.76 \mathrm{E}+01$ & $3.76 \mathrm{E}+01$ \\
\hline SN113 & $1.66 \mathrm{E}-06$ & $2.19 \mathrm{E}-30$ \\
\hline SN114 & $2.67 \mathrm{E}+01$ & $2.67 \mathrm{E}+01$ \\
\hline SN115 & $1.36 \mathrm{E}+01$ & $1.36 \mathrm{E}+01$ \\
\hline SN116 & $5.94 \mathrm{E}+02$ & $5.94 \mathrm{E}+02$ \\
\hline SN117 & $3.35 \mathrm{E}+02$ & $3.35 \mathrm{E}+02$ \\
\hline SN117M & $5.80 \mathrm{E}-41$ & $0.00 \mathrm{E}+00$ \\
\hline SN118 & $1.00 \mathrm{E}+03$ & $1.00 \mathrm{E}+03$ \\
\hline SN119 & $3.83 \mathrm{E}+02$ & $3.83 \mathrm{E}+02$ \\
\hline SN119M & 1.00E-02 & $6.06 \mathrm{E}-14$ \\
\hline SN120 & $1.36 \mathrm{E}+03$ & $1.36 \mathrm{E}+03$ \\
\hline SN121M & $2.26 \mathrm{E}-02$ & 1.60E-02 \\
\hline SN122 & $2.11 \mathrm{E}+02$ & $2.11 \mathrm{E}+02$ \\
\hline SN123 & 2.84E-05 & 1.49E-26 \\
\hline SN124 & $2.59 \mathrm{E}+02$ & $2.59 \mathrm{E}+02$ \\
\hline SN126 & $4.99 \mathrm{E}+01$ & $4.99 \mathrm{E}+01$ \\
\hline SB121 & $1.72 \mathrm{E}+01$ & $1.72 \mathrm{E}+01$ \\
\hline SB123 & $1.80 \mathrm{E}+01$ & $1.80 \mathrm{E}+01$ \\
\hline SB124 & $1.25 \mathrm{E}-10$ & $2.71 E-56$ \\
\hline SB125 & $6.45 \mathrm{E}+00$ & $1.24 \mathrm{E}-02$ \\
\hline SB126 & $2.37 \mathrm{E}-06$ & $2.37 \mathrm{E}-06$ \\
\hline SB126M & 1.80E-08 & 1.80E-08 \\
\hline TE122 & $2.23 \mathrm{E}+00$ & $2.23 \mathrm{E}+00$ \\
\hline TE123 & $4.15 E-02$ & $4.15 E-02$ \\
\hline TE123M & 2.11E-07 & $2.27 \mathrm{E}-30$ \\
\hline TE124 & $1.51 \mathrm{E}+00$ & $1.51 \mathrm{E}+00$ \\
\hline TE125 & $3.17 \mathrm{E}+01$ & $3.83 \mathrm{E}+01$ \\
\hline TE125M & 9.02E-02 & 1.73E-04 \\
\hline TE126 & $1.78 \mathrm{E}+00$ & $1.79 \mathrm{E}+00$ \\
\hline TE127 & $5.15 E-08$ & $3.13 E-33$ \\
\hline TE127M & 1.47E-05 & 8.93E-31 \\
\hline TE128 & $2.01 \mathrm{E}+02$ & $2.01 \mathrm{E}+02$ \\
\hline TE129 & $6.20 \mathrm{E}-20$ & $0.00 \mathrm{E}+00$ \\
\hline TE129M & 6.62E-17 & $0.00 \mathrm{E}+00$ \\
\hline TE130 & $6.44 \mathrm{E}+02$ & $6.44 \mathrm{E}+02$ \\
\hline I127 & $9.59 \mathrm{E}+01$ & $9.59 \mathrm{E}+01$ \\
\hline I129 & $3.13 \mathrm{E}+02$ & $3.13 \mathrm{E}+02$ \\
\hline XE127 & $5.27 \mathrm{E}-21$ & $0.00 \mathrm{E}+00$ \\
\hline XE128 & $1.07 \mathrm{E}+01$ & $1.07 \mathrm{E}+01$ \\
\hline XE129 & 9.97E-02 & 1.00E-01 \\
\hline XE130 & $3.48 \mathrm{E}+01$ & $3.48 \mathrm{E}+01$ \\
\hline XE131 & $5.73 \mathrm{E}+02$ & $5.73 \mathrm{E}+02$ \\
\hline XE131M & $2.34 \mathrm{E}-47$ & $0.00 \mathrm{E}+00$ \\
\hline XE132 & $2.16 \mathrm{E}+03$ & $2.16 \mathrm{E}+03$ \\
\hline XE134 & $2.65 \mathrm{E}+03$ & $2.65 \mathrm{E}+03$ \\
\hline XE136 & $4.01 \mathrm{E}+03$ & $4.01 \mathrm{E}+03$ \\
\hline CS133 & $1.78 \mathrm{E}+03$ & $1.78 \mathrm{E}+03$ \\
\hline CS134 & $5.71 \mathrm{E}+01$ & $1.28 \mathrm{E}-02$ \\
\hline CS135 & $7.72 E+02$ & $7.72 \mathrm{E}+02$ \\
\hline
\end{tabular}


Table A-1, continued

\begin{tabular}{|c|c|c|}
\hline Cooling Time & 5 Years & 30 Years \\
\hline ISOTOPE & g/MTIHM & g/MTIHM \\
\hline CS136 & $1.59 \mathrm{E}-42$ & $0.00 \mathrm{E}+00$ \\
\hline CS137 & $1.86 \mathrm{E}+03$ & $1.05 E+03$ \\
\hline BA132 & 4.70E-03 & $4.70 \mathrm{E}-03$ \\
\hline BA134 & $4.44 \mathrm{E}+02$ & $5.01 \mathrm{E}+02$ \\
\hline BA135 & $2.67 \mathrm{E}+00$ & $2.67 \mathrm{E}+00$ \\
\hline BA136 & $6.49 \mathrm{E}+01$ & $6.49 \mathrm{E}+01$ \\
\hline BA136M & 7.13E-50 & $0.00 \mathrm{E}+00$ \\
\hline BA137 & $3.65 \mathrm{E}+02$ & $1.18 \mathrm{E}+03$ \\
\hline BA137M & $2.85 E-04$ & 1.60E-04 \\
\hline BA138 & $2.30 \mathrm{E}+03$ & $2.30 \mathrm{E}+03$ \\
\hline BA140 & $2.07 \mathrm{E}-42$ & $0.00 \mathrm{E}+00$ \\
\hline LA138 & 8.07E-03 & 8.07E-03 \\
\hline LA139 & $2.17 \mathrm{E}+03$ & $2.17 \mathrm{E}+03$ \\
\hline LA140 & $3.13 E-43$ & $0.00 \mathrm{E}+00$ \\
\hline CE140 & $2.23 \mathrm{E}+03$ & $2.23 \mathrm{E}+03$ \\
\hline CE141 & 6.09E-16 & $0.00 \mathrm{E}+00$ \\
\hline CE142 & $2.02 \mathrm{E}+03$ & $2.02 \mathrm{E}+03$ \\
\hline CE144 & $4.00 \mathrm{E}+00$ & $8.56 \mathrm{E}-10$ \\
\hline PR141 & $1.98 \mathrm{E}+03$ & $1.98 \mathrm{E}+03$ \\
\hline PR143 & $6.08 \mathrm{E}-40$ & $0.00 \mathrm{E}+00$ \\
\hline PR144 & 1.69E-04 & $3.61 \mathrm{E}-14$ \\
\hline PR144M & 8.45E-07 & $1.81 \mathrm{E}-16$ \\
\hline ND142 & $8.08 \mathrm{E}+01$ & $8.08 \mathrm{E}+01$ \\
\hline ND143 & $1.16 \mathrm{E}+03$ & $1.16 \mathrm{E}+03$ \\
\hline ND144 & $2.60 \mathrm{E}+03$ & $2.60 \mathrm{E}+03$ \\
\hline ND145 & $1.10 \mathrm{E}+03$ & $1.10 \mathrm{E}+03$ \\
\hline ND146 & $1.35 \mathrm{E}+03$ & $1.35 \mathrm{E}+03$ \\
\hline ND147 & 1.39E-49 & $0.00 \mathrm{E}+00$ \\
\hline ND148 & $6.61 \mathrm{E}+02$ & $6.61 \mathrm{E}+02$ \\
\hline ND150 & $3.20 \mathrm{E}+02$ & $3.20 \mathrm{E}+02$ \\
\hline PM146 & $5.61 \mathrm{E}-03$ & 2.40E-04 \\
\hline PM147 & $3.47 \mathrm{E}+01$ & $4.70 \mathrm{E}-02$ \\
\hline PM148 & $4.72 \mathrm{E}-16$ & $0.00 \mathrm{E}+00$ \\
\hline PM148M & $6.45 \mathrm{E}-14$ & $0.00 \mathrm{E}+00$ \\
\hline SM146 & $2.15 E-02$ & 2.35E-02 \\
\hline SM147 & $2.07 \mathrm{E}+02$ & $2.42 \mathrm{E}+02$ \\
\hline SM148 & $4.09 E+02$ & $4.09 \mathrm{E}+02$ \\
\hline SM149 & $4.06 \mathrm{E}+00$ & $4.06 \mathrm{E}+00$ \\
\hline SM150 & $5.26 \mathrm{E}+02$ & $5.26 \mathrm{E}+02$ \\
\hline SM151 & $2.17 \mathrm{E}+01$ & $1.79 \mathrm{E}+01$ \\
\hline SM152 & $1.83 \mathrm{E}+02$ & $1.83 \mathrm{E}+02$ \\
\hline SM154 & $6.96 \mathrm{E}+01$ & $6.96 \mathrm{E}+01$ \\
\hline EU150 & 6.60E-07 & 4.08E-07 \\
\hline EU151 & 8.67E-01 & $4.66 \mathrm{E}+00$ \\
\hline EU152 & 4.91E-02 & 1.37E-02 \\
\hline EU153 & $2.27 \mathrm{E}+02$ & $2.27 \mathrm{E}+02$ \\
\hline EU154 & $5.67 \mathrm{E}+01$ & $7.56 \mathrm{E}+00$ \\
\hline EU155 & $1.65 \mathrm{E}+01$ & 5.01E-01 \\
\hline EU156 & 4.60E-36 & $0.00 \mathrm{E}+00$ \\
\hline
\end{tabular}


Table A-1, continued

\begin{tabular}{|c|c|c|}
\hline Cooling Time & 5 Years & 30 Years \\
\hline ISOTOPE & g/MTIHM & g/MTIHM \\
\hline GD152 & $1.19 \mathrm{E}-01$ & $1.29 \mathrm{E}-01$ \\
\hline GD153 & 6.90E-05 & 3.03E-16 \\
\hline GD154 & $3.90 \mathrm{E}+01$ & $8.81 \mathrm{E}+01$ \\
\hline GD155 & $1.69 \mathrm{E}+01$ & $3.29 \mathrm{E}+01$ \\
\hline GD156 & $2.12 \mathrm{E}+02$ & $2.12 \mathrm{E}+02$ \\
\hline GD157 & $2.50 \mathrm{E}-01$ & $2.50 \mathrm{E}-01$ \\
\hline GD158 & $4.74 \mathrm{E}+01$ & $4.74 \mathrm{E}+01$ \\
\hline GD160 & $2.97 \mathrm{E}+00$ & $2.97 \mathrm{E}+00$ \\
\hline TB159 & $5.17 \mathrm{E}+00$ & $5.17 \mathrm{E}+00$ \\
\hline TB160 & 5.26E-09 & $5.05 E-47$ \\
\hline DY160 & 8.55E-01 & 8.55E-01 \\
\hline DY161 & 8.34E-01 & 8.34E-01 \\
\hline DY162 & 6.74E-01 & 6.74E-01 \\
\hline DY163 & 6.98E-01 & 6.98E-01 \\
\hline DY164 & $1.76 \mathrm{E}-01$ & $1.76 \mathrm{E}-01$ \\
\hline HO165 & 4.39E-01 & 4.39E-01 \\
\hline HO166M & $6.68 \mathrm{E}-03$ & $6.58 \mathrm{E}-03$ \\
\hline ER166 & 1.47E-01 & 1.47E-01 \\
\hline ER167 & 6.95E-03 & 6.95E-03 \\
\hline ER168 & $1.62 \mathrm{E}-02$ & $1.62 \mathrm{E}-02$ \\
\hline TM169 & $1.57 \mathrm{E}-04$ & 1.57E-04 \\
\hline TM170 & 1.58E-09 & $6.62 \mathrm{E}-31$ \\
\hline TM171 & $6.57 \mathrm{E}-07$ & $7.91 \mathrm{E}-11$ \\
\hline YB170 & $8.10 \mathrm{E}-05$ & $8.10 \mathrm{E}-05$ \\
\hline YB171 & 7.84E-06 & 8.50E-06 \\
\hline LU175 & $1.41 \mathrm{E}-02$ & 1.41E-02 \\
\hline LU176 & $5.76 \mathrm{E}-04$ & 5.76E-04 \\
\hline LU177 & $5.64 \mathrm{E}-12$ & 1.04E-29 \\
\hline LU177M & $5.67 \mathrm{E}-10$ & $1.05 E-27$ \\
\hline HF174 & 7.33E-03 & 7.33E-03 \\
\hline HF175 & 1.23E-11 & 6.62E-51 \\
\hline HF176 & 4.63E-01 & 4.63E-01 \\
\hline HF177 & 7.63E-02 & 7.63E-02 \\
\hline HF178 & $1.43 \mathrm{E}+00$ & $1.43 \mathrm{E}+00$ \\
\hline HF179 & $6.58 \mathrm{E}+00$ & $6.58 \mathrm{E}+00$ \\
\hline HF180 & $1.09 \mathrm{E}+01$ & $1.09 \mathrm{E}+01$ \\
\hline HF181 & 4.16E-15 & $0.00 \mathrm{E}+00$ \\
\hline HF182 & $2.85 E-03$ & $2.85 E-03$ \\
\hline TA181 & 4.98E-01 & 4.98E-01 \\
\hline TA182 & 2.03E-07 & 9.97E-11 \\
\hline W180 & $7.45 \mathrm{E}-03$ & 7.45E-03 \\
\hline W181 & 6.15E-09 & $1.28 \mathrm{E}-31$ \\
\hline W182 & $1.03 \mathrm{E}+00$ & $1.03 \mathrm{E}+00$ \\
\hline W183 & $1.57 \mathrm{E}+00$ & $1.57 \mathrm{E}+00$ \\
\hline W184 & $2.71 \mathrm{E}+00$ & $2.71 \mathrm{E}+00$ \\
\hline W185 & 2.01E-10 & $5.04 \mathrm{E}-47$ \\
\hline W186 & $1.14 \mathrm{E}+00$ & $1.14 \mathrm{E}+00$ \\
\hline W188 & $2.20 \mathrm{E}-12$ & 5.43E-52 \\
\hline RE185 & 2.31E-02 & 2.31E-02 \\
\hline
\end{tabular}


Table A-1, continued

\begin{tabular}{|c|c|c|}
\hline Cooling Time & 5 Years & 30 Years \\
\hline ISOTOPE & g/MTIHM & g/MTIHM \\
\hline RE187 & $7.36 \mathrm{E}-01$ & $7.36 \mathrm{E}-01$ \\
\hline RE188 & $2.27 \mathrm{E}-14$ & 5.59E-54 \\
\hline OS186 & $2.31 \mathrm{E}-02$ & 2.31E-02 \\
\hline OS187 & 6.67E-11 & $3.22 \mathrm{E}-10$ \\
\hline OS188 & $2.22 \mathrm{E}-01$ & $2.22 \mathrm{E}-01$ \\
\hline OS189 & 1.04E-02 & 1.04E-02 \\
\hline OS190 & 2.47E-03 & 2.47E-03 \\
\hline IR191 & 1.75E-05 & 1.75E-05 \\
\hline IR192 & $6.79 \mathrm{E}-12$ & $6.15 E-12$ \\
\hline IR192M & 7.85E-09 & 7.31E-09 \\
\hline IR193 & $2.46 \mathrm{E}-06$ & $2.46 \mathrm{E}-06$ \\
\hline PT192 & $1.54 \mathrm{E}-05$ & $1.54 \mathrm{E}-05$ \\
\hline PT193 & $2.17 \mathrm{E}-07$ & $2.10 \mathrm{E}-07$ \\
\hline TL206 & $1.29 \mathrm{E}-16$ & $1.29 \mathrm{E}-16$ \\
\hline TL207 & $4.10 \mathrm{E}-14$ & $1.50 \mathrm{E}-13$ \\
\hline TL208 & 8.96E-11 & $1.22 \mathrm{E}-10$ \\
\hline TL209 & $6.07 \mathrm{E}-17$ & $7.16 \mathrm{E}-17$ \\
\hline PB204 & $1.37 \mathrm{E}-02$ & $1.37 \mathrm{E}-02$ \\
\hline PB205 & 4.96E-05 & 4.96E-05 \\
\hline PB206 & $2.21 \mathrm{E}-01$ & $2.21 \mathrm{E}-01$ \\
\hline PB207 & $2.39 \mathrm{E}-01$ & $2.39 \mathrm{E}-01$ \\
\hline PB208 & $5.27 \mathrm{E}-01$ & $5.28 \mathrm{E}-01$ \\
\hline PB209 & $2.53 \mathrm{E}-13$ & $2.98 \mathrm{E}-13$ \\
\hline PB210 & $5.40 \mathrm{E}-10$ & 1.13E-08 \\
\hline PB211 & $3.17 \mathrm{E}-13$ & $1.16 \mathrm{E}-12$ \\
\hline PB212 & $5.29 E-08$ & $7.20 \mathrm{E}-08$ \\
\hline PB214 & $7.48 \mathrm{E}-15$ & 9.59E-14 \\
\hline BI208 & 7.95E-06 & 7.95E-06 \\
\hline BI209 & 4.00E-01 & $4.00 \mathrm{E}-01$ \\
\hline $\mathrm{BI} 210$ & $3.32 \mathrm{E}-13$ & $6.95 \mathrm{E}-12$ \\
\hline $\mathrm{BI} 210 \mathrm{M}$ & 4.96E-05 & 4.96E-05 \\
\hline $\mathrm{BI} 211$ & $1.87 \mathrm{E}-14$ & $6.85 \mathrm{E}-14$ \\
\hline $\mathrm{Bl} 212$ & 5.01E-09 & 6.83E-09 \\
\hline $\mathrm{Bl} 213$ & 5.95E-14 & 7.01E-14 \\
\hline BI214 & 5.55E-15 & $7.12 \mathrm{E}-14$ \\
\hline PO210 & 1.07E-09 & $1.92 \mathrm{E}-10$ \\
\hline PO211 & 2.29E-19 & 8.40E-19 \\
\hline PO212 & 2.65E-19 & 3.62E-19 \\
\hline PO213 & 8.92E-23 & 1.05E-22 \\
\hline PO214 & 7.64E-22 & $9.80 \mathrm{E}-21$ \\
\hline PO215 & 2.65E-19 & 9.72E-19 \\
\hline PO216 & $2.11 \mathrm{E}-13$ & $2.88 \mathrm{E}-13$ \\
\hline PO218 & 8.67E-16 & 1.11E-14 \\
\hline AT217 & 7.14E-19 & 8.42E-19 \\
\hline RN219 & 6.01E-16 & $2.20 \mathrm{E}-15$ \\
\hline RN220 & 7.96E-11 & 1.09E-10 \\
\hline RN222 & 1.59E-12 & $2.04 \mathrm{E}-11$ \\
\hline FR221 & 6.49E-15 & 7.65E-15 \\
\hline FR223 & $2.79 E-15$ & 1.02E-14 \\
\hline
\end{tabular}


Table A-1, continued

\begin{tabular}{|c|c|c|}
\hline Cooling Time & 5 Years & 30 Years \\
\hline ISOTOPE & g/MTIHM & g/MTIHM \\
\hline RA223 & $1.53 \mathrm{E}-10$ & $5.60 \mathrm{E}-10$ \\
\hline RA224 & 4.61E-07 & $6.28 \mathrm{E}-07$ \\
\hline RA225 & 2.93E-11 & 3.46E-11 \\
\hline RA226 & 2.48E-07 & 3.18E-06 \\
\hline RA228 & $2.54 \mathrm{E}-13$ & $2.07 \mathrm{E}-12$ \\
\hline AC225 & $1.98 \mathrm{E}-11$ & $2.34 \mathrm{E}-11$ \\
\hline AC227 & 1.08E-07 & 3.96E-07 \\
\hline AC228 & $2.65 \mathrm{E}-17$ & $2.16 \mathrm{E}-16$ \\
\hline TH227 & $2.51 \mathrm{E}-10$ & $9.19 \mathrm{E}-10$ \\
\hline TH228 & 8.94E-05 & $1.22 \mathrm{E}-04$ \\
\hline TH229 & 5.41E-06 & 6.37E-06 \\
\hline TH230 & $5.08 \mathrm{E}-03$ & $2.28 \mathrm{E}-02$ \\
\hline TH231 & $2.18 \mathrm{E}-08$ & $2.19 \mathrm{E}-08$ \\
\hline TH232 & $1.57 \mathrm{E}-03$ & $6.11 \mathrm{E}-03$ \\
\hline TH234 & 1.32E-05 & 1.32E-05 \\
\hline PA231 & 8.95E-04 & 1.02E-03 \\
\hline PA233 & $4.08 \mathrm{E}-05$ & $4.20 \mathrm{E}-05$ \\
\hline PA234 & $1.99 \mathrm{E}-10$ & $1.99 \mathrm{E}-10$ \\
\hline PA234M & $4.46 \mathrm{E}-10$ & $4.46 \mathrm{E}-10$ \\
\hline U232 & $4.62 \mathrm{E}-03$ & $4.56 \mathrm{E}-03$ \\
\hline U233 & $4.30 \mathrm{E}-03$ & $1.40 \mathrm{E}-02$ \\
\hline U234 & $2.00 \mathrm{E}+02$ & $3.06 \mathrm{E}+02$ \\
\hline U235 & $5.37 \mathrm{E}+03$ & $5.38 \mathrm{E}+03$ \\
\hline U236 & $6.23 \mathrm{E}+03$ & $6.24 \mathrm{E}+03$ \\
\hline U237 & 3.89E-05 & 1.17E-05 \\
\hline U238 & $9.10 \mathrm{E}+05$ & $9.10 \mathrm{E}+05$ \\
\hline U240 & $2.41 \mathrm{E}-12$ & $2.41 \mathrm{E}-12$ \\
\hline NP235 & 5.34E-07 & $6.13 \mathrm{E}-14$ \\
\hline NP236 & $1.25 \mathrm{E}-03$ & $1.25 \mathrm{E}-03$ \\
\hline NP237 & $1.20 \mathrm{E}+03$ & $1.24 \mathrm{E}+03$ \\
\hline NP238 & 6.11E-07 & 5.45E-07 \\
\hline NP239 & $2.33 \mathrm{E}-04$ & 2.33E-04 \\
\hline NP240M & $2.11 \mathrm{E}-14$ & $2.11 \mathrm{E}-14$ \\
\hline PU236 & 1.15E-03 & 2.65E-06 \\
\hline PU237 & 8.38E-16 & $0.00 \mathrm{E}+00$ \\
\hline PU238 & $5.99 \mathrm{E}+02$ & $4.92 \mathrm{E}+02$ \\
\hline PU239 & $7.42 \mathrm{E}+03$ & $7.42 \mathrm{E}+03$ \\
\hline PU240 & $4.02 \mathrm{E}+03$ & $4.09 \mathrm{E}+03$ \\
\hline PU241 & $1.26 \mathrm{E}+03$ & $3.77 \mathrm{E}+02$ \\
\hline PU242 & $8.17 \mathrm{E}+02$ & $8.17 \mathrm{E}+02$ \\
\hline PU243 & $1.16 \mathrm{E}-12$ & 1.16E-12 \\
\hline PU244 & $1.26 \mathrm{E}-01$ & $1.26 \mathrm{E}-01$ \\
\hline AM241 & $4.10 \mathrm{E}+02$ & $1.25 \mathrm{E}+03$ \\
\hline AM242 & 3.90E-05 & 3.48E-05 \\
\hline AM242M & $3.26 \mathrm{E}+00$ & $2.91 \mathrm{E}+00$ \\
\hline AM243 & $2.71 \mathrm{E}+02$ & $2.71 \mathrm{E}+02$ \\
\hline AM244 & $1.76 \mathrm{E}-16$ & $1.76 \mathrm{E}-16$ \\
\hline CM241 & $1.29 \mathrm{E}-21$ & $0.00 \mathrm{E}+00$ \\
\hline CM242 & 1.86E-02 & 7.03E-03 \\
\hline
\end{tabular}


Table A-1, continued

\begin{tabular}{|l|c|c|}
\hline \multicolumn{1}{|c|}{ Cooling Time } & 5 Years & 30 Years \\
\hline ISOTOPE & g/MTIHM & g/MTIHM \\
\hline CM243 & $1.15 \mathrm{E}+00$ & $6.25 \mathrm{E}-01$ \\
\hline CM244 & $1.37 \mathrm{E}+02$ & $5.26 \mathrm{E}+01$ \\
\hline CM245 & $9.56 \mathrm{E}+00$ & $9.54 \mathrm{E}+00$ \\
\hline CM246 & $1.88 \mathrm{E}+00$ & $1.87 \mathrm{E}+00$ \\
\hline CM247 & $3.26 \mathrm{E}-02$ & $3.26 \mathrm{E}-02$ \\
\hline CM248 & $3.32 \mathrm{E}-03$ & $3.32 \mathrm{E}-03$ \\
\hline BK249 & $8.69 \mathrm{E}-07$ & $2.24 \mathrm{E}-15$ \\
\hline BK250 & $1.42 \mathrm{E}-14$ & $1.00 \mathrm{E}-19$ \\
\hline CF249 & $5.22 \mathrm{E}-05$ & $5.05 \mathrm{E}-05$ \\
\hline CF250 & $1.04 \mathrm{E}-05$ & $2.76 \mathrm{E}-06$ \\
\hline CF251 & $6.77 \mathrm{E}-06$ & $6.65 \mathrm{E}-06$ \\
\hline CF252 & $1.88 \mathrm{E}-06$ & $2.64 \mathrm{E}-09$ \\
\hline CF254 & $6.52 \mathrm{E}-19$ & $2.40 \mathrm{E}-64$ \\
\hline ES254 & $2.95 \mathrm{E}-11$ & $3.16 \mathrm{E}-21$ \\
\hline TOTAL & $1.44 \mathrm{E}+06$ & $1.44 \mathrm{E}+06$ \\
\hline Decay Heat (Watts/MT) & $\mathbf{3 , 5 3 2}$ & $\mathbf{1 , 4 3 8}$ \\
\hline
\end{tabular}


THIS PAGE INTENTIONALLY LEFT BLANK 


\section{Appendix B}

\section{Isotopic Compositions of Co-Extraction Borosilicate}

Glass 
Table B-1 Isotopic Composition of Co-Extraction Borosilicate Glass at 5, 30, 100 and 500 years Isotopic Composition (grams) of Co-Extraction Glass from reprocessing 51 GWd/MT LWR Fuel.

\begin{tabular}{|c|c|c|c|c|}
\hline Isotope & 5 Years & 30 Years & 100 Years & 500 Years \\
\hline He4 + actinide decay & $1.424 \mathrm{E}+00$ & $1.685 \mathrm{E}+00$ & $1.228 \mathrm{E}+01$ & $2.932 E+01$ \\
\hline C12 & $4.168 \mathrm{E}+02$ & $4.168 \mathrm{E}+02$ & $4.168 \mathrm{E}+02$ & $4.168 \mathrm{E}+02$ \\
\hline $\mathrm{C} 13$ & $3.614 \mathrm{E}+01$ & $3.614 \mathrm{E}+01$ & $3.614 \mathrm{E}+01$ & $3.614 \mathrm{E}+01$ \\
\hline C14 & 1.093E-04 & 1.093E-04 & $1.081 \mathrm{E}-04$ & $1.030 \mathrm{E}-04$ \\
\hline $\mathrm{N} 14+\mathrm{C} 14$ decay & 6.616E-08 & 7.939E-08 & $1.316 \mathrm{E}-06$ & $6.422 \mathrm{E}-06$ \\
\hline O16 & $5.610 \mathrm{E}+04$ & $5.610 \mathrm{E}+04$ & $5.610 \mathrm{E}+04$ & $5.610 \mathrm{E}+04$ \\
\hline O17 & $2.272 \mathrm{E}+01$ & $2.272 E+01$ & $2.272 E+01$ & $2.272 E+01$ \\
\hline O18 & $1.291 \mathrm{E}+02$ & $1.291 \mathrm{E}+02$ & $1.291 \mathrm{E}+02$ & $1.291 \mathrm{E}+02$ \\
\hline Rb85 + Kr85 decay & $8.536 \mathrm{E}+02$ & $8.536 \mathrm{E}+02$ & $8.536 \mathrm{E}+02$ & $8.536 \mathrm{E}+02$ \\
\hline $\mathrm{Rb87}$ & $1.980 \mathrm{E}+03$ & $1.980 E+03$ & $1.980 E+03$ & $1.980 E+03$ \\
\hline Sr86 + Rb86 decay & $5.048 \mathrm{E}+00$ & $5.048 \mathrm{E}+00$ & $5.048 \mathrm{E}+00$ & $5.048 \mathrm{E}+00$ \\
\hline Sr87 + Rb87 decay & $4.151 \mathrm{E}-02$ & $4.151 \mathrm{E}-02$ & 4.152E-02 & 4.153E-02 \\
\hline Sr88 & $2.841 E+03$ & $2.841 \mathrm{E}+03$ & $2.841 E+03$ & $2.841 E+03$ \\
\hline Sr89 & $2.242 \mathrm{E}-20$ & $1.489 \mathrm{E}-22$ & $2.900 \mathrm{E}-227$ & $0.000 \mathrm{E}+00$ \\
\hline Sr90 (100\% to Y90) & $3.352 \mathrm{E}+03$ & $3.273 E+03$ & $3.494 \mathrm{E}+02$ & 2.563E-02 \\
\hline Y89 + Sr89 decay & $3.700 \mathrm{E}+03$ & $3.700 \mathrm{E}+03$ & $3.700 \mathrm{E}+03$ & $3.700 E+03$ \\
\hline Y90 (Sr90 progeny) & 8.406E-01 & 8.208E-01 & 8.762E-02 & $6.427 \mathrm{E}-06$ \\
\hline Y91 & 3.429E-17 & $4.531 \mathrm{E}-19$ & 1.073E-195 & $0.000 E+00$ \\
\hline Zr90 + Sr90/Y90 decay & $4.237 \mathrm{E}+02$ & $5.025 E+02$ & $3.427 \mathrm{E}+03$ & $3.776 \mathrm{E}+03$ \\
\hline Zr91 + Y91 decay & 8.514E-08 & 8.514E-08 & 8.514E-08 & 8.514E-08 \\
\hline $\begin{array}{l}\text { Nb93 + Zr93/Nb93m } \\
\text { decay }\end{array}$ & 7.526E-03 & 8.112E-03 & 1.923E-02 & 1.932E-02 \\
\hline Nb93m (100\% to Nb93) & 1.179E-02 & $1.121 \mathrm{E}-02$ & 9.309E-05 & $1.304 \mathrm{E}-13$ \\
\hline $\mathrm{Nb94}$ & 6.339E-03 & 6.339E-03 & 6.318E-03 & $6.233 \mathrm{E}-03$ \\
\hline Nb95 (100\% to Mo95) & $2.692 \mathrm{E}-22$ & $2.007 \mathrm{E}-25$ & $0.000 \mathrm{E}+00$ & $0.000 \mathrm{E}+00$ \\
\hline $\begin{array}{l}\text { Nb95m ( } 94.4 \% \text { to Nb95, } \\
5.6 \% \text { to Mo95) }\end{array}$ & 1.792E-162 & 6.116E-193 & $0.000 E+00$ & $0.000 E+00$ \\
\hline Mo94 + Nb94 decay & 1.082E-06 & 1.299E-06 & $2.161 \mathrm{E}-05$ & 1.073E-04 \\
\hline $\begin{array}{l}\text { Mo95 + } \\
\text { Zr95/Nb95m/Nb95 decay }\end{array}$ & $6.081 \mathrm{E}+03$ & $6.081 \mathrm{E}+03$ & $6.081 E+03$ & $6.081 E+03$ \\
\hline Mo96 & $4.452 \mathrm{E}+02$ & $4.452 \mathrm{E}+02$ & $4.452 \mathrm{E}+02$ & $4.452 \mathrm{E}+02$ \\
\hline Mo97 & $6.545 E+03$ & $6.545 E+03$ & $6.545 E+03$ & $6.545 E+03$ \\
\hline Mo98 & $6.739 E+03$ & $6.739 E+03$ & $6.739 E+03$ & $6.739 \mathrm{E}+03$ \\
\hline Mo99 & $0.000 \mathrm{E}+00$ & $0.000 \mathrm{E}+00$ & $0.000 \mathrm{E}+00$ & $0.000 \mathrm{E}+00$ \\
\hline Mo100 & $7.743 E+03$ & $7.743 E+03$ & $7.743 E+03$ & $7.743 E+03$ \\
\hline Tc98 & 5.854E-02 & 5.854E-02 & 5.854E-02 & 5.854E-02 \\
\hline Tc99 & $6.178 \mathrm{E}+03$ & $6.178 \mathrm{E}+03$ & $6.176 \mathrm{E}+03$ & $6.168 \mathrm{E}+03$ \\
\hline Ru98 + Tc98 decay & 4.832E-08 & 5.798E-08 & 9.664E-07 & 4.832E-06 \\
\hline
\end{tabular}


Table B-1 (continued)

\begin{tabular}{|c|c|c|c|c|}
\hline Isotope & 5 Years & 30 Years & 100 Years & 500 Years \\
\hline Ru99 + Tc99 decay & $2.424 \mathrm{E}-01$ & $2.625 \mathrm{E}-01$ & $2.152 E+00$ & $1.018 \mathrm{E}+01$ \\
\hline Ru100 & $1.186 \mathrm{E}+03$ & $1.186 \mathrm{E}+03$ & $1.186 \mathrm{E}+03$ & $1.186 \mathrm{E}+03$ \\
\hline Ru101 & $6.334 \mathrm{E}+03$ & $6.334 \mathrm{E}+03$ & $6.334 \mathrm{E}+03$ & $6.334 \mathrm{E}+03$ \\
\hline Ru102 & $6.603 E+03$ & $6.603 E+03$ & $6.603 E+03$ & $6.603 E+03$ \\
\hline $\begin{array}{l}\text { Ru103 }(9.94 \% \text { to } \mathrm{Rh} 103 \\
90.06 \% \text { to } \mathrm{Rh} 103 \mathrm{~m})\end{array}$ & $2.685 \mathrm{E}-26$ & $4.268 \mathrm{E}-29$ & 3.630E-292 & $0.000 \mathrm{E}+00$ \\
\hline Ru104 & $4.659 E+03$ & $4.659 \mathrm{E}+03$ & $4.659 \mathrm{E}+03$ & $4.659 \mathrm{E}+03$ \\
\hline Ru106 (100\% to Rh106) & $1.175 \mathrm{E}+00$ & 5.907E-01 & $5.005 E-29$ & 1.754E-148 \\
\hline Rh102 & 7.517E-04 & 5.919E-04 & $1.034 \mathrm{E}-13$ & $3.113 E-55$ \\
\hline Rh102m & $0.000 \mathrm{E}+00$ & $0.000 \mathrm{E}+00$ & $0.000 \mathrm{E}+00$ & $0.000 \mathrm{E}+00$ \\
\hline $\begin{array}{l}\text { Rh103 + Ru103/Rh103m } \\
\text { decay }\end{array}$ & $3.297 \mathrm{E}+03$ & $3.297 \mathrm{E}+03$ & $3.297 \mathrm{E}+03$ & $3.297 \mathrm{E}+03$ \\
\hline Rh103m & $2.398 \mathrm{E}-29$ & 3.812E-32 & 3.242E-295 & $0.000 \mathrm{E}+00$ \\
\hline Rh106 (100\% to Pd106) & 1.105E-06 & 5.553E-07 & $4.705 E-35$ & 1.649E-154 \\
\hline $\mathrm{Pd} 102$ & 3.464E-04 & 3.783E-04 & 4.967E-04 & 4.967E-04 \\
\hline Pd104 & $2.526 \mathrm{E}+03$ & $2.526 \mathrm{E}+03$ & $2.526 \mathrm{E}+03$ & $2.526 \mathrm{E}+03$ \\
\hline Pd105 + Rh105 decay & $3.307 \mathrm{E}+03$ & 3.307E+03 & 3.307E+03 & $3.307 \mathrm{E}+03$ \\
\hline $\begin{array}{l}\text { Pd106 + Ru106/Rh106 } \\
\text { decay }\end{array}$ & $3.177 \mathrm{E}+03$ & $3.177 \mathrm{E}+03$ & $3.178 \mathrm{E}+03$ & $3.178 \mathrm{E}+03$ \\
\hline Pd107 & $1.940 \mathrm{E}+03$ & $1.940 \mathrm{E}+03$ & $1.940 \mathrm{E}+03$ & $1.940 \mathrm{E}+03$ \\
\hline Pd108 & $1.335 E+03$ & $1.335 \mathrm{E}+03$ & $1.335 E+03$ & $1.335 \mathrm{E}+03$ \\
\hline Pd110 & 4.427E+02 & 4.427E+02 & 4.427E+02 & 4.427E+02 \\
\hline Ag107 + Pd107 decay & $2.381 \mathrm{E}-03$ & $2.588 \mathrm{E}-03$ & 2.205E-02 & $1.049 \mathrm{E}-01$ \\
\hline Ag108 & 3.033E-14 & 3.017E-14 & $1.806 \mathrm{E}-14$ & $2.037 \mathrm{E}-15$ \\
\hline $\operatorname{Ag} 108 m(8.7 \%$ to $\mathrm{Ag} 108)$ & 9.829E-06 & 9.775E-06 & 5.853E-06 & $6.600 \mathrm{E}-07$ \\
\hline $\begin{array}{l}\text { Ag109 + Cd109/Ag109m } \\
\text { decay }\end{array}$ & $6.194 \mathrm{E}+02$ & $6.194 \mathrm{E}+02$ & $6.194 \mathrm{E}+02$ & $6.194 \mathrm{E}+02$ \\
\hline Ag109m & 2.363E-14 & $1.369 \mathrm{E}-14$ & 7.276E-37 & 1.192E-131 \\
\hline Ag110 & $4.880 \mathrm{E}-12$ & $1.771 \mathrm{E}-12$ & 7.605E-54 & 7.085E-230 \\
\hline $\begin{array}{l}\text { Ag110m (1.36\% to } \\
\text { Ag110) }\end{array}$ & 3.149E-04 & 1.143E-04 & $4.908 \mathrm{E}-46$ & 4.572E-222 \\
\hline Cd108 & $3.728 \mathrm{E}-03$ & 3.728E-03 & 3.732E-03 & 3.737E-03 \\
\hline Cd109 & 2.392E-08 & $1.386 \mathrm{E}-08$ & 7.364E-31 & 1.206E-125 \\
\hline Cd110 + Ag110m decay & $4.146 \mathrm{E}+02$ & $4.146 \mathrm{E}+02$ & $4.146 \mathrm{E}+02$ & $4.146 \mathrm{E}+02$ \\
\hline Cd111 + Ag111 decay & $2.439 \mathrm{E}+02$ & $2.439 \mathrm{E}+02$ & $2.439 \mathrm{E}+02$ & $2.439 \mathrm{E}+02$ \\
\hline $\mathrm{Cd} 111 \mathrm{~m}$ & $0.000 \mathrm{E}+00$ & $0.000 \mathrm{E}+00$ & $0.000 \mathrm{E}+00$ & $0.000 \mathrm{E}+00$ \\
\hline Cd112 + Pd112 decay & $1.459 \mathrm{E}+02$ & $1.459 \mathrm{E}+02$ & $1.459 \mathrm{E}+02$ & $1.459 \mathrm{E}+02$ \\
\hline Cd113 (100\% to In113) & $1.144 \mathrm{E}+00$ & $1.144 \mathrm{E}+00$ & $1.146 \mathrm{E}+00$ & $1.146 \mathrm{E}+00$ \\
\hline $\begin{array}{l}\text { Cd113m }(0.14 \% \text { to } \\
\text { Cd113, } 99.86 \% \text { to } \ln 113)\end{array}$ & $1.489 \mathrm{E}+00$ & $1.420 \mathrm{E}+00$ & 1.630E-02 & $9.037 \mathrm{E}-11$ \\
\hline Cd114 & $1.893 \mathrm{E}+02$ & $1.893 \mathrm{E}+02$ & $1.893 \mathrm{E}+02$ & $1.893 \mathrm{E}+02$ \\
\hline
\end{tabular}


Table B-1 (continued)

\begin{tabular}{|c|c|c|c|c|}
\hline Isotope & 5 Years & 30 Years & 100 Years & 500 Years \\
\hline Cd115m & $8.833 E-26$ & 3.023E-28 & $5.198 \mathrm{E}-260$ & $0.000 E+00$ \\
\hline Cd116 & $6.847 \mathrm{E}+01$ & $6.847 \mathrm{E}+01$ & $6.847 \mathrm{E}+01$ & $6.847 \mathrm{E}+01$ \\
\hline $\begin{array}{l}\text { In113 + Cd113/Cd113m } \\
\text { decay }\end{array}$ & 3.989E-01 & 4.679E-01 & $1.870 \mathrm{E}+00$ & $1.886 \mathrm{E}+00$ \\
\hline $\ln 115$ & $1.879 \mathrm{E}-13$ & 1.879E-13 & 1.879E-13 & 1.879E-13 \\
\hline In115m & 2.494E-32 & 8.537E-35 & $1.468 \mathrm{E}-266$ & $0.000 \mathrm{E}+00$ \\
\hline Sn114 + In114m decay & $2.281 \mathrm{E}-02$ & $2.281 \mathrm{E}-02$ & $2.281 \mathrm{E}-02$ & $2.281 \mathrm{E}-02$ \\
\hline $\begin{array}{l}\text { Sn115 + In115/Cd115 } \\
\text { decay }\end{array}$ & $2.673 E+00$ & $2.673 \mathrm{E}+00$ & $2.673 E+00$ & $2.673 E+00$ \\
\hline Sn116 & $6.691 \mathrm{E}+01$ & $6.691 \mathrm{E}+01$ & $6.691 \mathrm{E}+01$ & $6.691 \mathrm{E}+01$ \\
\hline Sn117 + Sn117m decay & $6.896 \mathrm{E}+01$ & $6.896 \mathrm{E}+01$ & $6.896 \mathrm{E}+01$ & $6.896 \mathrm{E}+01$ \\
\hline Sn118 & $6.987 \mathrm{E}+01$ & $6.987 \mathrm{E}+01$ & $6.987 \mathrm{E}+01$ & $6.987 \mathrm{E}+01$ \\
\hline Sn119 + Sn119m decay & $6.961 \mathrm{E}+01$ & $6.961 \mathrm{E}+01$ & $6.961 E+01$ & $6.961 \mathrm{E}+01$ \\
\hline Sn119m & 1.115E-05 & 3.969E-06 & $2.629 E-48$ & $8.617 \mathrm{E}-228$ \\
\hline Sn120 & $7.084 \mathrm{E}+01$ & $7.084 \mathrm{E}+01$ & $7.084 \mathrm{E}+01$ & $7.084 \mathrm{E}+01$ \\
\hline Sn121 (100\% to Sb121) & $1.221 \mathrm{E}-06$ & $1.204 \mathrm{E}-06$ & 3.270E-07 & 1.274E-09 \\
\hline $\begin{array}{l}\text { Sn121m }(77.6 \% \text { to } \\
\text { Sn121, 22.4\% to Sb121) }\end{array}$ & $2.572 \mathrm{E}-02$ & 2.537E-02 & 6.887E-03 & 2.683E-05 \\
\hline Sn122 & $7.780 \mathrm{E}+01$ & $7.780 \mathrm{E}+01$ & $7.780 \mathrm{E}+01$ & $7.780 \mathrm{E}+01$ \\
\hline Sn123 (100\% to Sb123) & 7.556E-09 & 1.064E-09 & 1.025E-89 & $0.000 \mathrm{E}+00$ \\
\hline Sn124 & $1.049 \mathrm{E}+02$ & $1.049 \mathrm{E}+02$ & $1.049 \mathrm{E}+02$ & $1.049 \mathrm{E}+02$ \\
\hline $\begin{array}{l}\text { Sn126 }(100 \% \text { to } \\
\text { Sb126m) }\end{array}$ & $2.308 \mathrm{E}+02$ & $2.308 \mathrm{E}+02$ & $2.307 \mathrm{E}+02$ & $2.300 \mathrm{E}+02$ \\
\hline Sb121 & $1.846 \mathrm{E}-03$ & 2.200E-03 & 2.068E-02 & 2.754E-02 \\
\hline Sb123 & 1.363E-04 & 1.363E-04 & 1.363E-04 & 1.363E-04 \\
\hline Sb126 (100\% to Te126) & 1.096E-05 & 1.096E-05 & 1.096E-05 & 1.093E-05 \\
\hline $\begin{array}{l}\text { Sb126m (14\% to Sb126, } \\
86 \% \text { to Te126) }\end{array}$ & 8.337E-08 & 8.337E-08 & 8.331E-08 & 8.308E-08 \\
\hline Te122 + Sb122 decay & $6.777 \mathrm{E}+00$ & $6.777 \mathrm{E}+00$ & $6.777 \mathrm{E}+00$ & $6.777 \mathrm{E}+00$ \\
\hline Te123 + Te123m decay & $1.151 \mathrm{E}-01$ & 1.151E-01 & 1.151E-01 & 1.151E-01 \\
\hline Te123m & $1.354 \mathrm{E}-11$ & $1.632 \mathrm{E}-12$ & 7.004E-99 & $0.000 \mathrm{E}+00$ \\
\hline $\begin{array}{l}\text { Te124 + Sb124/Sb124m } \\
\text { decay }\end{array}$ & $5.271 \mathrm{E}+00$ & $5.271 \mathrm{E}+00$ & $5.271 \mathrm{E}+00$ & $5.271 \mathrm{E}+00$ \\
\hline $\begin{array}{l}\text { Te125 + Sb125/Te125m } \\
\text { decay }\end{array}$ & $1.280 \mathrm{E}+02$ & $1.280 \mathrm{E}+02$ & $1.280 \mathrm{E}+02$ & $1.280 \mathrm{E}+02$ \\
\hline $\begin{array}{l}\text { Te125M (100\% to } \\
\text { Te125) }\end{array}$ & 1.376E-10 & $1.751 \mathrm{E}-12$ & 1.179E-190 & $0.000 \mathrm{E}+00$ \\
\hline $\begin{array}{l}\text { Te126 + } \\
\text { Sn126/Sb126m/Sb126 } \\
\text { decay }\end{array}$ & $7.098 \mathrm{E}+00$ & $7.099 \mathrm{E}+00$ & $7.250 \mathrm{E}+00$ & $7.888 \mathrm{E}+00$ \\
\hline Te127 (100\% to I127) & $2.502 \mathrm{E}-12$ & $2.452 \mathrm{E}-13$ & 3.723E-108 & $0.000 \mathrm{E}+00$ \\
\hline Te127m (97.6\% to & 7.146E-10 & 7.004E-11 & 1.063E-105 & $0.000 \mathrm{E}+00$ \\
\hline
\end{tabular}


Table B-1 (continued)

\begin{tabular}{|c|c|c|c|c|}
\hline Isotope & 5 Years & 30 Years & 100 Years & 500 Years \\
\hline Te127, $2.4 \%$ to I127) & & & & \\
\hline Te128 & $9.270 \mathrm{E}+02$ & $9.270 \mathrm{E}+02$ & $9.270 \mathrm{E}+02$ & $9.270 \mathrm{E}+02$ \\
\hline Te129 (100\% to I129) & $1.462 \mathrm{E}-35$ & 7.803E-39 & $0.000 E+00$ & $0.000 E+00$ \\
\hline $\begin{array}{l}\text { Te129m (65\% to Te129, } \\
35 \% \text { to I129) }\end{array}$ & $1.562 \mathrm{E}-32$ & 8.333E-36 & $0.000 \mathrm{E}+00$ & $0.000 \mathrm{E}+00$ \\
\hline Te130 & $2.972 E+03$ & $2.972 \mathrm{E}+03$ & $2.972 \mathrm{E}+03$ & $2.972 \mathrm{E}+03$ \\
\hline $\begin{array}{l}\text { I127+ } \\
\text { Sb127/Te127m/Te127 } \\
\text { decay }\end{array}$ & 7.927E-05 & 7.927E-05 & 7.927E-05 & 7.927E-05 \\
\hline 1129 & 3.615E-16 & 3.615E-16 & 3.615E-16 & 3.615E-16 \\
\hline Xe127 & 1.404E-51 & 1.343E-54 & $0.000 \mathrm{E}+00$ & $0.000 \mathrm{E}+00$ \\
\hline Xe128 & 4.227E-15 & 4.227E-15 & 4.227E-15 & 4.227E-15 \\
\hline Xe129 & $3.131 \mathrm{E}-17$ & $3.131 \mathrm{E}-17$ & $3.131 \mathrm{E}-17$ & $3.131 \mathrm{E}-17$ \\
\hline Xe130 & 1.384E-14 & $1.384 \mathrm{E}-14$ & 1.384E-14 & $1.384 \mathrm{E}-14$ \\
\hline Xe131 + I131 decay & 3.380E-13 & 3.380E-13 & 3.380E-13 & 3.380E-13 \\
\hline Xe132 & 1.050E-12 & $1.050 \mathrm{E}-12$ & $1.050 \mathrm{E}-12$ & $1.050 \mathrm{E}-12$ \\
\hline Xe134 & 1.350E-12 & $1.350 \mathrm{E}-12$ & $1.350 \mathrm{E}-12$ & $1.350 \mathrm{E}-12$ \\
\hline Xe136 & $2.037 \mathrm{E}-12$ & $2.037 \mathrm{E}-12$ & $2.037 \mathrm{E}-12$ & $2.037 \mathrm{E}-12$ \\
\hline $\begin{array}{l}\text { Cs133 + Xe133/Xe133m } \\
\text { decay }\end{array}$ & $8.775 E+03$ & $8.775 E+03$ & $8.775 E+03$ & $8.775 E+03$ \\
\hline Cs134 & $4.303 E+01$ & $3.075 \mathrm{E}+01$ & $5.854 \mathrm{E}-13$ & $2.415 \mathrm{E}-71$ \\
\hline Cs135 & $3.560 \mathrm{E}+03$ & $3.560 \mathrm{E}+03$ & $3.560 \mathrm{E}+03$ & $3.559 \mathrm{E}+03$ \\
\hline $\begin{array}{l}\text { Cs137 (94.4\% to } \\
\text { Ba137m, 5.6\% to Ba137) }\end{array}$ & $7.775 E+03$ & 7.597E+03 & $8.657 \mathrm{E}+02$ & 8.382E-02 \\
\hline Ba132 & $1.701 \mathrm{E}-02$ & $1.701 \mathrm{E}-02$ & $1.701 \mathrm{E}-02$ & $1.701 \mathrm{E}-02$ \\
\hline Ba134 & $1.824 \mathrm{E}+03$ & $1.836 \mathrm{E}+03$ & $1.867 \mathrm{E}+03$ & $1.867 \mathrm{E}+03$ \\
\hline Ba135 & $6.124 \mathrm{E}+00$ & $6.125 \mathrm{E}+00$ & $6.226 \mathrm{E}+00$ & $6.655 E+00$ \\
\hline Ba136 + Cs136 decay & $2.387 \mathrm{E}+02$ & $2.387 \mathrm{E}+02$ & 2.387E+02 & $2.387 \mathrm{E}+02$ \\
\hline Ba137 & $2.497 \mathrm{E}+03$ & $2.675 \mathrm{E}+03$ & $9.406 \mathrm{E}+03$ & $1.027 \mathrm{E}+04$ \\
\hline $\begin{array}{l}\text { Ba137m (100\% to } \\
\text { Ba137) }\end{array}$ & 1.187E-03 & 1.160E-03 & $1.322 \mathrm{E}-04$ & $1.280 \mathrm{E}-08$ \\
\hline Ba138 & $1.059 \mathrm{E}+04$ & $1.059 \mathrm{E}+04$ & $1.059 \mathrm{E}+04$ & $1.059 \mathrm{E}+04$ \\
\hline La138 & 4.187E-02 & 4.187E-02 & 4.187E-02 & 4.187E-02 \\
\hline La139 & $1.007 \mathrm{E}+04$ & $1.007 \mathrm{E}+04$ & $1.007 \mathrm{E}+04$ & $1.007 \mathrm{E}+04$ \\
\hline Ce140 & $1.044 \mathrm{E}+04$ & $1.044 \mathrm{E}+04$ & $1.044 \mathrm{E}+04$ & $1.044 \mathrm{E}+04$ \\
\hline Ce141 & $0.000 \mathrm{E}+00$ & $0.000 \mathrm{E}+00$ & $0.000 \mathrm{E}+00$ & $0.000 \mathrm{E}+00$ \\
\hline Ce142 & $9.318 E+03$ & $9.318 \mathrm{E}+03$ & $9.318 \mathrm{E}+03$ & $9.318 \mathrm{E}+03$ \\
\hline Ce143 & $0.000 \mathrm{E}+00$ & $0.000 \mathrm{E}+00$ & $0.000 \mathrm{E}+00$ & $0.000 \mathrm{E}+00$ \\
\hline $\begin{array}{l}\text { Ce144 (1.2\% to Pr144m, } \\
98.8 \% \text { to } \operatorname{Pr} 144)\end{array}$ & 2.774E-01 & $1.139 \mathrm{E}-01$ & $5.019 E-38$ & 9.893E-193 \\
\hline Pr141 + Ce144 decay & $9.200 \mathrm{E}+03$ & $9.200 \mathrm{E}+03$ & $9.200 \mathrm{E}+03$ & $9.200 \mathrm{E}+03$ \\
\hline
\end{tabular}


Table B-1 (continued)

\begin{tabular}{|c|c|c|c|c|}
\hline Isotope & 5 Years & 30 Years & 100 Years & 500 Years \\
\hline Pr144 (100\% to Nd144) & 1.171E-05 & 4.808E-06 & $2.119 \mathrm{E}-42$ & 4.177E-197 \\
\hline $\begin{array}{l}\text { Pr144m }(99.93 \% \text { to } \\
\text { Pr144, } 0.07 \% \text { to Nd144) }\end{array}$ & 5.854E-08 & $2.402 E-08$ & $1.059 \mathrm{E}-44$ & 2.087E-199 \\
\hline $\begin{array}{l}\text { Nd142 + Sm146/Pm146 } \\
\text { decay }\end{array}$ & $2.827 \mathrm{E}+02$ & $2.827 \mathrm{E}+02$ & $2.827 \mathrm{E}+02$ & $2.827 \mathrm{E}+02$ \\
\hline Nd143 & $6.065 E+03$ & $6.065 \mathrm{E}+03$ & $6.065 E+03$ & $6.065 \mathrm{E}+03$ \\
\hline $\mathrm{Nd} 144$ & $1.126 \mathrm{E}+04$ & $1.126 \mathrm{E}+04$ & $1.126 \mathrm{E}+04$ & $1.126 \mathrm{E}+04$ \\
\hline $\mathrm{Nd} 145$ & $5.320 E+03$ & $5.320 \mathrm{E}+03$ & $5.320 E+03$ & $5.320 \mathrm{E}+03$ \\
\hline Nd146 + Pm146 decay & $5.946 \mathrm{E}+03$ & $5.946 \mathrm{E}+03$ & $5.946 \mathrm{E}+03$ & $5.946 \mathrm{E}+03$ \\
\hline $\mathrm{Nd} 148$ & $3.063 E+03$ & $3.063 \mathrm{E}+03$ & $3.063 E+03$ & $3.063 E+03$ \\
\hline Nd150 & $1.486 \mathrm{E}+03$ & $1.486 \mathrm{E}+03$ & $1.486 \mathrm{E}+03$ & $1.486 \mathrm{E}+03$ \\
\hline Pm146 & $1.382 \mathrm{E}-02$ & $1.219 \mathrm{E}-02$ & 8.717E-08 & $1.109 \mathrm{E}-29$ \\
\hline Pm147 & $5.909 E+01$ & 4.537E+01 & 7.433E-10 & $9.438 \mathrm{E}-56$ \\
\hline Pm148 & $1.404 \mathrm{E}-28$ & 3.050E-31 & 1.473E-281 & $0.000 \mathrm{E}+00$ \\
\hline Pm148m & $1.916 \mathrm{E}-26$ & 4.163E-29 & 2.010E-279 & $0.000 \mathrm{E}+00$ \\
\hline Sm146 & 7.226E-02 & 7.287E-02 & 7.738E-02 & 7.738E-02 \\
\hline Sm147 & $1.285 \mathrm{E}+03$ & $1.299 \mathrm{E}+03$ & $1.344 \mathrm{E}+03$ & $1.344 \mathrm{E}+03$ \\
\hline $\begin{array}{l}\text { Sm148 + Pm148/148m } \\
\text { decay }\end{array}$ & $1.692 \mathrm{E}+03$ & $1.692 \mathrm{E}+03$ & $1.692 \mathrm{E}+03$ & $1.692 \mathrm{E}+03$ \\
\hline Sm149 & $2.403 E+01$ & $2.403 \mathrm{E}+01$ & $2.403 \mathrm{E}+01$ & $2.403 \mathrm{E}+01$ \\
\hline Sm150 & $2.603 E+03$ & $2.603 \mathrm{E}+03$ & $2.603 \mathrm{E}+03$ & $2.603 E+03$ \\
\hline Sm151 & $1.146 \mathrm{E}+02$ & $1.137 \mathrm{E}+02$ & $5.512 \mathrm{E}+01$ & $2.530 \mathrm{E}+00$ \\
\hline Sm152 & $9.659 \mathrm{E}+02$ & $9.659 \mathrm{E}+02$ & $9.660 \mathrm{E}+02$ & $9.660 \mathrm{E}+02$ \\
\hline Sm154 & $3.217 \mathrm{E}+02$ & $3.217 \mathrm{E}+02$ & $3.217 \mathrm{E}+02$ & $3.217 \mathrm{E}+02$ \\
\hline Eu150 & 2.214E-06 & $2.172 \mathrm{E}-06$ & 3.556E-07 & $1.608 \mathrm{E}-10$ \\
\hline Eu150m & $0.000 \mathrm{E}+00$ & $0.000 \mathrm{E}+00$ & $0.000 \mathrm{E}+00$ & $0.000 \mathrm{E}+00$ \\
\hline Eu151 & $9.279 \mathrm{E}+00$ & $1.016 \mathrm{E}+01$ & $6.874 \mathrm{E}+01$ & $1.213 E+02$ \\
\hline $\begin{array}{l}\text { Eu152 ( } 72.1 \% \text { to } S m 152, \\
27.9 \% \text { to } \mathrm{Gd} 152)\end{array}$ & $2.232 \mathrm{E}-01$ & 2.121E-01 & $1.762 \mathrm{E}-03$ & $2.468 \mathrm{E}-12$ \\
\hline Eu153 & $1.061 \mathrm{E}+03$ & $1.061 \mathrm{E}+03$ & $1.061 \mathrm{E}+03$ & $1.061 \mathrm{E}+03$ \\
\hline Eu154 & $1.590 \mathrm{E}+02$ & 1.467E+02 & 7.519E-02 & 7.496E-16 \\
\hline Eu155 & $3.434 \mathrm{E}+01$ & $2.986 \mathrm{E}+01$ & 5.877E-05 & 3.082E-29 \\
\hline Gd152 & 4.793E-01 & 4.824E-01 & 5.411E-01 & 5.416E-01 \\
\hline Gd153 & $1.089 \mathrm{E}-06$ & 3.824E-07 & 7.507E-50 & 1.391E-231 \\
\hline Gd154 & $2.326 \mathrm{E}+02$ & $2.450 \mathrm{E}+02$ & $3.916 \mathrm{E}+02$ & 3.917E+02 \\
\hline Gd155 & $1.058 \mathrm{E}+02$ & $1.103 \mathrm{E}+02$ & $1.401 \mathrm{E}+02$ & $1.401 \mathrm{E}+02$ \\
\hline Gd156 & $6.798 \mathrm{E}+02$ & $6.798 \mathrm{E}+02$ & $6.798 \mathrm{E}+02$ & $6.798 \mathrm{E}+02$ \\
\hline Gd157 & $1.033 \mathrm{E}+00$ & $1.033 \mathrm{E}+00$ & $1.033 \mathrm{E}+00$ & $1.033 \mathrm{E}+00$ \\
\hline Gd158 & $1.774 \mathrm{E}+02$ & $1.774 \mathrm{E}+02$ & $1.774 \mathrm{E}+02$ & $1.774 \mathrm{E}+02$ \\
\hline Gd160 & $1.129 \mathrm{E}+01$ & $1.129 \mathrm{E}+01$ & $1.129 \mathrm{E}+01$ & $1.129 \mathrm{E}+01$ \\
\hline
\end{tabular}


Table B-1 (continued)

\begin{tabular}{|c|c|c|c|c|}
\hline Isotope & 5 Years & 30 Years & 100 Years & 500 Years \\
\hline TI207 & $6.855 \mathrm{E}-18$ & 8.282E-18 & $1.782 \mathrm{E}-16$ & 9.914E-16 \\
\hline Tl208 & 2.065E-11 & $1.438 \mathrm{E}-11$ & $2.310 \mathrm{E}-14$ & 2.053E-14 \\
\hline TI209 & $1.639 \mathrm{E}-16$ & $1.642 \mathrm{E}-16$ & 4.193E-16 & $7.235 \mathrm{E}-15$ \\
\hline $\mathrm{Pb} 206$ & 5.992E-11 & $1.028 \mathrm{E}-10$ & 2.636E-07 & 1.008E-05 \\
\hline $\mathrm{Pb} 207$ & 2.907E-12 & 3.548E-12 & 6.493E-10 & $1.845 \mathrm{E}-08$ \\
\hline Pb208 & 9.634E-05 & $1.021 \mathrm{E}-04$ & 1.159E-04 & 1.187E-04 \\
\hline $\mathrm{Pb} 209$ & 7.058E-13 & 7.069E-13 & $1.805 \mathrm{E}-12$ & 3.115E-11 \\
\hline $\mathrm{Pb} 210$ & 1.164E-09 & 1.659E-09 & 2.152E-07 & 1.396E-06 \\
\hline $\mathrm{Pb} 211$ & 5.304E-17 & 6.407E-17 & $1.379 \mathrm{E}-15$ & 7.670E-15 \\
\hline $\mathrm{Pb} 212$ & 1.218E-08 & 8.486E-09 & 1.363E-11 & $1.211 \mathrm{E}-11$ \\
\hline $\mathrm{Pb} 214$ & 3.669E-14 & 4.402E-14 & 7.205E-13 & $3.451 \mathrm{E}-12$ \\
\hline Bi209 & 6.483E-09 & 7.784E-09 & 1.964E-07 & 9.746E-06 \\
\hline $\mathrm{Bi} 210$ & $7.166 \mathrm{E}-13$ & $1.021 \mathrm{E}-12$ & $1.325 \mathrm{E}-10$ & 8.594E-10 \\
\hline $\mathrm{Bi} 211$ & 3.129E-18 & 3.780E-18 & 8.136E-17 & $4.525 \mathrm{E}-16$ \\
\hline $\mathrm{Bi} 212$ & 1.155E-09 & 8.046E-10 & $1.292 \mathrm{E}-12$ & $1.148 \mathrm{E}-12$ \\
\hline $\mathrm{Bi} 213$ & $1.658 \mathrm{E}-13$ & $1.661 \mathrm{E}-13$ & $4.242 \mathrm{E}-13$ & 7.319E-12 \\
\hline $\mathrm{Bi} 214$ & $2.725 \mathrm{E}-14$ & 3.269E-14 & $5.351 \mathrm{E}-13$ & $2.563 \mathrm{E}-12$ \\
\hline Po210 & 2.011E-11 & 2.866E-11 & 3.718E-09 & 2.412E-08 \\
\hline Po211 & 3.856E-23 & 4.659E-23 & 1.003E-21 & $5.576 \mathrm{E}-21$ \\
\hline Po213 & $2.491 \mathrm{E}-22$ & $2.495 \mathrm{E}-22$ & $6.371 \mathrm{E}-22$ & $1.099 \mathrm{E}-20$ \\
\hline Po214 & 3.749E-21 & 4.498E-21 & 7.362E-20 & 3.527E-19 \\
\hline Po215 & $4.441 \mathrm{E}-23$ & 5.365E-23 & 1.155E-21 & $6.422 \mathrm{E}-21$ \\
\hline Po216 & 4.860E-14 & 3.385E-14 & $5.435 \mathrm{E}-17$ & $4.831 \mathrm{E}-17$ \\
\hline Po218 & $4.254 \mathrm{E}-15$ & 5.104E-15 & 8.353E-14 & $4.001 \mathrm{E}-13$ \\
\hline Rn219 & 1.007E-19 & $1.216 \mathrm{E}-19$ & 2.617E-18 & $1.456 \mathrm{E}-17$ \\
\hline $\mathrm{Rn} 220$ & $1.834 \mathrm{E}-11$ & 1.277E-11 & 2.051E-14 & 1.823E-14 \\
\hline $\mathrm{Rn} 222$ & 7.822E-12 & 9.384E-12 & $1.536 \mathrm{E}-10$ & 7.357E-10 \\
\hline Fr221 & $1.809 \mathrm{E}-14$ & $1.812 \mathrm{E}-14$ & 4.628E-14 & 7.986E-13 \\
\hline Fr223 & 4.671E-19 & 5.643E-19 & $1.215 \mathrm{E}-17$ & $6.755 \mathrm{E}-17$ \\
\hline Ra223 & $2.560 \mathrm{E}-14$ & 3.093E-14 & 6.657E-13 & 3.702E-12 \\
\hline Ra224 & 1.068E-07 & 7.438E-08 & $1.194 \mathrm{E}-10$ & $1.062 \mathrm{E}-10$ \\
\hline Ra225 & 8.182E-11 & 8.195E-11 & $2.093 \mathrm{E}-10$ & 3.611E-09 \\
\hline $\mathrm{Ra} 226$ & 1.217E-06 & 1.460E-06 & 2.389E-05 & 1.144E-04 \\
\hline $\mathrm{Ra} 228$ & $1.274 \mathrm{E}-12$ & $1.459 \mathrm{E}-12$ & 3.164E-12 & 3.255E-12 \\
\hline Ac225 & 5.526E-11 & 5.535E-11 & $1.414 \mathrm{E}-10$ & 2.439E-09 \\
\hline Ac227 & 1.810E-11 & $2.186 \mathrm{E}-11$ & 4.705E-10 & 2.617E-09 \\
\hline Ac228 & 1.330E-16 & $1.523 \mathrm{E}-16$ & 3.303E-16 & 3.397E-16 \\
\hline Th227 & 4.210E-14 & 5.086E-14 & $1.095 \mathrm{E}-12$ & $6.088 \mathrm{E}-12$ \\
\hline Th228 & 2.065E-05 & 1.438E-05 & 2.309E-08 & 2.053E-08 \\
\hline
\end{tabular}


Table B-1 (continued)

\begin{tabular}{|c|c|c|c|c|}
\hline Isotope & 5 Years & 30 Years & 100 Years & 500 Years \\
\hline Th229 & 1.508E-05 & 1.510E-05 & 3.856E-05 & $6.655 E-04$ \\
\hline Th230 & $2.755 \mathrm{E}-02$ & $2.755 \mathrm{E}-02$ & $2.771 \mathrm{E}-02$ & 3.083E-02 \\
\hline Th231 & 3.358E-11 & 3.358E-11 & 3.388E-11 & 3.629E-11 \\
\hline $\begin{array}{l}\text { Th232 + } \\
\text { U236/Pu240/Pu244 } \\
\text { decay }\end{array}$ & 6.735E-03 & $6.735 \mathrm{E}-03$ & $6.755 \mathrm{E}-03$ & 6.953E-03 \\
\hline Th234 & 1.443E-08 & 1.443E-08 & 1.443E-08 & 1.443E-08 \\
\hline Pa231 & 2.078E-07 & 2.157E-07 & 9.693E-07 & 4.275E-06 \\
\hline $\mathrm{Pa} 232$ & $6.952 \mathrm{E}-13$ & $6.952 \mathrm{E}-13$ & $6.948 \mathrm{E}-13$ & $6.931 \mathrm{E}-13$ \\
\hline $\mathrm{Pa} 233$ & 1.144E-04 & $1.146 \mathrm{E}-04$ & $1.255 \mathrm{E}-04$ & $1.574 \mathrm{E}-04$ \\
\hline $\mathrm{Pa} 234$ & 2.173E-13 & $2.173 \mathrm{E}-13$ & $2.173 \mathrm{E}-13$ & $2.173 \mathrm{E}-13$ \\
\hline $\mathrm{Pa} 234 \mathrm{~m}$ & 4.865E-13 & $4.865 \mathrm{E}-13$ & 4.865E-13 & $4.865 \mathrm{E}-13$ \\
\hline $\begin{array}{l}\text { U232 + Pu236/Np236 } \\
\text { decay }\end{array}$ & 1.034E-06 & $1.030 \mathrm{E}-06$ & 8.812E-07 & $7.858 \mathrm{E}-07$ \\
\hline U233 & 5.354E-03 & 6.427E-03 & 1.123E-01 & 6.486E-01 \\
\hline U234 & $2.400 \mathrm{E}-01$ & $2.485 \mathrm{E}-01$ & $1.198 \mathrm{E}+00$ & $4.044 \mathrm{E}+00$ \\
\hline U235 & $8.258 E+00$ & $8.259 \mathrm{E}+00$ & $8.332 E+00$ & $8.925 E+00$ \\
\hline U236 & $6.182 E+00$ & $6.191 \mathrm{E}+00$ & $9.164 \mathrm{E}+00$ & $2.476 \mathrm{E}+01$ \\
\hline U237 & $1.092 \mathrm{E}-07$ & $1.041 \mathrm{E}-07$ & 2.693E-09 & $1.531 \mathrm{E}-09$ \\
\hline U238 & $9.938 E+02$ & $9.938 \mathrm{E}+02$ & $9.938 E+02$ & $9.938 \mathrm{E}+02$ \\
\hline U240 & $1.777 \mathrm{E}-15$ & $1.777 \mathrm{E}-15$ & $1.792 \mathrm{E}-15$ & $1.856 \mathrm{E}-15$ \\
\hline Np236 & 1.417E-02 & 1.417E-02 & $1.416 \mathrm{E}-02$ & 1.413E-02 \\
\hline Np237 & $3.371 \mathrm{E}+03$ & $3.375 \mathrm{E}+03$ & 3.697E+03 & 4.637E+03 \\
\hline Np238 & $8.249 \mathrm{E}-07$ & $8.211 \mathrm{E}-07$ & 5.349E-07 & 8.631E-08 \\
\hline Np239 & 9.200E-04 & 9.199E-04 & 9.118E-04 & 8.782E-04 \\
\hline Np240m & $1.555 \mathrm{E}-17$ & $1.555 \mathrm{E}-17$ & $1.568 \mathrm{E}-17$ & $1.624 \mathrm{E}-17$ \\
\hline Pu236 & 2.224E-08 & 2.427E-08 & 3.160E-08 & 3.152E-08 \\
\hline Pu237 & $2.416 \mathrm{E}-31$ & 9.383E-34 & 2.295E-260 & $0.000 \mathrm{E}+00$ \\
\hline Pu238 & $1.093 E+00$ & $1.100 \mathrm{E}+00$ & $1.381 \mathrm{E}+00$ & 4.370E-01 \\
\hline Pu239 & $2.082 \mathrm{E}+01$ & $2.100 \mathrm{E}+01$ & $3.299 \mathrm{E}+01$ & $7.118 \mathrm{E}+01$ \\
\hline $\begin{array}{l}\text { Pu240 + Pu244/Cm244 } \\
\text { decay }\end{array}$ & $7.493 E+01$ & $8.658 \mathrm{E}+01$ & $3.742 \mathrm{E}+02$ & $3.665 E+02$ \\
\hline Pu241 & $3.528 \mathrm{E}+00$ & $3.365 \mathrm{E}+00$ & 8.705E-02 & 4.947E-02 \\
\hline $\begin{array}{l}\text { Pu242+Am242/242m } \\
\text { decay }\end{array}$ & 2.031E-02 & $2.432 \mathrm{E}-02$ & 3.401E-01 & $9.686 \mathrm{E}-01$ \\
\hline Pu243 & $1.918 \mathrm{E}-12$ & $1.918 \mathrm{E}-12$ & $1.918 \mathrm{E}-12$ & $1.918 \mathrm{E}-12$ \\
\hline Pu244 & 9.278E-05 & 9.279E-05 & $9.358 \mathrm{E}-05$ & 9.692E-05 \\
\hline Am241 & $2.348 \mathrm{E}+03$ & $2.344 \mathrm{E}+03$ & $2.019 \mathrm{E}+03$ & $1.064 \mathrm{E}+03$ \\
\hline Am242 & $5.265 \mathrm{E}-05$ & $5.241 \mathrm{E}-05$ & 3.414E-05 & $5.509 \mathrm{E}-06$ \\
\hline Am242M & $4.400 E+00$ & $4.380 \mathrm{E}+00$ & $2.853 E+00$ & 4.604E-01 \\
\hline
\end{tabular}


Table B-1 (continued)

\begin{tabular}{|l|l|l|l|l|}
\hline \multicolumn{1}{|c|}{ Isotope } & \multicolumn{1}{|c|}{$\mathbf{5}$ Years } & \multicolumn{1}{c|}{$\mathbf{3 0}$ Years } & \multicolumn{1}{c|}{$\mathbf{1 0 0}$ Years } & \multicolumn{1}{c|}{$\mathbf{5 0 0}$ Years } \\
\hline Am243 & $1.071 \mathrm{E}+03$ & $1.070 \mathrm{E}+03$ & $1.061 \mathrm{E}+03$ & $1.022 \mathrm{E}+03$ \\
\hline Cm241 & $2.325 \mathrm{E}-35$ & $2.055 \mathrm{E}-38$ & $0.000 \mathrm{E}+00$ & $0.000 \mathrm{E}+00$ \\
\hline $\begin{array}{l}\text { Cm242 + } \\
\text { Am242/Am242m decay }\end{array}$ & $1.067 \mathrm{E}-02$ & $1.063 \mathrm{E}-02$ & $6.923 \mathrm{E}-03$ & $1.117 \mathrm{E}-03$ \\
\hline Cm243 & $3.262 \mathrm{E}+00$ & $3.184 \mathrm{E}+00$ & $3.236 \mathrm{E}-01$ & $1.928 \mathrm{E}-05$ \\
\hline Cm244 & $3.157 \mathrm{E}+02$ & $3.038 \mathrm{E}+02$ & $8.316 \mathrm{E}+00$ & $1.863 \mathrm{E}-06$ \\
\hline Cm245 & $3.085 \mathrm{E}+01$ & $3.085 \mathrm{E}+01$ & $3.061 \mathrm{E}+01$ & $2.963 \mathrm{E}+01$ \\
\hline Cm246 & $3.931 \mathrm{E}+00$ & $3.930 \mathrm{E}+00$ & $3.876 \mathrm{E}+00$ & $3.656 \mathrm{E}+00$ \\
\hline Cm247 & $5.381 \mathrm{E}-02$ & $5.381 \mathrm{E}-02$ & $5.380 \mathrm{E}-02$ & $5.380 \mathrm{E}-02$ \\
\hline Cm248 & $4.152 \mathrm{E}-03$ & $4.152 \mathrm{E}-03$ & $4.152 \mathrm{E}-03$ & $4.148 \mathrm{E}-03$ \\
\hline & & & & $\mathbf{2 . 7 0 4 E + 0 5}$ \\
\hline Total & $\mathbf{2 . 7 0 4 E + 0 5}$ & $\mathbf{2 . 7 0 4 E + 0 5}$ & & $\mathbf{2 . 7 0 4 E + 0 5}$ \\
\hline
\end{tabular}


THIS PAGE INTENTIONALLY LEFT BLANK 
Appendix C

Isotopic Compositions of 50 GW-d/MT MOX Fuel 
Table C-1 50 GW-d/MT LWR Mixed Oxide Fuel Radionuclide Inventory.

\begin{tabular}{|c|c|c|c|c|}
\hline Burnup & \multicolumn{4}{|c|}{ 50,000 MW-d/MTIHM } \\
\hline Enrichment (\%) & \multicolumn{4}{|c|}{ 6.83 Fissile $\mathrm{Pu}$} \\
\hline Cooling Time (yr) & 5 & 30 & 100 & 500 \\
\hline ISOTOPE & GM/MTIHM & GM/MTIHM & GM/MTIHM & GM/MTIHM \\
\hline H 3 & $7.68 \mathrm{E}-02$ & $1.89 \mathrm{E}-02$ & $3.71 \mathrm{E}-04$ & $6.58 \mathrm{E}-14$ \\
\hline HE 4 & $3.21 \mathrm{E}+01$ & $5.82 \mathrm{E}+01$ & $1.11 \mathrm{E}+02$ & $2.65 E+02$ \\
\hline LI 6 & 3.54E-04 & $3.54 \mathrm{E}-04$ & $3.54 \mathrm{E}-04$ & 3.54E-04 \\
\hline LI 7 & $1.51 \mathrm{E}-05$ & 1.51E-05 & $1.51 \mathrm{E}-05$ & $1.51 \mathrm{E}-05$ \\
\hline BE 9 & $2.90 \mathrm{E}-05$ & $2.90 \mathrm{E}-05$ & $2.90 \mathrm{E}-05$ & $2.90 \mathrm{E}-05$ \\
\hline BE 10 & $1.94 \mathrm{E}-04$ & $1.94 \mathrm{E}-04$ & $1.94 \mathrm{E}-04$ & $1.94 \mathrm{E}-04$ \\
\hline C 14 & $3.91 \mathrm{E}-05$ & $3.90 \mathrm{E}-05$ & $3.87 \mathrm{E}-05$ & $3.69 \mathrm{E}-05$ \\
\hline ZN 66 & $3.03 E-08$ & $3.03 E-08$ & $3.03 E-08$ & $3.03 E-08$ \\
\hline ZN 67 & $9.22 \mathrm{E}-10$ & $9.22 \mathrm{E}-10$ & $9.22 \mathrm{E}-10$ & $9.22 \mathrm{E}-10$ \\
\hline ZN 68 & $1.20 \mathrm{E}-11$ & 1.20E-11 & 1.20E-11 & $1.20 \mathrm{E}-11$ \\
\hline ZN 70 & $0.00 \mathrm{E}+00$ & $0.00 \mathrm{E}+00$ & $0.00 \mathrm{E}+00$ & $0.00 \mathrm{E}+00$ \\
\hline SE 76 & 1.12E-02 & $1.12 \mathrm{E}-02$ & $1.12 \mathrm{E}-02$ & $1.12 \mathrm{E}-02$ \\
\hline SE 77 & $1.24 \mathrm{E}+00$ & $1.24 \mathrm{E}+00$ & $1.24 \mathrm{E}+00$ & $1.24 \mathrm{E}+00$ \\
\hline SE 78 & $3.35 E+00$ & $3.35 E+00$ & $3.35 E+00$ & $3.35 \mathrm{E}+00$ \\
\hline SE 79 & $7.44 \mathrm{E}+00$ & $7.44 \mathrm{E}+00$ & $7.43 \mathrm{E}+00$ & $7.40 \mathrm{E}+00$ \\
\hline SE 80 & $1.61 \mathrm{E}+01$ & $1.61 \mathrm{E}+01$ & $1.61 \mathrm{E}+01$ & $1.61 \mathrm{E}+01$ \\
\hline SE 82 & $3.48 \mathrm{E}+01$ & $3.48 \mathrm{E}+01$ & $3.48 \mathrm{E}+01$ & $3.48 \mathrm{E}+01$ \\
\hline KR 80 & 5.73E-04 & $5.73 \mathrm{E}-04$ & $5.73 \mathrm{E}-04$ & 5.73E-04 \\
\hline KR 81 & $7.18 \mathrm{E}-05$ & $7.18 \mathrm{E}-05$ & $7.18 \mathrm{E}-05$ & 7.17E-05 \\
\hline KR 82 & $1.57 \mathrm{E}+00$ & $1.57 \mathrm{E}+00$ & $1.57 \mathrm{E}+00$ & $1.57 \mathrm{E}+00$ \\
\hline KR 83 & 4.46E+01 & 4.46E+01 & 4.46E+01 & $4.46 \mathrm{E}+01$ \\
\hline KR 84 & $1.04 \mathrm{E}+02$ & $1.04 \mathrm{E}+02$ & $1.04 \mathrm{E}+02$ & $1.04 \mathrm{E}+02$ \\
\hline KR 85 & $1.48 \mathrm{E}+01$ & $2.94 \mathrm{E}+00$ & $3.18 \mathrm{E}-02$ & $1.86 \mathrm{E}-13$ \\
\hline KR 86 & $1.57 \mathrm{E}+02$ & $1.57 \mathrm{E}+02$ & $1.57 \mathrm{E}+02$ & $1.57 \mathrm{E}+02$ \\
\hline RB 85 & $9.09 \mathrm{E}+01$ & $1.03 E+02$ & $1.06 \mathrm{E}+02$ & $1.06 \mathrm{E}+02$ \\
\hline RB 87 & $1.96 \mathrm{E}+02$ & $1.96 \mathrm{E}+02$ & $1.96 \mathrm{E}+02$ & $1.96 \mathrm{E}+02$ \\
\hline SR 86 & $5.10 \mathrm{E}-01$ & $5.10 \mathrm{E}-01$ & $5.10 \mathrm{E}-01$ & $5.10 \mathrm{E}-01$ \\
\hline SR 87 & $5.98 \mathrm{E}-03$ & $5.98 \mathrm{E}-03$ & $5.98 \mathrm{E}-03$ & $5.98 \mathrm{E}-03$ \\
\hline SR 88 & $2.74 \mathrm{E}+02$ & $2.74 \mathrm{E}+02$ & $2.74 \mathrm{E}+02$ & $2.74 \mathrm{E}+02$ \\
\hline SR 89 & 2.16E-10 & $0.00 \mathrm{E}+00$ & $0.00 \mathrm{E}+00$ & $0.00 \mathrm{E}+00$ \\
\hline SR 90 & $3.61 \mathrm{E}+02$ & $1.99 \mathrm{E}+02$ & $3.76 \mathrm{E}+01$ & $2.76 \mathrm{E}-03$ \\
\hline Y 89 & $3.47 \mathrm{E}+02$ & $3.47 \mathrm{E}+02$ & $3.47 E+02$ & $3.47 \mathrm{E}+02$ \\
\hline Y 90 & $9.05 \mathrm{E}-02$ & 4.99E-02 & $9.43 \mathrm{E}-03$ & $6.91 \mathrm{E}-07$ \\
\hline Y 91 & $1.13 \mathrm{E}-08$ & $0.00 \mathrm{E}+00$ & $0.00 \mathrm{E}+00$ & $0.00 \mathrm{E}+00$ \\
\hline ZR 90 & $6.63 \mathrm{E}+01$ & $2.28 \mathrm{E}+02$ & $3.90 \mathrm{E}+02$ & $4.27 \mathrm{E}+02$ \\
\hline ZR 91 & $5.01 \mathrm{E}+02$ & $5.01 \mathrm{E}+02$ & $5.01 \mathrm{E}+02$ & $5.01 \mathrm{E}+02$ \\
\hline ZR 92 & $6.08 \mathrm{E}+02$ & $6.08 \mathrm{E}+02$ & $6.08 \mathrm{E}+02$ & $6.08 \mathrm{E}+02$ \\
\hline
\end{tabular}


Table C-1 (continued)

\begin{tabular}{|c|c|c|c|c|}
\hline \multirow{3}{*}{$\begin{array}{c}\text { Burnup } \\
\text { Enrichment (\%) } \\
\text { Cooling Time (yr) }\end{array}$} & \multicolumn{4}{|c|}{ 50,000 MW-d/MTIHM } \\
\hline & \multicolumn{4}{|c|}{ 6.83 Fissile $\mathrm{Pu}$} \\
\hline & 5 & 30 & 100 & 500 \\
\hline ISOTOPE & GM/MTIHM & GM/MTIHM & GM/MTIHM & GM/MTIHM \\
\hline ZR 93 & $7.64 \mathrm{E}+02$ & $7.64 \mathrm{E}+02$ & 7.64E+02 & 7.64E+02 \\
\hline ZR 94 & 8.57E+02 & 8.57E+02 & 8.57E+02 & $8.57 \mathrm{E}+02$ \\
\hline ZR 95 & $1.53 \mathrm{E}-07$ & $0.00 \mathrm{E}+00$ & $0.00 \mathrm{E}+00$ & $0.00 \mathrm{E}+00$ \\
\hline ZR 96 & $1.03 E+03$ & 1.03E+03 & $1.03 E+03$ & $1.03 E+03$ \\
\hline NB 93 & 5.43E-04 & 5.96E-03 & $2.90 \mathrm{E}-02$ & 1.67E-01 \\
\hline NB 93M & $1.96 \mathrm{E}-03$ & $5.20 \mathrm{E}-03$ & $6.42 \mathrm{E}-03$ & $6.45 E-03$ \\
\hline NB 94 & 2.17E-03 & 2.17E-03 & 2.16E-03 & $2.14 \mathrm{E}-03$ \\
\hline NB 95 & $1.93 \mathrm{E}-07$ & $0.00 \mathrm{E}+00$ & $0.00 \mathrm{E}+00$ & $0.00 \mathrm{E}+00$ \\
\hline NB 95M & 6.38E-11 & $0.00 \mathrm{E}+00$ & $0.00 \mathrm{E}+00$ & $0.00 \mathrm{E}+00$ \\
\hline MO 95 & $9.17 \mathrm{E}+02$ & $9.17 \mathrm{E}+02$ & $9.17 \mathrm{E}+02$ & $9.17 \mathrm{E}+02$ \\
\hline MO 96 & $5.71 \mathrm{E}+01$ & $5.71 \mathrm{E}+01$ & $5.71 \mathrm{E}+01$ & $5.71 \mathrm{E}+01$ \\
\hline MO 97 & $1.10 \mathrm{E}+03$ & $1.10 \mathrm{E}+03$ & $1.10 \mathrm{E}+03$ & $1.10 \mathrm{E}+03$ \\
\hline MO 98 & $1.19 \mathrm{E}+03$ & $1.19 \mathrm{E}+03$ & $1.19 \mathrm{E}+03$ & $1.19 \mathrm{E}+03$ \\
\hline MO100 & $1.42 \mathrm{E}+03$ & $1.42 \mathrm{E}+03$ & $1.42 \mathrm{E}+03$ & $1.42 \mathrm{E}+03$ \\
\hline TC 98 & 1.47E-02 & 1.47E-02 & 1.47E-02 & 1.47E-02 \\
\hline TC 99 & $1.11 \mathrm{E}+03$ & $1.11 \mathrm{E}+03$ & $1.11 \mathrm{E}+03$ & $1.11 \mathrm{E}+03$ \\
\hline RU 99 & 2.54E-02 & 1.16E-01 & 3.69E-01 & $1.81 \mathrm{E}+00$ \\
\hline RU100 & $2.01 \mathrm{E}+02$ & $2.01 \mathrm{E}+02$ & $2.01 \mathrm{E}+02$ & $2.01 \mathrm{E}+02$ \\
\hline RU101 & $1.24 \mathrm{E}+03$ & $1.24 \mathrm{E}+03$ & $1.24 \mathrm{E}+03$ & $1.24 \mathrm{E}+03$ \\
\hline RU102 & $1.41 \mathrm{E}+03$ & $1.41 \mathrm{E}+03$ & $1.41 \mathrm{E}+03$ & $1.41 \mathrm{E}+03$ \\
\hline RU103 & 5.52E-13 & $0.00 \mathrm{E}+00$ & $0.00 \mathrm{E}+00$ & $0.00 \mathrm{E}+00$ \\
\hline RU104 & $1.34 \mathrm{E}+03$ & $1.34 \mathrm{E}+03$ & $1.34 \mathrm{E}+03$ & $1.34 \mathrm{E}+03$ \\
\hline RU106 & $1.11 \mathrm{E}+01$ & 3.79E-07 & $0.00 \mathrm{E}+00$ & $0.00 \mathrm{E}+00$ \\
\hline $\mathrm{RH} 102$ & 1.01E-03 & 2.56E-06 & 1.39E-13 & $0.00 \mathrm{E}+00$ \\
\hline $\mathrm{RH} 103$ & $9.21 \mathrm{E}+02$ & $9.21 \mathrm{E}+02$ & $9.21 \mathrm{E}+02$ & $9.21 \mathrm{E}+02$ \\
\hline RH103M & 4.95E-16 & $0.00 \mathrm{E}+00$ & $0.00 \mathrm{E}+00$ & $0.00 \mathrm{E}+00$ \\
\hline $\mathrm{RH} 106$ & 1.04E-05 & $3.56 \mathrm{E}-13$ & $0.00 \mathrm{E}+00$ & $0.00 \mathrm{E}+00$ \\
\hline PD104 & $5.18 \mathrm{E}+02$ & $5.18 \mathrm{E}+02$ & $5.18 \mathrm{E}+02$ & $5.18 \mathrm{E}+02$ \\
\hline PD105 & $1.08 \mathrm{E}+03$ & $1.08 \mathrm{E}+03$ & $1.08 \mathrm{E}+03$ & $1.08 \mathrm{E}+03$ \\
\hline PD106 & $1.12 \mathrm{E}+03$ & $1.13 \mathrm{E}+03$ & $1.13 \mathrm{E}+03$ & $1.13 \mathrm{E}+03$ \\
\hline PD107 & $7.68 \mathrm{E}+02$ & $7.68 \mathrm{E}+02$ & $7.68 \mathrm{E}+02$ & $7.68 \mathrm{E}+02$ \\
\hline PD108 & $5.41 \mathrm{E}+02$ & $5.41 \mathrm{E}+02$ & $5.41 \mathrm{E}+02$ & $5.41 \mathrm{E}+02$ \\
\hline PD110 & 1.77E+02 & 1.77E+02 & 1.77E+02 & 1.77E+02 \\
\hline AG107 & 5.67E-04 & 2.62E-03 & 8.36E-03 & 4.11E-02 \\
\hline AG108 & $1.25 \mathrm{E}-14$ & 1.09E-14 & 7.44E-15 & 8.39E-16 \\
\hline AG108M & 3.96E-06 & 3.45E-06 & 2.36E-06 & 2.66E-07 \\
\hline
\end{tabular}


Table C-1 (continued)

\begin{tabular}{|c|c|c|c|c|}
\hline \multirow{3}{*}{$\begin{array}{c}\text { Burnup } \\
\text { Enrichment (\%) } \\
\text { Cooling Time (yr) }\end{array}$} & \multicolumn{4}{|c|}{ 50,000 MW-d/MTIHM } \\
\hline & \multicolumn{4}{|c|}{ 6.83 Fissile $\mathrm{Pu}$} \\
\hline & 5 & 30 & 100 & 500 \\
\hline ISOTOPE & GM/MTIHM & GM/MTIHM & GM/MTIHM & GM/MTIHM \\
\hline AG109 & $2.41 \mathrm{E}+02$ & $2.41 \mathrm{E}+02$ & $2.41 \mathrm{E}+02$ & $2.41 \mathrm{E}+02$ \\
\hline AG109M & $2.73 \mathrm{E}-13$ & $3.25 \mathrm{E}-19$ & $0.00 \mathrm{E}+00$ & $0.00 \mathrm{E}+00$ \\
\hline AG110 & 2.91E-10 & $2.91 \mathrm{E}-21$ & $0.00 \mathrm{E}+00$ & $0.00 \mathrm{E}+00$ \\
\hline AG110M & 1.92E-02 & $1.92 \mathrm{E}-13$ & $0.00 \mathrm{E}+00$ & $0.00 \mathrm{E}+00$ \\
\hline CD108 & 2.70E-03 & 2.70E-03 & 2.70E-03 & 2.70E-03 \\
\hline CD109 & 2.76E-07 & 3.29E-13 & $0.00 \mathrm{E}+00$ & $0.00 \mathrm{E}+00$ \\
\hline CD110 & 1.97E+02 & 1.97E+02 & 1.97E+02 & 1.97E+02 \\
\hline CD111 & $9.27 \mathrm{E}+01$ & $9.27 \mathrm{E}+01$ & $9.27 \mathrm{E}+01$ & $9.27 \mathrm{E}+01$ \\
\hline CD112 & 4.91E+01 & 4.91E+01 & 4.91E+01 & 4.91E+01 \\
\hline CD113 & $5.51 \mathrm{E}-01$ & $5.51 \mathrm{E}-01$ & 5.52E-01 & 5.52E-01 \\
\hline CD113M & 5.93E-01 & $1.81 \mathrm{E}-01$ & $6.50 \mathrm{E}-03$ & 3.63E-11 \\
\hline CD114 & $5.52 \mathrm{E}+01$ & $5.52 \mathrm{E}+01$ & $5.52 \mathrm{E}+01$ & $5.52 \mathrm{E}+01$ \\
\hline CD115M & 4.09E-14 & $0.00 \mathrm{E}+00$ & $0.00 \mathrm{E}+00$ & $0.00 \mathrm{E}+00$ \\
\hline CD116 & $1.62 \mathrm{E}+01$ & $1.62 \mathrm{E}+01$ & $1.62 \mathrm{E}+01$ & $1.62 \mathrm{E}+01$ \\
\hline IN113 & 2.16E-01 & $6.28 \mathrm{E}-01$ & 8.02E-01 & 8.08E-01 \\
\hline IN113M & $0.00 \mathrm{E}+00$ & $0.00 \mathrm{E}+00$ & $0.00 \mathrm{E}+00$ & $0.00 \mathrm{E}+00$ \\
\hline IN114 & 5.52E-20 & $0.00 \mathrm{E}+00$ & $0.00 \mathrm{E}+00$ & $0.00 \mathrm{E}+00$ \\
\hline IN114M & 3.43E-15 & $0.00 \mathrm{E}+00$ & $0.00 \mathrm{E}+00$ & $0.00 \mathrm{E}+00$ \\
\hline IN115 & 4.04E+00 & 4.04E+00 & 4.04E+00 & 4.04E+00 \\
\hline IN115M & 1.16E-20 & $0.00 \mathrm{E}+00$ & $0.00 \mathrm{E}+00$ & $0.00 \mathrm{E}+00$ \\
\hline SN114 & 7.43E-03 & 7.43E-03 & 7.43E-03 & 7.43E-03 \\
\hline SN115 & $6.90 \mathrm{E}-01$ & $6.90 \mathrm{E}-01$ & $6.90 \mathrm{E}-01$ & $6.90 \mathrm{E}-01$ \\
\hline SN116 & $1.66 \mathrm{E}+01$ & $1.66 \mathrm{E}+01$ & $1.66 \mathrm{E}+01$ & $1.66 \mathrm{E}+01$ \\
\hline SN117 & $1.58 \mathrm{E}+01$ & $1.58 \mathrm{E}+01$ & $1.58 \mathrm{E}+01$ & $1.58 \mathrm{E}+01$ \\
\hline SN118 & $1.60 \mathrm{E}+01$ & $1.60 \mathrm{E}+01$ & $1.60 \mathrm{E}+01$ & $1.60 \mathrm{E}+01$ \\
\hline SN119 & $1.63 \mathrm{E}+01$ & $1.63 \mathrm{E}+01$ & $1.63 \mathrm{E}+01$ & $1.63 \mathrm{E}+01$ \\
\hline SN119M & $4.20 \mathrm{E}-04$ & $2.54 \mathrm{E}-15$ & $0.00 \mathrm{E}+00$ & $0.00 \mathrm{E}+00$ \\
\hline SN120 & $1.62 \mathrm{E}+01$ & $1.62 \mathrm{E}+01$ & $1.62 \mathrm{E}+01$ & $1.62 \mathrm{E}+01$ \\
\hline SN121M & 8.55E-03 & $6.05 E-03$ & $2.29 \mathrm{E}-03$ & 8.92E-06 \\
\hline SN122 & $1.73 \mathrm{E}+01$ & $1.73 \mathrm{E}+01$ & $1.73 \mathrm{E}+01$ & $1.73 \mathrm{E}+01$ \\
\hline SN123 & 2.73E-05 & $1.47 \mathrm{E}-26$ & $0.00 \mathrm{E}+00$ & $0.00 \mathrm{E}+00$ \\
\hline SN124 & $2.31 \mathrm{E}+01$ & $2.31 \mathrm{E}+01$ & $2.31 \mathrm{E}+01$ & $2.31 \mathrm{E}+01$ \\
\hline SN126 & 5.57E+01 & $5.57 \mathrm{E}+01$ & $5.56 \mathrm{E}+01$ & $5.55 \mathrm{E}+01$ \\
\hline SB121 & $1.51 \mathrm{E}+01$ & $1.51 \mathrm{E}+01$ & $1.51 \mathrm{E}+01$ & $1.51 \mathrm{E}+01$ \\
\hline SB123 & $1.84 \mathrm{E}+01$ & $1.84 \mathrm{E}+01$ & $1.84 \mathrm{E}+01$ & $1.84 \mathrm{E}+01$ \\
\hline SB124 & $1.01 \mathrm{E}-10$ & $0.00 \mathrm{E}+00$ & $0.00 \mathrm{E}+00$ & $0.00 \mathrm{E}+00$ \\
\hline
\end{tabular}


Table C-1 (continued)

\begin{tabular}{|c|c|c|c|c|}
\hline \multirow{3}{*}{$\begin{array}{c}\text { Burnup } \\
\text { Enrichment (\%) } \\
\text { Cooling Time (yr) }\end{array}$} & \multicolumn{4}{|c|}{ 50,000 MW-d/MTIHM } \\
\hline & \multicolumn{4}{|c|}{ 6.83 Fissile $\mathrm{Pu}$} \\
\hline & 5 & 30 & 100 & 500 \\
\hline ISOTOPE & GM/MTIHM & GM/MTIHM & GM/MTIHM & GM/MTIHM \\
\hline SB125 & $6.92 \mathrm{E}+00$ & 1.33E-02 & $3.28 \mathrm{E}-10$ & $0.00 \mathrm{E}+00$ \\
\hline SB126 & $2.64 \mathrm{E}-06$ & $2.64 \mathrm{E}-06$ & $2.64 \mathrm{E}-06$ & $2.64 \mathrm{E}-06$ \\
\hline SB126M & 2.01E-08 & 2.01E-08 & 2.01E-08 & 2.00E-08 \\
\hline TE122 & $1.54 \mathrm{E}+00$ & $1.54 \mathrm{E}+00$ & $1.54 \mathrm{E}+00$ & $1.54 \mathrm{E}+00$ \\
\hline TE123 & $2.72 \mathrm{E}-02$ & $2.72 \mathrm{E}-02$ & $2.72 \mathrm{E}-02$ & $2.72 \mathrm{E}-02$ \\
\hline TE123M & $1.06 \mathrm{E}-07$ & $0.00 \mathrm{E}+00$ & $0.00 \mathrm{E}+00$ & $0.00 \mathrm{E}+00$ \\
\hline TE124 & $1.23 \mathrm{E}+00$ & $1.23 \mathrm{E}+00$ & $1.23 \mathrm{E}+00$ & $1.23 \mathrm{E}+00$ \\
\hline TE125 & $3.13 E+01$ & 3.83E+01 & 3.84E+01 & 3.84E+01 \\
\hline TE125M & 9.68E-02 & $1.86 \mathrm{E}-04$ & 4.59E-12 & $0.00 \mathrm{E}+00$ \\
\hline TE126 & $1.81 \mathrm{E}+00$ & $1.82 \mathrm{E}+00$ & $1.85 \mathrm{E}+00$ & $2.00 \mathrm{E}+00$ \\
\hline TE127 & 5.93E-08 & $1.50 \mathrm{E}-31$ & $0.00 \mathrm{E}+00$ & $0.00 \mathrm{E}+00$ \\
\hline TE127M & 1.69E-05 & 4.27E-29 & $0.00 \mathrm{E}+00$ & $0.00 \mathrm{E}+00$ \\
\hline TE128 & $2.10 \mathrm{E}+02$ & $2.10 \mathrm{E}+02$ & $2.10 \mathrm{E}+02$ & $2.10 \mathrm{E}+02$ \\
\hline TE129 & $6.77 \mathrm{E}-20$ & $0.00 \mathrm{E}+00$ & $0.00 \mathrm{E}+00$ & $0.00 \mathrm{E}+00$ \\
\hline TE129M & 7.23E-17 & $0.00 \mathrm{E}+00$ & $0.00 \mathrm{E}+00$ & $0.00 \mathrm{E}+00$ \\
\hline TE130 & $6.34 \mathrm{E}+02$ & $6.34 \mathrm{E}+02$ & $6.34 \mathrm{E}+02$ & $6.34 \mathrm{E}+02$ \\
\hline $\mid 127$ & $1.16 \mathrm{E}+02$ & $1.16 \mathrm{E}+02$ & $1.16 \mathrm{E}+02$ & $1.16 \mathrm{E}+02$ \\
\hline 1129 & $3.47 \mathrm{E}+02$ & $3.47 \mathrm{E}+02$ & $3.47 \mathrm{E}+02$ & $3.47 \mathrm{E}+02$ \\
\hline XE127 & $5.65 \mathrm{E}-21$ & $0.00 \mathrm{E}+00$ & $0.00 \mathrm{E}+00$ & $0.00 \mathrm{E}+00$ \\
\hline XE128 & $1.02 \mathrm{E}+01$ & $1.02 \mathrm{E}+01$ & $1.02 \mathrm{E}+01$ & $1.02 \mathrm{E}+01$ \\
\hline XE129 & 6.56E-02 & 6.60E-02 & 6.71E-02 & 7.32E-02 \\
\hline XE130 & $2.19 \mathrm{E}+01$ & $2.19 \mathrm{E}+01$ & $2.19 \mathrm{E}+01$ & $2.19 \mathrm{E}+01$ \\
\hline XE131 & $6.44 \mathrm{E}+02$ & $6.44 \mathrm{E}+02$ & $6.44 \mathrm{E}+02$ & $6.44 \mathrm{E}+02$ \\
\hline XE132 & $1.82 \mathrm{E}+03$ & $1.82 \mathrm{E}+03$ & $1.82 \mathrm{E}+03$ & $1.82 \mathrm{E}+03$ \\
\hline XE134 & $2.17 \mathrm{E}+03$ & $2.17 \mathrm{E}+03$ & $2.17 \mathrm{E}+03$ & $2.17 \mathrm{E}+03$ \\
\hline XE136 & $3.20 \mathrm{E}+03$ & $3.20 \mathrm{E}+03$ & $3.20 \mathrm{E}+03$ & $3.20 \mathrm{E}+03$ \\
\hline CS133 & $1.60 \mathrm{E}+03$ & $1.60 \mathrm{E}+03$ & $1.60 \mathrm{E}+03$ & $1.60 \mathrm{E}+03$ \\
\hline CS134 & $3.91 \mathrm{E}+01$ & 8.75E-03 & $5.28 \mathrm{E}-13$ & $0.00 \mathrm{E}+00$ \\
\hline CS135 & $9.17 \mathrm{E}+02$ & $9.17 \mathrm{E}+02$ & $9.17 \mathrm{E}+02$ & $9.17 \mathrm{E}+02$ \\
\hline CS137 & $1.61 \mathrm{E}+03$ & $9.06 \mathrm{E}+02$ & $1.80 \mathrm{E}+02$ & $1.74 \mathrm{E}-02$ \\
\hline BA132 & 4.32E-03 & 4.32E-03 & 4.32E-03 & 4.32E-03 \\
\hline BA134 & $2.79 \mathrm{E}+02$ & $3.18 \mathrm{E}+02$ & $3.18 \mathrm{E}+02$ & $3.18 \mathrm{E}+02$ \\
\hline BA135 & $9.66 \mathrm{E}-01$ & 9.73E-01 & 9.92E-01 & $1.10 \mathrm{E}+00$ \\
\hline BA136 & $5.96 \mathrm{E}+01$ & $5.96 \mathrm{E}+01$ & $5.96 \mathrm{E}+01$ & $5.96 \mathrm{E}+01$ \\
\hline BA137 & $2.84 \mathrm{E}+02$ & $9.93 \mathrm{E}+02$ & $1.72 \mathrm{E}+03$ & $1.90 \mathrm{E}+03$ \\
\hline BA137M & 2.47E-04 & 1.39E-04 & 2.75E-05 & 2.66E-09 \\
\hline
\end{tabular}


Table C-1 (continued)

\begin{tabular}{|c|c|c|c|c|}
\hline \multirow{3}{*}{$\begin{array}{c}\text { Burnup } \\
\text { Enrichment (\%) } \\
\text { Cooling Time (yr) }\end{array}$} & \multicolumn{4}{|c|}{ 50,000 MW-d/MTIHM } \\
\hline & \multicolumn{4}{|c|}{ 6.83 Fissile $\mathrm{Pu}$} \\
\hline & 5 & 30 & 100 & 500 \\
\hline ISOTOPE & GM/MTIHM & GM/MTIHM & GM/MTIHM & GM/MTIHM \\
\hline BA138 & $1.78 \mathrm{E}+03$ & $1.78 \mathrm{E}+03$ & $1.78 \mathrm{E}+03$ & $1.78 \mathrm{E}+03$ \\
\hline LA138 & $3.28 \mathrm{E}-03$ & $3.28 \mathrm{E}-03$ & 3.28E-03 & $3.28 \mathrm{E}-03$ \\
\hline LA139 & $1.72 \mathrm{E}+03$ & $1.72 \mathrm{E}+03$ & $1.72 \mathrm{E}+03$ & $1.72 \mathrm{E}+03$ \\
\hline CE140 & $1.72 \mathrm{E}+03$ & $1.72 \mathrm{E}+03$ & $1.72 \mathrm{E}+03$ & $1.72 \mathrm{E}+03$ \\
\hline CE142 & $1.51 \mathrm{E}+03$ & $1.51 \mathrm{E}+03$ & $1.51 \mathrm{E}+03$ & $1.51 \mathrm{E}+03$ \\
\hline CE144 & $3.85 \mathrm{E}+00$ & $8.22 \mathrm{E}-10$ & $6.90 \mathrm{E}-37$ & $0.00 \mathrm{E}+00$ \\
\hline PR141 & $1.56 \mathrm{E}+03$ & $1.56 \mathrm{E}+03$ & $1.56 \mathrm{E}+03$ & $1.56 \mathrm{E}+03$ \\
\hline PR144 & $1.62 \mathrm{E}-04$ & 3.47E-14 & 4.04E-43 & $0.00 \mathrm{E}+00$ \\
\hline PR144M & $8.12 \mathrm{E}-07$ & $1.74 \mathrm{E}-16$ & $0.00 \mathrm{E}+00$ & $0.00 \mathrm{E}+00$ \\
\hline ND142 & $3.38 \mathrm{E}+01$ & $3.38 \mathrm{E}+01$ & $3.38 \mathrm{E}+01$ & $3.38 \mathrm{E}+01$ \\
\hline ND143 & $1.10 \mathrm{E}+03$ & $1.10 \mathrm{E}+03$ & $1.10 \mathrm{E}+03$ & $1.10 \mathrm{E}+03$ \\
\hline ND144 & $1.53 \mathrm{E}+03$ & $1.54 \mathrm{E}+03$ & $1.54 \mathrm{E}+03$ & $1.54 \mathrm{E}+03$ \\
\hline ND145 & $8.63 E+02$ & $8.63 E+02$ & $8.63 E+02$ & $8.63 E+02$ \\
\hline ND146 & $9.55 \mathrm{E}+02$ & $9.55 \mathrm{E}+02$ & $9.55 \mathrm{E}+02$ & $9.55 \mathrm{E}+02$ \\
\hline ND148 & $5.63 E+02$ & $5.63 E+02$ & $5.63 E+02$ & $5.63 E+02$ \\
\hline ND150 & $3.33 E+02$ & 3.33E+02 & 3.33E+02 & $3.33 E+02$ \\
\hline PM146 & 6.73E-03 & 2.88E-04 & 4.25E-08 & $0.00 \mathrm{E}+00$ \\
\hline PM147 & $4.26 \mathrm{E}+01$ & 5.77E-02 & $5.36 \mathrm{E}-10$ & $0.00 \mathrm{E}+00$ \\
\hline PM148 & $7.89 \mathrm{E}-16$ & $0.00 \mathrm{E}+00$ & $0.00 \mathrm{E}+00$ & $0.00 \mathrm{E}+00$ \\
\hline PM148M & 1.08E-13 & $0.00 \mathrm{E}+00$ & $0.00 \mathrm{E}+00$ & $0.00 \mathrm{E}+00$ \\
\hline SM146 & 1.60E-02 & 1.84E-02 & 1.85E-02 & 1.85E-02 \\
\hline SM147 & $2.12 \mathrm{E}+02$ & $2.55 \mathrm{E}+02$ & $2.55 \mathrm{E}+02$ & $2.55 \mathrm{E}+02$ \\
\hline SM148 & $3.09 \mathrm{E}+02$ & $3.09 \mathrm{E}+02$ & $3.09 \mathrm{E}+02$ & $3.09 \mathrm{E}+02$ \\
\hline SM149 & $6.71 \mathrm{E}+00$ & $6.71 \mathrm{E}+00$ & $6.71 \mathrm{E}+00$ & $6.71 \mathrm{E}+00$ \\
\hline SM150 & $4.64 \mathrm{E}+02$ & $4.64 \mathrm{E}+02$ & $4.64 \mathrm{E}+02$ & $4.64 \mathrm{E}+02$ \\
\hline SM151 & $3.41 \mathrm{E}+01$ & $2.82 \mathrm{E}+01$ & $1.64 \mathrm{E}+01$ & 7.54E-01 \\
\hline SM152 & $2.04 \mathrm{E}+02$ & $2.04 \mathrm{E}+02$ & $2.04 \mathrm{E}+02$ & $2.04 \mathrm{E}+02$ \\
\hline SM154 & $9.76 \mathrm{E}+01$ & $9.76 \mathrm{E}+01$ & $9.76 \mathrm{E}+01$ & $9.76 \mathrm{E}+01$ \\
\hline EU150 & 1.67E-06 & 1.03E-06 & 2.68E-07 & $1.21 \mathrm{E}-10$ \\
\hline EU151 & $1.39 E+00$ & 7.37E+00 & $1.91 \mathrm{E}+01$ & $3.48 \mathrm{E}+01$ \\
\hline EU152 & $1.20 \mathrm{E}-01$ & 3.35E-02 & $9.45 \mathrm{E}-04$ & $1.32 \mathrm{E}-12$ \\
\hline EU153 & $2.50 \mathrm{E}+02$ & $2.50 \mathrm{E}+02$ & $2.50 \mathrm{E}+02$ & $2.50 \mathrm{E}+02$ \\
\hline EU154 & $6.30 \mathrm{E}+01$ & $8.40 \mathrm{E}+00$ & 2.98E-02 & 2.97E-16 \\
\hline EU155 & $2.15 \mathrm{E}+01$ & 6.52E-01 & 3.67E-05 & 1.92E-29 \\
\hline GD152 & $5.54 \mathrm{E}-02$ & 7.94E-02 & $8.85 \mathrm{E}-02$ & 8.87E-02 \\
\hline GD153 & 1.91E-04 & 8.39E-16 & $0.00 \mathrm{E}+00$ & $0.00 \mathrm{E}+00$ \\
\hline
\end{tabular}


Table C-1 (continued)

\begin{tabular}{|c|c|c|c|c|}
\hline \multirow{3}{*}{$\begin{array}{c}\text { Burnup } \\
\text { Enrichment (\%) } \\
\text { Cooling Time (yr) }\end{array}$} & \multicolumn{4}{|c|}{ 50,000 MW-d/MTIHM } \\
\hline & \multicolumn{4}{|c|}{ 6.83 Fissile $\mathrm{Pu}$} \\
\hline & 5 & 30 & 100 & 500 \\
\hline ISOTOPE & GM/MTIHM & GM/MTIHM & GM/MTIHM & GM/MTIHM \\
\hline GD154 & 4.16E+01 & $9.61 \mathrm{E}+01$ & $1.05 \mathrm{E}+02$ & $1.05 E+02$ \\
\hline GD155 & $2.23 \mathrm{E}+01$ & $4.31 \mathrm{E}+01$ & $4.38 \mathrm{E}+01$ & $4.38 \mathrm{E}+01$ \\
\hline GD156 & $1.71 \mathrm{E}+02$ & $1.71 \mathrm{E}+02$ & $1.71 \mathrm{E}+02$ & $1.71 \mathrm{E}+02$ \\
\hline GD157 & 3.95E-01 & 3.95E-01 & 3.95E-01 & 3.95E-01 \\
\hline GD158 & $6.04 \mathrm{E}+01$ & $6.04 \mathrm{E}+01$ & $6.04 \mathrm{E}+01$ & $6.04 \mathrm{E}+01$ \\
\hline GD160 & $4.82 \mathrm{E}+00$ & $4.82 \mathrm{E}+00$ & $4.82 \mathrm{E}+00$ & $4.82 \mathrm{E}+00$ \\
\hline TB159 & $9.58 \mathrm{E}+00$ & $9.58 \mathrm{E}+00$ & $9.58 \mathrm{E}+00$ & $9.58 \mathrm{E}+00$ \\
\hline TB160 & 7.87E-09 & $0.00 \mathrm{E}+00$ & $0.00 \mathrm{E}+00$ & $0.00 \mathrm{E}+00$ \\
\hline HO165 & 5.90E-01 & 5.90E-01 & 5.90E-01 & 5.90E-01 \\
\hline $\mathrm{HO} 166 \mathrm{M}$ & 7.22E-03 & 7.12E-03 & $6.84 \mathrm{E}-03$ & $5.43 \mathrm{E}-03$ \\
\hline TM169 & 2.80E-04 & 2.80E-04 & 2.80E-04 & 2.80E-04 \\
\hline TM170 & 2.13E-09 & $0.00 \mathrm{E}+00$ & $0.00 \mathrm{E}+00$ & $0.00 \mathrm{E}+00$ \\
\hline TM171 & $6.44 \mathrm{E}-07$ & 7.74E-11 & 8.25E-22 & $0.00 \mathrm{E}+00$ \\
\hline TL206 & 4.24E-27 & $4.24 \mathrm{E}-27$ & $4.24 \mathrm{E}-27$ & 4.23E-27 \\
\hline TL207 & 1.98E-14 & 7.74E-14 & 1.70E-13 & 5.82E-13 \\
\hline TL208 & 6.57E-12 & 5.90E-12 & 3.01E-12 & 7.20E-14 \\
\hline TL209 & 7.21E-18 & $1.79 \mathrm{E}-17$ & $1.26 \mathrm{E}-16$ & 7.26E-15 \\
\hline PB206 & 1.50E-11 & 3.78E-09 & 5.53E-07 & 3.19E-04 \\
\hline PB207 & 5.06E-09 & 1.02E-07 & 7.88E-07 & 1.23E-05 \\
\hline PB208 & 8.95E-06 & 6.33E-05 & 1.63E-04 & 2.65E-04 \\
\hline PB209 & 3.00E-14 & 7.46E-14 & 5.26E-13 & 3.02E-11 \\
\hline PB210 & $2.18 \mathrm{E}-10$ & 1.69E-08 & 7.59E-07 & 7.55E-05 \\
\hline PB211 & 1.53E-13 & 5.99E-13 & 1.32E-12 & 4.50E-12 \\
\hline PB212 & 3.88E-09 & 3.48E-09 & 1.78E-09 & 4.25E-11 \\
\hline PB214 & 5.51E-15 & 1.69E-13 & $3.56 \mathrm{E}-12$ & 2.04E-10 \\
\hline $\mathrm{BI} 208$ & 4.58E-16 & 4.58E-16 & 4.58E-16 & 4.58E-16 \\
\hline $\mathrm{BI} 209$ & $3.52 \mathrm{E}-10$ & 2.60E-09 & 3.48E-08 & 7.62E-06 \\
\hline $\mathrm{BI} 210$ & 1.34E-13 & $1.04 \mathrm{E}-11$ & 4.67E-10 & 4.64E-08 \\
\hline BI210M & 1.63E-15 & $1.63 \mathrm{E}-15$ & $1.63 \mathrm{E}-15$ & $1.63 \mathrm{E}-15$ \\
\hline $\mathrm{BI} 211$ & $9.03 \mathrm{E}-15$ & 3.53E-14 & 7.77E-14 & $2.66 \mathrm{E}-13$ \\
\hline $\mathrm{BI} 212$ & 3.68E-10 & 3.30E-10 & $1.68 \mathrm{E}-10$ & 4.03E-12 \\
\hline $\mathrm{BI} 213$ & 7.06E-15 & $1.75 \mathrm{E}-14$ & $1.24 \mathrm{E}-13$ & 7.10E-12 \\
\hline $\mathrm{BI} 214$ & 4.09E-15 & $1.25 \mathrm{E}-13$ & 2.64E-12 & $1.51 \mathrm{E}-10$ \\
\hline $\mathrm{PO} 210$ & 3.12E-12 & $2.88 \mathrm{E}-10$ & 1.29E-08 & $1.28 \mathrm{E}-06$ \\
\hline $\mathrm{PO} 211$ & 1.11E-19 & 4.33E-19 & 9.53E-19 & $3.26 \mathrm{E}-18$ \\
\hline $\mathrm{PO} 212$ & $1.95 \mathrm{E}-20$ & $1.75 \mathrm{E}-20$ & 8.91E-21 & $2.13 \mathrm{E}-22$ \\
\hline
\end{tabular}


Table C-1 (continued)

\begin{tabular}{|c|c|c|c|c|}
\hline \multirow{3}{*}{$\begin{array}{c}\text { Burnup } \\
\text { Enrichment (\%) } \\
\text { Cooling Time (yr) }\end{array}$} & \multicolumn{4}{|c|}{ 50,000 MW-d/MTIHM } \\
\hline & \multicolumn{4}{|c|}{ 6.83 Fissile $\mathrm{Pu}$} \\
\hline & 5 & 30 & 100 & 500 \\
\hline ISOTOPE & GM/MTIHM & GM/MTIHM & GM/MTIHM & GM/MTIHM \\
\hline PO213 & 1.06E-23 & 2.63E-23 & 1.86E-22 & 1.07E-20 \\
\hline $\mathrm{PO} 214$ & $5.63 \mathrm{E}-22$ & $1.72 \mathrm{E}-20$ & 3.64E-19 & $2.08 \mathrm{E}-17$ \\
\hline PO215 & $1.28 \mathrm{E}-19$ & 5.01E-19 & $1.10 \mathrm{E}-18$ & 3.77E-18 \\
\hline PO216 & $1.55 \mathrm{E}-14$ & $1.39 \mathrm{E}-14$ & 7.09E-15 & $1.70 \mathrm{E}-16$ \\
\hline PO218 & $6.38 \mathrm{E}-16$ & $1.96 \mathrm{E}-14$ & 4.13E-13 & $2.36 \mathrm{E}-11$ \\
\hline AT217 & $8.48 \mathrm{E}-20$ & $2.11 \mathrm{E}-19$ & $1.49 \mathrm{E}-18$ & 8.54E-17 \\
\hline RN219 & $2.90 \mathrm{E}-16$ & $1.14 \mathrm{E}-15$ & $2.50 \mathrm{E}-15$ & 8.54E-15 \\
\hline RN220 & $5.84 \mathrm{E}-12$ & $5.24 \mathrm{E}-12$ & $2.68 \mathrm{E}-12$ & $6.40 \mathrm{E}-14$ \\
\hline RN222 & 1.17E-12 & 3.60E-11 & 7.59E-10 & 4.35E-08 \\
\hline FR221 & 7.70E-16 & $1.91 \mathrm{E}-15$ & $1.35 \mathrm{E}-14$ & $7.75 \mathrm{E}-13$ \\
\hline FR223 & 1.35E-15 & 5.26E-15 & 1.16E-14 & $3.96 \mathrm{E}-14$ \\
\hline RA223 & 7.38E-11 & 2.89E-10 & $6.35 \mathrm{E}-10$ & 2.17E-09 \\
\hline RA224 & 3.38E-08 & 3.04E-08 & $1.55 \mathrm{E}-08$ & 3.71E-10 \\
\hline RA225 & $3.48 \mathrm{E}-12$ & 8.65E-12 & $6.10 \mathrm{E}-11$ & 3.50E-09 \\
\hline RA226 & 1.83E-07 & 5.60E-06 & 1.18E-04 & 6.76E-03 \\
\hline RA228 & 2.14E-13 & $1.68 \mathrm{E}-12$ & $6.54 \mathrm{E}-12$ & 3.78E-11 \\
\hline AC225 & 2.35E-12 & 5.84E-12 & 4.12E-11 & 2.37E-09 \\
\hline AC227 & 5.21E-08 & 2.04E-07 & 4.49E-07 & $1.54 \mathrm{E}-06$ \\
\hline AC228 & 2.23E-17 & $1.75 \mathrm{E}-16$ & 6.83E-16 & 3.94E-15 \\
\hline TH227 & $1.21 \mathrm{E}-10$ & 4.74E-10 & 1.04E-09 & 3.57E-09 \\
\hline TH228 & $6.55 \mathrm{E}-06$ & 5.90E-06 & 3.01E-06 & 7.20E-08 \\
\hline TH229 & $6.42 \mathrm{E}-07$ & $1.59 \mathrm{E}-06$ & 1.12E-05 & $6.46 \mathrm{E}-04$ \\
\hline TH230 & 5.49E-03 & 5.05E-02 & 3.54E-01 & $3.88 \mathrm{E}+00$ \\
\hline TH231 & 1.65E-08 & 1.66E-08 & 1.68E-08 & 1.84E-08 \\
\hline TH232 & 1.30E-03 & 4.95E-03 & $1.54 \mathrm{E}-02$ & 8.23E-02 \\
\hline TH234 & 1.24E-05 & $1.24 \mathrm{E}-05$ & $1.24 \mathrm{E}-05$ & $1.24 \mathrm{E}-05$ \\
\hline PA231 & 4.48E-04 & 5.46E-04 & 8.24E-04 & 2.49E-03 \\
\hline PA233 & 3.03E-05 & 4.18E-05 & 9.00E-05 & 2.95E-04 \\
\hline PA234 & $1.86 \mathrm{E}-10$ & $1.86 \mathrm{E}-10$ & $1.86 \mathrm{E}-10$ & $1.86 \mathrm{E}-10$ \\
\hline PA234M & 4.17E-10 & 4.17E-10 & 4.17E-10 & 4.17E-10 \\
\hline U232 & 2.80E-04 & 2.20E-04 & 1.12E-04 & 2.69E-06 \\
\hline U233 & 4.84E-03 & 1.33E-02 & 5.63E-02 & 8.19E-01 \\
\hline U234 & $3.42 \mathrm{E}+02$ & $9.32 \mathrm{E}+02$ & $2.08 \mathrm{E}+03$ & $3.59 \mathrm{E}+03$ \\
\hline U235 & $4.05 E+03$ & $4.08 \mathrm{E}+03$ & $4.14 \mathrm{E}+03$ & $4.51 \mathrm{E}+03$ \\
\hline U236 & $4.99 \mathrm{E}+03$ & $5.05 \mathrm{E}+03$ & $5.23 \mathrm{E}+03$ & $6.25 \mathrm{E}+03$ \\
\hline U237 & $3.18 \mathrm{E}-04$ & 9.56E-05 & $3.30 \mathrm{E}-06$ & $6.50 \mathrm{E}-09$ \\
\hline
\end{tabular}


Table C-1 (continued)

\begin{tabular}{|c|c|c|c|c|}
\hline \multirow{3}{*}{$\begin{array}{c}\text { Burnup } \\
\text { Enrichment (\%) } \\
\text { Cooling Time (yr) }\end{array}$} & \multicolumn{4}{|c|}{ 50,000 MW-d/MTIHM } \\
\hline & \multicolumn{4}{|c|}{ 6.83 Fissile $\mathrm{Pu}$} \\
\hline & 5 & 30 & 100 & 500 \\
\hline ISOTOPE & GM/MTIHM & GM/MTIHM & GM/MTIHM & GM/MTIHM \\
\hline U238 & $8.51 \mathrm{E}+05$ & $8.51 \mathrm{E}+05$ & $8.51 \mathrm{E}+05$ & $8.51 \mathrm{E}+05$ \\
\hline U240 & 4.14E-12 & 4.14E-12 & 4.14E-12 & 4.14E-12 \\
\hline NP235 & $0.00 \mathrm{E}+00$ & $0.00 \mathrm{E}+00$ & $0.00 \mathrm{E}+00$ & $0.00 \mathrm{E}+00$ \\
\hline NP236 & 5.69E-03 & 5.69E-03 & 5.68E-03 & 5.67E-03 \\
\hline NP237 & 8.91E+02 & $1.23 \mathrm{E}+03$ & $2.65 \mathrm{E}+03$ & $8.70 \mathrm{E}+03$ \\
\hline NP238 & $7.18 \mathrm{E}-06$ & $6.40 \mathrm{E}-06$ & $4.65 \mathrm{E}-06$ & $7.51 \mathrm{E}-07$ \\
\hline NP239 & 1.69E-03 & $1.68 \mathrm{E}-03$ & 1.67E-03 & $1.61 \mathrm{E}-03$ \\
\hline NP240M & 3.62E-14 & 3.62E-14 & 3.62E-14 & 3.62E-14 \\
\hline PU236 & 9.91E-09 & 1.27E-08 & 1.27E-08 & 1.27E-08 \\
\hline PU237 & $1.04 \mathrm{E}-15$ & $0.00 \mathrm{E}+00$ & $0.00 \mathrm{E}+00$ & $0.00 \mathrm{E}+00$ \\
\hline PU238 & $3.35 \mathrm{E}+03$ & $2.75 \mathrm{E}+03$ & $1.59 \mathrm{E}+03$ & 7.06E+01 \\
\hline PU239 & $3.31 \mathrm{E}+04$ & $3.31 \mathrm{E}+04$ & $3.30 \mathrm{E}+04$ & $3.27 \mathrm{E}+04$ \\
\hline PU240 & $2.44 \mathrm{E}+04$ & $2.48 \mathrm{E}+04$ & $2.49 \mathrm{E}+04$ & $2.39 \mathrm{E}+04$ \\
\hline PU241 & $1.03 E+04$ & $3.09 \mathrm{E}+03$ & $1.06 \mathrm{E}+02$ & 2.10E-01 \\
\hline PU242 & 8.91E+03 & $8.91 \mathrm{E}+03$ & $8.91 \mathrm{E}+03$ & $8.90 \mathrm{E}+03$ \\
\hline PU243 & $5.16 \mathrm{E}-12$ & 5.16E-12 & 5.16E-12 & 5.16E-12 \\
\hline PU244 & 2.16E-01 & 2.16E-01 & 2.16E-01 & 2.16E-01 \\
\hline AM241 & $4.49 E+03$ & $1.13 E+04$ & $1.29 E+04$ & $6.84 \mathrm{E}+03$ \\
\hline AM242 & 4.58E-04 & 4.09E-04 & 2.97E-04 & 4.79E-05 \\
\hline AM242M & $3.83 E+01$ & $3.42 \mathrm{E}+01$ & $2.48 \mathrm{E}+01$ & $4.01 \mathrm{E}+00$ \\
\hline AM243 & $1.96 \mathrm{E}+03$ & $1.96 \mathrm{E}+03$ & 1.94E+03 & 1.87E+03 \\
\hline AM244 & $0.00 \mathrm{E}+00$ & $0.00 \mathrm{E}+00$ & $0.00 \mathrm{E}+00$ & $0.00 \mathrm{E}+00$ \\
\hline CM241 & 7.43E-20 & $0.00 \mathrm{E}+00$ & $0.00 \mathrm{E}+00$ & $0.00 \mathrm{E}+00$ \\
\hline CM242 & 2.05E-01 & 8.26E-02 & 6.00E-02 & 9.69E-03 \\
\hline CM243 & 1.07E+01 & $5.83 E+00$ & $1.06 \mathrm{E}+00$ & 6.33E-05 \\
\hline CM244 & $8.51 \mathrm{E}+02$ & $3.27 \mathrm{E}+02$ & $2.24 \mathrm{E}+01$ & 5.03E-06 \\
\hline CM245 & $1.31 \mathrm{E}+02$ & $1.31 \mathrm{E}+02$ & $1.30 \mathrm{E}+02$ & $1.26 \mathrm{E}+02$ \\
\hline CM246 & 7.32E+00 & $7.30 \mathrm{E}+00$ & $7.22 \mathrm{E}+00$ & $6.81 \mathrm{E}+00$ \\
\hline CM247 & 1.45E-01 & 1.45E-01 & 1.45E-01 & 1.45E-01 \\
\hline CM248 & 1.10E-02 & 1.10E-02 & 1.10E-02 & 1.10E-02 \\
\hline BK249 & $3.25 \mathrm{E}-06$ & 8.38E-15 & 7.41E-39 & $0.00 \mathrm{E}+00$ \\
\hline CF249 & 2.13E-04 & 2.06E-04 & 1.79E-04 & 8.13E-05 \\
\hline CF250 & 2.74E-05 & 7.28E-06 & 1.78E-07 & 4.98E-15 \\
\hline CF251 & 1.75E-05 & 1.71E-05 & 1.62E-05 & 1.19E-05 \\
\hline CF252 & 2.46E-06 & 3.46E-09 & $3.56 \mathrm{E}-17$ & $0.00 \mathrm{E}+00$ \\
\hline
\end{tabular}


Table C-1 (continued)

\begin{tabular}{|c|c|c|c|c|}
\hline Burnup & \multicolumn{4}{|c|}{ 50,000 MW-d/MTIHM } \\
\hline Enrichment (\%) & \multicolumn{4}{|c|}{ 6.83 Fissile $\mathrm{Pu}$} \\
\hline Cooling Time (yr) & 5 & 30 & 100 & 500 \\
\hline ISOTOPE & GM/MTIHM & GM/MTIHM & GM/MTIHM & GM/MTIHM \\
\hline Subtotal & $1.00 \mathrm{E}+06$ & $1.00 \mathrm{E}+06$ & $1.00 \mathrm{E}+06$ & $1.00 \mathrm{E}+06$ \\
\hline O16 & $1.27 \mathrm{E}+05$ & $1.27 \mathrm{E}+05$ & $1.27 \mathrm{E}+05$ & $1.27 \mathrm{E}+05$ \\
\hline TOTAL & $1.13 E+06$ & $1.13 E+06$ & $1.13 E+06$ & $1.13 E+06$ \\
\hline $\begin{array}{l}\text { Decay Heat } \\
\text { (Watts/MT) }\end{array}$ & 6,940 & 4,325 & 2,520 & 814 \\
\hline $\begin{array}{l}\text { Hulls and Hardware } \\
\text { (kg/MT) }\end{array}$ & 344 & 344 & 344 & 344 \\
\hline
\end{tabular}




\section{Appendix D}

\section{Sodium Fast Reactor Equilibrium Core Overall Material Balance for $\mathrm{CR}=0.75$}


Table D-1 Oxide Equilibrium Core LWR SNF CR=0.75.

\begin{tabular}{|c|c|c|c|c|c|c|}
\hline $\begin{array}{c}\text { Mass } \\
\text { Isotopes }(\mathrm{kg})\end{array}$ & $\begin{array}{l}\text { Reactor } \\
\text { Full Core } \\
\text { Initial } \\
\text { Charge }\end{array}$ & $\begin{array}{c}\text { Reactor } \\
\text { Annual } \\
\text { Fresh } \\
\text { Fuel }\end{array}$ & $\begin{array}{c}\text { Reactor } \\
\text { Annual } \\
\text { SNF at } \\
\text { Discharge }\end{array}$ & $\begin{array}{l}\text { Reactor } \\
\text { Annual } \\
\text { SNF at } \\
2 \text { yr Aged }\end{array}$ & $\begin{array}{c}\text { Annual } \\
\text { TRU } \\
\text { Burned }\end{array}$ & $\begin{array}{c}\text { Depleted } \\
\text { U for FR } \\
\text { Fuel }\end{array}$ \\
\hline \multicolumn{7}{|c|}{ Primary Fuel Isotopes } \\
\hline U234 & 13.12 & 2.18 & 2.12 & 2.36 & & \\
\hline U235 & 8.48 & 1.41 & 0.83 & 0.84 & & 0.61 \\
\hline U236 & 8.33 & 1.38 & 1.38 & 1.42 & & \\
\hline U237 & - & - & 0.01 & 0.00 & & \\
\hline U238 & $12,134.83$ & $2,016.32$ & $1,711.95$ & $1,711.95$ & & 304.38 \\
\hline U239 & - & - & 0.00 & - & & \\
\hline Np237 & 54.08 & 8.99 & 4.59 & 4.65 & 4.40 & \\
\hline Np239 & - & - & 0.33 & 0.00 & $(0.33)$ & \\
\hline Pu238 & 105.32 & 17.50 & 15.69 & 16.15 & 1.81 & \\
\hline Pu239 & $1,804.73$ & 299.87 & 259.95 & 260.27 & 39.93 & \\
\hline Pu240 & $1,266.21$ & 210.39 & 194.43 & 195.19 & 15.96 & \\
\hline Pu241 & 235.20 & 39.08 & 31.86 & 28.98 & 7.22 & \\
\hline Pu242 & 286.16 & 47.55 & 42.46 & 42.47 & 5.08 & \\
\hline Pu243 & - & - & 0.00 & 0.00 & $(0.00)$ & \\
\hline Am241 & 112.77 & 18.74 & 14.59 & 17.42 & 4.15 & \\
\hline Am242m & 7.05 & 1.17 & 1.02 & 1.01 & 0.16 & \\
\hline Am243 & 90.05 & 14.96 & 13.80 & 13.80 & 1.16 & \\
\hline Cm242 & 0.69 & 0.11 & 0.75 & 0.04 & $(0.63)$ & \\
\hline $\mathrm{Cm} 243$ & 0.51 & 0.08 & 0.09 & 0.08 & $(0.00)$ & \\
\hline $\mathrm{Cm} 244$ & 63.20 & 10.50 & 10.60 & 9.82 & $(0.10)$ & \\
\hline $\mathrm{Cm} 245$ & 18.47 & 3.07 & 3.10 & 3.10 & $(0.03)$ & \\
\hline Total TRU & 4,044 & 672 & 593 & 593 & 78.78 & \\
\hline Total HM & 16,225 & $2,696.0$ & $2,309.5$ & $2,309.5$ & & 305.0 \\
\hline$\%$ Enrichment & 24.9 & 24.9 & 25.7 & 25.7 & & \\
\hline \multicolumn{7}{|l|}{ Fission } \\
\hline $\mathrm{I}, \mathrm{C}, \mathrm{H}, \mathrm{Kr}, \mathrm{Xe}$ & - & - & 43.69 & 43.68 & & \\
\hline $\mathrm{Cs}, \mathrm{Sr}, \mathrm{Ba}, \mathrm{Rb}$ & - & - & 59.96 & 59.04 & & \\
\hline $\mathrm{Ag}, \mathrm{Pd}, \mathrm{Ru}$ & - & - & 66.28 & 66.28 & & \\
\hline Total & - & - & 93 & 92 & & \\
\hline $\mathrm{Y}$ & - & - & 2.59 & 2.55 & & \\
\hline Tc & - & - & 8.38 & 8.40 & & \\
\hline Mo & - & - & 31.73 & 32.07 & & \\
\hline others & - & - & 48.43 & 49.71 & & \\
\hline Total Fission & - & - & 354.14 & 354.14 & & \\
\hline Total Fuel & 16,225 & 2,696 & 2,664 & 2,664 & & \\
\hline \multicolumn{7}{|l|}{ Hardware } \\
\hline Assemblies & 144 & 23.14 & 23.14 & 23.14 & & \\
\hline Mass HT-9 & 46,890 & 7,535 & 7,535 & 7,535 & & \\
\hline
\end{tabular}




\section{Appendix E}

\section{Isotopic Composition of Borosilicate Glass from the}

New Extraction Process 
Table E-1 Isotopic Composition of New Extraction Borosilicate Glass from Reprocessing $51 \mathrm{GW}-d / M T$ LWR Fuel, at 5, 30, 100 and 500 yr Out-of-Reactor.

\begin{tabular}{|c|c|c|c|c|}
\hline Isotope & 5 Years & 30 Years & 100 Years & 500 Years \\
\hline He4 + actinide decay & 1.238E-03 & 1.500E-03 & $2.037 \mathrm{E}-03$ & $2.590 \mathrm{E}-03$ \\
\hline C12 & $7.245 \mathrm{E}+02$ & $7.245 E+02$ & $7.245 E+02$ & $7.245 \mathrm{E}+02$ \\
\hline C13 & $6.281 \mathrm{E}+01$ & $6.281 \mathrm{E}+01$ & $6.281 \mathrm{E}+01$ & $6.281 \mathrm{E}+01$ \\
\hline C14 & 1.900E-04 & $1.900 \mathrm{E}-04$ & 1.900E-04 & $1.899 \mathrm{E}-04$ \\
\hline $\mathrm{N} 14+\mathrm{C} 14$ decay & $1.150 \mathrm{E}-07$ & 1.380E-07 & 1.840E-07 & 2.299E-07 \\
\hline O16 & $8.780 \mathrm{E}+04$ & $8.780 \mathrm{E}+04$ & $8.780 \mathrm{E}+04$ & $8.780 \mathrm{E}+04$ \\
\hline $\mathrm{O} 17$ & $3.556 \mathrm{E}+01$ & $3.556 \mathrm{E}+01$ & $3.556 \mathrm{E}+01$ & $3.556 \mathrm{E}+01$ \\
\hline O18 & $2.020 \mathrm{E}+02$ & $2.020 \mathrm{E}+02$ & $2.020 \mathrm{E}+02$ & $2.020 \mathrm{E}+02$ \\
\hline Rb85 + Kr85 decay & $1.484 \mathrm{E}+03$ & $1.484 \mathrm{E}+03$ & $1.484 \mathrm{E}+03$ & $1.484 \mathrm{E}+03$ \\
\hline $\mathrm{Rb87}$ & $3.441 \mathrm{E}+03$ & $3.441 \mathrm{E}+03$ & $3.441 \mathrm{E}+03$ & $3.441 \mathrm{E}+03$ \\
\hline Sr86 + Rb86 decay & $7.428 \mathrm{E}-01$ & $7.428 \mathrm{E}-01$ & $7.428 \mathrm{E}-01$ & $7.428 \mathrm{E}-01$ \\
\hline Sr87 + Rb87 decay & 6.109E-03 & 6.109E-03 & 6.109E-03 & 6.109E-03 \\
\hline Sr87m & $0.000 \mathrm{E}+00$ & $0.000 \mathrm{E}+00$ & $0.000 \mathrm{E}+00$ & $0.000 \mathrm{E}+00$ \\
\hline Sr88 & $4.180 \mathrm{E}+02$ & $4.180 \mathrm{E}+02$ & $4.180 \mathrm{E}+02$ & $4.180 \mathrm{E}+02$ \\
\hline Sr89 & $3.299 \mathrm{E}-21$ & $2.191 \mathrm{E}-23$ & 9.663E-28 & $4.261 \mathrm{E}-32$ \\
\hline Sr90 (100\% to Y90) & $4.932 \mathrm{E}+02$ & $4.816 \mathrm{E}+02$ & $4.592 \mathrm{E}+02$ & $4.379 \mathrm{E}+02$ \\
\hline Y89 + Sr89 decay & $6.431 \mathrm{E}+03$ & $6.431 \mathrm{E}+03$ & $6.431 \mathrm{E}+03$ & $6.431 \mathrm{E}+03$ \\
\hline Y89m & $0.000 \mathrm{E}+00$ & $0.000 \mathrm{E}+00$ & $0.000 \mathrm{E}+00$ & $0.000 \mathrm{E}+00$ \\
\hline Y90 (Sr90 progeny) & $1.237 \mathrm{E}-01$ & $1.208 \mathrm{E}-01$ & $1.152 \mathrm{E}-01$ & $1.098 \mathrm{E}-01$ \\
\hline Y90m & $0.000 \mathrm{E}+00$ & $0.000 \mathrm{E}+00$ & $0.000 \mathrm{E}+00$ & $0.000 \mathrm{E}+00$ \\
\hline Y91 & $5.960 \mathrm{E}-17$ & 7.875E-19 & $1.375 \mathrm{E}-22$ & $2.400 \mathrm{E}-26$ \\
\hline Zr90 + Sr90/Y90 decay & $6.385 \mathrm{E}+01$ & $7.546 \mathrm{E}+01$ & $9.785 \mathrm{E}+01$ & $1.192 \mathrm{E}+02$ \\
\hline Zr91 + Y91 decay & $1.480 \mathrm{E}-07$ & $1.480 \mathrm{E}-07$ & $1.480 \mathrm{E}-07$ & $1.480 \mathrm{E}-07$ \\
\hline $\begin{array}{l}\text { Nb93 + Zr93/Nb93m } \\
\text { decay }\end{array}$ & $1.308 \mathrm{E}-02$ & $1.410 \mathrm{E}-02$ & 1.599E-02 & $1.769 \mathrm{E}-02$ \\
\hline Nb93m (100\% to Nb93) & $2.050 \mathrm{E}-02$ & $1.948 \mathrm{E}-02$ & $1.759 \mathrm{E}-02$ & $1.589 \mathrm{E}-02$ \\
\hline $\mathrm{Nb94}$ & $1.102 \mathrm{E}-02$ & $1.102 \mathrm{E}-02$ & $1.102 \mathrm{E}-02$ & $1.102 \mathrm{E}-02$ \\
\hline $\mathrm{Nb94m}$ & $0.000 \mathrm{E}+00$ & $0.000 \mathrm{E}+00$ & $0.000 \mathrm{E}+00$ & $0.000 E+00$ \\
\hline Nb95 (100\% to Mo95) & 4.679E-22 & $3.489 \mathrm{E}-25$ & $1.939 \mathrm{E}-31$ & $1.078 \mathrm{E}-37$ \\
\hline $\begin{array}{l}\mathrm{Nb95m}(94.4 \% \text { to } \mathrm{Nb95}, \\
5.6 \% \text { to Mo95) }\end{array}$ & 3.115E-162 & 1.063E-192 & $1.238 \mathrm{E}-253$ & $0.000 \mathrm{E}+00$ \\
\hline Mo94 + Nb94 decay & $1.881 \mathrm{E}-06$ & 2.257E-06 & 3.010E-06 & $3.762 \mathrm{E}-06$ \\
\hline $\begin{array}{l}\text { Mo95 + } \\
\text { Zr95/Nb95m/Nb95 decay }\end{array}$ & $9.974 \mathrm{E}+03$ & $9.974 \mathrm{E}+03$ & $9.974 \mathrm{E}+03$ & $9.974 \mathrm{E}+03$ \\
\hline Mo96 & $7.302 \mathrm{E}+02$ & $7.302 \mathrm{E}+02$ & $7.302 \mathrm{E}+02$ & $7.302 \mathrm{E}+02$ \\
\hline Mo97 & $1.074 \mathrm{E}+04$ & $1.074 \mathrm{E}+04$ & $1.074 \mathrm{E}+04$ & $1.074 \mathrm{E}+04$ \\
\hline Mo98 & $1.105 \mathrm{E}+04$ & $1.105 \mathrm{E}+04$ & $1.105 \mathrm{E}+04$ & $1.105 \mathrm{E}+04$ \\
\hline Mo100 & $1.270 \mathrm{E}+04$ & $1.270 \mathrm{E}+04$ & $1.270 \mathrm{E}+04$ & $1.270 \mathrm{E}+04$ \\
\hline Tc98 & $1.009 \mathrm{E}-01$ & $1.009 \mathrm{E}-01$ & $1.009 \mathrm{E}-01$ & $1.009 \mathrm{E}-01$ \\
\hline Tc99 & $1.064 \mathrm{E}+04$ & $1.064 \mathrm{E}+04$ & $1.064 \mathrm{E}+04$ & $1.064 \mathrm{E}+04$ \\
\hline Ru98 + Tc98 decay & 8.324E-08 & $9.989 \mathrm{E}-08$ & $1.332 \mathrm{E}-07$ & $1.665 \mathrm{E}-07$ \\
\hline Ru99 + Tc99 decay & 4.065E-01 & $4.412 \mathrm{E}-01$ & 5.104E-01 & 5.797E-01 \\
\hline Ru100 & $1.950 \mathrm{E}+03$ & $1.950 \mathrm{E}+03$ & $1.950 \mathrm{E}+03$ & $1.950 \mathrm{E}+03$ \\
\hline
\end{tabular}


Table E-1 (continued)

\begin{tabular}{|c|c|c|c|c|}
\hline Isotope & 5 Years & 30 Years & 100 Years & 500 Years \\
\hline Ru101 & $1.042 \mathrm{E}+04$ & $1.042 \mathrm{E}+04$ & $1.042 \mathrm{E}+04$ & $1.042 E+04$ \\
\hline Ru102 & $1.086 \mathrm{E}+04$ & $1.086 \mathrm{E}+04$ & $1.086 \mathrm{E}+04$ & $1.086 \mathrm{E}+04$ \\
\hline $\begin{array}{l}\text { Ru103 }(9.94 \% \text { to } R h 103, \\
90.06 \% \text { to } R \text { h103m) }\end{array}$ & 4.415E-26 & $7.020 \mathrm{E}-29$ & $1.774 \mathrm{E}-34$ & $4.486 \mathrm{E}-40$ \\
\hline Ru104 & $7.663 \mathrm{E}+03$ & $7.663 \mathrm{E}+03$ & $7.663 \mathrm{E}+03$ & $7.663 \mathrm{E}+03$ \\
\hline Ru106 (100\% to Rh106) & $1.932 \mathrm{E}+00$ & 9.715E-01 & $2.456 \mathrm{E}-01$ & $6.207 \mathrm{E}-02$ \\
\hline Rh102 & $1.302 \mathrm{E}-03$ & $1.025 \mathrm{E}-03$ & $6.358 \mathrm{E}-04$ & $3.942 \mathrm{E}-04$ \\
\hline $\begin{array}{l}\text { Rh103 + Ru103/Rh103m } \\
\text { decay }\end{array}$ & $5.711 \mathrm{E}+03$ & $5.711 \mathrm{E}+03$ & $5.711 \mathrm{E}+03$ & $5.711 \mathrm{E}+03$ \\
\hline Rh103m & $3.943 \mathrm{E}-29$ & $6.270 \mathrm{E}-32$ & $1.585 \mathrm{E}-37$ & 4.006E-43 \\
\hline Rh106 (100\% to Pd106) & 1.816E-06 & 9.133E-07 & $2.308 \mathrm{E}-07$ & 5.835E-08 \\
\hline Pd102 & 6.000E-04 & 6.554E-04 & 7.334E-04 & 7.817E-04 \\
\hline $\mathrm{Pd} 104$ & $3.391 E+03$ & $3.391 \mathrm{E}+03$ & $3.391 \mathrm{E}+03$ & $3.391 E+03$ \\
\hline Pd105 + Rh105 decay & $4.440 \mathrm{E}+03$ & $4.440 \mathrm{E}+03$ & $4.440 \mathrm{E}+03$ & $4.440 \mathrm{E}+03$ \\
\hline $\begin{array}{l}\text { Pd106 + Ru106/Rh106 } \\
\text { decay }\end{array}$ & $4.276 \mathrm{E}+03$ & $4.277 \mathrm{E}+03$ & $4.278 \mathrm{E}+03$ & $4.278 \mathrm{E}+03$ \\
\hline Pd107 & $2.605 \mathrm{E}+03$ & $2.605 \mathrm{E}+03$ & $2.605 \mathrm{E}+03$ & $2.605 \mathrm{E}+03$ \\
\hline Pd107m & $0.000 \mathrm{E}+00$ & $0.000 \mathrm{E}+00$ & $0.000 \mathrm{E}+00$ & $0.000 \mathrm{E}+00$ \\
\hline Pd108 & $1.793 \mathrm{E}+03$ & $1.793 \mathrm{E}+03$ & $1.793 \mathrm{E}+03$ & $1.793 E+03$ \\
\hline Pd110 & $5.944 \mathrm{E}+02$ & $5.944 \mathrm{E}+02$ & $5.944 \mathrm{E}+02$ & $5.944 \mathrm{E}+02$ \\
\hline Ag107 + Pd107 decay & $3.683 E-03$ & 3.961E-03 & 4.517E-03 & 5.073E-03 \\
\hline Ag108 & $5.168 \mathrm{E}-14$ & $5.140 \mathrm{E}-14$ & 5.084E-14 & 5.029E-14 \\
\hline $\mathrm{Ag} 108 \mathrm{~m}(8.7 \%$ to $\mathrm{Ag} 108)$ & 1.675E-05 & 1.665E-05 & 1.647E-05 & 1.629E-05 \\
\hline $\begin{array}{l}\text { Ag109 + Cd109/Ag109m } \\
\text { decay }\end{array}$ & $1.055 \mathrm{E}+03$ & $1.055 \mathrm{E}+03$ & $1.055 \mathrm{E}+03$ & $1.055 \mathrm{E}+03$ \\
\hline Ag109m & 4.104E-14 & $2.378 \mathrm{E}-14$ & $7.985 \mathrm{E}-15$ & $2.681 \mathrm{E}-15$ \\
\hline Ag110 & $8.314 \mathrm{E}-12$ & $3.018 \mathrm{E}-12$ & 3.977E-13 & $5.241 \mathrm{E}-14$ \\
\hline $\begin{array}{l}\text { Ag110m (1.36\% to } \\
\text { Ag110) }\end{array}$ & 5.365E-04 & $1.948 \mathrm{E}-04$ & 2.567E-05 & 3.382E-06 \\
\hline Cd108 & $6.473 \mathrm{E}-03$ & 6.474E-03 & $6.474 \mathrm{E}-03$ & $6.474 \mathrm{E}-03$ \\
\hline Cd109 & 4.154E-08 & $2.407 \mathrm{E}-08$ & 8.082E-09 & 2.714E-09 \\
\hline Cd110 + Ag110m decay & $7.200 \mathrm{E}+02$ & $7.200 \mathrm{E}+02$ & $7.200 \mathrm{E}+02$ & $7.200 \mathrm{E}+02$ \\
\hline Cd111 + Ag111 decay & $4.236 \mathrm{E}+02$ & $4.236 \mathrm{E}+02$ & $4.236 \mathrm{E}+02$ & $4.236 \mathrm{E}+02$ \\
\hline Cd112 + Pd112 decay & $2.533 \mathrm{E}+02$ & $2.533 \mathrm{E}+02$ & $2.533 \mathrm{E}+02$ & $2.533 \mathrm{E}+02$ \\
\hline Cd113 (100\% to $\ln 113)$ & $1.986 \mathrm{E}+00$ & $1.986 \mathrm{E}+00$ & $1.987 \mathrm{E}+00$ & $1.987 \mathrm{E}+00$ \\
\hline $\begin{array}{l}\text { Cd113m }(0.14 \% \text { to } \\
\text { Cd113, } 99.86 \% \text { to } \ln 113)\end{array}$ & $2.586 \mathrm{E}+00$ & $2.466 \mathrm{E}+00$ & $2.242 \mathrm{E}+00$ & $2.039 \mathrm{E}+00$ \\
\hline Cd114 & $3.288 \mathrm{E}+02$ & $3.288 \mathrm{E}+02$ & $3.288 \mathrm{E}+02$ & $3.288 \mathrm{E}+02$ \\
\hline Cd115m & $1.534 \mathrm{E}-25$ & $5.250 \mathrm{E}-28$ & $6.152 \mathrm{E}-33$ & $7.208 E-38$ \\
\hline Cd116 & $1.189 \mathrm{E}+02$ & $1.189 \mathrm{E}+02$ & $1.189 \mathrm{E}+02$ & $1.189 \mathrm{E}+02$ \\
\hline $\begin{array}{l}\text { In113 + Cd113/Cd113m } \\
\text { decay }\end{array}$ & $6.926 \mathrm{E}-01$ & $8.124 \mathrm{E}-01$ & $1.036 \mathrm{E}+00$ & $1.239 \mathrm{E}+00$ \\
\hline $\ln 115$ & $3.263 \mathrm{E}-13$ & $3.263 \mathrm{E}-13$ & $3.263 \mathrm{E}-13$ & $3.263 \mathrm{E}-13$ \\
\hline $\ln 115 \mathrm{~m}$ & $4.330 \mathrm{E}-32$ & 1.482E-34 & $1.737 \mathrm{E}-39$ & $2.035 \mathrm{E}-44$ \\
\hline Sn114 + In114m decay & $1.526 \mathrm{E}-02$ & 1.526E-02 & $1.526 \mathrm{E}-02$ & 1.526E-02 \\
\hline
\end{tabular}


Table E-1 (continued)

\begin{tabular}{|c|c|c|c|c|}
\hline Isotope & 5 Years & 30 Years & 100 Years & 500 Years \\
\hline $\begin{array}{l}\text { Sn115 + In115/Cd115 } \\
\text { decay }\end{array}$ & $1.789 \mathrm{E}+00$ & $1.789 \mathrm{E}+00$ & $1.789 \mathrm{E}+00$ & $1.789 \mathrm{E}+00$ \\
\hline Sn116 & $4.477 \mathrm{E}+01$ & $4.477 \mathrm{E}+01$ & $4.477 \mathrm{E}+01$ & $4.477 \mathrm{E}+01$ \\
\hline Sn117 + Sn117m decay & $4.614 \mathrm{E}+01$ & $4.614 \mathrm{E}+01$ & $4.614 \mathrm{E}+01$ & $4.614 \mathrm{E}+01$ \\
\hline Sn118 & $4.676 \mathrm{E}+01$ & $4.676 \mathrm{E}+01$ & $4.676 \mathrm{E}+01$ & $4.676 \mathrm{E}+01$ \\
\hline Sn119 + Sn119m decay & $4.658 \mathrm{E}+01$ & $4.658 \mathrm{E}+01$ & $4.658 \mathrm{E}+01$ & $4.658 \mathrm{E}+01$ \\
\hline Sn119m & 7.464E-06 & $2.656 \mathrm{E}-06$ & 3.364E-07 & $4.260 \mathrm{E}-08$ \\
\hline Sn120 & $4.741 \mathrm{E}+01$ & $4.741 \mathrm{E}+01$ & $4.741 \mathrm{E}+01$ & $4.741 \mathrm{E}+01$ \\
\hline Sn121 (100\% to Sb121) & $8.171 \mathrm{E}-07$ & 8.059E-07 & 7.838E-07 & 7.624E-07 \\
\hline $\begin{array}{l}\text { Sn121m }(77.6 \% \text { to } \\
\text { Sn121, 22.4\% to Sb121) }\end{array}$ & 1.721E-02 & 1.697E-02 & 1.651E-02 & 1.606E-02 \\
\hline Sn122 & $5.207 \mathrm{E}+01$ & $5.207 \mathrm{E}+01$ & $5.207 \mathrm{E}+01$ & $5.207 \mathrm{E}+01$ \\
\hline Sn123 (100\% to Sb123) & 5.056E-09 & $7.122 \mathrm{E}-10$ & $1.413 \mathrm{E}-11$ & $2.803 E-13$ \\
\hline Sn124 & $7.023 E+01$ & $7.023 E+01$ & $7.023 E+01$ & $7.023 E+01$ \\
\hline $\begin{array}{l}\text { Sn126 (100\% to } \\
\text { Sb126m) }\end{array}$ & $1.545 \mathrm{E}+02$ & $1.545 E+02$ & $1.545 \mathrm{E}+02$ & $1.545 \mathrm{E}+02$ \\
\hline Sb121 & 1.235E-03 & 1.472E-03 & 1.937E-03 & 2.388E-03 \\
\hline Sb123 & 9.120E-05 & 9.120E-05 & 9.121E-05 & 9.121E-05 \\
\hline Sb126 (100\% to Te126) & 7.337E-06 & 7.337E-06 & 7.337E-06 & 7.337E-06 \\
\hline $\begin{array}{l}\text { Sb126m (14\% to Sb126, } \\
86 \% \text { to } \mathrm{Te} 126)\end{array}$ & 5.579E-08 & 5.579E-08 & 5.579E-08 & 5.579E-08 \\
\hline Te122 + Sb122 decay & $1.117 \mathrm{E}+01$ & $1.117 \mathrm{E}+01$ & $1.117 \mathrm{E}+01$ & $1.117 \mathrm{E}+01$ \\
\hline Te123 + Te123m decay & 1.896E-01 & $1.896 \mathrm{E}-01$ & 1.896E-01 & $1.896 \mathrm{E}-01$ \\
\hline Te123m & $2.231 \mathrm{E}-11$ & $2.690 \mathrm{E}-12$ & 3.909E-14 & 5.682E-16 \\
\hline $\begin{array}{l}\text { Te124 + Sb124/Sb124m } \\
\text { decay }\end{array}$ & $8.685 E+00$ & $8.685 E+00$ & $8.685 E+00$ & $8.685 \mathrm{E}+00$ \\
\hline $\begin{array}{l}\text { Te125 + Sb125/Te125m } \\
\text { decay }\end{array}$ & $2.109 \mathrm{E}+02$ & $2.109 E+02$ & $2.109 \mathrm{E}+02$ & $2.109 E+02$ \\
\hline $\begin{array}{l}\text { Te125M (100\% to } \\
\text { Te125) }\end{array}$ & $2.267 \mathrm{E}-10$ & $2.884 \mathrm{E}-12$ & $4.668 \mathrm{E}-16$ & $7.556 \mathrm{E}-20$ \\
\hline $\begin{array}{l}\text { Te126 + } \\
\text { Sn126/Sb126m/Sb126 } \\
\text { decay }\end{array}$ & $1.169 \mathrm{E}+01$ & $1.169 \mathrm{E}+01$ & $1.169 \mathrm{E}+01$ & $1.169 \mathrm{E}+01$ \\
\hline Te127 (100\% to I127) & $4.122 \mathrm{E}-12$ & $4.041 \mathrm{E}-13$ & $3.882 \mathrm{E}-15$ & $3.729 \mathrm{E}-17$ \\
\hline $\begin{array}{l}\text { Te127m (97.6\% to } \\
\text { Te127, 2.4\% to I127) }\end{array}$ & 1.177E-09 & $1.154 \mathrm{E}-10$ & 1.109E-12 & 1.065E-14 \\
\hline Te128 & $1.527 \mathrm{E}+03$ & $1.527 \mathrm{E}+03$ & $1.527 \mathrm{E}+03$ & $1.527 \mathrm{E}+03$ \\
\hline Te129 (100\% to I129) & $2.410 \mathrm{E}-35$ & $1.286 \mathrm{E}-38$ & $3.660 \mathrm{E}-45$ & $1.042 \mathrm{E}-51$ \\
\hline $\begin{array}{l}\text { Te129m (65\% to Te129, } \\
\text { 35\% to I129) }\end{array}$ & $2.573 \mathrm{E}-32$ & 1.373E-35 & 3.909E-42 & 1.113E-48 \\
\hline Te130 & $4.897 \mathrm{E}+03$ & $4.897 E+03$ & $4.897 \mathrm{E}+03$ & $4.897 E+03$ \\
\hline $\begin{array}{l}\text { l127+ } \\
\text { Sb127/Te127m/Te127 } \\
\text { decay }\end{array}$ & 1.306E-04 & $1.306 \mathrm{E}-04$ & 1.306E-04 & 1.306E-04 \\
\hline 1129 & $5.957 \mathrm{E}-16$ & 5.957E-16 & 5.957E-16 & 5.957E-16 \\
\hline Xe127 & $2.440 \mathrm{E}-51$ & $2.334 \mathrm{E}-54$ & $2.136 \mathrm{E}-60$ & $1.954 \mathrm{E}-66$ \\
\hline
\end{tabular}


Table E-1 (continued)

\begin{tabular}{|c|c|c|c|c|}
\hline Isotope & 5 Years & 30 Years & 100 Years & 500 Years \\
\hline Xe128 & 7.347E-15 & 7.347E-15 & 7.347E-15 & $7.347 \mathrm{E}-15$ \\
\hline Xe129 & $5.441 \mathrm{E}-17$ & $5.441 \mathrm{E}-17$ & $5.441 \mathrm{E}-17$ & $5.441 \mathrm{E}-17$ \\
\hline Xe130 & $2.406 \mathrm{E}-14$ & $2.406 \mathrm{E}-14$ & $2.406 \mathrm{E}-14$ & $2.406 \mathrm{E}-14$ \\
\hline Xe131 + I131 decay & $5.875 \mathrm{E}-13$ & 5.875E-13 & $5.875 \mathrm{E}-13$ & $5.875 \mathrm{E}-13$ \\
\hline Xe132 & 1.825E-12 & $1.825 \mathrm{E}-12$ & $1.825 \mathrm{E}-12$ & $1.825 \mathrm{E}-12$ \\
\hline Xe134 & $2.346 \mathrm{E}-12$ & $2.346 \mathrm{E}-12$ & $2.346 \mathrm{E}-12$ & $2.346 \mathrm{E}-12$ \\
\hline Xe136 & 3.540E-12 & $3.540 \mathrm{E}-12$ & $3.540 \mathrm{E}-12$ & $3.540 \mathrm{E}-12$ \\
\hline $\begin{array}{l}\text { Cs133 + Xe133/Xe133m } \\
\text { decay }\end{array}$ & $1.215 \mathrm{E}+04$ & $1.215 \mathrm{E}+04$ & $1.215 \mathrm{E}+04$ & $1.215 \mathrm{E}+04$ \\
\hline Cs134 & $5.959 E+01$ & $4.258 \mathrm{E}+01$ & $2.174 \mathrm{E}+01$ & $1.110 \mathrm{E}+01$ \\
\hline Cs135 & $4.930 \mathrm{E}+03$ & $4.930 \mathrm{E}+03$ & $4.930 \mathrm{E}+03$ & $4.930 \mathrm{E}+03$ \\
\hline $\begin{array}{l}\text { Cs137 (94.4\% to } \\
\text { Ba137m, 5.6\% to Ba137) }\end{array}$ & $1.077 \mathrm{E}+04$ & $1.052 \mathrm{E}+04$ & $1.005 \mathrm{E}+04$ & $9.593 \mathrm{E}+03$ \\
\hline Ba132 & $2.956 \mathrm{E}-08$ & $2.956 \mathrm{E}-08$ & $2.956 \mathrm{E}-08$ & $2.956 \mathrm{E}-08$ \\
\hline Ba134 & $2.603 E+02$ & $2.773 \mathrm{E}+02$ & $2.981 \mathrm{E}+02$ & $3.088 \mathrm{E}+02$ \\
\hline Ba135 & 7.440E-03 & $8.925 \mathrm{E}-03$ & $1.190 \mathrm{E}-02$ & $1.487 \mathrm{E}-02$ \\
\hline Ba136 + Cs136 decay & $4.149 \mathrm{E}-04$ & 4.149E-04 & 4.149E-04 & 4.149E-04 \\
\hline Ba137 & $1.319 \mathrm{E}+03$ & $1.565 E+03$ & $2.040 \mathrm{E}+03$ & $2.494 \mathrm{E}+03$ \\
\hline $\begin{array}{l}\text { Ba137m (100\% to } \\
\text { Ba137) }\end{array}$ & 1.644E-03 & 1.606E-03 & 1.534E-03 & 1.465E-03 \\
\hline Ba138 & 1.840E-02 & 1.840E-02 & 1.840E-02 & $1.840 \mathrm{E}-02$ \\
\hline La138 & $7.278 \mathrm{E}-02$ & $7.278 \mathrm{E}-02$ & $7.278 \mathrm{E}-02$ & $7.278 \mathrm{E}-02$ \\
\hline La139 & $1.750 \mathrm{E}+04$ & $1.750 \mathrm{E}+04$ & $1.750 \mathrm{E}+04$ & $1.750 \mathrm{E}+04$ \\
\hline Ce140 & $1.815 \mathrm{E}+04$ & $1.815 \mathrm{E}+04$ & $1.815 \mathrm{E}+04$ & $1.815 \mathrm{E}+04$ \\
\hline Ce142 & $1.620 \mathrm{E}+04$ & $1.620 \mathrm{E}+04$ & $1.620 \mathrm{E}+04$ & $1.620 \mathrm{E}+04$ \\
\hline $\begin{array}{l}\text { Ce144 (1.2\% to Pr144m, } \\
98.8 \% \text { to } \operatorname{Pr} 144)\end{array}$ & $4.822 \mathrm{E}-01$ & $1.979 \mathrm{E}-01$ & 3.334E-02 & 5.616E-03 \\
\hline Pr141 + Ce144 decay & $1.599 \mathrm{E}+04$ & $1.599 E+04$ & $1.599 \mathrm{E}+04$ & $1.599 \mathrm{E}+04$ \\
\hline Pr144 (100\% to Nd144) & $2.036 \mathrm{E}-05$ & $8.356 \mathrm{E}-06$ & $1.408 \mathrm{E}-06$ & $2.371 \mathrm{E}-07$ \\
\hline $\begin{array}{l}\text { Pr144m }(99.93 \% \text { to } \\
\text { Pr144, } 0.07 \% \text { to Nd144) }\end{array}$ & 1.017E-07 & 4.176E-08 & 7.034E-09 & 1.185E-09 \\
\hline $\begin{array}{l}\text { Nd142 + Sm146/Pm146 } \\
\text { decay }\end{array}$ & $4.913 E+02$ & $4.913 \mathrm{E}+02$ & $4.913 \mathrm{E}+02$ & $4.913 \mathrm{E}+02$ \\
\hline $\mathrm{Nd} 143$ & $1.054 \mathrm{E}+04$ & $1.054 \mathrm{E}+04$ & $1.054 \mathrm{E}+04$ & $1.054 \mathrm{E}+04$ \\
\hline Nd144 & $1.957 \mathrm{E}+04$ & $1.957 \mathrm{E}+04$ & 1.957E+04 & $1.957 \mathrm{E}+04$ \\
\hline Nd145 & $9.247 \mathrm{E}+03$ & $9.247 \mathrm{E}+03$ & $9.247 \mathrm{E}+03$ & $9.247 \mathrm{E}+03$ \\
\hline Nd146 + Pm146 decay & $1.033 \mathrm{E}+04$ & $1.033 E+04$ & $1.033 \mathrm{E}+04$ & $1.033 E+04$ \\
\hline Nd148 & $5.323 \mathrm{E}+03$ & $5.323 \mathrm{E}+03$ & $5.323 \mathrm{E}+03$ & $5.323 \mathrm{E}+03$ \\
\hline Nd150 & $2.583 \mathrm{E}+03$ & $2.583 E+03$ & $2.583 \mathrm{E}+03$ & $2.583 E+03$ \\
\hline Pm146 & 2.403E-02 & $2.118 \mathrm{E}-02$ & 1.646E-02 & $1.279 \mathrm{E}-02$ \\
\hline Pm147 & $1.027 \mathrm{E}+02$ & $7.887 E+01$ & $4.650 \mathrm{E}+01$ & $2.741 \mathrm{E}+01$ \\
\hline Pm148 & $2.440 \mathrm{E}-28$ & $5.301 \mathrm{E}-31$ & $2.503 \mathrm{E}-36$ & $1.182 \mathrm{E}-41$ \\
\hline $\mathrm{Pm} 148 \mathrm{~m}$ & 3.330E-26 & 7.237E-29 & 3.417E-34 & 1.614E-39 \\
\hline Sm146 & 1.250E-01 & 1.261E-01 & $1.278 \mathrm{E}-01$ & 1.292E-01 \\
\hline
\end{tabular}


Table E-1 (continued)

\begin{tabular}{|c|c|c|c|c|}
\hline Isotope & 5 Years & 30 Years & 100 Years & 500 Years \\
\hline Sm147 & $2.224 \mathrm{E}+03$ & $2.248 \mathrm{E}+03$ & $2.280 \mathrm{E}+03$ & $2.299 E+03$ \\
\hline $\begin{array}{l}\text { Sm148 + Pm148/148m } \\
\text { decay }\end{array}$ & $2.925 \mathrm{E}+03$ & $2.925 \mathrm{E}+03$ & $2.925 \mathrm{E}+03$ & $2.925 \mathrm{E}+03$ \\
\hline Sm149 & $4.155 \mathrm{E}+01$ & $4.155 \mathrm{E}+01$ & $4.155 \mathrm{E}+01$ & $4.155 E+01$ \\
\hline Sm150 & $4.501 \mathrm{E}+03$ & $4.501 \mathrm{E}+03$ & $4.501 \mathrm{E}+03$ & $4.501 \mathrm{E}+03$ \\
\hline Sm151 & $1.982 \mathrm{E}+02$ & $1.966 \mathrm{E}+02$ & $1.936 \mathrm{E}+02$ & $1.907 \mathrm{E}+02$ \\
\hline Sm152 & $1.670 \mathrm{E}+03$ & $1.670 \mathrm{E}+03$ & $1.670 \mathrm{E}+03$ & $1.670 \mathrm{E}+03$ \\
\hline Sm154 & $5.564 \mathrm{E}+02$ & $5.564 \mathrm{E}+02$ & $5.564 \mathrm{E}+02$ & $5.564 \mathrm{E}+02$ \\
\hline Eu150 & 3.841E-06 & 3.768E-06 & 3.626E-06 & 3.489E-06 \\
\hline Eu151 & 1.607E+01 & $1.759 \mathrm{E}+01$ & $2.060 \mathrm{E}+01$ & $2.356 \mathrm{E}+01$ \\
\hline $\begin{array}{l}\text { Eu152 (72.1\% to Sm152, } \\
27.9 \% \text { to Gd152) }\end{array}$ & 3.872E-01 & 3.679E-01 & 3.323E-01 & 3.001E-01 \\
\hline Eu153 & $1.840 \mathrm{E}+03$ & $1.840 \mathrm{E}+03$ & $1.840 \mathrm{E}+03$ & $1.840 \mathrm{E}+03$ \\
\hline Eu154 & $2.759 \mathrm{E}+02$ & $2.545 \mathrm{E}+02$ & $2.166 \mathrm{E}+02$ & $1.844 \mathrm{E}+02$ \\
\hline Eu155 & $5.956 \mathrm{E}+01$ & $5.179 \mathrm{E}+01$ & $3.916 \mathrm{E}+01$ & $2.961 \mathrm{E}+01$ \\
\hline Gd152 & 8.329E-01 & 8.383E-01 & $8.482 \mathrm{E}-01$ & $8.572 \mathrm{E}-01$ \\
\hline Gd153 & 1.892E-06 & $6.646 \mathrm{E}-07$ & $8.202 E-08$ & $1.012 \mathrm{E}-08$ \\
\hline Gd154 & $4.041 \mathrm{E}+02$ & $4.254 \mathrm{E}+02$ & $4.633 E+02$ & $4.956 \mathrm{E}+02$ \\
\hline Gd155 & $1.837 \mathrm{E}+02$ & $1.915 \mathrm{E}+02$ & $2.041 \mathrm{E}+02$ & $2.137 \mathrm{E}+02$ \\
\hline Gd156 & $1.182 \mathrm{E}+03$ & $1.182 E+03$ & $1.182 \mathrm{E}+03$ & $1.182 \mathrm{E}+03$ \\
\hline Gd157 & $1.795 \mathrm{E}+00$ & $1.795 \mathrm{E}+00$ & $1.795 \mathrm{E}+00$ & $1.795 \mathrm{E}+00$ \\
\hline Gd158 & $3.082 \mathrm{E}+02$ & $3.082 \mathrm{E}+02$ & $3.082 \mathrm{E}+02$ & $3.082 \mathrm{E}+02$ \\
\hline Gd160 & $1.963 \mathrm{E}+01$ & $1.963 E+01$ & $1.963 \mathrm{E}+01$ & $1.963 E+01$ \\
\hline TI207 & 1.192E-17 & 1.440E-17 & 1.946E-17 & $2.463 \mathrm{E}-17$ \\
\hline Tl208 & 3.590E-11 & $2.500 \mathrm{E}-11$ & 1.214E-11 & 5.904E-12 \\
\hline T1209 & $2.838 \mathrm{E}-16$ & $2.838 \mathrm{E}-16$ & $2.838 \mathrm{E}-16$ & 2.837E-16 \\
\hline Pb206 & 1.042E-10 & $1.786 \mathrm{E}-10$ & $4.169 \mathrm{E}-10$ & $8.021 \mathrm{E}-10$ \\
\hline Pb207 & 2.257E-12 & $3.265 \mathrm{E}-12$ & 5.861E-12 & 9.239E-12 \\
\hline $\mathrm{Pb} 208$ & 1.675E-04 & 1.774E-04 & 1.892E-04 & 1.949E-04 \\
\hline Pb209 & $1.222 \mathrm{E}-12$ & $1.222 \mathrm{E}-12$ & $1.222 \mathrm{E}-12$ & $1.222 \mathrm{E}-12$ \\
\hline $\mathrm{Pb} 210$ & 2.023E-09 & 2.884E-09 & 5.024E-09 & 7.694E-09 \\
\hline $\mathrm{Pb} 211$ & $9.223 \mathrm{E}-17$ & $1.114 \mathrm{E}-16$ & $1.505 \mathrm{E}-16$ & $1.905 \mathrm{E}-16$ \\
\hline $\mathrm{Pb} 212$ & 2.118E-08 & 1.475E-08 & 7.161E-09 & 3.483E-09 \\
\hline $\mathrm{Pb} 214$ & $6.378 \mathrm{E}-14$ & 7.652E-14 & 1.020E-13 & $1.274 \mathrm{E}-13$ \\
\hline Bi209 & 1.125E-08 & 1.351E-08 & 1.801E-08 & 2.250E-08 \\
\hline $\mathrm{Bi} 210$ & $1.246 \mathrm{E}-12$ & $1.775 \mathrm{E}-12$ & 3.093E-12 & 4.736E-12 \\
\hline $\mathrm{Bi} 210 \mathrm{~m}$ & $0.000 \mathrm{E}+00$ & $0.000 E+00$ & $0.000 \mathrm{E}+00$ & $0.000 E+00$ \\
\hline Bi211 & 5.441E-18 & $6.574 \mathrm{E}-18$ & 8.882E-18 & $1.124 \mathrm{E}-17$ \\
\hline $\mathrm{Bi} 212$ & 2.008E-09 & 1.398E-09 & 6.789E-10 & 3.302E-10 \\
\hline $\mathrm{Bi} 213$ & $2.871 \mathrm{E}-13$ & $2.871 \mathrm{E}-13$ & $2.871 \mathrm{E}-13$ & $2.870 \mathrm{E}-13$ \\
\hline Bi214 & $4.736 \mathrm{E}-14$ & 5.682E-14 & 7.573E-14 & 9.463E-14 \\
\hline Po210 & 3.495E-11 & 4.982E-11 & 8.680E-11 & $1.329 \mathrm{E}-10$ \\
\hline Po211 & $6.706 \mathrm{E}-23$ & $8.102 E-23$ & 1.095E-22 & $1.385 \mathrm{E}-22$ \\
\hline Po213 & 4.313E-22 & 4.312E-22 & 4.311E-22 & 4.311E-22 \\
\hline
\end{tabular}


Table E-1 (continued)

\begin{tabular}{|c|c|c|c|c|}
\hline Isotope & 5 Years & 30 Years & 100 Years & 500 Years \\
\hline Po214 & 6.517E-21 & $7.819 E-21$ & $1.042 \mathrm{E}-20$ & $1.302 \mathrm{E}-20$ \\
\hline Po215 & 7.723E-23 & $9.331 \mathrm{E}-23$ & $1.261 \mathrm{E}-22$ & 1.595E-22 \\
\hline Po216 & $8.446 \mathrm{E}-14$ & $5.883 \mathrm{E}-14$ & $2.856 \mathrm{E}-14$ & $1.389 \mathrm{E}-14$ \\
\hline Po218 & 7.394E-15 & $8.871 \mathrm{E}-15$ & 1.182E-14 & 1.477E-14 \\
\hline At217 & $3.450 \mathrm{E}-18$ & $3.450 \mathrm{E}-18$ & $3.449 \mathrm{E}-18$ & $3.449 \mathrm{E}-18$ \\
\hline Rn219 & 1.750E-19 & $2.115 \mathrm{E}-19$ & 2.857E-19 & 3.616E-19 \\
\hline Rn220 & $3.188 \mathrm{E}-11$ & $2.220 \mathrm{E}-11$ & $1.078 \mathrm{E}-11$ & $5.243 \mathrm{E}-12$ \\
\hline Rn222 & 1.360E-11 & 1.631E-11 & $2.174 \mathrm{E}-11$ & $2.716 \mathrm{E}-11$ \\
\hline Fr221 & $3.133 \mathrm{E}-14$ & $3.133 \mathrm{E}-14$ & $3.132 \mathrm{E}-14$ & $3.131 \mathrm{E}-14$ \\
\hline Fr223 & 8.123E-19 & 9.815E-19 & 1.326E-18 & $1.678 \mathrm{E}-18$ \\
\hline Ra223 & $4.452 \mathrm{E}-14$ & 5.379E-14 & $7.267 \mathrm{E}-14$ & $9.198 \mathrm{E}-14$ \\
\hline Ra224 & 1.856E-07 & 1.293E-07 & 6.277E-08 & 3.053E-08 \\
\hline Ra225 & $1.417 \mathrm{E}-10$ & $1.417 \mathrm{E}-10$ & $1.416 \mathrm{E}-10$ & $1.416 \mathrm{E}-10$ \\
\hline Ra226 & 2.115E-06 & $2.537 \mathrm{E}-06$ & 3.382E-06 & $4.225 \mathrm{E}-06$ \\
\hline Ra228 & $2.215 \mathrm{E}-12$ & $2.536 \mathrm{E}-12$ & $3.088 \mathrm{E}-12$ & 3.536E-12 \\
\hline Ac225 & $9.569 \mathrm{E}-11$ & $9.568 \mathrm{E}-11$ & $9.566 \mathrm{E}-11$ & $9.565 \mathrm{E}-11$ \\
\hline Ac227 & $3.147 \mathrm{E}-11$ & 3.802E-11 & $5.136 \mathrm{E}-11$ & $6.501 \mathrm{E}-11$ \\
\hline Ac228 & $2.312 \mathrm{E}-16$ & $2.647 \mathrm{E}-16$ & $3.223 \mathrm{E}-16$ & $3.690 \mathrm{E}-16$ \\
\hline Th227 & $7.321 \mathrm{E}-14$ & $8.846 \mathrm{E}-14$ & $1.195 \mathrm{E}-13$ & $1.512 \mathrm{E}-13$ \\
\hline Th228 & 3.589E-05 & 2.500E-05 & 1.213E-05 & 5.903E-06 \\
\hline Th229 & 2.611E-05 & 2.610E-05 & $2.610 \mathrm{E}-05$ & 2.609E-05 \\
\hline Th230 & 4.788E-02 & 4.788E-02 & 4.788E-02 & 4.788E-02 \\
\hline Th231 & 5.862E-11 & 5.863E-11 & 5.863E-11 & 5.864E-11 \\
\hline $\begin{array}{l}\text { Th232 + } \\
\text { U236/Pu240/Pu244 } \\
\text { decay }\end{array}$ & 1.171E-02 & 1.171E-02 & 1.171E-02 & 1.171E-02 \\
\hline Th234 & 2.519E-08 & 2.519E-08 & $2.519 \mathrm{E}-08$ & 2.519E-08 \\
\hline Pa231 & 3.614E-07 & 3.754E-07 & 4.033E-07 & 4.312E-07 \\
\hline Pa233 & 1.924E-10 & 2.727E-10 & 4.699E-10 & 7.117E-10 \\
\hline Pa234 & $3.793 \mathrm{E}-13$ & $3.793 \mathrm{E}-13$ & $3.793 \mathrm{E}-13$ & $3.793 \mathrm{E}-13$ \\
\hline Pa234m & 8.493E-13 & 8.493E-13 & 8.493E-13 & 8.493E-13 \\
\hline $\begin{array}{l}\text { U232 + Pu236/Np236 } \\
\text { decay }\end{array}$ & $1.778 \mathrm{E}-06$ & $1.761 \mathrm{E}-06$ & 1.727E-06 & 1.694E-06 \\
\hline U233 & 6.153E-06 & 6.155E-06 & 6.162E-06 & 6.173E-06 \\
\hline U234 & 4.016E-01 & 4.122E-01 & 4.334E-01 & 4.542E-01 \\
\hline U235 & $1.442 \mathrm{E}+01$ & $1.442 \mathrm{E}+01$ & $1.442 \mathrm{E}+01$ & $1.442 \mathrm{E}+01$ \\
\hline U236 & $1.076 \mathrm{E}+01$ & $1.076 \mathrm{E}+01$ & $1.077 \mathrm{E}+01$ & $1.077 \mathrm{E}+01$ \\
\hline U237 & 1.576E-07 & $1.502 \mathrm{E}-07$ & 1.364E-07 & $1.239 \mathrm{E}-07$ \\
\hline U238 & $1.735 \mathrm{E}+03$ & $1.735 \mathrm{E}+03$ & $1.735 \mathrm{E}+03$ & $1.735 \mathrm{E}+03$ \\
\hline U240 & $2.572 \mathrm{E}-15$ & $2.572 \mathrm{E}-15$ & $2.572 \mathrm{E}-15$ & $2.572 \mathrm{E}-15$ \\
\hline Np237 & 5.668E-03 & 8.033E-03 & 1.384E-02 & 2.096E-02 \\
\hline Np239 & $1.432 \mathrm{E}-21$ & 1.432E-21 & $1.431 \mathrm{E}-21$ & $1.431 \mathrm{E}-21$ \\
\hline $\mathrm{Np} 240 \mathrm{~m}$ & $2.251 \mathrm{E}-17$ & $2.251 \mathrm{E}-17$ & $2.251 \mathrm{E}-17$ & $2.251 \mathrm{E}-17$ \\
\hline Pu236 & $6.254 \mathrm{E}-12$ & 4.905E-12 & 3.016E-12 & $1.855 \mathrm{E}-12$ \\
\hline
\end{tabular}


Table E-1 (continued)

\begin{tabular}{|l|l|l|l|l|}
\hline \multicolumn{1}{|c|}{ Isotope } & \multicolumn{1}{|c|}{ 5 Years } & \multicolumn{1}{c|}{ 30 Years } & \multicolumn{1}{c|}{ 100 Years } & \multicolumn{1}{c|}{ 500 Years } \\
\hline Pu237 & $3.500 \mathrm{E}-31$ & $1.359 \mathrm{E}-33$ & $2.050 \mathrm{E}-38$ & $3.092 \mathrm{E}-43$ \\
\hline Pu238 & $1.382 \mathrm{E}+00$ & $1.372 \mathrm{E}+00$ & $1.350 \mathrm{E}+00$ & $1.329 \mathrm{E}+00$ \\
\hline Pu239 & $2.885 \mathrm{E}+01$ & $2.885 \mathrm{E}+01$ & $2.885 \mathrm{E}+01$ & $2.884 \mathrm{E}+01$ \\
\hline $\begin{array}{l}\text { Pu240 + Pu244/Cm244 } \\
\text { decay }\end{array}$ & $1.368 \mathrm{E}+01$ & $1.368 \mathrm{E}+01$ & $1.368 \mathrm{E}+01$ & $1.367 \mathrm{E}+01$ \\
\hline Pu241 & $5.094 \mathrm{E}+00$ & $4.855 \mathrm{E}+00$ & $4.410 \mathrm{E}+00$ & $4.005 \mathrm{E}+00$ \\
\hline Pu244 & $1.343 \mathrm{E}-04$ & $1.343 \mathrm{E}-04$ & $1.343 \mathrm{E}-04$ & $1.343 \mathrm{E}-04$ \\
\hline Am241 & $1.380 \mathrm{E}+00$ & $1.617 \mathrm{E}+00$ & $2.057 \mathrm{E}+00$ & $2.454 \mathrm{E}+00$ \\
\hline Am243 & $1.666 \mathrm{E}-15$ & $1.666 \mathrm{E}-15$ & $1.666 \mathrm{E}-15$ & $1.665 \mathrm{E}-15$ \\
\hline & & & & \\
\hline Total & $\mathbf{3 . 9 4 5 E + 0 5}$ & $\mathbf{3 . 9 4 5 E + 0 5}$ & $\mathbf{3 . 9 4 5 E + 0 5}$ & $\mathbf{3 . 9 4 5 E + 0 5}$ \\
\hline
\end{tabular}




\section{Appendix F}

\section{Isotopic Composition of Electrochemical Process}

Wastes 
Table F-1 Isotopic Composition of E-Chem Glass Bonded Zeolite from Reprocessing of Metal Fuel from SFRs with CR $=0.75$ and $100 \mathrm{GW}$-d/MT Burnup, at 5, 30, 100 and $500 \mathrm{yr}$ Out-of-Reactor.

\begin{tabular}{|l|l|l|l|l|}
\hline \multicolumn{1}{|c|}{ Isotope } & \multicolumn{1}{|c|}{ 5 Years } & \multicolumn{1}{c|}{ 30 Years } & \multicolumn{1}{c|}{ 100 Years } & \multicolumn{1}{c|}{ 500 Years } \\
\hline Sr86 + Rb86 decay & $7.479 \mathrm{E}+00$ & $7.479 \mathrm{E}+00$ & $7.479 \mathrm{E}+00$ & $7.479 \mathrm{E}+00$ \\
\hline Sr87 + Rb87 decay & $1.475 \mathrm{E}-01$ & $1.475 \mathrm{E}-01$ & $1.475 \mathrm{E}-01$ & $1.475 \mathrm{E}-01$ \\
\hline Sr88 & $5.754 \mathrm{E}+02$ & $5.754 \mathrm{E}+02$ & $5.754 \mathrm{E}+02$ & $5.754 \mathrm{E}+02$ \\
\hline Sr89 & $1.803 \mathrm{E}-14$ & $6.482 \mathrm{E}-69$ & $2.332 \mathrm{E}-221$ & $0.000 \mathrm{E}+00$ \\
\hline Sr90 (100\% to Y90) & $7.146 \mathrm{E}+02$ & $3.942 \mathrm{E}+02$ & $7.449 \mathrm{E}+01$ & $5.464 \mathrm{E}-03$ \\
\hline Y89+ Sr89 decay & $1.396 \mathrm{E}-03$ & $1.396 \mathrm{E}-03$ & $1.396 \mathrm{E}-03$ & $1.396 \mathrm{E}-03$ \\
\hline Y90 (Sr90 progeny) & $1.792 \mathrm{E}-01$ & $9.885 \mathrm{E}-02$ & $1.868 \mathrm{E}-02$ & $1.370 \mathrm{E}-06$ \\
\hline Zr90 + Sr90/Y90 decay & $9.013 \mathrm{E}+01$ & $4.107 \mathrm{E}+02$ & $7.304 \mathrm{E}+02$ & $8.049 \mathrm{E}+02$ \\
\hline $\begin{array}{l}\text { I127+ } \\
\text { Sb127/Te127m/Te127 } \\
\text { decay }\end{array}$ & $2.591 \mathrm{E}+02$ & $2.591 \mathrm{E}+02$ & $2.591 \mathrm{E}+02$ & $2.591 \mathrm{E}+02$ \\
\hline I129 & & & & \\
\hline Xe129 & $7.835 \mathrm{E}+02$ & $7.835 \mathrm{E}+02$ & $7.835 \mathrm{E}+02$ & $7.835 \mathrm{E}+02$ \\
\hline $\begin{array}{l}\text { Cs133 + Xe133/Xe133m } \\
\text { decay }\end{array}$ & $1.730 \mathrm{E}-04$ & $1.038 \mathrm{E}-03$ & $3.459 \mathrm{E}-03$ & $1.730 \mathrm{E}-02$ \\
\hline Cs134 & $3.759 \mathrm{E}+03$ & $3.759 \mathrm{E}+03$ & $3.759 \mathrm{E}+03$ & $3.759 \mathrm{E}+03$ \\
\hline Cs135 & $9.054 \mathrm{E}+00$ & $2.031 \mathrm{E}-03$ & $1.232 \mathrm{E}-13$ & $5.081 \mathrm{E}-72$ \\
\hline $\begin{array}{l}\text { Cs137 (94.4\% to } \\
\text { Ba137m, 5.6\% to Ba137) }\end{array}$ & $3.171 \mathrm{E}+03$ & $1.780 \mathrm{E}+03$ & $3.531 \mathrm{E}+02$ & $3.419 \mathrm{E}-02$ \\
\hline Ba134 & $1.430 \mathrm{E}+02$ & $1.521 \mathrm{E}+02$ & $1.521 \mathrm{E}+02$ & $1.521 \mathrm{E}+02$ \\
\hline Ba135 & $8.131 \mathrm{E}-02$ & $1.133 \mathrm{E}-01$ & $2.029 \mathrm{E}-01$ & $7.149 \mathrm{E}-01$ \\
\hline Ba136 + Cs136 decay & $1.847 \mathrm{E}+02$ & $1.847 \mathrm{E}+02$ & $1.847 \mathrm{E}+02$ & $1.847 \mathrm{E}+02$ \\
\hline Ba137 & $7.618 \mathrm{E}+02$ & $2.153 \mathrm{E}+03$ & $3.580 \mathrm{E}+03$ & $3.933 \mathrm{E}+03$ \\
\hline $\begin{array}{l}\text { Ba137m (100\% to } \\
\text { Ba137) }\end{array}$ & $4.842 \mathrm{E}-04$ & $2.717 \mathrm{E}-04$ & $5.391 \mathrm{E}-05$ & $5.220 \mathrm{E}-09$ \\
\hline Ba138 & $3.835 \mathrm{E}+03$ & $3.835 \mathrm{E}+03$ & $3.835 \mathrm{E}+03$ & $3.835 \mathrm{E}+03$ \\
\hline Total & & & & $\mathbf{1 . 9 1 8 E + 0 4}$ \\
\hline
\end{tabular}


Table F-2 Isotopic Composition of E-Chem Lanthanide Glass from Reprocessing of Metal Fuel from SFRs with CR = 0.75 and $100 \mathrm{GW}-\mathrm{d} / \mathrm{MT}$ Burnup, at 5, 30, 100 and 500 yr Out-ofReactor.

\begin{tabular}{|c|c|c|c|c|}
\hline Isotope & 5 Years & 30 Years & 100 Years & 500 Years \\
\hline He4 + actinide decay & 5.578E-04 & $2.635 \mathrm{E}-03$ & 5.940E-03 & $1.457 \mathrm{E}-02$ \\
\hline Cr52 & $6.147 \mathrm{E}+05$ & $6.147 E+05$ & $6.147 \mathrm{E}+05$ & $6.147 E+05$ \\
\hline Fe56 & $2.152 E+06$ & $2.152 E+06$ & $2.152 \mathrm{E}+06$ & $2.152 E+06$ \\
\hline Ni58 & $3.074 \mathrm{E}+05$ & $3.074 \mathrm{E}+05$ & $3.074 \mathrm{E}+05$ & $3.074 \mathrm{E}+05$ \\
\hline Rb85 + Kr85 decay & 8.443E-03 & 8.443E-03 & 8.443E-03 & 8.443E-03 \\
\hline $\mathrm{Rb87}$ & 1.899E-02 & 1.899E-02 & 1.899E-02 & 1.899E-02 \\
\hline Sr86 + Rb86 decay & 3.215E-04 & 3.215E-04 & 3.215E-04 & 3.215E-04 \\
\hline Sr87 + Rb87 decay & 6.338E-06 & $6.338 \mathrm{E}-06$ & $6.338 \mathrm{E}-06$ & $6.338 \mathrm{E}-06$ \\
\hline Sr88 & 2.473E-02 & $2.473 \mathrm{E}-02$ & 2.473E-02 & 2.473E-02 \\
\hline Sr89 & $7.750 \mathrm{E}-19$ & $2.786 \mathrm{E}-73$ & $1.002 E-225$ & $0.000 \mathrm{E}+00$ \\
\hline Sr90 (100\% to Y90) & 3.072E-02 & 1.694E-02 & $3.202 E-03$ & $2.349 \mathrm{E}-07$ \\
\hline Y89 + Sr89 decay & 3.244E-02 & $3.244 \mathrm{E}-02$ & $3.244 \mathrm{E}-02$ & 3.244E-02 \\
\hline Y90 (Sr90 progeny) & 7.704E-06 & 4.249E-06 & 8.030E-07 & 5.890E-11 \\
\hline Y91 & $1.535 \mathrm{E}-16$ & $1.626 \mathrm{E}-63$ & 4.802E-195 & $0.000 \mathrm{E}+00$ \\
\hline Zr90 + Sr90/Y90 decay & 3.883E-03 & 1.766E-02 & 3.141E-02 & $3.461 \mathrm{E}-02$ \\
\hline Zr91 + Y91 decay & 3.811E-07 & 3.811E-07 & 3.811E-07 & 3.811E-07 \\
\hline $\begin{array}{l}\text { Nb93 + Zr93/Nb93m } \\
\text { decay }\end{array}$ & 9.509E-04 & $2.174 \mathrm{E}-03$ & $2.636 \mathrm{E}-03$ & $2.650 \mathrm{E}-03$ \\
\hline Nb93m (100\% to Nb93) & 1.699E-03 & 4.750E-04 & $1.341 \mathrm{E}-05$ & $1.878 \mathrm{E}-14$ \\
\hline $\mathrm{Nb94}$ & 6.509E-03 & 6.504E-03 & 6.488E-03 & $6.400 \mathrm{E}-03$ \\
\hline Nb95 (100\% to Mo95) & $8.391 \mathrm{E}-18$ & $5.434 \mathrm{E}-96$ & $0.000 \mathrm{E}+00$ & $0.000 \mathrm{E}+00$ \\
\hline $\begin{array}{l}\mathrm{Nb95m}(94.4 \% \text { to } \mathrm{Nb95}, \\
5.6 \% \text { to Mo95) }\end{array}$ & $1.006 \mathrm{E}-157$ & $0.000 \mathrm{E}+00$ & $0.000 \mathrm{E}+00$ & $0.000 \mathrm{E}+00$ \\
\hline Mo94 + Nb94 decay & $1.111 \mathrm{E}-06$ & $6.665 \mathrm{E}-06$ & $2.219 \mathrm{E}-05$ & $1.102 \mathrm{E}-04$ \\
\hline $\begin{array}{l}\text { Mo95 + } \\
\text { Zr95/Nb95m/Nb95 decay }\end{array}$ & $1.531 \mathrm{E}+03$ & $1.531 \mathrm{E}+03$ & $1.531 \mathrm{E}+03$ & $1.531 \mathrm{E}+03$ \\
\hline Mo96 & $4.676 \mathrm{E}+01$ & $4.676 \mathrm{E}+01$ & $4.676 \mathrm{E}+01$ & $4.676 \mathrm{E}+01$ \\
\hline Mo97 & $1.712 \mathrm{E}+03$ & $1.712 \mathrm{E}+03$ & $1.712 \mathrm{E}+03$ & $1.712 \mathrm{E}+03$ \\
\hline Mo98 & $1.922 \mathrm{E}+03$ & $1.922 \mathrm{E}+03$ & $1.922 \mathrm{E}+03$ & $1.922 \mathrm{E}+03$ \\
\hline Mo99 & $0.000 \mathrm{E}+00$ & $0.000 \mathrm{E}+00$ & $0.000 \mathrm{E}+00$ & $0.000 \mathrm{E}+00$ \\
\hline Mo100 & $2.199 \mathrm{E}+03$ & $2.199 \mathrm{E}+03$ & $2.199 \mathrm{E}+03$ & $2.199 \mathrm{E}+03$ \\
\hline Tc99 & $1.950 \mathrm{E}+03$ & $1.950 \mathrm{E}+03$ & $1.949 \mathrm{E}+03$ & $1.947 \mathrm{E}+03$ \\
\hline Ru99 + Tc99 decay & $5.854 \mathrm{E}-02$ & $2.171 \mathrm{E}-01$ & $6.612 \mathrm{E}-01$ & $3.197 \mathrm{E}+00$ \\
\hline Ru100 & $8.613 \mathrm{E}+01$ & $8.613 E+01$ & $8.613 E+01$ & $8.613 E+01$ \\
\hline Ru101 & $2.068 \mathrm{E}+03$ & $2.068 \mathrm{E}+03$ & $2.068 \mathrm{E}+03$ & $2.068 \mathrm{E}+03$ \\
\hline Ru102 & $2.511 \mathrm{E}+03$ & $2.511 \mathrm{E}+03$ & $2.511 \mathrm{E}+03$ & $2.511 \mathrm{E}+03$ \\
\hline $\begin{array}{l}\text { Ru103 (9.94\% to Rh103, } \\
90.06 \% \text { to } \mathrm{Rh} 103 \mathrm{~m})\end{array}$ & $2.278 \mathrm{E}-18$ & $2.466 \mathrm{E}-88$ & $3.080 \mathrm{E}-284$ & $0.000 \mathrm{E}+00$ \\
\hline Ru104 & $2.261 \mathrm{E}+03$ & $2.261 \mathrm{E}+03$ & $2.261 \mathrm{E}+03$ & $2.261 \mathrm{E}+03$ \\
\hline Ru106 (100\% to Rh106) & $3.761 \mathrm{E}+00$ & $1.286 \mathrm{E}-07$ & $1.602 \mathrm{E}-28$ & 5.615E-148 \\
\hline $\begin{array}{l}\text { Rh103 + Ru103/Rh103m } \\
\text { decay }\end{array}$ & $2.419 \mathrm{E}+03$ & $2.419 \mathrm{E}+03$ & $2.419 \mathrm{E}+03$ & $2.419 \mathrm{E}+03$ \\
\hline
\end{tabular}


Table F-2 (continued)

\begin{tabular}{|c|c|c|c|c|}
\hline Isotope & 5 Years & 30 Years & 100 Years & 500 Years \\
\hline Rh103m & $2.035 E-21$ & $2.203 E-91$ & $2.751 \mathrm{E}-287$ & $0.000 \mathrm{E}+00$ \\
\hline Rh106 (100\% to Pd106) & 3.535E-06 & $1.209 \mathrm{E}-13$ & 1.506E-34 & $5.278 \mathrm{E}-154$ \\
\hline Pd104 & $1.416 \mathrm{E}-02$ & $1.416 \mathrm{E}-02$ & $1.416 \mathrm{E}-02$ & $1.416 \mathrm{E}-02$ \\
\hline Pd105 + Rh105 decay & $1.659 \mathrm{E}+03$ & $1.659 \mathrm{E}+03$ & $1.659 \mathrm{E}+03$ & $1.659 \mathrm{E}+03$ \\
\hline $\begin{array}{l}\text { Pd106 + Ru106/Rh106 } \\
\text { decay }\end{array}$ & $1.700 \mathrm{E}+03$ & $1.703 E+03$ & $1.703 \mathrm{E}+03$ & $1.703 E+03$ \\
\hline Pd107 & $9.785 \mathrm{E}+02$ & $9.785 \mathrm{E}+02$ & $9.785 \mathrm{E}+02$ & $9.784 \mathrm{E}+02$ \\
\hline Pd108 & $8.271 E+02$ & $8.271 \mathrm{E}+02$ & $8.271 E+02$ & $8.271 E+02$ \\
\hline Pd110 & $2.251 \mathrm{E}+02$ & $2.251 \mathrm{E}+02$ & $2.251 \mathrm{E}+02$ & $2.251 \mathrm{E}+02$ \\
\hline Ag107 + Pd107 decay & $9.714 \mathrm{E}-04$ & $3.581 \mathrm{E}-03$ & 1.089E-02 & $5.265 \mathrm{E}-02$ \\
\hline Ag108 & $3.242 \mathrm{E}-14$ & $2.828 \mathrm{E}-14$ & 1.930E-14 & $2.177 \mathrm{E}-15$ \\
\hline $\mathrm{Ag} 108 \mathrm{~m}$ (8.7\% to $\mathrm{Ag} 108)$ & $1.050 \mathrm{E}-05$ & 9.164E-06 & 6.255E-06 & 7.053E-07 \\
\hline $\begin{array}{l}\text { Ag109 + Cd109/Ag109m } \\
\text { decay }\end{array}$ & $5.271 \mathrm{E}+02$ & $5.271 E+02$ & $5.271 E+02$ & $5.271 E+02$ \\
\hline Ag109m & $5.068 \mathrm{E}-15$ & $6.036 \mathrm{E}-21$ & $1.560 \mathrm{E}-37$ & $2.555 \mathrm{E}-132$ \\
\hline Ag110 & $6.457 \mathrm{E}-12$ & $6.429 \mathrm{E}-23$ & 1.006E-53 & $9.375 \mathrm{E}-230$ \\
\hline $\begin{array}{l}\text { Ag110m (1.36\% to } \\
\text { Ag110) }\end{array}$ & 4.167E-04 & $4.148 \mathrm{E}-15$ & 6.494E-46 & $6.050 \mathrm{E}-222$ \\
\hline Cd108 & 2.169E-05 & 2.303E-05 & 2.594E-05 & 3.149E-05 \\
\hline Cd109 & 5.130E-09 & $6.109 \mathrm{E}-15$ & 1.579E-31 & $2.586 \mathrm{E}-126$ \\
\hline Cd110 + Ag110m decay & $4.919 \mathrm{E}+01$ & $4.919 \mathrm{E}+01$ & $4.919 \mathrm{E}+01$ & $4.919 \mathrm{E}+01$ \\
\hline Cd111 + Ag111 decay & $1.173 E+02$ & $1.173 E+02$ & $1.173 E+02$ & $1.173 E+02$ \\
\hline Cd112 + Pd112 decay & $8.134 \mathrm{E}+01$ & $8.134 \mathrm{E}+01$ & $8.134 \mathrm{E}+01$ & $8.134 \mathrm{E}+01$ \\
\hline Cd113 (100\% to $\operatorname{In} 113)$ & $4.172 E+01$ & $4.173 E+01$ & $4.173 E+01$ & $4.173 E+01$ \\
\hline $\begin{array}{l}\text { Cd113m }(0.14 \% \text { to } \\
\text { Cd113, } 99.86 \% \text { to } \ln 113)\end{array}$ & $1.885 \mathrm{E}+00$ & $5.745 \mathrm{E}-01$ & 2.063E-02 & 1.144E-10 \\
\hline Cd114 & $3.848 \mathrm{E}+01$ & $3.848 \mathrm{E}+01$ & $3.848 \mathrm{E}+01$ & $3.848 \mathrm{E}+01$ \\
\hline Cd115m & $8.492 \mathrm{E}-19$ & $1.947 \mathrm{E}-80$ & 4.997E-253 & $0.000 \mathrm{E}+00$ \\
\hline Cd116 & $2.316 \mathrm{E}+01$ & $2.316 \mathrm{E}+01$ & $2.316 \mathrm{E}+01$ & $2.316 \mathrm{E}+01$ \\
\hline $\begin{array}{l}\text { In113 + Cd113/Cd113m } \\
\text { decay }\end{array}$ & 5.049E-01 & $1.814 \mathrm{E}+00$ & $2.367 \mathrm{E}+00$ & $2.387 \mathrm{E}+00$ \\
\hline $\ln 115$ & 1.807E-06 & 1.807E-06 & 1.807E-06 & $1.807 \mathrm{E}-06$ \\
\hline $\ln 115 \mathrm{~m}$ & $2.398 \mathrm{E}-25$ & 5.499E-87 & $1.411 \mathrm{E}-259$ & $0.000 \mathrm{E}+00$ \\
\hline Sn114 + In114m decay & 1.229E-02 & 1.229E-02 & 1.229E-02 & $1.229 \mathrm{E}-02$ \\
\hline $\begin{array}{l}\text { Sn115 + In115/Cd115 } \\
\text { decay }\end{array}$ & 9.066E-01 & 9.066E-01 & $9.066 \mathrm{E}-01$ & 9.066E-01 \\
\hline Sn116 & $2.030 \mathrm{E}+00$ & $2.030 \mathrm{E}+00$ & $2.030 \mathrm{E}+00$ & $2.030 \mathrm{E}+00$ \\
\hline Sn117 + Sn117m decay & $2.274 \mathrm{E}+01$ & $2.274 \mathrm{E}+01$ & $2.274 \mathrm{E}+01$ & $2.274 \mathrm{E}+01$ \\
\hline Sn118 & $2.436 \mathrm{E}+01$ & $2.436 \mathrm{E}+01$ & $2.436 \mathrm{E}+01$ & $2.436 \mathrm{E}+01$ \\
\hline Sn119 + Sn119m decay & $2.324 \mathrm{E}+01$ & $2.324 \mathrm{E}+01$ & $2.324 \mathrm{E}+01$ & $2.324 \mathrm{E}+01$ \\
\hline Sn119m & 1.336E-04 & 8.092E-16 & $3.150 \mathrm{E}-47$ & $1.032 \mathrm{E}-226$ \\
\hline Sn120 & $2.422 \mathrm{E}+01$ & $2.422 \mathrm{E}+01$ & $2.422 \mathrm{E}+01$ & $2.422 \mathrm{E}+01$ \\
\hline Sn121 (100\% to Sb121) & $2.219 \mathrm{E}-06$ & $1.569 \mathrm{E}-06$ & 5.943E-07 & 2.315E-09 \\
\hline $\begin{array}{l}\text { Sn121m (77.6\% to } \\
\text { Sn121, 22.4\% to Sb121) }\end{array}$ & 4.674E-02 & 3.305E-02 & $1.252 \mathrm{E}-02$ & 4.877E-05 \\
\hline
\end{tabular}


Table F-2 (continued)

\begin{tabular}{|c|c|c|c|c|}
\hline Isotope & 5 Years & 30 Years & 100 Years & 500 Years \\
\hline Sn122 & $2.721 \mathrm{E}+01$ & $2.721 \mathrm{E}+01$ & $2.721 \mathrm{E}+01$ & $2.721 E+01$ \\
\hline Sn123 (100\% to Sb123) & 1.946E-06 & $1.019 \mathrm{E}-27$ & $2.641 \mathrm{E}-87$ & $0.000 \mathrm{E}+00$ \\
\hline Sn124 & $4.328 \mathrm{E}+01$ & $4.328 \mathrm{E}+01$ & $4.328 \mathrm{E}+01$ & $4.328 \mathrm{E}+01$ \\
\hline $\begin{array}{l}\text { Sn126 }(100 \% \text { to } \\
\text { Sb126m) }\end{array}$ & $1.060 \mathrm{E}+02$ & $1.059 \mathrm{E}+02$ & $1.059 \mathrm{E}+02$ & $1.056 \mathrm{E}+02$ \\
\hline Sb121 & 3.354E-03 & 1.705E-02 & $3.758 \mathrm{E}-02$ & 5.005E-02 \\
\hline Sb123 & $3.510 \mathrm{E}-02$ & $3.510 \mathrm{E}-02$ & $3.510 \mathrm{E}-02$ & 3.510E-02 \\
\hline Sb126 (100\% to Te126) & 5.034E-06 & 5.033E-06 & 5.030E-06 & 5.016E-06 \\
\hline $\begin{array}{l}\text { Sb126m (14\% to Sb126, } \\
86 \% \text { to Te126) }\end{array}$ & 3.827E-08 & 3.827E-08 & 3.825E-08 & 3.814E-08 \\
\hline Te122 + Sb122 decay & 9.826E-01 & 9.826E-01 & 9.826E-01 & 9.826E-01 \\
\hline Te123 + Te123m decay & 1.420E-02 & 1.420E-02 & 1.420E-02 & 1.420E-02 \\
\hline Te123m & $4.455 \mathrm{E}-10$ & $4.773 E-33$ & $2.304 \mathrm{E}-97$ & $0.000 E+00$ \\
\hline $\begin{array}{l}\text { Te124 + Sb124/Sb124m } \\
\text { decay }\end{array}$ & $1.144 \mathrm{E}+00$ & $1.144 \mathrm{E}+00$ & $1.144 \mathrm{E}+00$ & $1.144 \mathrm{E}+00$ \\
\hline $\begin{array}{l}\text { Te125 + Sb125/Te125m } \\
\text { decay }\end{array}$ & $4.642 \mathrm{E}+01$ & $4.642 \mathrm{E}+01$ & $4.642 \mathrm{E}+01$ & $4.642 \mathrm{E}+01$ \\
\hline $\begin{array}{l}\text { Te125M (100\% to } \\
\text { Te125) }\end{array}$ & 1.208E-10 & 4.964E-58 & 1.035E-190 & $0.000 \mathrm{E}+00$ \\
\hline $\begin{array}{l}\text { Te126 + } \\
\text { Sn126/Sb126m/Sb126 } \\
\text { decay }\end{array}$ & $5.965 E+00$ & $5.984 \mathrm{E}+00$ & $6.035 E+00$ & $6.328 \mathrm{E}+00$ \\
\hline Te127 (100\% to I127) & $9.609 \mathrm{E}-10$ & $5.820 \mathrm{E}-35$ & 1.430E-105 & $0.000 \mathrm{E}+00$ \\
\hline $\begin{array}{l}\text { Te127m ( } 97.6 \% \text { to } \\
\text { Te127, } 2.4 \% \text { to I127) }\end{array}$ & $2.744 \mathrm{E}-07$ & $1.662 \mathrm{E}-32$ & $4.084 \mathrm{E}-103$ & $0.000 \mathrm{E}+00$ \\
\hline Te128 & $3.369 \mathrm{E}+02$ & $3.369 \mathrm{E}+02$ & $3.369 \mathrm{E}+02$ & $3.369 \mathrm{E}+02$ \\
\hline Te129 (100\% to I129) & $4.435 \mathrm{E}-26$ & $6.703 E-108$ & $0.000 \mathrm{E}+00$ & $0.000 \mathrm{E}+00$ \\
\hline $\begin{array}{l}\text { Te129m (65\% to Te129, } \\
\text { 35\% to I129) }\end{array}$ & $4.736 \mathrm{E}-23$ & $7.158 \mathrm{E}-105$ & $0.000 E+00$ & $0.000 \mathrm{E}+00$ \\
\hline Te130 & $1.005 \mathrm{E}+03$ & $1.005 \mathrm{E}+03$ & $1.005 \mathrm{E}+03$ & $1.005 \mathrm{E}+03$ \\
\hline $\begin{array}{l}\text { I127+ } \\
\text { Sb127/Te127m/Te127 } \\
\text { decay }\end{array}$ & $4.158 \mathrm{E}-02$ & $4.158 \mathrm{E}-02$ & $4.158 \mathrm{E}-02$ & $4.158 \mathrm{E}-02$ \\
\hline 1129 & 3.368E-02 & 3.368E-02 & 3.368E-02 & 3.368E-02 \\
\hline Xe129 & 7.435E-09 & $4.461 \mathrm{E}-08$ & 1.487E-07 & 7.435E-07 \\
\hline $\begin{array}{l}\text { Cs133 + Xe133/Xe133m } \\
\text { decay }\end{array}$ & 1.616E-01 & 1.616E-01 & 1.616E-01 & 1.616E-01 \\
\hline Cs134 & 3.892E-04 & 8.732E-08 & 5.294E-18 & $2.184 \mathrm{E}-76$ \\
\hline Cs135 & 1.826E-01 & 1.826E-01 & 1.826E-01 & $1.826 \mathrm{E}-01$ \\
\hline $\begin{array}{l}\text { Cs137 (94.4\% to } \\
\text { Ba137m, 5.6\% to Ba137) }\end{array}$ & 1.363E-01 & 7.650E-02 & 1.518E-02 & $1.470 \mathrm{E}-06$ \\
\hline Ba134 & $6.148 \mathrm{E}-03$ & 6.537E-03 & 6.537E-03 & $6.537 \mathrm{E}-03$ \\
\hline Ba135 & 3.495E-06 & 4.871E-06 & 8.723E-06 & 3.073E-05 \\
\hline Ba136 + Cs136 decay & 7.939E-03 & 7.939E-03 & 7.939E-03 & 7.939E-03 \\
\hline Ba137 & $3.275 \mathrm{E}-02$ & 9.256E-02 & 1.539E-01 & 1.691E-01 \\
\hline Ba137m (100\% to & 2.081E-08 & 1.168E-08 & 2.317E-09 & $2.244 \mathrm{E}-13$ \\
\hline
\end{tabular}


Table F-2 (continued)

\begin{tabular}{|c|c|c|c|c|}
\hline Isotope & 5 Years & 30 Years & 100 Years & 500 Years \\
\hline \multicolumn{5}{|l|}{ Ba137) } \\
\hline Ba138 & 1.649E-01 & 1.649E-01 & 1.649E-01 & 1.649E-01 \\
\hline La138 & $2.283 E-07$ & 2.283E-07 & 2.283E-07 & 2.283E-07 \\
\hline La139 & 1.516E-01 & 1.516E-01 & 1.516E-01 & 1.516E-01 \\
\hline Ce140 & 1.429E-01 & 1.429E-01 & 1.429E-01 & 1.429E-01 \\
\hline Ce142 & 1.257E-01 & 1.257E-01 & 1.257E-01 & 1.257E-01 \\
\hline $\begin{array}{l}\text { Ce144 (1.2\% to Pr144m, } \\
98.8 \% \text { to Pr144) }\end{array}$ & 4.609E-05 & 9.874E-15 & $8.338 E-42$ & 1.643E-196 \\
\hline Pr141 + Ce144 decay & 1.458E-01 & 1.458E-01 & 1.458E-01 & 1.458E-01 \\
\hline Pr144 (100\% to Nd144) & 1.946E-09 & 4.169E-19 & 3.520E-46 & $6.938 E-201$ \\
\hline $\begin{array}{l}\text { Pr144m (99.93\% to } \\
\text { Pr144, 0.07\% to Nd144) }\end{array}$ & $9.724 \mathrm{E}-12$ & 2.083E-21 & $1.759 \mathrm{E}-48$ & $3.467 \mathrm{E}-203$ \\
\hline $\begin{array}{l}\text { Nd142 + Sm146/Pm146 } \\
\text { decay }\end{array}$ & 1.294E-03 & 1.294E-03 & 1.294E-03 & 1.294E-03 \\
\hline $\mathrm{Nd} 143$ & 1.150E-01 & 1.150E-01 & 1.150E-01 & 1.150E-01 \\
\hline Nd144 & 1.089E-01 & 1.090E-01 & 1.090E-01 & 1.090E-01 \\
\hline Nd145 & 7.912E-02 & 7.912E-02 & 7.912E-02 & 7.912E-02 \\
\hline Nd146 + Pm146 decay & $7.942 \mathrm{E}-02$ & 7.942E-02 & 7.942E-02 & 7.942E-02 \\
\hline Nd148 & 4.779E-02 & 4.779E-02 & 4.779E-02 & 4.779E-02 \\
\hline Nd150 & 2.893E-02 & 2.893E-02 & 2.893E-02 & 2.893E-02 \\
\hline Pm147 & $8.936 \mathrm{E}+01$ & 1.210E-01 & 1.124E-09 & 1.427E-55 \\
\hline Pm148 & $5.406 \mathrm{E}-21$ & $1.443 \mathrm{E}-87$ & $5.672 \mathrm{E}-274$ & $0.000 \mathrm{E}+00$ \\
\hline Pm148m & 7.380E-19 & 1.971E-85 & 7.743E-272 & $0.000 \mathrm{E}+00$ \\
\hline Sm147 & $8.823 \mathrm{E}+02$ & $9.715 \mathrm{E}+02$ & $9.716 \mathrm{E}+02$ & $9.716 \mathrm{E}+02$ \\
\hline $\begin{array}{l}\text { Sm148 + Pm148/148m } \\
\text { decay }\end{array}$ & $1.425 \mathrm{E}+02$ & $1.425 E+02$ & $1.425 \mathrm{E}+02$ & $1.425 \mathrm{E}+02$ \\
\hline Sm149 & $6.507 \mathrm{E}+02$ & $6.507 \mathrm{E}+02$ & $6.507 \mathrm{E}+02$ & $6.507 \mathrm{E}+02$ \\
\hline Sm150 & $9.098 \mathrm{E}+01$ & $9.098 \mathrm{E}+01$ & $9.098 \mathrm{E}+01$ & $9.098 \mathrm{E}+01$ \\
\hline Sm151 & $3.566 \mathrm{E}+02$ & $2.941 \mathrm{E}+02$ & $1.715 \mathrm{E}+02$ & $7.874 \mathrm{E}+00$ \\
\hline Sm152 & $3.941 \mathrm{E}+02$ & $3.941 \mathrm{E}+02$ & $3.941 \mathrm{E}+02$ & $3.941 \mathrm{E}+02$ \\
\hline Sm154 & $1.573 \mathrm{E}+02$ & $1.573 \mathrm{E}+02$ & $1.573 \mathrm{E}+02$ & $1.573 \mathrm{E}+02$ \\
\hline Eu151 & $1.400 \mathrm{E}+01$ & 7.647E+01 & $1.991 \mathrm{E}+02$ & $3.627 \mathrm{E}+02$ \\
\hline $\begin{array}{l}\text { Eu152 (72.1\% to Sm152, } \\
27.9 \% \text { to Gd152) }\end{array}$ & 1.833E-05 & $5.126 \mathrm{E}-06$ & 1.447E-07 & $2.027 \mathrm{E}-16$ \\
\hline Eu153 & $1.018 \mathrm{E}-02$ & $1.018 \mathrm{E}-02$ & $1.018 \mathrm{E}-02$ & $1.018 \mathrm{E}-02$ \\
\hline Eu154 & $7.591 \mathrm{E}-04$ & 1.012E-04 & 3.589E-07 & $3.578 \mathrm{E}-21$ \\
\hline Eu155 & $1.744 \mathrm{E}-03$ & 5.298E-05 & 2.986E-09 & $1.566 \mathrm{E}-33$ \\
\hline Gd152 & 1.927E-05 & 2.295E-05 & 2.434E-05 & $2.438 \mathrm{E}-05$ \\
\hline Gd153 & 7.513E-11 & 3.293E-22 & 5.181E-54 & $9.600 \mathrm{E}-236$ \\
\hline Gd154 & 7.710E-04 & 1.429E-03 & 1.530E-03 & 1.530E-03 \\
\hline Gd155 & 4.439E-03 & 6.130E-03 & 6.183E-03 & 6.183E-03 \\
\hline Gd156 & 4.829E-03 & 4.829E-03 & $4.829 \mathrm{E}-03$ & 4.829E-03 \\
\hline Gd157 & $2.596 \mathrm{E}-03$ & 2.596E-03 & $2.596 \mathrm{E}-03$ & 2.596E-03 \\
\hline Gd158 & $2.341 \mathrm{E}-03$ & 2.341E-03 & $2.341 \mathrm{E}-03$ & $2.341 \mathrm{E}-03$ \\
\hline
\end{tabular}


Table F-2 (continued)

\begin{tabular}{|c|c|c|c|c|}
\hline Isotope & 5 Years & 30 Years & 100 Years & 500 Years \\
\hline Gd160 & 6.421E-04 & $6.421 E-04$ & $6.421 \mathrm{E}-04$ & 6.421E-04 \\
\hline Tl207 & 4.064E-22 & $1.424 \mathrm{E}-20$ & 1.515E-19 & 3.596E-18 \\
\hline TI208 & 2.749E-14 & 3.736E-14 & 1.907E-14 & 4.054E-16 \\
\hline TI209 & $9.788 \mathrm{E}-23$ & 1.132E-21 & $1.005 \mathrm{E}-20$ & 3.931E-19 \\
\hline $\mathrm{Pb} 206$ & $1.105 \mathrm{E}-16$ & $1.741 \mathrm{E}-13$ & 3.159E-11 & $1.958 \mathrm{E}-08$ \\
\hline $\mathrm{Pb} 207$ & 4.223E-14 & 5.334E-14 & 4.339E-13 & $4.640 \mathrm{E}-11$ \\
\hline $\mathrm{Pb} 208$ & 1.666E-08 & 3.314E-07 & 9.674E-07 & 1.615E-06 \\
\hline $\mathrm{Pb} 209$ & $4.215 \mathrm{E}-19$ & $4.876 \mathrm{E}-18$ & $4.327 \mathrm{E}-17$ & 1.693E-15 \\
\hline $\mathrm{Pb} 210$ & $2.483 \mathrm{E}-15$ & $8.256 \mathrm{E}-13$ & 4.463E-11 & 4.712E-09 \\
\hline $\mathrm{Pb} 211$ & 3.144E-21 & 1.101E-19 & 1.172E-18 & $2.782 \mathrm{E}-17$ \\
\hline $\mathrm{Pb} 212$ & 1.622E-11 & $2.204 \mathrm{E}-11$ & 1.125E-11 & $2.392 \mathrm{E}-13$ \\
\hline $\mathrm{Pb} 214$ & 1.222E-19 & 8.771E-18 & $2.105 \mathrm{E}-16$ & $1.269 \mathrm{E}-14$ \\
\hline Bi209 & $1.817 \mathrm{E}-15$ & $1.081 \mathrm{E}-13$ & $2.748 \mathrm{E}-12$ & $4.576 \mathrm{E}-10$ \\
\hline $\mathrm{Bi} 210$ & 1.529E-18 & 5.083E-16 & $2.748 \mathrm{E}-14$ & $2.901 \mathrm{E}-12$ \\
\hline $\mathrm{Bi} 211$ & $1.855 \mathrm{E}-22$ & $6.498 \mathrm{E}-21$ & 6.916E-20 & $1.641 \mathrm{E}-18$ \\
\hline $\mathrm{Bi} 212$ & $1.537 \mathrm{E}-12$ & $2.090 \mathrm{E}-12$ & $1.067 \mathrm{E}-12$ & $2.267 \mathrm{E}-14$ \\
\hline $\mathrm{Bi} 213$ & 9.902E-20 & $1.146 \mathrm{E}-18$ & $1.017 \mathrm{E}-17$ & 3.977E-16 \\
\hline Bi214 & $9.071 \mathrm{E}-20$ & $6.514 \mathrm{E}-18$ & $1.563 \mathrm{E}-16$ & 9.425E-15 \\
\hline Po210 & $4.290 \mathrm{E}-17$ & $1.426 \mathrm{E}-14$ & 7.711E-13 & 8.141E-11 \\
\hline Po211 & $2.286 \mathrm{E}-27$ & $8.008 E-26$ & 8.524E-25 & $2.023 \mathrm{E}-23$ \\
\hline Po213 & $1.487 \mathrm{E}-28$ & $1.720 \mathrm{E}-27$ & $1.527 \mathrm{E}-26$ & 5.973E-25 \\
\hline Po214 & $1.248 \mathrm{E}-26$ & $8.963 \mathrm{E}-25$ & $2.151 \mathrm{E}-23$ & $1.297 \mathrm{E}-21$ \\
\hline Po215 & 2.633E-27 & $9.223 \mathrm{E}-26$ & $9.817 \mathrm{E}-25$ & $2.330 \mathrm{E}-23$ \\
\hline Po216 & $6.467 \mathrm{E}-17$ & 8.792E-17 & $4.488 \mathrm{E}-17$ & 9.538E-19 \\
\hline Po218 & 1.416E-20 & 1.017E-18 & 2.440E-17 & 1.471E-15 \\
\hline At217 & $1.190 \mathrm{E}-24$ & $1.376 \mathrm{E}-23$ & $1.221 \mathrm{E}-22$ & $4.778 \mathrm{E}-21$ \\
\hline Rn219 & $5.968 \mathrm{E}-24$ & $2.090 \mathrm{E}-22$ & $2.225 \mathrm{E}-21$ & $5.280 \mathrm{E}-20$ \\
\hline $\mathrm{Rn} 220$ & $2.441 \mathrm{E}-14$ & 3.318E-14 & 1.694E-14 & $3.600 \mathrm{E}-16$ \\
\hline $\mathrm{Rn} 222$ & $2.604 \mathrm{E}-17$ & $1.870 \mathrm{E}-15$ & 4.487E-14 & $2.705 \mathrm{E}-12$ \\
\hline Fr221 & $1.080 \mathrm{E}-20$ & $1.250 \mathrm{E}-19$ & $1.109 \mathrm{E}-18$ & 4.339E-17 \\
\hline Fr223 & $2.769 \mathrm{E}-23$ & $9.701 \mathrm{E}-22$ & 1.033E-20 & $2.450 \mathrm{E}-19$ \\
\hline Ra223 & $1.518 \mathrm{E}-18$ & 5.317E-17 & $5.659 \mathrm{E}-16$ & $1.343 \mathrm{E}-14$ \\
\hline Ra224 & $1.421 \mathrm{E}-10$ & $1.932 \mathrm{E}-10$ & 9.864E-11 & $2.096 \mathrm{E}-12$ \\
\hline Ra225 & $4.886 \mathrm{E}-17$ & $5.652 \mathrm{E}-16$ & 5.015E-15 & $1.962 \mathrm{E}-13$ \\
\hline Ra226 & 4.050E-12 & $2.908 \mathrm{E}-10$ & 6.980E-09 & $4.208 \mathrm{E}-07$ \\
\hline Ra228 & $1.080 \mathrm{E}-19$ & $2.841 \mathrm{E}-18$ & $2.386 \mathrm{E}-17$ & 4.978E-16 \\
\hline Ac225 & 3.300E-17 & 3.817E-16 & 3.388E-15 & $1.325 \mathrm{E}-13$ \\
\hline Ac227 & 1.073E-15 & 3.758E-14 & $4.000 \mathrm{E}-13$ & 9.493E-12 \\
\hline Ac228 & $1.128 \mathrm{E}-23$ & $2.965 \mathrm{E}-22$ & $2.491 \mathrm{E}-21$ & $5.195 \mathrm{E}-20$ \\
\hline Th227 & $2.496 \mathrm{E}-18$ & 8.743E-17 & 9.306E-16 & 2.209E-14 \\
\hline Th228 & 2.748E-08 & 3.735E-08 & 1.907E-08 & $4.053 \mathrm{E}-10$ \\
\hline Th229 & 9.003E-12 & $1.041 \mathrm{E}-10$ & 9.242E-10 & 3.616E-08 \\
\hline Th230 & 2.026E-07 & 2.830E-06 & 2.139E-05 & 2.436E-04 \\
\hline
\end{tabular}


Table F-2 (continued)

\begin{tabular}{|c|c|c|c|c|}
\hline Isotope & 5 Years & 30 Years & 100 Years & 500 Years \\
\hline Th231 & 1.987E-14 & 3.195E-14 & $6.573 E-14$ & $2.576 \mathrm{E}-13$ \\
\hline $\begin{array}{l}\text { Th232 + } \\
\text { U236/Pu240/Pu244 } \\
\text { decay }\end{array}$ & 1.082E-09 & 9.478E-09 & 5.988E-08 & 1.102E-06 \\
\hline Th234 & $1.651 \mathrm{E}-10$ & $1.651 \mathrm{E}-10$ & $1.651 \mathrm{E}-10$ & $1.651 \mathrm{E}-10$ \\
\hline Pa231 & 2.222E-11 & 1.764E-10 & $9.897 \mathrm{E}-10$ & 1.634E-08 \\
\hline Pa233 & 3.194E-09 & 3.739E-09 & 5.652E-09 & 1.366E-08 \\
\hline Pa234 & $2.487 \mathrm{E}-15$ & $2.487 \mathrm{E}-15$ & $2.487 \mathrm{E}-15$ & $2.487 \mathrm{E}-15$ \\
\hline Pa234m & 5.568E-15 & 5.568E-15 & $5.568 \mathrm{E}-15$ & $5.568 \mathrm{E}-15$ \\
\hline $\begin{array}{l}\text { U232 + Pu236/Np236 } \\
\text { decay }\end{array}$ & 1.451E-06 & $1.408 \mathrm{E}-06$ & 7.182E-07 & 1.526E-08 \\
\hline U233 & 4.932E-07 & $1.301 \mathrm{E}-06$ & 4.379E-06 & 4.214E-05 \\
\hline U234 & 1.865E-02 & 5.562E-02 & 1.283E-01 & $2.279 \mathrm{E}-01$ \\
\hline U235 & 4.887E-03 & 7.857E-03 & 1.617E-02 & $6.336 \mathrm{E}-02$ \\
\hline U236 & 8.113E-03 & 1.499E-02 & 3.450E-02 & 1.438E-01 \\
\hline U237 & 8.785E-09 & 2.639E-09 & $9.246 \mathrm{E}-11$ & 1.598E-12 \\
\hline U238 & $1.137 \mathrm{E}+01$ & $1.137 \mathrm{E}+01$ & 1.137E+01 & $1.137 \mathrm{E}+01$ \\
\hline U240 & $6.188 \mathrm{E}-17$ & $6.249 \mathrm{E}-17$ & $6.421 \mathrm{E}-17$ & $7.404 \mathrm{E}-17$ \\
\hline Np237 & 9.408E-02 & 1.101E-01 & 1.665E-01 & 4.024E-01 \\
\hline Np238 & 2.374E-09 & 2.118E-09 & 1.539E-09 & $2.484 \mathrm{E}-10$ \\
\hline Np239 & 1.548E-07 & 1.544E-07 & 1.534E-07 & $1.477 \mathrm{E}-07$ \\
\hline Np240m & 5.415E-19 & $5.468 \mathrm{E}-19$ & 5.619E-19 & $6.479 \mathrm{E}-19$ \\
\hline Pu236 & 3.277E-07 & $7.513 \mathrm{E}-10$ & 3.054E-17 & $1.781 \mathrm{E}-59$ \\
\hline Pu238 & 2.092E-01 & $1.728 \mathrm{E}-01$ & 1.013E-01 & $5.388 \mathrm{E}-03$ \\
\hline Pu239 & $4.196 \mathrm{E}+00$ & $4.194 \mathrm{E}+00$ & $4.187 \mathrm{E}+00$ & $4.145 \mathrm{E}+00$ \\
\hline $\begin{array}{l}\text { Pu240 + Pu244/Cm244 } \\
\text { decay }\end{array}$ & $2.608 \mathrm{E}+00$ & $2.659 \mathrm{E}+00$ & $2.674 \mathrm{E}+00$ & $2.565 \mathrm{E}+00$ \\
\hline Pu241 & 2.839E-01 & 8.529E-02 & 2.988E-03 & 5.165E-05 \\
\hline $\begin{array}{l}\text { Pu242+Am242/242m } \\
\text { decay }\end{array}$ & $6.261 \mathrm{E}-05$ & 3.590E-04 & 1.062E-03 & 3.190E-03 \\
\hline Pu243 & 4.949E-14 & 4.949E-14 & 4.949E-14 & 4.949E-14 \\
\hline Pu244 & 3.232E-06 & 3.264E-06 & 3.354E-06 & 3.867E-06 \\
\hline Am241 & 2.958E-01 & 4.781E-01 & 5.033E-01 & 2.673E-01 \\
\hline Am242 & 1.515E-07 & $1.352 \mathrm{E}-07$ & 9.825E-08 & $1.586 \mathrm{E}-08$ \\
\hline Am242M & 1.266E-02 & 1.130E-02 & 8.210E-03 & $1.325 \mathrm{E}-03$ \\
\hline Am243 & 1.801E-01 & 1.797E-01 & 1.785E-01 & 1.719E-01 \\
\hline $\begin{array}{l}\text { Cm242+ } \\
\text { Am242/Am242m decay }\end{array}$ & 3.081E-05 & $2.742 \mathrm{E}-05$ & 1.993E-05 & $3.215 E-06$ \\
\hline $\mathrm{Cm} 243$ & 7.652E-04 & 4.166E-04 & 7.592E-05 & 4.521E-09 \\
\hline $\mathrm{Cm} 244$ & 9.639E-02 & 3.702E-02 & 2.539E-03 & $5.687 \mathrm{E}-10$ \\
\hline $\mathrm{Cm} 245$ & 3.221E-02 & 3.214E-02 & 3.196E-02 & 3.093E-02 \\
\hline $\mathrm{Cm} 246$ & 1.709E-02 & 1.703E-02 & 1.686E-02 & 1.590E-02 \\
\hline $\mathrm{Cm} 247$ & 1.388E-03 & $1.388 \mathrm{E}-03$ & 1.388E-03 & $1.388 \mathrm{E}-03$ \\
\hline $\mathrm{Cm} 248$ & 6.384E-04 & 6.384E-04 & 6.383E-04 & 6.378E-04 \\
\hline
\end{tabular}


Table F-2 (continued)

\begin{tabular}{|c|c|c|c|c|}
\hline Isotope & \multicolumn{1}{|c|}{ 5 Years } & 30 Years & 100 Years & 500 Years \\
\hline & & & & \\
\hline Total & $3.103 E+06$ & $3.103 E+06$ & $3.103 E+06$ & $3.103 E+06$ \\
\hline
\end{tabular}


Table F-3 Isotopic Composition of E-Chem Metal Alloy from Reprocessing of Metal Fuel from SFRs with CR = 0.75 and $100 \mathrm{GW}$-d/MT Burnup, at 5, 30, 100 and 500 yr Out-of-

Reactor.

\begin{tabular}{|c|c|c|c|c|}
\hline Isotope & 5 Years & 30 Years & 100 Years & 500 Years \\
\hline Rb85 + Kr85 decay & $8.968 E+01$ & $8.968 \mathrm{E}+01$ & $8.968 \mathrm{E}+01$ & $8.968 E+01$ \\
\hline $\mathrm{Rb87}$ & $2.017 \mathrm{E}+02$ & $2.017 \mathrm{E}+02$ & $2.017 \mathrm{E}+02$ & $2.017 \mathrm{E}+02$ \\
\hline Sr86 + Rb86 decay & $3.415 \mathrm{E}+00$ & $3.415 \mathrm{E}+00$ & $3.415 \mathrm{E}+00$ & $3.415 E+00$ \\
\hline Sr87 + Rb87 decay & 6.732E-02 & $6.732 \mathrm{E}-02$ & $6.732 \mathrm{E}-02$ & $6.732 \mathrm{E}-02$ \\
\hline Sr88 & $2.627 \mathrm{E}+02$ & $2.627 \mathrm{E}+02$ & $2.627 \mathrm{E}+02$ & $2.627 \mathrm{E}+02$ \\
\hline Sr89 & $8.231 \mathrm{E}-15$ & $2.959 E-69$ & 1.065E-221 & $0.000 \mathrm{E}+00$ \\
\hline Sr90 (100\% to Y90) & $3.263 \mathrm{E}+02$ & $1.800 \mathrm{E}+02$ & $3.401 \mathrm{E}+01$ & $2.495 \mathrm{E}-03$ \\
\hline Y89 + Sr89 decay & $6.373 \mathrm{E}-04$ & $6.373 E-04$ & $6.373 E-04$ & 6.373E-04 \\
\hline Y90 (Sr90 progeny) & 8.183E-02 & 4.513E-02 & 8.529E-03 & $6.256 \mathrm{E}-07$ \\
\hline Zr90 + Sr90/Y90 decay & $4.115 \mathrm{E}+01$ & $1.875 E+02$ & $3.335 \mathrm{E}+02$ & $3.675 E+02$ \\
\hline $\begin{array}{l}\text { I127 + } \\
\text { Sb127/Te127m/Te127 } \\
\text { decay }\end{array}$ & 1.183E+02 & $1.183 E+02$ & 1.183E+02 & $1.183 E+02$ \\
\hline 1129 & $3.577 \mathrm{E}+02$ & $3.577 \mathrm{E}+02$ & $3.577 \mathrm{E}+02$ & $3.577 \mathrm{E}+02$ \\
\hline Xe129 & 7.896E-05 & $4.738 \mathrm{E}-04$ & $1.579 \mathrm{E}-03$ & 7.896E-03 \\
\hline $\begin{array}{l}\text { Cs133 + Xe133/Xe133m } \\
\text { decay }\end{array}$ & $1.716 \mathrm{E}+03$ & $1.716 \mathrm{E}+03$ & $1.716 \mathrm{E}+03$ & $1.716 \mathrm{E}+03$ \\
\hline Cs134 & $4.134 \mathrm{E}+00$ & $9.275 \mathrm{E}-04$ & $5.623 \mathrm{E}-14$ & $2.320 \mathrm{E}-72$ \\
\hline Cs135 & $1.939 \mathrm{E}+03$ & $1.939 \mathrm{E}+03$ & $1.939 \mathrm{E}+03$ & $1.939 \mathrm{E}+03$ \\
\hline $\begin{array}{l}\text { Cs137 (94.4\% to } \\
\text { Ba137m, 5.6\% to Ba137) }\end{array}$ & $1.448 \mathrm{E}+03$ & $8.125 E+02$ & $1.612 \mathrm{E}+02$ & $1.561 \mathrm{E}-02$ \\
\hline Ba134 & $6.530 \mathrm{E}+01$ & $6.943 E+01$ & $6.943 \mathrm{E}+01$ & $6.943 E+01$ \\
\hline Ba135 & 3.713E-02 & $5.174 \mathrm{E}-02$ & $9.265 \mathrm{E}-02$ & 3.264E-01 \\
\hline Ba136 + Cs136 decay & $8.432 E+01$ & $8.432 E+01$ & $8.432 \mathrm{E}+01$ & $8.432 E+01$ \\
\hline Ba137 & $3.478 \mathrm{E}+02$ & $9.831 \mathrm{E}+02$ & $1.634 \mathrm{E}+03$ & $1.796 \mathrm{E}+03$ \\
\hline $\begin{array}{l}\text { Ba137m (100\% to } \\
\text { Ba137) }\end{array}$ & $2.211 \mathrm{E}-04$ & $1.241 \mathrm{E}-04$ & $2.461 \mathrm{E}-05$ & 2.383E-09 \\
\hline Ba138 & $1.751 \mathrm{E}+03$ & $1.751 \mathrm{E}+03$ & $1.751 \mathrm{E}+03$ & $1.751 \mathrm{E}+03$ \\
\hline La138 & $4.371 \mathrm{E}-02$ & $4.371 \mathrm{E}-02$ & $4.371 \mathrm{E}-02$ & $4.371 \mathrm{E}-02$ \\
\hline La139 & $2.903 \mathrm{E}+04$ & $2.903 \mathrm{E}+04$ & $2.903 \mathrm{E}+04$ & $2.903 \mathrm{E}+04$ \\
\hline Ce140 & $2.736 \mathrm{E}+04$ & $2.736 \mathrm{E}+04$ & $2.736 \mathrm{E}+04$ & $2.736 \mathrm{E}+04$ \\
\hline Ce142 & $2.407 \mathrm{E}+04$ & $2.407 \mathrm{E}+04$ & $2.407 \mathrm{E}+04$ & $2.407 \mathrm{E}+04$ \\
\hline $\begin{array}{l}\text { Ce144 (1.2\% to Pr144m, } \\
98.8 \% \text { to } \operatorname{Pr} 144)\end{array}$ & $8.826 \mathrm{E}+00$ & 1.891E-09 & $1.597 \mathrm{E}-36$ & 3.147E-191 \\
\hline Pr141 + Ce144 decay & $2.792 \mathrm{E}+04$ & $2.792 \mathrm{E}+04$ & $2.792 \mathrm{E}+04$ & $2.792 \mathrm{E}+04$ \\
\hline Pr144 (100\% to Nd144) & $3.726 \mathrm{E}-04$ & 7.984E-14 & $6.742 \mathrm{E}-41$ & 1.329E-195 \\
\hline $\begin{array}{l}\text { Pr144m (99.93\% to } \\
\text { Pr144, 0.07\% to Nd144) }\end{array}$ & 1.862E-06 & $3.990 \mathrm{E}-16$ & $3.369 \mathrm{E}-43$ & $6.640 \mathrm{E}-198$ \\
\hline $\begin{array}{l}\text { Nd142 + Sm146/Pm146 } \\
\text { decay }\end{array}$ & $2.479 \mathrm{E}+02$ & $2.479 \mathrm{E}+02$ & $2.479 \mathrm{E}+02$ & $2.479 \mathrm{E}+02$ \\
\hline $\mathrm{Nd} 143$ & $2.203 E+04$ & $2.203 E+04$ & $2.203 \mathrm{E}+04$ & $2.203 E+04$ \\
\hline Nd144 & $2.086 \mathrm{E}+04$ & $2.087 \mathrm{E}+04$ & $2.087 \mathrm{E}+04$ & $2.087 \mathrm{E}+04$ \\
\hline Nd145 & $1.515 E+04$ & $1.515 E+04$ & $1.515 E+04$ & $1.515 E+04$ \\
\hline
\end{tabular}


Table F-3 (continued)

\begin{tabular}{|l|l|l|l|l|}
\hline \multicolumn{1}{|c|}{ Isotope } & \multicolumn{1}{|c|}{ 5 Years } & \multicolumn{1}{c|}{ 30 Years } & \multicolumn{1}{c|}{ 100 Years } & \multicolumn{1}{c|}{ 500 Years } \\
\hline Nd146 + Pm146 decay & $1.521 \mathrm{E}+04$ & $1.521 \mathrm{E}+04$ & $1.521 \mathrm{E}+04$ & $1.521 \mathrm{E}+04$ \\
\hline Nd148 & $9.152 \mathrm{E}+03$ & $9.152 \mathrm{E}+03$ & $9.152 \mathrm{E}+03$ & $9.152 \mathrm{E}+03$ \\
\hline Nd150 & $5.540 \mathrm{E}+03$ & $5.540 \mathrm{E}+03$ & $5.540 \mathrm{E}+03$ & $5.540 \mathrm{E}+03$ \\
\hline Sm152 & $7.345 \mathrm{E}-01$ & $2.558 \mathrm{E}+00$ & $3.245 \mathrm{E}+00$ & $3.265 \mathrm{E}+00$ \\
\hline Eu151 & $1.178 \mathrm{E}+02$ & $1.178 \mathrm{E}+02$ & $1.178 \mathrm{E}+02$ & $1.178 \mathrm{E}+02$ \\
\hline $\begin{array}{l}\text { Eu152 (72.1\% to Sm152, } \\
27.9 \% \text { to Gd152) }\end{array}$ & $3.510 \mathrm{E}+00$ & $9.817 \mathrm{E}-01$ & $2.771 \mathrm{E}-02$ & $3.881 \mathrm{E}-11$ \\
\hline Eu153 & $1.949 \mathrm{E}+03$ & $1.949 \mathrm{E}+03$ & $1.949 \mathrm{E}+03$ & $1.949 \mathrm{E}+03$ \\
\hline Eu154 & $1.454 \mathrm{E}+02$ & $1.938 \mathrm{E}+01$ & $6.873 \mathrm{E}-02$ & $6.852 \mathrm{E}-16$ \\
\hline Eu155 & $3.340 \mathrm{E}+02$ & $1.014 \mathrm{E}+01$ & $5.717 \mathrm{E}-04$ & $2.998 \mathrm{E}-28$ \\
\hline Gd152 & $3.689 \mathrm{E}+00$ & $4.395 \mathrm{E}+00$ & $4.661 \mathrm{E}+00$ & $4.669 \mathrm{E}+00$ \\
\hline Gd153 & $1.439 \mathrm{E}-05$ & $6.305 \mathrm{E}-17$ & $9.922 \mathrm{E}-49$ & $1.838 \mathrm{E}-230$ \\
\hline Gd154 & $1.476 \mathrm{E}+02$ & $2.736 \mathrm{E}+02$ & $2.929 \mathrm{E}+02$ & $2.930 \mathrm{E}+02$ \\
\hline Gd155 & $8.501 \mathrm{E}+02$ & $1.174 \mathrm{E}+03$ & $1.184 \mathrm{E}+03$ & $1.184 \mathrm{E}+03$ \\
\hline Gd156 & $9.248 \mathrm{E}+02$ & $9.248 \mathrm{E}+02$ & $9.248 \mathrm{E}+02$ & $9.248 \mathrm{E}+02$ \\
\hline Gd157 & $4.972 \mathrm{E}+02$ & $4.972 \mathrm{E}+02$ & $4.972 \mathrm{E}+02$ & $4.972 \mathrm{E}+02$ \\
\hline Gd158 & $4.483 \mathrm{E}+02$ & $4.483 \mathrm{E}+02$ & $4.483 \mathrm{E}+02$ & $4.483 \mathrm{E}+02$ \\
\hline Gd160 & $1.230 \mathrm{E}+02$ & $1.230 \mathrm{E}+02$ & $1.230 \mathrm{E}+02$ & $1.230 \mathrm{E}+02$ \\
\hline & & & & \\
\hline Total & $\mathbf{2 . 1 0 9 E + 0 5}$ & $\mathbf{2 . 1 0 9 E + 0 5}$ & $\mathbf{2 . 1 0 9 E + 0 5}$ & $\mathbf{2 . 1 0 9 E + 0 5}$ \\
\hline
\end{tabular}


THIS PAGE INTENTIONALLY LEFT BLANK 


\section{Appendix G}

\section{Mathematical Models for Thermal Analysis of Reference Disposal Concepts}

\section{G.1 Introduction}

There are two modeling methods that can be applied to the geometry described in Section 5.1 for thermal analysis: analytical solutions and numerical simulation. The analysis presented in this report is limited to analytical models implemented in MathCAD 15 ${ }^{\circledR}$, Microsoft Excel ${ }^{\circledR} 2007$, and MatLab ${ }^{\circledR}$ Version 7.3. We note that coupled THMC processes may also be active, but the effects on temperature would be limited in mined geologic settings with low-permeability materials, and would be evaluated as FEPs in analysis of waste isolation performance.

Section G.2 describes the input variables, Section G.3 describes the transient analytic model in the host rock, and Section G.4 describes the steady state multi-layer analytical model that determines the temperatures at the surface of each of the internal EBS barriers, ending at the surface of the waste package. Section G.5 describes model limitations and potential future considerations.

The transient model described in Section G.3 (referred to here as the "external calculation") is in a homogeneous medium (i.e., the EBS is assumed to have the properties of the geologic medium). The homogeneity permits use of superposed analytic solutions for point, infinite line, and finite line sources that in combination represent the repository layout. The "calculation radius" for the external calculation is generally at the interface between the EBS and the geologic medium, although, for salt, it was placed somewhat further from the WP centerline due to the non-concentric geometry of backfilled salt alcoves.

The temperature histories within the EBS (referred to here as the "internal calculation") are derived from the waste package line load heat source, using the time-dependent results of the external calculation. The internal calculation is steady-state at each point in time, which is equivalent to assuming that the heat flow through the calculation radius at any given time is nearly equal to the heat generation in the waste at that time. This is a reasonable assumption except at the very early times in which the EBS temperatures are changing rapidly due to the change in boundary condition after emplacement. This calculation is conservative in the sense that the steady-state model is a one-dimensional model that effectively assumes an infinite line source with the waste package internal line loading. 


\section{G.2 Variables Used in the Analytical Models}

The input variables in the analytical models are in the form of several vectors and matrices of data, keyed to two index values. The index WF varies from 1 to 6 and represents the waste forms (UOX, Co-Extraction, MOX, new extraction, E-Chem ceramic, and E-Chem metal), and the index RT varies from 1 to 4 and represents rock types (crystalline/granite, clay, salt, and deep borehole) of the repository host rock.

For each repository design combination of rock type and waste form, there are specified EBS radii as discussed in Section 5.1. In the transient analytical model in the host rock, only the calculation radius and axial and lateral WP spacing are included from the geometry data. The radial dimensions of the EBS components are used in the internal steady state analytical model that starts at the "calculation radius" and extends to the surface of the waste package.

\section{G.2.1 Host Rock Property Data}

The host rock properties consist of a single homogenous set of properties representing an isotropic infinite medium, with the properties assumed at $100^{\circ} \mathrm{C}$ to approximate the situation after waste emplacement. This assumption is appropriate for crystalline rock and clay/shale concepts for which the target maximum temperature is $100^{\circ} \mathrm{C}$ (and thermal resistance could be dominated by the same clay buffer that could be impacted by excessive temperature). For the salt concept, $100^{\circ} \mathrm{C}$ approximates the mid-point of the range of expected temperature throughout the near field where heat is dissipated from the waste package. The properties of crushed salt backfill are utilized in the quasi-steady-state model of the EBS, and are listed under EBS Material Property Data discussed in Section G.2.2.

The thermal conductivity $(\mathrm{W} / \mathrm{m}-\mathrm{K})$ is designated $\mathrm{K}_{\text {th }}$, and $\alpha$ is the thermal diffusivity $\left(\mathrm{m}^{2} / \mathrm{s}\right)$ : HOST ROCK PROPERTY DATA

$$
\text { Rock_type := }\left(\begin{array}{c}
\text { "Granite" } \\
\text { "Clay" } \\
\text { "Salt" } \\
\text { "Deep Borehole" }
\end{array}\right) \quad \text { Kth :=( }\left(\begin{array}{c}
2.5 \\
1.75 \\
4.2 \\
3.0
\end{array}\right) \cdot \frac{\mathrm{W}}{\mathrm{m} \cdot \mathrm{K}}
$$

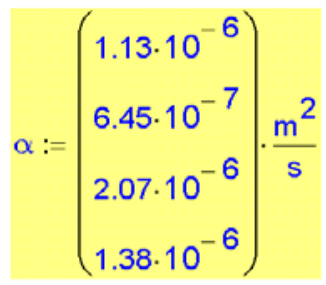

\section{G.2.2 Repository Reference Design Data}

Figures 5.1-3 through 5.1-6 show the EBS design data. The "calculation radius" is $4.0 \mathrm{~m}$ for salt, and is the largest EBS dimension for the other three geologic media. The other variables considered in the analytical model include waste package length, emplacement drift spacing, and waste package spacing within each emplacement drift.

Waste Package Length: 
SELECT WASTE FORM INPUT DATA

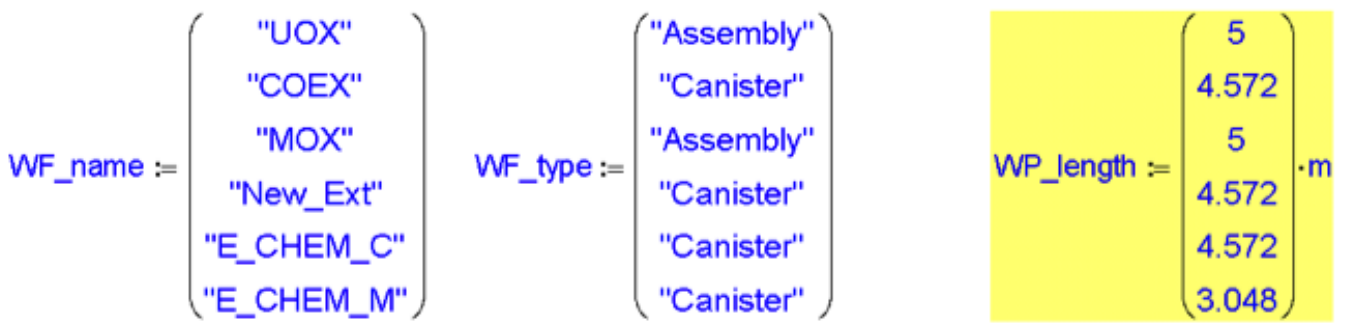

\section{Emplacement Drift Radius ("Calculation Radius”):}

The calculation radius is the host rock surface interface with the EBS, and it varies by both waste form (the rows in the matrix below) and rock type (the columns in the matrix). The radius of the deep borehole design is based on the maximum feasible drill casing. The columns of the matrix are the four media (crystalline/granite, clay, salt, and deep borehole), and the rows are the six waste forms (UOX, Co-Extraction, MOX, new extraction, EC-C, and EC-M).

The calculation radius also varies with the number of assemblies assumed per waste package. The 4-assembly (UOX or MOX) waste package can also be used with spacers to hold 2, 3 or 4 assemblies, and the calculation radius in the matrix below is consistent with the 4-assembly waste package design. The same model was used with different inputs for the 1-assembly and 12-assembly waste package designs to evaluate sensitivity of the results as a function of the number of assemblies.

$$
\text { drift_r }:=\left(\begin{array}{cccc}
0.83 & 1.321 & 4 & 0.188 \\
0.755 & 0.370 & 4 & 0.198 \\
0.83 & 1.321 & 4 & 0.188 \\
0.755 & 0.370 & 4 & 0.198 \\
0.755 & 0.370 & 4 & 0.198 \\
0.755 & 0.370 & 4 & 0.198
\end{array}\right) \cdot m
$$

\section{Repository Design - Lateral Spacing, Axial Spacing and Depth:}

Lateral spacing (in the " $\mathrm{x}$ " direction) is comparable to center-to-center borehole or drift spacing, which is conceptually comparable to the emplacement drift spacing in the Yucca Mountain repository design concept. Axial spacing (in the " $y$ " direction) is comparable to the waste package center-to-center spacing within a given emplacement borehole, series of alcoves, or drift.

Depth is self-explanatory. The depth of the crystalline, clay, and salt repository reference concepts was assumed to be $500 \mathrm{~m}$, and the depth of the deep borehole design was assumed to be $5,000 \mathrm{~m}$. The models assume a geothermal temperature gradient of $25 \mathrm{C}^{\circ}$ per $1,000 \mathrm{~m}$ depth (Brady et al. 2009, p. 22; Fetter 1994, p. 281; and DOE 2000, p. 89) resulting in different ambient temperatures in the host rock with depth. These input variables are all keyed to the rock type index ("granite," clay, salt, and deep borehole). 


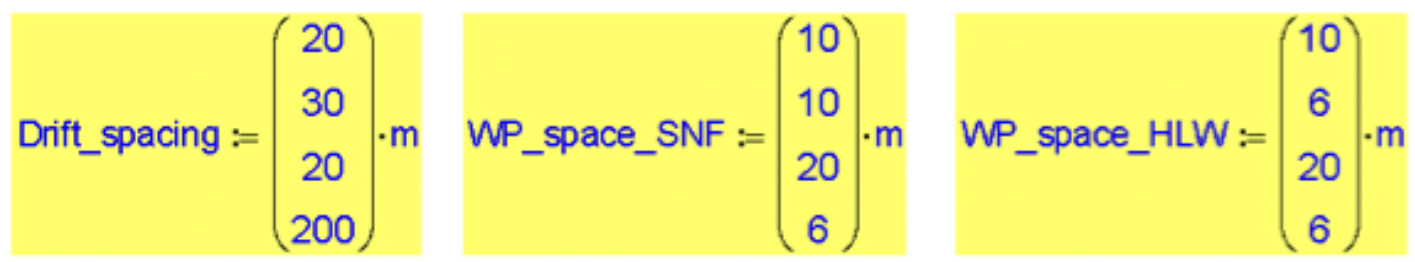

Repository Design - EBS Component Data:

The selection of the particular reference design configurations is discussed in Section 5.1. In the steady-state internal model calculation, all of the EBS components are assumed to be concentric cylindrical shells, as shown in Figure 5.1-1.

The specific inputs required for the internal calculation are documented in Figures 5.1-3 to 5.1-6, and they include the material type of each EBS component, inner and outer radius of each component, and the thermal conductivity of the material.

\section{G.2.3 Waste Form Count}

The time-dependent decay heat data discussed in Section 5.1.3 is expressed per SNF assembly or per HLW canister, and is multiplied by the waste form count (WF_count) to obtain the heat source per waste package.

The waste form count for the deep borehole reference repository is based on the fixed maximum diameter of the drill casing. For the SNF waste forms, rod consolidation is assumed, enabling a single assembly to fit within the narrow borehole diameter $(\mathrm{WF}$ count $=1$ ). For the HLW waste forms, the length of the canister is assumed to be the same as a single canister (based on manufacturing constraints), but the diameter is limited by the drill casing, which results in less than $30 \%$ of the inventory and heat per canister in the deep borehole design, as compared to the other three geologic media $\left(\mathrm{WF} \_\right.$count $=$dbh_cnt $)$.

The parameter dbh_cnt $=0.291$ for the ratio of the small canister internal cross-sectional area divided by the standard HLW canister area. The input matrix below shows the waste form count of 4 assemblies in crystalline/granite, clay, and salt, and is adjusted accordingly for cases evaluating 1-assembly and 12-assembly waste package in parametric study cases.

$$
\text { WF_count }:=\left(\begin{array}{cccc}
4 & 4 & 4 & 1 \\
1 & 1 & 1 & \mathrm{dbh} \text { cnt } \\
4 & 4 & 4 & 1 \\
1 & 1 & 1 & \mathrm{dbh} \text { cnt } \\
1 & 1 & 1 & \mathrm{dbh} \text { _cnt } \\
1 & 1 & 1 & \mathrm{dbh} \text { _cnt }
\end{array}\right)
$$

\section{G.2.4 The Effects of Surface Decay Storage}

Surface storage times of 10, 50, 100, and 200 years were evaluated for all cases analyzed, and input as a vector variable $\mathrm{T}_{\text {store }}$. The model used was adapted from a Yucca Mountain model that had a ventilation efficiency during the preclosure period $\left(\mathrm{V}_{\mathrm{dur}}\right)$. In the modified model, the effect of surface storage was the same as the effect of a ventilation system removing the decay heat at 
$100 \%$ efficiency during the surface storage period $\left(\mathrm{T}_{\text {store }}\right)$. This same model can also be used, in the future, to consider potential effects of surface storage followed by some limited ventilation time after emplacement, with a ventilation heat removal efficiency $\left(\mathrm{V}_{\text {eff }}\right)$ of less than $100 \%$.

\section{G.2.5 Heat Source Calculation}

The analytic model incorporates three types of heat sources

- $\mathrm{Q}_{\mathrm{L} \text { wp }}$ - representing a single waste package of interest (as a finite line source), where the line load heat source internal to a single waste package is calculated. The units are $\mathrm{W} / \mathrm{m}$.

- $\mathrm{Q}_{\mathrm{L} \_a v g}$ - representing an average line load of adjacent emplacement drifts or boreholes (as an infinite line source). The line load heat source represents an average heat load accounting for axial waste package spacing. The units are $\mathrm{W} / \mathrm{m}$.

- $\mathrm{Q}_{\mathrm{wp}}$ - representing a single adjacent waste package (as a point source), where the point source heat load is the total heat source for a waste package. The units are W.

The three heat sources accounting for the effects of surface storage times are calculated as follows:

$$
\begin{aligned}
& \text { Veff }:=1.00 \quad \text { Assume } 100 \% \text { efficiency (equivalent to surface storage), where Vdur }=\text { Tstore } \\
& Q_{L \_w p}\left(t, T_{\text {store }}, w f, r t\right):=\frac{Q(t, w f) \cdot W F \_ \text {count }_{W f}, r t}{W P \_ \text {length }} \cdot\left[1-\text { Veff } \cdot\left(t \leq T_{\text {store }}\right)\right] \\
& Q_{L_{-} \text {avg }}\left(t, T_{\text {store }}, w f, r t\right):=\frac{Q(t, w f) \cdot W F_{-} \text {count }_{W f}, t t}{W P_{-} \text {spacing }} \cdot\left[1-V \text { eff } \cdot\left(t \leq T_{\text {store }}\right)\right] \\
& Q_{w p}\left(t, T_{\text {store }}, w f, r t\right):=Q(t, w f) W_{F} \text { count } w_{W f}, t t \cdot\left[1-V e f f \cdot\left(t \leq T_{\text {store }}\right)\right]
\end{aligned}
$$

Where $\mathrm{Q}(\mathrm{t}, \mathrm{wf})$ is a continuous decay heat source function for one unit (an assembly or a canister) of waste form. $\mathrm{Q}(\mathrm{t}, \mathrm{wf})$ is evaluated in MathCAD ${ }^{\circledR}$ using a cubic spline interpolation function that is a good fit through the tabular data points which are input to the model. The cubic spline interpolation is stable and provides a good fit for the time period of interest in this calculation. However, when the decay heat values become small in the very long term, the cubic spline can become unstable and result in oscillating values. Those time periods are better addressed using a linear spline interpolation function.

\section{G.3 Host Rock Temperature Transient Analytical Model}

This model assumes an infinite medium of a given rock type, where the EBS and WP are modeled as continuous rock to the central line or point source, and the rock temperature at the calculation radius is evaluated based on the rock properties and the time-dependent heat source. 
This model consists of three components that sum together to represent the repository design. They include a central finite line source representing the waste package of interest, eight adjacent infinite line sources (four on each side of the central waste package) representing (laterally spaced) adjacent emplacement arrays, and eight adjacent point sources aligned axially with the central waste package finite line source (four on each side of the central waste package) representing adjacent waste packages.

The solution for the finite line source is derived from the point source solution as described in Sutton et al. 2011 (Section 8.1.2), and is also documented in SNL 2007. The solution for the infinite line source is presented in Carslaw and Jaeger 1959 (Section 10.3, equation 1), and also described in Sutton et al. 2011 (Section 8.1.3). The equation for the temperature transient solution for a point source is based on Carslaw and Jaeger 1959 (Section 10.4, page 261).

The one-dimensional temperature transient is the sum of the contributions from these terms as a function of radial distance and time, and is evaluated at the calculation radius (drift_r). In the current analysis, the number of adjacent lateral line sources $\left(\mathrm{N}_{\text {drifts }}\right)$, and the number of axially adjacent waste packages $\left(\mathrm{N}_{\mathrm{adj}}\right)$ were both set equal to 4 . Note that for the second and third terms, the distance is calculated to a location at the crown of the emplacement borehole or drift (see Figure 5.1-2)

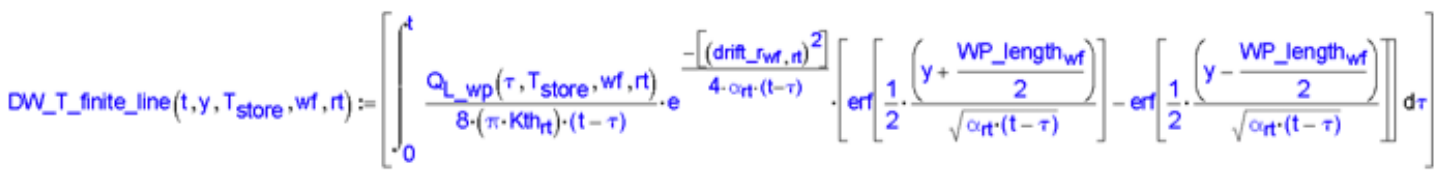

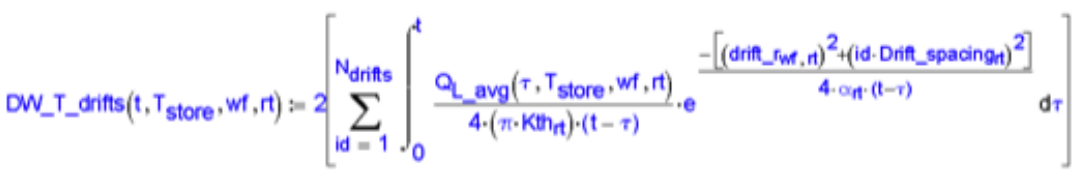

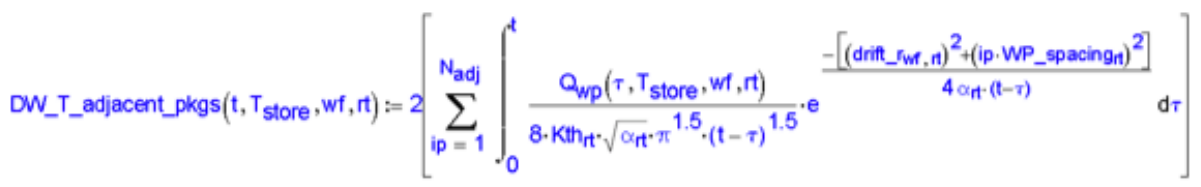

\section{G.4 Waste Package and EBS Steady-State Temperature Calculation}

As described in Section 5.1, it is assumed that at any given point at time, the relatively low thermal mass of the EBS components compared to the essentially infinite geologic medium, can be considered to be at a quasi-steady state condition.

The model for a multi-layer cylindrical steady-state temperature solution is derived from Kreith 1966 (Section 2-2, equation 2-19). In this geometry, the analytical solution is a one-dimensional (radial heat flow) model assuming an infinite line as the heat source. That particular equation is an example of two concentric cylindrical components, such as a steel pipe covered by asbestos insulation with internal convection from a hot fluid (with a convection coefficient $h_{i}$ ), and external convection to air (with a convection coefficient $h_{0}$ ). It includes four thermal resistance components - two conduction only resistances representing the pipe and the insulation, and two convection boundary layer resistances (internal and external). 
Total heat transfer is defined as $\mathrm{Q}=\mathrm{U} * \mathrm{~A}_{\text {outside }} *\left(\mathrm{~T}_{\text {inside }}-\mathrm{T}_{\text {outside }}\right)$

Where the conductance, $\mathrm{U}$, is the reciprocal of the sum of the resistances:

$$
\mathrm{U}=\frac{1}{\frac{\mathrm{r}_{3}}{\mathrm{r}_{1} \cdot \mathrm{h}_{\mathrm{i}}}+\frac{\mathrm{r}_{3} \ln \left(\frac{\mathrm{r}_{2}}{\mathrm{r}_{1}}\right)}{\mathrm{k}_{1}}+\frac{\mathrm{r}_{3} \ln \left(\frac{\mathrm{r}_{3}}{\mathrm{r}_{2}}\right)}{\mathrm{k}_{2}}+\frac{1}{\mathrm{~h}_{\mathrm{o}}}}
$$

Where $r_{3}$ is the outside surface of the insulation, $r_{2}$ is the outside surface of the pipe, and $r_{1}$ is the inside surface of the pipe

The heat flux per exterior unit area is defined as $\mathrm{q}_{\mathrm{A}}=\mathrm{Q} / \mathrm{A}_{\text {outside }}$

By conservation of energy at steady state, the temperature at the surface of each layer can be calculated as follows:

$$
q_{A}=\frac{\left(T_{i}-T_{1}\right)}{R_{i}}=\frac{\left(T_{1}-T_{2}\right)}{R_{1}}=\frac{\left(T_{2}-T_{3}\right)}{R_{2}}=\frac{\left(T_{3}-T_{0}\right)}{R_{0}}
$$

Where $T_{i}$ is the inside fluid temperature, $T_{1}$ is the pipe wall internal surface temperature, $T_{2}$ is the pipe wall external temperature (and the insulation internal surface temperature), $T_{3}$ is the insulation external surface temperature, and $\mathrm{T}_{0}$ is the air temperature. This equation and the approach were input into $\mathrm{MathCad}^{\circledR}$, and validated against Kreith 1966 (example problem 2-7)

Application of this approach to the EBS components drops the convection resistance terms (i.e., $\mathrm{T}_{\mathrm{i}}=\mathrm{T}_{1}$ and $\mathrm{T}_{\mathrm{o}}=\mathrm{T}_{3}$ ) and uses a series of thermal resistance values calculated on the basis of the EBS component radii and thermal conductivities. The following equation shows the thermal resistance terms all the way to the surface of the waste form, but the calculation results documented in this report stop at the surface of the waste package.

$$
\mathrm{U}_{\text {overall }}=\frac{1}{\mathrm{R}_{\text {canister }}+\mathrm{R}_{\text {waste_pkg }}+\mathrm{R}_{\text {buffer }}+\mathrm{R}_{\text {envelope }}+\mathrm{R}_{\text {backfill }}+\mathrm{R}_{\text {liner }}}
$$

The approach is modified somewhat to be applied to a line load $(\mathrm{W} / \mathrm{m})$ instead of an areal heat flux of $\left(\mathrm{W} / \mathrm{m}^{2}\right)$, by substituting $\mathrm{q}_{\mathrm{L}}=\mathrm{q}_{\mathrm{A}} * 2 \pi \mathrm{r}_{\text {outside. }}$. One example, for the outer surface temperature of the backfill, is the following:

$$
\mathrm{T}_{\text {BACKFILL }}=\mathrm{T}_{\text {DW }}+\frac{\mathrm{q}_{\mathrm{L}}}{2 \cdot \pi \cdot \mathrm{r}_{\mathrm{DW}}} \cdot \mathrm{R}_{\text {LINER }}=\mathrm{T}_{\text {DW }}+\frac{\mathrm{q}_{\mathrm{L}} \cdot \mathrm{r}_{\mathrm{DW}} \cdot \ln \left(\frac{\mathrm{r}_{\text {DW }}}{\mathrm{r}_{\text {BACKFILL }}}\right)}{2 \cdot \pi \cdot \mathrm{r}_{\mathrm{DW}} \mathrm{k}_{\text {LINER }}}=\mathrm{T}_{\mathrm{DW}}+\frac{\mathrm{q}_{\mathrm{L}}}{2 \cdot \pi \cdot \mathrm{k}_{\text {LINER }}} \cdot \ln \left(\frac{{ }^{\mathrm{r}_{D W}}}{\mathrm{r}_{\text {BACKFILL }}}\right)
$$

where $\mathrm{k}_{\mathrm{LINER}}$ is the liner thermal conductivity.

It is assumed that the EBS (except for the salt case) responds quickly (low thermal mass), and the heat flux at the calculation radius is always the same as the heat source, with a small time delay. The timing of the peak temperature at the calculation radius is more dependent on the rate the heat moves away from that surface into the infinite mass of host rock (and with the rate that heat 
arrives from the other adjacent heat sources) with respect to the rate that the decay heat curve is dropping.

This process (the heat flux at the calculation radius feeding the outside calculation) would differ significantly if the EBS possessed a wide range of thermal conductivities (higher for realistic cases, and lower for substituting host rock). In fact, the primary difference is the magnitude of the thermal gradient required to force that same heat flux out of the surface at the calculation radius. The thermal gradient increases with thermal resistance, until the calculated heat flux equals the steady-state heat flux

As the thermal resistance goes up, the thermal gradient gets steeper until the calculated heat flux with the higher resistance matches the required "steady state" heat flux.

The normalized thermal resistance for each layer associated with the calculations for SNF and HLW in the four geologic media are shown in Figure G.4-1, below.

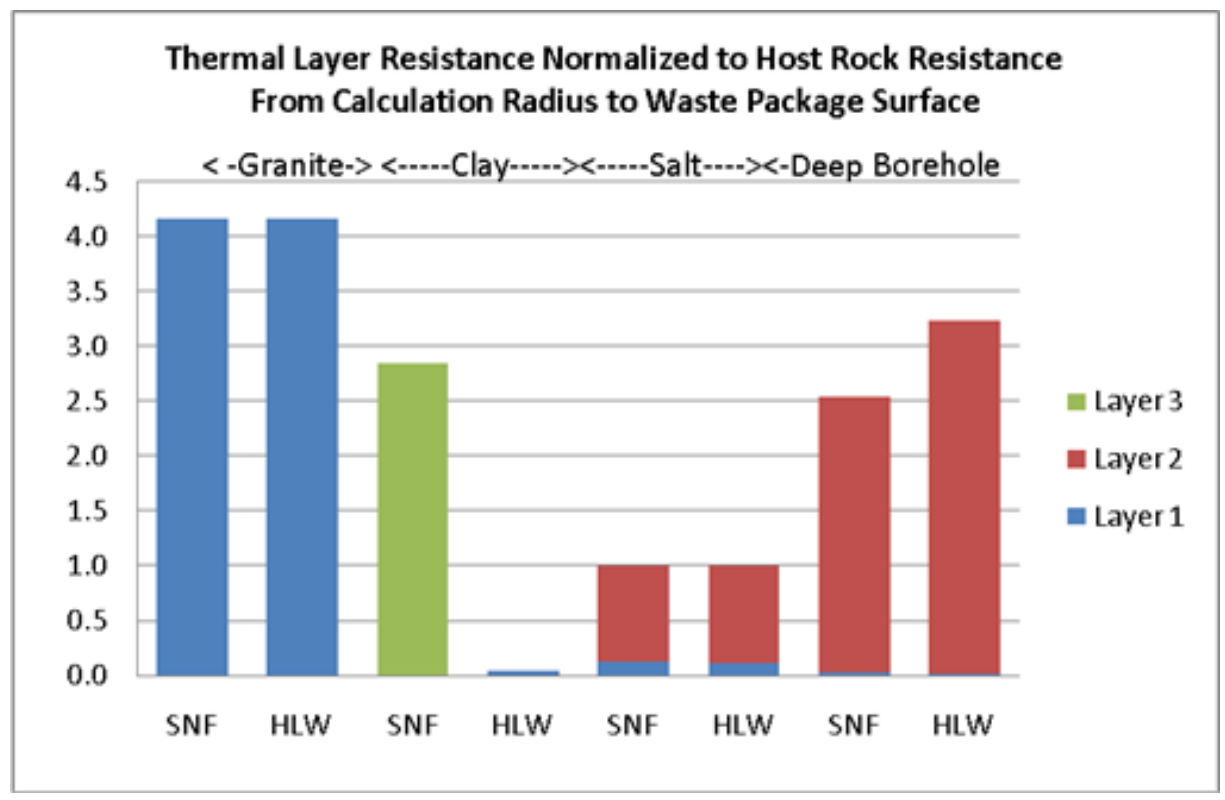

Figure G.4-1 Normalized Thermal Resistance of Each EBS Layer.

\section{G.5 Model Limitations and Potential Future Model Improvements}

The current set of analytical models assumes constant thermal properties for the host rock, and some of the thermal properties, such as thermal conductivity and thermal diffusivity are functions of temperature, porosity, or moisture content that can vary over time. This has not been addressed, except in an effort to bound the variation of salt properties by using crushed and intact salt properties as bounding cases.

Clayton and Gable (2009, Section 3.1) provide data addressing the thermal conductivity and diffusivity of intact salt with temperature (Equation 3.1), and of crushed salt with porosity and temperature (Equation 3.4). The authors also provide a discussion of the time for reconsolidation of crushed salt to intact salt (ibid Figure 4.18). Figures G.5-1 and G.5-2 are derived from the equations and data in Clayton and Gable (2009, Section 3.1). 
Conductivity of Crushed Salt vs Porosity and Temperature

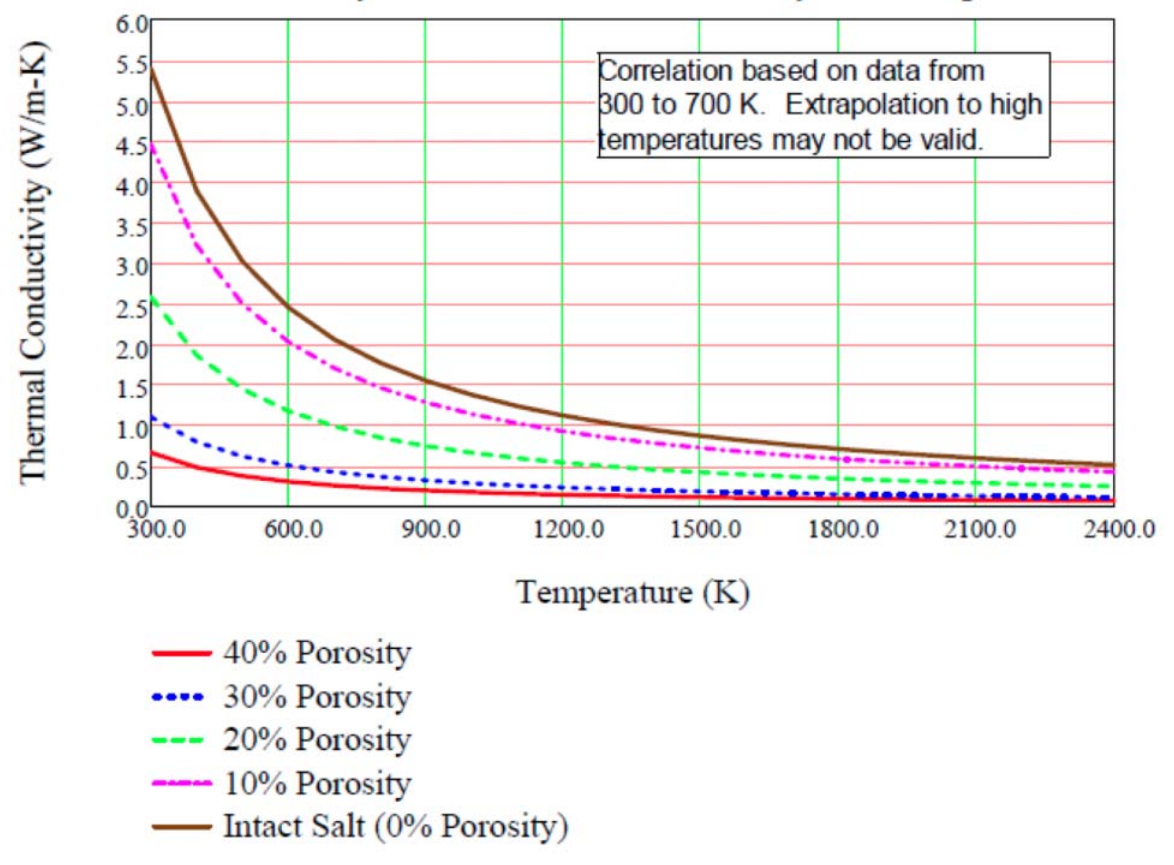

Figure G.5-1 Effects of Porosity and Temperature on Thermal Conductivity of Crushed Salt.

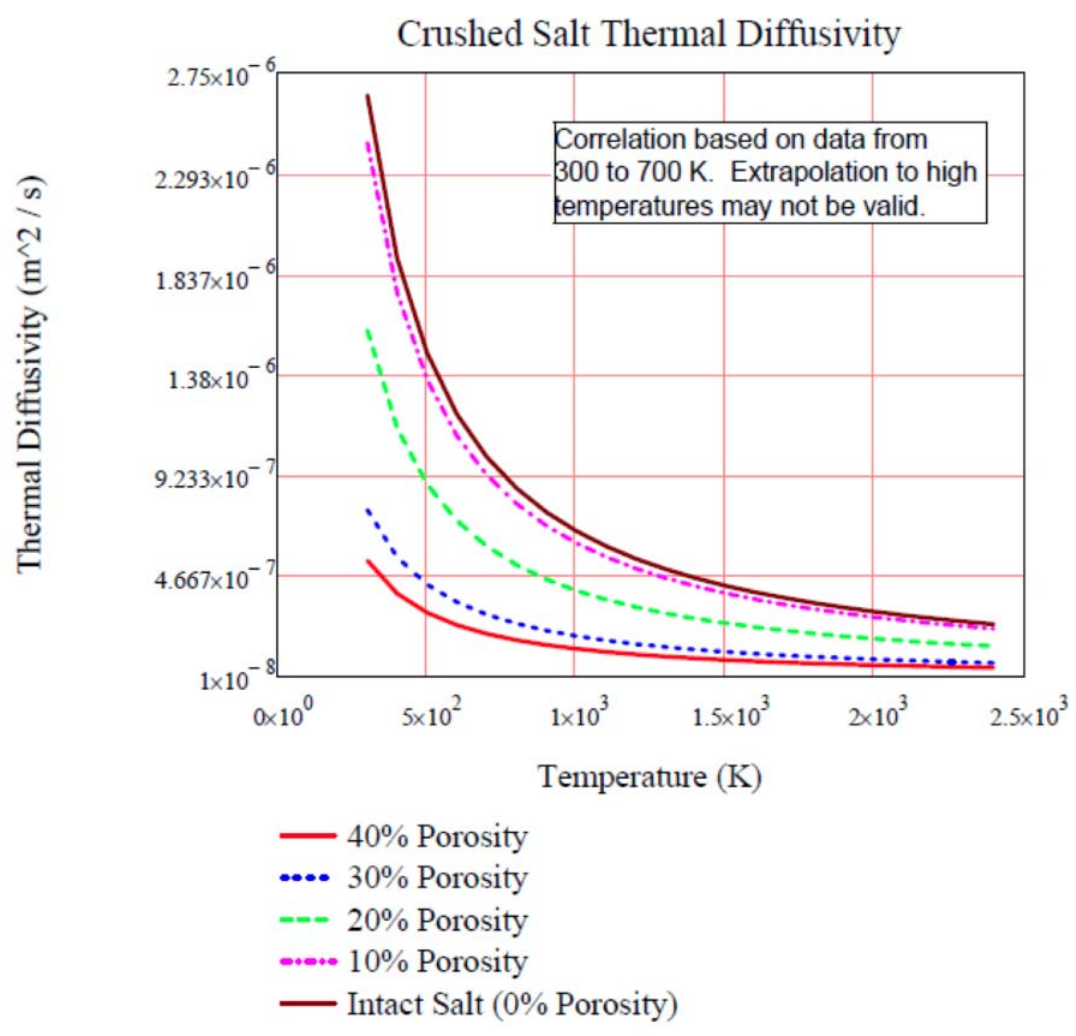


Figure G.5-2 Effects of Porosity and Temperature on Thermal Diffusivity of Crushed Salt. The model assumes zero contact resistance between the various layers of the EBS, and also assumes that there is no settling of buffer or backfill materials, i.e. that there are no air gaps. Both of these potential additional resistances can be addressed.

In a given region, if there is an air gap instead of buffer or backfill material, for example, there will be radiation heat transfer in that region. However, this can be modeled as a linearized "effective" radiation heat transfer coefficient as follows:

$$
\mathrm{Q}_{\text {radiant }}=\sigma \cdot \varepsilon \cdot \mathrm{A} \cdot\left(\mathrm{T}_{1}{ }^{4}-\mathrm{T}_{2}{ }^{4}\right)=\sigma \cdot \varepsilon \cdot \mathrm{A} \cdot\left(\mathrm{T}_{1}{ }^{2}-\mathrm{T}_{2}{ }^{2}\right) \cdot\left(\mathrm{T}_{1}{ }^{2}+\mathrm{T}_{2}{ }^{2}\right)
$$

where $\sigma$ is the Stefan-Boltzmann constant and $\varepsilon$ is the emissivity of the surface.

$$
\mathrm{Q}_{\text {radiant }}=\sigma \cdot \varepsilon \cdot \mathrm{A} \cdot\left(\mathrm{T}_{1}-\mathrm{T}_{2}\right)\left(\mathrm{T}_{1}+\mathrm{T}_{2}\right) \cdot\left(\mathrm{T}_{1}^{2}+\mathrm{T}_{2}^{2}\right)
$$

We can then define $h_{\text {rad }}$ as follows:

$$
\mathrm{h}_{\mathrm{rad}}=\sigma \cdot \varepsilon \cdot\left(\mathrm{T}_{1}+\mathrm{T}_{2}\right) \cdot\left(\mathrm{T}_{1}{ }^{2}+\mathrm{T}_{2}{ }^{2}\right) \quad \text { Such that } \quad \mathrm{Q}_{\mathrm{radiant}}=\mathrm{h}_{\mathrm{rad}} \cdot \mathrm{A} \cdot\left(\mathrm{T}_{1}-\mathrm{T}_{2}\right) \quad \mathrm{R}_{\mathrm{rad}}:=\frac{1}{\mathrm{~h}_{\mathrm{rad}}}
$$

Then the radiant resistance term can be treated just like an internal or external heat transfer coefficient. However, since $h_{\text {rad }}$ is a function of temperature, an initial guess and an iteration process (or a MathCAD Solve Block) are needed to converge on the solution to the temperature distribution. 
THIS PAGE INTENTIONALLY LEFT BLANK 


\section{Appendix $\mathbf{H}$}

\section{Results From Thermal Analysis of Reference Disposal Concepts}




\section{H.1 Introduction}

The assumptions, inputs, models and solutions for the thermal behavior in clay, crystalline/granite, salt and deep borehole are documented in Section 5 of this report.

Section H.2 "Contributions to Total System Heat from the Central Waste Package, Axial and Lateral Heat Sources" contains Figures H.2-1 to H.2-24 that show the relative contributions from the central waste package, the axial waste packages along the central emplacement line (4 on either side of the central package) and the lateral emplacement lines (4 on each side of the central line) to the total emplacement temperature.

Section H.3 "Transient Temperature in the Host Rock" contains Figures H.3-1 to H.3-24 that show the overall transient temperature in each host rock media at the calculation radius for 3 storage times, namely 10,50 and 100 years.

Section H.4 "Waste Package Surface Temperature" contains Figures H.4-1 to H.4-24 that show the waste package surface temperature based on steady state calculations at each point in time through the corresponding layers of the EBS components.

Section H.5 "Waste Package Peak Temperature as a Function of Storage Time and Number of Assemblies" contains Figures H.5-1 to H.5-6 that show the waste package peak temperature as a function of storage time and number of assemblies or canisters within a waste package.

Section H.6 "Trade-off of Storage Time and Waste Package Capacity" contains Figures H.6-1 and H.6-2 that show the trade-off between storage time and waste package capacity. 


\section{H.2 Contributions to Total System Heat from the Central Waste Package, Axial and Lateral Heat Sources}

This section documents calculation of temperature at a specified calculation radius in a homogeneous medium with a combination of finite line (central package), individual points (adjacent waste packages), and infinite lines (adjacent lines of waste packages).

The calculation radii for the four disposal concepts are:

- Crystalline/Granite: SNF 0.83 m, HLW 0.76 m

- Clay: SNF $1.32 \mathrm{~m}$, HLW $0.37 \mathrm{~m}$

- Salt: SNF and HLW $4 \mathrm{~m}$

- Deep borehole: SNF $0.19 \mathrm{~m}$, HLW $0.20 \mathrm{~m}$

The number of assemblies or canisters per waste package is indicated in the figure captions that also define shorthand notation that is used in subsequent sections of this appendix. 


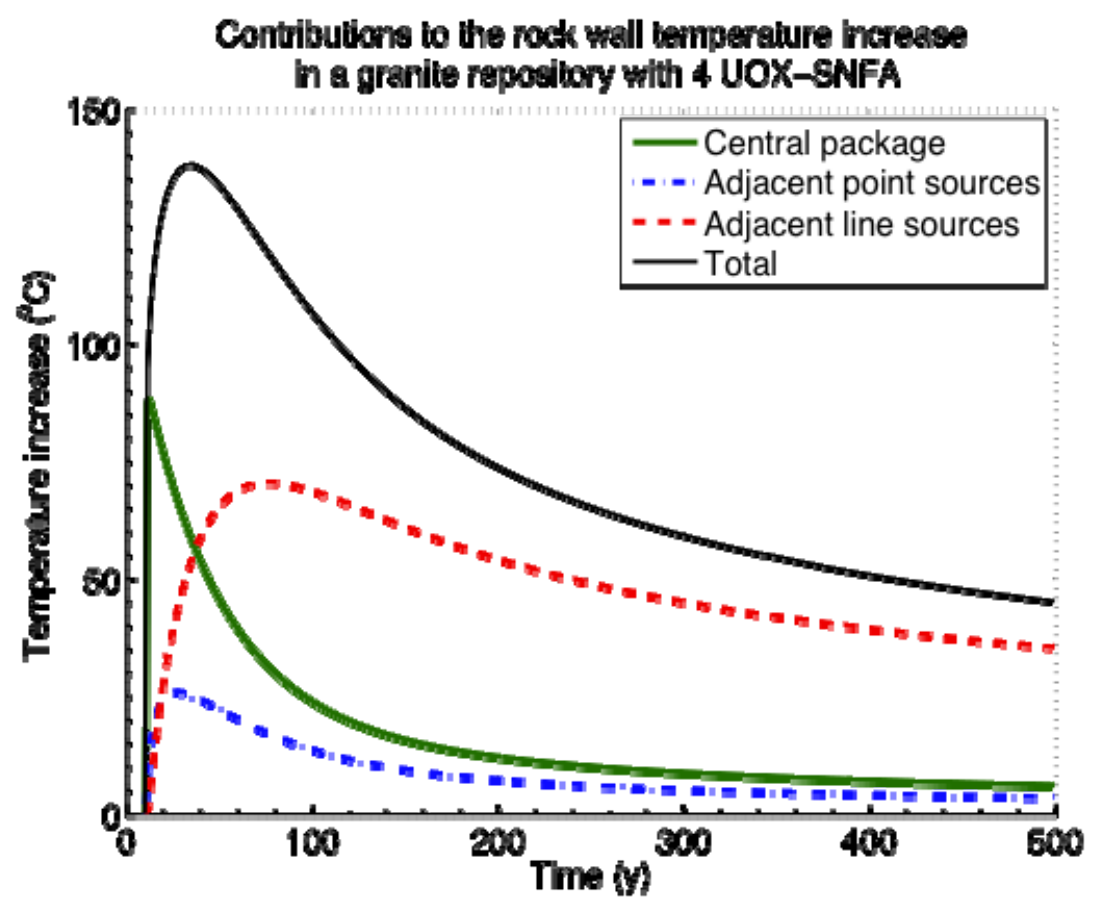

Figure H.2-1 Contributions to Temperature at the "Calculation Radius" from the Central Package, Adjacent Packages, and Neighboring Drifts, for Packages Containing 4 UOX Assemblies (UOX-4) in Crystalline Rock.

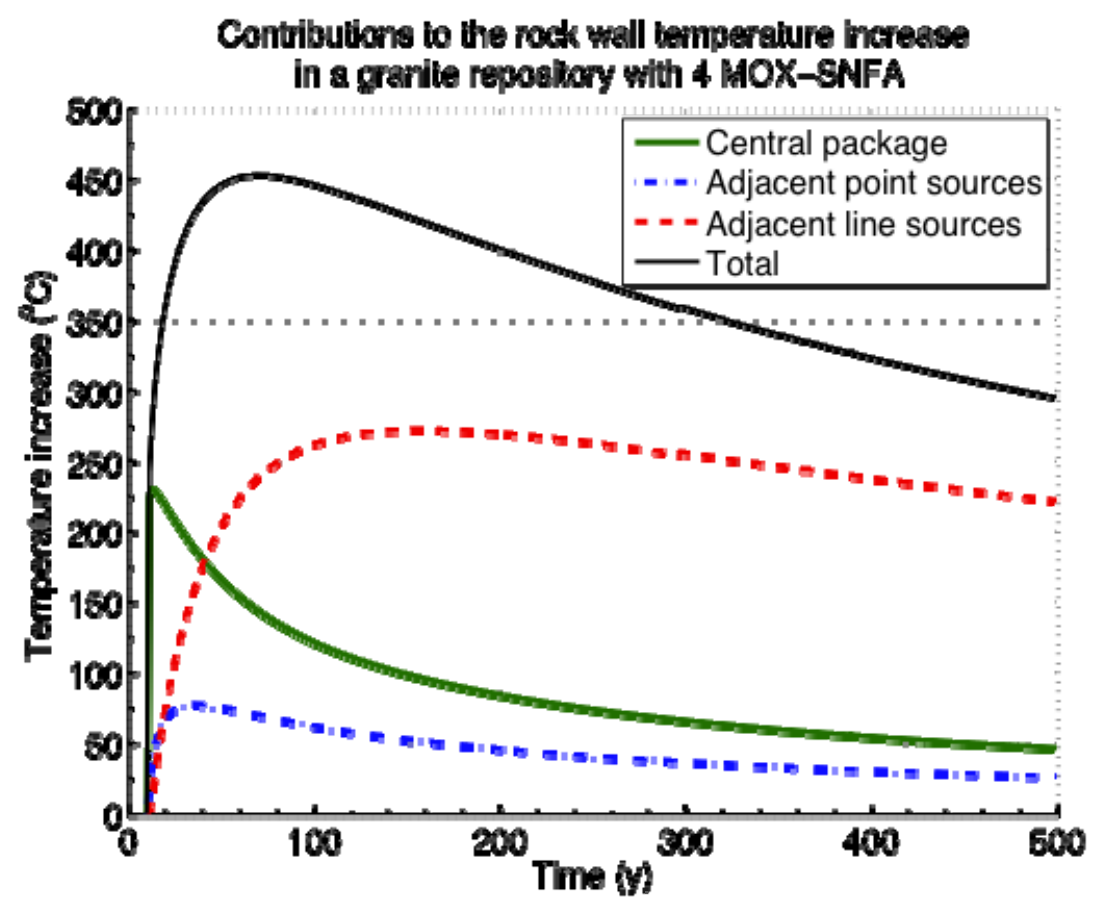

Figure H.2-2 Contributions to Temperature at the "Calculation Radius" from the Central Package, Adjacent Packages, and Neighboring Drifts, for Packages Containing 4 MOX Assemblies (MOX-4) in Crystalline Rock. 


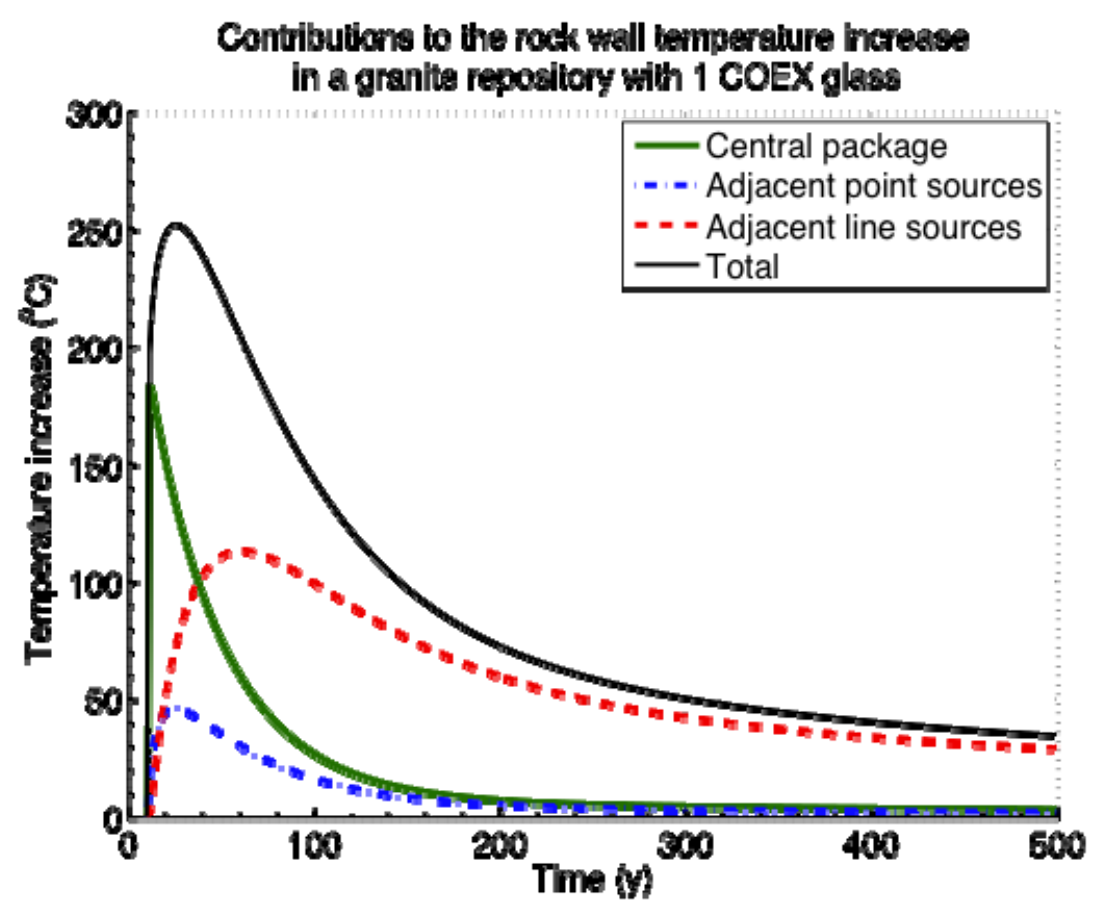

Figure H.2-3 Contributions to Temperature at the "Calculation Radius" from the Central Package, Adjacent Packages, and Neighboring Drifts, for Packages Containing a Single Co-Extraction HLW (Co-Extraction-1) Canister, in Crystalline Rock.

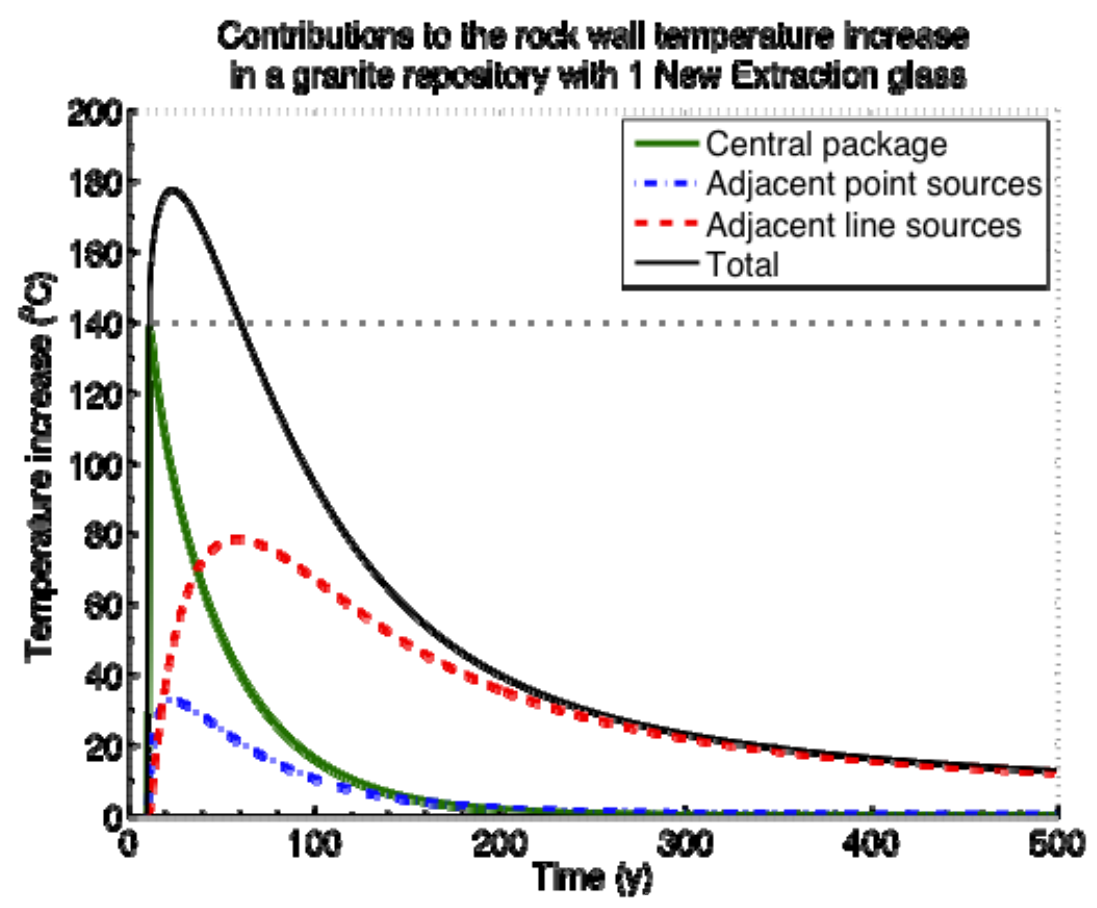

Figure H.2-4 Contributions to Temperature at the "Calculation Radius" from the Central Package, Adjacent Packages, and Neighboring Drifts, for Packages Containing a Single New Extraction HLW (New Extraction-1) Canister, in Crystalline Rock. 


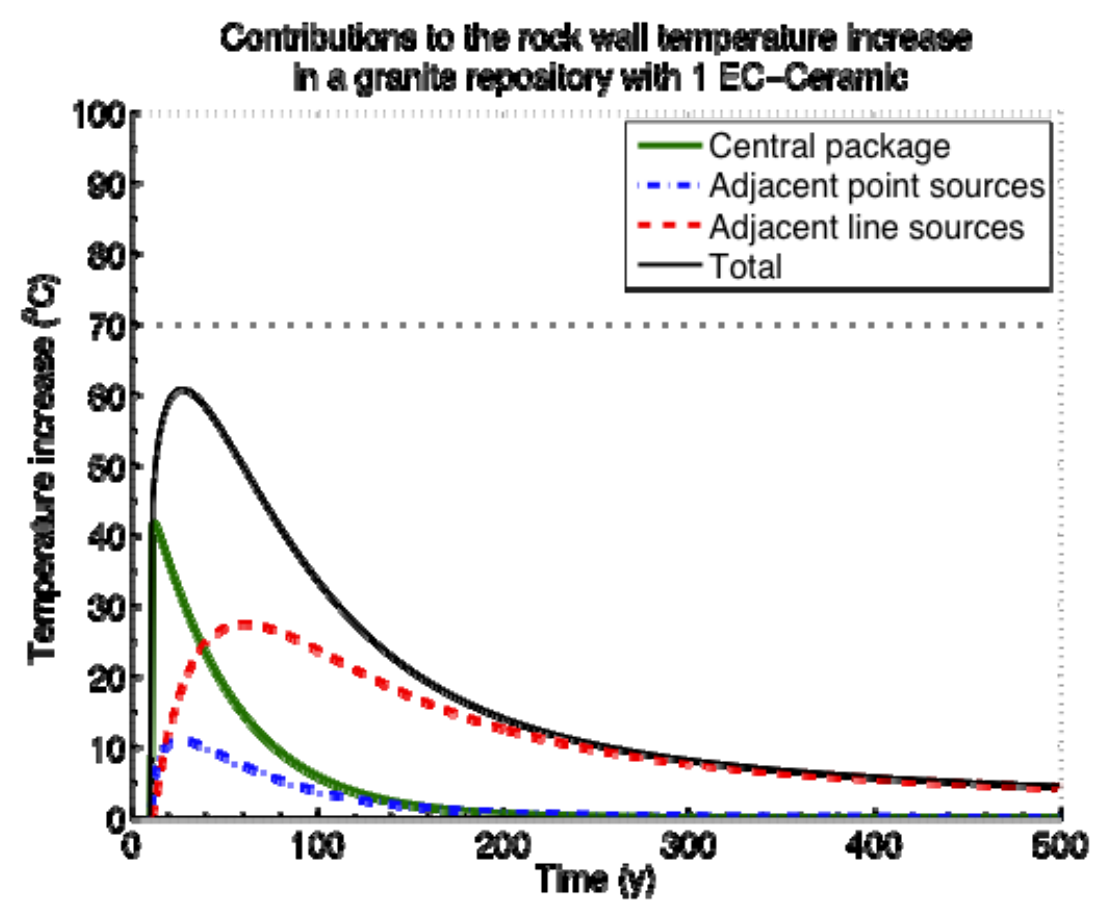

Figure H.2-5 Contributions to Temperature at the "Calculation Radius" from the Central Package, Adjacent Packages, and Neighboring Drifts, for Packages Containing a Single EC-Ceramic HLW (ECC-1) Canister, in Crystalline Rock.

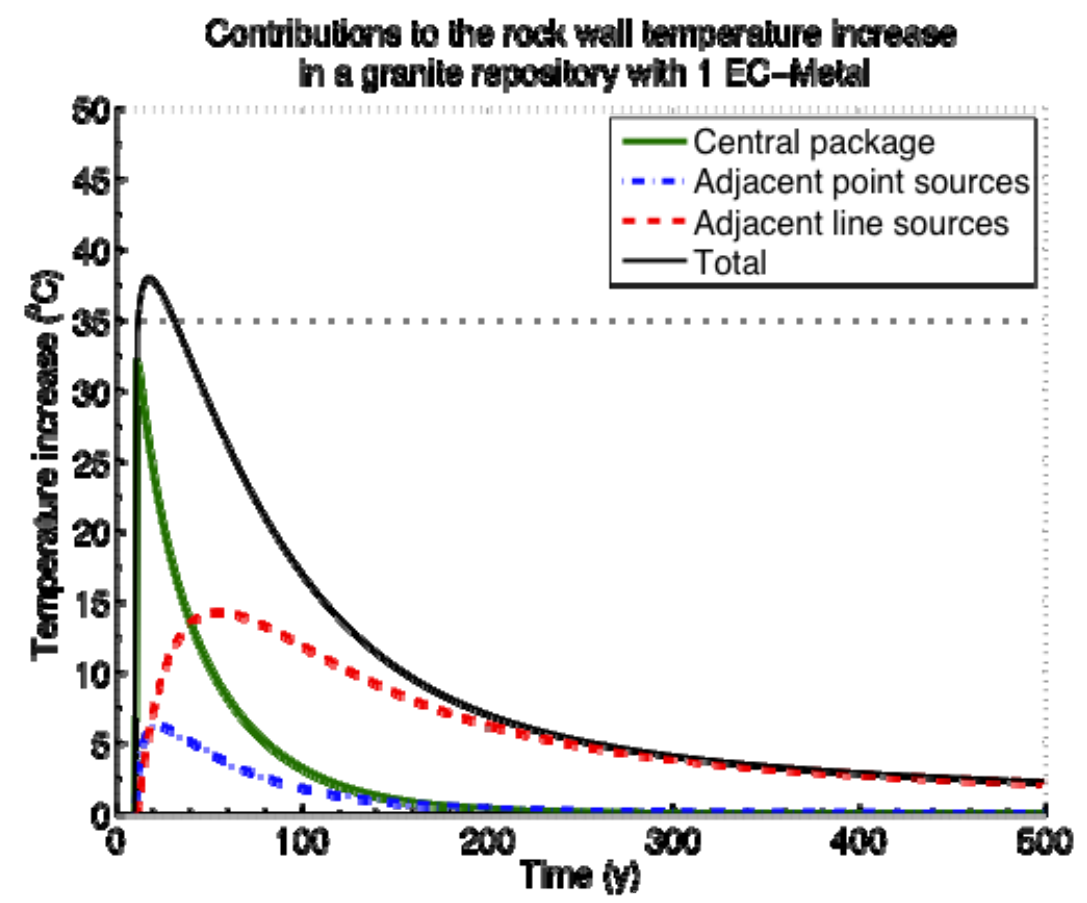

Figure H.2-6 Contributions to Temperature at the "Calculation Radius" from the Central Package, Adjacent Packages, and Neighboring Drifts, for Packages Containing a Single EC-Metal HLW (ECM-1) Canister, in Crystalline Rock. 


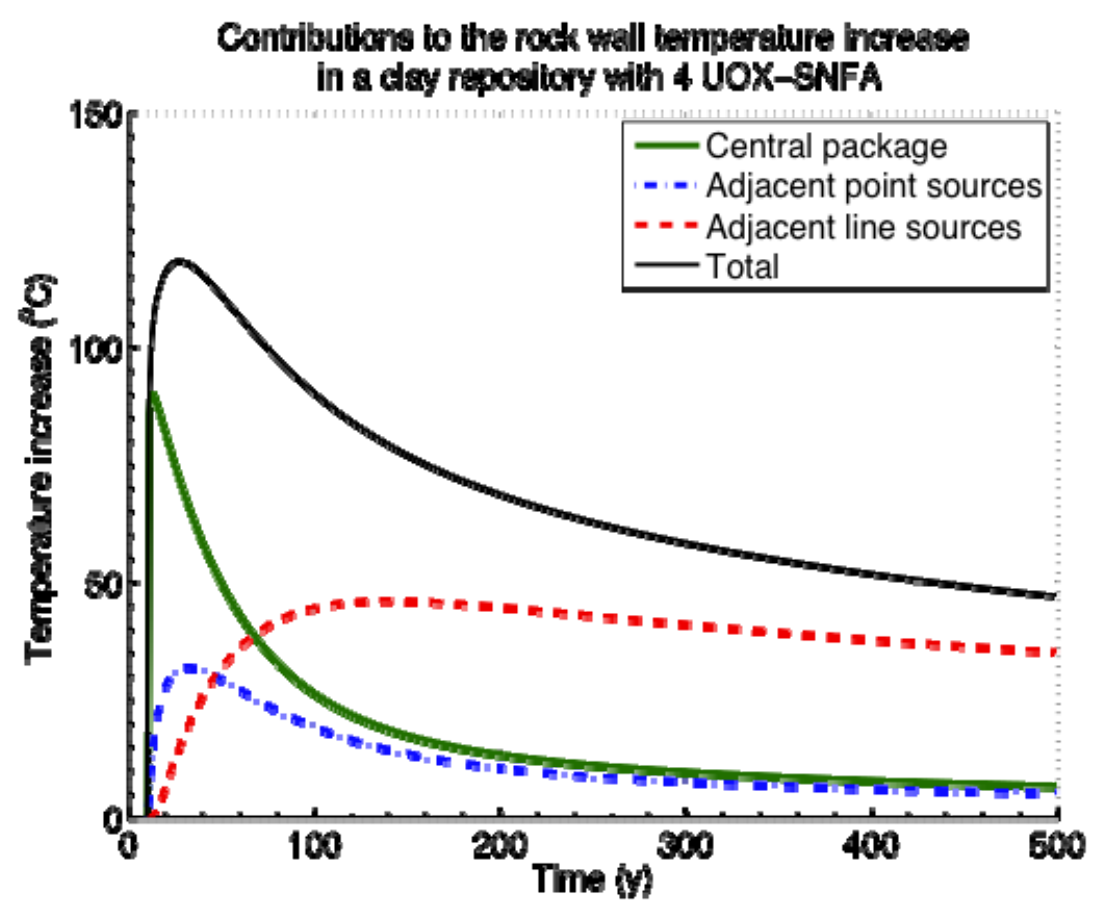

Figure H.2-7 Contributions to Rock Temperature at the "Calculation Radius" from the Central Package, Adjacent Packages, and Neighboring Drifts for UOX-4 in Clay/Shale.

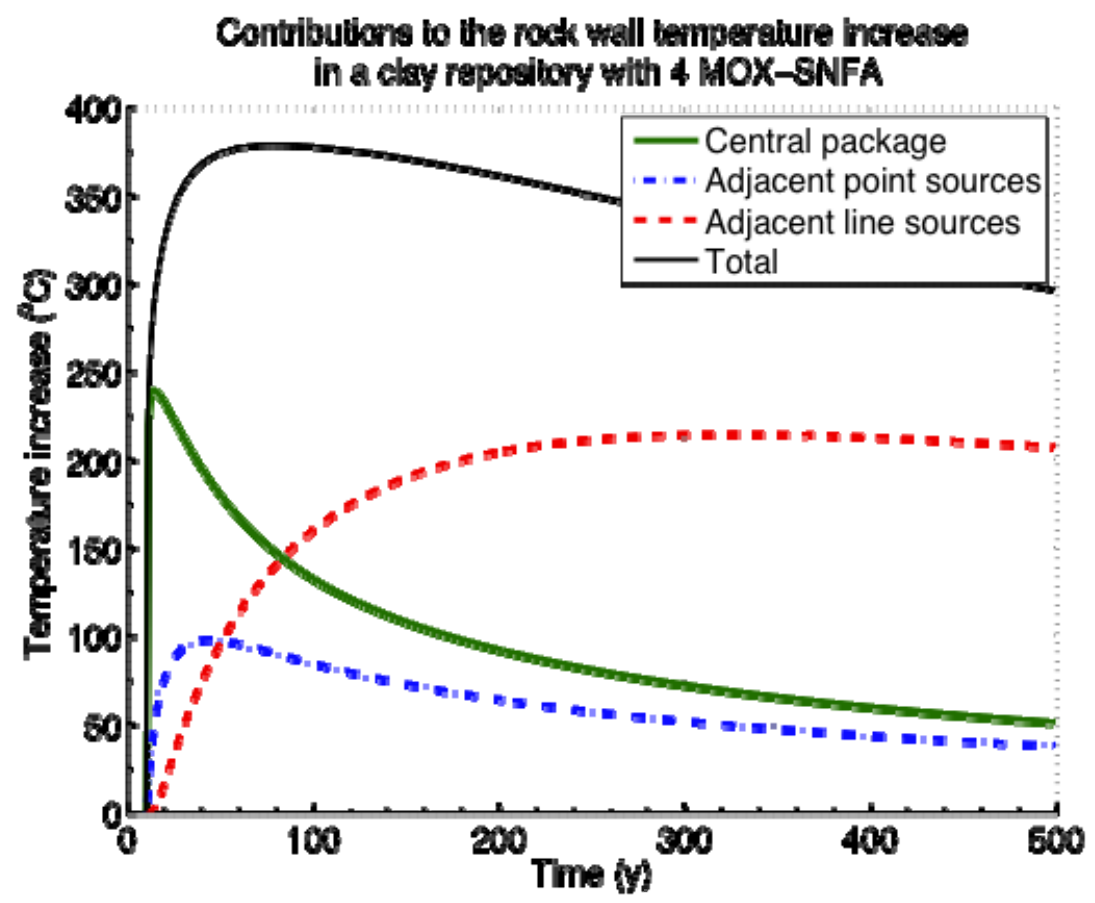

Figure H.2-8 Contributions to Rock Temperature at the "Calculation Radius" from the Central Package, Adjacent Packages, and Neighboring Drifts for MOX-4 in Clay/Shale. 


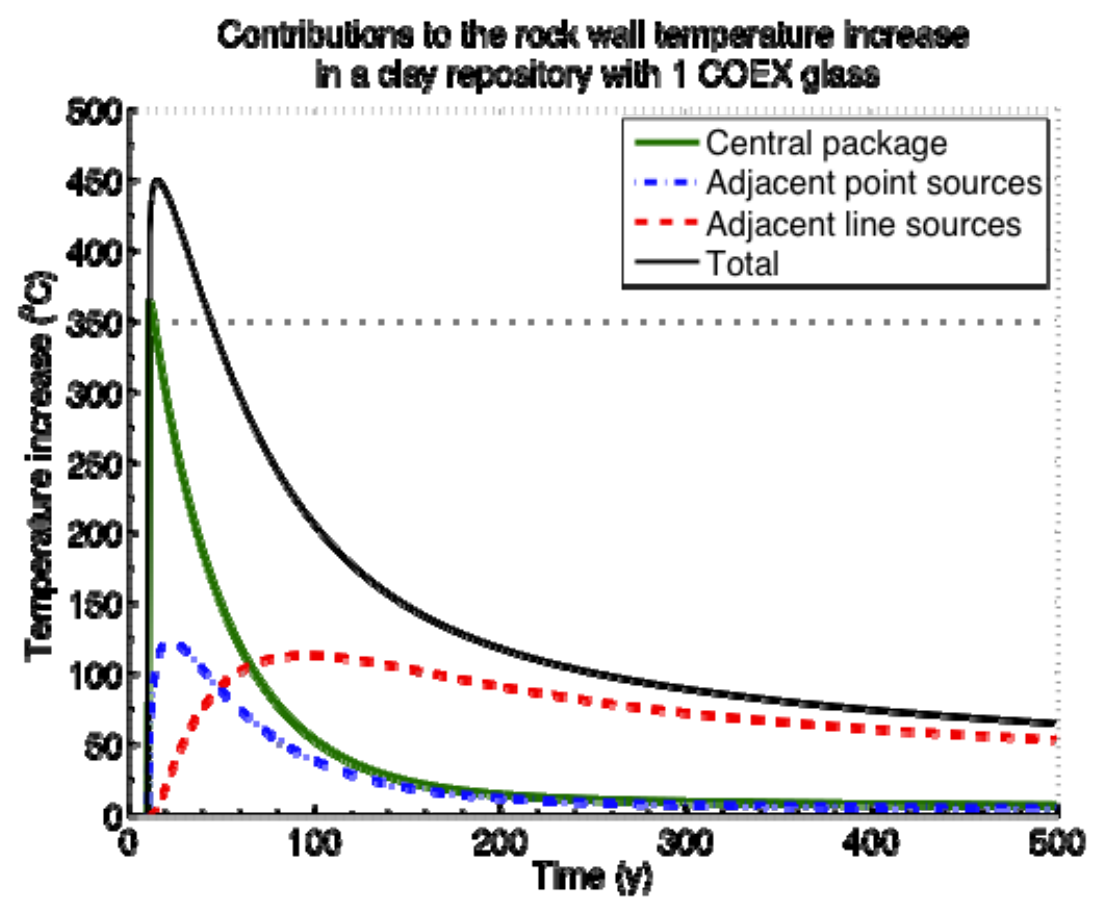

Figure H.2-9 Contributions to Rock Temperature at the "Calculation Radius" from the Central Package, Adjacent Packages, and Neighboring Drifts for Co-Extraction-1 in Clay/Shale.

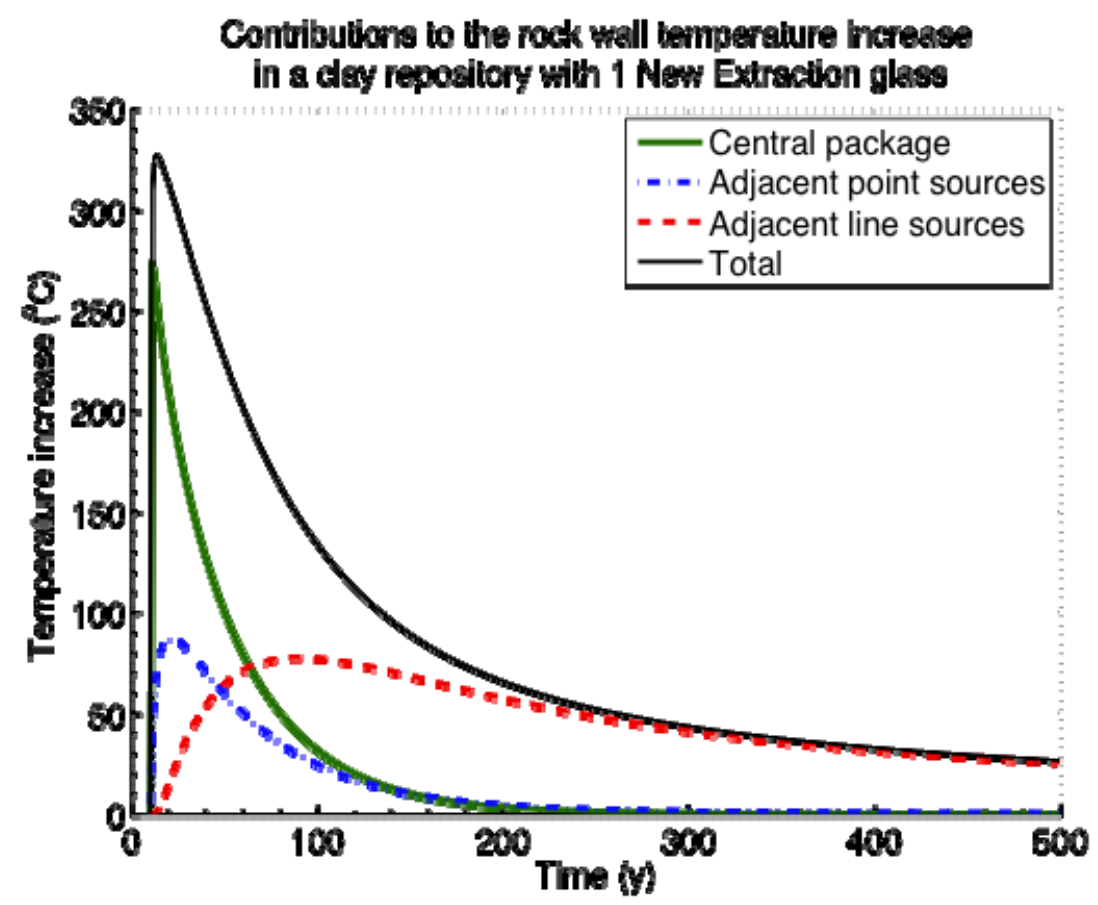

Figure H.2-10 Contributions to Rock Temperature at the "Calculation Radius" from the Central Package, Adjacent Packages, and Neighboring Drifts for New Extraction-1 in Clay/Shale. 


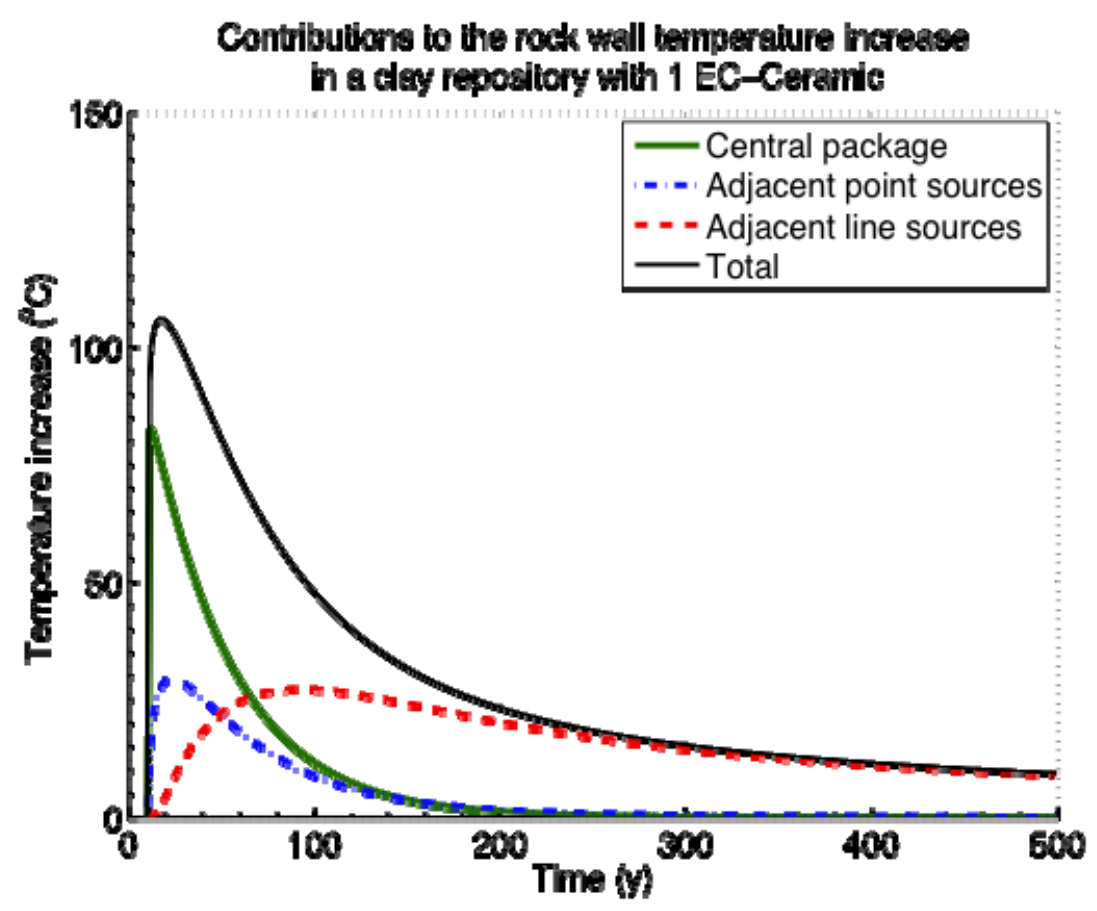

Figure H.2-11 Contributions to Rock Temperature at the "Calculation Radius" from the Central Package, Adjacent Packages, and Neighboring Drifts for ECC-1 in Clay/Shale.

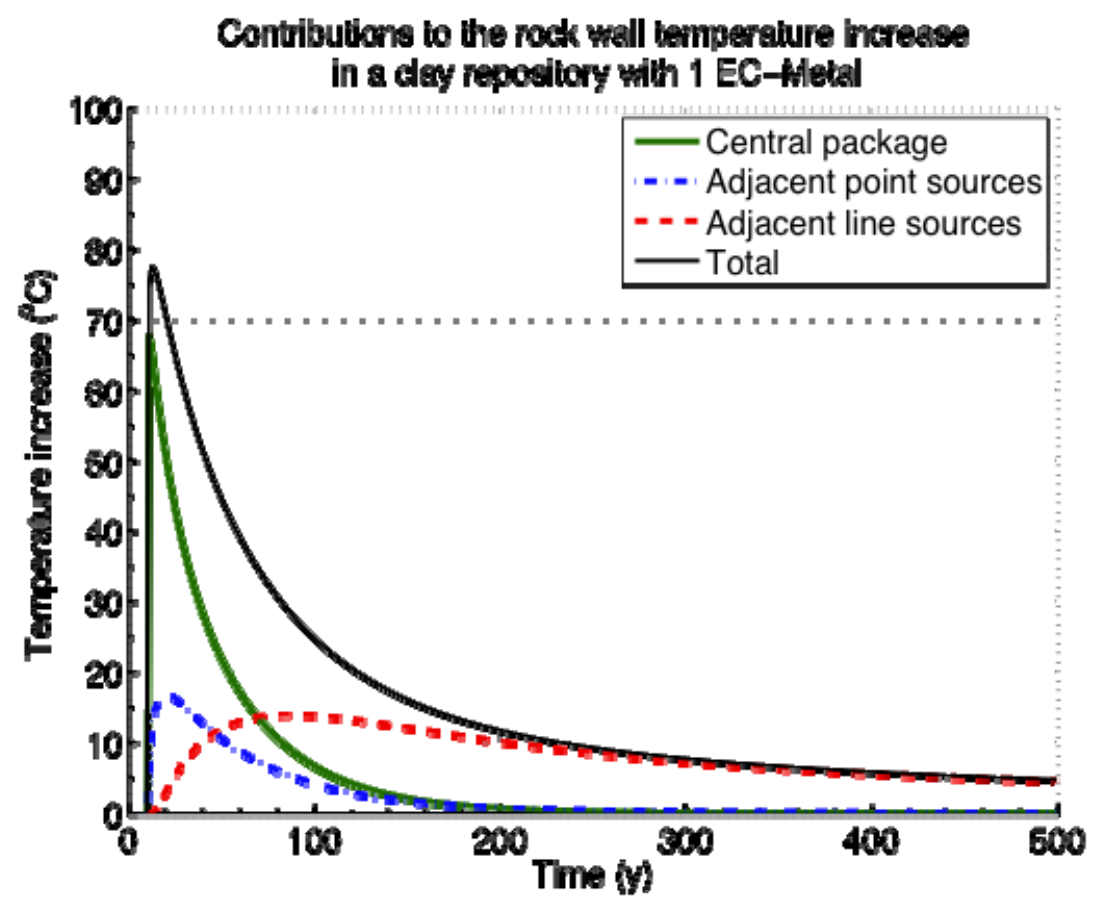

Figure H.2-12 Contributions to Rock Temperature at the "Calculation Radius" from the Central Package, Adjacent Packages, and Neighboring Drifts for ECM-1 in Clay/Shale. 


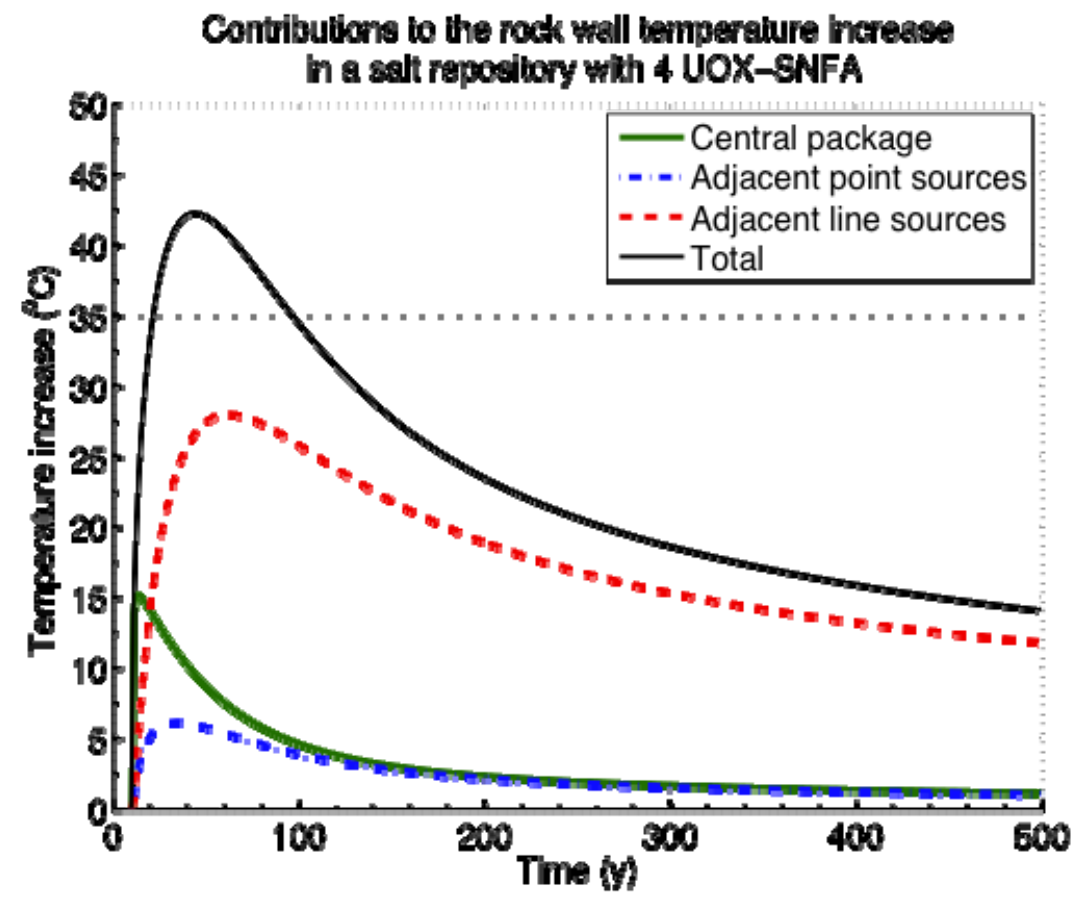

Figure H.2-13 Contributions to Rock Temperature at the "Calculation Radius" from the Central Package, Adjacent Packages, and Neighboring Drifts for UOX-4 in Salt.

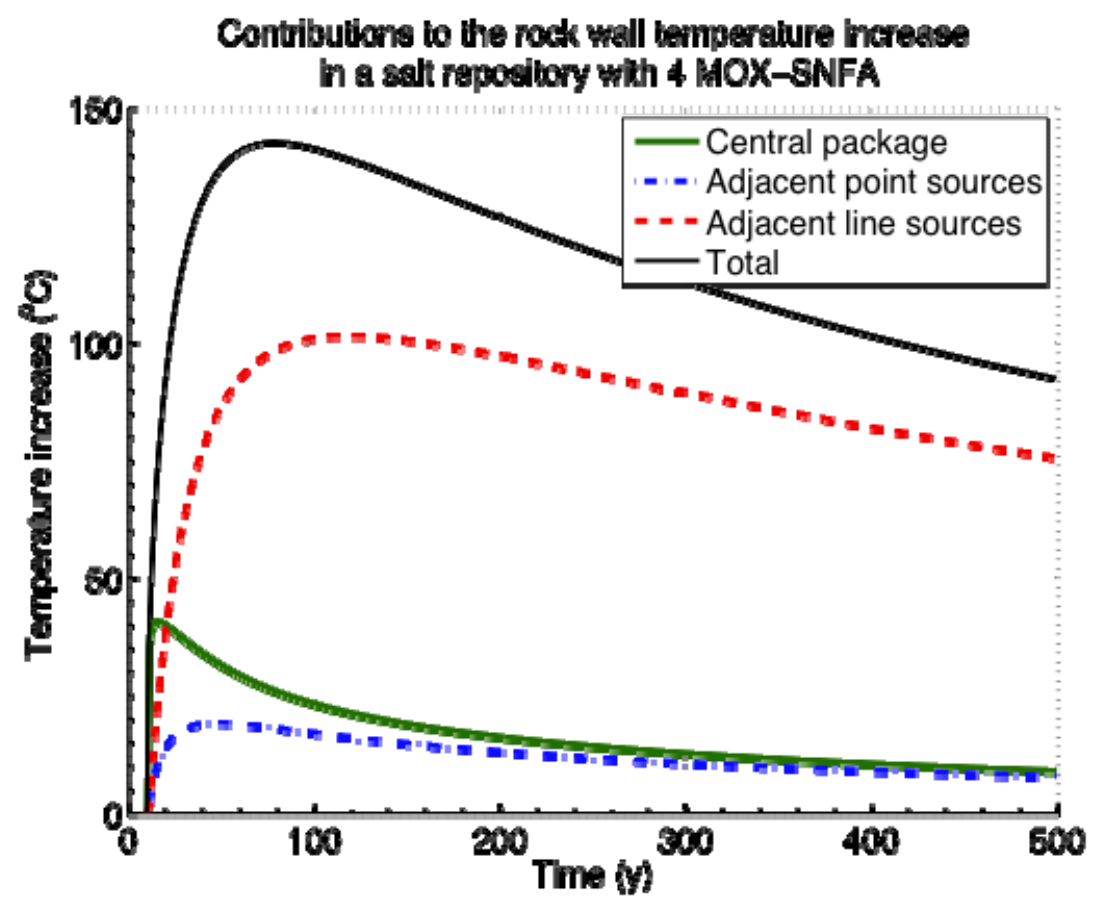

Figure H.2-14 Contributions to Rock Temperature at the "Calculation Radius" from the Central Package, Adjacent Packages, and Neighboring Drifts for MOX-4 in Salt. 


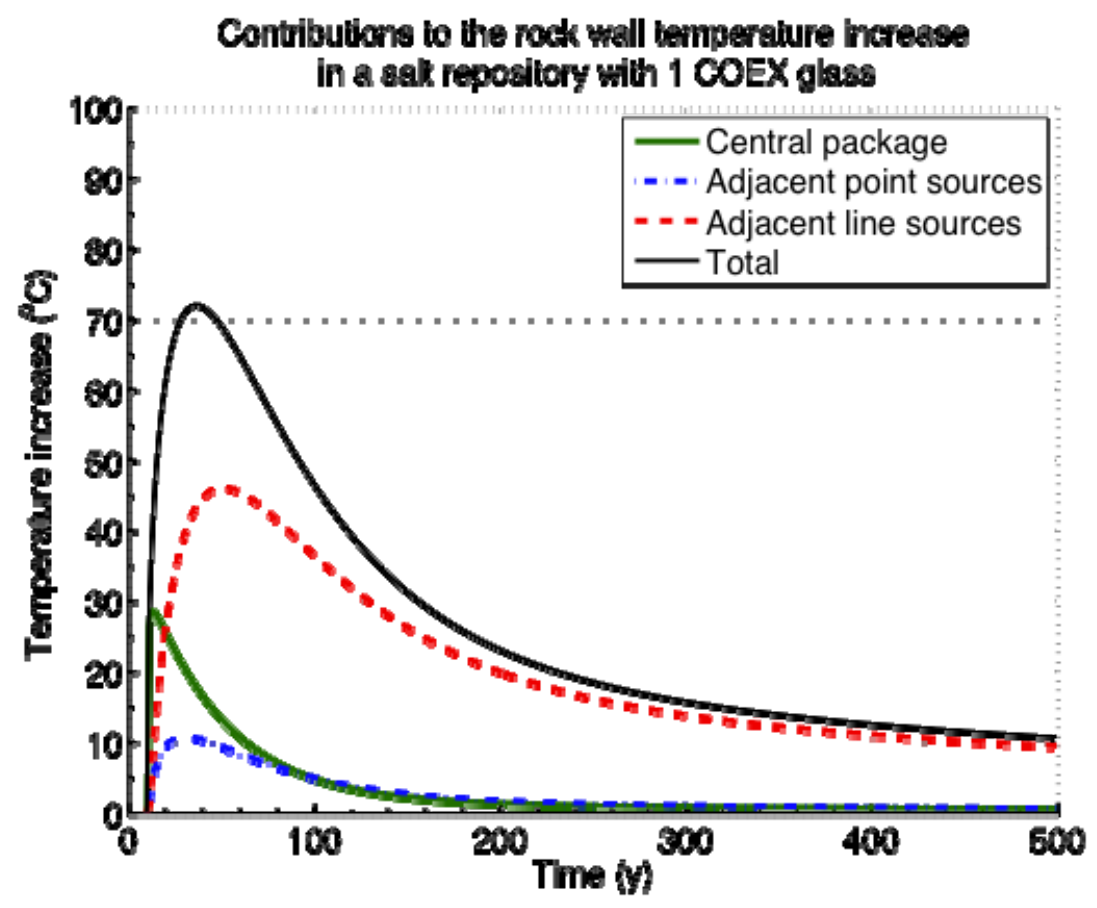

Figure H.2-15 Contributions to Rock Temperature at the "Calculation Radius" from the Central Package, Adjacent Packages, and Neighboring Drifts for Co-Extraction-1 in Salt.

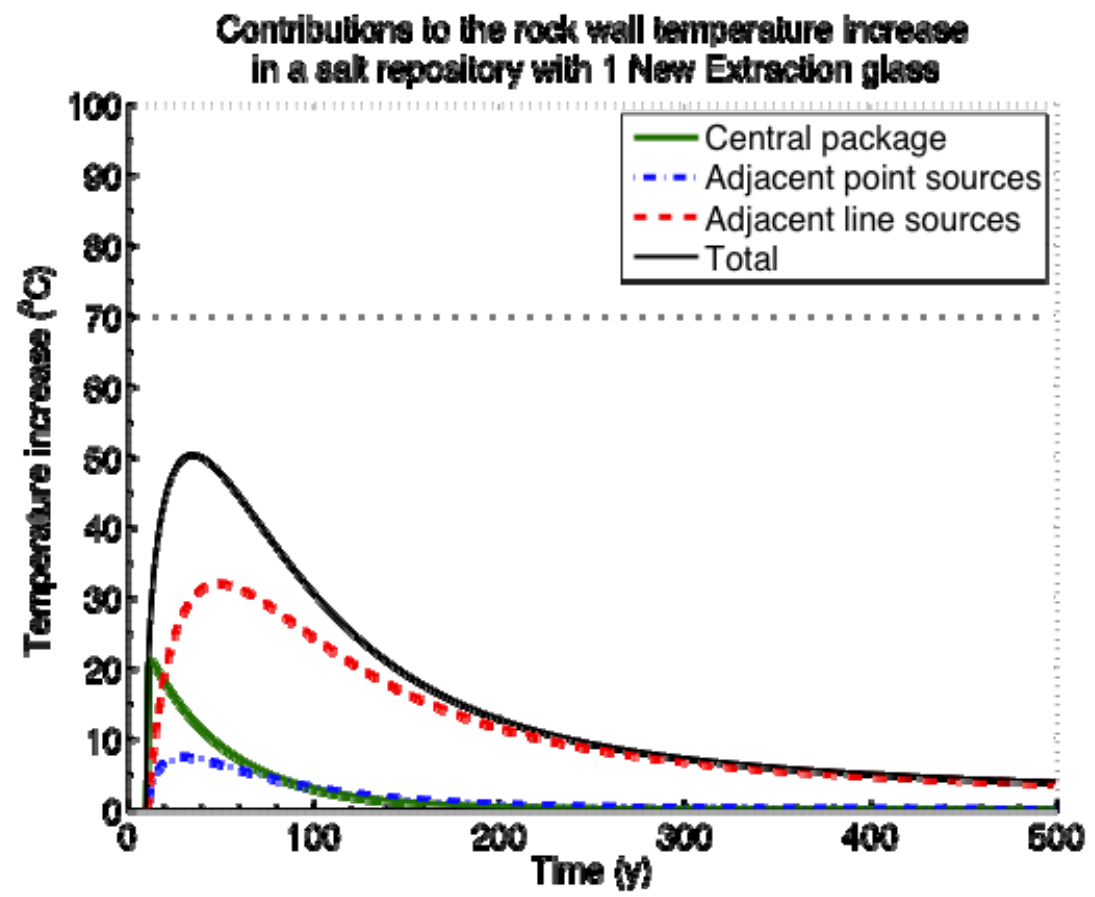

Figure H.2-16 Contributions to Rock Temperature at the "Calculation Radius" from the Central Package, Adjacent Packages, and Neighboring Drifts for New Extraction-1 in Salt. 


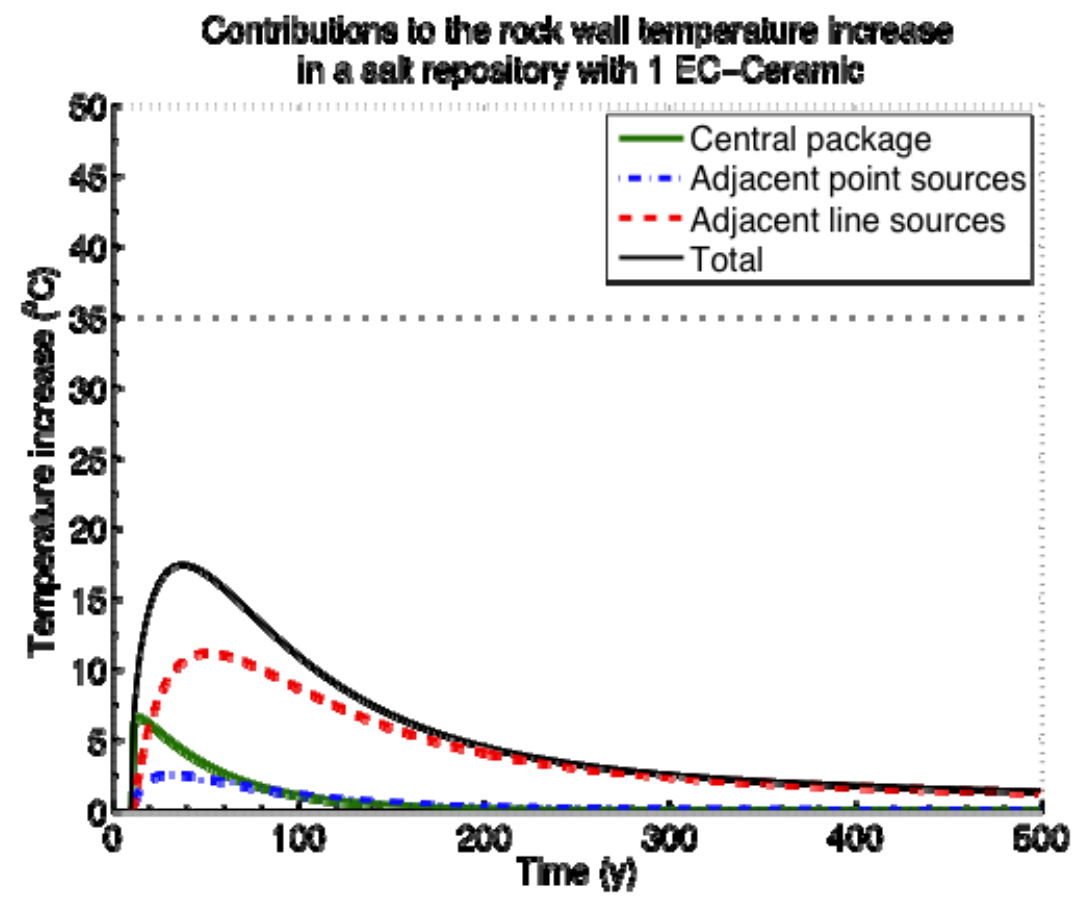

Figure H.2-17 Contributions to Rock Temperature at the "Calculation Radius" from the Central Package, Adjacent Packages, and Neighboring Drifts for ECC-1 in Salt.

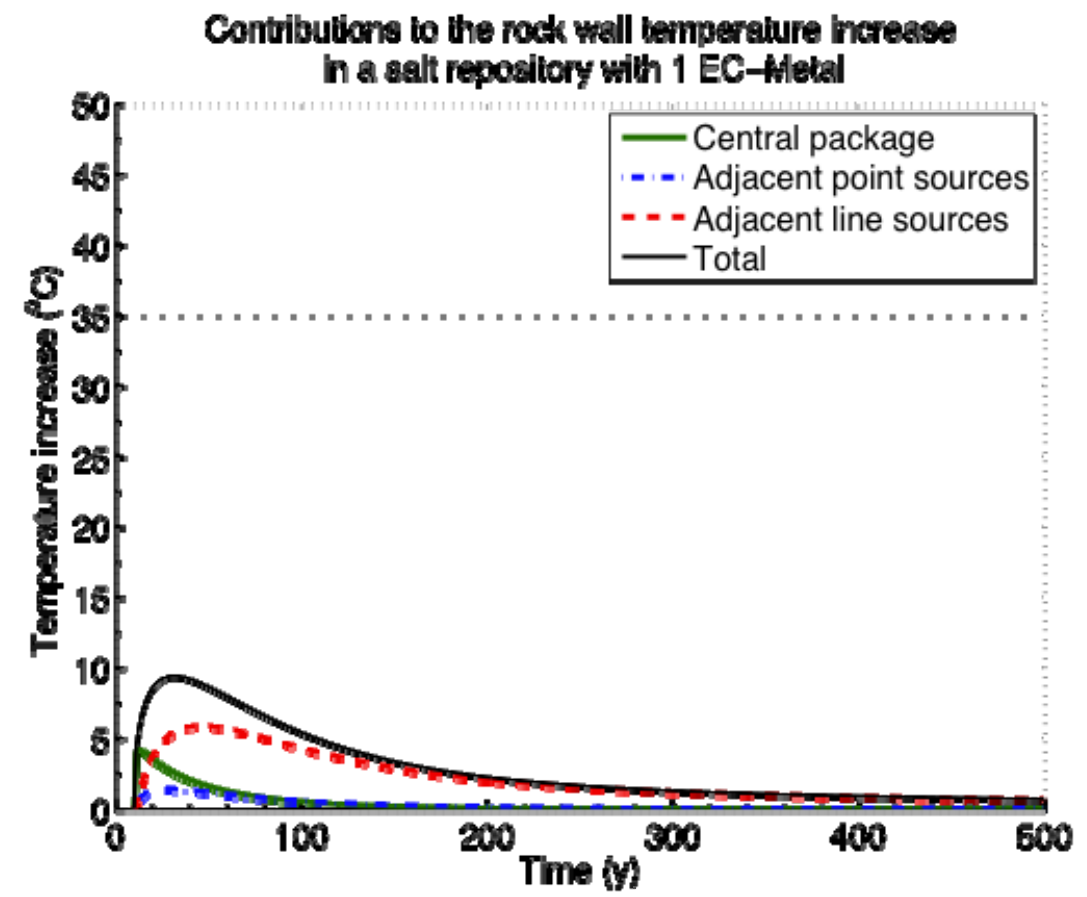

Figure H.2-18 Contributions to Rock Temperature at the "Calculation Radius" from the Central Package, Adjacent Packages, and Neighboring Drifts for ECM-1 in Salt. 


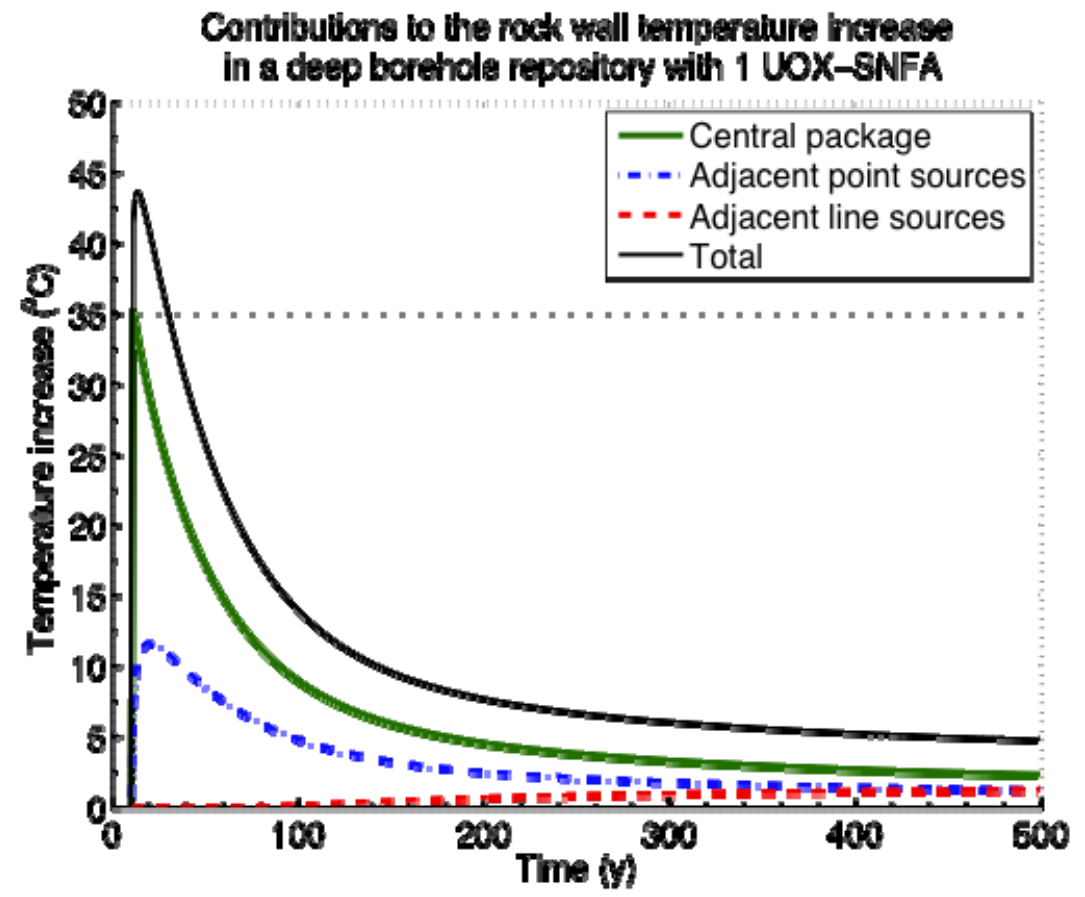

Figure H.2-19 Contributions to Temperature at the "Calculation Radius" from the Central Package, Adjacent Packages, and Neighboring Boreholes, for UOX-1 in a Deep Borehole.

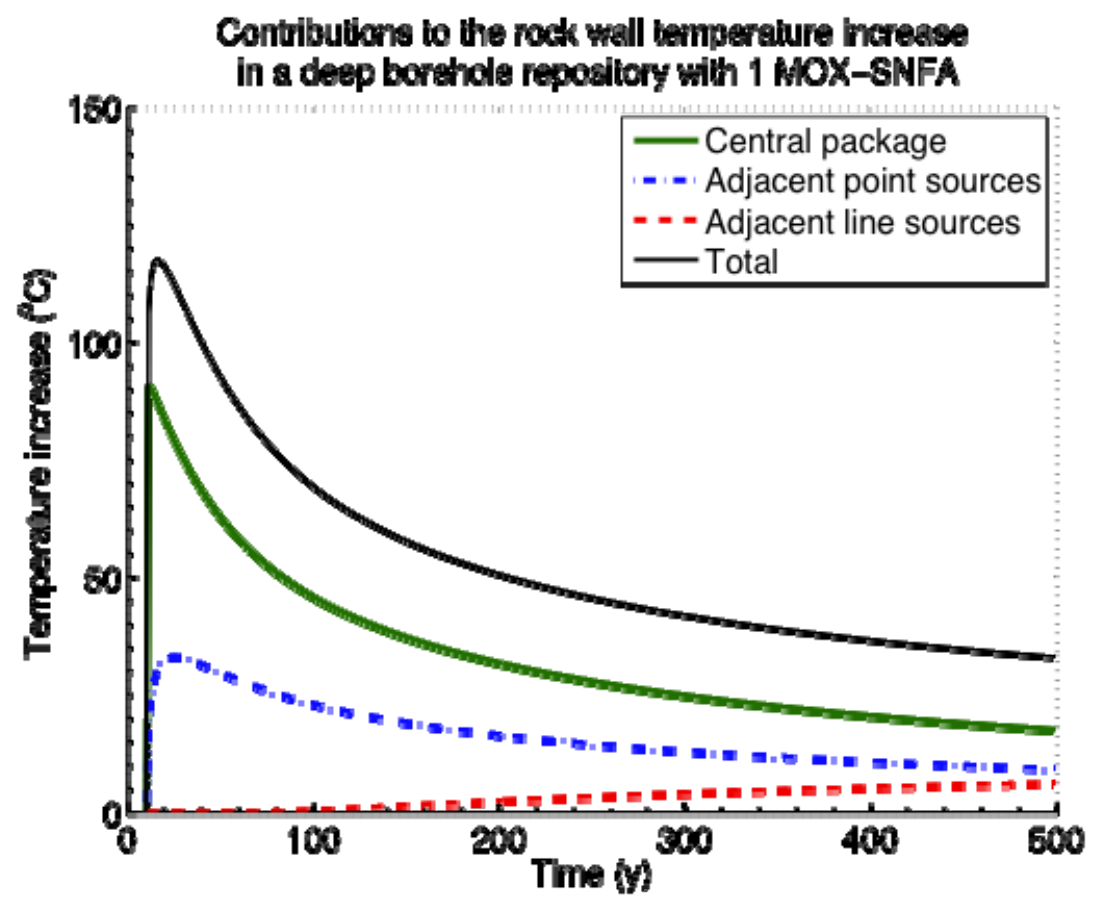

Figure H.2-20 Contributions to Temperature at the "Calculation Radius" from the Central Package, Adjacent Packages, and Neighboring Boreholes, for MOX-1 in a Deep Borehole. 


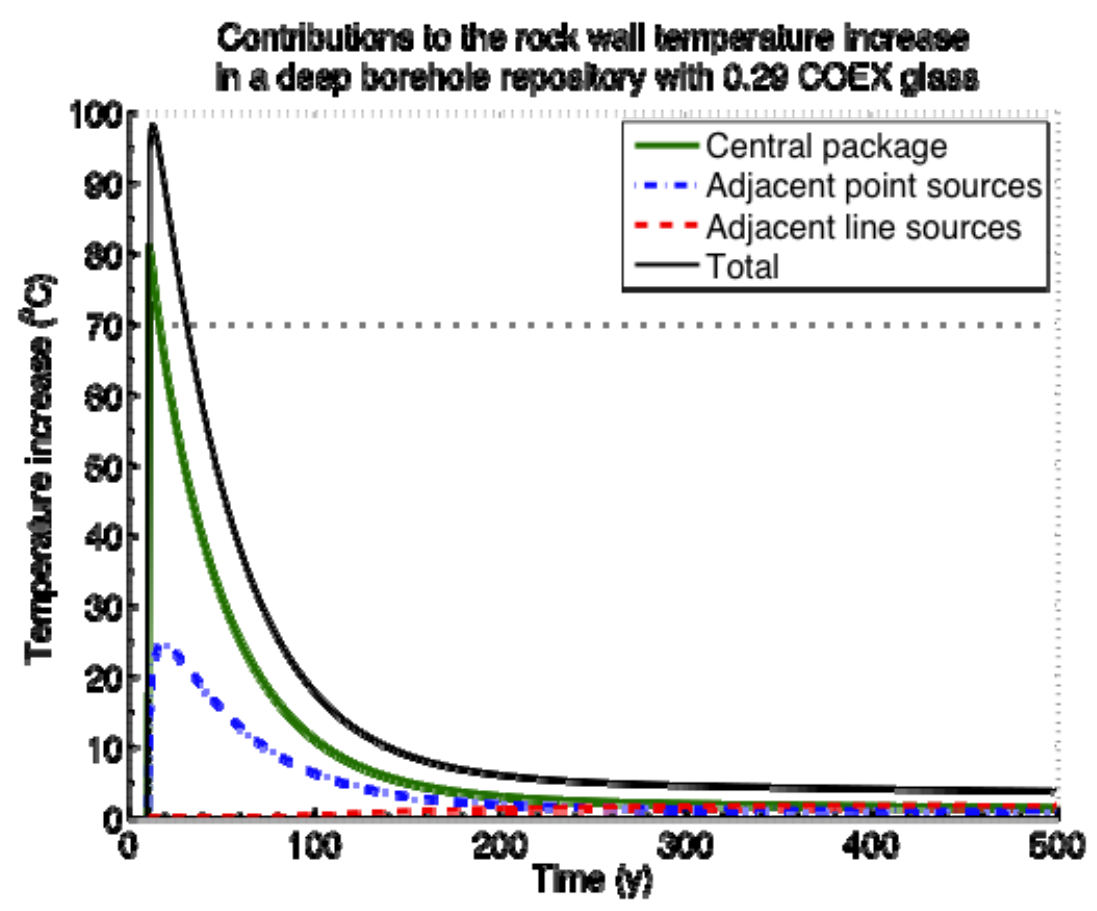

Figure H.2-21 Contributions to Temperature at the "Calculation Radius" from the Central Package, Adjacent Packages, and Neighboring Boreholes, for One Narrow Co-Extraction (Co-Extraction-0.291) HLW Canister in a Deep Borehole.

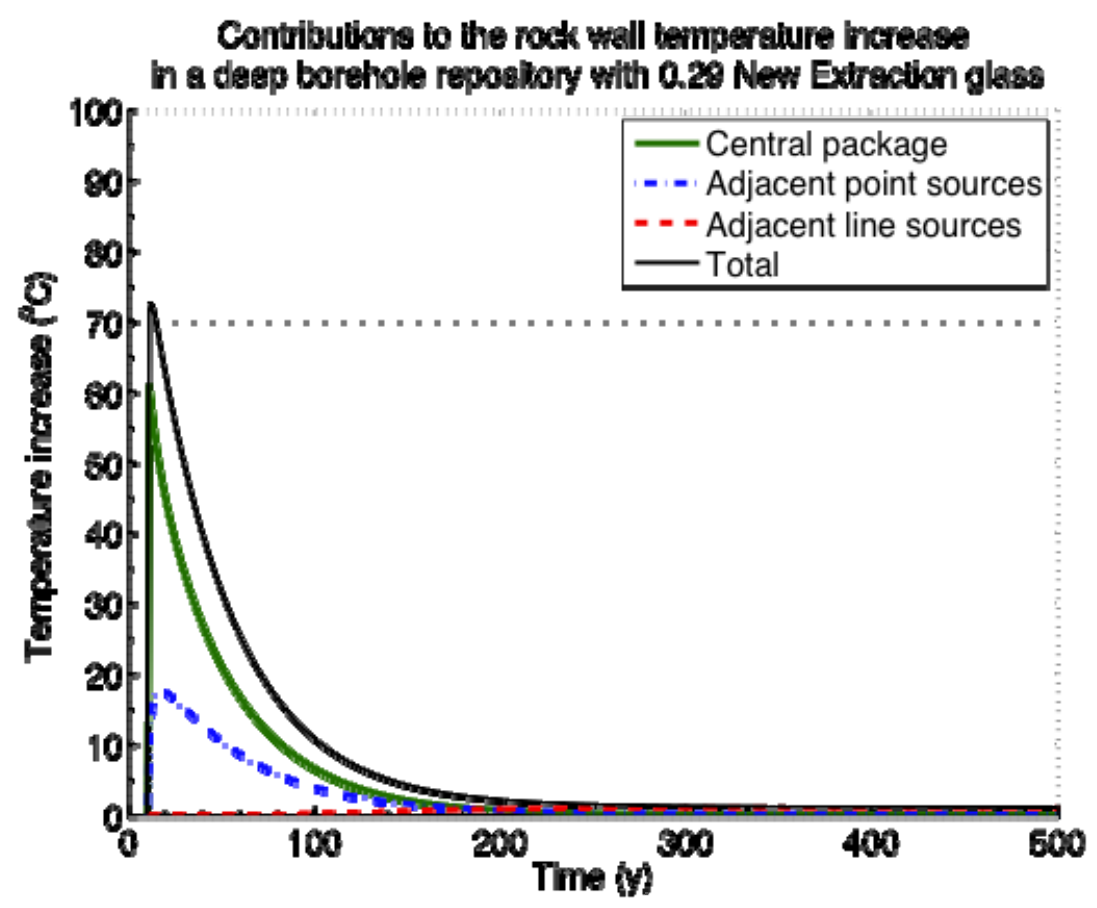

Figure H.2-22 Contributions to Temperature at the "Calculation Radius" from the Central Package, Adjacent Packages, and Neighboring Boreholes, for One Narrow New Extraction (New Extraction-0.291) HLW Canister in a Deep Borehole. 


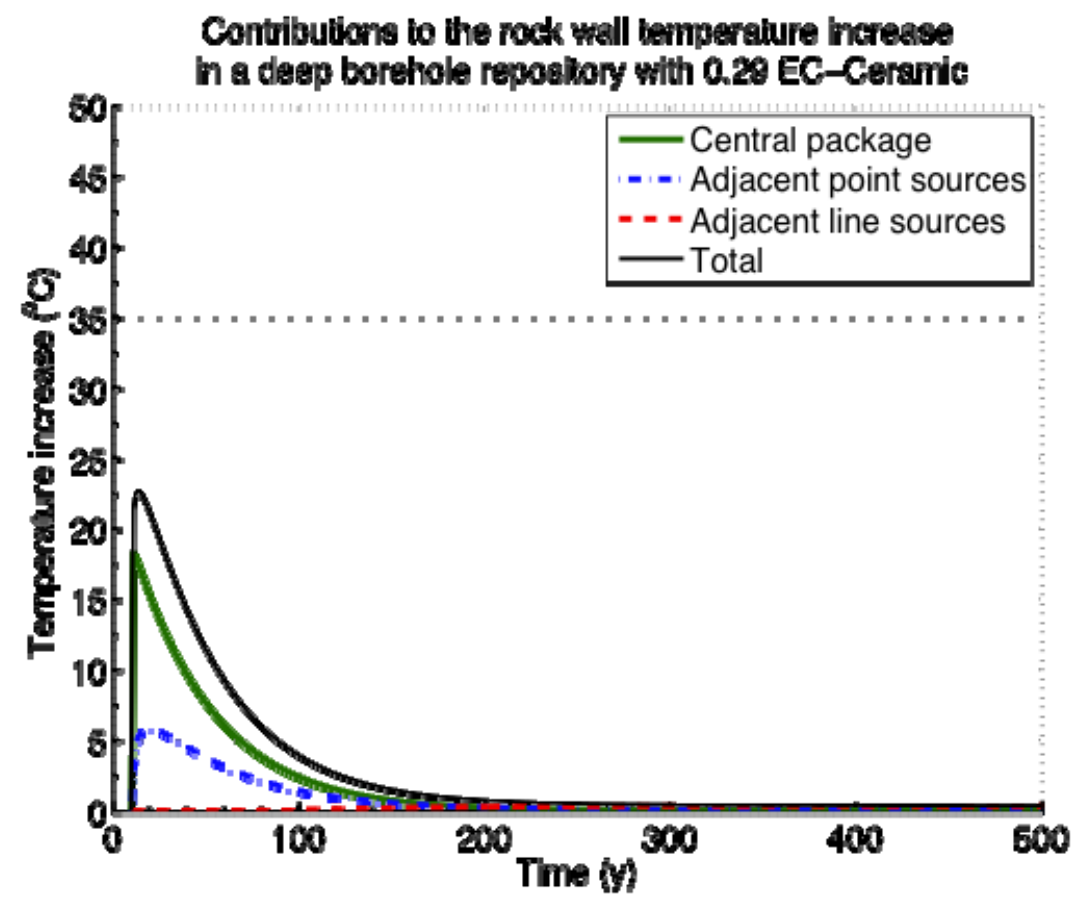

Figure H.2-23 Contributions to Temperature at the "Calculation Radius" from the Central Package, Adjacent Packages, and Neighboring Boreholes, for One Narrow EC-Ceramic (ECC-0.291) HLW Canister in a Deep Borehole.

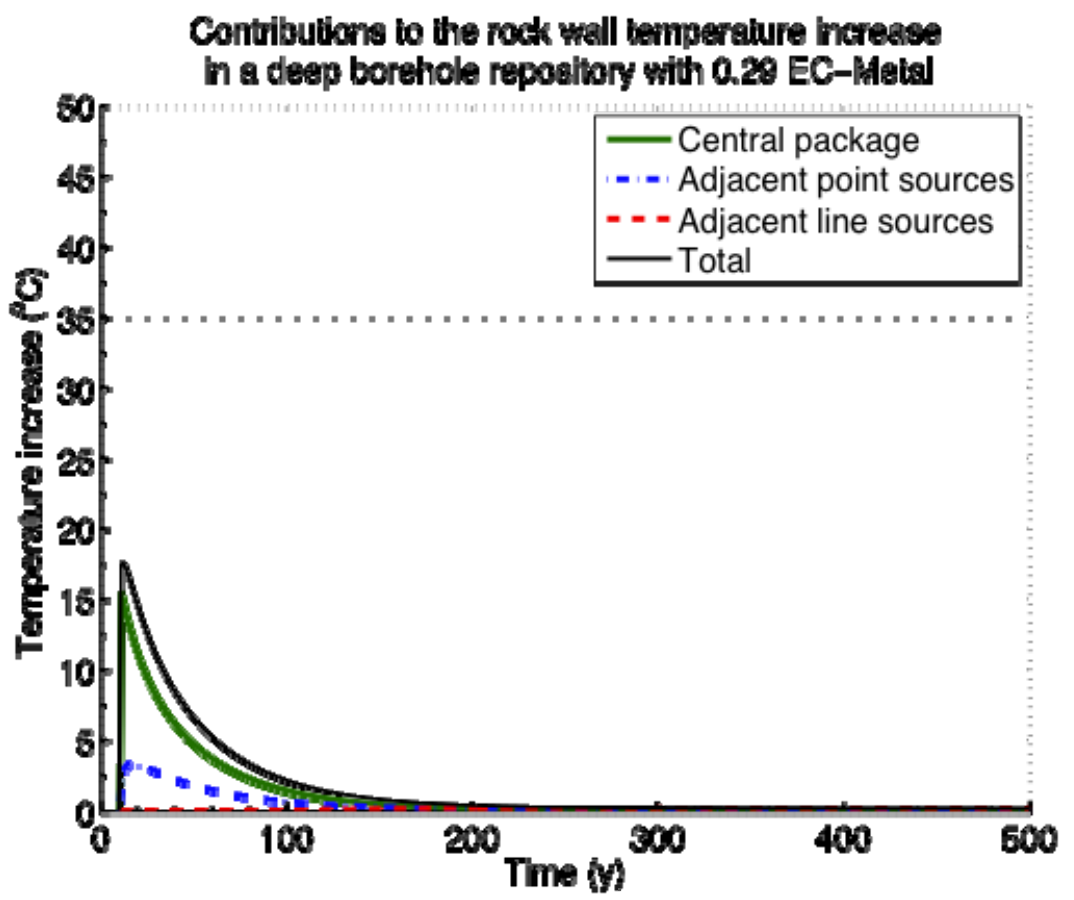

Figure H.2-24 Contributions to Temperature at the "Calculation Radius" from the Central Package, Adjacent Packages, and Neighboring Boreholes, for One Narrow EC-Metal (ECM-0.291) HLW Canister in a Deep Borehole. 


\section{H.3 Host Rock Temperature Histories}

The calculation radii for the four media are as follows:

- Crystalline/Granite: SNF 0.83 m, HLW 0.76 m

- Clay: SNF 1.32 m, HLW 0.37 m

- Salt: SNF and HLW $4 \mathrm{~m}$

- Deep borehole: SNF 0.19 m, HLW 0.20 m

The number of assemblies or canisters per waste package are as defined in Section H.2, except as indicated in the figure captions below.

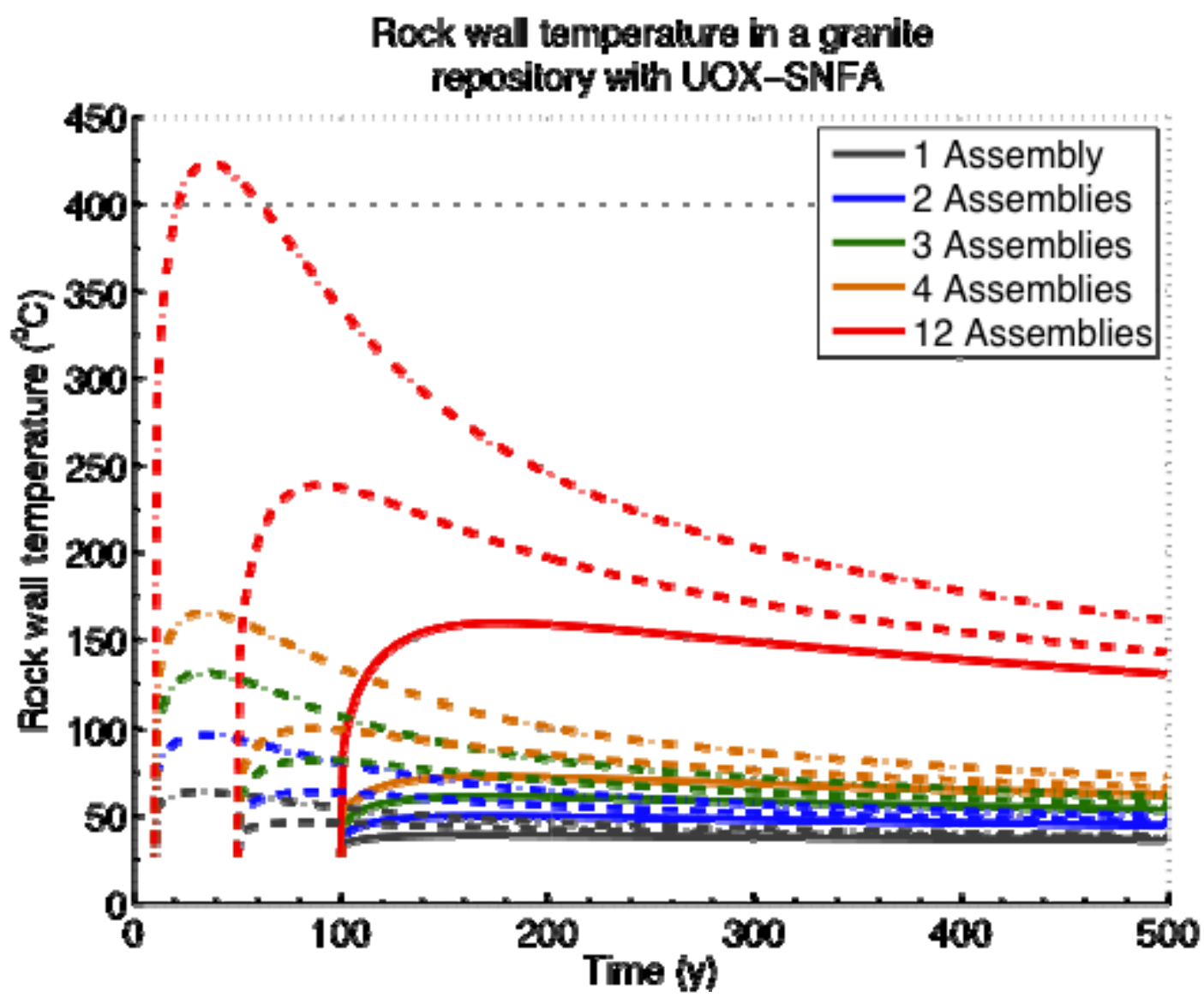

Figure H.3-1 Host Rock Temperature at the "Calculation Radius" After Decay Storage of 10, 50 and 100 yr, for a Waste Package Containing 1, 2, 3, 4 and 12 UOX Assemblies in Crystalline Rock. 


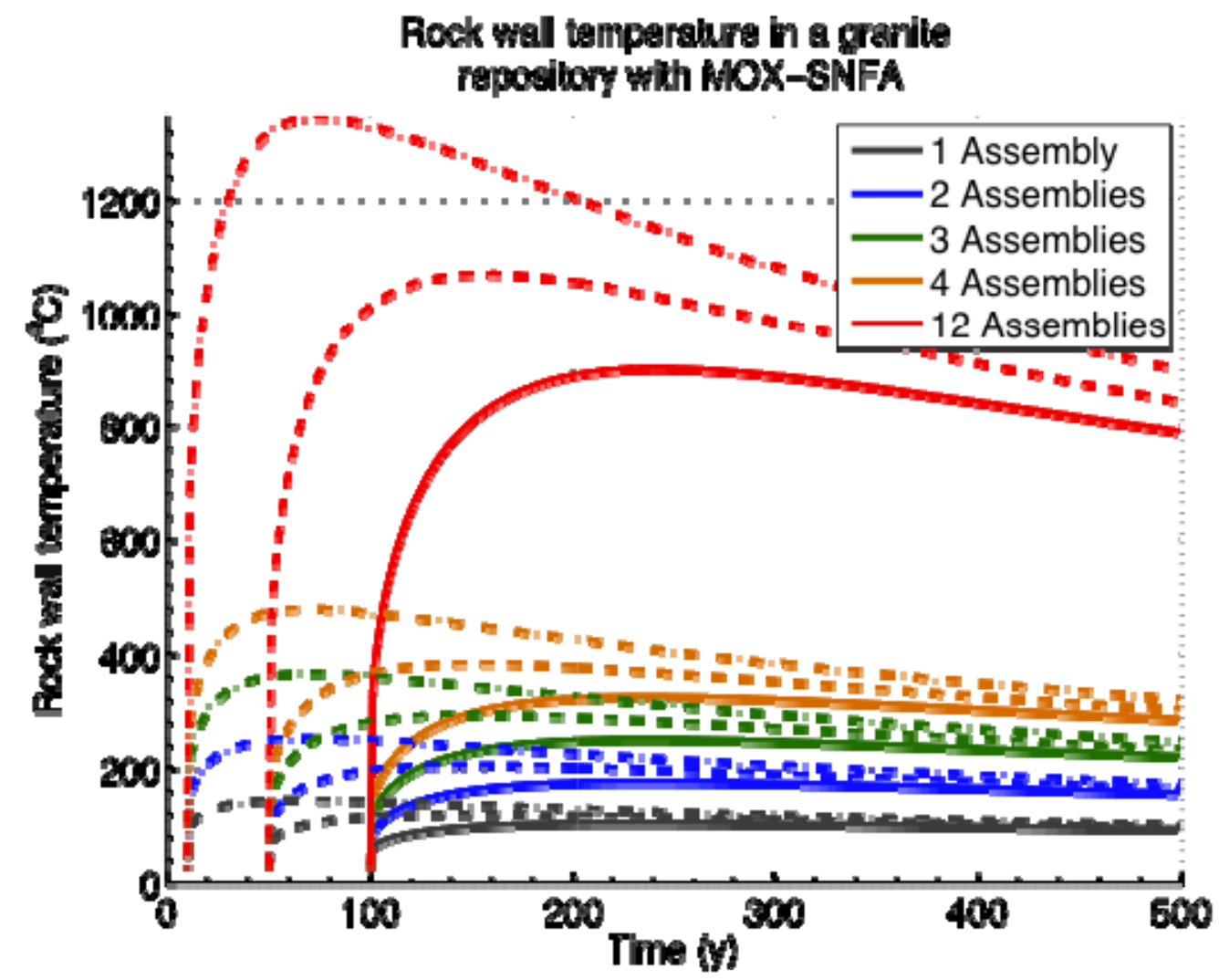

Figure H.3-2 Host Rock Temperature at the "Calculation Radius" After Decay Storage of 10, 50 and 100 yr, for a Waste Package Containing 1, 2, 3, 4 and 12 MOX Assemblies in Crystalline Rock. 


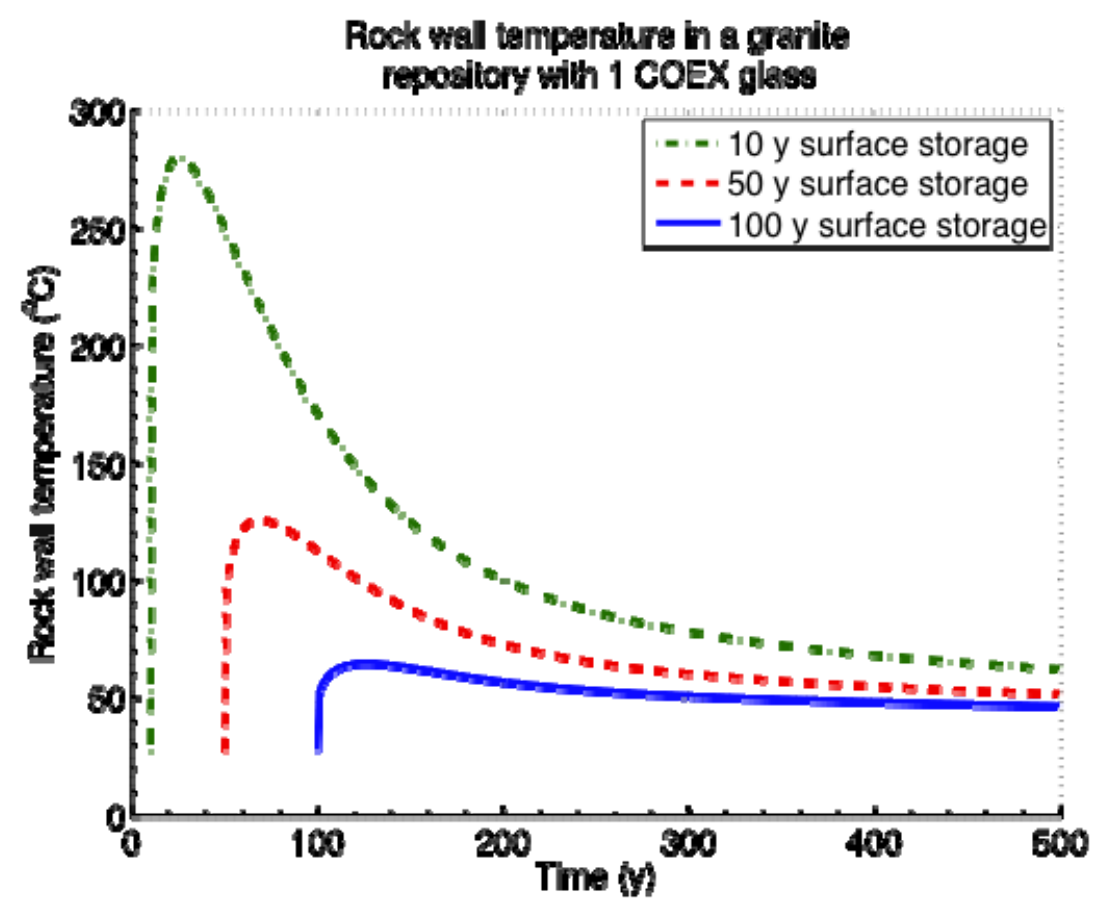

Figure H.3-3 Host Rock Temperature at the "Calculation Radius" After Decay Storage of 10, 50 and $100 \mathrm{yr}$, for Co-Extraction-1 in Crystalline Rock.

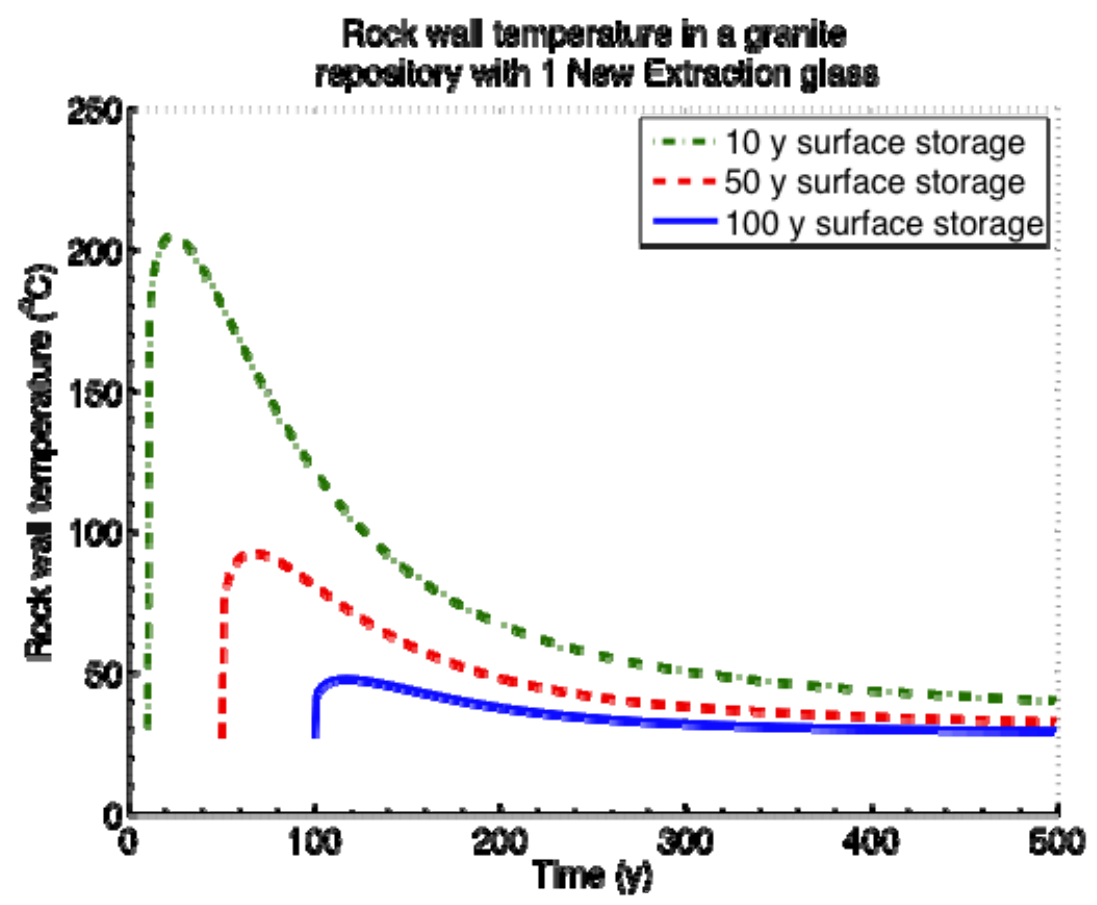

Figure H.3-4 Host Rock Temperature at the "Calculation Radius" After Decay Storage of 10, 50 and 100 yr, for New Extraction-1 in Crystalline Rock. 


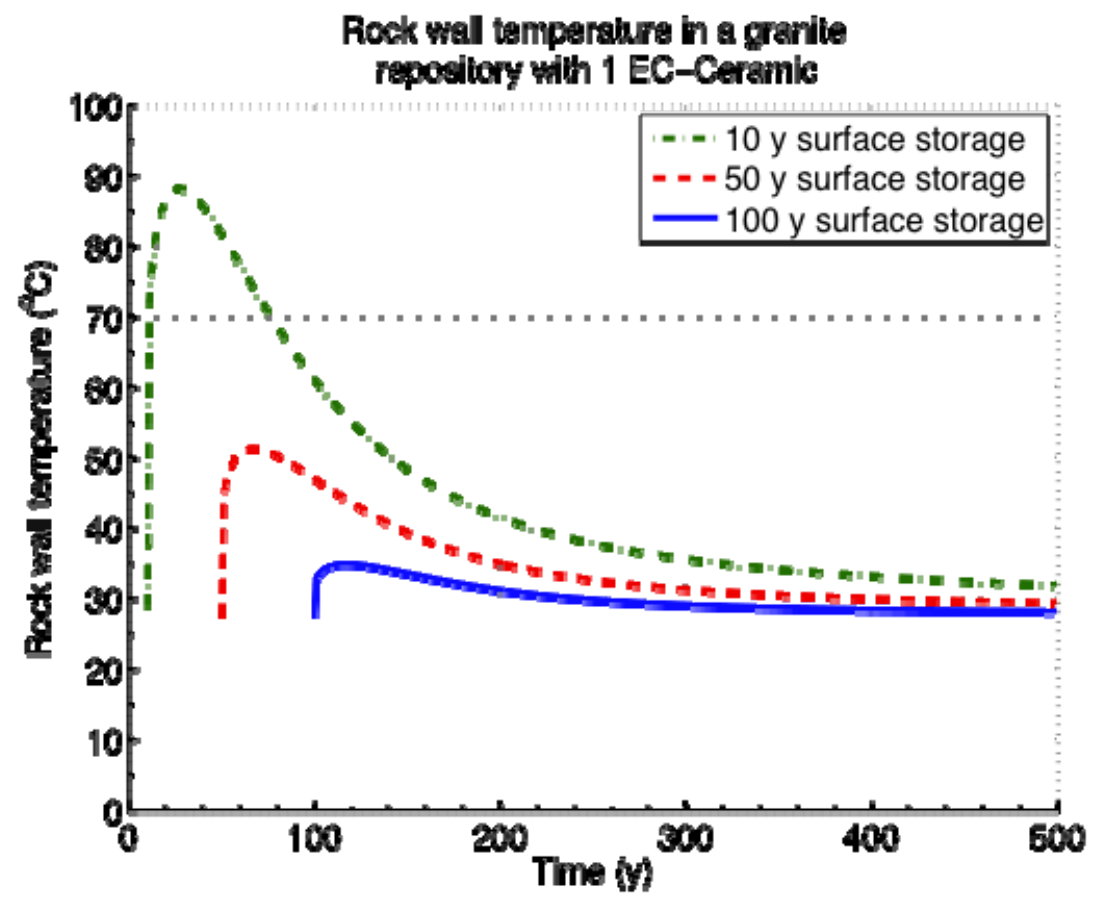

Figure H.3-5 Host Rock Temperature at the "Calculation Radius" After Decay Storage of 10, 50 and $100 \mathrm{yr}$, for ECC-1 in Crystalline Rock.

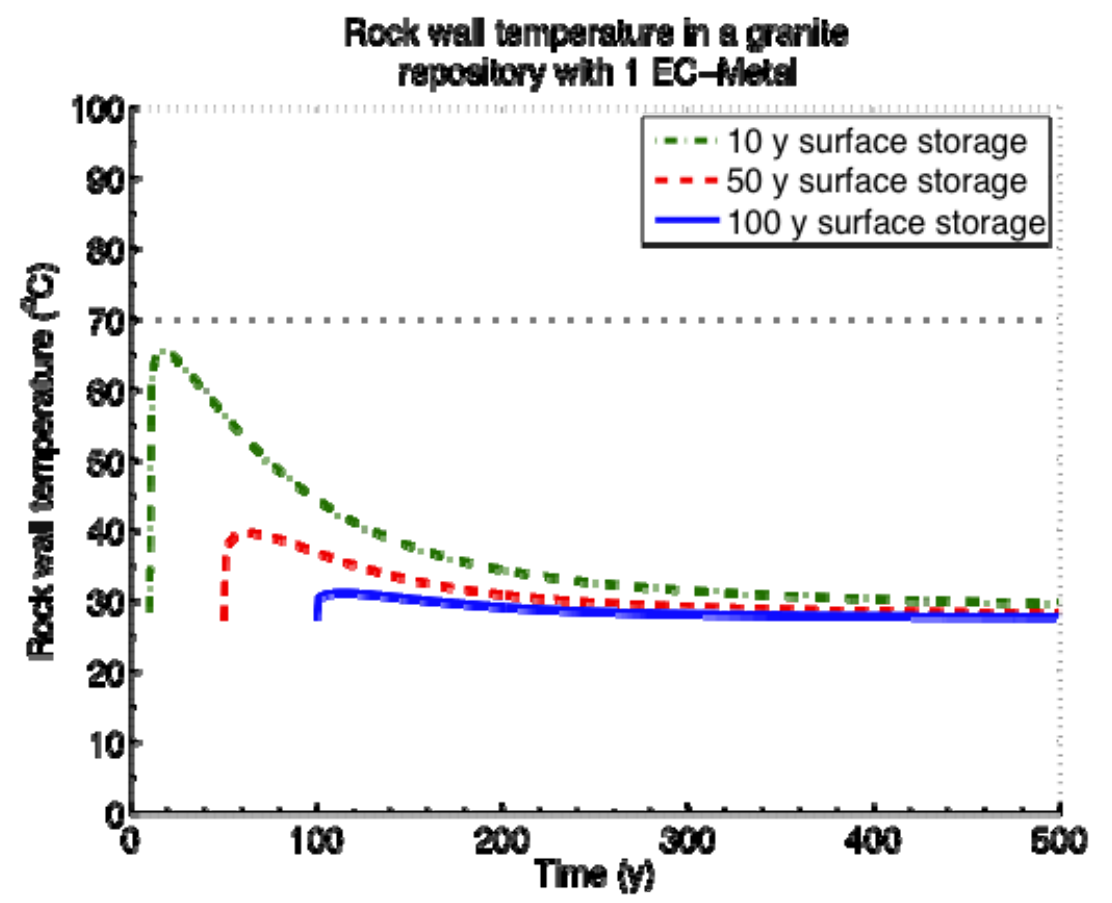

Figure H.3-6 Host Rock Temperature at the "Calculation Radius" After Decay Storage of 10, 50 and 100 yr, for ECM-1 in Crystalline Rock. 


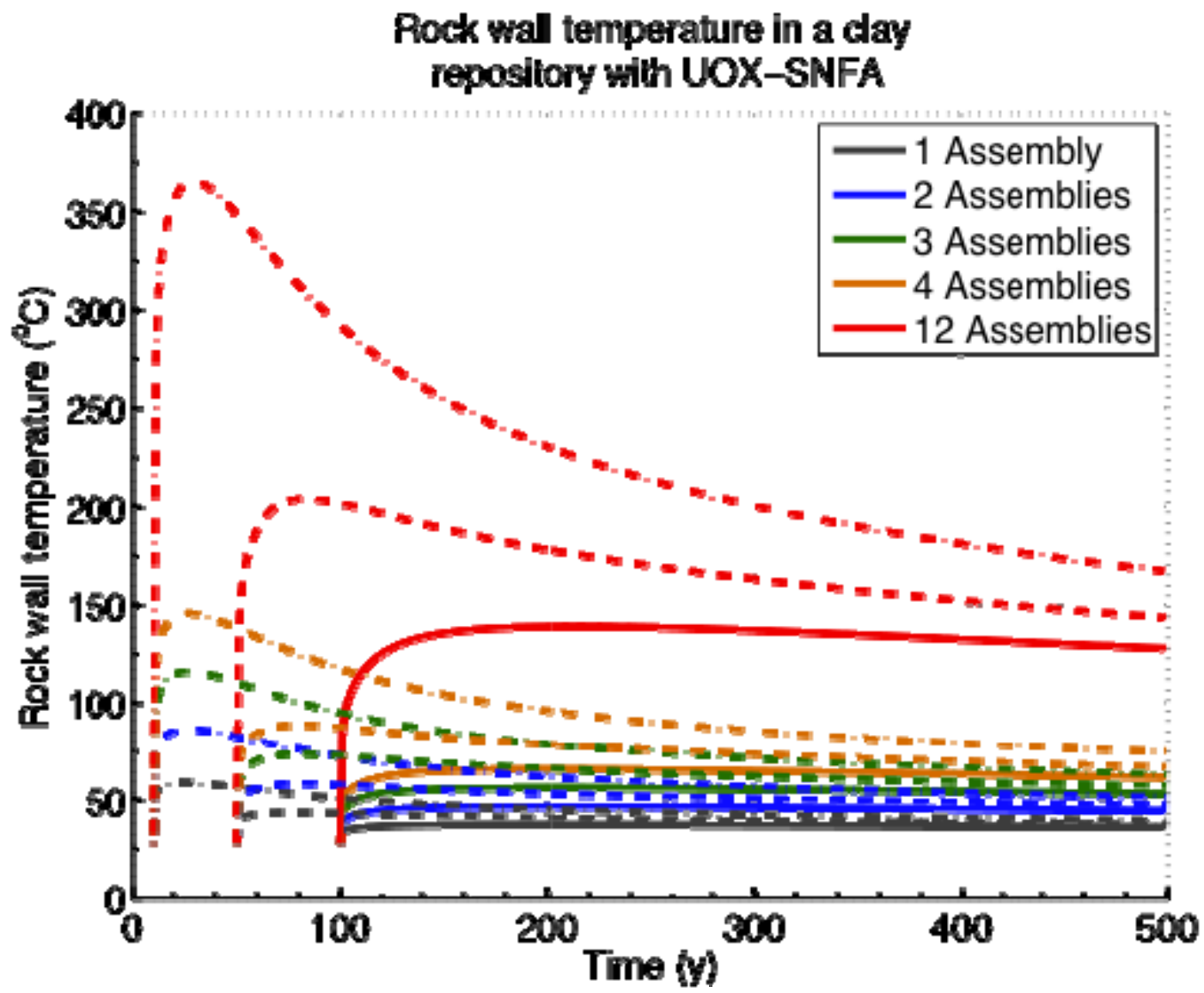

Figure H.3-7 Host Rock Temperature After Decay Storage of 10, 50 and 100 yr, for Waste Packages Containing 1, 2, 3, 4 and 12 UOX Assemblies in Clay/Shale. 


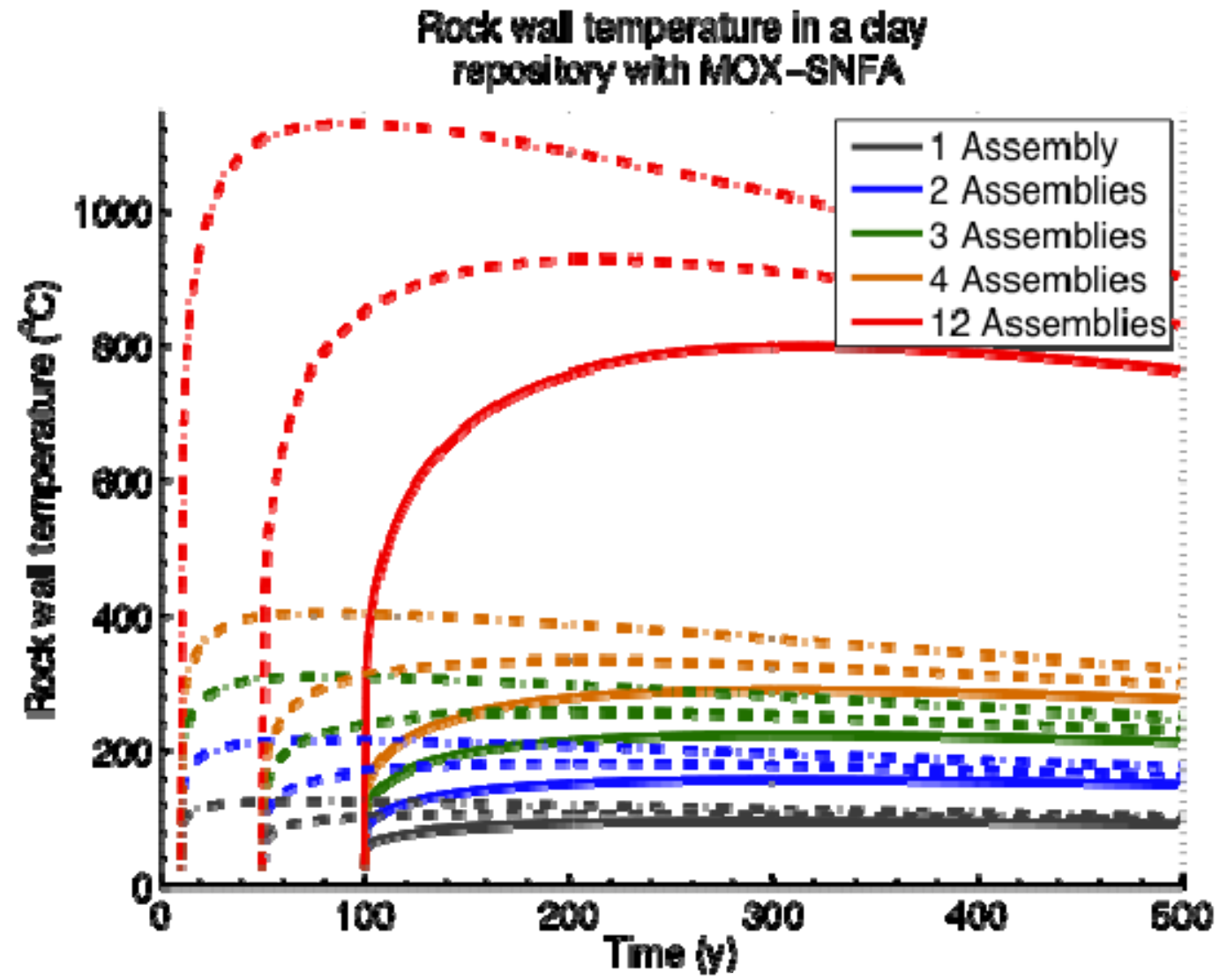

Figure H.3-8 Host Rock Temperature After Decay Storage of 10, 50 and 100 yr, for Waste Packages Containing 1, 2, 3, 4 and 12 MOX Assemblies in Clay/Shale. 


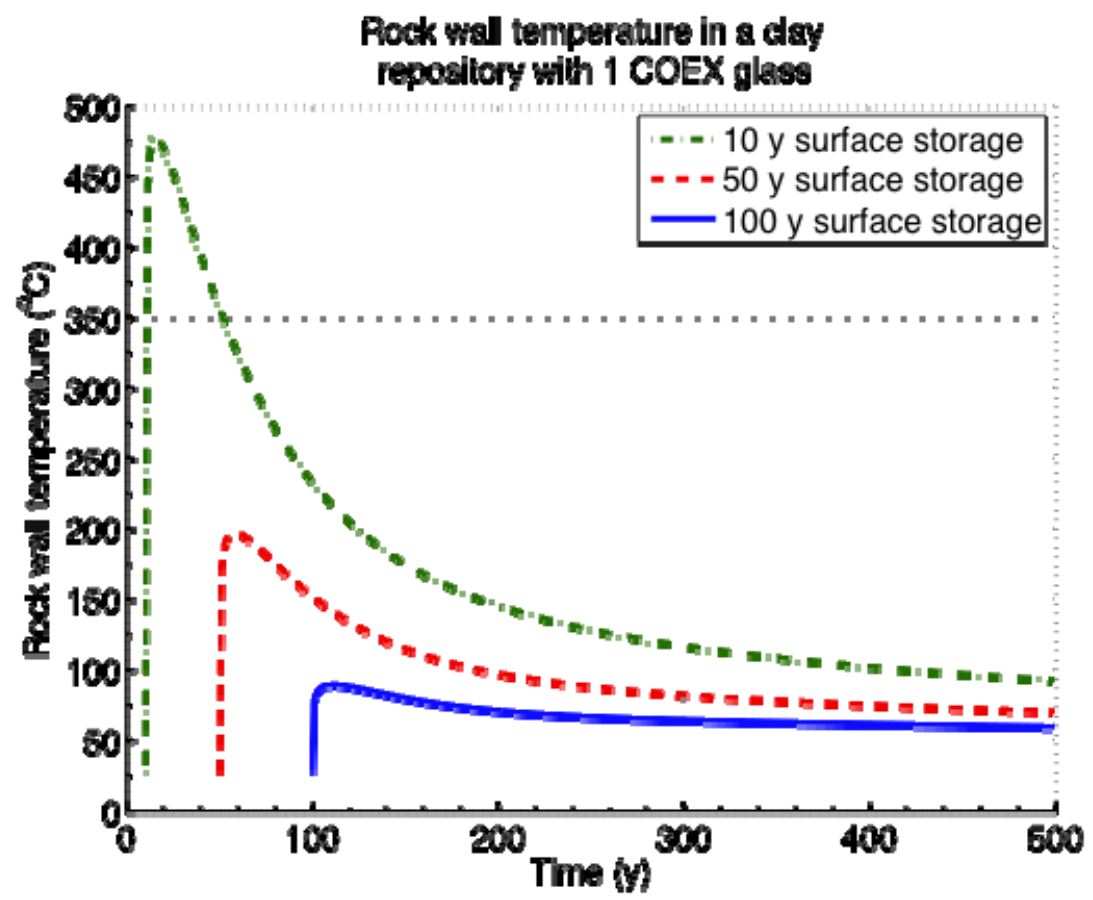

Figure H.3-9 Host Rock Temperature at the "Calculation Radius" After Decay Storage of 10, 50 and 100 yr, for Co-Extraction-1 in Clay/Shale.

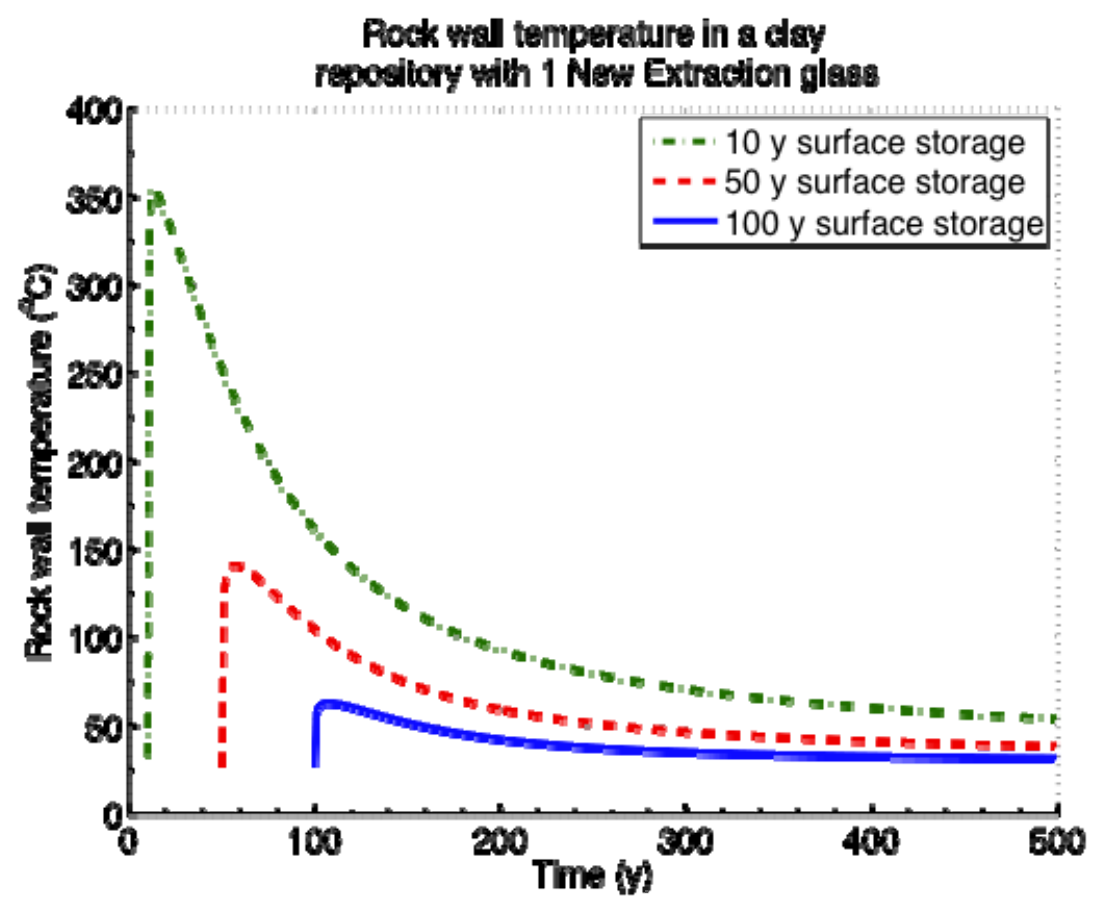

Figure H.3-10 Host Rock Temperature at the "Calculation Radius" After Decay Storage of 10, 50 and 100 yr, for New Extraction-1 in Clay/Shale. 


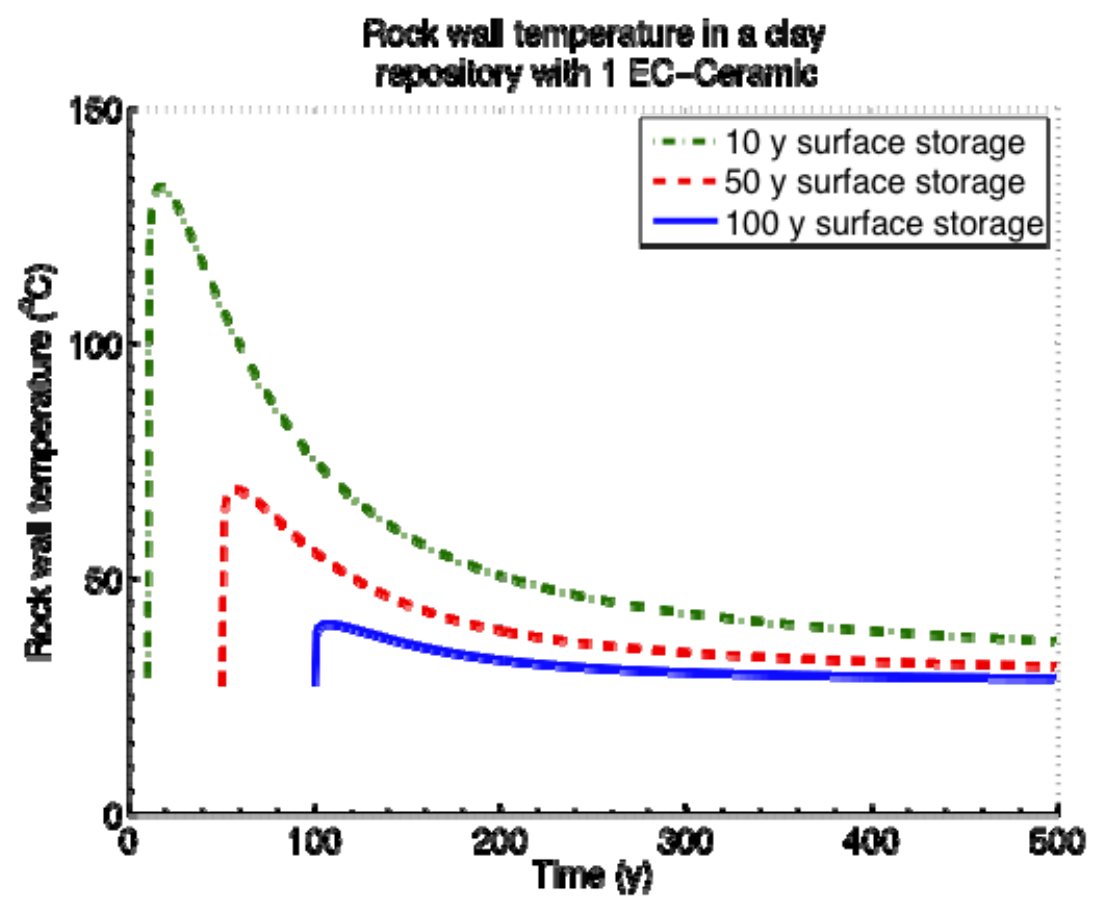

Figure H.3-11 Host Rock Temperature at the "Calculation Radius" After Decay Storage of 10, 50 and 100 yr, for ECC-1 in ClaylShale.

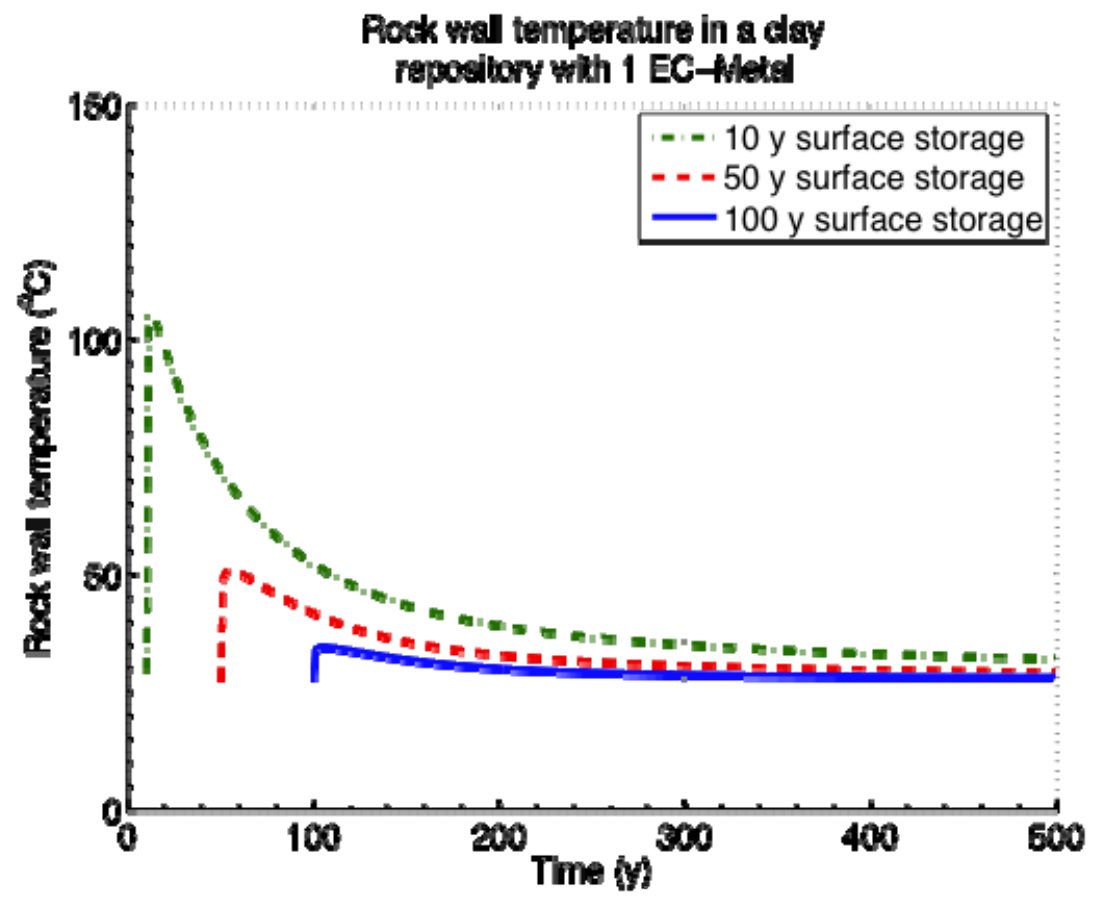

Figure H.3-12 Host Rock Temperature at the "Calculation Radius" After Decay Storage of 10, 50 and $100 \mathrm{yr}$, for ECM-1 in Clay/Shale. 


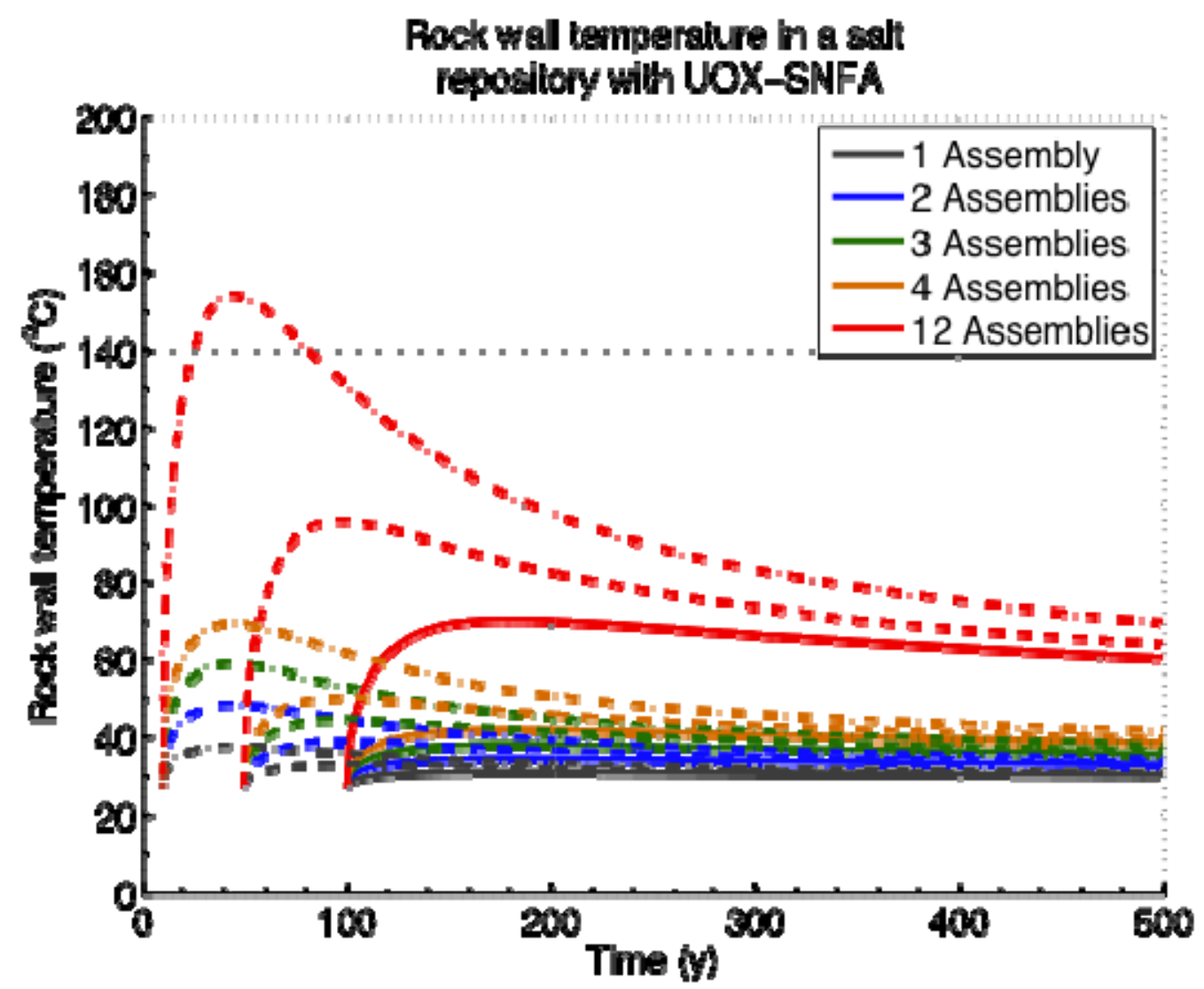

Figure H.3-13 Host Rock Temperature at the "Calculation Radius" After Decay Storage of 10, 50 and 100 yr, for Waste Packages Containing 1, 2, 3, 4 and 12 UOX Assemblies in Salt. 


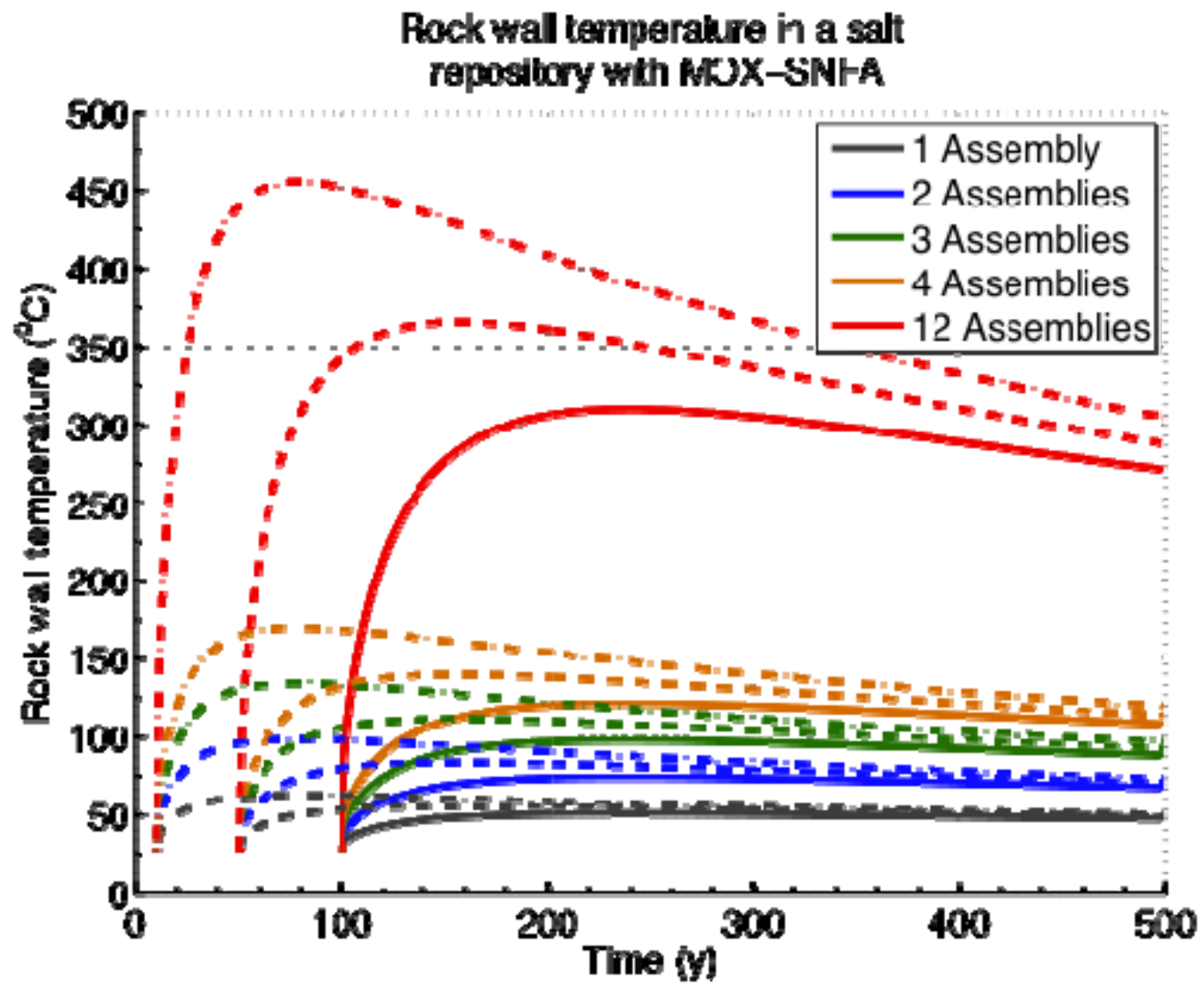

Figure H.3-14 Host Rock Temperature at the "Calculation Radius" After Decay Storage of 10, 50 and 100 yr, for Waste Packages Containing 1, 2, 3, 4 and 12 MOX Assemblies in Salt. 


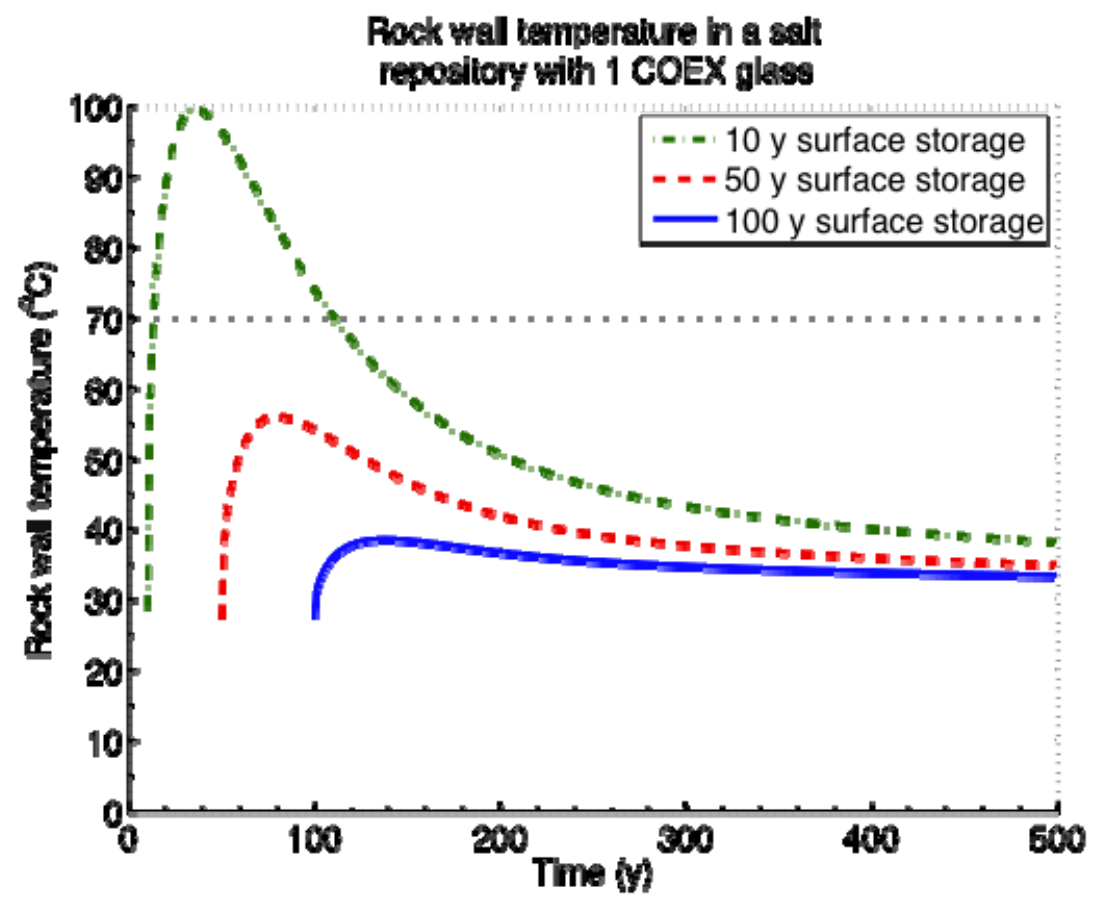

Figure H.3-15 Host Rock Temperature at the "Calculation Radius" After Decay Storage of 10, 50 and 100 yr, for Co-Extraction-1 in Salt.

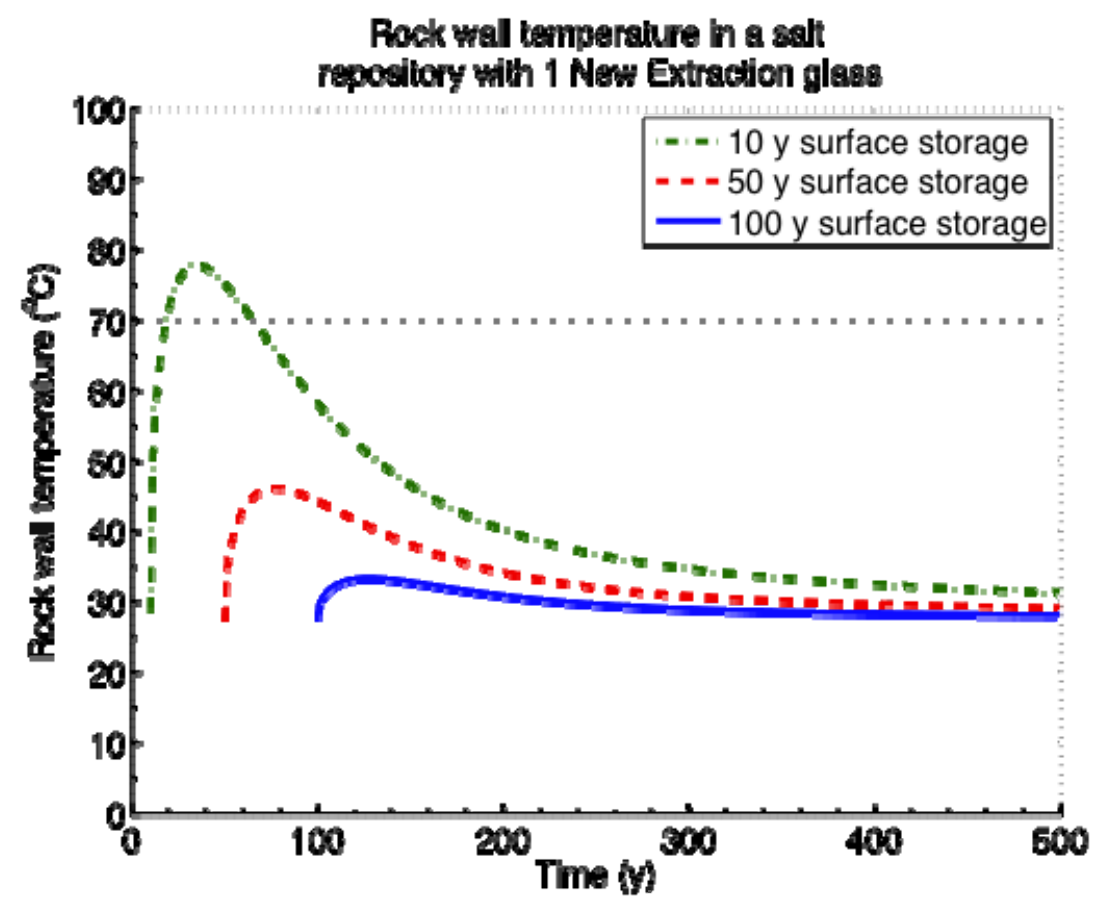

Figure H.3-16 Host Rock Temperature at the "Calculation Radius" After Decay Storage of 10, 50 and 100 yr, for New Extraction-1 in Salt. 


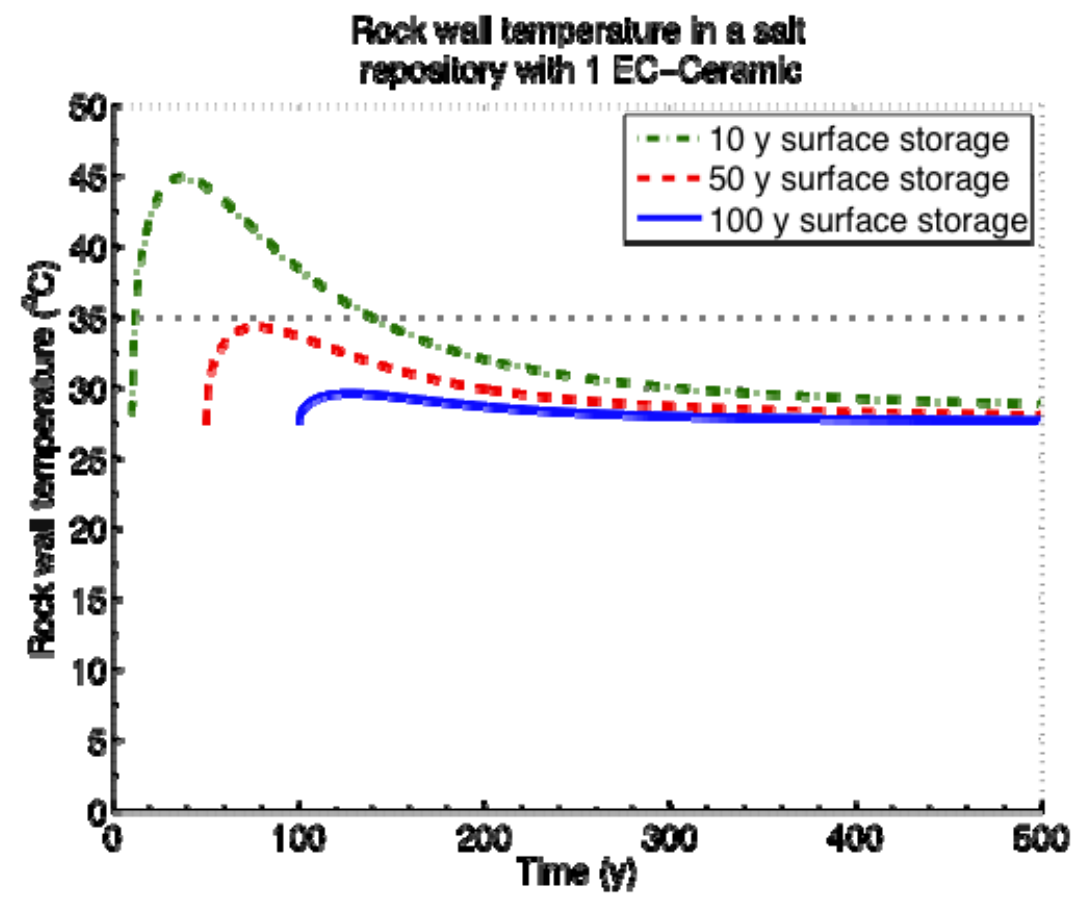

Figure H.3-17 Host Rock Temperature at the "Calculation Radius" After Decay Storage of 10, 50 and $100 \mathrm{yr}$, for ECC-1 in Salt.

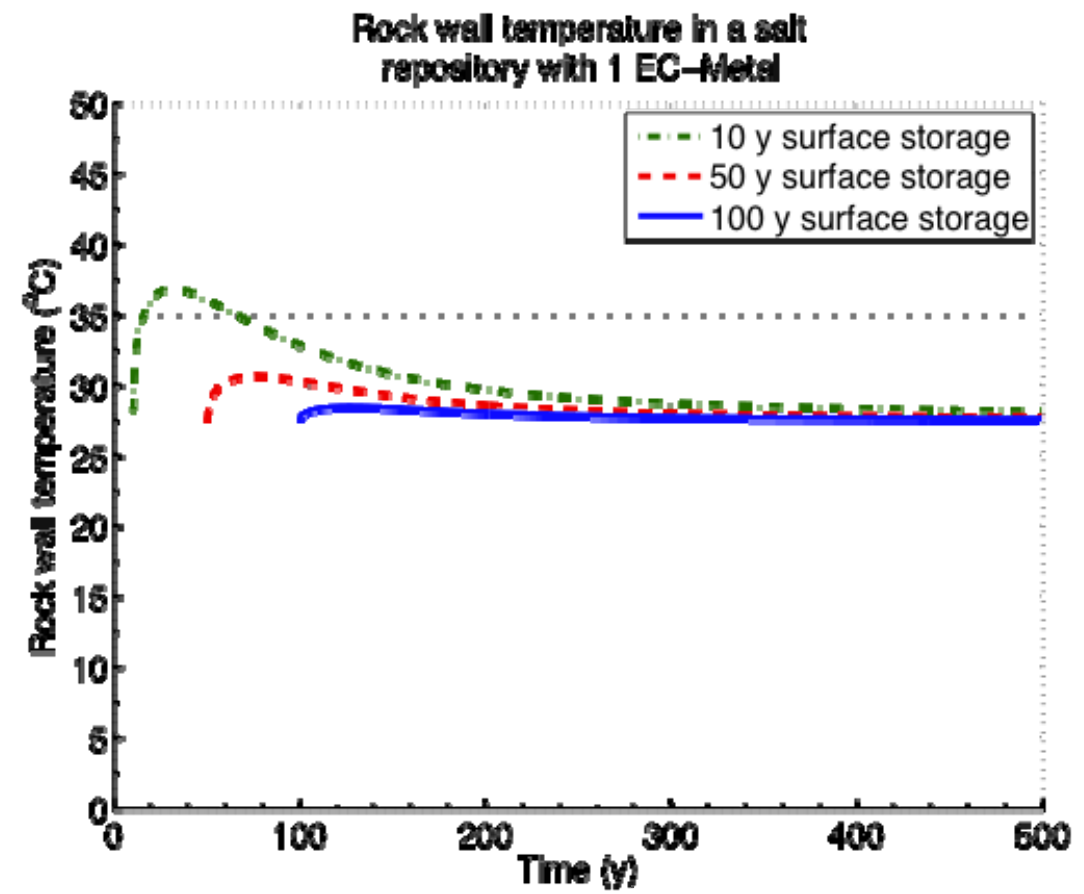

Figure H.3-18 Host Rock Temperature at the "Calculation Radius" After Decay Storage of 10, 50 and $100 \mathrm{yr}$, for ECM-1 in Salt. 


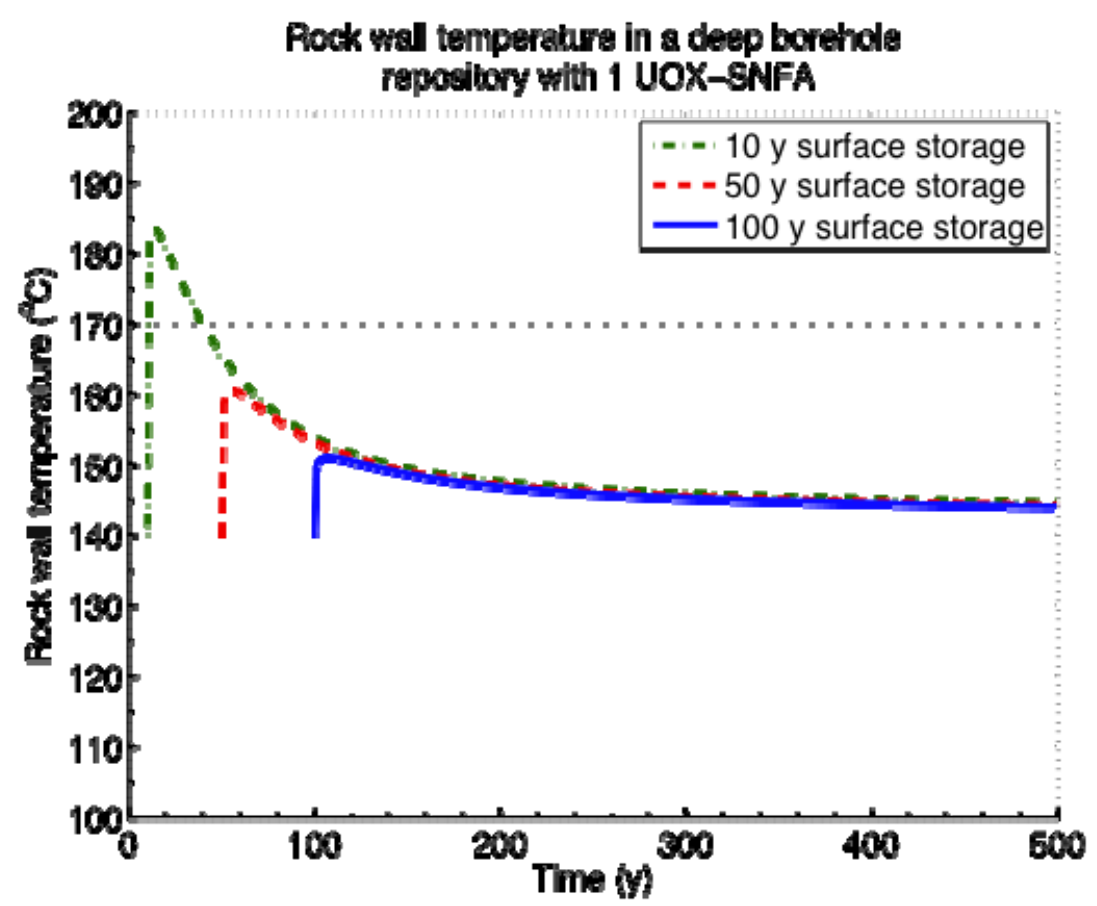

Figure H.3-19 Host Rock Temperature at the "Calculation Radius" After Decay Storage of 10, 50 and $100 \mathrm{yr}$, for UOX-1 in a Deep Borehole.

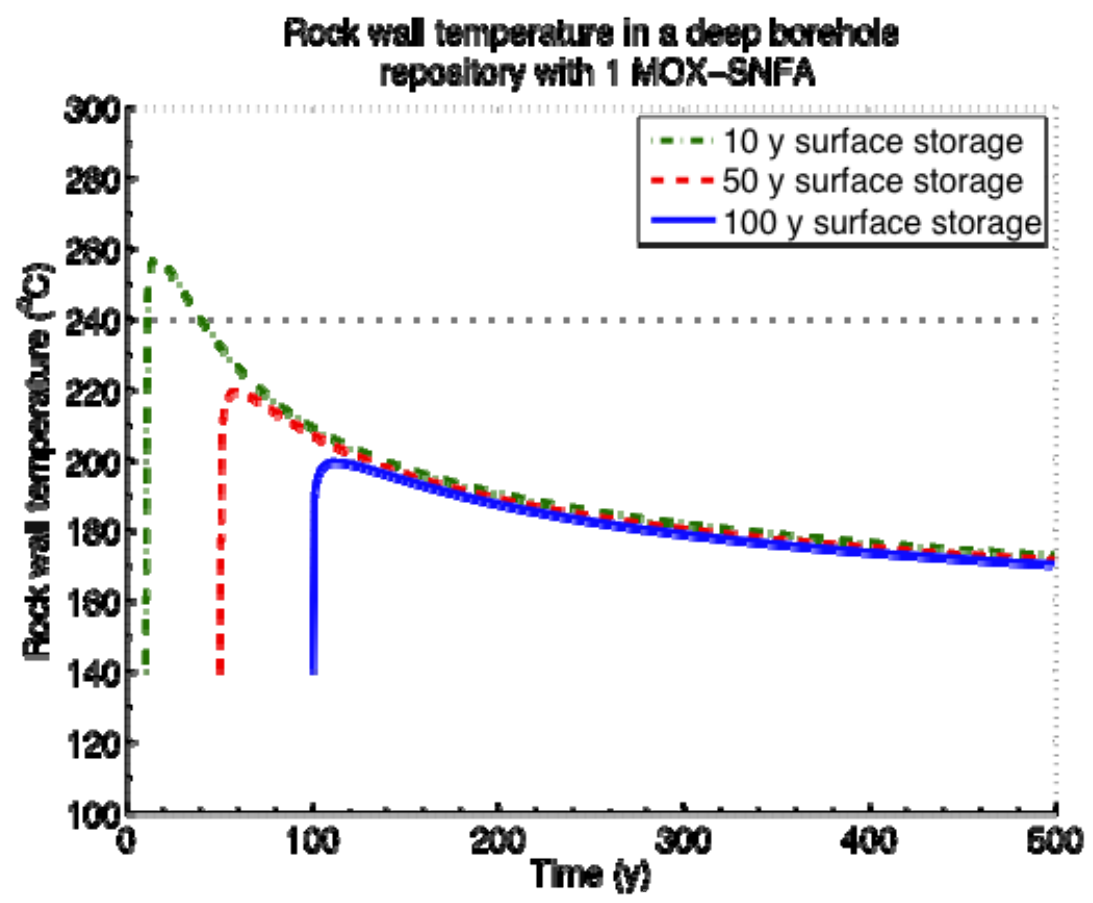

Figure H.3-20 Host Rock Temperature at the "Calculation Radius" After Decay Storage of 10, 50 and $100 \mathrm{yr}$, for MOX-1 in a Deep Borehole. 


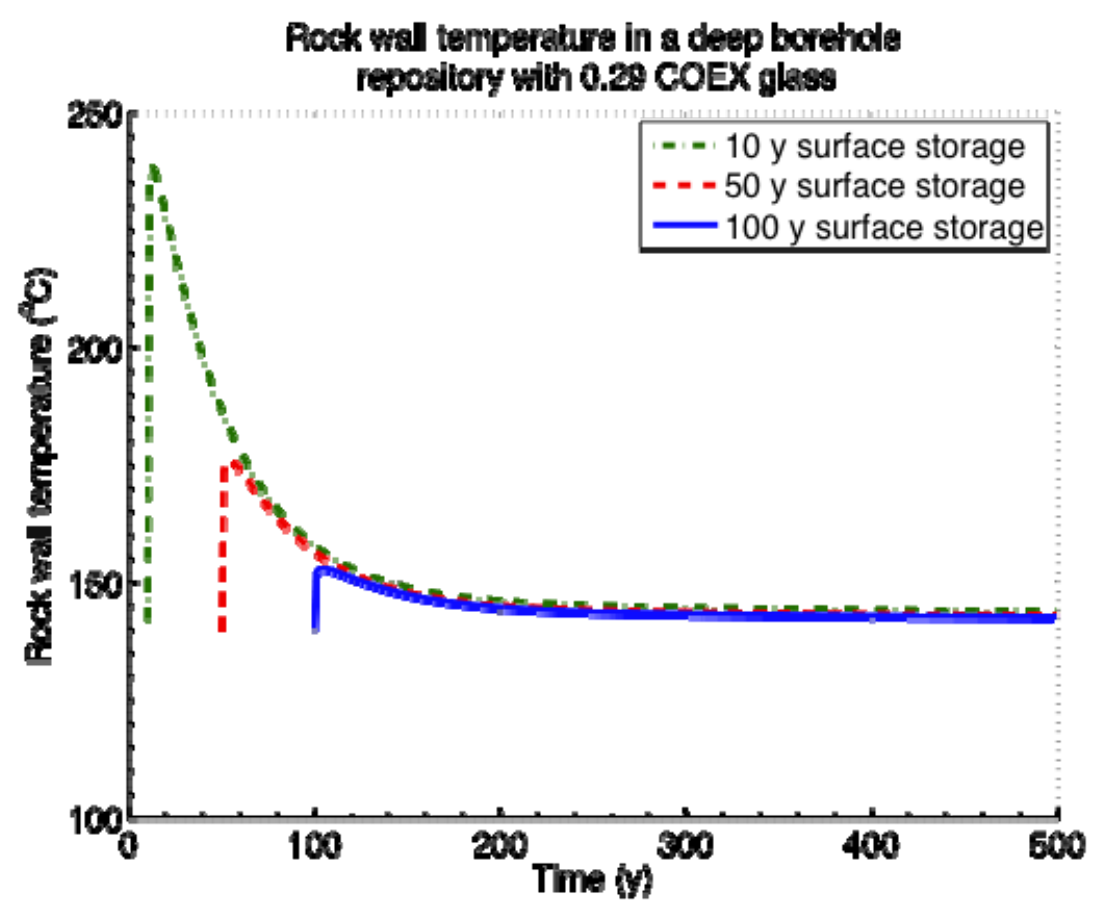

Figure H.3-21 Host Rock Temperature at the "Calculation Radius" After Decay Storage of 10, 50 and 100 yr, for Co-Extraction-0.291 in a Deep Borehole.

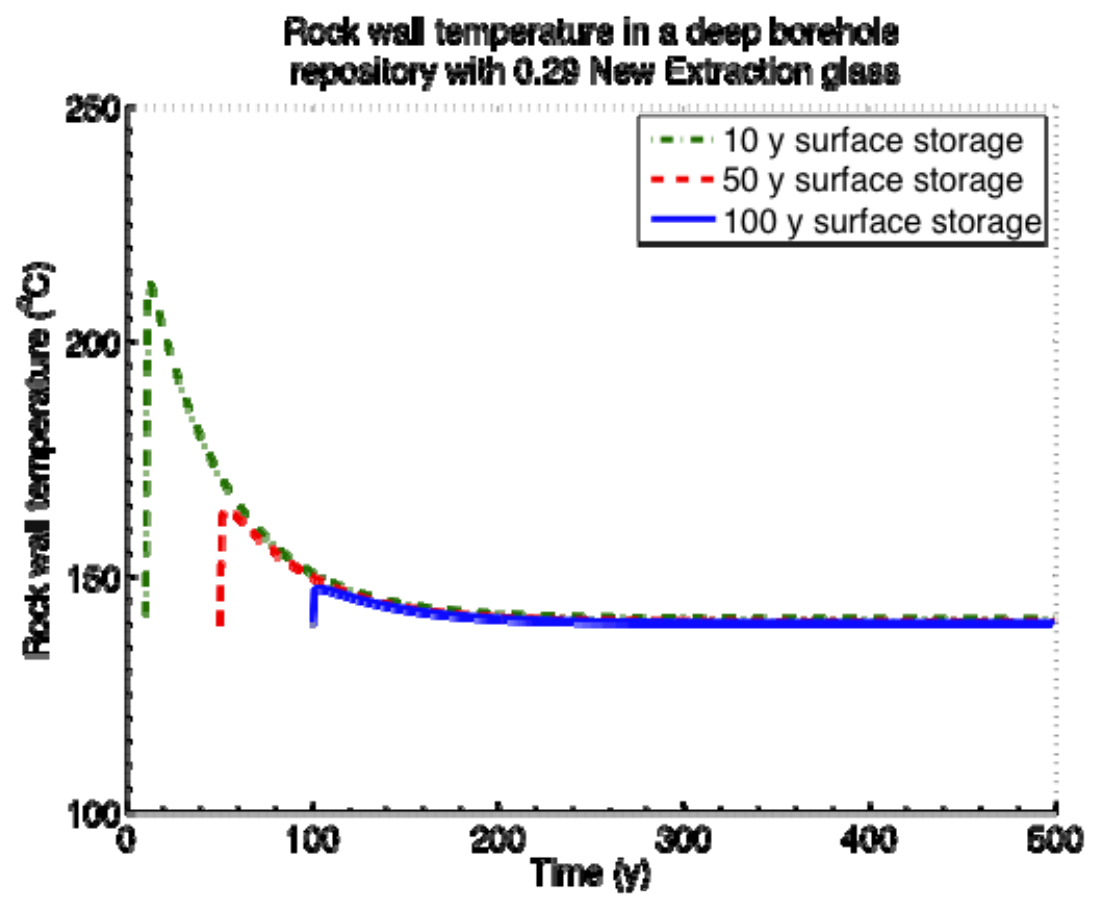

Figure H.3-22 Host Rock Temperature at the "Calculation Radius" After Decay Storage of 10, 50 and 100 yr, for New Extraction-0.291 in a Deep Borehole. 


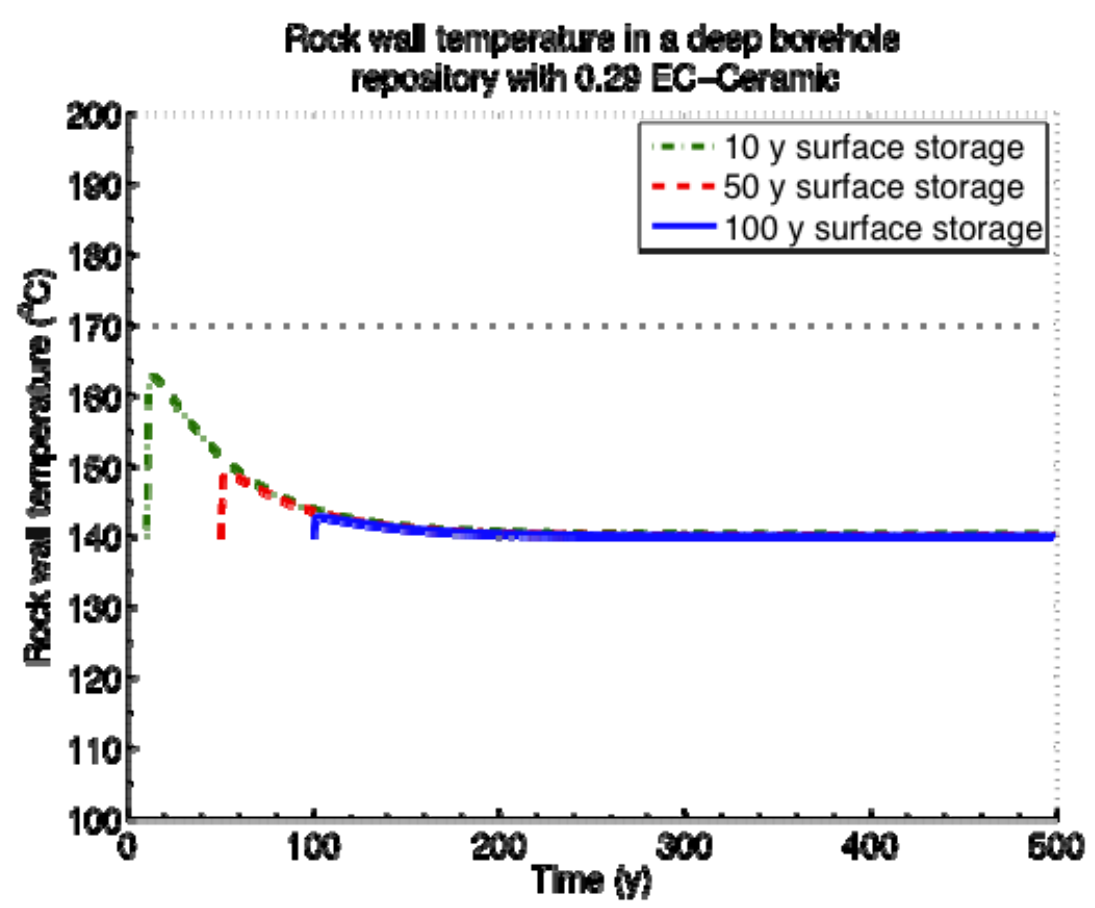

Figure H.3-23 Host Rock Temperature at the "Calculation Radius" After Decay Storage of 10, 50 and $100 \mathrm{yr}$, for ECC-0.291 in a Deep Borehole.

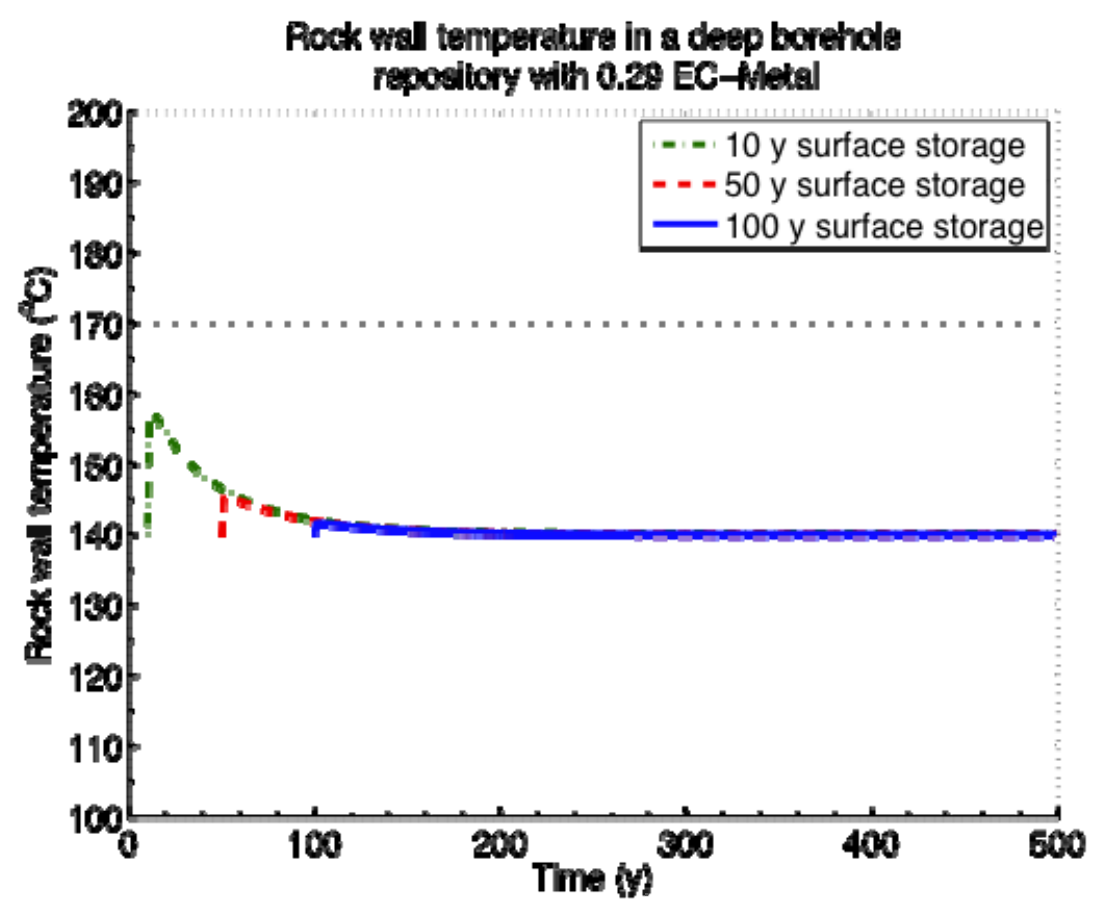

Figure H.3-24 Host Rock Temperature at the "Calculation Radius" After Decay Storage of 10, 50 and $100 \mathrm{yr}$, for ECM-0.291 in a Deep Borehole. 


\section{H.4 Waste Package Surface Temperature}

This section shows the results of the quasi-steady calculation at each point in time inward from the "calculation radius" to the outer surface of the waste package. The calculation uses the temperature result from the homogeneous calculation in Section H.3 above.

The number of assemblies or canisters per waste package are as defined in Section H.2, except as indicated in the figure captions below. 


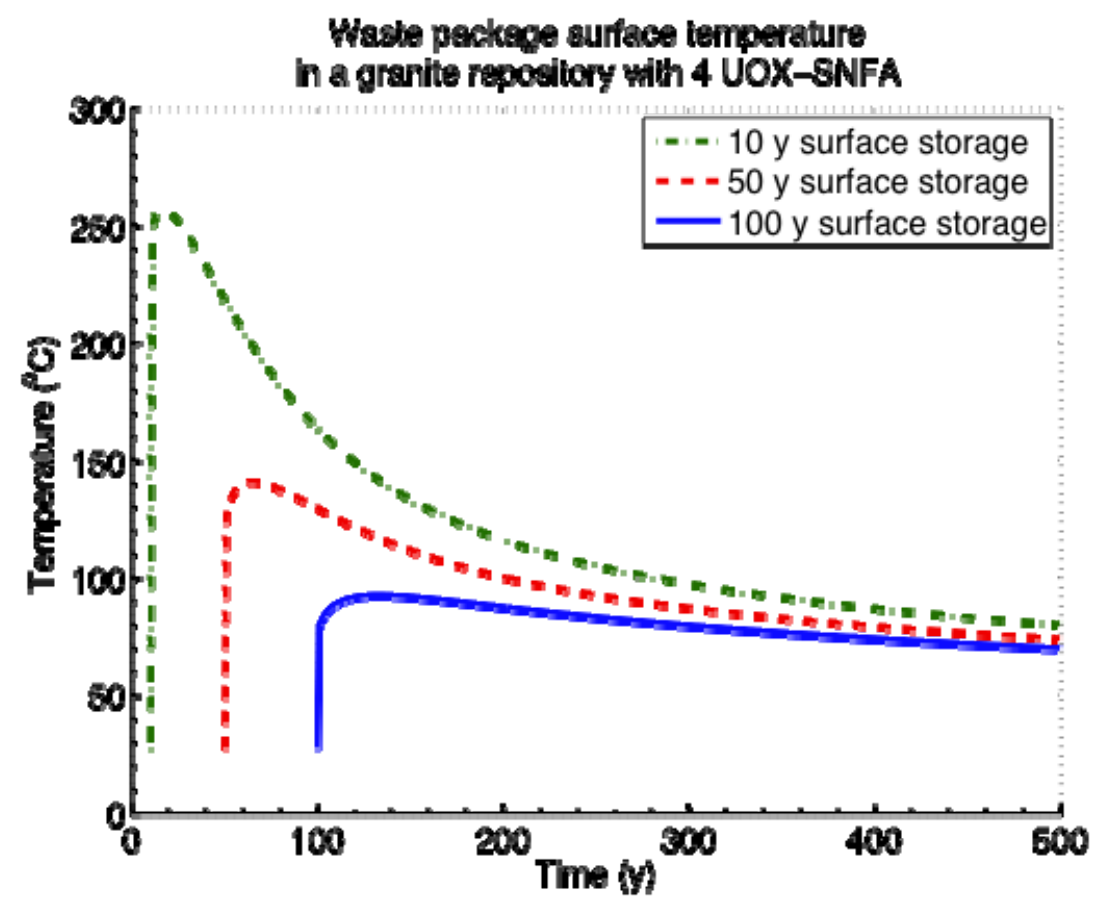

Figure H.4-1 Calculated Waste Package Temperature After Storage Times of 10, 50 and 100 yr for UOX-4 in Crystalline Rock.

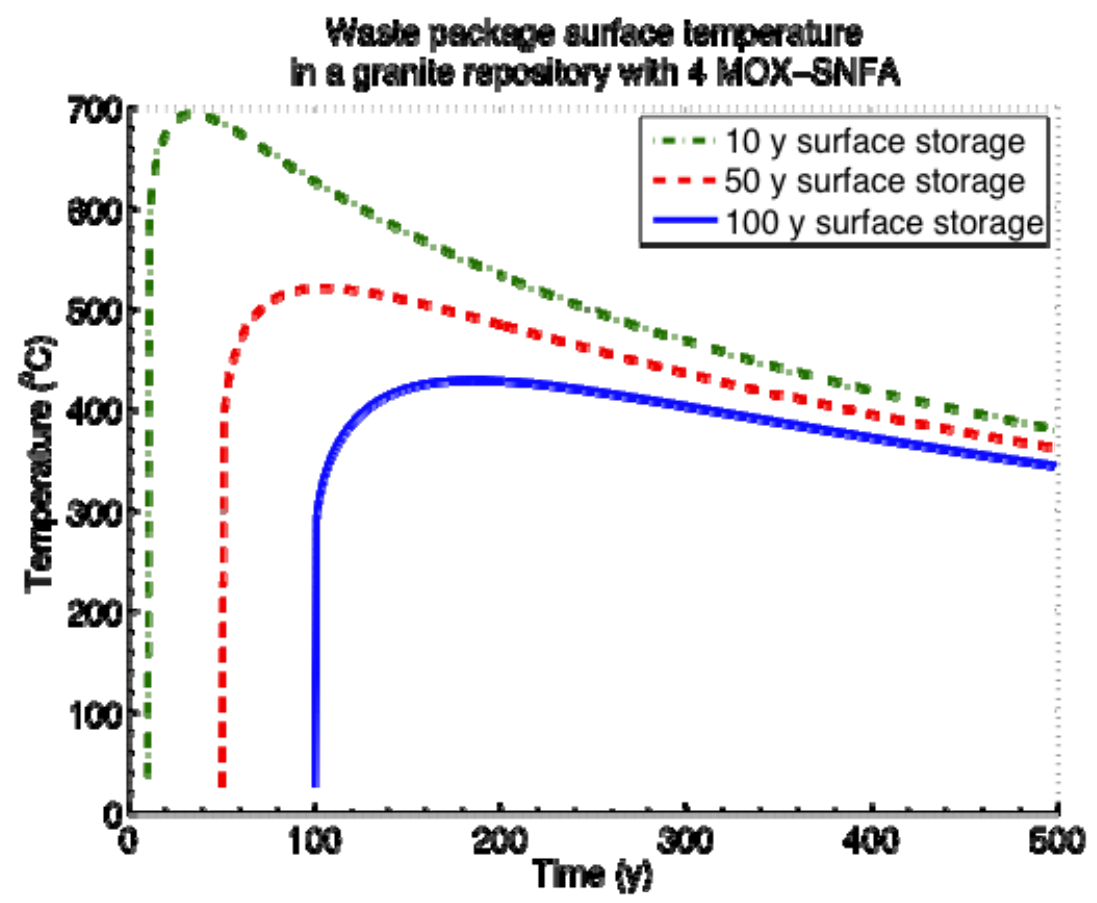

Figure H.4-2 Calculated Waste Package Temperature After Storage Times of 10, 50 and 100 yr for MOX-4 in Crystalline Rock. 


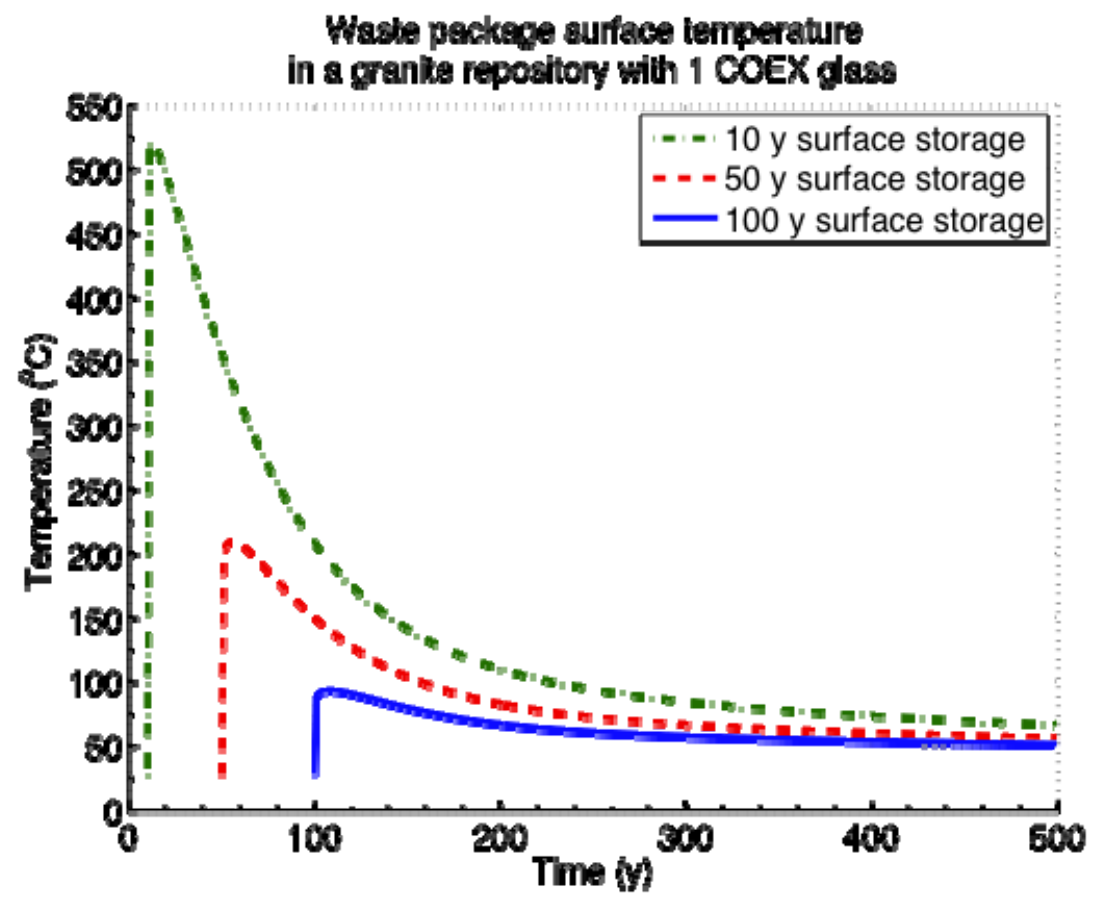

Figure H.4-3 Calculated Waste Package Temperature After Storage Times of 10, 50 and 100 yr for Co-Extraction-1 in Crystalline Rock.

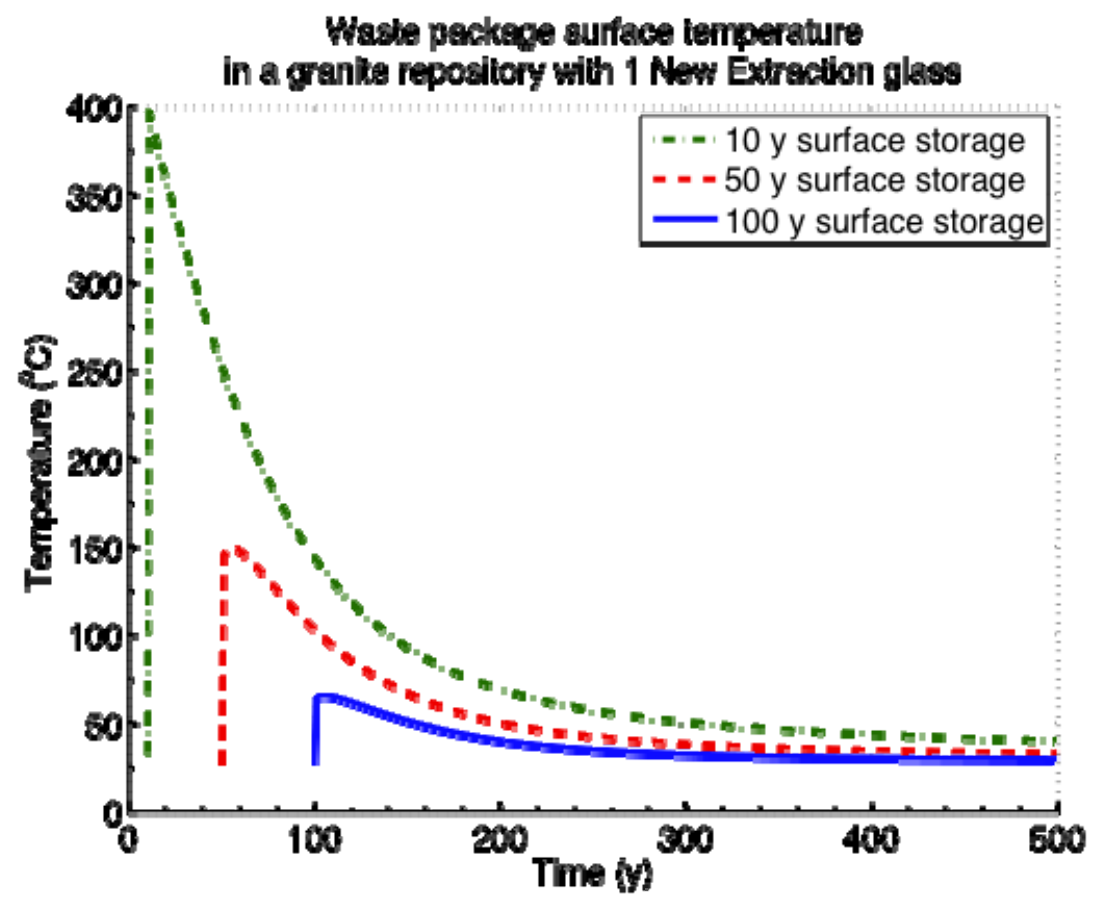

Figure H.4-4 Calculated Waste Package Temperature After Storage Times of 10, 50 and 100 yr for New Extraction-1 in Crystalline Rock. 


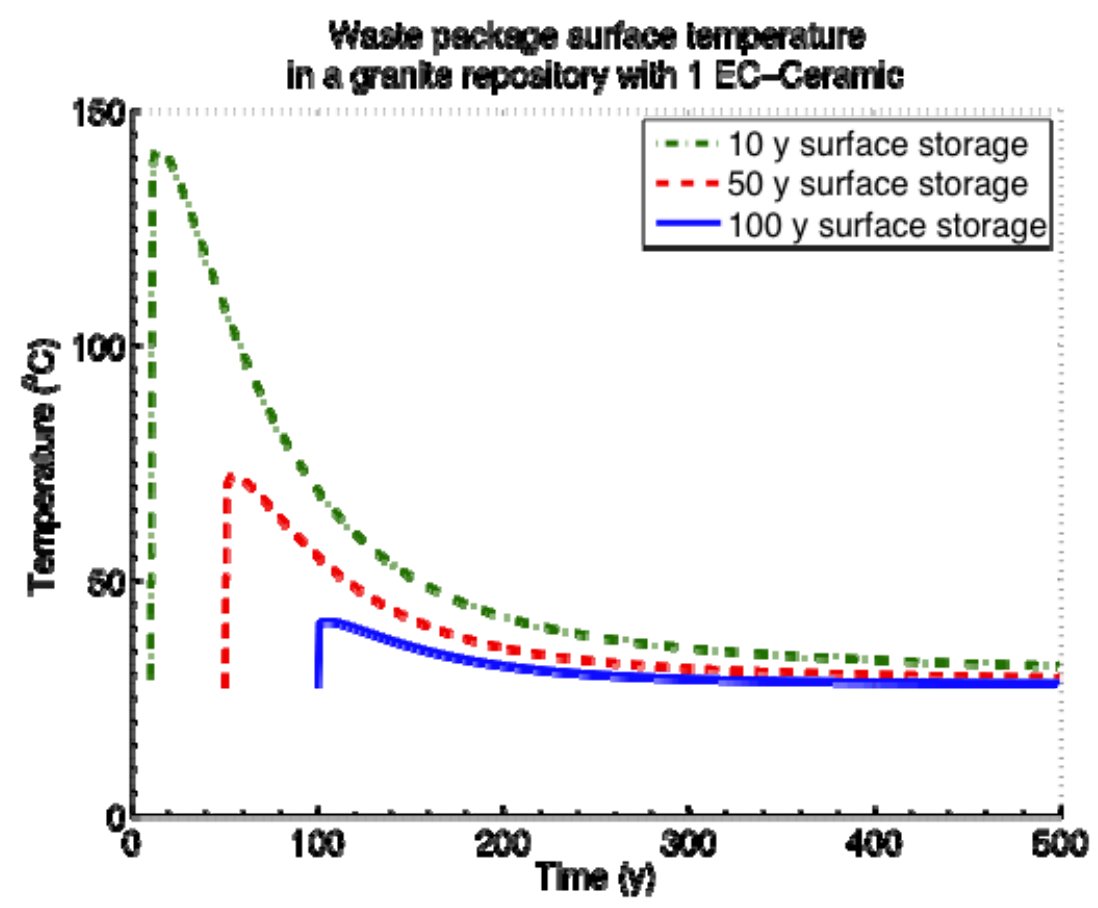

Figure H.4-5 Calculated Waste Package Temperature After Storage Times of 10, 50 and 100 yr for ECC-1 in Crystalline Rock.

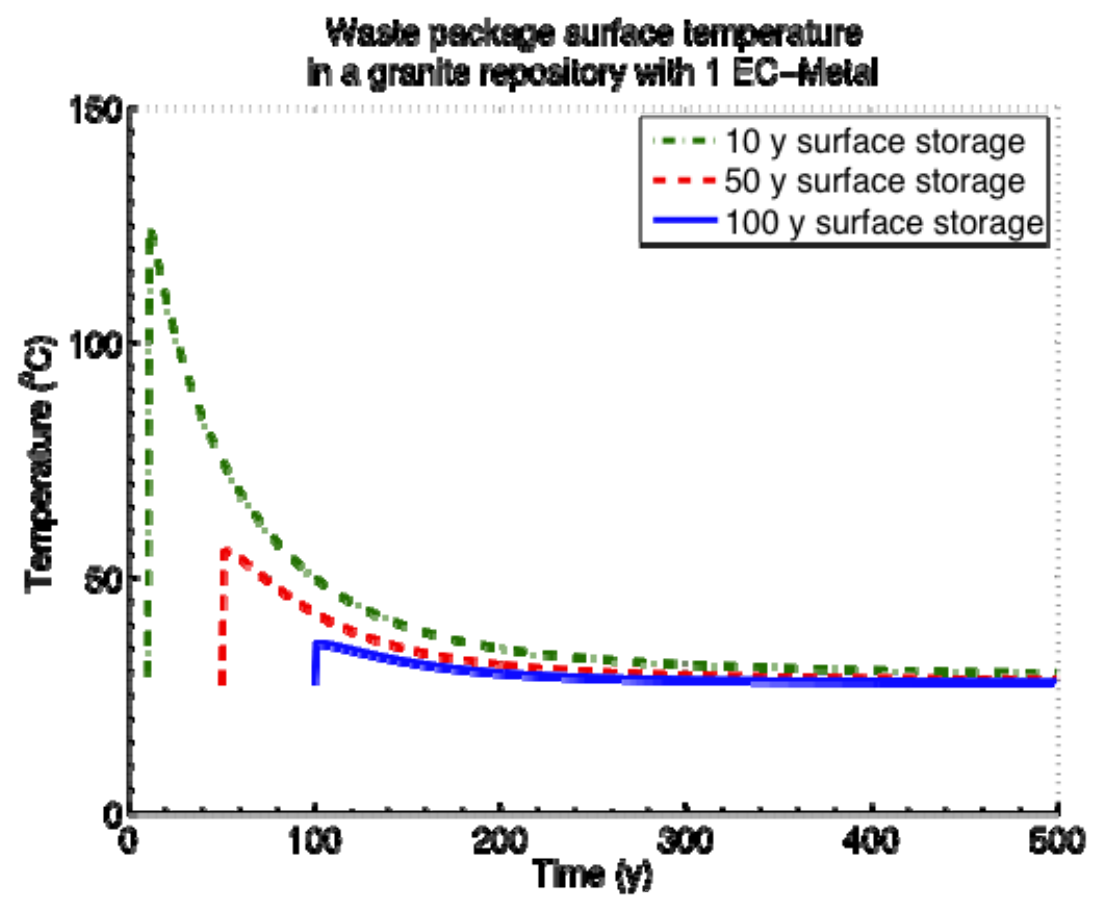

Figure H.4-6 Calculated Waste Package Temperature After Storage Times of 10, 50 and 100 yr for ECM-1 in Crystalline Rock. 


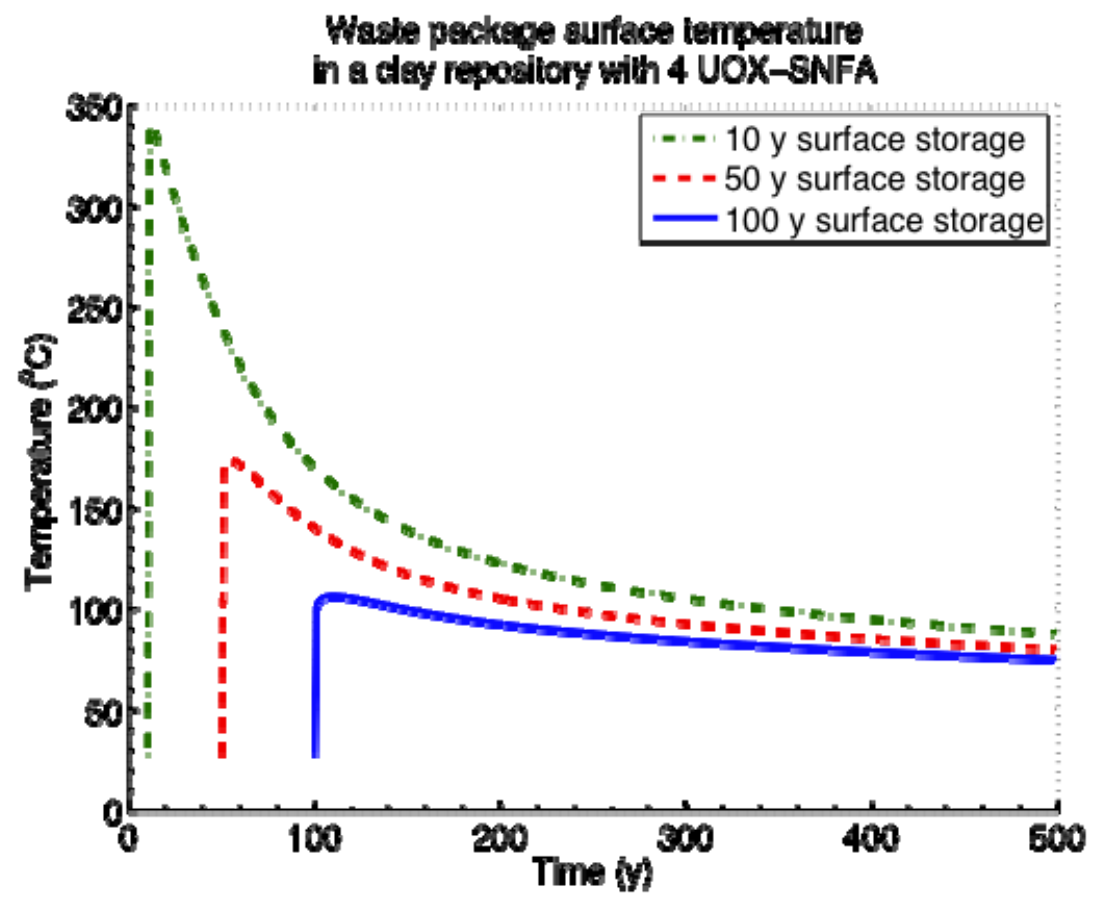

Figure H.4-7 Calculated Waste Package Temperature After Storage Times of 10, 50 and 100 yr for UOX-4 in Clay/Shale.

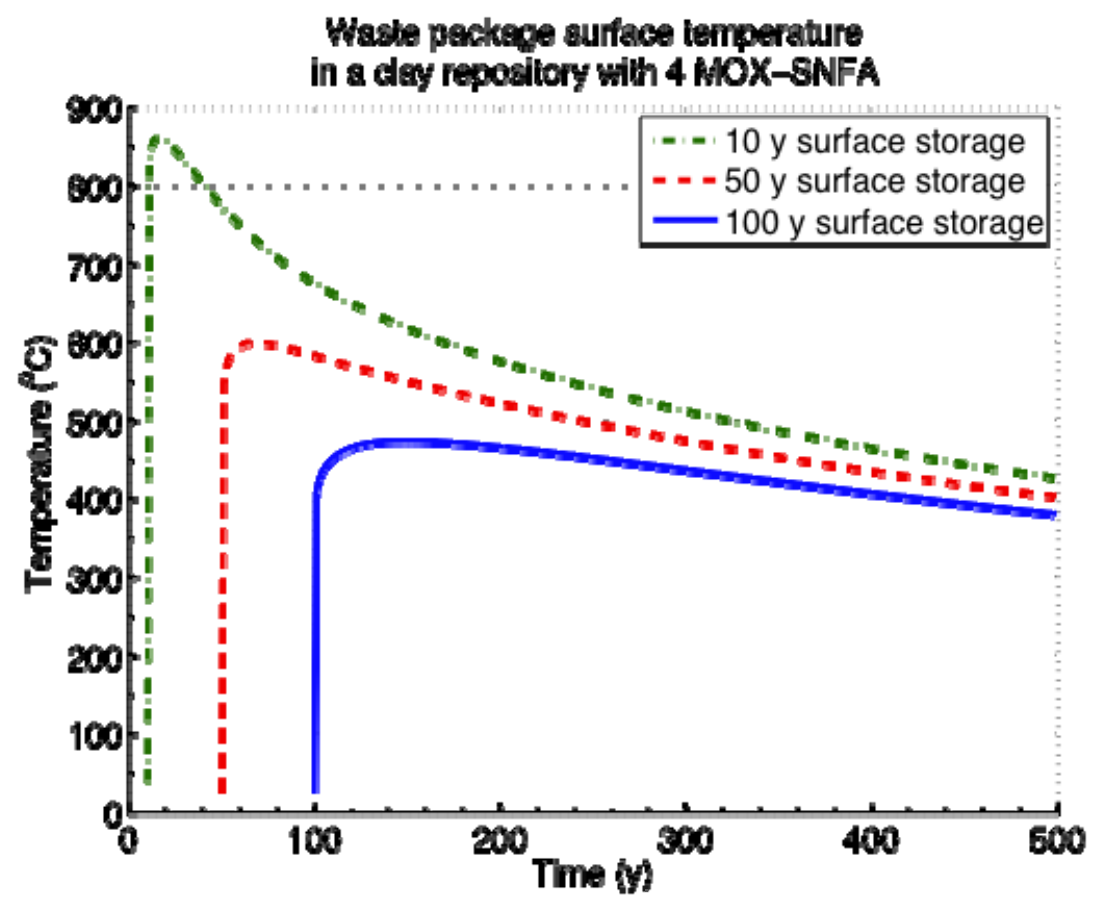

Figure H.4-8 Calculated Waste Package Temperature After Storage Times of 10, 50 and 100 yr for MOX-4 in Clay/Shale. 


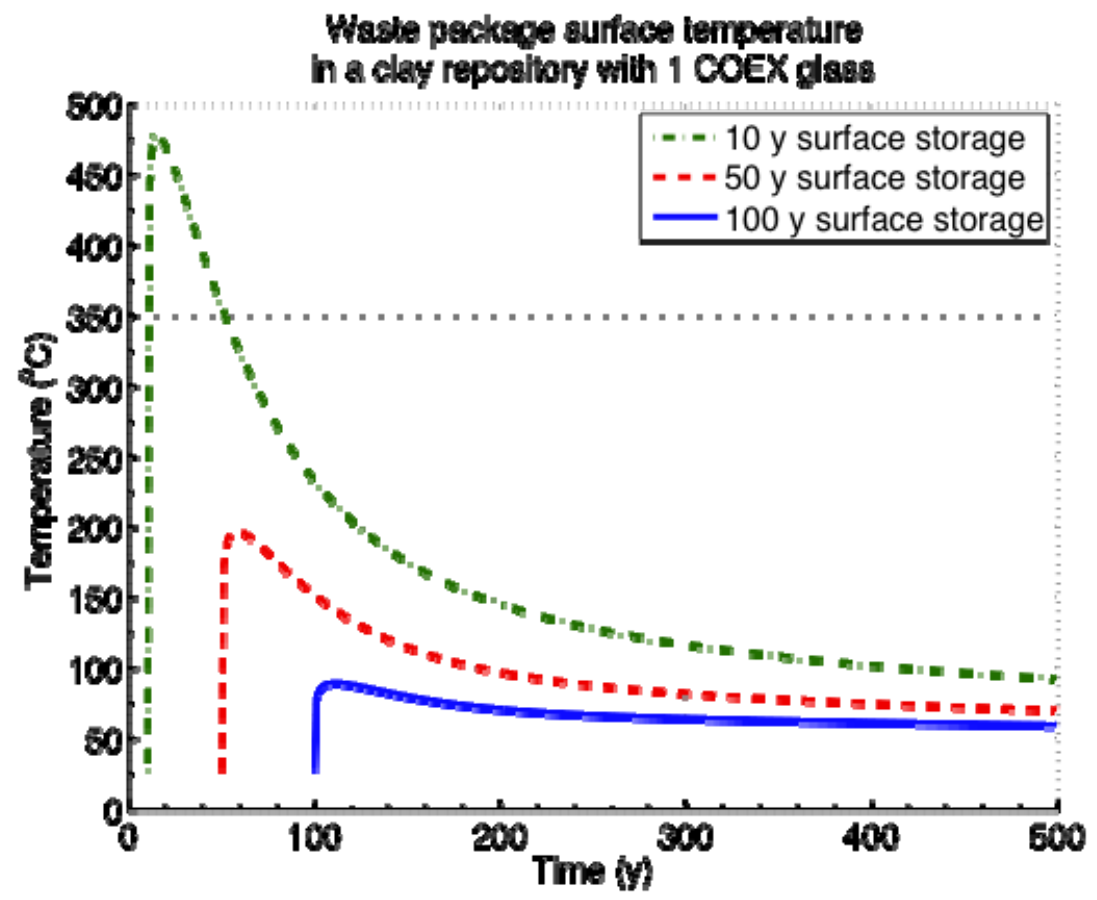

Figure H.4-9 Calculated Waste Package Temperature After Storage Times of 10, 50 and 100 yr for Co-Extraction-1 in Clay/Shale.

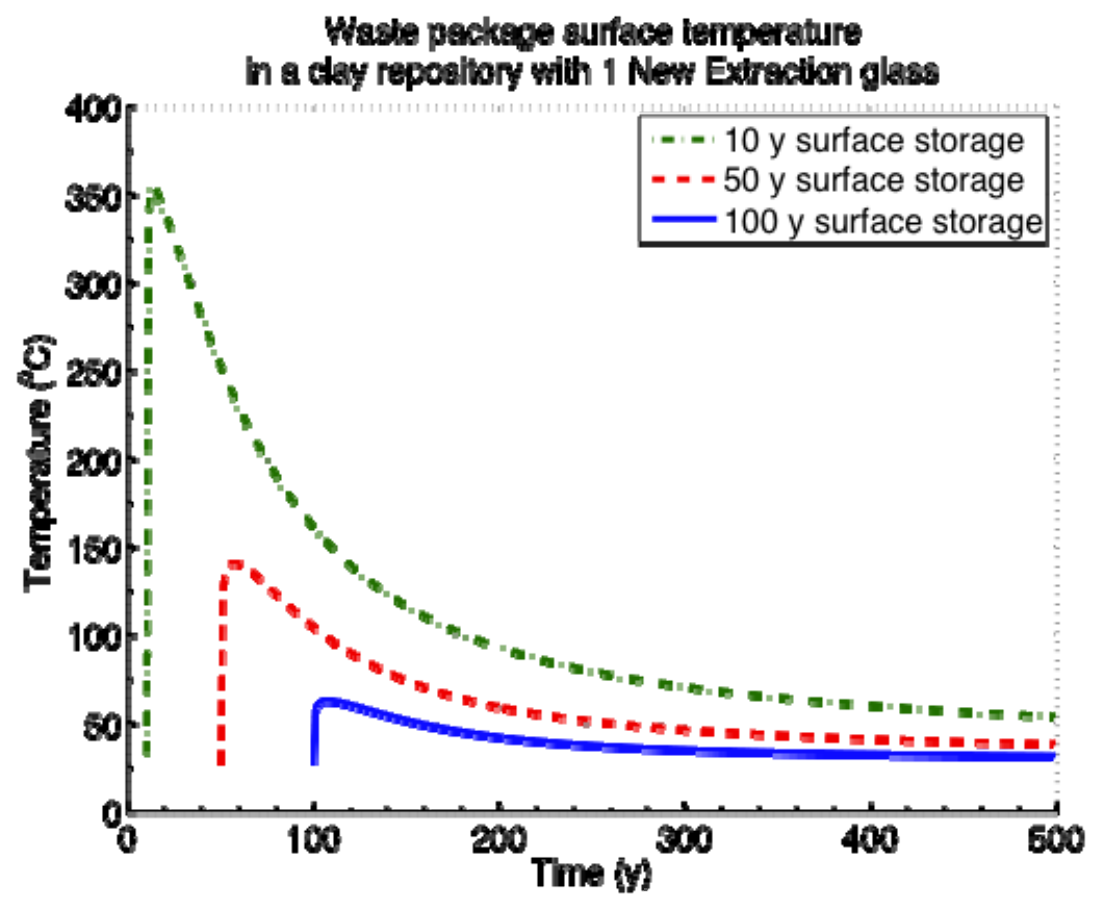

Figure H.4-10 Calculated Waste Package Temperature After Storage Times of 10, 50 and 100 yr for New Extraction-1 in ClaylShale. 


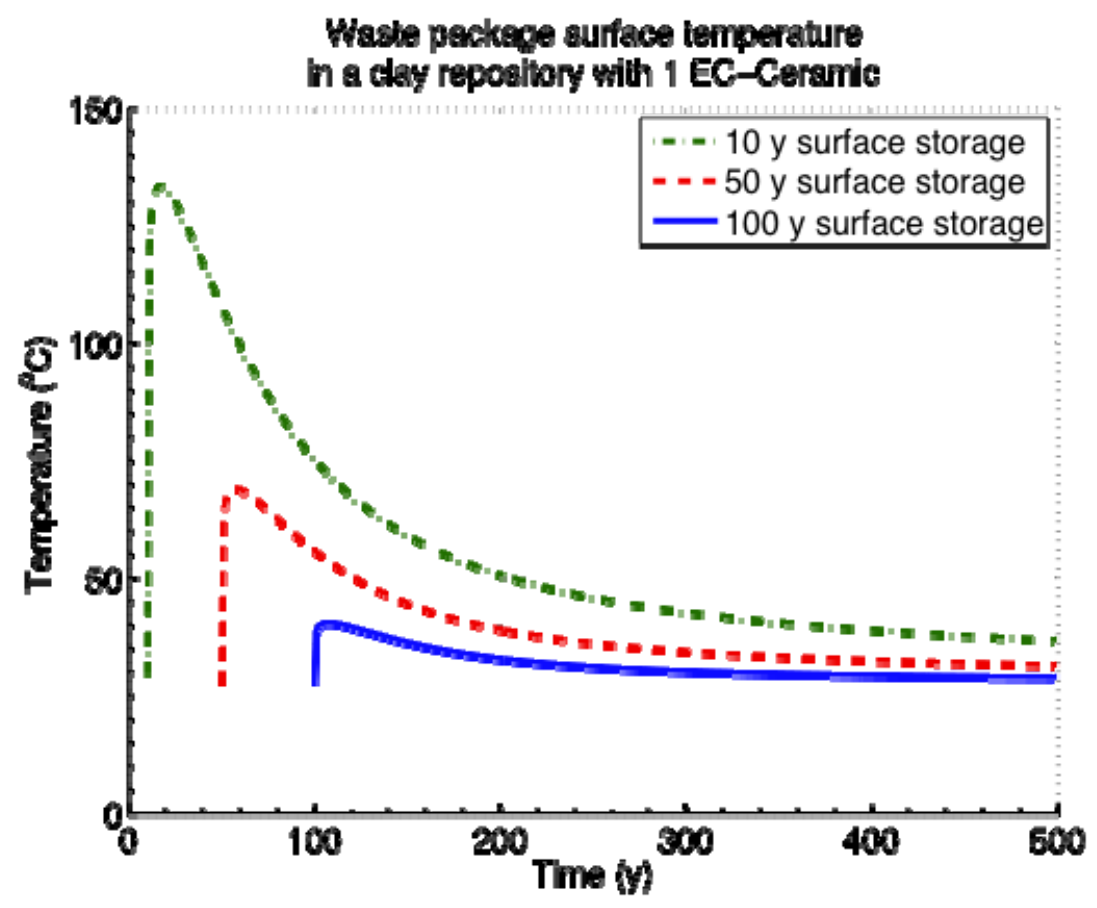

Figure H.4-11 Calculated Waste Package Temperature After Storage Times of 10, 50 and 100 yr for ECC-1 in Clay/Shale.

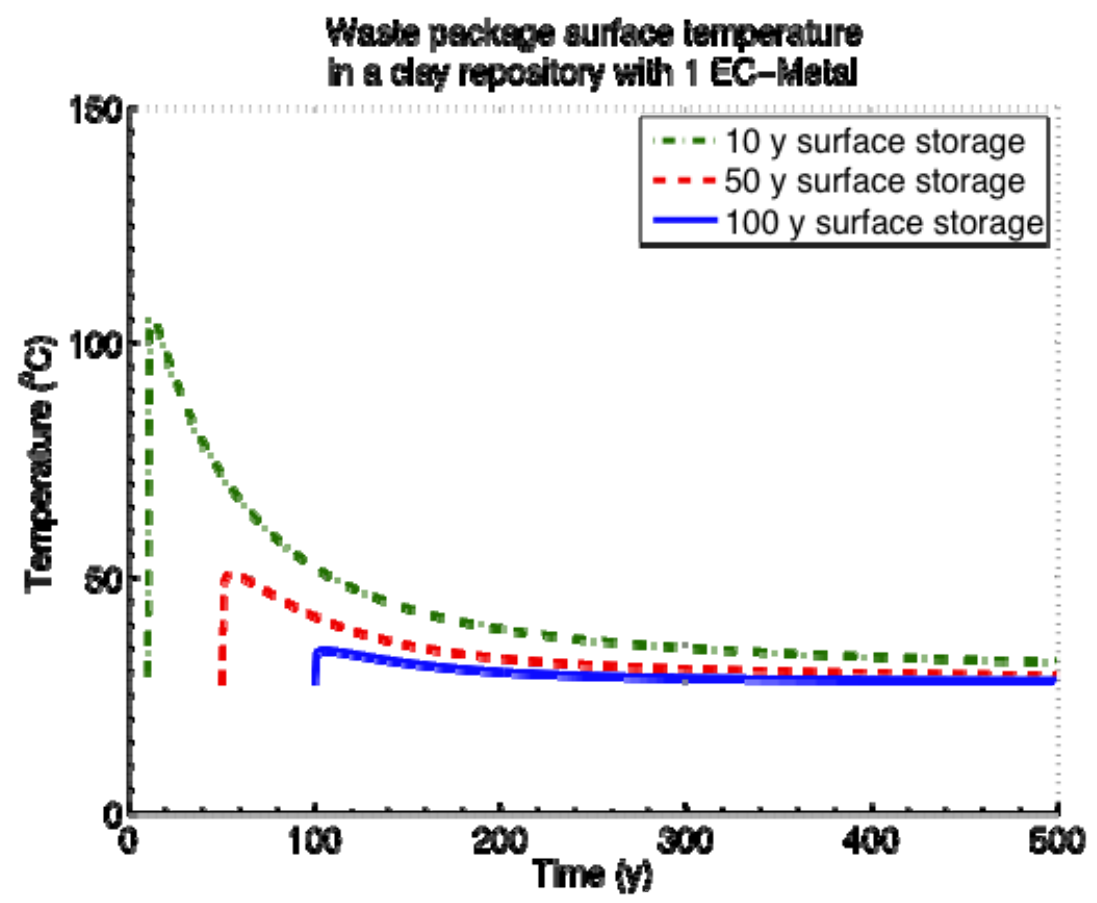

Figure H.4-12 Calculated Waste Package Temperature After Storage Times of 10, 50 and 100 yr for ECM-1 in ClaylShale. 


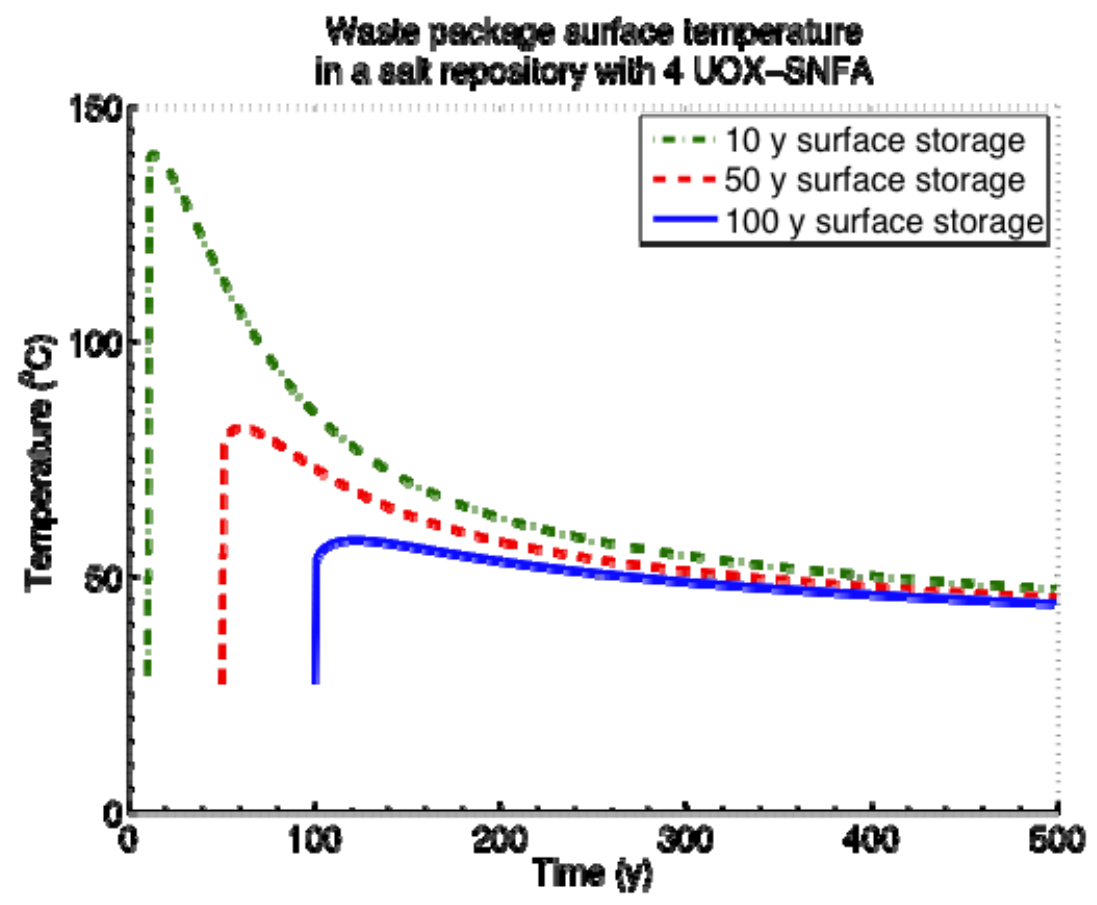

Figure H.4-13 Calculated Waste Package Temperature After Decay Storage of 10, 50 and 100 yr for UOX-4 in Salt (75\% of intact salt conductivity).

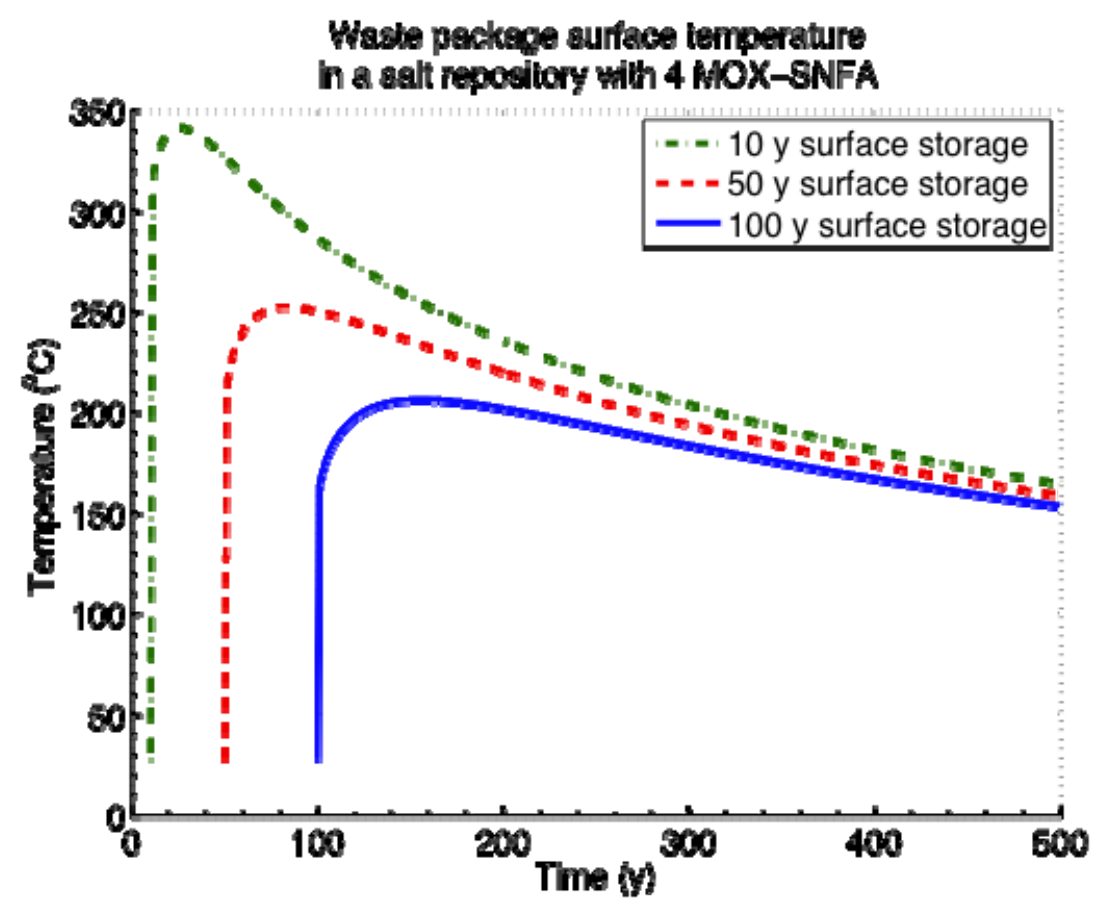

Figure H.4-14 Calculated Waste Package Temperature After Decay Storage of 10, 50 and 100 yr for MOX-4 in Salt (75\% of intact salt conductivity). 


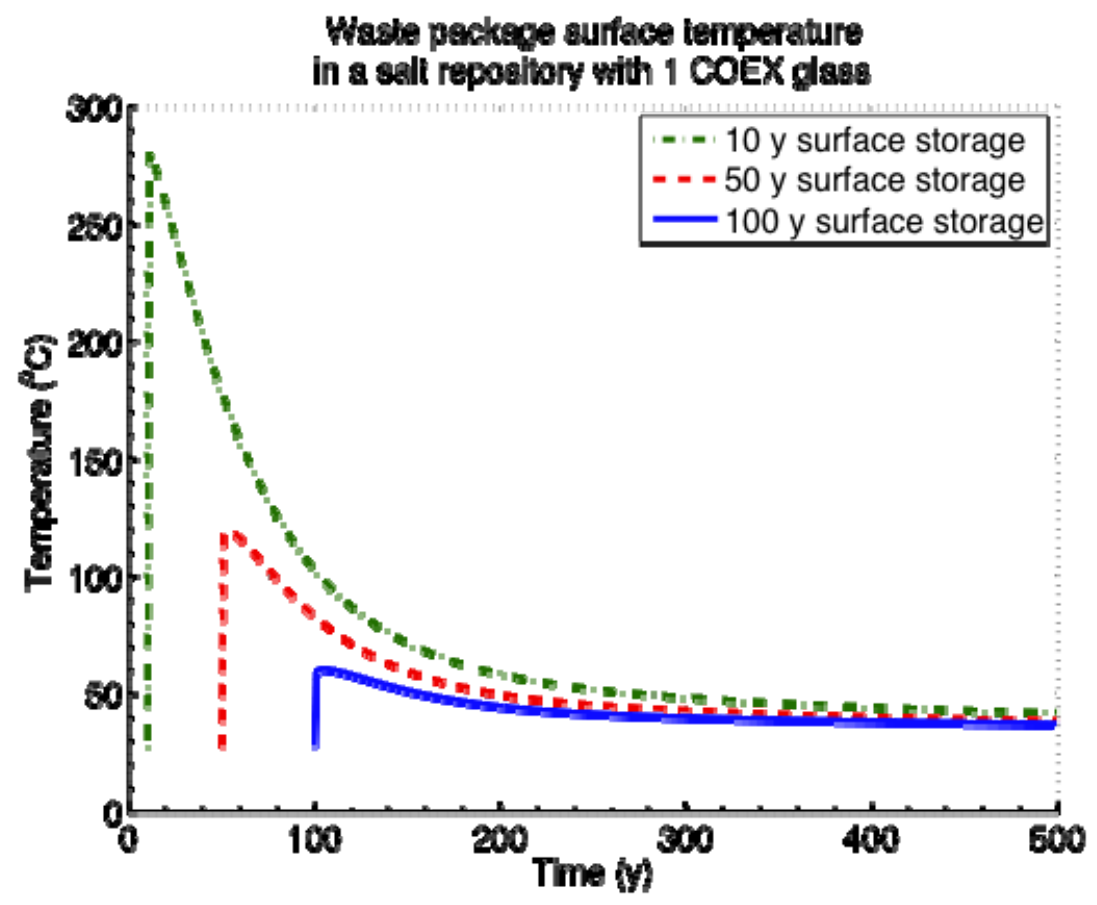

Figure H.4-15 Calculated Waste Package Temperature After Decay Storage of 10, 50 and 100 yr for Co-Extraction-1 in Salt (75\% of intact salt conductivity).

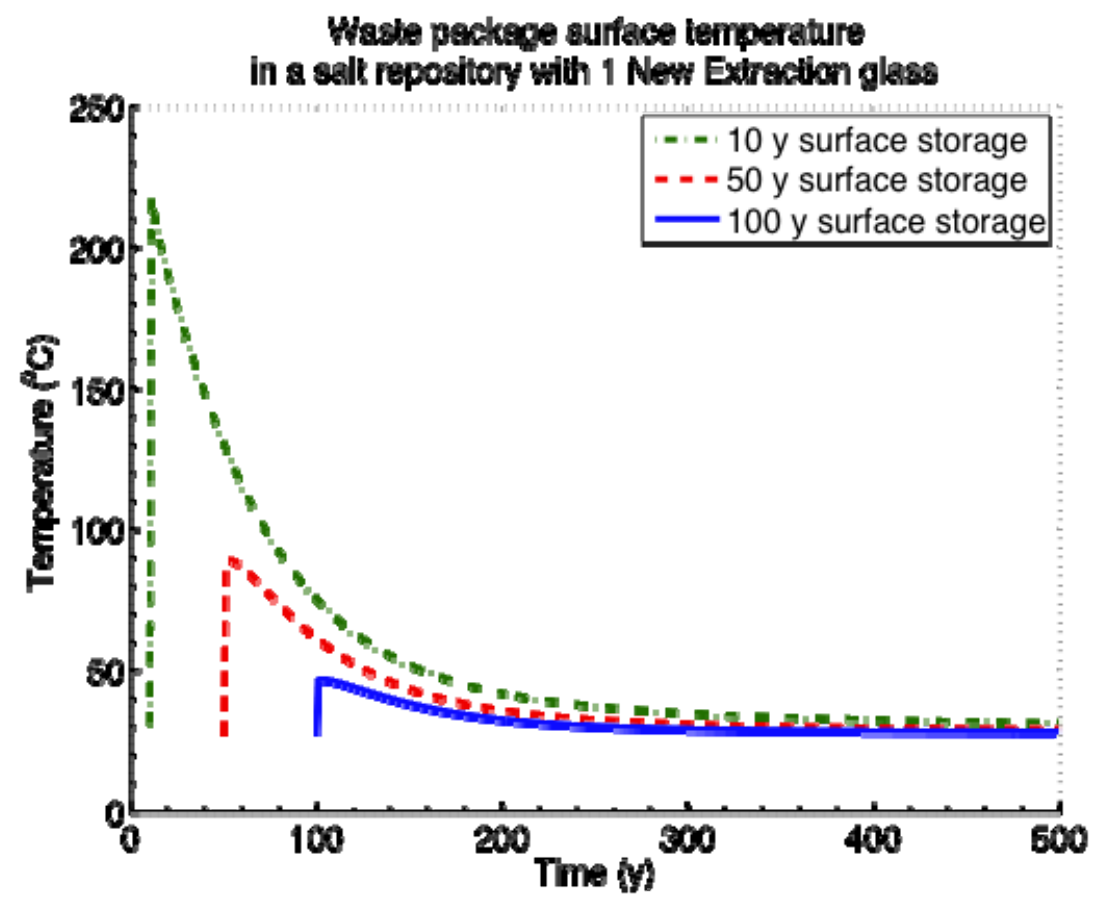

Figure H.4-16 Calculated Waste Package Temperature After Decay Storage of 10, 50 and 100 yr for New Extraction-1 in Salt (75\% of intact salt conductivity). 


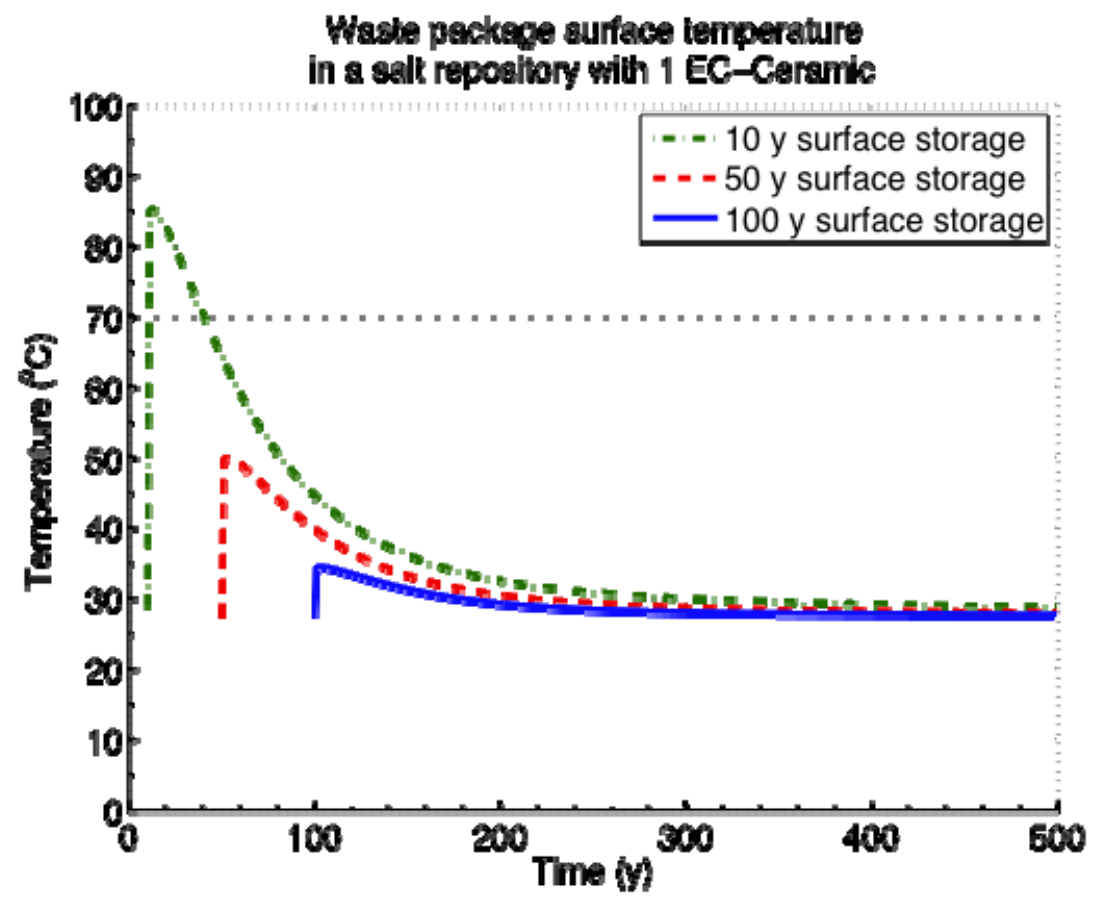

Figure H.4-17 Calculated Waste Package Temperature After Decay Storage of 10, 50 and $100 \mathrm{yr}$ for ECC-1 in Salt (75\% of intact salt conductivity).

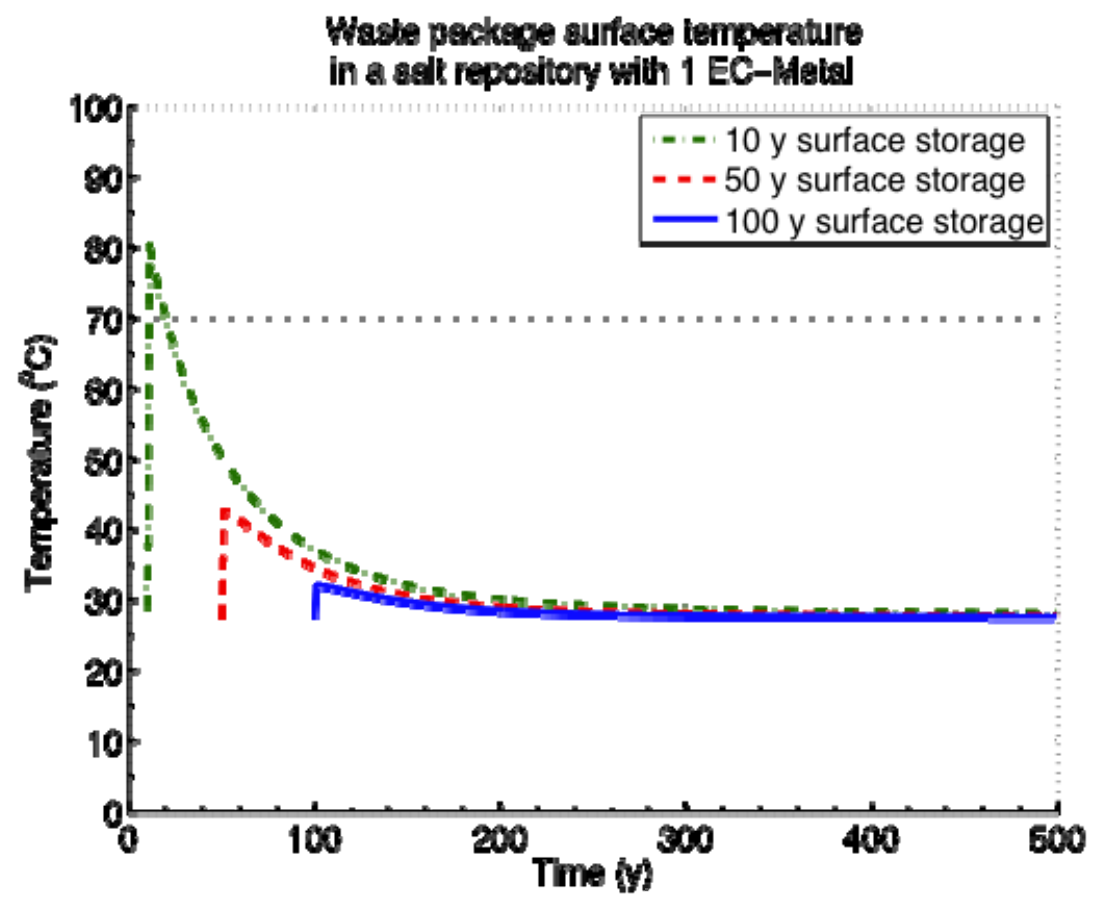

Figure H.4-18 Calculated Waste Package Temperature After Decay Storage of 10, 50 and 100 yr for ECM-1 in Salt (75\% of intact salt conductivity). 


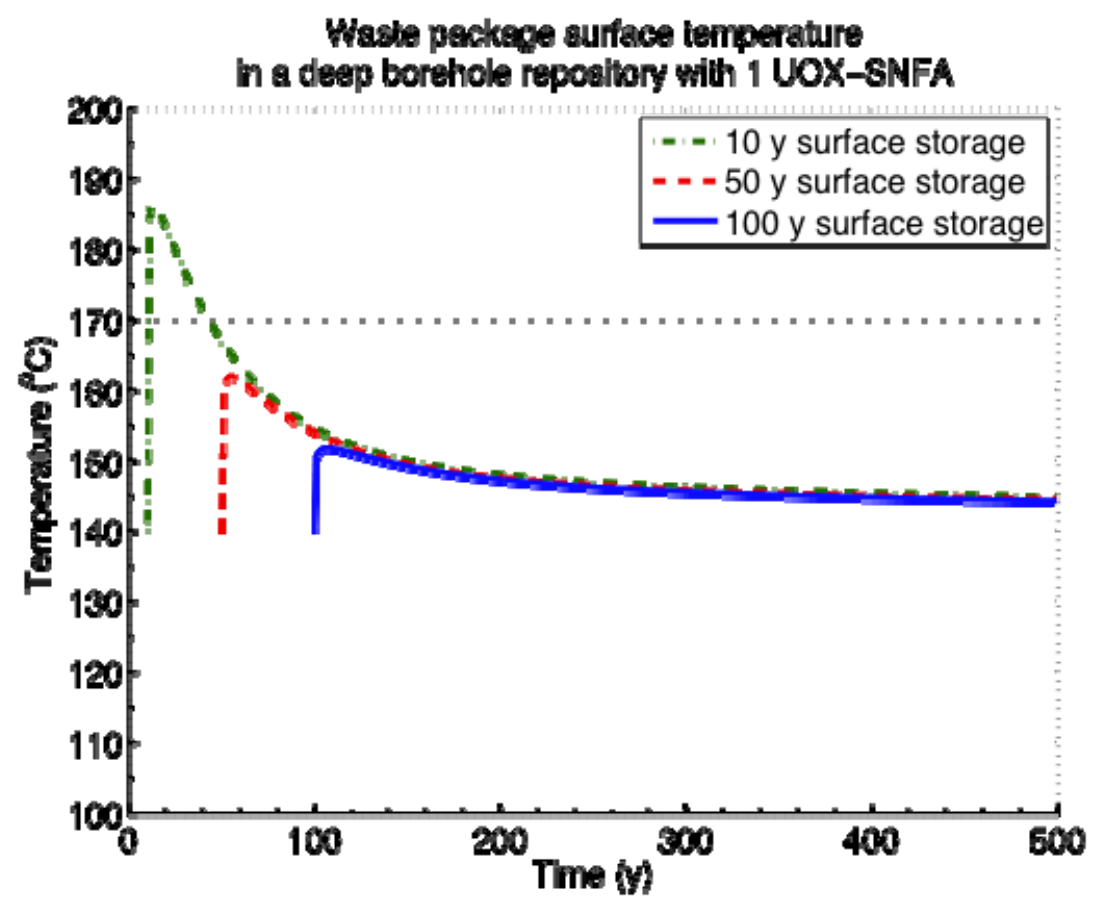

Figure H.4-19 Calculated Waste Package Temperature After Decay Storage of 10, 50 and 100 yr for UOX-1 in a Deep Borehole.

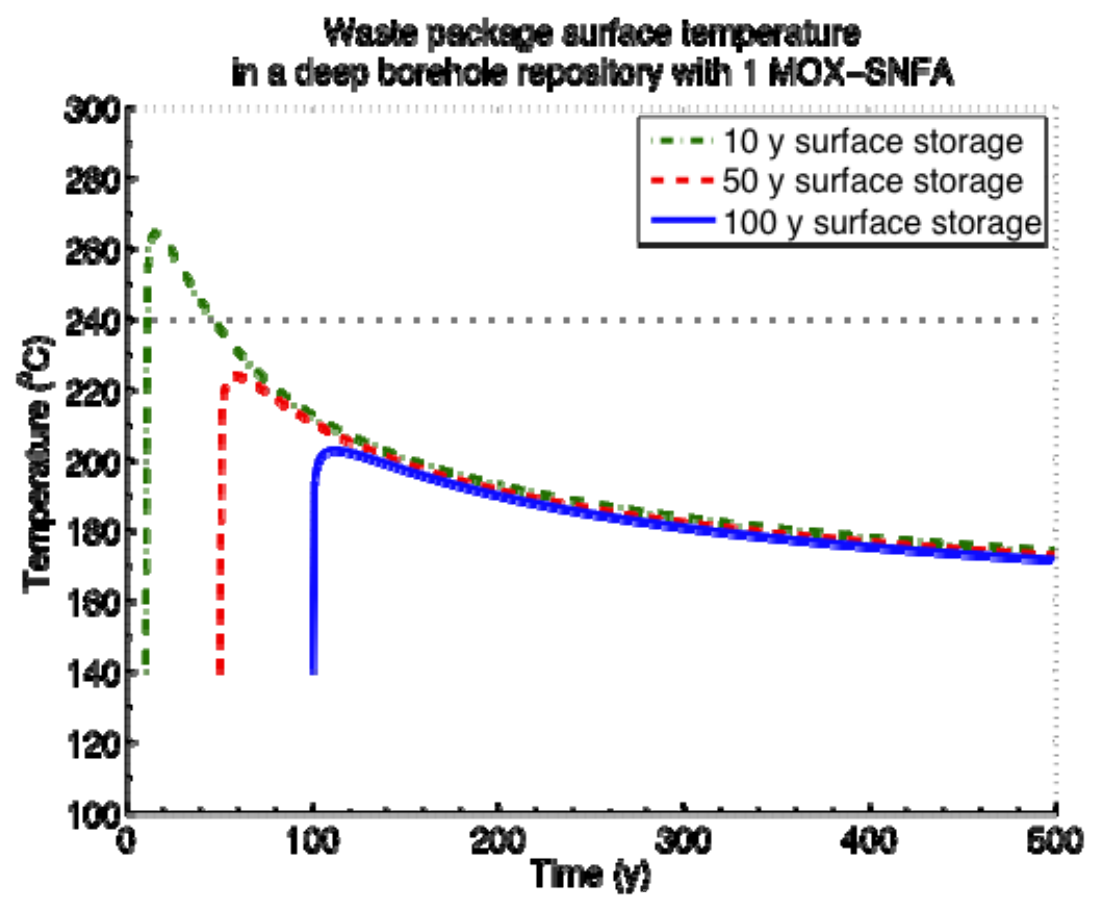

Figure H.4-20 Calculated Waste Package Temperature After Decay Storage of 10, 50 and 100 yr for MOX-1 in a Deep Borehole. 


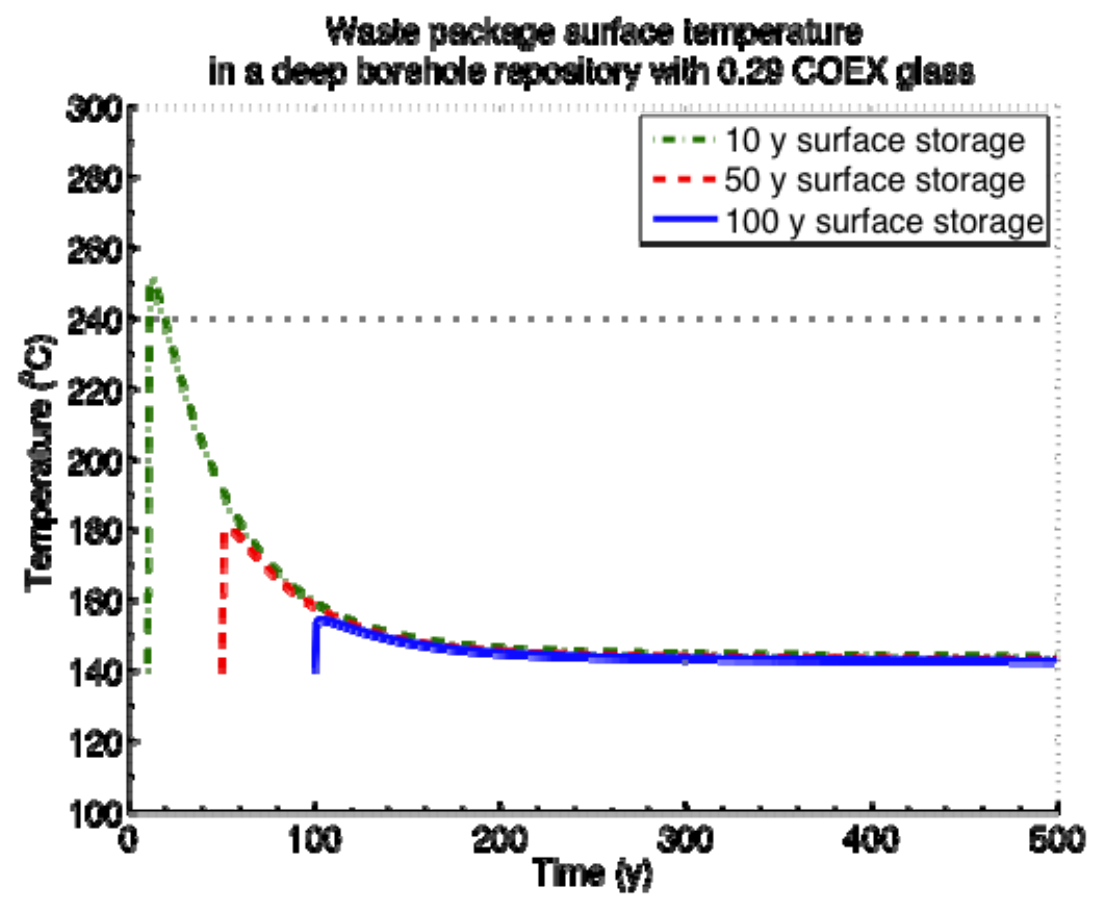

Figure H.4-21 Calculated Waste Package Temperature After Decay Storage of 10, 50 and 100 yr for Co-Extraction-0.291 in a Deep Borehole.

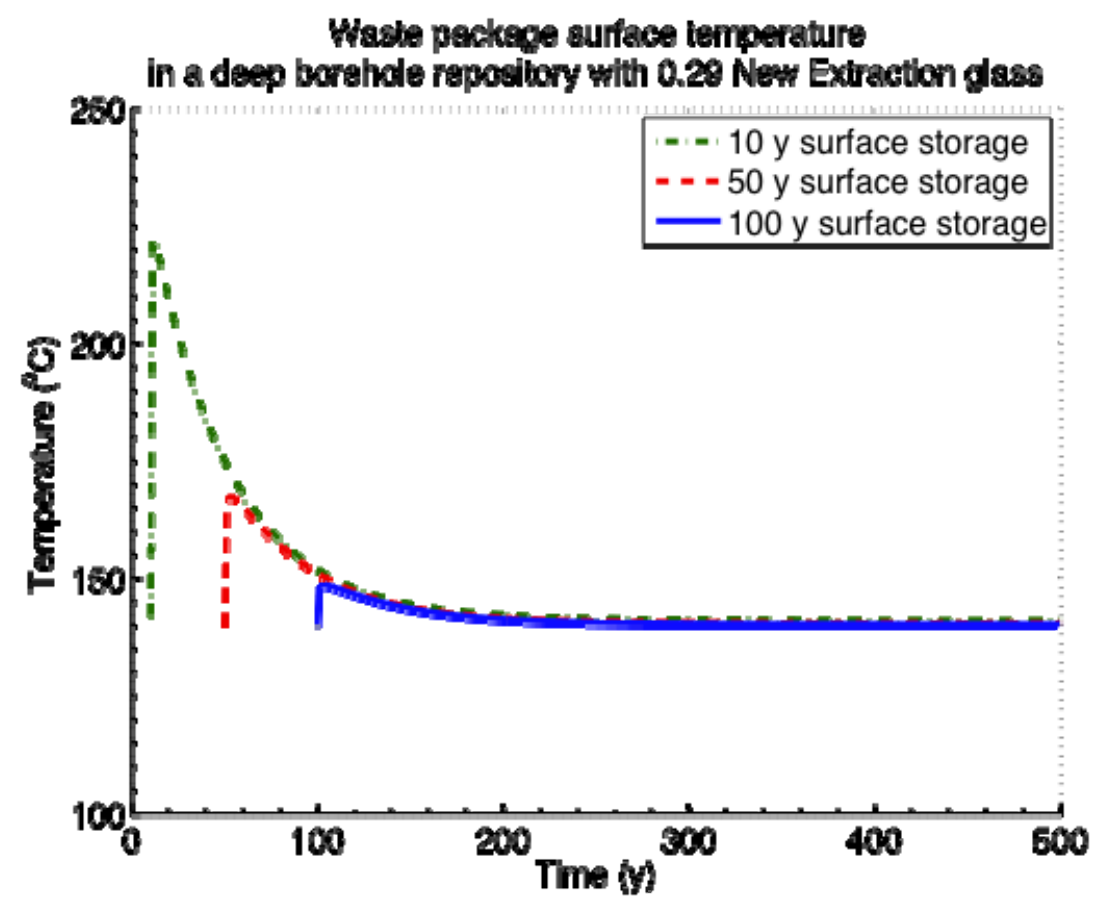

Figure H.4-22 Calculated Waste Package Temperature After Decay Storage of 10, 50 and 100 yr for New Extraction-0.291 in a Deep Borehole. 


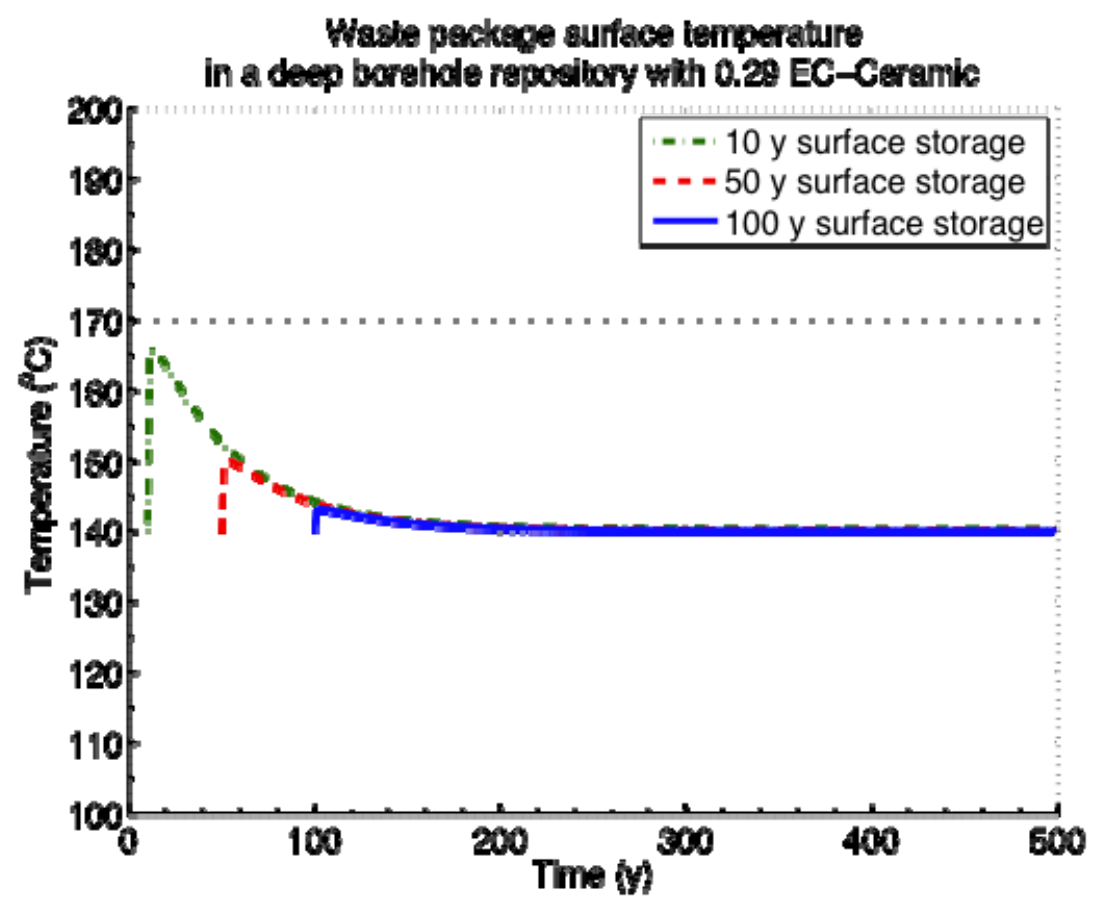

Figure H.4-23 Calculated Waste Package Temperature After Decay Storage of 10, 50 and 100 yr for ECC-0.291 in a Deep Borehole.

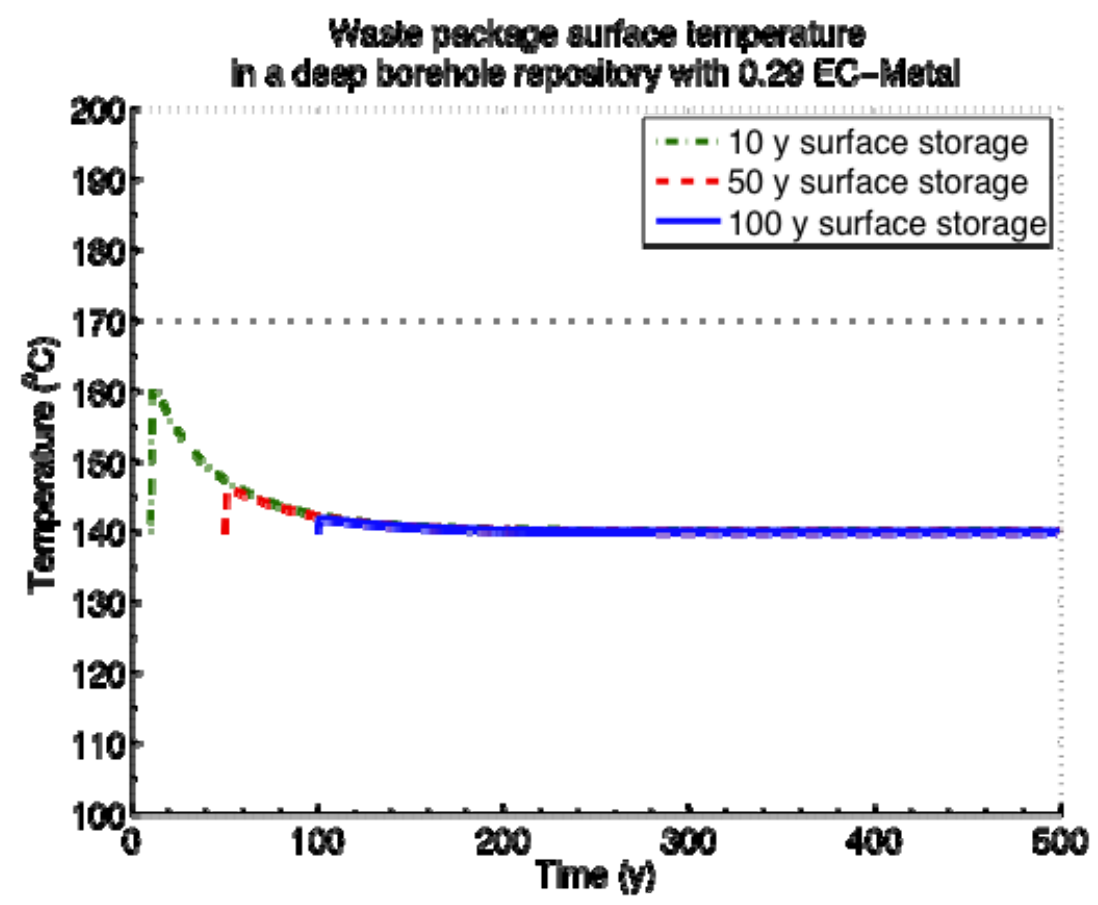

Figure H.4-24 Calculated Waste Package Temperature After Decay Storage of 10, 50 and 100 yr for ECM-0.291 in a Deep Borehole. 


\section{H.5 Waste Package Peak Temperature as a Function of Decay Storage and Waste Package Capacity}

For crystalline, clay/shale, and salt media the peak waste package temperature was calculated for storage times ranging from 10 years to 1400 years, for packages containing one, two, three, four and 12 UOX or MOX assemblies. The extended range of decay storage time is not intended to imply that such a waste management strategy could be implemented, but it allows interpolation rather than extrapolation, when constructing the trade curves in the following section. The figures in this section are plotted out to 300 years to show the detail for shorter storage periods. 


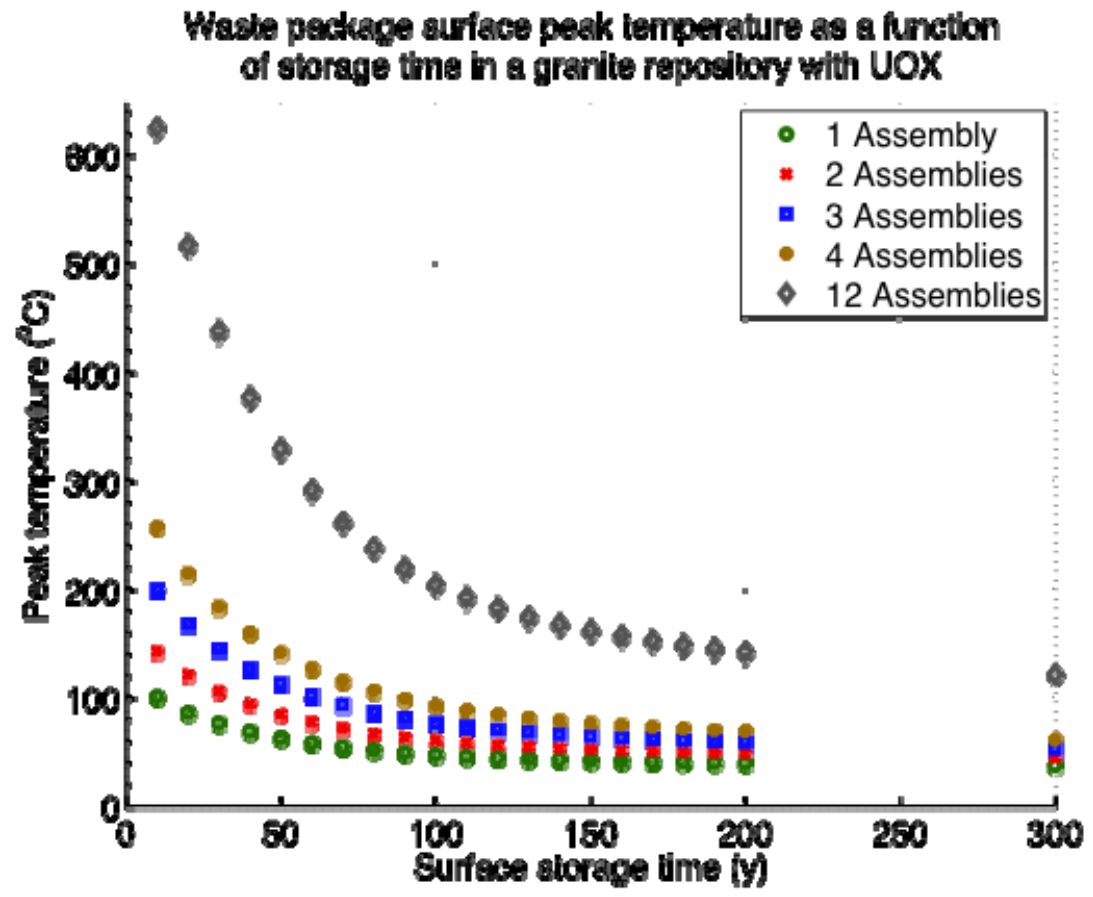

Figure H.5-1 Peak Waste Package Surface Temperature as a Function of Decay Storage for UOX in Crystalline Rock.

Wale package aurace peak temperature as a function of storage tine in a gravile reposikn with MOX

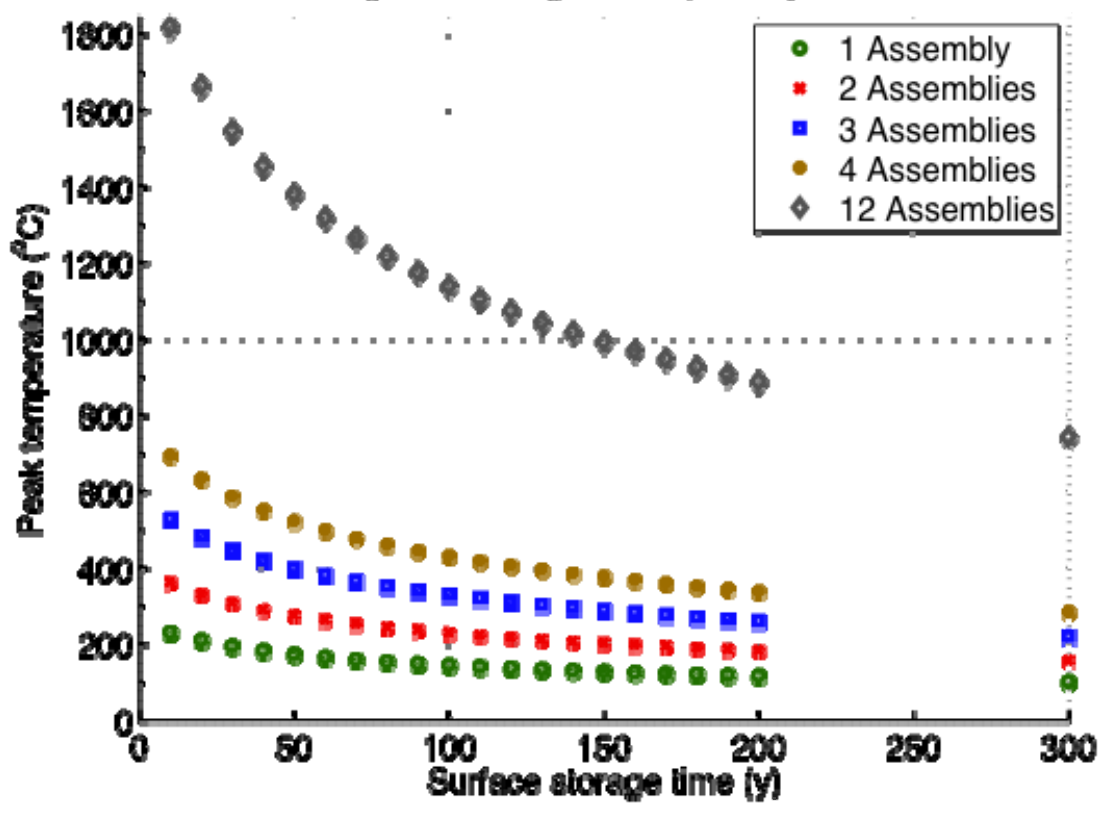

Figure H.5-2 Peak Waste Package Surface Temperature as a Function of Decay Storage for MOX in Crystalline Rock. 


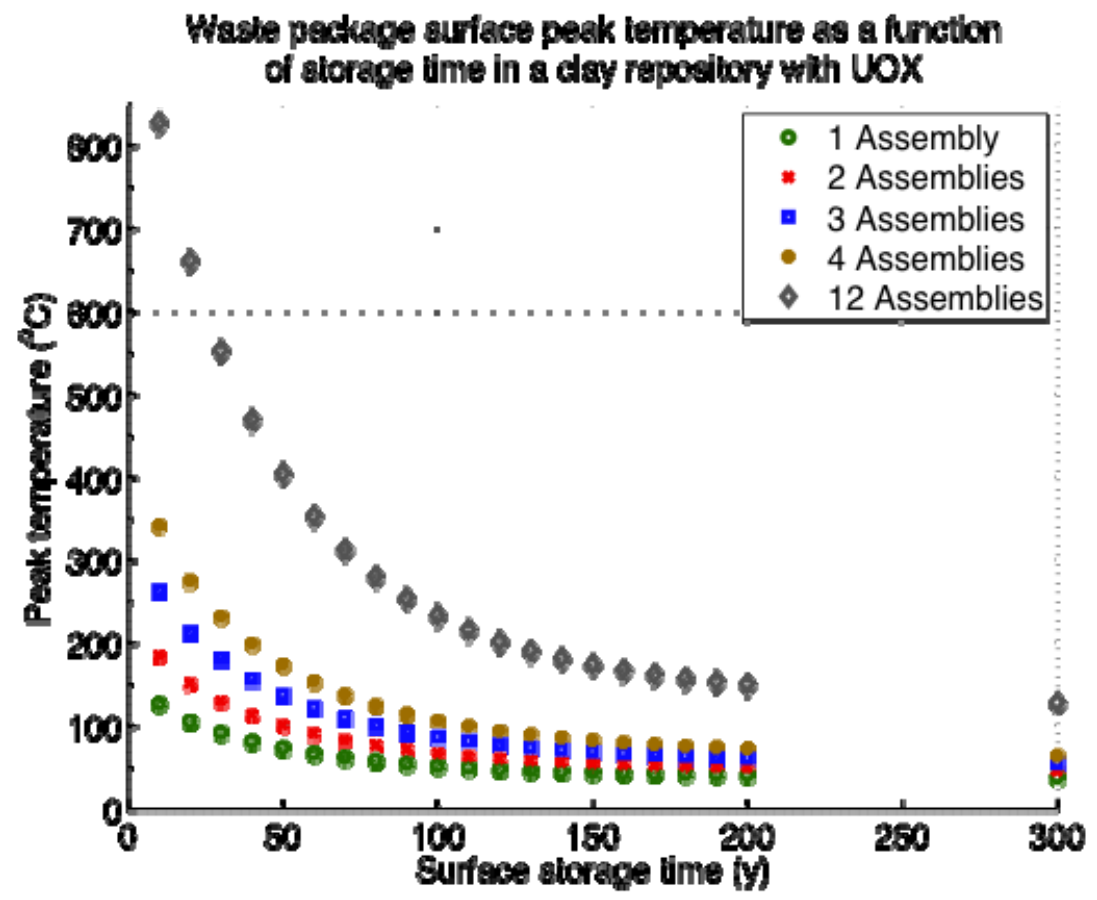

Figure H.5-3 Peak Waste Package Surface Temperature as a Function of Decay Storage for UOX in ClaylShale.

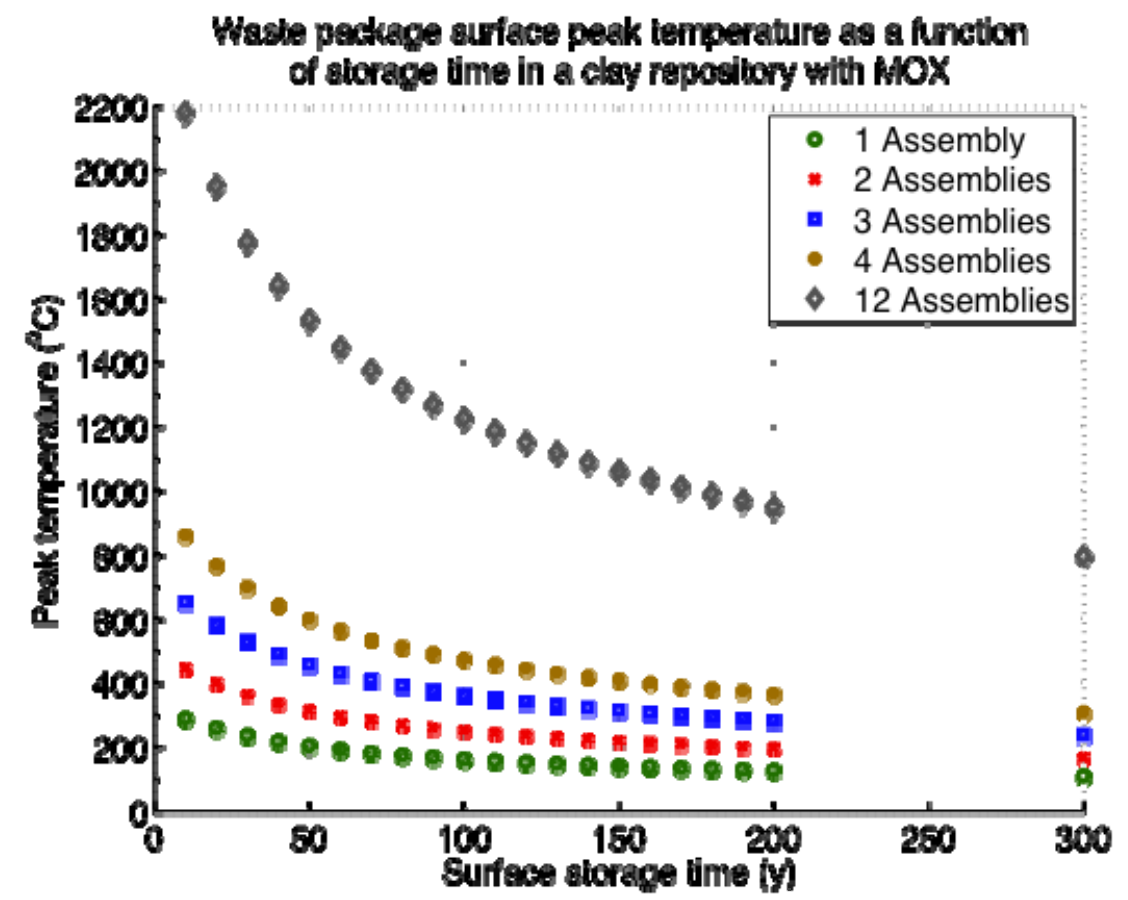

Figure H.5-4 Peak Waste Package Surface Temperature as a Function of Decay Storage for MOX in Clay/Shale. 


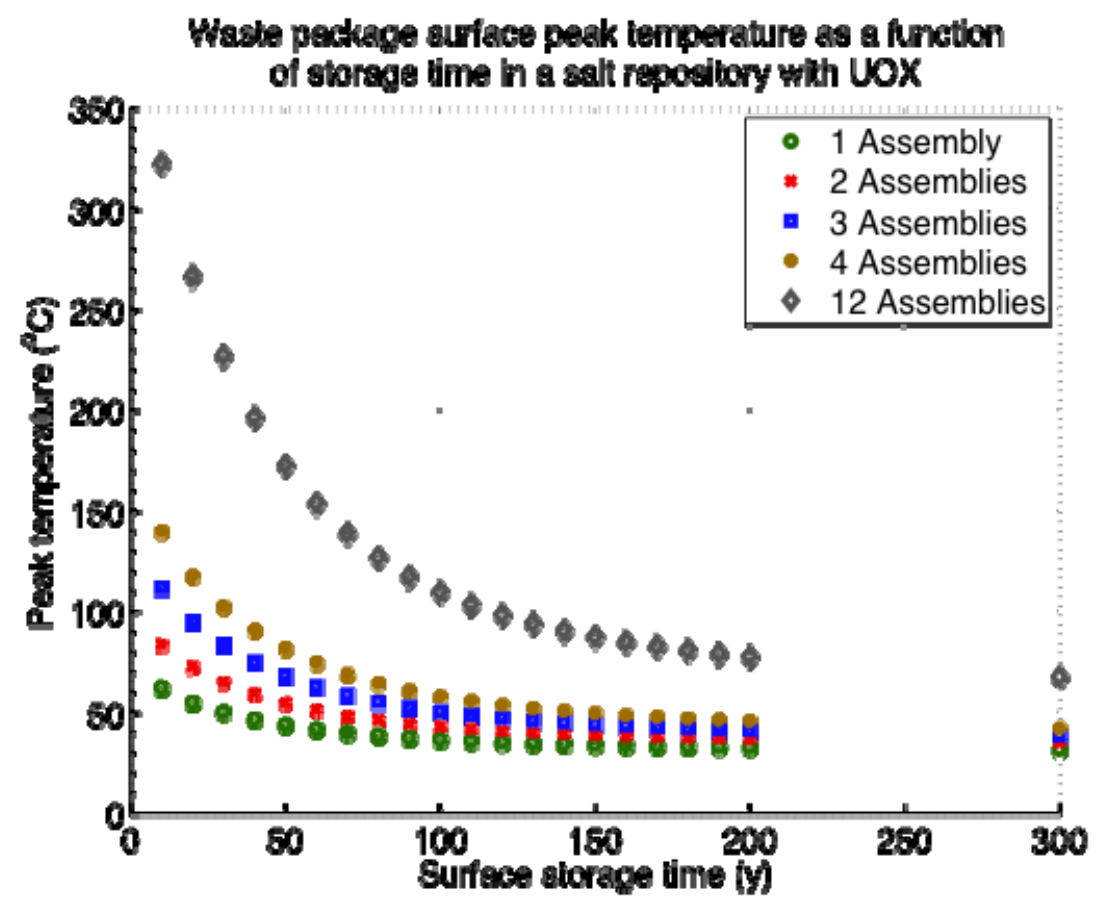

Figure H.5-5 Peak Waste Package Surface Temperature as a Function of Decay Storage for UOX in Salt (75\% of intact salt conductivity).

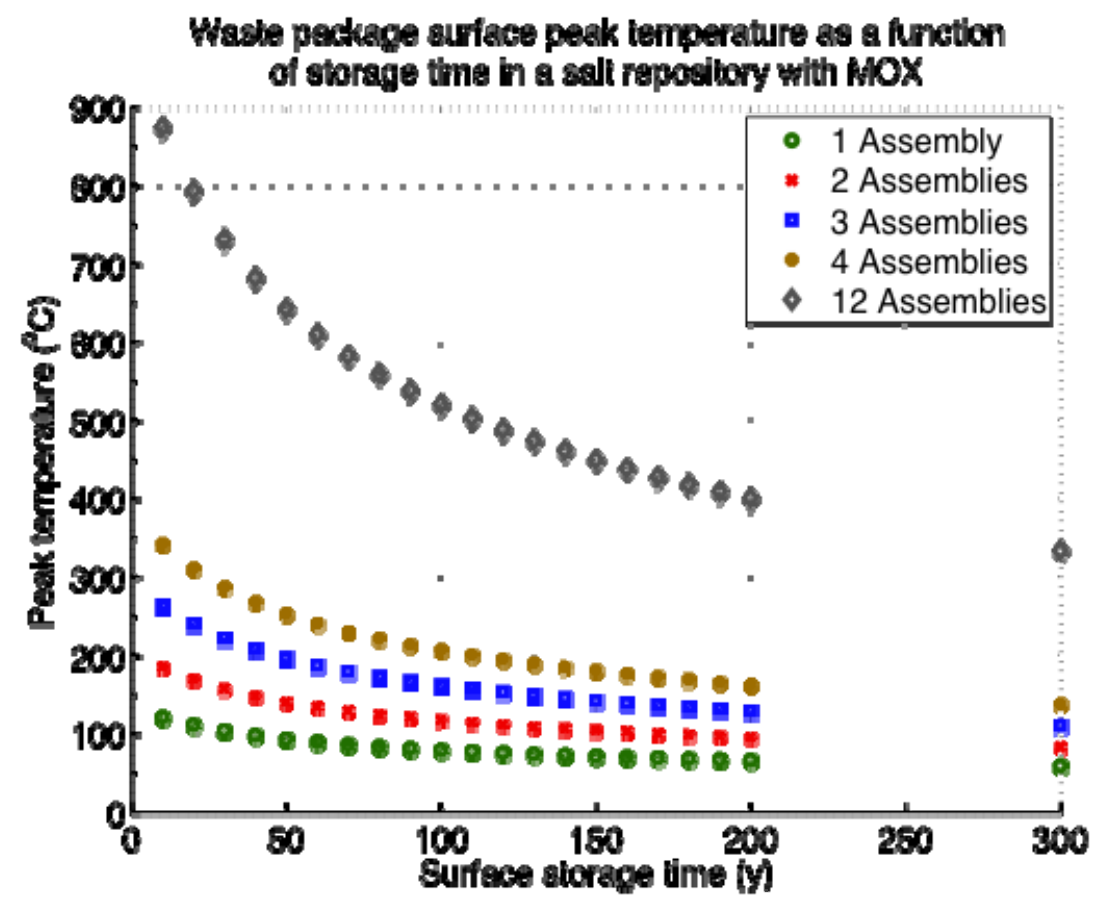

Figure H.5-6 Peak Waste Package Surface Temperature as a Function of Decay Storage for MOX in Salt (75\% of intact salt conductivity). 


\section{H.6 Trade-off of Storage Time and Waste Package Capacity}

This section documents calculation of the minimum surface decay storage time required to maintain the peak waste package surface temperature below prescribed limits. This storage time was determined by interpolating the peak temperature data (plotted in Section H.5 for times up to 300 years). Decay heat values were available starting from 5 year, so decay storage times less than 5 years were not considered.

The waste package surface target values for maximum temperatures (Section 4.1.1.2) used for these calculations are:

- Crystalline/Granite (clay buffer): $100^{\circ} \mathrm{C}$

- Clay/shale: $100^{\circ} \mathrm{C}$

- Salt: $200^{\circ} \mathrm{C}$ 


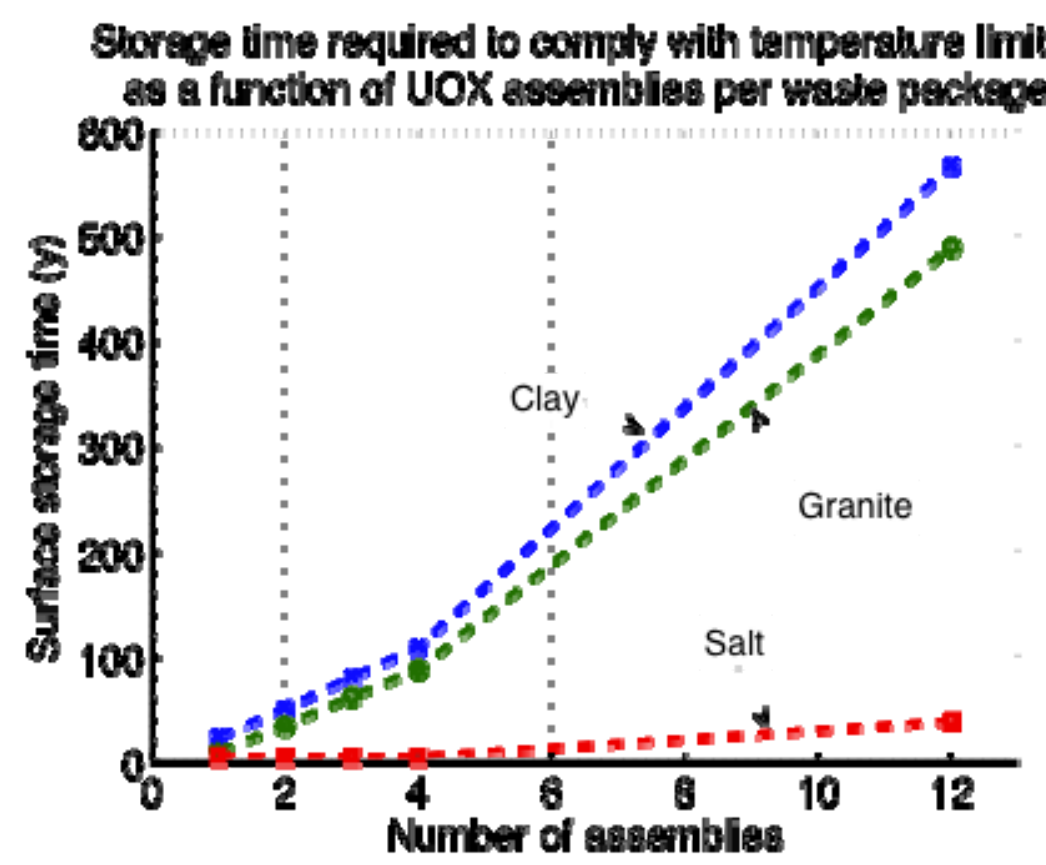

Figure H.6-1 Minimum Decay Storage Needed to Meet Prescribed Maximum Waste Package Temperatures, as a Function of UOX Assemblies per Package in Crystalline, Clay/Shale, and Salt (75\% of intact salt conductivity).

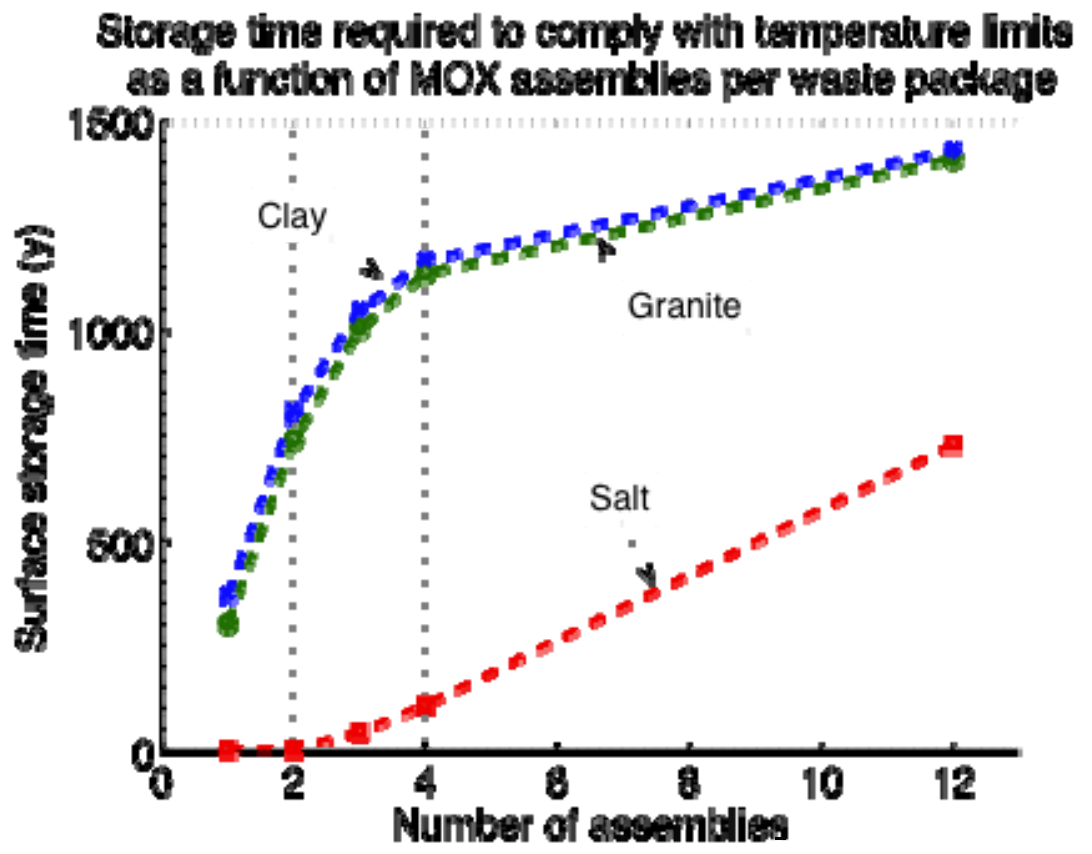

Figure H.6-2 Minimum Decay Storage Needed to Meet Prescribed Maximum Waste Package Temperatures, as a Function of MOX Assemblies per Package in Crystalline, Clay/Shale, and Salt (75\% of intact salt conductivity). 
THIS PAGE INTENTIONALLY LEFT BLANK 


\section{Appendix I}

\section{Disposal System Catalog}




\section{Introduction}

Investigation of disposal of used nuclear fuel or high-level waste has been ongoing for more than 50 years, during which time a wide range of alternative geologic settings and concepts of operation has been proposed. This history has been summarized by several authors, most recently Rechard et al. (2011). Reference design concepts are selected from this historical range in Section 5. This appendix depicts the wider historical range, using outline format and tree diagrams (Figures A-1 through A-6).

\section{I.1 Waste Form}

\section{Used Nuclear Fuel}

1.1. LWR U-oxide

\subsubsection{Fuel assemblies}

1.1.2. Rod consolidation

1.2. Defense fuels

1.3. Advanced fuels

1.4. Other

\section{High-Level Waste}

2.1. Vitric

2.2. Ceramic

2.3. Metallic

2.4. Other

\section{TRU/ILW Waste}

3.1. Vitric

3.2. Ceramic

3.3. Compacted

3.4. Cemented

3.5. Other

\section{Low-Level Waste}

4.1. Compacted

4.2. Cemented

4.3. Other

\section{Greater-than-Class C Waste}

\section{I.2 Geologic Setting}

\section{Host Medium Characteristics}

1.1. Hard rock

1.1.3. Crystalline/Granite

1.1.3.1. Fractured

1.1.3.2. Unfractured

1.1.4. Volcanic tuff 
1.1.5. Basalt

1.1.6. Crystalline basement

1.2. Soft rock

1.2.1. Plastic clay

1.2.2. Shale

1.2.2.1. Soft (claystone, mudstone)

1.2.2.2. Indurated

1.2.3. Salt

1.2.3.3. Bedded

1.2.3.4. Domal

1.2.4. Carbonates

1.2.5. Chalk/marl

1.2.6. Alluvium

1.3. Seabed

1.3.1. Littoral

1.3.2. Trench/subduction zone

1.4. Non-host units

\section{Hydrogeologic Setting}

2.1. Unsaturated

2.2.1. Alluvial basin

2.2.2. Upland, deep water table

2.2. Saturated

2.2.1. Island

2.2.2. Archipelago

2.2.3. Sedimentary basin

2.2.4. Crystalline

2.2.5. Fractured

2.2.6. Unfractured

2.2.7. Basement

2.2.8. Hydraulic sump

2.3. Surface hydrogeology

2.3.1. Lacustrine/oceanic

2.3.2. Arid desert

2.3.3. Semi-arid

2.3.4. Temperate

2.3.5. Glacial

2.3.6. Alpine 


\section{Geochemical setting}

3.1. Oxidizing

3.2.1. Unsaturated

3.2.2. Saturated-fresh

3.2. Reducing

3.2.1. Source controlled

3.2.2. Host rock constituents

3.2.2.1. Natural organic matter

3.2.2.2. Sulfides

3.2.2.3. Other

3.3. Radionuclide sorbing

3.4. Saline groundwater

3.4.1. Seawater

3.4.2. Deep brine

\section{Geomechanical Setting}

4.1. In Situ Stress

4.1.1. Overburden

4.1.2. Tectonic

4.1.3. Residual

4.1.4. Excavation/operation induced

4.1.5. Thermomechanical stress

4.2. Excavation damage

4.3. Rockfall/rock burst

4.4. Ground motion

4.4.1. Seismicity

4.4.2. Landslide

4.4.3. Fault displacement

4.5. Erosion

4.6. Isostasy

\section{I.3 Engineering Concept of Operations}

\section{Mined Repository}

1.1. Waste canister

\subsubsection{Multipurpose}

1.1.1.1. Transport/aging/disposal

1.1.1.2. Dual-purpose canister

1.1.1.3. Other 
1.1.2. Pour canister

1.1.3. Cementitious

1.1.4. Deep borehole canister

1.1.5. Other

1.2. Waste package (disposal overpack)

1.2.1. Short containment lifetime

1.2.1.1. Steel

1.2.1.2. Cast iron

1.2.2. Long containment lifetime

1.2.2.1. Corrosion resistant

1.2.2.1.1. Copper

1.2.2.1.2. Steel

1.2.2.1.3. Ni-alloy

1.2.2.1.4. Titanium

1.2.2.1.5. Cementitious

1.2.2.1.6. Coatings

1.2.2.1.6.1. Amorphous metal

1.2.2.1.6.2. Other

1.2.2.1.7. Multi-layer

1.2.2.1.8. Closure

1.2.2.2. Corrosion allowance

1.2.2.2.1. Steel

1.2.2.2.2. Cast iron

1.2.2.2.3. Other

1.2.3. Insert/basket

1.2.3.1. Steel

1.2.3.2. Cast iron

1.2.3.3. Criticality control elements

1.2.3.4. Heat transfer elements

1.2.4. Chemical conditioning

1.2.4.1. Cast iron

1.2.4.2. Steel shot

1.2.4.3. Depleted U

1.2.4.4. Other

1.2.5. Penetrator

1.3. Mined Disposal

1.3.1. Emplacement mode

1.3.1.1. In-drift 


\subsubsection{Borehole}

\subsection{Vertical}

\subsection{Horizontal}

1.3.2. Ex-Container EBS

1.3.2.1. Enclosed

1.3.2.1.1. Buffer

1.3.2.1.2. Prefabricated, envelope

1.3.2.1.3. Liner

1.3.2.1.4. Backfill

1.3.2.1.5. Richards barrier

\subsubsection{Open}

1.3.2.2.1. Drip shield

1.3.2.2.2. Vault

1.3.2.3. Other EBS features

$$
\begin{array}{ll}
\text { 1.3.2.3.1. } & \text { Seals } \\
\text { 1.3.2.3.2. } & \text { Plugs } \\
1.3 .2 .3 .3 . & \text { Getters }
\end{array}
$$

1.3.3. Secondary waste disposal

1.3.4. Other engineered structures

1.3.4.1. Ground support

1.3.4.2. Waste package support

1.3.4.3. Invert

1.3.4.4. Conveyance

1.3.5. Repository operations

1.3.6. Performance monitoring

1.3.7. Repository closure

\section{Greater Confinement Disposal (LLW)}

3. Shallow Disposal (LLW)

3.1. Landfill

3.2. Buried vault

\section{Deep Borehole Disposal}

5. Seabed Disposal 


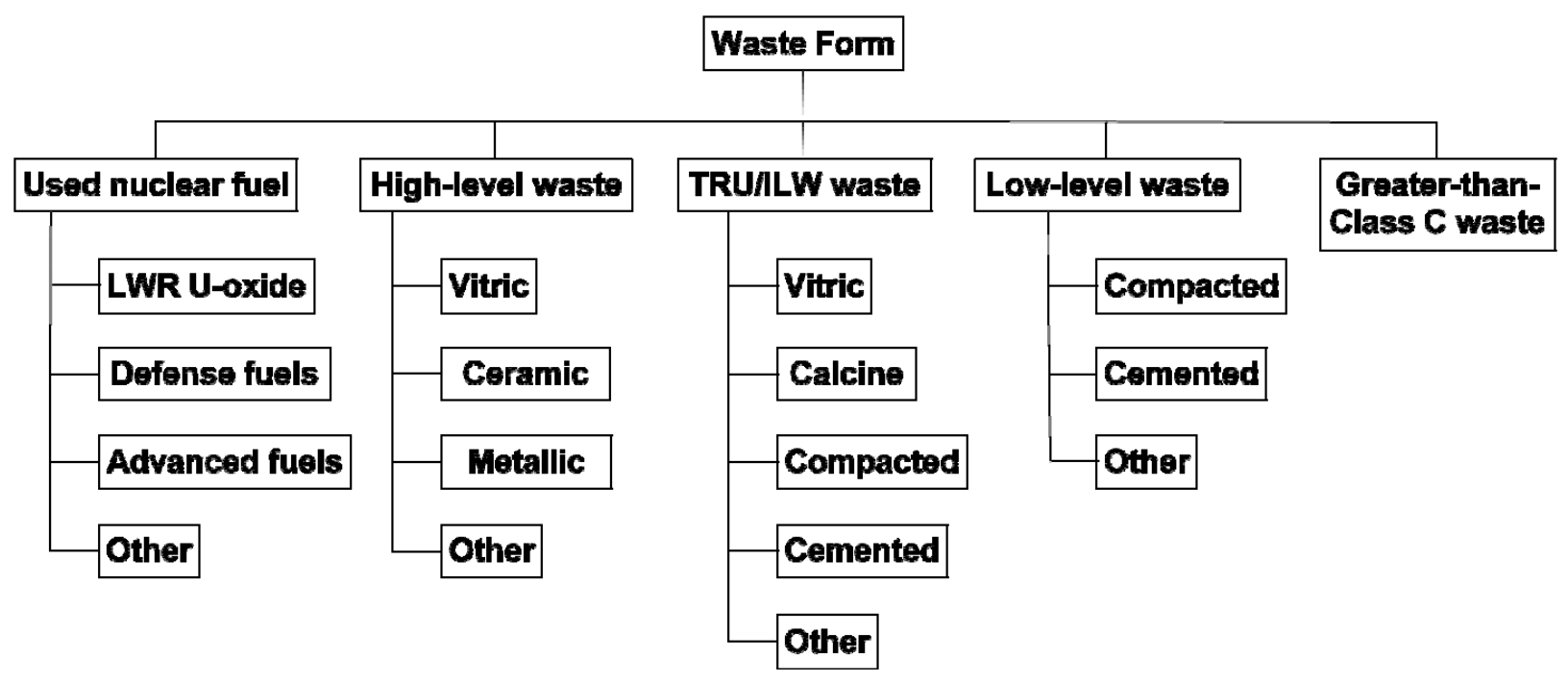

Figure I-1 Potential Range of Waste Form Types for Geologic Disposal.

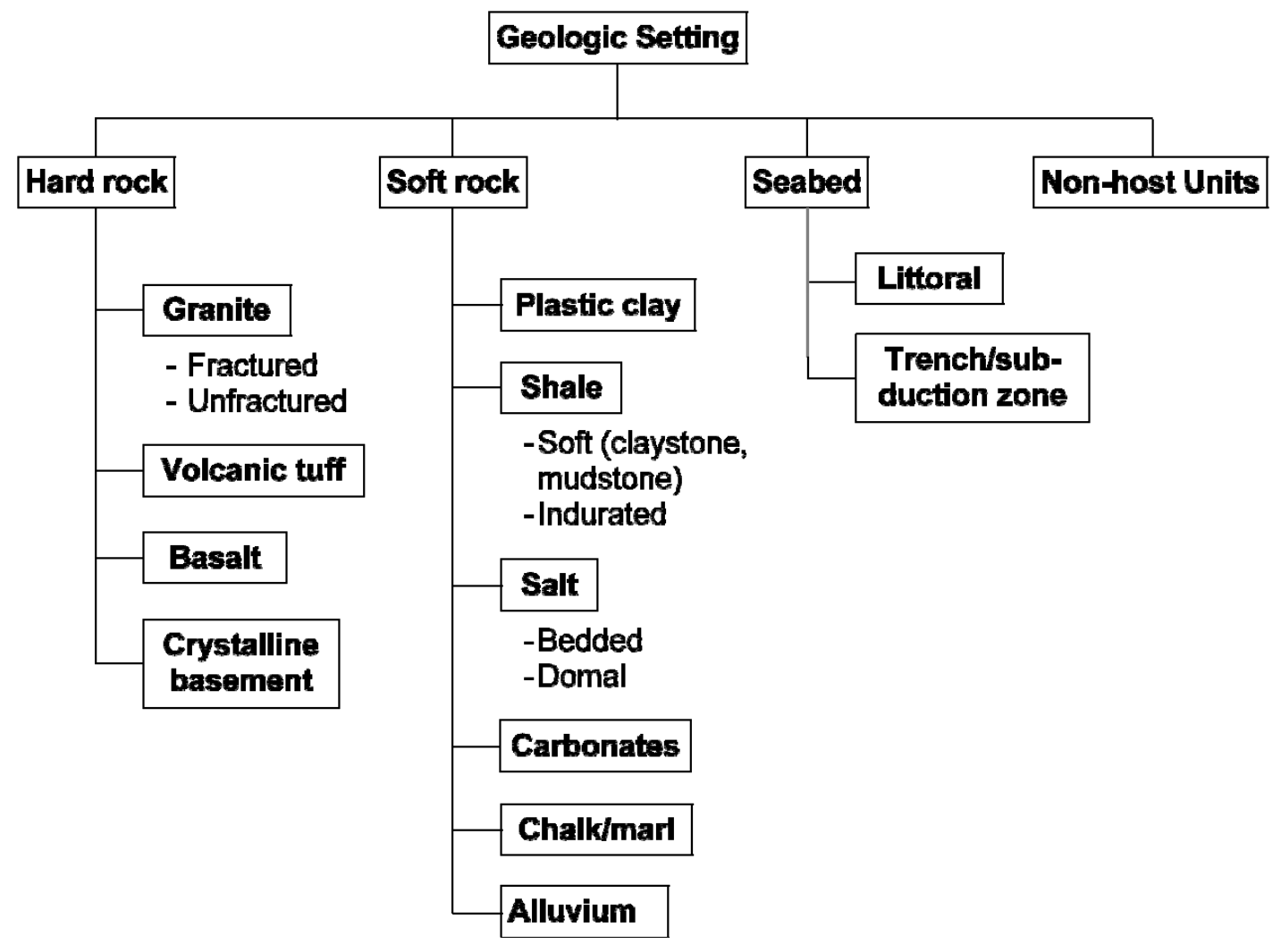

Figure I-2 Geologic Settings Considered for Disposal of SNF and HLW. 


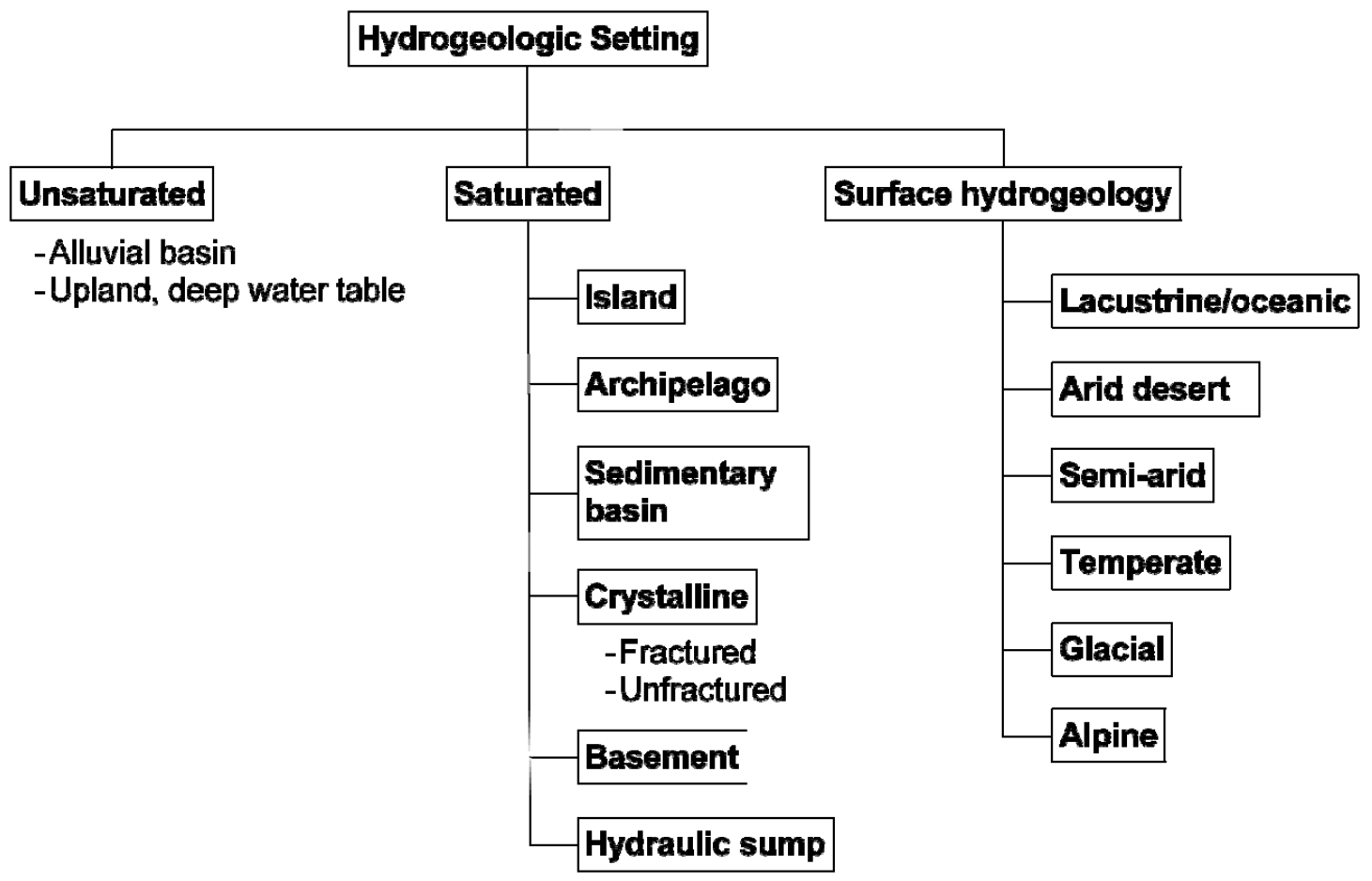

Figure I-3 Hydrogeologic Settings Considered for Disposal of SNF and HLW.

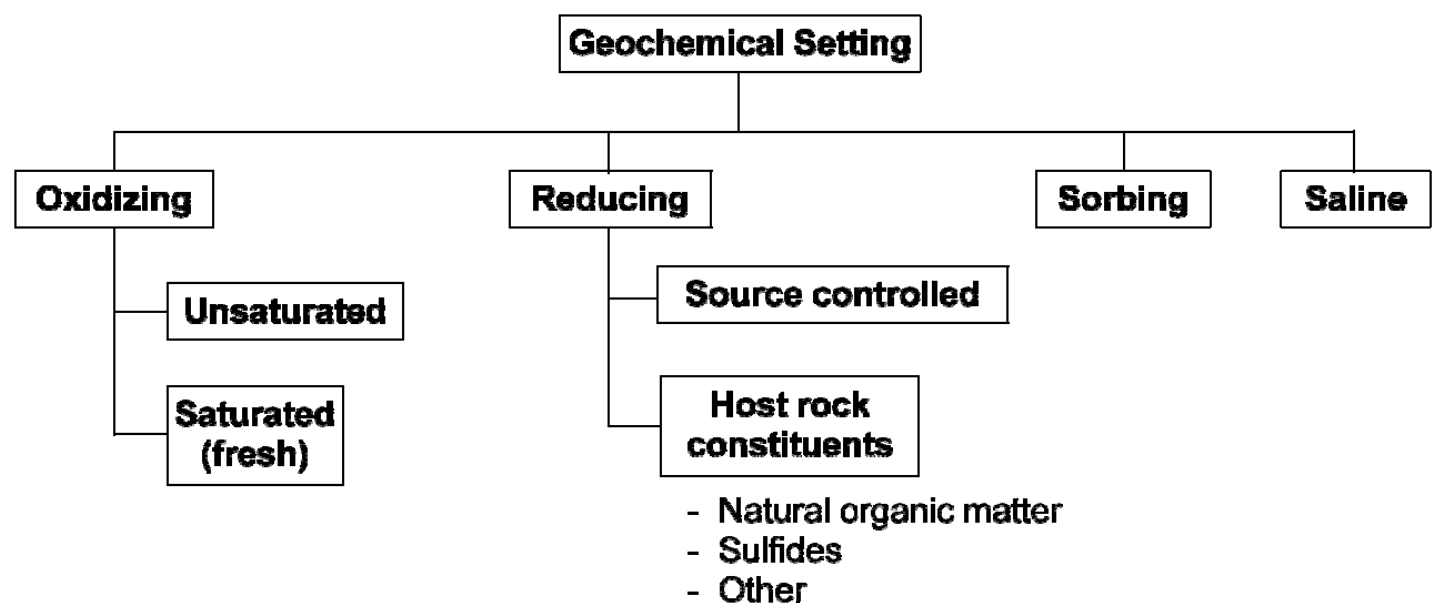

Figure I-4 Host Rock Geochemical Settings Considered for Disposal of SNF and HLW. 
Figure I-5 Geomechanical Settings Considered for Disposal of SNF and HLW.

Figure I-6 Engineered Features Considered for Disposal of SNF and HLW. 


\section{I.4 Discussion}

The UFD campaign developed a generic FEP list in 2010, for which six potential waste form groupings and eight potential disposal concept/geologic setting groupings were identified, as a reasonable range of reference disposal concepts and geologic settings. All of these waste form groupings, geologic settings, and design concepts are included in this appendix. In addition this outline also contains many FEP that are consistent with the FEP list, such as attributes of the geologic setting and the engineered barrier features. The focus here is on disposal system features that could be important in siting or conceptual design. 


\section{Appendix $\mathrm{J}$}

\section{Disposal Cost Summary}




\section{Introduction}

This appendix summarizes the two documents which are the most current and comprehensive sources of information on the estimated cost of disposal for SNF from once-through fuel cycles, and HLW from modified-open or full-recycle fuel cycles, in the U.S. These sources benefit from the considerable work that has been done in the past few years to estimate costs for geologic disposal, both in the U.S. and internationally. The purpose here is to support recommendations in Section 6 for how that body of knowledge can be used to further the goals of this multi-year analysis of reference disposal concepts in the U.S. The two sources discussed here (with some of their supporting references) are the cost module of the Advanced Fuel Cycle Initiative (AFCI) Cost Basis (Shropshire et al. 2009) and the cost information provided by Nutt (2009).

\section{AFCI Cost Basis Module}

The Advanced Fuel Cycle Initiative (AFCI) Cost Basis (Shropshire et al. 2009) provides cost data to support analysis of all aspects of future nuclear FCs. The report provides documentation and tools for estimating FC costs and integrating cost data into economic models. The cost data of interest here describe the elements of SNF and HLW disposal in geologic repositories (Module L). This module reflects the most recent life-cycle cost analysis for the proposed Yucca Mountain repository (DOE 2008c). Additional information was obtained from the ongoing AFCI R\&D program and international repository programs. The international studies encompass different disposal concepts and geologic settings (salt, tuff, clay, granite, etc.).

Life cycle costs for geologic disposal typically include three major types of activities: 1) the repository itself, 2) transportation, and 3) management and oversight. Module L of the AFCI Cost Basis covers disposal of SNF and HLW, but does not cover waste conditioning, packaging or transportation (these are addressed in other modules).

Repository cost estimates are based on both capital and operating expenses. These may overlap in time, as the repository implementation schedule may allow construction to continue after operations begin. Capital costs considered in the AFCI Cost Basis include

- Siting, characterization, and development of the license application;

- Engineering, procurement, and construction of the required surface facilities (e.g., receipt facility, canister receipt and closure, initial handling, wet handling) and subsurface facilities (e.g., main access tunnels and emplacement drifts or boreholes) needed for initial operations;

- Design and procurement of the waste container;

- Physical security systems; and

- Program management.

Operating costs are divided into three phases of repository operation: emplacement, monitoring, and closure and sealing. Emplacement phase activities considered in Module L include: receiving shipped waste, transfer of waste to disposal containers, and emplacement in mined (or drilled) underground openings. Some waste management schemes include using repository facilities for interim storage of SNF it is recycled or directly disposed. Additional costs for interim surface storage (storage pads, waste handling, repackaging, etc.) are not included in Module L (but are addressed in other modules). 
The Advanced Fuel Cycle Cost Basis explores the use of scaling factors. Several studies have tried to define the basic scaling relationships between cost and the size or capacity of the repository, and those studies are summarized in the AFCI Cost Basis. Although there is considerable uncertainty in estimating SNF/HLW disposal costs, there does appear to be an economy of scale with respect to disposal costs. The authors suggest that

"...there is a minimum facility size of approximately 10,000 MTHM, where up to this capacity there is very little economy of scale. In larger facilities an economy of scale may exist if the site was originally characterized to provide for future expansion, there is no major change to the waste stream (e.g., from SNF to cycled products in HLW) or packaging concepts (transportation and disposal canister repackaging), and the facility receiving throughput remains the same. Under these conditions, a scaling factor of approximately $0.6-0.75$ would seem appropriate."

Noting the high degree of uncertainty with respect to disposal concepts, siting, and associated costs, the authors recommend using broad uncertainty ranges for all cost estimates. Cost summaries are provided for SNF disposal (Module L1) and HLW disposal of recycled SNF (Module L2-1) and activated metal (Module L2-2). High-level cost estimates are summarized in Tables J-1 and J-2 (based on Tables L-7 and L-8 of Shropshire et al. 2009). The summary estimates show nominal estimates for normalized disposal cost, and an uncertainty range around each estimate.

The AFCI Cost Basis report also includes a survey of cost estimates for international programs to dispose of SNF and HLW, based mainly on Nutt (2009) as discussed below.

Table J-1 Cost Summary for Geologic Disposal of SNF (AFCI 2009).

\begin{tabular}{|c|c|c|c|}
\hline $\begin{array}{l}\text { Reference Cost and } \\
\text { Capacity (2009\$US) }\end{array}$ & $\begin{array}{l}\text { Nominal Cost } \\
\text { (2009\$U) }\end{array}$ & $\begin{array}{l}\text { Low Cost Range } \\
\text { (2009\$U) }\end{array}$ & $\begin{array}{l}\text { High Cost Range } \\
\text { (2009\$U) }\end{array}$ \\
\hline TSLCC \$96.18B & $\$ 650 / \mathrm{kg} \mathrm{HM}$ & $\$ 400 / \mathrm{kg} \mathrm{HM}$ & $\$ 1,000 / \mathrm{kg} \mathrm{HM}$ \\
\hline $\begin{array}{l}\text { (122,100 MTHM; } \\
\text { DOE 2008c) }\end{array}$ & $\begin{array}{l}\text { Rationale: } \\
\text { 1) Future new } \\
\text { geologic } \\
\text { repository costs } \\
\text { will be very } \\
\text { similar to YMP. }\end{array}$ & $\begin{array}{l}\text { Rationale: } \\
\text { 1) Continuation of } \\
\text { the 1mill/kWh fee } \\
\text { basis; } \\
\text { 2) Costs are similar } \\
\text { to the average } \\
\text { costs of } \\
\text { international } \\
\text { facilities; and } \\
\text { 3) Based on large } \\
\text { facilities with good } \\
\text { economies of } \\
\text { scale. }\end{array}$ & $\begin{array}{l}\text { Rationale: } \\
\text { 1) Costs increase as a } \\
\text { result of new } \\
\text { regulatory policies,; } \\
\text { 2) More expensive } \\
\text { design due to new } \\
\text { geology and site } \\
\text { characteristics; and } \\
\text { 3) Less economical } \\
\text { facility size. }\end{array}$ \\
\hline
\end{tabular}

The AFCI Cost Basis authors postulated that “...per unit of energy produced, the cost for disposal of recycled SNF is expected to be less than from unprocessed SNF. By reprocessing the SNF, many of the heat-producing radionuclides are removed, allowing for more efficient disposal." 
In the AFCI Cost Basis study, the costs for disposal of HLW from reprocessing SNF (Module L2-1) are derived from the cost of direct disposal of SNF (Module L1), using a waste loading factor multiplier for selected radionuclides (e.g., fission products). Thus, whereas the nominal cost for SNF disposition is $\$ 650 / \mathrm{kg} \mathrm{HM}$, or $\$ 16,250 / \mathrm{kg}$ fission products (FPs) based on an average FP composition of $4 \%$ of initial heavy metal fuel content. The FP waste loading of HLW is estimated to be increased by a factor of 2 to 10, with a nominal loading factor of 2.5. Therefore, the related HLW disposal costs (Module L1-2) are estimated to range from $\$ 1,625 / \mathrm{kg}$ FP to $\$ 8,125 / \mathrm{kg}$ FP, with a nominal cost of $\$ 6,500 / \mathrm{kg}$ FP (Table J-2). Note that these costs are tied to the defined nominal cost for SNF disposal, and should be recalculated if that estimate is changed. The estimate is applicable to full-recycle fuel cycle strategies but would need modification for modified-open strategies that involve direct disposal of some SNF. Also, the non-heat generating secondary wastes from reprocessing would require additional disposal capacity, either in near-surface or deep geologic disposal facilities.

The HLW disposition cost for activated hulls (not the fission products or used fuel) is provided in Module L2-2 (Table J-2). These costs are estimated similarly to Module L1, with a low range cost of $\$ 400 / \mathrm{kg}$ metal, nominal $\$ 650 / \mathrm{kg}$ metal, and high $\$ 1,000 / \mathrm{kg}$ metal.

Table J-2 Cost Summary for Geologic Disposal of HLW (FCl 2009).

\begin{tabular}{|c|c|c|c|}
\hline $\begin{array}{l}\text { Reference Cost and } \\
\text { Capacity (2009\$U) }\end{array}$ & $\begin{array}{c}\text { Nominal Cost } \\
(2009 \$ \text { US) }\end{array}$ & $\begin{array}{c}\text { Low Cost Range } \\
\text { (2009\$US) }\end{array}$ & $\begin{array}{l}\text { High Cost Range } \\
\text { (2009\$U) }\end{array}$ \\
\hline $\begin{array}{l}\text { Based on } \$ 650 / \mathrm{kg} \mathrm{HM} \\
\text { disposal cost for SNF }\end{array}$ & $\begin{array}{l}\quad \$ 6,500 / \mathrm{kg} \mathrm{FP} \\
\text { Basis: } \\
\text { Nominal SNF } \\
\text { cost with a FP } \\
\text { waste loading of } \\
2.5 x \text {. }\end{array}$ & $\begin{array}{l}\quad \$ 1,625 / \mathrm{kg} \mathrm{FP} \\
\text { Basis: } \\
\text { Nominal SNF } \\
\text { cost with a FP } \\
\text { waste loading of } \\
\text { 10x. }\end{array}$ & $\begin{array}{l}\quad \$ 8,125 / \mathrm{kg} \mathrm{FP} \\
\text { Basis: } \\
\text { Nominal SNF cost } \\
\text { with a FP waste } \\
\text { loading of } 2 x\end{array}$ \\
\hline $\begin{array}{l}\text { Assume disposal cost } \\
\text { for activated metal is the } \\
\text { same as for SNF }\end{array}$ & $\$ 650 / \mathrm{kg}$ metal & $\$ 400 / \mathrm{kg}$ metal & $\$ 1,000 / \mathrm{kg}$ metal \\
\hline
\end{tabular}

\section{Comparison of Estimates for Cost of SNF and HLW Disposal Internationally}

The report by Nutt (2009) surveyed cost information from the Nuclear Energy Agency (NEA) (1993), a follow-on report (NEA 2003), and several other international reports. This review contrasted fixed costs with operating costs for geologic disposal, where fixed costs include siting, characterization, licensing, engineering, design, management, monitoring, and repository closure. There is no international convention for defining and reporting such costs, and no practical way to fully reconcile the published international information, so some ambiguity remains in the cost comparisons for different countries. This situation is most likely manifested in estimates of "total cost" that don't include some fixed costs as listed above, or waste packaging cost, etc. Fixed costs across the international programs vary as a percentage of total cost from 10 to $80 \%$, which probably reflects the different definitions. Economy of scale was 
identified in cost estimates for disposal facilities with larger capacity, showing the influence of fixed costs on the system cost structure.

An important contribution of this review (Nutt 2009) was normalization of total disposal system costs to electricity generated (Table J-3). The range of cost estimates for disposal of SNF, from all sources, was $0.4 \mathrm{M}$ to $2.7 \mathrm{M} 2007$ US per TW-hr. The NEA (2003) report states that less volume of HLW is produced than SNF, when normalized to energy produced. We note that such a comparison is more complicated if low-heat or non-heat generating wastes from reprocessing are considered, or if disposal of recycled $\mathrm{U}$ from reprocessing is included.

Disposal cost for the proposed Yucca Mountain repository are comparable to the NEA estimates (Table J-3). The Yucca Mountain repository would contain government-owned wastes in addition to commercial SNF, and the government-owned fraction varies from $9 \%$ to $\sim 20 \%$ depending on the method used to calculate allocation (i.e., financial, waste tonnage, number of waste packages, etc.). Government- owned HLW and SNF are not typical of commercial SNF and have different associated costs. Tabulated total costs for a Yucca Mountain repository are for the case of a limited repository expansion to accommodate 109,300 MT of commercial SNF and 12,800 MTHM-equivalent for government-owned wastes.

International estimates of disposal cost are available from Belgium, Canada, Czech Republic, Finland, France, Hungary, Japan, Sweden, and Switzerland (Nutt 2009). A generic U.S. salt repository has also been evaluated (Carter et al. 2011b). For this study, we tabulate summary estimates for the largest programs in clay/shale (France) and crystalline rock (Sweden), and for the generic salt repository (Table J-3). The French repository program was estimated in 2005 to have a total cost of 15 B Euro, which is converted to 19.8 B 2007\$US. The French estimates includes all elements from repository siting through emplacement. The U.S. generic salt repository cost range is comparatively low but does not include siting, characterization, and licensing, or the cost of surface storage of HLW which may be needed as discussed in Sections 5.3 and 6 of this report. Waste overpacks are not used for HLW canisters in clay/shale (France) and salt (generic salt repository), which significantly lowers estimates for total cost of disposal.

Finally, we note that none of the cost estimates discussed here have taken into account the cost implications from such thermal management measures as: 1) thermal optimization of panels within a repository by adjusting waste package size, spacing, and decay storage time; 2) codisposal of heat generating HLW and/or SNF with non-heat generating HLW, by alternating waste package types; and 3) disposal of non-heat generating LLW and/or GTCC waste in the unused volume, in geologic repositories for HLW or SNF. Section 6 provides further discussion of possible future work. 
Table J-3 Cost Summary from Nutt (2009).

\begin{tabular}{|c|c|c|c|c|c|}
\hline \multicolumn{2}{|c|}{ Estimate } & $\begin{array}{l}\text { Capacity } \\
\text { (MTHM) }\end{array}$ & $\begin{array}{c}\text { Electricity } \\
\text { Generation } \\
\text { (TW-hr) }\end{array}$ & $\begin{array}{l}\text { Cost Normalized to } \\
\text { Mass }(\$ / \mathrm{kg})\end{array}$ & $\begin{array}{l}\text { Normalized to } \\
\text { Electricity Produced } \\
\text { (\$M/TW-hr) }\end{array}$ \\
\hline \multicolumn{6}{|c|}{ SNF } \\
\hline \multicolumn{2}{|c|}{ NEA (2003; all) } & & NA & 330 to 660 & 1.2 to 2.3 \\
\hline \multicolumn{2}{|c|}{$\begin{array}{l}\text { Yucca Mountain } \\
\text { (DOE 2008c; volcanic tuff) }\end{array}$} & 109,300 & 31,500 & 450 to 550 & 1.5 to 1.9 \\
\hline \multicolumn{2}{|c|}{$\begin{array}{l}\text { Sweden } \\
\text { (SKB 2003; crystalline) }\end{array}$} & 9740 & 2,760 & 350 & 1.2 \\
\hline \multicolumn{6}{|c|}{ HLW } \\
\hline \multicolumn{2}{|c|}{ NEA (2003; all) } & NA & NA & 88 to 220 & 0.3 to 0.75 \\
\hline \multicolumn{2}{|c|}{$\begin{array}{l}\text { France } \\
\text { (Andra 2005a; clay/shale) }\end{array}$} & 45,000 & 16,000 & 440 & 1.2 \\
\hline \multirow{2}{*}{$\begin{array}{l}\text { U.S. } \\
\text { (Carter et al. } \\
\text { 2011b; salt) }\end{array}$} & $\begin{array}{l}(40 \mathrm{yr} \\
\text { case })\end{array}$ & 83,000 & \multirow{2}{*}{ Note 1} & 140 to 200 & \multirow{2}{*}{ Note 1} \\
\hline & $\begin{array}{l}(100 \mathrm{yr} \\
\text { case })\end{array}$ & 263,000 & & 87 to 116 & \\
\hline \multicolumn{6}{|l|}{$\begin{aligned} & \text { Notes: } \\
& 1 . \quad \text { Actu }\end{aligned}$} \\
\hline
\end{tabular}




\section{Distribution}

\section{External:}

1 James Blink

Lawrence Livermore National Laboratory

PO Box 808, L-090

Livermore, CA 94550

1 Joe T. Carter

Savannah River Nuclear Solutions

Building 703-42A

Aiken, SC 29808

1 Robert L. Howard

Oak Ridge National Laboratory

MS 6170

PO Box 2008

Oak Ridge, TN 37831-2008

\section{Internal:}

3 MS0734 Peter N. Swift 6225

1 MS0736 Evaristo J. Bonano 6220

1 MS0771 Stanley A. Orrell 6200

1 MS0899 Technical Library 9536 (electronic copy) 
